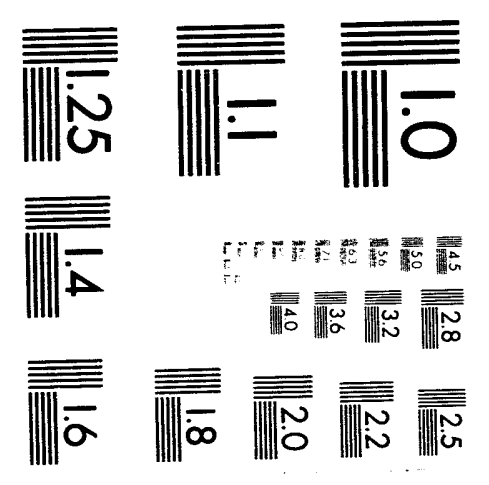



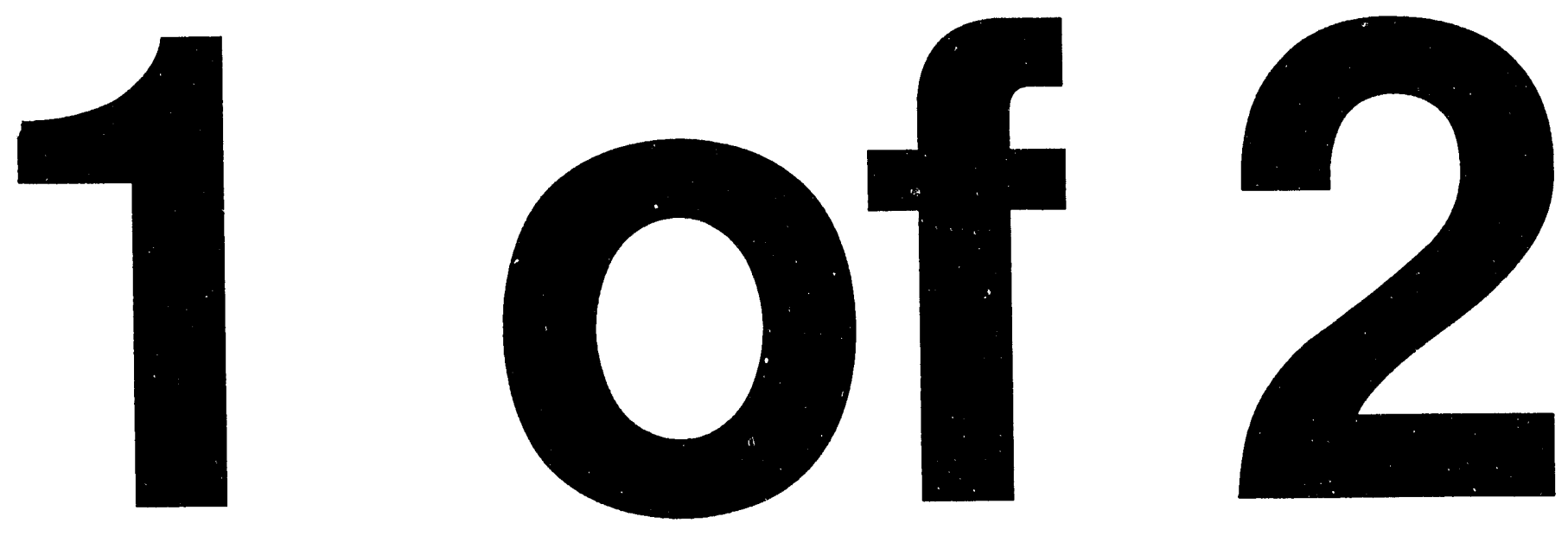
DOE/EIA-0035(94/01)

Distribution Category UC-950

\section{Monthly Energy Review}

\section{January 1994}

Energy Information Administration

Office of Energy Markets and End Use

U.S. Department of Energy

Washington, DC 20585

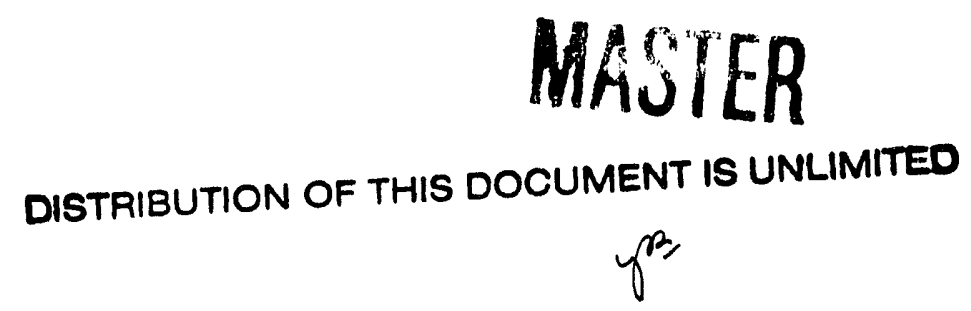

This report was prepared by the Energy Information Administration, the independent statistical and analytical agency within the Department of Energy. The information contained herein should not be construed as advocating or reflecting any policy position of the Department of Energy or any other organization. 


\section{Contacts}

The Monthly Energy Review is prepared by the Energy Information Adininistration. General information may be obtained from W. Cal vin Kilgore, Director, Office of Energy Markets and End Use, 202-586-1617; Lynda T. Carlson, Director, Energy End Use and Integrated Statistics Division, 202-586-1112; and Katherine E. Seiferlein, Chief, Integrated Statistics Branch, 202-586-5692. Questions and comments concerning the contents of the Monthly Energy Review may be directed to the Principal Analyst, Chuck Allen, 202-586-5692, or to Diane D. Perrith, 202-586-2788, Carol Swiggins, 202-586-5743, or the following subject specialists:

Features

Barbara T. Fichman

202-586-5737

Section 1. Energy Overview

Tables 1.1-1.5 .

Alethea K. Jennings

202-586-9160

Tables 1.6-1.12

Dianne R. Dunn

202-586-2792

Section 2. Energy Consumption

Alethea K. Jennings

202-586-9160

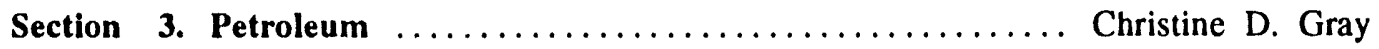

202-586-8995

Section

4. Natural Gas

Donna Guerrina

202-586-6135

Section

5. Oil and Gas Resource Development

Herbert T. Black

202-586-4055

Section

6. Coal

Paulette Young

202-254-5481

Section

7. Electricity

Deborah Bolden

202-254-5663

Section

8. Nuclear Energy

Douglas C. Bonnar

202-254-5560

Section 9. Energy Prices

Petroleum $\ldots \ldots \ldots \ldots \ldots \ldots \ldots \ldots \ldots \ldots$ Elizabeth Scott

202-586-1258

Natural Gas

Donna Guerrina

202-586-6135

Electricity

Retail Prices ........................ Deborah Bolden

202-254-5663

Fossil-Fuel Receipts

Sandra Smith

202-254-5632

Section 10. International Energy

Petroleum

Production

Patricia Smith

202-586-6925

Consumption and Stocks .

H. Vicky McLaine

202-586-9412

Nuclear Electricity Gross Generation

Douglas C. Bonnar

202-254-5560

Requests for additional information on other energy statistics available from the Energy Information Administration and questions concerning subscriptions and report distribution may be directed to the National Energy Information Center, 202-586-8800 (TTY, for people who are deaf or hard of hearing, 202-586-1181). 


\section{Contents}

Page

Energy Previtw: Commercial Buildings Energy Consumption Survey, Preliminary Estimates, $1992 \ldots \ldots \ldots \ldots \ldots \ldots . \quad 1$

Section 1. Energy Overview $\ldots \ldots \ldots \ldots \ldots \ldots \ldots \ldots \ldots \ldots \ldots, 5$

Section 2. Energy Consumption $\ldots \ldots \ldots \ldots \ldots \ldots \ldots \ldots \ldots \ldots, 25$

Section 3. Petroleum $\ldots \ldots \ldots \ldots \ldots \ldots \ldots \ldots \ldots \ldots \ldots, 43$

Section 4. Natural Gas ......................... 73

Section 5. Oil and Gas Resource Development ............. 83

Section 6. Coal ................................ 87

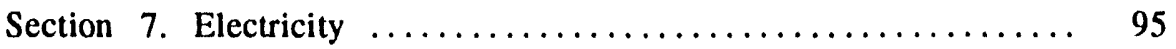

Section 8. Nuclear Energy ......................... 105

Section 9. Energy Prices $\ldots \ldots \ldots \ldots \ldots \ldots \ldots \ldots \ldots \ldots \ldots, 111$

Section 10. International Energy $\ldots \ldots \ldots \ldots \ldots \ldots \ldots \ldots \ldots \ldots \ldots$

Appendix A. Thermal Conversion Factors ................ 145

Appendix B. Metric and Other Physical Conversion Factors ....... 155

Appendix C. List of Features ...................... 157

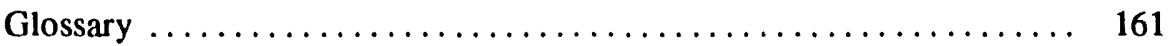


Section 1. Energy Overview

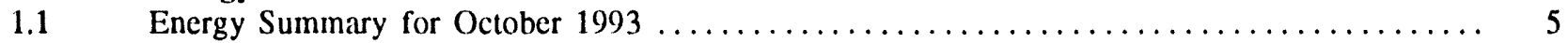

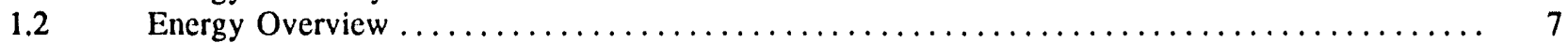

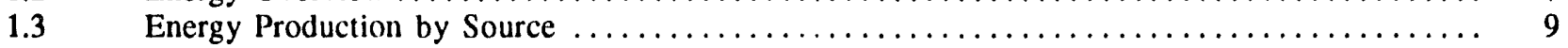

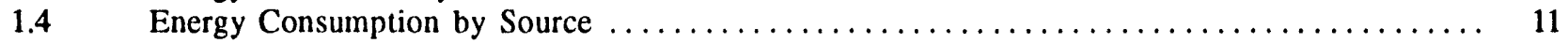

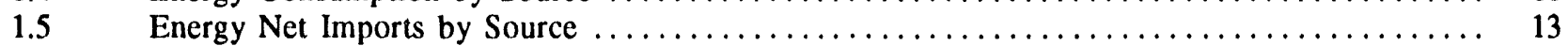

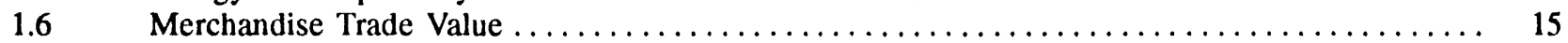

1.7 Energy Consumption per Dollar of Gross Domestic Product $\ldots \ldots \ldots \ldots \ldots \ldots \ldots \ldots \ldots \ldots .16$

$1.8 \quad$ U.S. Dependence on Petroleum Net Imports $\ldots \ldots \ldots \ldots \ldots \ldots \ldots \ldots \ldots \ldots \ldots \ldots \ldots \ldots$

1.9 Cost of Fuels to End Users in Constant $(1982-1984)$ Dollars $\ldots \ldots \ldots \ldots \ldots \ldots \ldots \ldots \ldots \ldots, 18$

$1.10 \quad$ Passenger Car Efficiency .......................................... 19

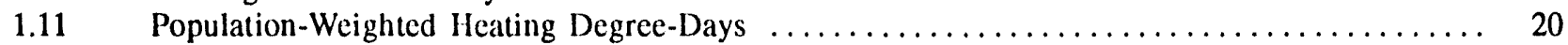

1.12 Population-Weighted Cooling Degree-Days $\ldots \ldots \ldots \ldots \ldots \ldots \ldots \ldots \ldots \ldots \ldots \ldots \ldots \ldots$

\section{Section 2. Energy Consumption}

$2.1 \quad$ Energy Consumption Summary for October $1993 \ldots \ldots \ldots \ldots \ldots \ldots \ldots \ldots \ldots \ldots \ldots \ldots$

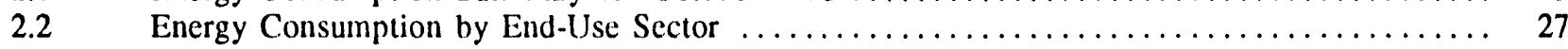

$2.3 \quad$ Residential and Commercial Energy Consumption $\ldots \ldots \ldots \ldots \ldots \ldots \ldots \ldots \ldots \ldots \ldots \ldots$

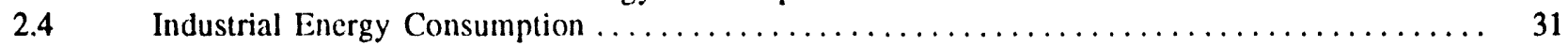

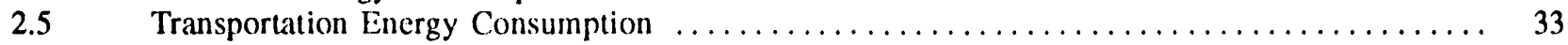

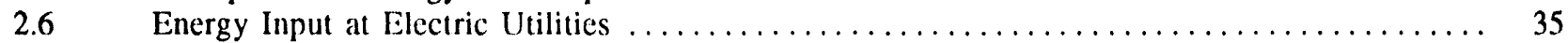

Section 3. Petroleum

3.1 Petroleum Overview

3.1a Field Production, Stock Change, Petroleum Products Supplied, and Ending Stocks ... 44

$3.1 \mathrm{~b}$ Imports, Exports, and Net Imports .......................... 45

3.2 Crude Oil Supply and Disposition

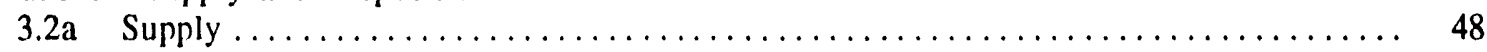

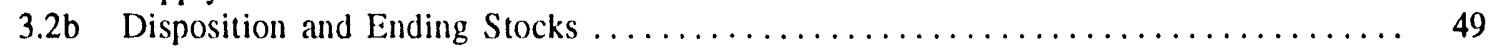

$3.3 \quad$ Petroleum Imports
$3.3 \mathrm{a}$ Algeria, Iraq, Kuwait, and Libya $\ldots \ldots \ldots \ldots \ldots \ldots \ldots \ldots \ldots \ldots \ldots \ldots \ldots \ldots$

3.3b Qatar, Saudi Arabia, U.A.E., and Total Arab OPEC .................. 51

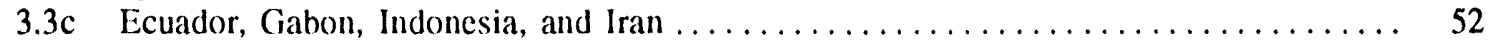

3.3d Nigeria, Venezuela, Total Non-Arab OPEC, and Total OPEC .............. 53

3.3e Angola, Australia, Bahama Islands, Brazil, Canada, and China . . . . . . . . . . 54

3.3f Colombia, Ecuador, Italy, Malaysia, Mexico, and Netherlands ............... 55

3.3g Netherland Antilles, Norway, Puerto Rico, Russia, Spain, and Trinidad and Tobago .. 56

3.3h United Kingdom, Virgin Islands, Other Non-OPEC, Total Non-OPEC, and Total

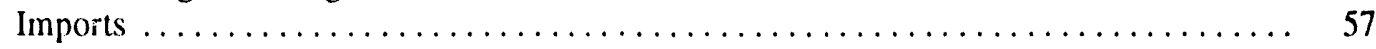

3.4 Finished Motor Gasoline Supply and Disposition $\ldots \ldots \ldots \ldots \ldots \ldots \ldots \ldots \ldots \ldots \ldots \ldots \ldots$

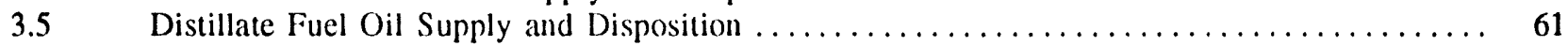

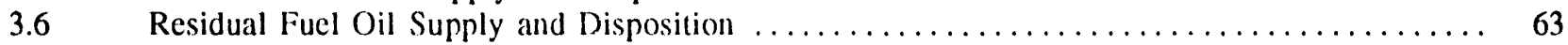

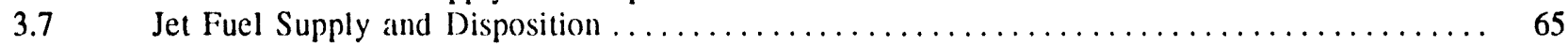

3.8 Liquefied Petroleum Gases Supply and Disposition $\ldots \ldots \ldots \ldots \ldots \ldots \ldots \ldots \ldots \ldots \ldots \ldots$

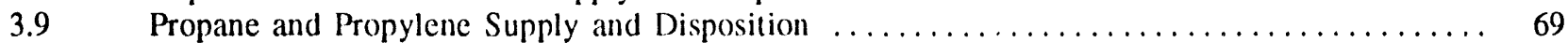

$3.10 \quad$ Other Petroleum Products Supply and Disposition $\ldots \ldots \ldots \ldots \ldots \ldots \ldots \ldots \ldots \ldots \ldots$

Section 4. Natural Gas

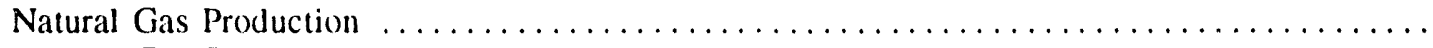

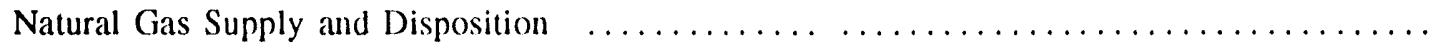

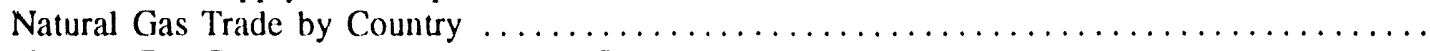

Natural Gas Consumption by End-Use Sector $\ldots \ldots \ldots \ldots \ldots \ldots \ldots \ldots \ldots \ldots \ldots \ldots \ldots$

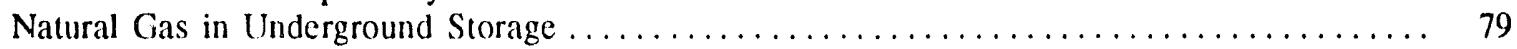

Section 5. Oil and Gas Resource Development

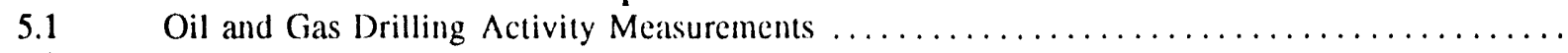

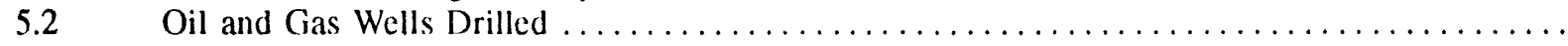




\section{Tables (Continued)}

Section 6. Coal

Page

$6.1 \quad$ Coal Overview . . . . . . . . .

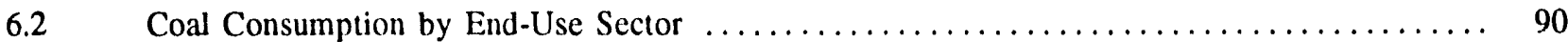

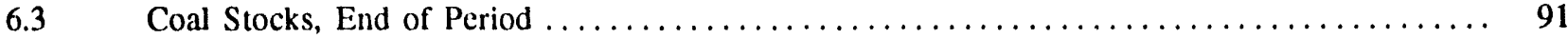

Section 7. Electricity

7.1

7.2

7.3

7.4

Electric Utility Net Generation of Electricity

Electricity Sales by End-Use Sector ................................... 99

Electric Utilitiy Consumption of Fossil Fue!s to Generate Electricity . . . . . . . . . . . . 101

Electric Utility Stocks of Coal and Petroleum, End of Period .................... 102

Section 8. Nuclear Energy

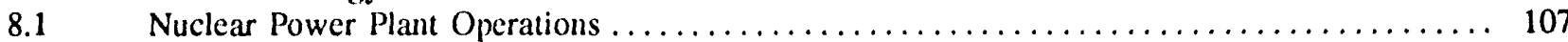

$8.2 \quad$ Nuclear Generating Units, End of Period ................................ 108

Section 9. Energy Prices

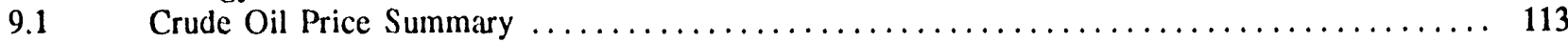

$9.2 \quad$ F.O.B. Cost of Crude Oil Imports from Selected Countries $\ldots \ldots \ldots \ldots \ldots \ldots \ldots \ldots \ldots \ldots 114$

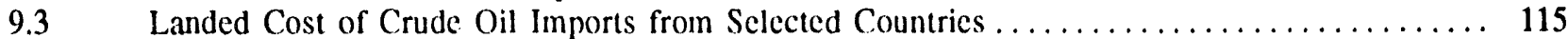

9.4 Motor Gasoline Retail Prices, U.S. City Average $\ldots \ldots \ldots \ldots \ldots \ldots \ldots \ldots \ldots \ldots \ldots \ldots$

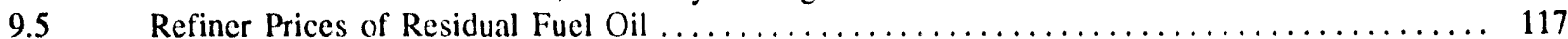

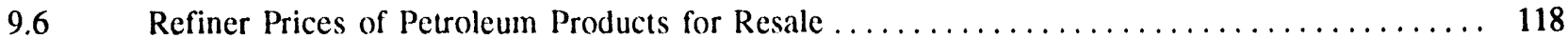

9.7 Refiner Prices of Petroleum Products to End Users . . . . . . . . . . . . . . . . . . . . . . 119

9.8 No. 2 Distillate Prices to Residences

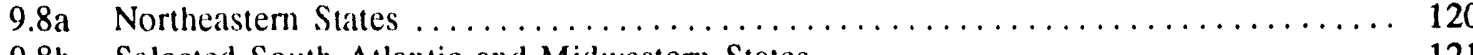

$9.8 \mathrm{~b}$ Selected South Atlantic and Midwestern States ........................ 121

$9.8 \mathrm{c}$ Selected Western States and U.S. Average . . . . . . . . . . . . . . . . . . . . 122

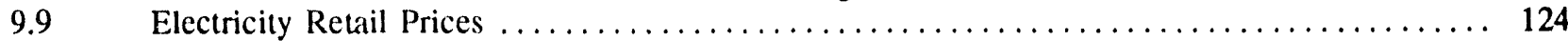

9.10 Quantity and Cost of Fossil-Fuel Receipts at Steam-Electric Utility Plants ............. 125

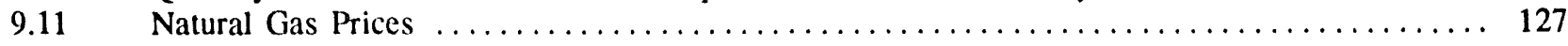

Section 10. International Energy

10.1 World Crude Oil Production

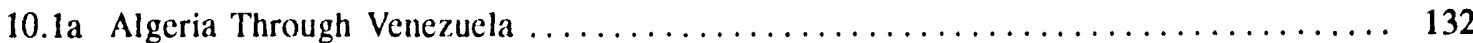

10.1b Total OPEC, Canada Through Former U.S.S.R., and World ................ 133

10.2 Petroleum Consumption in OECD Countries .............................. 137

10.3 Petroleum Stocks in OECD Countries, End of Period . . . . . . . . . . . . . . . . . . . 139

$10.4 \begin{array}{r}\text { Nuclear Electricity Gross Generation } \\ 10.4 \mathrm{a} \text { Argentina Through India } \ldots \ldots \ldots \ldots \ldots \ldots \ldots \ldots \ldots \ldots \ldots \ldots \ldots \ldots \ldots \ldots \ldots \ldots\end{array}$

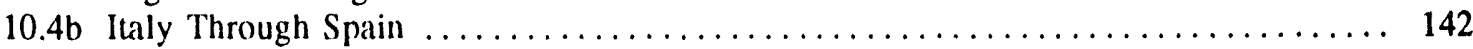

$10.4 \mathrm{c}$ Sweden Through United States and Total $\ldots \ldots \ldots \ldots \ldots \ldots \ldots \ldots \ldots \ldots \ldots \ldots \ldots \ldots$

Appendix A. Thermal Conversion Factors

A1. Approximate Heat Content of Petroleum Products $\ldots \ldots \ldots \ldots \ldots \ldots \ldots \ldots \ldots \ldots \ldots \ldots$

A2. Approximate Heat Content of Crude Oil, Crude Oil and Products, and Natural Gas Plant Liquids 146

A3. Approximate Heat Content of Petroleum Product Weighted Averages $\ldots \ldots \ldots \ldots \ldots \ldots \ldots . \ldots 146$

A4. Approximate Heat Content of Natural Gas . . . . . . . . . . . . . . . . . . . . . . . . . 147

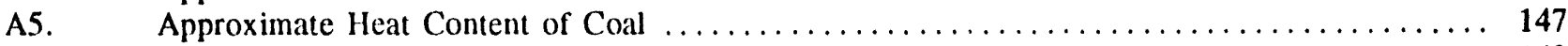

A6. Approximate Heat Content of Bituminous Coal and Lignite $\ldots \ldots \ldots \ldots \ldots \ldots \ldots \ldots \ldots \ldots 148$

A7. Approximate Heat Content of Anthracite and Coal Coke $\ldots \ldots \ldots \ldots \ldots \ldots \ldots \ldots \ldots \ldots .148$

A8. Approximate Heat Rates for Electricity ................................. 149

Appendix B. Metric and Other Physical Conversion Factors

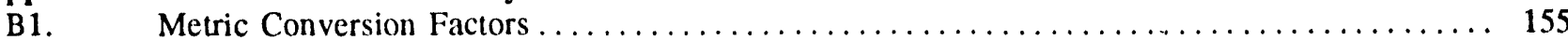

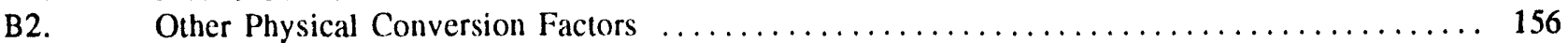

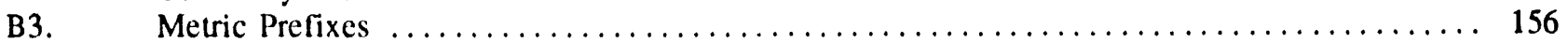




\section{Figures}

Section 1. Energy Overview Page

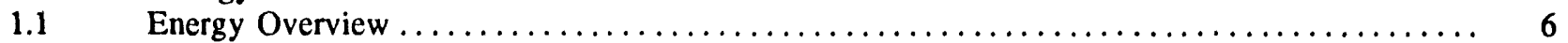

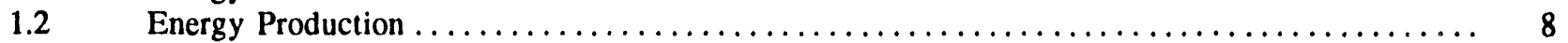

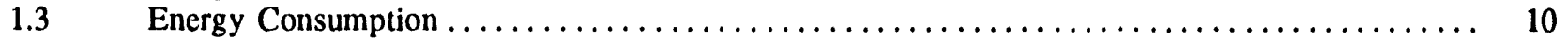

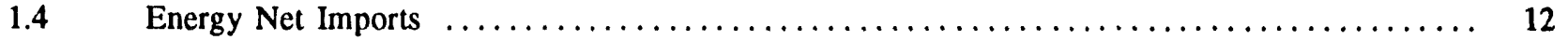

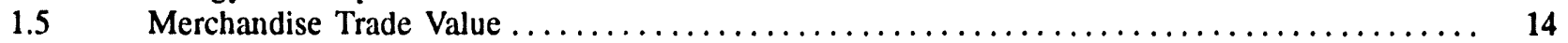

1.6 Energy Consumption per Dollar of Gross National Product $\ldots \ldots \ldots \ldots \ldots \ldots$

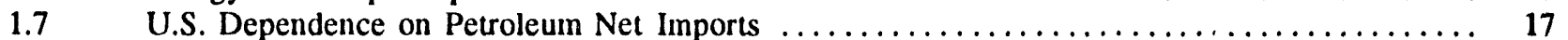

1.8 Cost of Fuels to End Users in Constant $(1982-1984)$ Dollars . . . . . . . . . . . . . . . 18

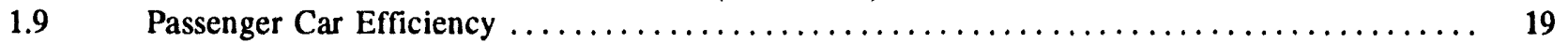

\section{Section 2. Energy Consumption}

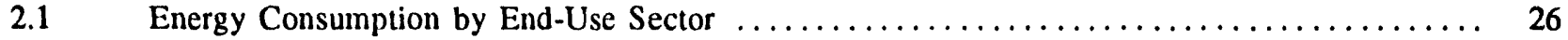

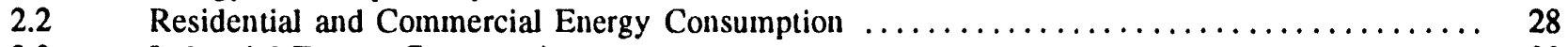

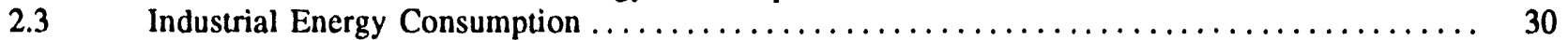

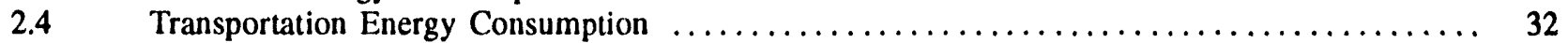

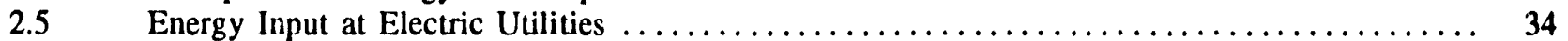

Section 3. Petroleum

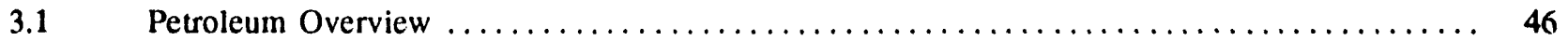

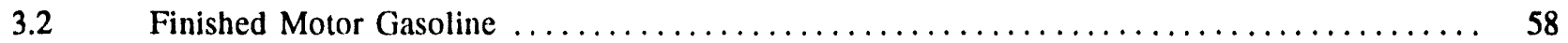

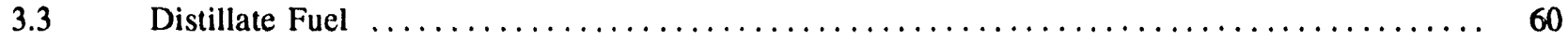

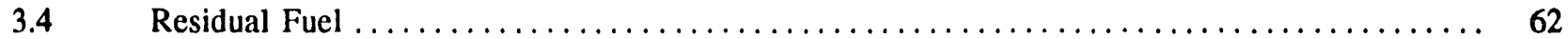

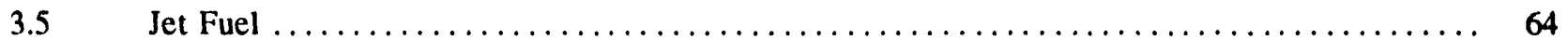

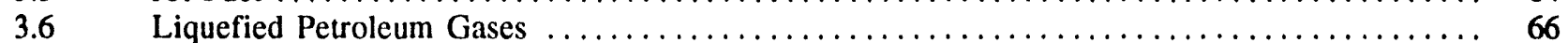

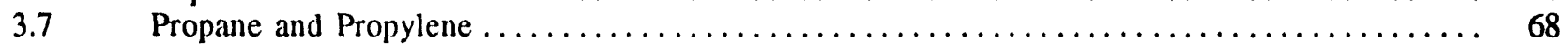

Section 4. Natural Gas

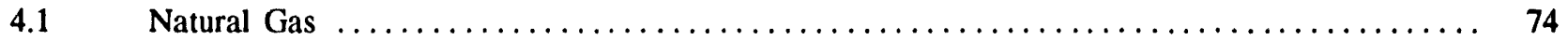

Section 5. Oil and Gas Resource Development

$5.1 \quad$ Oil and Gas Resource Development Indicators $\ldots \ldots \ldots \ldots \ldots \ldots$

Section 6. Coal

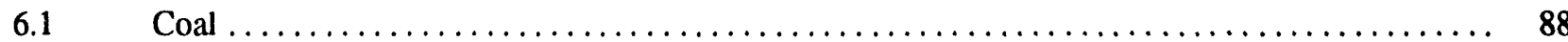

Section 7. Electricity

$7.1 \quad$ Electric Utility Net Generation of Electricity $\ldots \ldots \ldots \ldots \ldots \ldots \ldots$

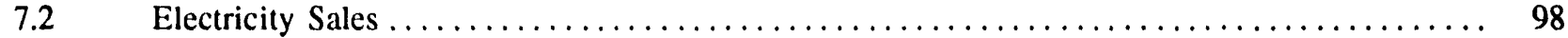

Electric Utility Consumption and Stocks of Fossil Fuels $\ldots \ldots \ldots \ldots \ldots$

Section 8. Nuclear Energy

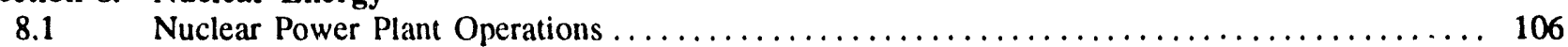

Section 9. Energy Prices

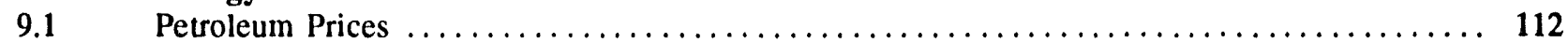

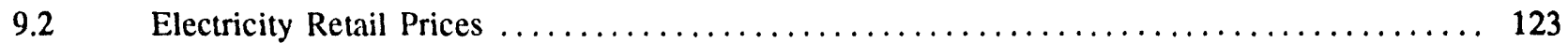

9.3 Cost of Fossil-Fuel Receipts at Steam-Electric Plants $\ldots \ldots \ldots \ldots \ldots \ldots \ldots \ldots$

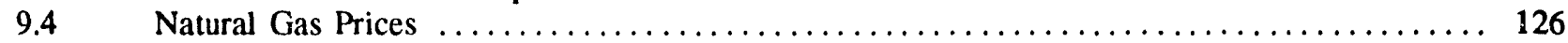

Section 10. International Energy

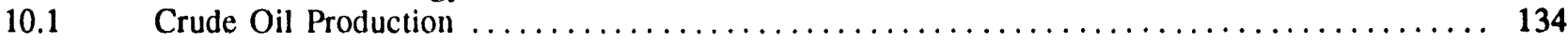

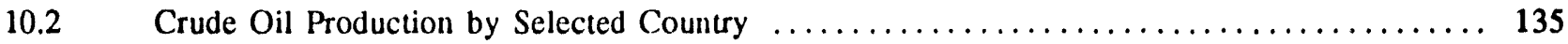

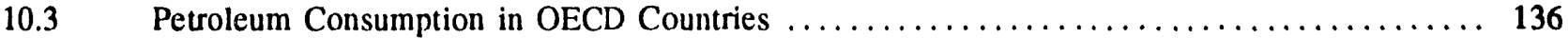

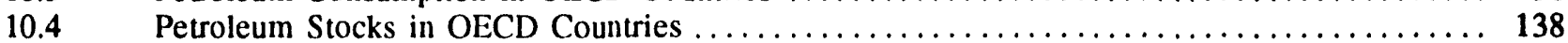

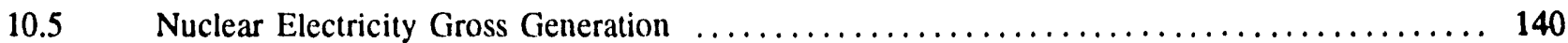




\section{Commercial Buildings Energy Consumption Survey}

\section{Preliminary Estimates, 1992}

The Commercial Buildings Energy Consumption Survey (CBECS) is conducted by the Energy Information Administration (EIA) every 3 years to provide data on energy consumption and expenditures for U.S. commercial buildings and on energy-related characteristics of those buildings. Data from the 1989 CBECS indicate that commercial buildings consumed about 5.8 quadrillion Btu that year (the most recent year for which such data are available).

The CBECS is a national multistage probability sample survey that is conducted in two parts. The first part is a personal interview with building managers, tenants, or owners. The interview collects data about the physical characteristics of the building, such as size, year constructed, and predominant wall and roof materials; how the building is used; the energy sources and energy-related equipment used; and conservation measures undertaken for the building. The second part of CBECS is a mail survey of the energy suppliers to the buildings. The energy suppliers' survey collects data about energy consumption and expenditures.

The 1992 survey collected new data on energy management in commercial buildings (including demand-side management participation and the presence of a building energy manager); energy-related equipment, such as water heaters, computers, and heating, ventilating, and cooling systems; and energy-related space functions.

The commercial buildings sector, more than the residential or manufacturing sectors, displays a diversity of building structures, activities, and energy-related characteristics. Preliminary estimates indicate that in 1992 there were approximately 4.8 million buildings, representing approximately 67.9 billion square feet of commercial floorspace, in the United States (Figure 1). Energy-related characteristics of commercial buildings located throughout the United States varied widely (Table 1). The preliminary estimates presented in this Energy Preview may be revised prior to publication of the two reports based on the survey results: Commercial Buildings Characteristics 1992 and Commercial Buildings Consumption and Expenditures 1992.

Figure 1. Commercial Buildings and Floorspace by Region, 1992

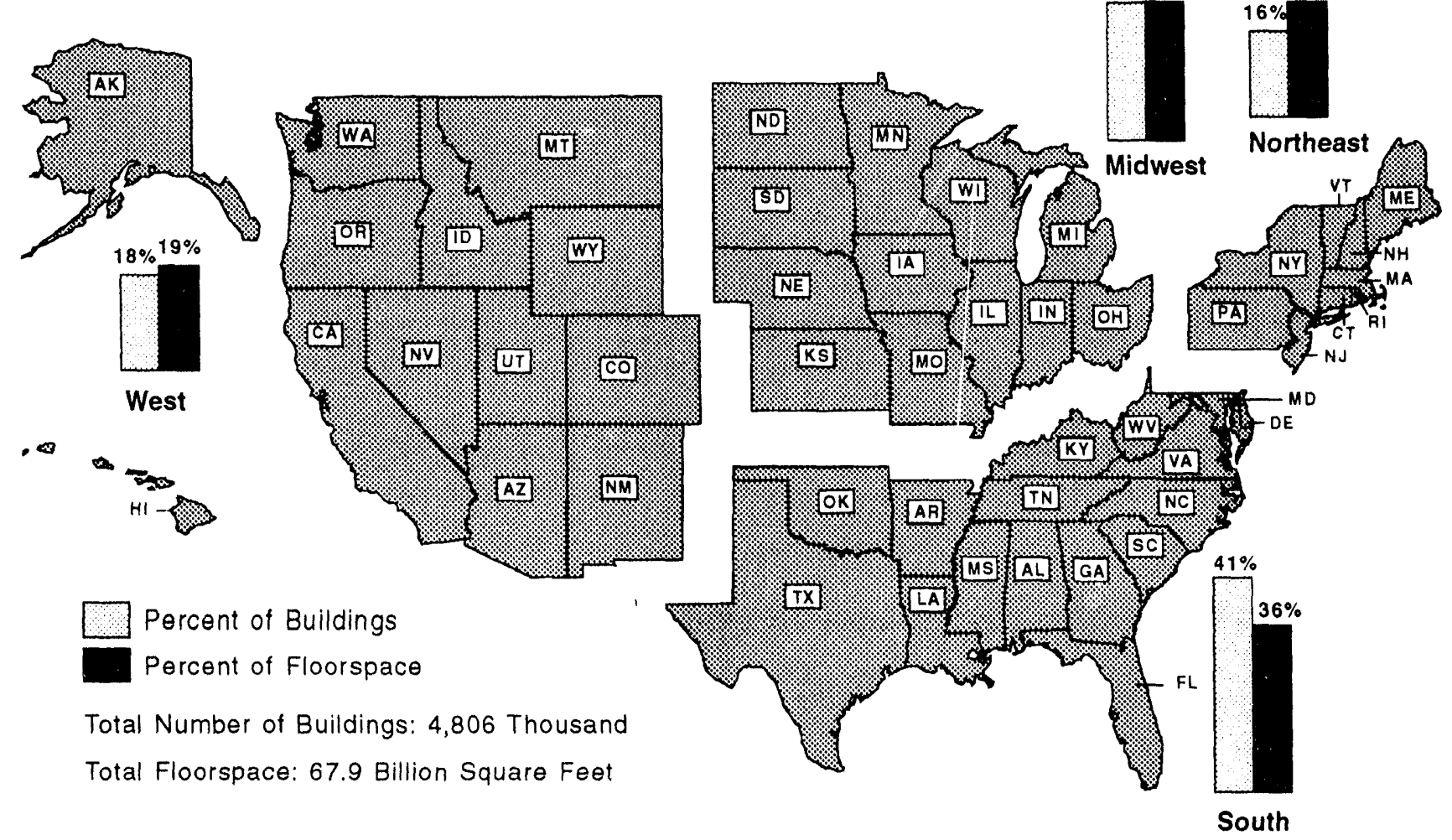

Source: Energy Information Administration, Form ElA-871A, "Building Questionnaire," 1992 Commercial Buildings Energy Consumption Survey. 
Number of Bulldings (thousand)
Total Floorspace

(million square feet)

All All

Bullding Characteristics Bulldings Northeast Midwest South West Bulldings Northeast Midwest South

West

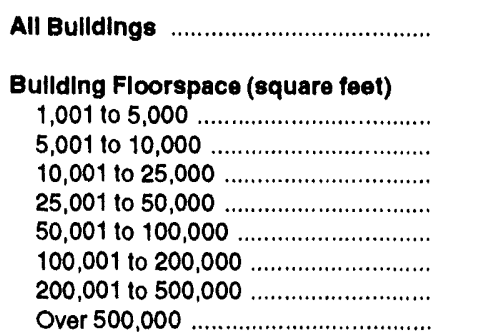

$\begin{array}{rrrrr}4,806 & 771 & 1,202 & 1,963 & 870 \\ 2,681 & 383 & 676 & 1,171 & 4 \\ 975 & 180 & 241 & 370 & 184 \\ 647 & 109 & 163 & 239 & 1 \\ 280 & 54 & 66 & 106 & \\ 116 & 25 & 29 & 41 \\ 71 & 12 & 15 & 26 \\ 26 & 5 & 10 & 6 & \\ 9 & 2 & 2 & 4\end{array}$

67,876
7,327
7,199
10,375
10,069
8,062
9,678
7,889
7,278


8,470
757
1,491
1,763
2,891
12,402
12,319
1,652
4,556
820
3,747
11,484
1,130
4,396

13,400

$17,280 \quad 24,577$

12,619

Princlpal Bullding Activity

Education .....

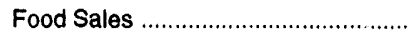

Food Service

Health Care

Lodging

and Service ......................

Office

Parking .

Public Assembly

Religious Word Salety ....................

Warehouse

Other.

Vacant

$\begin{array}{rr}301 & 38 \\ 130 & 0 \\ 260 & 5 \\ 63 & 12 \\ 154 & 3 \\ 1,272 & 246 \\ 749 & 126 \\ 24 & \\ 278 & 40 \\ 60 & 16 \\ 366 & 30 \\ 761 & 109 \\ 69 & 16 \\ 319 & 36\end{array}$

$\begin{array}{rrrr}38 & 46 & 112 & 104 \\ Q & 29 & 57 & 32 \\ 54 & 73 & 83 & 50 \\ 12 & 14 & 15 & 23 \\ 31 & 26 & 56 & 41 \\ 246 & 329 & 510 & 187 \\ 126 & 170 & 299 & 154 \\ 5 & 11 & 2 & \\ 40 & 76 & 120 & 43 \\ 16 & 0 & 24 & \\ 30 & 86 & 194 & 56 \\ 109 & 233 & 316 & 103 \\ 16 & 18 & 21 & 15 \\ 36 & 80 & 153 & 50\end{array}$

Year Constructed

1899 or Before ................................... 169

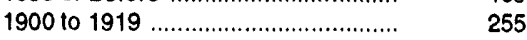

1920 to 1945

1946 to 1959

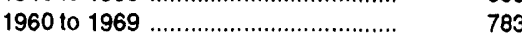

1970 to 1979 ...................................... 982

1980 to 1989

1990 to 1992

$\begin{array}{rrrr}52 & 78 & 26 & \\ 62 & 105 & 66 & 22 \\ 166 & 193 & 257 & 109 \\ 124 & 208 & 368 & 179 \\ 122 & 174 & 324 & 163 \\ 118 & 248 & 426 & 190 \\ 112 & 158 & 444 & 170 \\ 14 & 38 & 51 & 25\end{array}$

1,721

3,608

8,712

10,421

12,612

14,014

14,287

2,502

1,074
1,337
1,663
1,976
1,752
1,598
1,696
2,303

1,889
1,763

1,763

2,689

2,353

2,097

2,048

2,839

1,601

3,155

2,723

3,782

3,696

2,842

3,720

1,968

1,208

1,376

2,241

2,043

1,371

2,311

1,386

683

Energy Sources

(more than one may apply)

Electrlclty ....................................... 4,616

Natural Gas ................................... $\quad 2,665$

Fuel Oll

District Heat

District Chilled Water

Propane ...

2,665
559

95

28
337

163

755
370
284
23
2
71
33

$\begin{array}{rrr}1,139 & 1,876 & 84 \\ 847 & 888 & 56 \\ 79 & 182 & 1 \\ 24 & 28 & 21 \\ 7 & 10 & \\ 80 & 153 & \\ 46 & 62 & 23\end{array}$

66,549

13,235

45,097

13,218

5,339

2,066

3,393

1,968

2386

2,620

1,496

445

386
616

2798

2,525

$\mathrm{Q}$
777

269

452

1,763

199

182

432

487

577

3.156

2,804

861

Q

1,137

3,108

301

1,043

245
407

209

597

1,043

4,233

4,152

2,269

238

1,366

4,964

383

208

292

654

2,214

2,838

272

649

792

1,649

248

1,041

Energy End Use

(more than one may apply)

Heated Bulldings ........................... 4,178

Alr-Conditioned Bulldings .................... $3,5, \quad$

Buildings with Water Heating ..............

Buildings with Cooking

Bulldings with Manufacturing ............. 121

$\begin{array}{rrrr}694 & 1,047 & 1,687 & 750 \\ 521 & 784 & 1,569 & 627 \\ 625 & 906 & 1,307 & 664 \\ 142 & 201 & 257 & 134 \\ 26 & 38 & 37 & 19\end{array}$

61,996

57,041

58,479

23,065

676

1,052

2,655

2,070

2,485

2,123

2,053

720

1,246

2,296

2,629

2,652

4,086

2,982

167

788

Q

2,646

1,115

3,898
4,914

1,825

2,562

2,865

4,940

6,317

2,934

Percent of Floorspace Heated

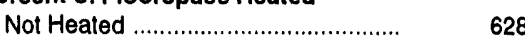

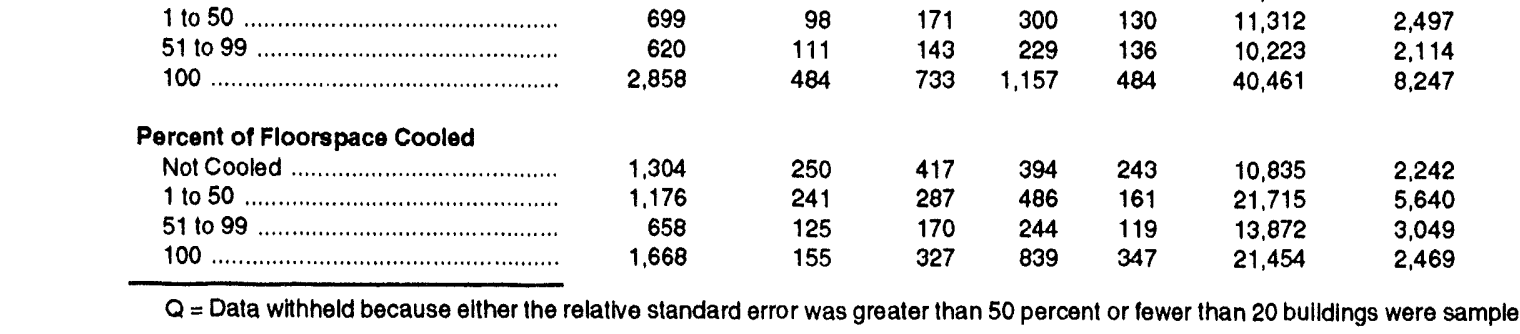

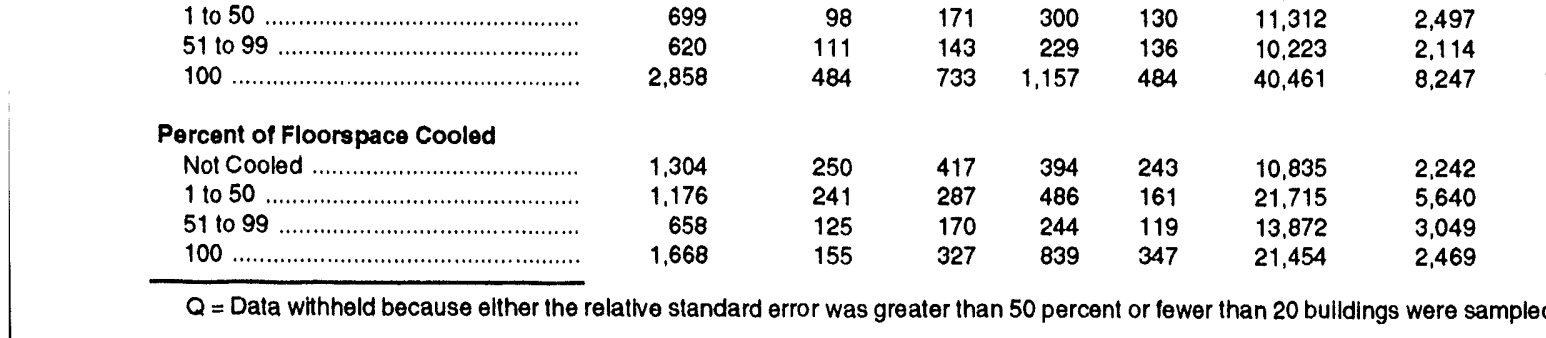

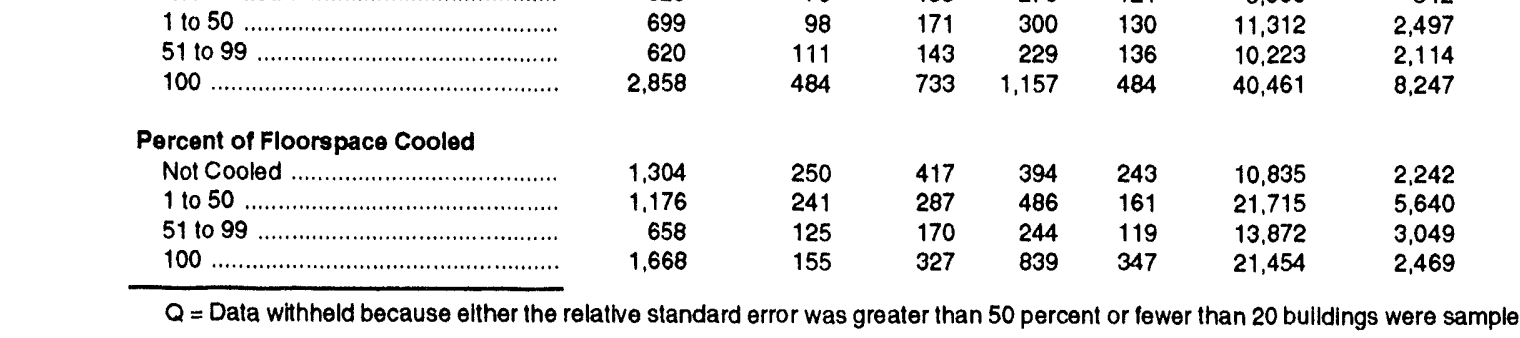

$\begin{array}{llll}76 & 155 & 276 & 121\end{array}$

3,174

12,858
11,158
12,410
5,740
756

16,303

14,383

15,460

$5,800 \quad-7,768$

21,205
19,592
7,768

11,176

$\begin{array}{rr}5,800 & 7,768 \\ 895 & 1,039\end{array}$

10,296

11,017

3,757

484

$$
100
$$

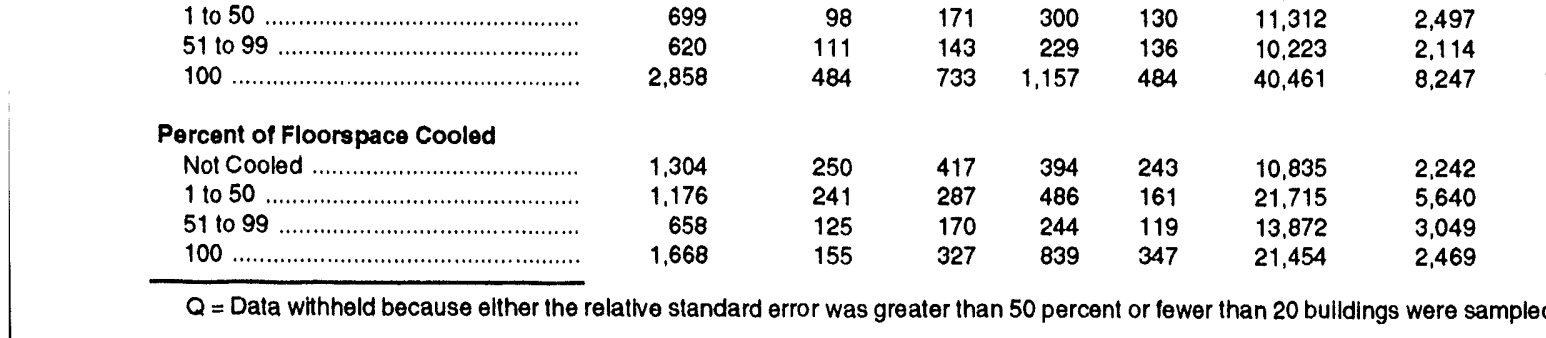

76
98
111
484

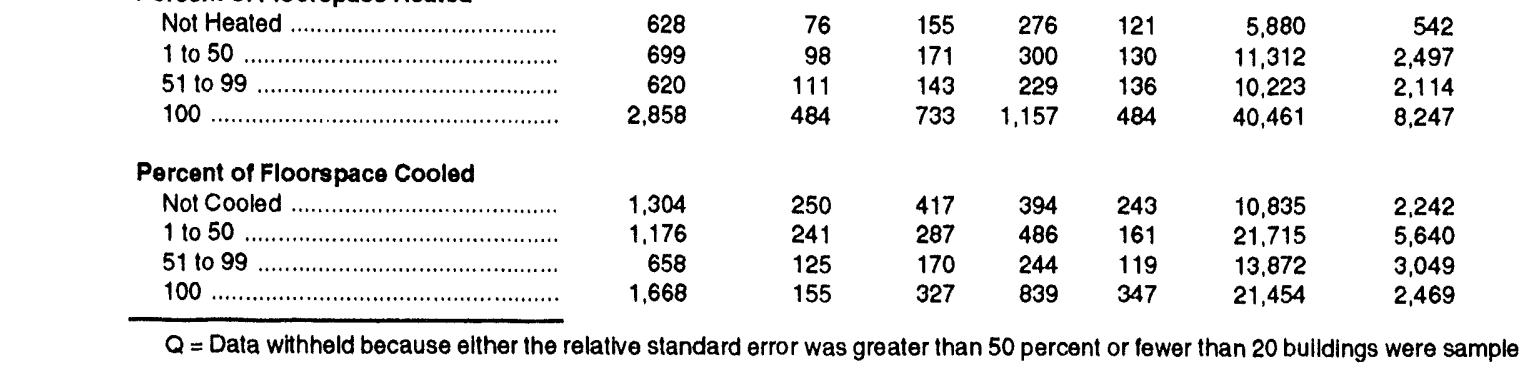

542

2,918

1,443

$3,115 \quad 2,744$

$11,933 \quad 14,120$

6,162

3,372

2,323

$6,318 \quad 6,482 \quad 3,275$

$\begin{array}{lll}3,825 & 4,097 & 2,902\end{array}$

$4,240 \quad 10,627$

4,118

\footnotetext{
$Q=$ Data withheld because either the relattve standard error was greater than 50 percent or fewer than 20 bulldings were sampled.
} 
Table 1. Selected Building Characteristics by Census Region, Preliminary Estimates, 1992 (Continued)

Number of Bulldings

(thousand)
Total Floorspace

(million square feet)
Bullding Characteristics

\section{All}

Buildings Northeast Midwest
All

South West Buildings Northeast Midwest South

West

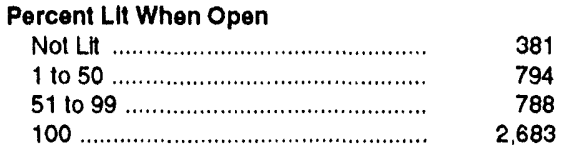

$\begin{array}{rr}42 & 124 \\ 152 & 226 \\ 174 & 200 \\ 390 & 626\end{array}$

$\begin{array}{rr}167 & 48 \\ 304 & 112 \\ 268 & 145 \\ 1,116 & 552\end{array}$

2,316
6,344
11,518
31,994

373
1,235
2,926
6,050

$\begin{array}{rr}773 & 731 \\ 1,645 & 2,274 \\ 3,163 & 3,001 \\ 8,106 & 11,510\end{array}$

440

1,191

2,427

6,329

Heating Equipment

(more than one may apply)

Heat Pumps

Furnaces......

450

1,676

1,465

Indlvidual Space Heaters

District Steam or Hot Water

Bollers

Packaged Heating Units

638

815

Other

$\begin{array}{rr}40 & 28 \\ 290 & 592 \\ 220 & 377 \\ 30 & 26 \\ 263 & 194 \\ 85 & 123 \\ 11 & 10\end{array}$

$\begin{array}{rr}281 & 100 \\ 548 & 247 \\ 621 & 247 \\ 29 & 21 \\ 112 & 69 \\ 395 & 212 \\ Q & Q\end{array}$

6,909

11,762

17,714

5,242

16,875

12,800

722

\section{1,349 \\ 2,131 \\ 3,641 \\ 1,593 \\ 5,214 \\ 2,118 \\ 95}

$\begin{array}{rrr}1,218 & 2,740 & 1,601 \\ 4,501 & 3,043 & 2,088 \\ 5,281 & 5,747 & 3,046 \\ 1,892 & 875 & 882 \\ 5,308 & 3,888 & 2,465 \\ 2,798 & 4,833 & 3,051 \\ 210 & Q & Q\end{array}$

\section{Coollng Equlpment}

(more than one may apply)

Residential-Type Central Air

Heat Pumps .............
Individual Air Condtioners

District Chilled Water

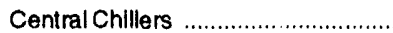

Packaged Air-Condtioning Units ....

Swamp Coolers

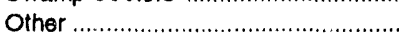

816

457

1,025

32

145
1,398

170

Bullding Shell Conservation Features

(more than one may apply)

Roof or Celling Insulation

Wall Insulation ...............................

Storm or Multiple Glazing .................

Tinted Reflective or Shading Glass ..

Exterior or Interior Shading

or Awnings .........

Windows That Open .........................

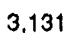

3.131

2,123

1,642

1,054

1,825

2,115

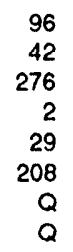

277

30

232

7
34

334

Q

$Q$

$\begin{array}{rr}370 & 82 \\ 289 & 97 \\ 427 & 90 \\ 13 & 10 \\ 56 & 26 \\ 555 & 301 \\ 31 & 130 \\ Q & Q\end{array}$

7.474

6,901

12,655

1,961

11,071

22,060

1.648

338

1,350

1,293

4,552

248

2,436

4,729

$Q$
$Q$

2,721

1,230

3,861

574

2,894
5,574

5,574

Q

39,976

25,895

23,822

21,144

27,741

22,537

8,261

5,802

6,900

3,742

5,420

6,228

10,701

10,701
6,792

7,965

5,795

6,910

6,339
2,572

2,764

3,080

724

3,517

7,218

308
$Q$

13,084

8,265

6,029

6,403

9,212

6,590

11,757

15,849

2.665

3,555

3,71

5,497

2,653

3,571

12,067

2,726

3,225

8,219

HVAC $^{a}$ Maintenance ....................... $\quad 2,501$

506

589

$923 \quad 483$

40,232

9,236

10,710

$\begin{array}{rrrr}3,065 & 3,387 & 3,488 & 2,672 \\ 613 & 1,373 & 577 & 660 \\ 963 & 780 & 627 & 1,231 \\ 2,053 & 2,043 & 2,418 & 3,111 \\ 2,126 & 3,015 & 2,292 & 2,066 \\ 691 & 722 & 422 & 861\end{array}$

4,281
4,126
2,595
1,143
260

$\begin{array}{rr}724 & 1,094 \\ 707 & 1,069 \\ 514 & 618 \\ 241 & 299 \\ 57 & 67\end{array}$

$\begin{array}{rr}1,656 & 806 \\ 1,575 & 774 \\ 954 & 509 \\ 343 & 259 \\ 82 & 55\end{array}$

10,619
10,327
9,388
5,493
1,293

13,741

13,341

10,954

6,630

1,130
16,631

15,964

12,354

5,878
1,300
10,234

9,754

8,359

5,943

${ }^{a}$ Heating, ventilation, and air conditioning.

$Q=$ Data withheld because elther the relative standard error was greater than 50 percent or fewer than 20 bulldings were sampled. 
Table 1. Selected Building Characteristics by Census Region, Preliminary Estimates, 1992 (Continued)

\begin{tabular}{|c|c|c|c|c|c|c|c|c|c|c|}
\hline \multirow[b]{2}{*}{ Building Characterlatics } & \multicolumn{5}{|c|}{$\begin{array}{l}\text { Number of Bulldings } \\
\text { (thousand) }\end{array}$} & \multicolumn{5}{|c|}{$\begin{array}{l}\text { Total Floorspace } \\
\text { (million square feet) }\end{array}$} \\
\hline & $\begin{array}{c}\text { All } \\
\text { Bulldlings }\end{array}$ & Northeast & Mldwest & South & West & $\begin{array}{c}\text { All } \\
\text { Bulldings }\end{array}$ & Northeast & Midwest & South & West \\
\hline \multicolumn{11}{|l|}{$\begin{array}{l}\text { Energy Management Practlces } \\
\text { (more than one may apply) }\end{array}$} \\
\hline 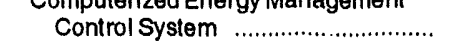 & 248 & 41 & 72 & 72 & 62 & 13,580 & 2,724 & 4,424 & 3,481 & 2,951 \\
\hline \multicolumn{11}{|l|}{ Demand-Side Management } \\
\hline Participation ......................... & 337 & 104 & 70 & 82 & 82 & 10,000 & 3,087 & 2,647 & 2,337 & 1,929 \\
\hline Bullding Shell Program .................. & 39 & 14 & 10 & 9 & 7 & 1,205 & 217 & 516 & 254 & 218 \\
\hline 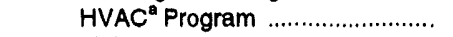 & 165 & 32 & 35 & 55 & 43 & 5,904 & 1,475 & 1,745 & 1.479 & 1,205 \\
\hline 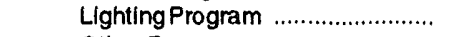 & 244 & 89 & 50 & 52 & 53 & 7,663 & 2,693 & 2,077 & 1.439 & 1,453 \\
\hline Other Programs ............................... & 122 & 32 & 28 & 38 & 24 & 5,455 & 1,455 & 1,553 & 1,541 & 906 \\
\hline 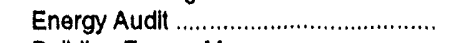 & 456 & 124 & 112 & 112 & 98 & 12,248 & 3,525 & 3,741 & 2,754 & 2,228 \\
\hline Bullding Energy Manager .......................... & 49 & 8 & 11 & 16 & 14 & 1,746 & 291 & 512 & 634 & 309 \\
\hline \multicolumn{11}{|l|}{ Predominant Wall Materlals } \\
\hline 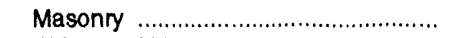 & 3,115 & 503 & 759 & 1,261 & $5 ९ 2$ & 43,585 & 9,981 & 12,914 & 17,174 & 8,517 \\
\hline Siding or Shingles & 764 & 176 & 198 & 257 & 133 & 3,873 & 1,008 & 1.017 & 1,052 & 796 \\
\hline 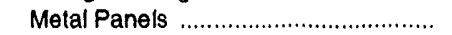 & 745 & 68 & 215 & 372 & 90 & 7,392 & 930 & 1,774 & 3.900 & 789 \\
\hline 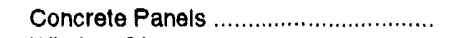 & 87 & 6 & 12 & 36 & 34 & 4.961 & 1,003 & 741 & 1.461 & 1.755 \\
\hline 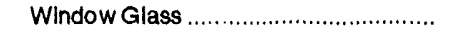 & 46 & 12 & Q & 18 & 8 & 2,028 & 372 & 524 & 709 & 423 \\
\hline 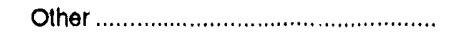 & 47 & 6 & 9 & 19 & 13 & 1.037 & 106 & 310 & 281 & $Q$ \\
\hline \multicolumn{11}{|l|}{ Predominant Roof Materials } \\
\hline 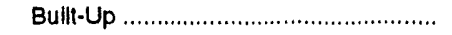 & 1,642 & 226 & 346 & 665 & 405 & 30,257 & 4,889 & 6,375 & 11,653 & 7,341 \\
\hline 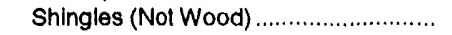 & 1,381 & 278 & 369 & 532 & 202 & 10,570 & 2,434 & 3,213 & 3,168 & 1,755 \\
\hline 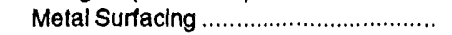 & 1,037 & 106 & 269 & 537 & 126 & 9.019 & 853 & 2,064 & 5,098 & 1.004 \\
\hline 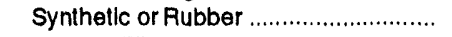 & 386 & 100 & 152 & $9 i$ & 35 & 11,702 & 3,757 & 4,318 & 2,615 & 1,012 \\
\hline 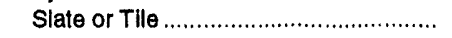 & 155 & 40 & 23 & 45 & 47 & 1,998 & 526 & 385 & 577 & 511 \\
\hline 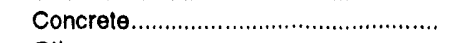 & 37 & 2 & 5 & 20 & 9 & 2,544 & 556 & $Q$ & 917 & 506 \\
\hline 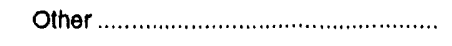 & 167 & 19 & 38 & 65 & 46 & 1,786 & 384 & 361 & 551 & 490 \\
\hline \multicolumn{11}{|l|}{ Ownershlp and Occupancy } \\
\hline Nongovermment Owned .......................... & 4,206 & 683 & 1,070 & 1,729 & 725 & 52,752 & 9,978 & 13,127 & 19,480 & 10,167 \\
\hline 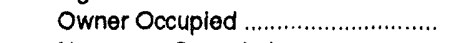 & 3,192 & 552 & 844 & 1,267 & 529 & 38,403 & 7,311 & 10,421 & 13,503 & 7,168 \\
\hline 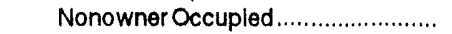 & 817 & 112 & 173 & 361 & 171 & 12,273 & 2,350 & 2,211 & 5,177 & 2,534 \\
\hline Unoccupled .......................................... & 197 & 19 & 53 & 101 & 24 & 2,077 & 316 & 495 & 800 & 465 \\
\hline 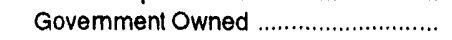 & 599 & 88 & 132 & 234 & 146 & 15,124 & 3,422 & 4,153 & 5,097 & 2,452 \\
\hline
\end{tabular}

a Heating, ventllation, and air conditioning.

$Q=$ Data withheld because elther the relative standard error was greater than 50 percent or fewer than 20 bulldings were sampled.

Source: Energy Intormation Administration, Form EIA-871A, "Building Questionnaire," 1992 Commercial Buildings Energy Consumption Survey. 


\section{Section 1. Energy Overview}

Energy production during October 1993 totaled 5.5quadrillion Btu, a 3.0-percent decrease from the level of production during October 1992. Coal production decreased 5.6 percent, petroleum production decreased 3.4 percent, and natural gas production increased 1.9 percent. All other forms of energy production combined were down 6.0 percent from the level of production during October 1992.

Energy consumption during October 1993 totaled 6.7 quadrillion Btu, 0.9 percent above the level of consumption during October 1992. Natural gas consumption increased 6.5 percent, coal consumption rose 2.9 percent, and petroleum consumption was down 1.3 percent. Consumption of all other forms of energy combined decreased 5.5 percent from the level 1 year earlier.

Net imports of energy during October 1993 totaled 1.6 quadrillion Btu, 12.6 percent above the level of net imports 1 year earlier. Net imports of petroleum increased 8.6 percent, and net imports of natural gas were up 10.3 percent. Net exports of coal fell 21.7 percent from the level in October 1992.

\section{Table 1.1 Energy Summary for October 1993}

(Quadrillion Btu)

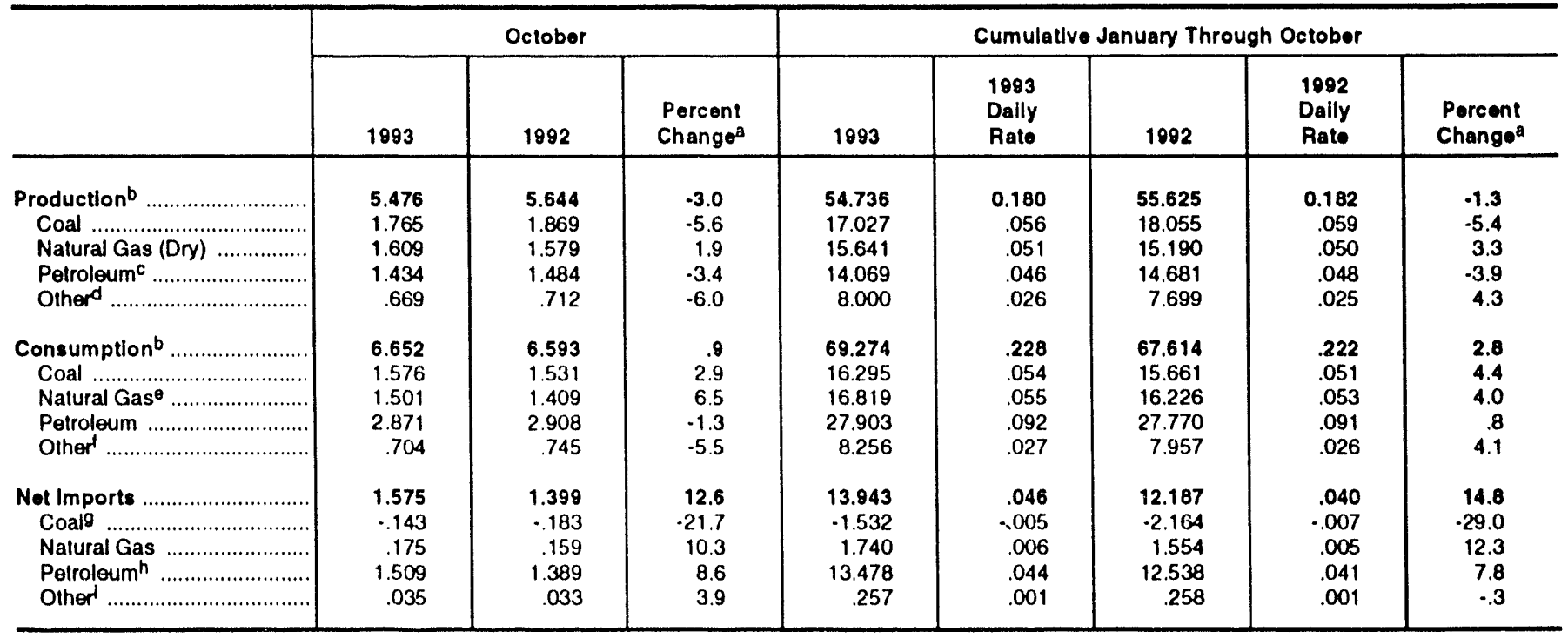

Based on daily rates prior to rounding.

- Due to a lack of consistent historical data, some renewable energy sources are not included. For example, in 1991, 3.3 quadrillion Bitu of renewable energy consumed by U.S. electric utitities to generate electricity for distribution is included, but an estimated 3.4 quadrillion Btu of renewable energy used by other sectors is not included.

c Includes crude oil, lease condensate, and natural gas plant liquids.

d "Other' is hydroelectric and nuclear electric power, and electricity generated for distribution from wood, waste, geothermal, wind, photovollaic, and solar thermal energy.

- Includes supplemental gaseous fuels.
1 "Other" is hydroelectric and nuclear electric power; electricity generated sor distribution trom wood, waste, geothermal, wind, photovoltaic, and solar thermal energy; and net imponts of electricity and coal coke.

g Minus sign indicales exports are greater than imports.

$h$ Includes crude oil, lease condensate, petroleum products, pentanes plus, untinished oils, gasoline blending components, and imports of crude oil for the Sirategic Petroleum Reserve.

I "Other" is net imports of electricity and coal coke.

Nole: Totals may not equal sum of components due to independent rounding.

Sources: Tables 1.3, 1.4, and 1.5. 
Figure 1.1 Energy Overview

(Quadrillion Btu)

Consumption, Production, and Imports, 1973-1992

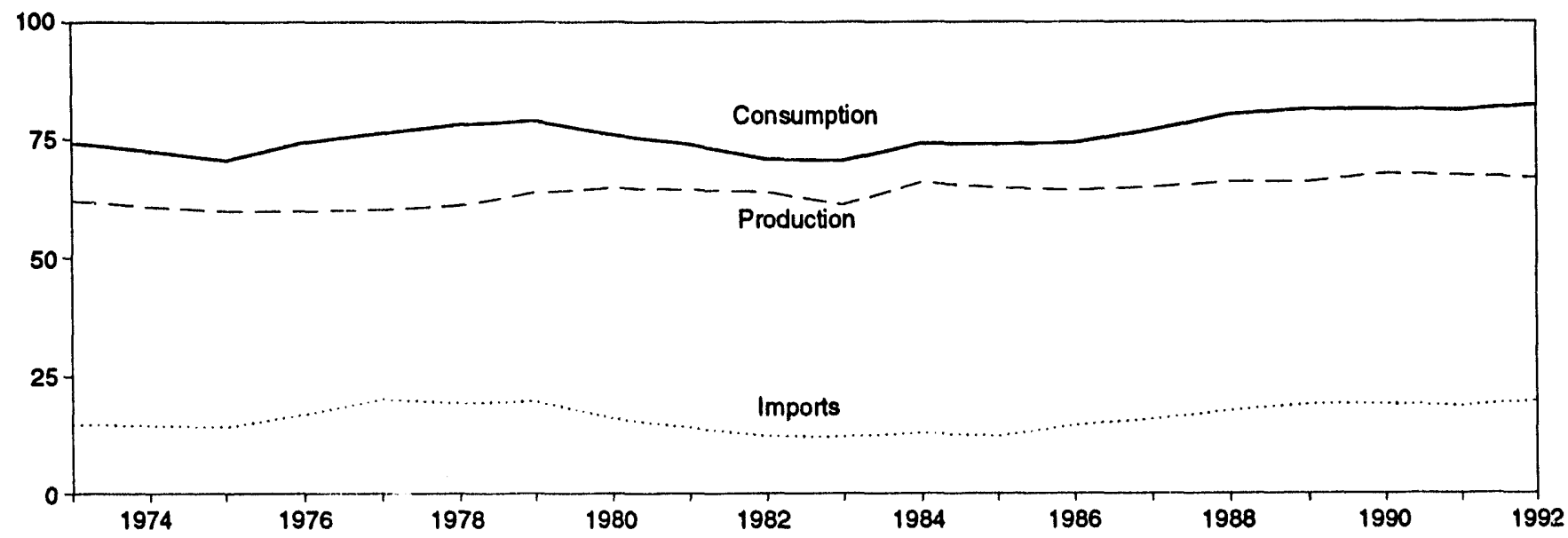

Consumption, Production, and Imports, Monthly

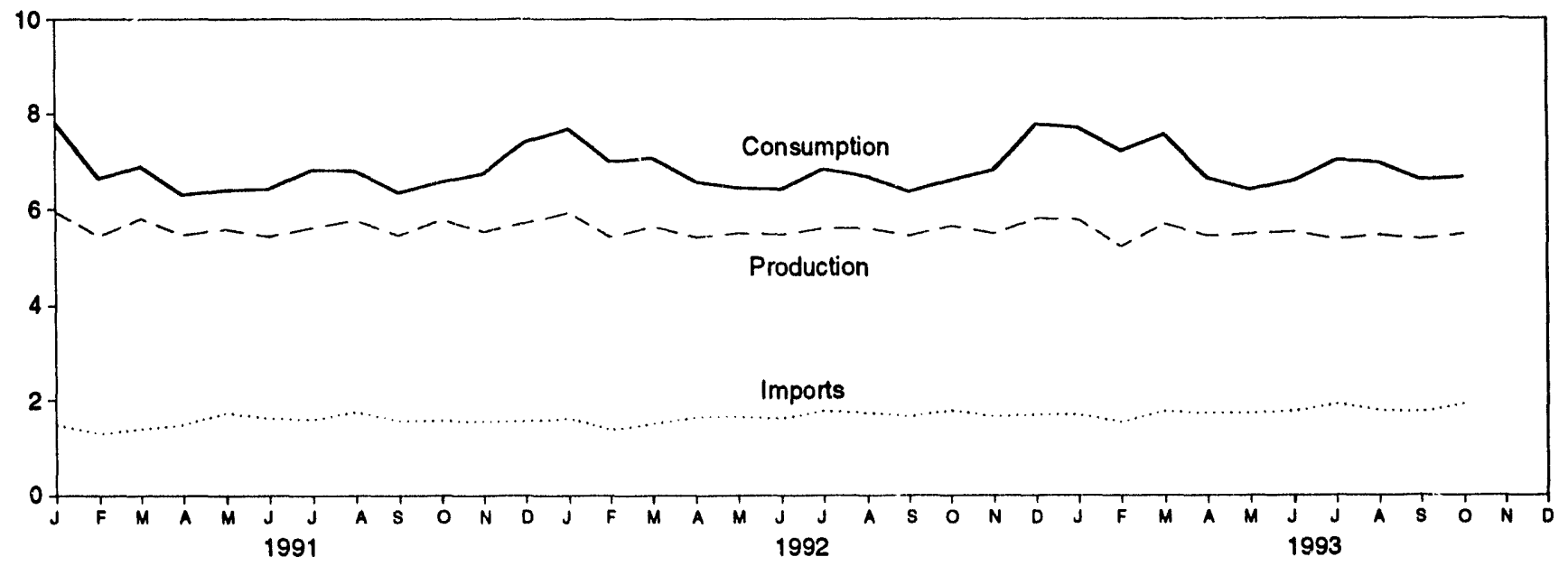

Overview, October 1993

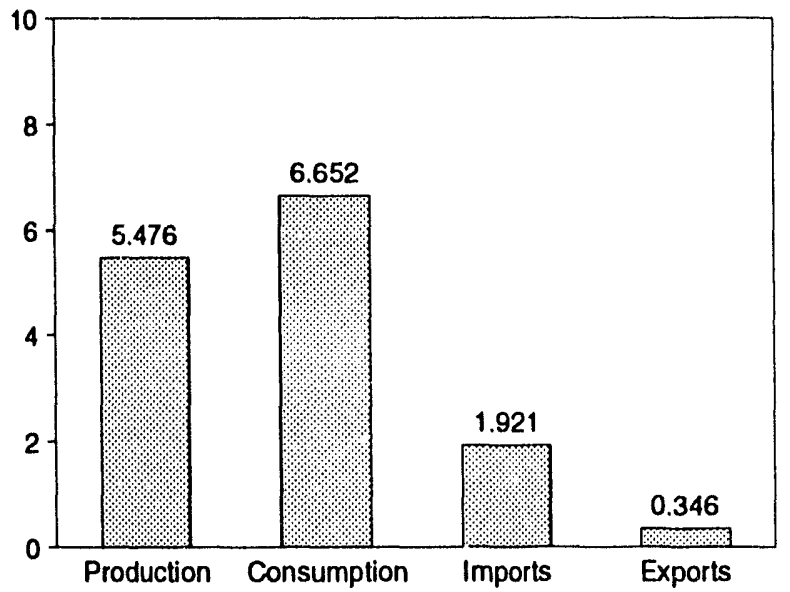

Net Imports, January-October

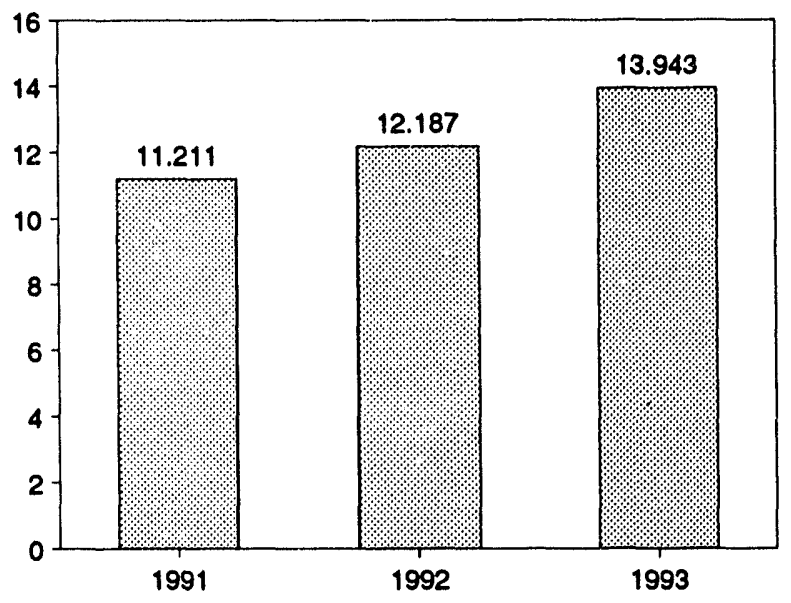

Note: Because vertical scales differ, graphs should not be compared.

Source: Table 1.2. 


\begin{tabular}{|c|c|c|c|c|c|}
\hline & Productiona & Consumption ${ }^{a, b}$ & Imports & Exports & Net Imports \\
\hline 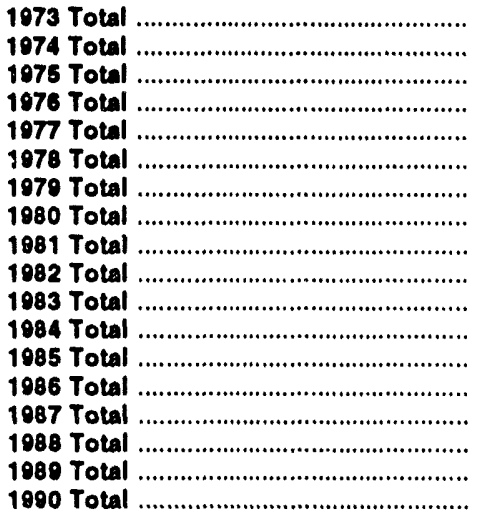 & $\begin{array}{l}62.060 \\
60.835 \\
59.860 \\
59.892 \\
60.219 \\
61.103 \\
63.801 \\
64.761 \\
64.421 \\
63.862 \\
61.279 \\
65.062 \\
64.871 \\
64.350 \\
64.852 \\
66.105 \\
66.129 \\
67.853\end{array}$ & $\begin{array}{l}\mathbf{7 4 . 2 8 2} \\
\mathbf{7 2 . 5 4 3} \\
\mathbf{7 0 . 5 4 6} \\
\mathbf{7 4 . 3 6 2} \\
\mathbf{7 6 . 2 8 8} \\
\mathbf{7 8 . 0 8 9} \\
\mathbf{7 8 . 8 9 8} \\
\mathbf{7 5 . 9 5 5} \\
\mathbf{7 3 . 9 9 0} \\
\mathbf{7 0 . 8 4 8} \\
\mathbf{7 0 . 5 2 4} \\
\mathbf{7 4 . 1 4 4} \\
\mathbf{7 3 . 9 8 1} \\
\mathbf{7 4 . 2 9 7} \\
\mathbf{7 6 . 8 9 4} \\
80.218 \\
\mathbf{8 1 . 3 2 5} \\
81.265\end{array}$ & $\begin{array}{l}14.731 \\
14.413 \\
14.111 \\
16.837 \\
20.090 \\
19.254 \\
19.616 \\
15.971 \\
13.975 \\
12.092 \\
12.027 \\
12.767 \\
12.103 \\
14.438 \\
15.764 \\
17.564 \\
18.947 \\
18.987\end{array}$ & $\begin{array}{l}2.051 \\
2.223 \\
2.350 \\
2.188 \\
2.071 \\
1.031 \\
2.870 \\
3.723 \\
4.320 \\
4.633 \\
3.717 \\
3.804 \\
4.231 \\
4.055 \\
3.853 \\
4.415 \\
4.765 \\
4.010\end{array}$ & $\begin{array}{r}12.680 \\
12.100 \\
11.752 \\
14.648 \\
18.010 \\
17.323 \\
16.746 \\
12.247 \\
9.646 \\
7.460 \\
8.310 \\
8.963 \\
7.872 \\
10.382 \\
11.911 \\
13.149 \\
14.181 \\
14.077\end{array}$ \\
\hline 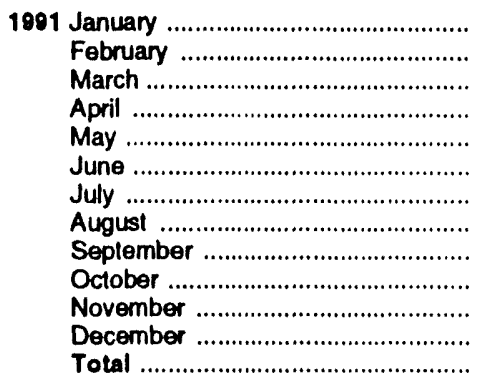 & $\begin{array}{r}5.941 \\
5.438 \\
5.803 \\
5.460 \\
5.578 \\
5.429 \\
5.613 \\
5.763 \\
5.450 \\
5.771 \\
5.530 \\
5.708 \\
67.484\end{array}$ & $\begin{array}{r}7.795 \\
6.643 \\
6.893 \\
6.302 \\
6.394 \\
6.421 \\
6.818 \\
6.798 \\
6.344 \\
6.561 \\
6.740 \\
7.408 \\
81.116\end{array}$ & $\begin{array}{r}1.483 \\
1.294 \\
1.391 \\
1.482 \\
1.731 \\
1.622 \\
1.593 \\
1.754 \\
1.562 \\
1.562 \\
1.548 \\
1.556 \\
18.577\end{array}$ & $\begin{array}{l}.397 \\
.462 \\
.395 \\
.326 \\
.489 \\
.423 \\
.457 \\
.448 \\
.432 \\
.432 \\
.464 \\
.495 \\
5.220\end{array}$ & $\begin{array}{r}1.085 \\
.832 \\
.996 \\
1.156 \\
1.241 \\
1.199 \\
1.136 \\
1.306 \\
1.130 \\
1.130 \\
1.084 \\
1.062 \\
13.357\end{array}$ \\
\hline 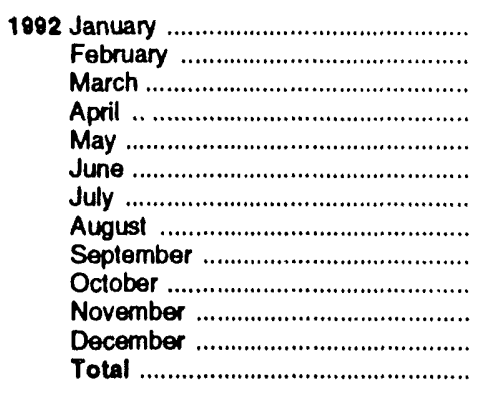 & $\begin{array}{l}A_{5} 5.923 \\
A_{5.419} \\
A_{5.634} \\
A_{5.411} \\
A_{5.495} \\
A_{5.465} \\
A_{5.592} \\
A_{5.598} \\
A_{5.443} \\
R_{5.644} \\
A_{5.483} \\
A_{5.796} \\
A_{66.904}\end{array}$ & 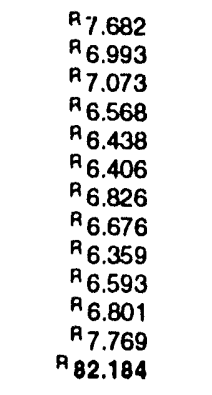 & $\begin{array}{r}1.615 \\
1.377 \\
1.500 \\
1.639 \\
1.642 \\
1.610 \\
1.770 \\
1.727 \\
1.654 \\
1.782 \\
1.650 \\
1.688 \\
18.652\end{array}$ & $\begin{array}{r}.458 \\
.372 \\
.416 \\
.413 \\
.434 \\
.426 \\
.441 \\
.367 \\
.417 \\
.383 \\
.428 \\
.462 \\
R_{5.017}\end{array}$ & $\begin{array}{r}1.157 \\
1.005 \\
1.084 \\
1.226 \\
1.207 \\
1.183 \\
1.329 \\
1.360 \\
1.237 \\
1.399 \\
1.221 \\
R 1.227 \\
\mathrm{R}_{1} 14.635\end{array}$ \\
\hline 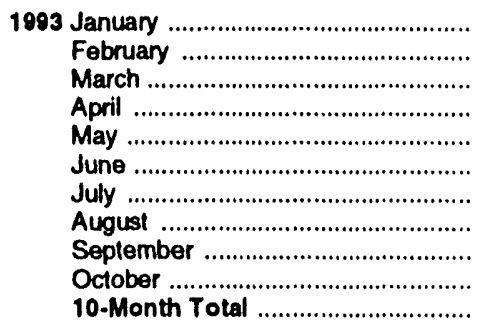 & $\begin{array}{l}R_{5.773} \\
R_{5.214} \\
R_{5.681} \\
R_{5.432} \\
R_{5.472} \\
R_{5.520} \\
R_{5.359} \\
R_{5.447} \\
R_{5.361} \\
5.476 \\
\mathbf{5 4 . 7 3 6}\end{array}$ & $\begin{array}{r}R_{7.696} \\
A_{7.211} \\
R_{7.552} \\
{ }^{R_{6.633}} \\
{ }^{A_{6.394}} \\
6.573 \\
\text { A }_{7.011} \\
6.959 \\
6.593 \\
6.652 \\
69.274\end{array}$ & $\begin{array}{r}1.695 \\
1.530 \\
1.763 \\
1.719 \\
1.722 \\
1.767 \\
1.914 \\
1.779 \\
1.745 \\
1.921 \\
17.556\end{array}$ & $\begin{array}{l}.398 \\
.362 \\
.347 \\
.344 \\
.382 \\
.406 \\
.375 \\
.317 \\
.337 \\
.346 \\
3.613\end{array}$ & $\begin{array}{r}1.297 \\
1.168 \\
1.416 \\
1.376 \\
1.340 \\
1.361 \\
1.540 \\
1.462 \\
1.408 \\
1.575 \\
13.943\end{array}$ \\
\hline 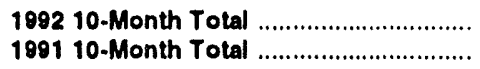 & $\begin{array}{l}55.625 \\
56.246\end{array}$ & $\begin{array}{l}67.614 \\
66.968\end{array}$ & $\begin{array}{l}16.314 \\
15.473\end{array}$ & $\begin{array}{l}4.127 \\
4.262\end{array}$ & $\begin{array}{l}12.187 \\
11.211\end{array}$ \\
\hline
\end{tabular}

a Due to a lack of consistent historical data, some renewable energy sources are not included. For example, in 1991, 3.3 quadrillion Btu of renewable energy consumed by U.S. electric utilities to generale electricity for distribution is included, but an estimated 3.4 quadrillion Btu of renewable energy used by other sectors is not included.

$b$ The sum of domestic energy production and nel imports of energy does nol equal domestic energy consumption. The diflerence is attributed to stock changes; losses and gains in conversion, transportation, and distribution; the addition of blending compounds; shipments of anthracite to U.S. Armed
Forces in Europe; and adjustments to account for discrepancies between reporting systerns.

$R=$ Revised data.

Noles: - For definitions, see Notes 1 through 4 at end of section. - Geographic coverage is the 50 States and the District of Columbia. - Totats may not equal sum of components due to independent rounding.

Sources: - Production: Table 1.3. - Consumption: Table 1.4. - Imports and Exports: Tables 3.1b, 4.2, 6.1, A2-A8, and Section 2, "Energy Consumption Notes and Sources," Notes 8 and 9. - Not Imports: Table 1.5. 
Figure 1.2 Energy Production

(Quadrillion Btu)

Total Production, 1973-1992

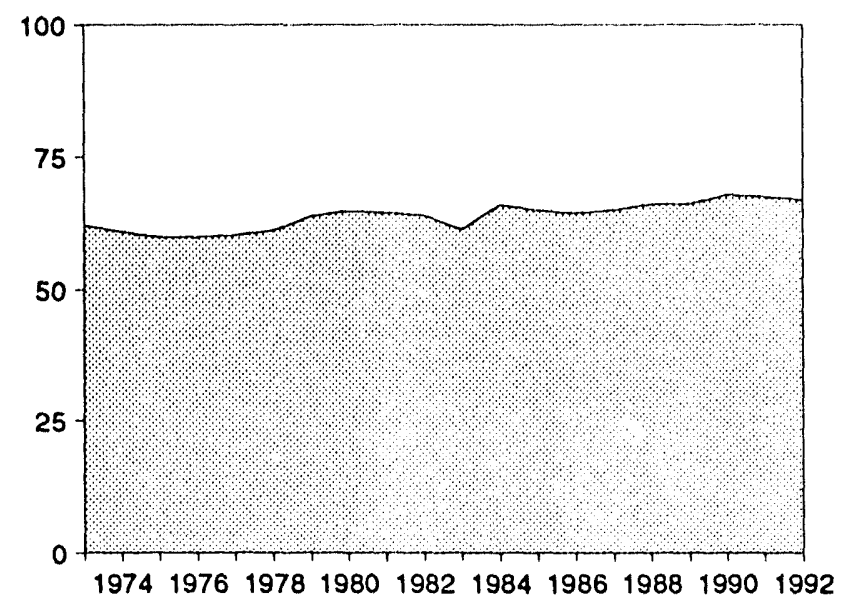

Production by Major Sources, 1973-1992

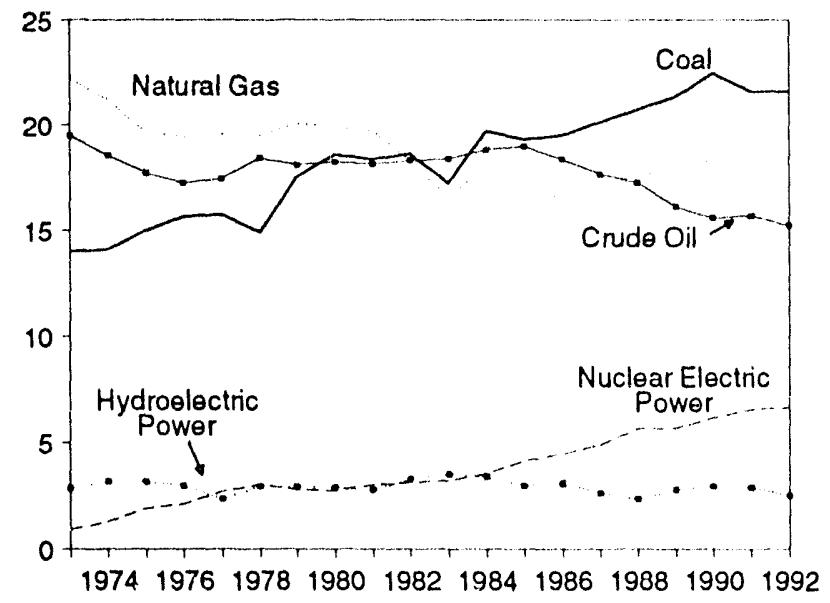

Total Production, January-October

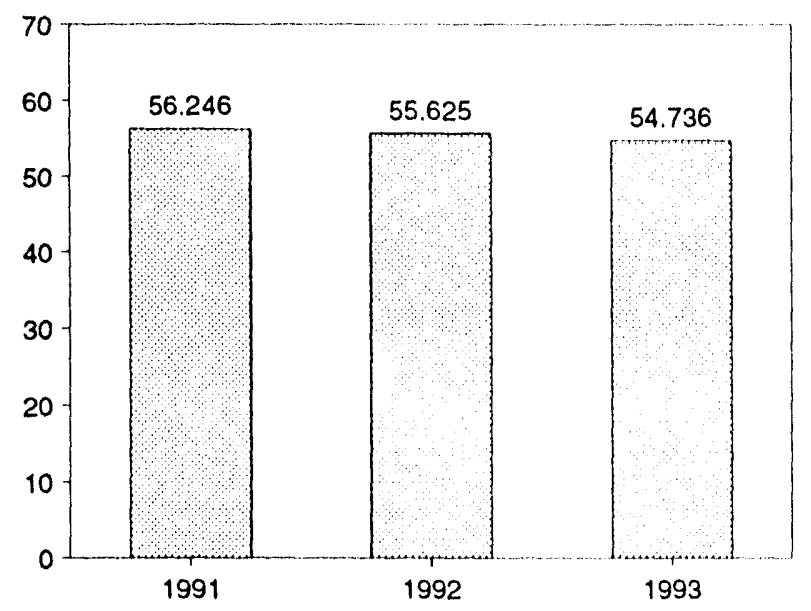

Total Production, Monthly

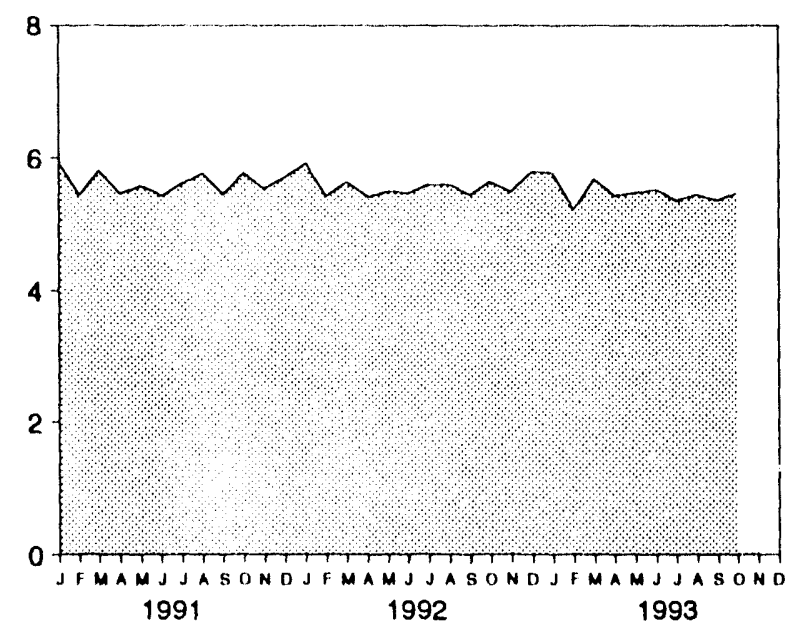

Production by Major Sources, Monthly

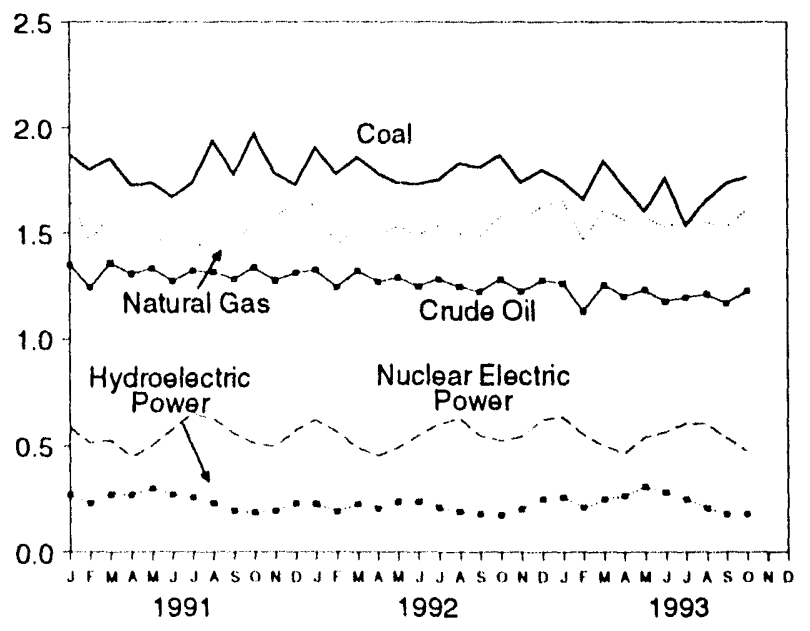

Production by Major Sources, October 1993

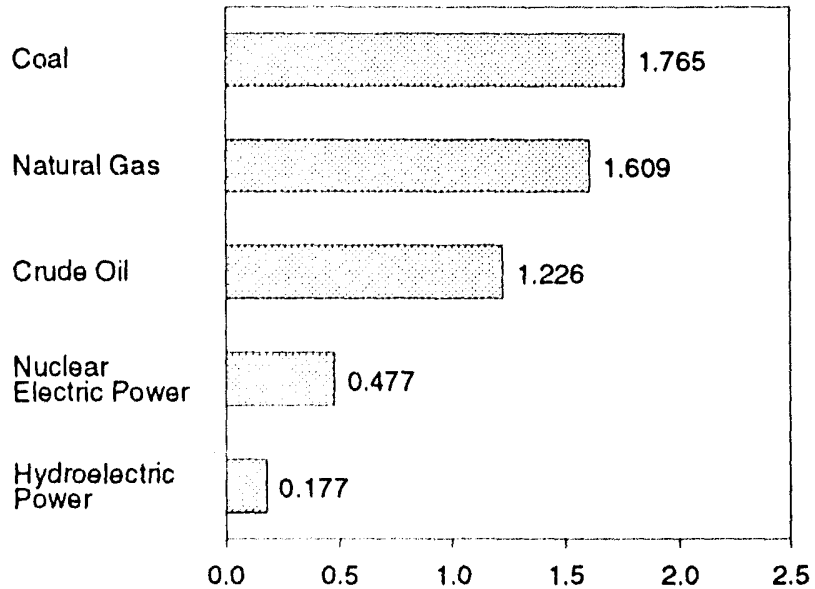

Note: Because vertical scales differ, graphs should not be compared. Source: Table 1.3. 
Table 1.3 Energy Production by Source

(Quadrillion Btu)

\begin{tabular}{|c|c|c|c|c|c|c|c|c|c|}
\hline & Coal & $\begin{array}{c}\text { Natural } \\
\text { Gas } \\
\text { (Dry) }\end{array}$ & $\begin{array}{c}\text { Crude } \\
\text { Olla }\end{array}$ & $\begin{array}{c}\text { Natural } \\
\text { Gas Plant } \\
\text { Liquids }\end{array}$ & $\begin{array}{c}\text { Nuclear } \\
\text { Eloctric } \\
\text { Power }\end{array}$ & $\begin{array}{l}\text { Hydro- } \\
\text { electric } \\
\text { Power }\end{array}$ & $\begin{array}{c}\text { Geothermal } \\
\text { Energy }\end{array}$ & Otherc & Totald \\
\hline 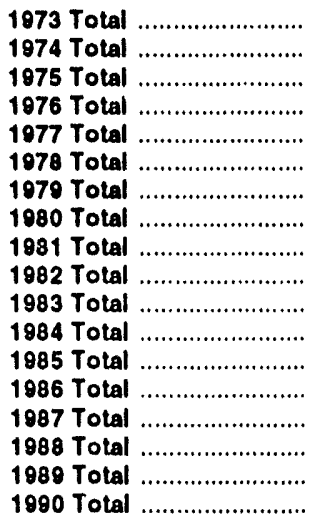 & $\begin{array}{l}13.993 \\
14.074 \\
14.990 \\
15.654 \\
15.755 \\
14.010 \\
17.539 \\
18.597 \\
18.376 \\
18.639 \\
17.246 \\
18.719 \\
18.325 \\
18.510 \\
20.142 \\
20.737 \\
21.345 \\
22.456\end{array}$ & $\begin{array}{l}22.187 \\
21.210 \\
19.640 \\
18.480 \\
19.565 \\
19.485 \\
20.076 \\
19.908 \\
19.698 \\
18.319 \\
16.593 \\
18.008 \\
16.980 \\
16.541 \\
17.136 \\
17.599 \\
17.847 \\
18.362\end{array}$ & $\begin{array}{l}18.493 \\
18.575 \\
17.729 \\
17.262 \\
17.454 \\
18.434 \\
18.104 \\
18.249 \\
18.146 \\
18.309 \\
18.392 \\
18.848 \\
18.992 \\
18.376 \\
17.675 \\
17.279 \\
16.117 \\
15.571\end{array}$ & $\begin{array}{l}2.569 \\
2.471 \\
2.374 \\
2.327 \\
2.327 \\
2.245 \\
2.286 \\
2.254 \\
2.307 \\
2.191 \\
2.184 \\
2.274 \\
2.241 \\
2.149 \\
2.215 \\
2.260 \\
2.158 \\
2.175\end{array}$ & $\begin{array}{l}0.910 \\
1.272 \\
1.900 \\
2.111 \\
2.702 \\
3.024 \\
2.776 \\
2.739 \\
3.008 \\
3.131 \\
3.203 \\
3.553 \\
4.149 \\
4.471 \\
4.906 \\
5.661 \\
5.677 \\
6.161\end{array}$ & $\begin{array}{l}2.861 \\
3.177 \\
3.155 \\
2.076 \\
2.333 \\
2.937 \\
2.931 \\
2.800 \\
2.758 \\
3.266 \\
3.527 \\
3.386 \\
2.970 \\
3.071 \\
2.635 \\
2.334 \\
2.767 \\
2.826\end{array}$ & $\begin{array}{l}0.043 \\
.053 \\
.070 \\
.078 \\
.077 \\
.064 \\
.084 \\
.110 \\
.123 \\
.105 \\
.129 \\
.165 \\
.188 \\
.219 \\
.229 \\
.217 \\
.107 \\
.181\end{array}$ & $\begin{array}{l}0.003 \\
.003 \\
.002 \\
.003 \\
.005 \\
.003 \\
.005 \\
.005 \\
.004 \\
.003 \\
.004 \\
.009 \\
.015 \\
.012 \\
.016 \\
.017 \\
.020 \\
.021\end{array}$ & $\begin{array}{l}62.060 \\
60.835 \\
59.860 \\
59.892 \\
60.210 \\
61.103 \\
63.801 \\
64.761 \\
64.421 \\
63.962 \\
61.279 \\
65.962 \\
64.871 \\
64.350 \\
64.952 \\
66.105 \\
66.120 \\
67.853\end{array}$ \\
\hline 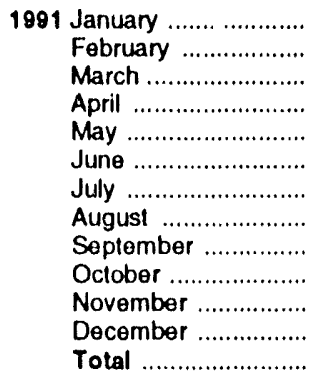 & $\begin{array}{r}1.870 \\
1.800 \\
1.853 \\
1.727 \\
1.739 \\
1.673 \\
1.738 \\
1.937 \\
1.777 \\
1.969 \\
1.782 \\
1.730 \\
21.594\end{array}$ & $\begin{array}{r}1.658 \\
1.459 \\
1.581 \\
1.506 \\
1.497 \\
1.427 \\
1.441 \\
1.447 \\
1.440 \\
1.554 \\
1.574 \\
1.645 \\
18.229\end{array}$ & $\begin{array}{r}1.348 \\
1.240 \\
1.357 \\
1.306 \\
1.332 \\
1.274 \\
1.321 \\
1.315 \\
1.282 \\
1.337 \\
1.275 \\
1.312 \\
15.701\end{array}$ & $\begin{array}{l}.194 \\
.181 \\
.199 \\
.190 \\
.196 \\
.186 \\
.191 \\
.192 \\
.185 \\
.199 \\
.194 \\
.199 \\
2.306\end{array}$ & $\begin{array}{l}.584 \\
.514 \\
.528 \\
.447 \\
.502 \\
.582 \\
.652 \\
.628 \\
.557 \\
.512 \\
.497 \\
.576 \\
6.579\end{array}$ & $\begin{array}{l}.269 \\
.229 \\
.270 \\
.269 \\
.298 \\
.271 \\
.254 \\
.228 \\
.193 \\
.184 \\
.192 \\
.229 \\
2.885\end{array}$ & $\begin{array}{l}.015 \\
.013 \\
.015 \\
.013 \\
.014 \\
.014 \\
.014 \\
.014 \\
.013 \\
.014 \\
.015 \\
.015 \\
.170\end{array}$ & $\begin{array}{l}.002 \\
.002 \\
.002 \\
.002 \\
.002 \\
.002 \\
.002 \\
.002 \\
.002 \\
.002 \\
.002 \\
.002 \\
.021\end{array}$ & $\begin{array}{r}5.941 \\
5.438 \\
5.803 \\
5.460 \\
5.578 \\
5.429 \\
5.613 \\
5.763 \\
5.450 \\
5.771 \\
5.530 \\
5.708 \\
67.484\end{array}$ \\
\hline 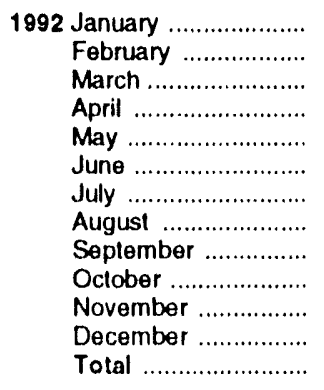 & 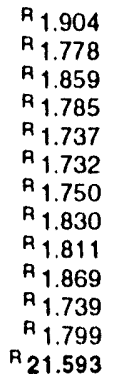 & $\begin{array}{r}1.633 \\
1.440 \\
1.519 \\
1.491 \\
1.529 \\
1.488 \\
1.536 \\
1.495 \\
1.481 \\
1.579 \\
1.559 \\
1.626 \\
18.375\end{array}$ & $\begin{array}{r}1.323 \\
1.243 \\
1.321 \\
1.269 \\
1.289 \\
1.247 \\
1.282 \\
1.245 \\
1.223 \\
1.281 \\
1.222 \\
1.277 \\
15.223\end{array}$ & $\begin{array}{l}.199 \\
.187 \\
.200 \\
.193 \\
.200 \\
.194 \\
.198 \\
.193 \\
.189 \\
.203 \\
.200 \\
.206 \\
2.363\end{array}$ & $\begin{array}{l}.621 \\
.567 \\
.492 \\
.454 \\
.490 \\
.550 \\
.602 \\
.630 \\
.547 \\
.524 \\
.545 \\
.624 \\
6.646\end{array}$ & $\begin{array}{l}.226 \\
.189 \\
.226 \\
.204 \\
.234 \\
.238 \\
.207 \\
.189 \\
.177 \\
.172 \\
.202 \\
.249 \\
2.513\end{array}$ & $\begin{array}{l}.015 \\
.013 \\
.015 \\
.014 \\
.014 \\
.014 \\
.014 \\
.014 \\
.013 \\
.014 \\
.014 \\
.014 \\
.170\end{array}$ & $\begin{array}{l}.002 \\
.002 \\
.002 \\
.001 \\
.002 \\
.002 \\
.002 \\
.002 \\
.002 \\
.002 \\
.002 \\
.002 \\
.022\end{array}$ & $\begin{array}{l}A_{5} 5.923 \\
A_{5.419} \\
A_{5.634} \\
A_{5.411} \\
A_{5.495} \\
A_{5} 5.465 \\
A_{5.592} \\
R_{5.598} \\
R_{5.443} \\
A_{5} 5.644 \\
A_{5.483} \\
P_{5.796} \\
{ }^{2} 66.904\end{array}$ \\
\hline 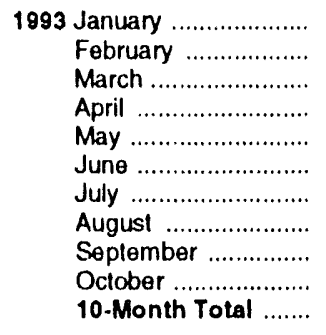 & $\begin{array}{l}A_{1} 1.749 \\
R_{1} 1.658 \\
A_{1} 1.841 \\
A_{1} 1.721 \\
A_{1} 1.603 \\
A_{1} 1.760 \\
A_{1} 1.537 \\
A_{1} 1.656 \\
R_{1} 1.737 \\
1.765 \\
17.027\end{array}$ & $\begin{array}{r}1.654 \\
\text { ค } 1.465 \\
1.610 \\
1.564 \\
1.576 \\
1.529 \\
1.554 \\
\text { R } 1.552 \\
\text { ค } 1.529 \\
1.609 \\
15.641\end{array}$ & $\begin{array}{r}1.260 \\
1.130 \\
1.254 \\
1.200 \\
1.229 \\
1.176 \\
1.196 \\
1.210 \\
1.168 \\
1.226 \\
12.048\end{array}$ & $\begin{array}{l}.204 \\
.188 \\
.212 \\
.204 \\
.203 \\
.198 \\
.203 \\
.204 \\
.196 \\
.208 \\
2.020\end{array}$ & $\begin{array}{l}.634 \\
.551 \\
.501 \\
.464 \\
.541 \\
.565 \\
.607 \\
.604 \\
.537 \\
.477 \\
5.481\end{array}$ & $\begin{array}{l}.256 \\
.207 \\
.247 \\
.264 \\
.307 \\
.279 \\
.247 \\
.206 \\
.179 \\
.177 \\
2.369\end{array}$ & $\begin{array}{l}.014 \\
.013 \\
.014 \\
.014 \\
.012 \\
.012 \\
.014 \\
.014 \\
.013 \\
.013 \\
.133\end{array}$ & $\begin{array}{l}.002 \\
.002 \\
.002 \\
.002 \\
.001 \\
.001 \\
.001 \\
.002 \\
.002 \\
.002 \\
.017\end{array}$ & 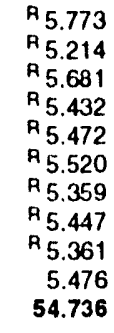 \\
\hline $\begin{array}{l}1892 \text { 10-Month Total ....... } \\
1991 \text { 10-Month Total ....... }\end{array}$ & $\begin{array}{l}18.055 \\
18.082\end{array}$ & $\begin{array}{l}15.190 \\
15.010\end{array}$ & $\begin{array}{l}12.724 \\
13.113\end{array}$ & $\begin{array}{l}1.857 \\
1.913\end{array}$ & $\begin{array}{l}5.477 \\
5.506\end{array}$ & $\begin{array}{l}2.062 \\
2.464\end{array}$ & $\begin{array}{l}.142 \\
.140\end{array}$ & $\begin{array}{l}.018 \\
.017\end{array}$ & $\begin{array}{l}55.625 \\
56.246\end{array}$ \\
\hline
\end{tabular}

a Includes lease condensate.

b Electric utility and industrial generation.

c "Other" production is electricity generated for distribution from wood, waste, wind, photovoltaic, and solar thermal energy.

d Due to a lack of consistent historical dala, some renewable energy sources are not included. For example, in 1991, 3.3 quadrillion Btu of renewable energy consumed by U.S. electric utilities to generale electricity for distribution is included, but an estimated 3.4 quadrillion Btu of renewable energy used by other sectors is not included.

$R=$ Revised data.
.
Notes: - See Note 1 at end of section. - Geographic coverage is the 50 States and the District of Columbia. - Totals may not equal sum of components due to independent rounding.

Sources: - Coal: Tables 6.1 and A5-A7. - Natural Gas (Dry): Tables 4.1 and A4. Crude Oll and Natural Gas Plant Liquids: Tables 3.ta and A2. - Nuclear Electric Power: Tables 7.1 and A8. - Hydroolectric Power: Table 7.1; Section 2. "Energy Consumption Notes and Sources," Nole 8; and Table A8. - Geothermal Energy and Other: Section 2, "Energy Consumption Notes and Sources," Nole 7, and Table AB. 
Figure 1.3 Energy Consumption

(Quadrillion Btu)

Total Consumption, 1973-1992

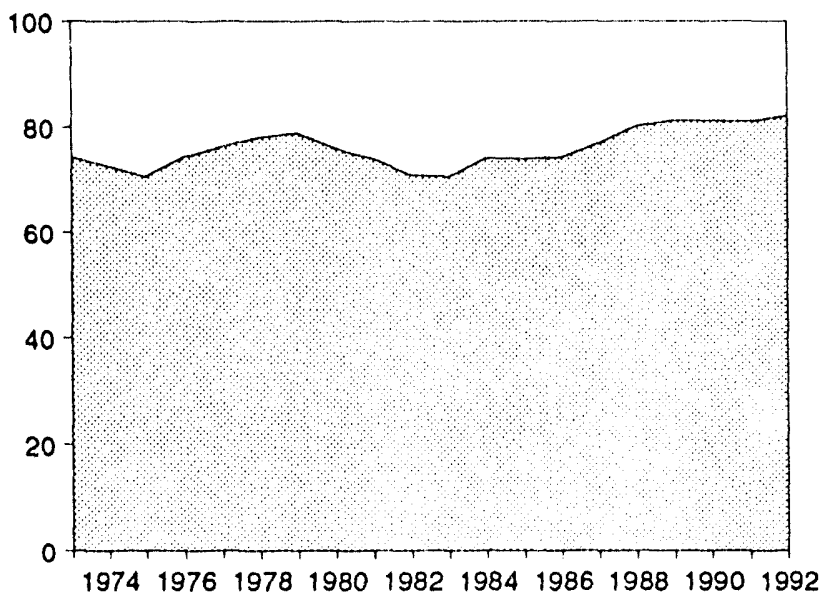

Consumption by Major Sources, 1973-1992

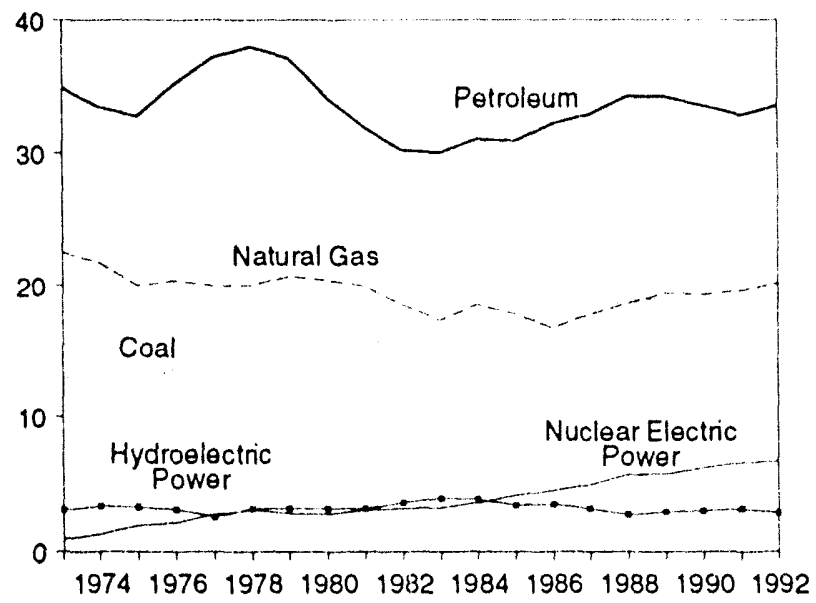

Total Consumption, January-October

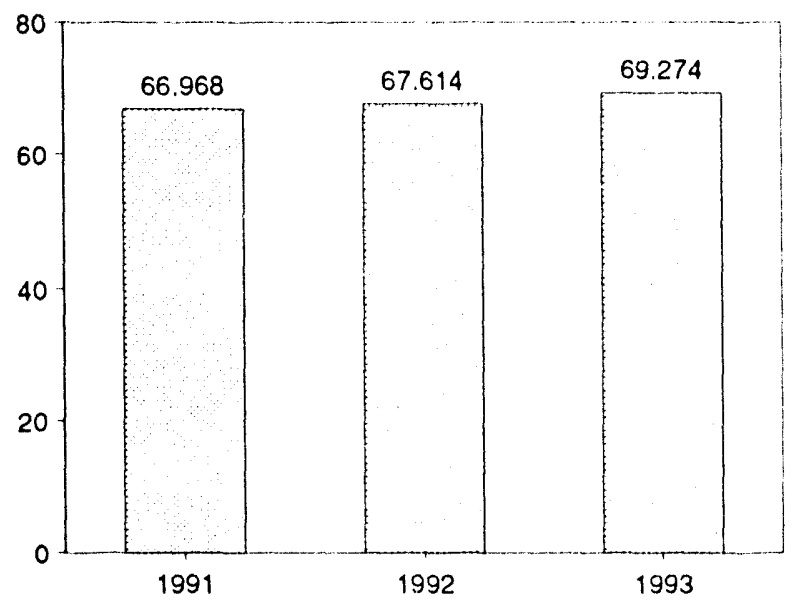

Total Consumption, Monthly

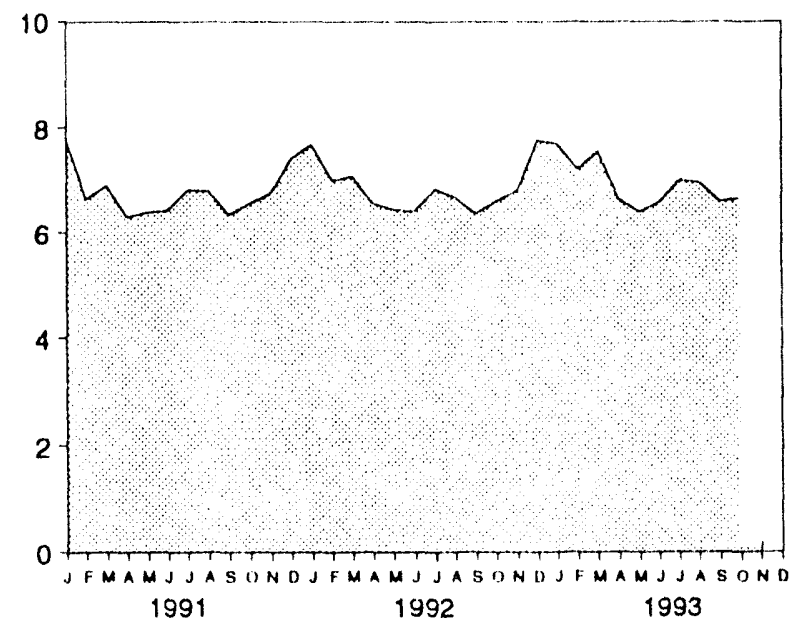

Consumption by Major Sources, Monthly

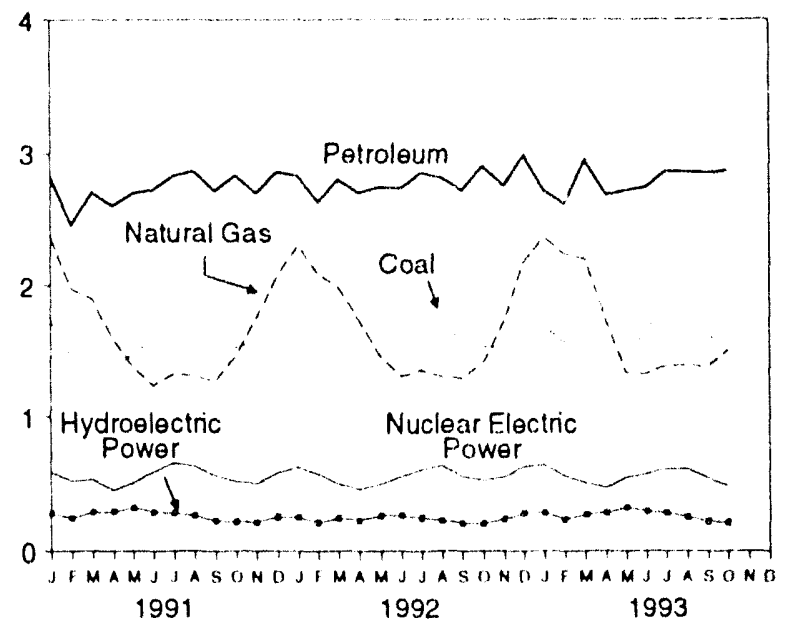

Consumption by Major Sources, October 1993

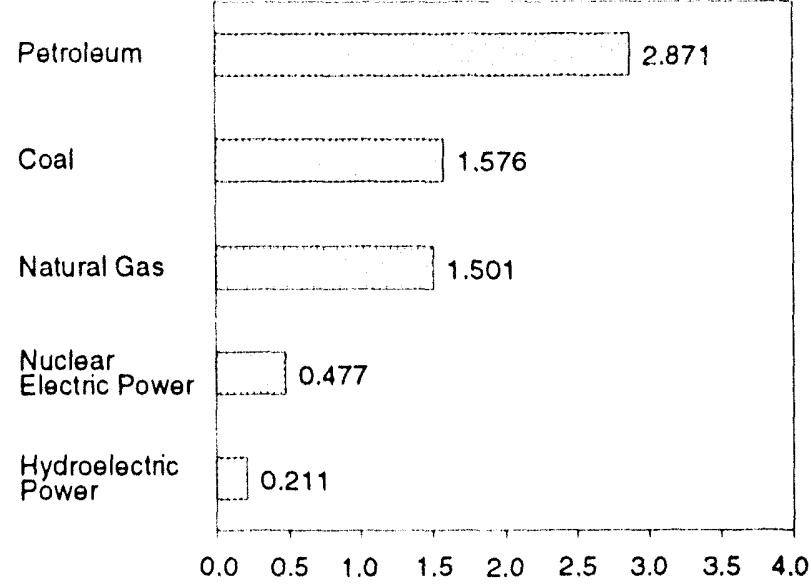

Note: Because vertical scales differ, graphs should not be compared. Source: Table 1.4. 


\begin{tabular}{|c|c|c|c|c|c|c|c|c|}
\hline & Coal & $\begin{array}{c}\text { Natural } \\
\text { Gasa }\end{array}$ & Potroleum & $\begin{array}{c}\text { Nuclear } \\
\text { Electric } \\
\text { Power }\end{array}$ & $\begin{array}{l}\text { Hydro- } \\
\text { lectrlc } \\
\text { Power }\end{array}$ & $\begin{array}{c}\text { Geothermal } \\
\text { Energy }\end{array}$ & Otherc & Totald \\
\hline 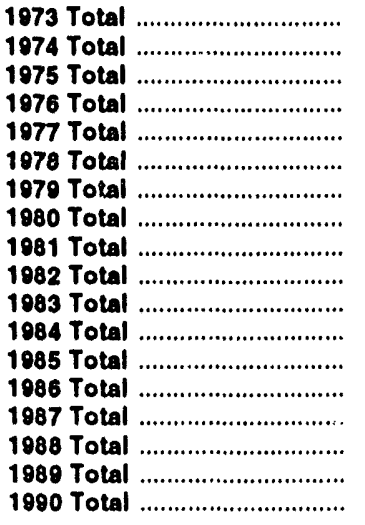 & $\begin{array}{l}12.971 \\
12.663 \\
12.663 \\
13.584 \\
13.922 \\
13.765 \\
15.039 \\
15.423 \\
15.907 \\
15.322 \\
15.894 \\
17.071 \\
17.478 \\
17.261 \\
18.008 \\
18.846 \\
18.925 \\
18.101\end{array}$ & $\begin{array}{l}22.512 \\
21.732 \\
19.948 \\
20.345 \\
19.931 \\
20.000 \\
20.666 \\
20.394 \\
19.928 \\
18.505 \\
17.357 \\
18.507 \\
17.834 \\
16.708 \\
17.744 \\
18.552 \\
19.384 \\
10.296\end{array}$ & $\begin{array}{l}34.840 \\
33.455 \\
32.731 \\
35.175 \\
37.122 \\
37.965 \\
37.123 \\
34.202 \\
31.031 \\
30.231 \\
30.054 \\
31.051 \\
30.922 \\
32.196 \\
32.865 \\
34.222 \\
34.211 \\
33.553\end{array}$ & $\begin{array}{l}0.910 \\
1.272 \\
1.900 \\
2.111 \\
2.702 \\
3.024 \\
2.776 \\
2.730 \\
3.008 \\
3.131 \\
3.203 \\
3.553 \\
4.149 \\
4.471 \\
4.906 \\
5.661 \\
5.677 \\
6.161\end{array}$ & $\begin{array}{l}3.010 \\
3.309 \\
3.210 \\
3.066 \\
2.515 \\
3.141 \\
3.141 \\
3.118 \\
3.105 \\
3.572 \\
3.899 \\
3.800 \\
3.398 \\
3.446 \\
3.117 \\
2.662 \\
2.881 \\
2.946\end{array}$ & $\begin{array}{r}0.043 \\
.053 \\
.070 \\
.078 \\
.077 \\
.064 \\
.084 \\
.110 \\
.123 \\
.105 \\
.120 \\
.165 \\
.198 \\
.210 \\
.229 \\
.217 \\
.197 \\
.181\end{array}$ & $\begin{array}{r}.0 .004 \\
.059 \\
.016 \\
.003 \\
.020 \\
.128 \\
.068 \\
-.031 \\
-.012 \\
.018 \\
-.012 \\
-.002 \\
.001 \\
. .004 \\
.024 \\
.057 \\
.051 \\
.026\end{array}$ & $\begin{array}{l}74.282 \\
72.543 \\
70.546 \\
74.362 \\
76.288 \\
78.089 \\
78.898 \\
75.055 \\
73.990 \\
70.848 \\
70.524 \\
74.144 \\
73.981 \\
74.297 \\
76.894 \\
80.218 \\
81.325 \\
81.265\end{array}$ \\
\hline 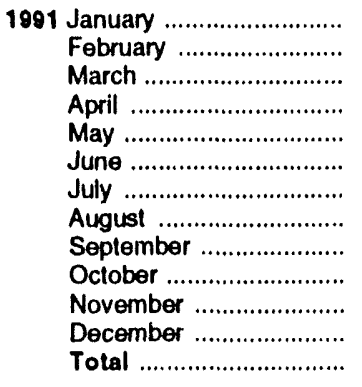 & $\begin{array}{r}1.728 \\
1.444 \\
1.463 \\
1.357 \\
1.480 \\
1.577 \\
1.718 \\
1.717 \\
1.558 \\
1.523 \\
1.570 \\
1.635 \\
18.770\end{array}$ & $\begin{array}{r}2.367 \\
1.969 \\
1.895 \\
1.589 \\
1.377 \\
1.235 \\
1.322 \\
1.312 \\
1.268 \\
1.461 \\
1.742 \\
2.069 \\
19.606\end{array}$ & $\begin{array}{r}2.819 \\
2.463 \\
2.706 \\
2.607 \\
2.702 \\
2.726 \\
2.832 \\
2.868 \\
2.721 \\
2.837 \\
2.702 \\
2.862 \\
32.845\end{array}$ & $\begin{array}{l}.584 \\
.514 \\
.528 \\
.447 \\
.502 \\
.582 \\
.652 \\
.628 \\
.557 \\
.512 \\
.497 \\
.576 \\
6.579\end{array}$ & $\begin{array}{l}.278 \\
.237 \\
.283 \\
.287 \\
.317 \\
.286 \\
.275 \\
.259 \\
.221 \\
.213 \\
.211 \\
.249 \\
3.115\end{array}$ & $\begin{array}{l}.015 \\
.013 \\
.015 \\
.013 \\
.014 \\
.014 \\
.014 \\
.014 \\
.013 \\
.014 \\
.015 \\
.015 \\
.170\end{array}$ & $\begin{array}{l}.003 \\
.002 \\
.003 \\
.002 \\
.002 \\
.000 \\
.005 \\
.000 \\
.006 \\
.001 \\
.003 \\
.002 \\
.030\end{array}$ & $\begin{array}{r}7.795 \\
6.643 \\
6.893 \\
6.302 \\
6.394 \\
6.421 \\
6.818 \\
6.798 \\
6.344 \\
6.561 \\
6.740 \\
7.408 \\
81.116\end{array}$ \\
\hline 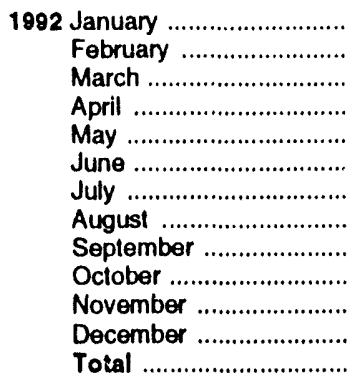 & 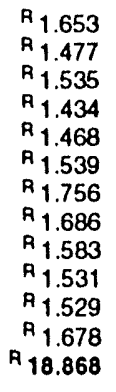 & $\begin{array}{r}2.306 \\
2.091 \\
1.984 \\
1.735 \\
1.460 \\
1.302 \\
1.351 \\
1.302 \\
1.286 \\
1.409 \\
1.722 \\
2.182 \\
20.131\end{array}$ & $\begin{array}{r}2.835 \\
2.634 \\
2.804 \\
2.704 \\
2.747 \\
2.738 \\
2.857 \\
2.821 \\
2.722 \\
2.908 \\
2.756 \\
2.988 \\
33.514\end{array}$ & $\begin{array}{l}.621 \\
.567 \\
.492 \\
.454 \\
.490 \\
.550 \\
.602 \\
.630 \\
.547 \\
.524 \\
.545 \\
.624 \\
6.646\end{array}$ & $\begin{array}{r}.247 \\
.206 \\
.238 \\
.223 \\
.256 \\
.258 \\
.243 \\
.221 \\
.205 \\
.203 \\
.231 \\
.276 \\
2.806\end{array}$ & $\begin{array}{l}.015 \\
.013 \\
.015 \\
.014 \\
.014 \\
.014 \\
.014 \\
.014 \\
.013 \\
.014 \\
.014 \\
.014 \\
.170\end{array}$ & $\begin{array}{l}.006 \\
.004 \\
.005 \\
.005 \\
.002 \\
.005 \\
.003 \\
.003 \\
.003 \\
.004 \\
.003 \\
.007 \\
.049\end{array}$ & 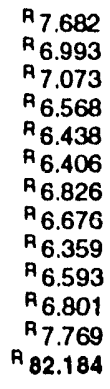 \\
\hline 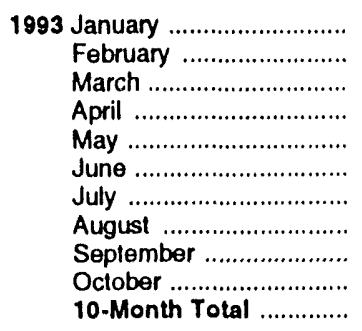 & 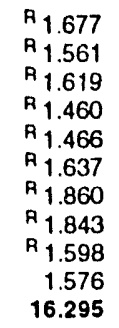 & $\begin{array}{r}2.366 \\
\mathrm{P}_{2} .236 \\
2.200 \\
1.723 \\
1.330 \\
\mathrm{~A} 1.318 \\
1.384 \\
\mathrm{R} 1.385 \\
\mathrm{R} 1.376 \\
1.501 \\
16.819\end{array}$ & $\begin{array}{r}2.720 \\
2.619 \\
2.948 \\
2.689 \\
2.723 \\
2.747 \\
2.868 \\
2.862 \\
2.856 \\
2.871 \\
27.903\end{array}$ & $\begin{array}{l}.634 \\
.551 \\
.501 \\
.464 \\
.541 \\
.565 \\
.607 \\
.604 \\
.537 \\
.477 \\
\mathbf{5 . 4 8 1}\end{array}$ & $\begin{array}{l}.279 \\
.229 \\
.266 \\
.279 \\
.318 \\
.290 \\
.278 \\
.248 \\
.213 \\
.211 \\
2.610\end{array}$ & $\begin{array}{l}.014 \\
.013 \\
.014 \\
.014 \\
.012 \\
.012 \\
.014 \\
.014 \\
.013 \\
.013 \\
.133\end{array}$ & $\begin{array}{l}.006 \\
.001 \\
.005 \\
.004 \\
.004 \\
.004 \\
.001 \\
.004 \\
.001 \\
.003 \\
.033\end{array}$ & $\begin{array}{r}{ }^{A} 7.696 \\
R_{7.211} \\
A_{7.552} \\
\text { P }_{6.633} \\
\text { R }_{6.394} \\
6.573 \\
\text { P }_{7.011} \\
6.959 \\
6.593 \\
6.652 \\
68.274\end{array}$ \\
\hline $\begin{array}{l}1892 \text { 10-Month Total ............. } \\
1891 \text { 10-Month Total ............. }\end{array}$ & $\begin{array}{l}15.661 \\
15.566\end{array}$ & $\begin{array}{l}16.226 \\
15.796\end{array}$ & $\begin{array}{l}27.770 \\
27.282\end{array}$ & $\begin{array}{l}5.477 \\
5.506\end{array}$ & $\begin{array}{l}2.299 \\
2.655\end{array}$ & $\begin{array}{l}.142 \\
.140\end{array}$ & $\begin{array}{l}.039 \\
.025\end{array}$ & $\begin{array}{l}67.614 \\
66.968\end{array}$ \\
\hline
\end{tabular}

a Includes supplemental gaseous fuels.

b Electric utility and industrial generation and net imports of electricity.

c "Other" consumption is net imports of coal coke and electricity generated for distribution from wood, wasle, wind, photovoltaic, and solar thermal energy.

Due to a lack of consistent historical data, some renewable energy sources are not included. For example, in 1991, 3.3 quadrillion Btu of renewable energy consumed by U.S. electric utilities to generate electricity for distribution is included, but an estimated 3.4 quadrillion Blu of renewable energy used by other sectors is not included.
$\mathrm{R}=$ Revised data

Notes: - See Note 2 at end of section. - Geographic coverage is the $\mathbf{5 0}$ States and the District of Columbia. - Tolals may not equal sum of components due to independent rounding.

Sources: - Coal: Tables 6.1 and A5-A7. - Natural Gas: Tables 4.2 and A4. - Petroleum: Tables 3.1a and A3. - Nuclear Electric Power: Tables 7.1 and $A 8$. - Hydroolectric Power: Table 7.1; Section 2, "Energy Consumption Notes and Sources," Note 8; and Table A8. - Geothermal Energy and Other: Section 2. "Energy Consumption Notes and Sources," Nole 7, and Tabie A8. 
Figure 1.4 Energy Net Imports

(Quadrillion Btu, Except as Noted)

Total Net Imports, 1973-1992

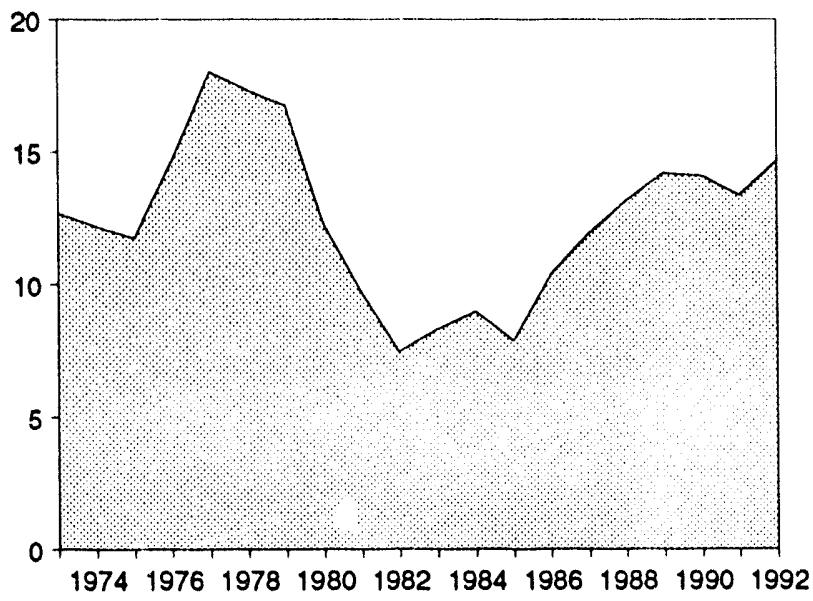

Net Imports by Major Sources, 1973-1992

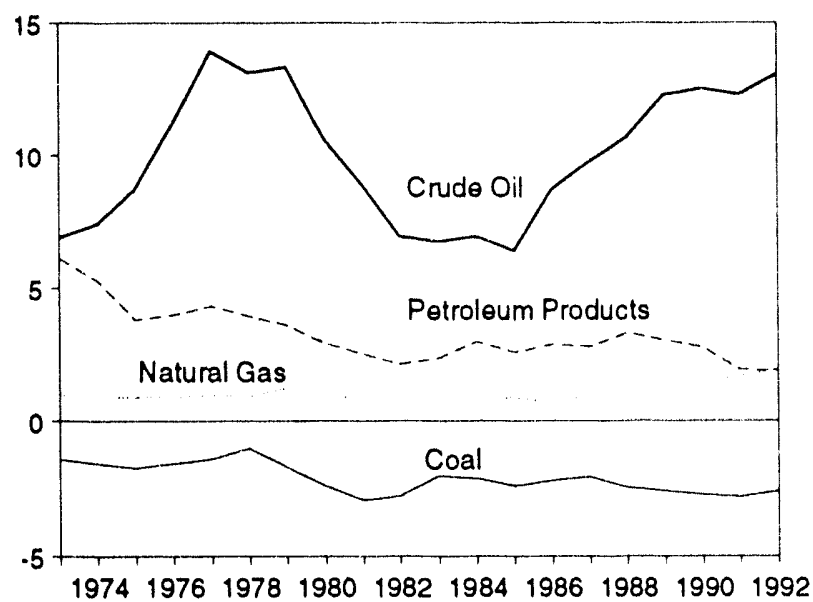

Net Imports by Major Sources,

October 1993

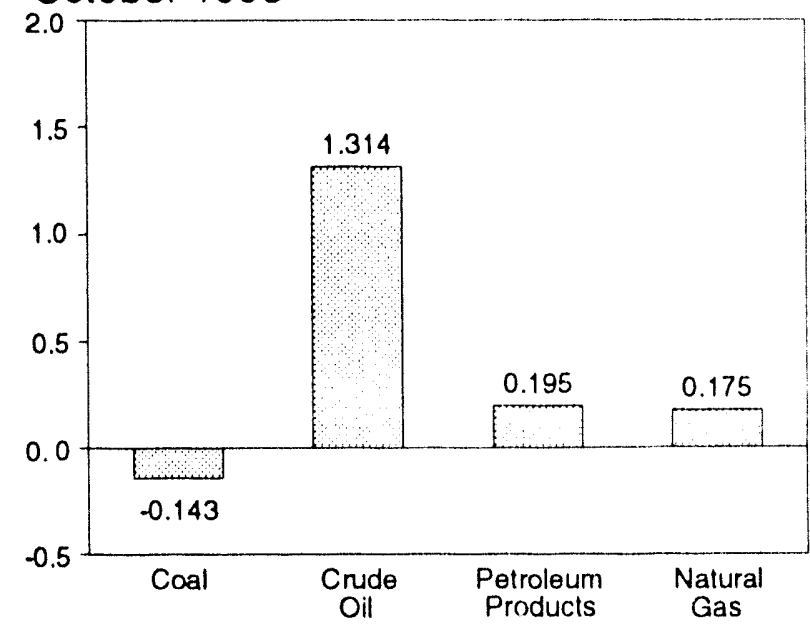

Net Imports, Monthly

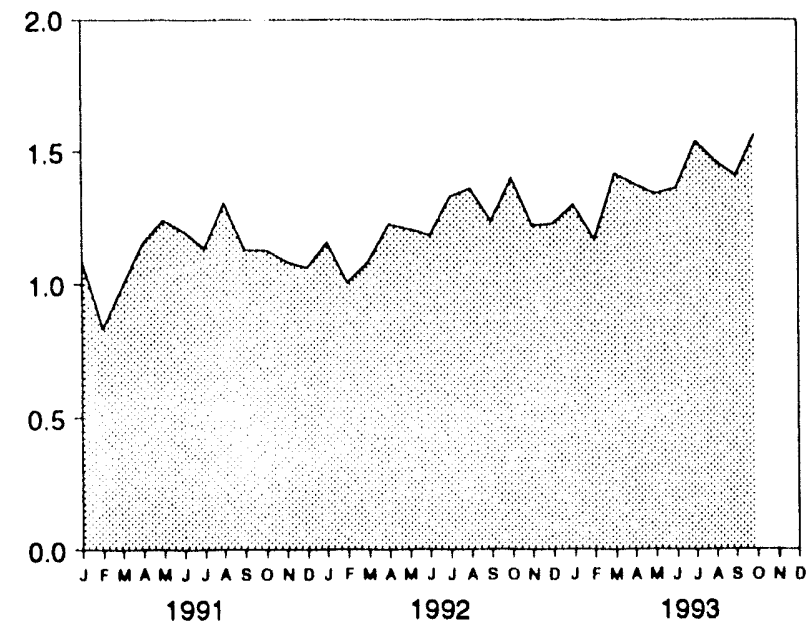

Net Imports by Major Sources, Monthly

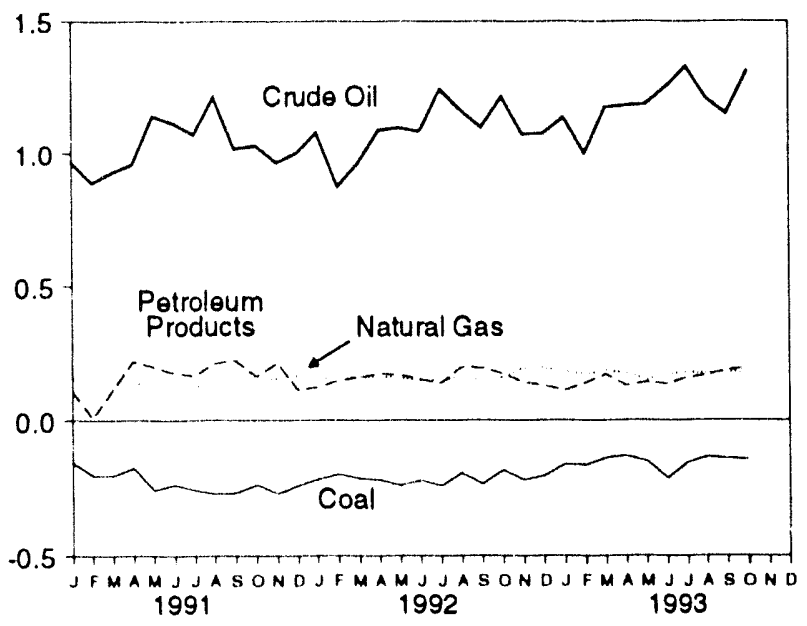

Net Imports as Share of Consumption, January-October

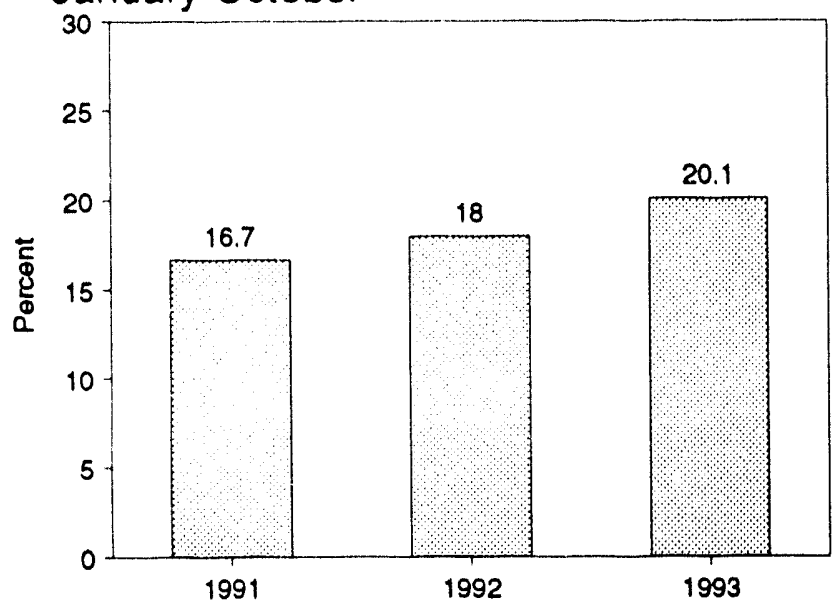

Note: Because vertical scales differ, graphs should not be compared. Sources: Tables 1.4 and 1.5 . 


\begin{tabular}{|c|c|c|c|c|c|c|c|}
\hline & Coal & $\begin{array}{l}\text { Natural } \\
\text { Gas }\end{array}$ & $\begin{array}{c}\text { Crude } \\
\text { Olla }\end{array}$ & $\begin{array}{l}\text { Potroloum } \\
\text { Productsb }\end{array}$ & Electricltyc & $\begin{array}{l}\text { Coal } \\
\text { Coke }\end{array}$ & Total \\
\hline 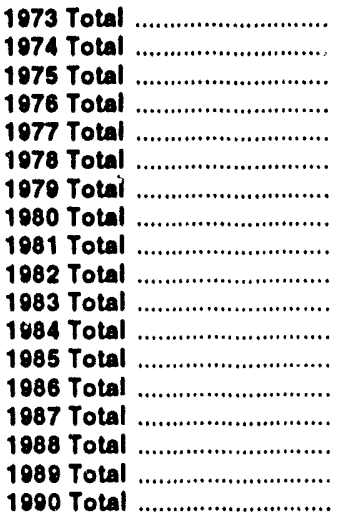 & $\begin{array}{l}-1.422 \\
-1.568 \\
-1.738 \\
-1.567 \\
-1.401 \\
-1.004 \\
-1.702 \\
-2.391 \\
-2.918 \\
-2.768 \\
-2.013 \\
-2.119 \\
-2.389 \\
-2.193 \\
-2.049 \\
-2.446 \\
-2.566 \\
-2.705\end{array}$ & $\begin{array}{r}0.981 \\
.007 \\
.004 \\
.022 \\
.981 \\
.041 \\
1.243 \\
.057 \\
.857 \\
.898 \\
.885 \\
.792 \\
.896 \\
.686 \\
.037 \\
1.221 \\
1.278 \\
1.464\end{array}$ & $\begin{array}{r}6.883 \\
7.389 \\
8.708 \\
11.221 \\
13.921 \\
13.125 \\
13.328 \\
10.586 \\
8.854 \\
6.917 \\
6.731 \\
6.918 \\
6.381 \\
8.676 \\
9.748 \\
10.698 \\
12.296 \\
12.536\end{array}$ & $\begin{array}{l}6.097 \\
5.273 \\
3.800 \\
3.982 \\
4.321 \\
3.932 \\
3.603 \\
2.912 \\
2.522 \\
2.128 \\
2.351 \\
2.070 \\
2.570 \\
2.855 \\
2.784 \\
3.308 \\
3.029 \\
2.757\end{array}$ & $\begin{array}{r}0.148 \\
.133 \\
.064 \\
.080 \\
.182 \\
.204 \\
.211 \\
.217 \\
.347 \\
.306 \\
.372 \\
.414 \\
.428 \\
.375 \\
.483 \\
.328 \\
.113 \\
.020\end{array}$ & $\begin{array}{r}-0.007 \\
.058 \\
.014 \\
(8) \\
.015 \\
.125 \\
.063 \\
-.035 \\
-.016 \\
-.022 \\
-.016 \\
-.011 \\
-.013 \\
-.017 \\
.009 \\
.040 \\
.030 \\
.005\end{array}$ & $\begin{array}{r}12.680 \\
12.190 \\
11.752 \\
14.648 \\
18.010 \\
17.323 \\
16.746 \\
12.247 \\
9.646 \\
7.460 \\
8.310 \\
8.963 \\
7.872 \\
10.382 \\
11.911 \\
13.149 \\
14.181 \\
14.077\end{array}$ \\
\hline 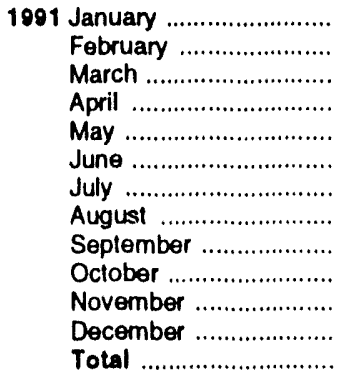 & $\begin{array}{l}-.156 \\
-.202 \\
-.203 \\
-.176 \\
-.256 \\
-.236 \\
-.256 \\
-.270 \\
-.267 \\
-.237 \\
-.270 \\
-.240 \\
-2.769\end{array}$ & $\begin{array}{l}.156 \\
.129 \\
.143 \\
.137 \\
.135 \\
.128 \\
.129 \\
.119 \\
.125 \\
.144 \\
.156 \\
.165 \\
1.666\end{array}$ & $\begin{array}{r}.967 \\
.889 \\
.928 \\
.958 \\
1.144 \\
1.117 \\
1.073 \\
1.215 \\
1.018 \\
1.031 \\
.965 \\
1.002 \\
12.308\end{array}$ & $\begin{array}{l}.108 \\
.008 \\
.113 \\
.219 \\
.199 \\
.176 \\
.166 \\
.212 \\
.223 \\
.162 \\
.213 \\
.114 \\
1.012\end{array}$ & $\begin{array}{l}.009 \\
.007 \\
.013 \\
.018 \\
.019 \\
.016 \\
.021 \\
.031 \\
.028 \\
.029 \\
.019 \\
.021 \\
.231\end{array}$ & $\begin{array}{r}.001 \\
.001 \\
.002 \\
.001 \\
.001 \\
.001 \\
.003 \\
.002 \\
.004 \\
.001 \\
.001 \\
(s) \\
.009\end{array}$ & $\begin{array}{r}1.085 \\
.832 \\
.996 \\
1.156 \\
1.241 \\
1.199 \\
1.136 \\
1.306 \\
1.130 \\
1.130 \\
1.084 \\
1.062 \\
13.357\end{array}$ \\
\hline 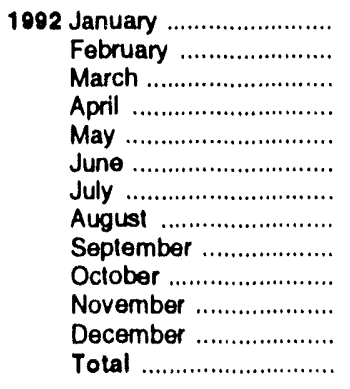 & $\begin{array}{r}-.218 \\
-.198 \\
\circ . .214 \\
-.219 \\
-.240 \\
. .221 \\
. .241 \\
-.194 \\
-.235 \\
-.183 \\
-.219 \\
. .204 \\
-2.587\end{array}$ & $\begin{array}{l}.150 \\
.163 \\
.160 \\
.160 \\
.157 \\
.146 \\
.153 \\
.158 \\
.149 \\
.159 \\
.194 \\
.193 \\
1.941\end{array}$ & $\begin{array}{r}1.078 \\
.873 \\
.963 \\
1.090 \\
1.099 \\
1084 \\
1.245 \\
1.168 \\
1.099 \\
1.217 \\
1.074 \\
1.076 \\
13.065\end{array}$ & $\begin{array}{l}.122 \\
.146 \\
.160 \\
.173 \\
.168 \\
.152 \\
.137 \\
.197 \\
.195 \\
.173 \\
.142 \\
.129 \\
1.895\end{array}$ & $\begin{array}{l}.021 \\
.018 \\
.012 \\
.019 \\
.022 \\
.020 \\
.036 \\
.031 \\
.028 \\
.031 \\
.029 \\
.027 \\
.293\end{array}$ & $\begin{array}{l}.004 \\
.003 \\
.003 \\
.003 \\
.001 \\
.003 \\
.001 \\
.001 \\
.001 \\
.002 \\
.001 \\
.005 \\
.027\end{array}$ & $\begin{array}{r}1.157 \\
1.005 \\
1.084 \\
1.226 \\
1.207 \\
1.183 \\
1.329 \\
1.360 \\
1.237 \\
1.399 \\
1.221 \\
R_{1} 1.227 \\
\mathrm{R}_{14.635}\end{array}$ \\
\hline 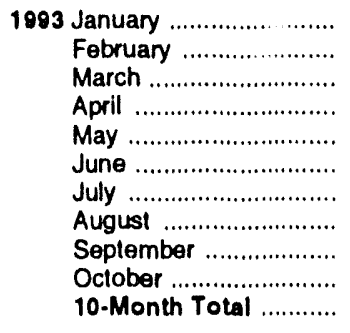 & $\begin{array}{l}-.162 \\
-.164 \\
-.137 \\
-.131 \\
-.151 \\
-.213 \\
-.156 \\
-.134 \\
-.141 \\
-.143 \\
-1.532\end{array}$ & $\begin{array}{l}.182 \\
.172 \\
.184 \\
.175 \\
.150 \\
.170 \\
.178 \\
.175 \\
.179 \\
.175 \\
1.740\end{array}$ & $\begin{array}{r}1.138 \\
.999 \\
1.177 \\
1.184 \\
1.188 \\
1.255 \\
1.329 \\
1.211 \\
1.153 \\
1.314 \\
11.948\end{array}$ & $\begin{array}{l}.111 \\
.139 \\
.170 \\
.129 \\
.140 \\
.135 \\
.158 \\
.167 \\
.186 \\
.195 \\
1.530\end{array}$ & $\begin{array}{l}E .023 \\
E .022 \\
E .019 \\
E .016 \\
E .011 \\
E .011 \\
E .031 \\
E .041 \\
E .033 \\
E .033 \\
E .241\end{array}$ & $\begin{array}{r}.004 \\
(s) \\
.003 \\
.002 \\
.002 \\
.003 \\
(s) \\
.002 \\
.001 \\
.001 \\
.016\end{array}$ & $\begin{array}{r}1.297 \\
1.168 \\
1.416 \\
1.376 \\
1.340 \\
1.361 \\
1.540 \\
1.462 \\
1.408 \\
1.575 \\
13.943\end{array}$ \\
\hline $\begin{array}{l}1992 \text { 10-Month Total .......... } \\
1991 \text { 10-Month Total .......... }\end{array}$ & $\begin{array}{l}-2.164 \\
-2.258\end{array}$ & $\begin{array}{l}1.554 \\
1.346\end{array}$ & $\begin{array}{l}10.915 \\
10.341\end{array}$ & $\begin{array}{l}1.624 \\
1.585\end{array}$ & $\begin{array}{l}.237 \\
.181\end{array}$ & $\begin{array}{l}.021 \\
.007\end{array}$ & $\begin{array}{l}12.187 \\
11.211\end{array}$ \\
\hline
\end{tabular}

a Crude oil, lease condensate, and imports of crude oil for the Strategic Petroleum Reserve.

$\mathrm{b}$ Pelroleum products, unlinished oils, pentanes plus, and gasoline blending components.

$c$ Assumed to be hydroelectricity and estimated at the average input heat rate for lossitluel sleam-electric power plant generation, which has ranged Irom 10.2 thousand Btu to 10.5 thousand Blu per kilowatthour since 1973. Actual heat rates applied in converting kilowatthours to Blu are listed by year in Table A8.

$E=$ Estimate. $(\mathrm{s})=$ Less than +0.5 trillion Btu and greater than -0.5 trillion Btu.
Notes: - See Notes 3 and 4 at end of section. - Net imports equal imports minus exports. Minus sign indicates exports are greater than imports. - Geographic coverage is the 50 States and the District of Columbia.

- Totals may not equal sum of components due to independent rounding.

Sources: - Coal: Tables 6.1 and A5-A7. - Natural Gas: Tables 4.2 and A4. - Crude Oll and Potroloum Products: Tables $3.1 \mathrm{~b}$ and A2. - Electricity: Section 2, "Energy Consumption Notes and Sources," Note 8, and Table AB. - Coal Coke: Section 2, "Energy Consumption Notes and Sources," Nole 9, and Table A7. 
Figure 1.5 Merchandise Trade Value

(Billion Dollars)

Imports and Exports, 1974-1992

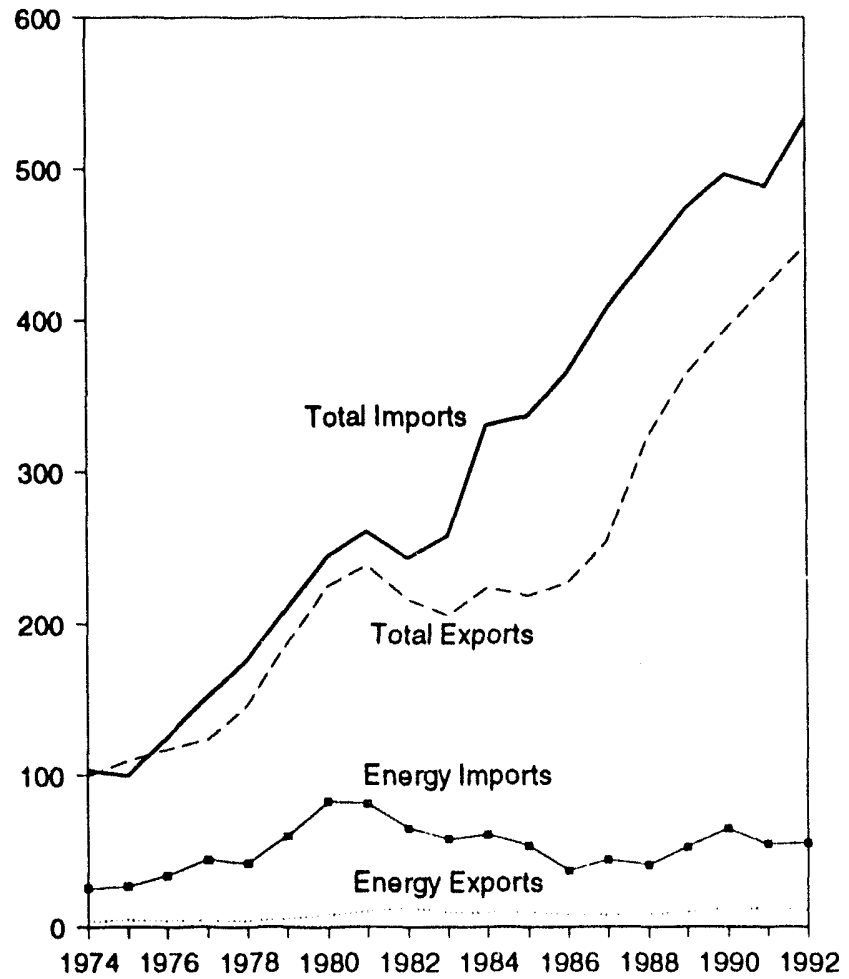

Trade Balance, 1974-1992

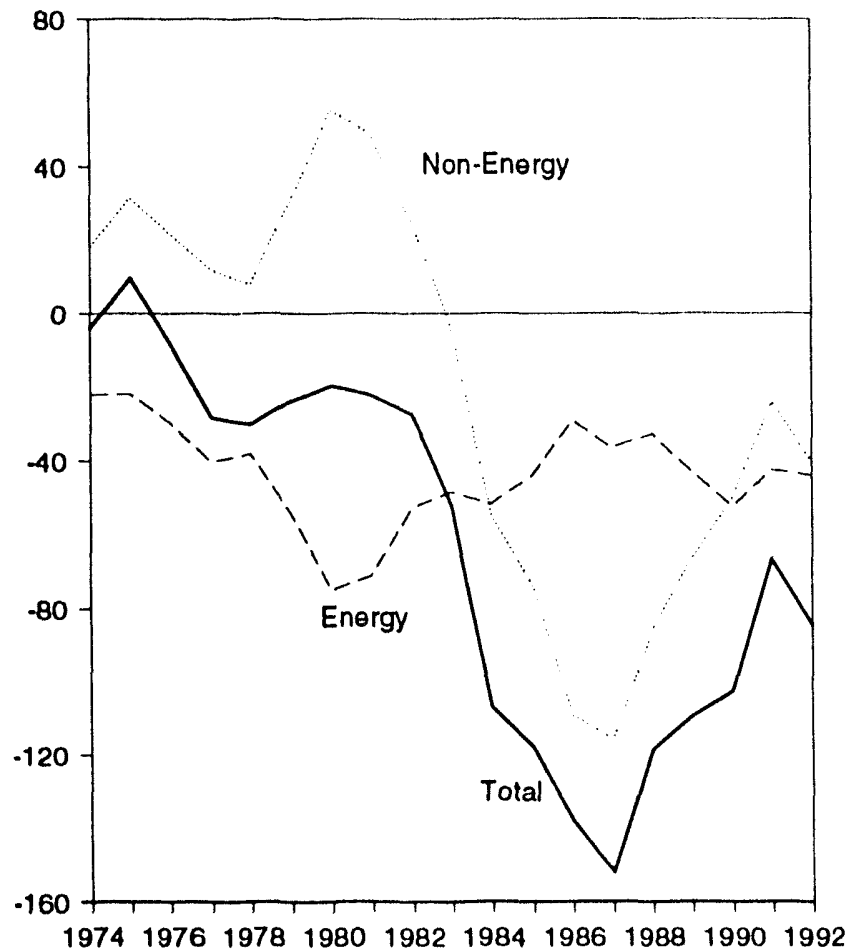

Imports and Exports, Monthly

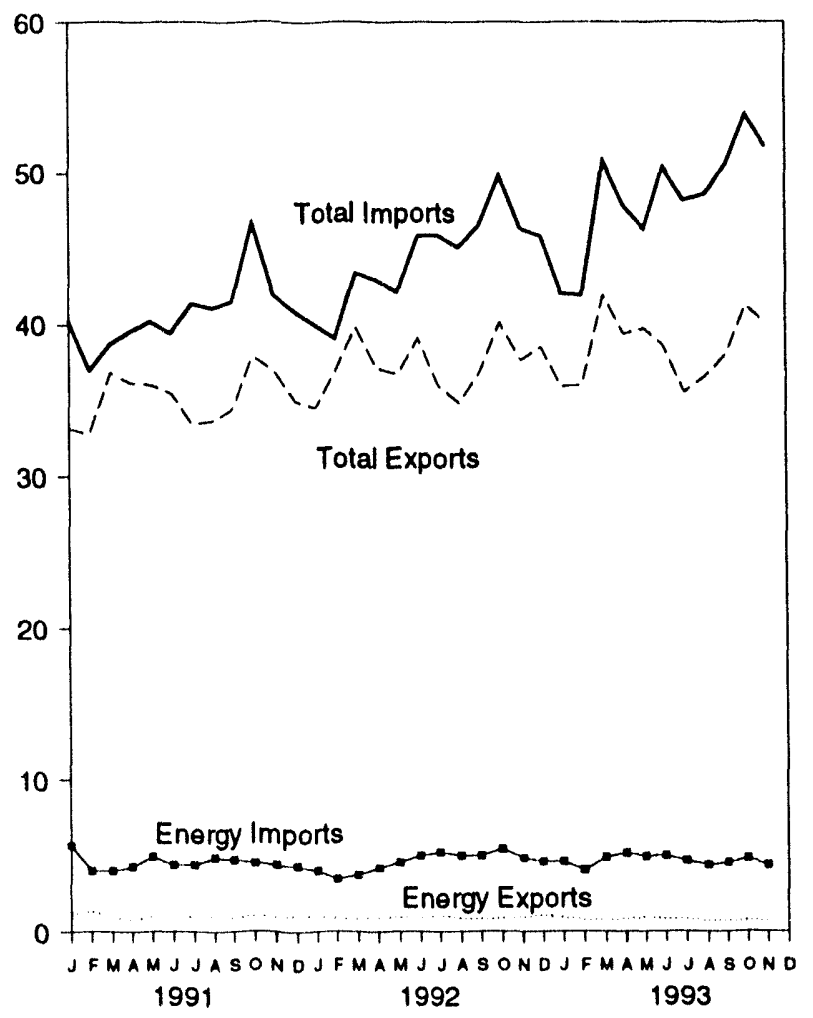

Trade Balance, Monthly

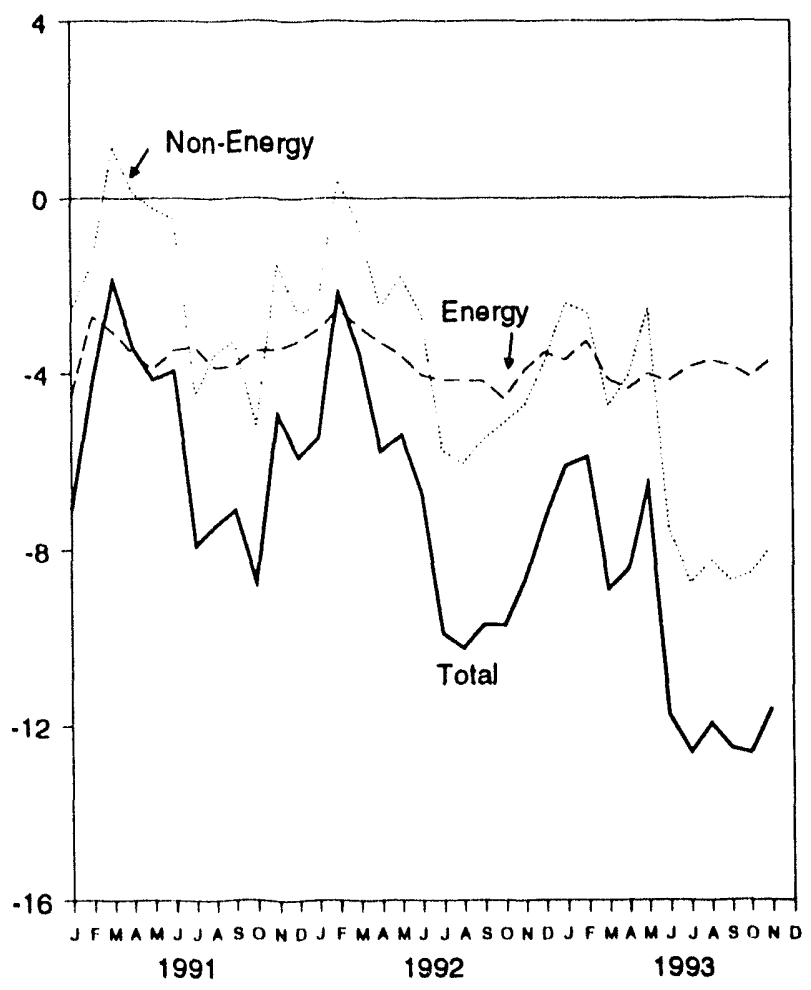

Note: Because vertical scales differ, graphs should not be compared. Source: Table 1.6. 


\begin{tabular}{|c|c|c|c|c|c|c|c|c|c|c|}
\hline & \multicolumn{3}{|c|}{ Petroloum } & \multicolumn{3}{|c|}{ Energy } & \multirow{2}{*}{$\begin{array}{c}\text { Non- } \\
\text { Energy } \\
\text { Balance }\end{array}$} & \multicolumn{3}{|c|}{ Total Merchandise } \\
\hline & Exports & Imports & Balance & Exports & Imports & Balance & & Exports & Imports & Balance \\
\hline 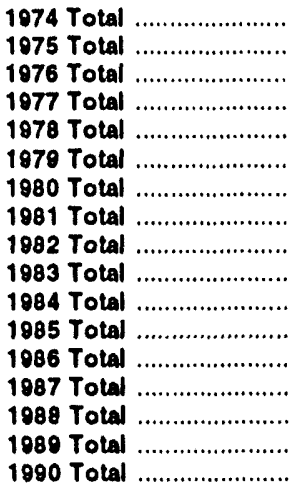 & $\begin{array}{r}792 \\
907 \\
998 \\
1,276 \\
1,561 \\
1,914 \\
2,833 \\
3,696 \\
5,947 \\
4,557 \\
4,470 \\
4,707 \\
3,640 \\
3,922 \\
3,693 \\
5,021 \\
6,901\end{array}$ & $\begin{array}{l}24,668 \\
25,197 \\
32,226 \\
42,368 \\
39,526 \\
56,715 \\
78,637 \\
76,659 \\
60,458 \\
53,217 \\
56,924 \\
50,475 \\
35,142 \\
42,285 \\
38,787 \\
49,704 \\
61,583\end{array}$ & $\begin{array}{l}-23,876 \\
-24,289 \\
-31,228 \\
-41,083 \\
-37,965 \\
-54,801 \\
-75,803 \\
-72,963 \\
-54,511 \\
-48,659 \\
-52,454 \\
-45,768 \\
-31,503 \\
-38,363 \\
-35,094 \\
-44,683 \\
-54,682\end{array}$ & $\begin{array}{r}3,444 \\
4,470 \\
4,226 \\
4,184 \\
3,881 \\
5,621 \\
7,882 \\
10,279 \\
12,729 \\
9,500 \\
9,311 \\
9,871 \\
8,115 \\
7,713 \\
8,235 \\
9,869 \\
12,233\end{array}$ & $\begin{array}{l}25,454 \\
26,476 \\
33,986 \\
44,537 \\
42,096 \\
59,998 \\
82,924 \\
81,360 \\
65,409 \\
57,952 \\
60,980 \\
53,917 \\
37,310 \\
44,220 \\
41,042 \\
52,770 \\
64,661\end{array}$ & $\begin{array}{l}-22,010 \\
-22,006 \\
-28,770 \\
-40,354 \\
-38,215 \\
-54,377 \\
-74,942 \\
-71,081 \\
-52,680 \\
-48,452 \\
-51,669 \\
-43,946 \\
-29,195 \\
-36,506 \\
-32,806 \\
-42,910 \\
-52,428\end{array}$ & $\begin{array}{r}18,126 \\
31,557 \\
21,050 \\
12,001 \\
8,010 \\
30,455 \\
55,246 \\
48,814 \\
25,170 \\
-3,057 \\
-55,033 \\
-73,765 \\
-109,084 \\
-115,613 \\
-85,720 \\
-66,490 \\
-50,068\end{array}$ & $\begin{array}{r}99,437 \\
108,856 \\
116,794 \\
123,182 \\
145,847 \\
186,363 \\
225,566 \\
238,715 \\
216,442 \\
205,630 \\
223,976 \\
218,815 \\
227,150 \\
254,122 \\
322,426 \\
363,812 \\
393,592\end{array}$ & $\begin{array}{r}103,321 \\
99,305 \\
124,614 \\
151,534 \\
176,052 \\
210,285 \\
245,262 \\
260,982 \\
243,952 \\
258,048 \\
330,678 \\
336,526 \\
365,438 \\
406,241 \\
440,952 \\
473,211 \\
496,088\end{array}$ & $\begin{array}{r}-3,884 \\
9,551 \\
-7,820 \\
-28,353 \\
-30,205 \\
-23,922 \\
-19,696 \\
-22,267 \\
-27,510 \\
-52,409 \\
-106,703 \\
-117,712 \\
-138,279 \\
-152,119 \\
-118,526 \\
-109,390 \\
-102,496\end{array}$ \\
\hline 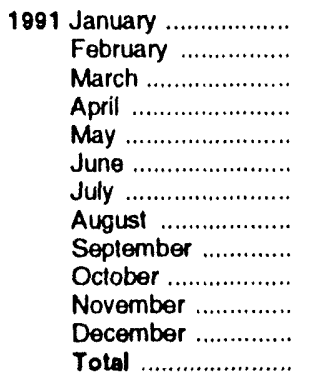 & $\begin{array}{r}881 \\
928 \\
565 \\
397 \\
562 \\
506 \\
513 \\
495 \\
415 \\
584 \\
488 \\
620 \\
6,954\end{array}$ & $\begin{array}{r}5,361 \\
3,741 \\
3,729 \\
4,030 \\
4,699 \\
4,177 \\
4,133 \\
4,641 \\
4,475 \\
4,226 \\
4,112 \\
4,028 \\
51,350\end{array}$ & $\begin{array}{l}-4,480 \\
-2,813 \\
-3,164 \\
-3,633 \\
-4,137 \\
-3,671 \\
-3,620 \\
-4,146 \\
-4,060 \\
-3,642 \\
-3,623 \\
-3,408 \\
-44,396\end{array}$ & $\begin{array}{r}1,188 \\
1,327 \\
951 \\
748 \\
1,031 \\
936 \\
987 \\
998 \\
884 \\
1,031 \\
943 \\
1,058 \\
12,081\end{array}$ & $\begin{array}{r}5,698 \\
4,032 \\
4,003 \\
4,286 \\
4,957 \\
4,408 \\
4,388 \\
4,876 \\
4,723 \\
4,533 \\
4,399 \\
4,326 \\
54,628\end{array}$ & $\begin{array}{l}-4,509 \\
-2,705 \\
-3,051 \\
-3,538 \\
-3,926 \\
-3,473 \\
-3,401 \\
-3,879 \\
-3,839 \\
-3,502 \\
-3,456 \\
-3,268 \\
-42,548\end{array}$ & $\begin{array}{r}-2,569 \\
-1,496 \\
1,163 \\
128 \\
-231 \\
-476 \\
-4,493 \\
-3,571 \\
-3,271 \\
-5,232 \\
-1,486 \\
-2,640 \\
-24,175\end{array}$ & $\begin{array}{r}33,165 \\
32,775 \\
36,820 \\
36,137 \\
36,024 \\
35,480 \\
33,444 \\
33,633 \\
34,391 \\
37,897 \\
36,970 \\
34,996 \\
421,730\end{array}$ & $\begin{array}{r}40,244 \\
36,976 \\
38,708 \\
39,548 \\
40,181 \\
39,428 \\
41,338 \\
41,082 \\
41,502 \\
46,631 \\
41,911 \\
40,904 \\
488,453\end{array}$ & $\begin{array}{l}-7,079 \\
-4,201 \\
-1,889 \\
-3,411 \\
-4,158 \\
-3,948 \\
-7,894 \\
-7,450 \\
-7,111 \\
-8,735 \\
-4,942 \\
-5,908 \\
-66,723\end{array}$ \\
\hline 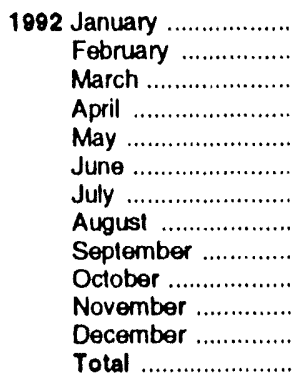 & $\begin{array}{r}602 \\
454 \\
419 \\
511 \\
535 \\
548 \\
654 \\
503 \\
428 \\
506 \\
550 \\
700 \\
6,412\end{array}$ & $\begin{array}{r}3,683 \\
3,165 \\
3,477 \\
3,931 \\
4,274 \\
4,713 \\
4,912 \\
4,702 \\
4,680 \\
5,047 \\
4,462 \\
4,172 \\
51,217\end{array}$ & $\begin{array}{r}-3,082 \\
\cdot 2,711 \\
-3,058 \\
\cdot 3,420 \\
-3,738 \\
-4,165 \\
-4,258 \\
-4,199 \\
-4,252 \\
-4,541 \\
-3,912 \\
-3,471 \\
-44,805\end{array}$ & $\begin{array}{r}1,007 \\
879 \\
831 \\
932 \\
968 \\
958 \\
1,067 \\
867 \\
839 \\
874 \\
940 \\
1,093 \\
11,254\end{array}$ & $\begin{array}{r}4,016 \\
3,452 \\
3,762 \\
4,215 \\
4,573 \\
5,007 \\
5,222 \\
5,034 \\
5,026 \\
5,456 \\
4,873 \\
4,621 \\
55,256\end{array}$ & $\begin{array}{r}-3,009 \\
-2,573 \\
-2,931 \\
-3,283 \\
-3,605 \\
-4,049 \\
-4,155 \\
-4,167 \\
-4,187 \\
-4,582 \\
-3,933 \\
-3,529 \\
-44,002\end{array}$ & $\begin{array}{r}-2,461 \\
396 \\
-596 \\
-2,489 \\
-1,804 \\
-2,669 \\
-5,738 \\
-6,051 \\
-5,506 \\
-5,124 \\
-4,711 \\
-3,747 \\
-40,500\end{array}$ & $\begin{array}{r}34,514 \\
36,898 \\
39,817 \\
37,154 \\
36,737 \\
39,094 \\
35,979 \\
34,838 \\
36,811 \\
40,115 \\
37,670 \\
38,537 \\
448,164\end{array}$ & $\begin{array}{r}39,984 \\
39,075 \\
43,344 \\
42,925 \\
42,146 \\
45,812 \\
45,872 \\
45,055 \\
46,503 \\
49,820 \\
46,314 \\
45,813 \\
532,665\end{array}$ & $\begin{array}{r}-5,470 \\
-2,178 \\
-3,527 \\
-5,772 \\
-5,409 \\
-6,718 \\
-9,893 \\
-10,218 \\
-9,693 \\
-9,706 \\
-8,644 \\
-7,276 \\
-84,501\end{array}$ \\
\hline 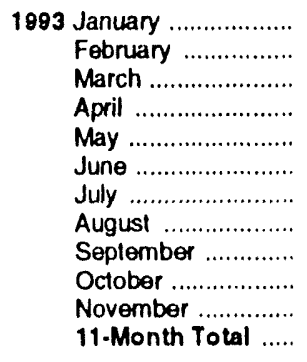 & $\begin{array}{r}617 \\
467 \\
488 \\
583 \\
647 \\
439 \\
514 \\
444 \\
436 \\
467 \\
478 \\
5,579\end{array}$ & $\begin{array}{r}4,254 \\
3,699 \\
4,492 \\
4,845 \\
4,614 \\
4,707 \\
4,320 \\
4,031 \\
4,171 \\
4,450 \\
3,990 \\
47,573\end{array}$ & $\begin{array}{l}-3,637 \\
-3,232 \\
-4,004 \\
-4,262 \\
-3,967 \\
-4,269 \\
-3,806 \\
-3,587 \\
-3,735 \\
-3,983 \\
-3,512 \\
-41,994\end{array}$ & $\begin{array}{r}936 \\
789 \\
768 \\
835 \\
944 \\
826 \\
818 \\
703 \\
723 \\
759 \\
716 \\
8,818\end{array}$ & $\begin{array}{r}4,642 \\
4,070 \\
4,910 \\
5,191 \\
4,969 \\
5,023 \\
4,679 \\
4,404 \\
4,549 \\
4,854 \\
4,418 \\
51,708\end{array}$ & $\begin{array}{l}-3,706 \\
-3,281 \\
-4,142 \\
-4,357 \\
-4,024 \\
-4,197 \\
-3,862 \\
-3,700 \\
-3,826 \\
-4,094 \\
-3,702 \\
-42,890\end{array}$ & $\begin{array}{r}\cdot 2,407 \\
-2,625 \\
-4,745 \\
-4,072 \\
-2,518 \\
\cdot 7,552 \\
-8,747 \\
-8,249 \\
-8,690 \\
+-8,543 \\
-7,917 \\
-66,064\end{array}$ & $\begin{array}{r}35,922 \\
36,004 \\
41,895 \\
39,374 \\
39,751 \\
38,616 \\
35,529 \\
36,624 \\
38,052 \\
\mathbf{4} 1,230 \\
40,136 \\
423,132\end{array}$ & $\begin{array}{r}42,035 \\
41,909 \\
50,781 \\
47,802 \\
46,293 \\
50,365 \\
48,138 \\
48,573 \\
50,567 \\
\text { R } 53,867 \\
51,756 \\
\mathbf{5 3 2 , 0 8 6}\end{array}$ & $\begin{array}{r}-6,113 \\
-5,905 \\
-8,886 \\
-8,428 \\
-6,542 \\
-11,749 \\
-12,609 \\
-11,949 \\
-12,516 \\
{ }^{\circ} .12,638 \\
-11,619 \\
-108,954\end{array}$ \\
\hline $\begin{array}{l}199211 \text {-Month Total ..... } \\
199111 \text {-Month Total ..... }\end{array}$ & $\begin{array}{l}5,711 \\
6,334\end{array}$ & $\begin{array}{l}47,045 \\
47,322\end{array}$ & $\begin{array}{l}-41,334 \\
-40,988\end{array}$ & $\begin{array}{l}10,161 \\
11,023\end{array}$ & $\begin{array}{l}50,634 \\
50,303\end{array}$ & $\begin{array}{l}-40,473 \\
-39,280\end{array}$ & $\begin{array}{l}-36,753 \\
-21,536\end{array}$ & $\begin{array}{l}409,627 \\
386,734\end{array}$ & $\begin{array}{l}486,852 \\
447,549\end{array}$ & $\begin{array}{l}-77,226 \\
-60,816\end{array}$ \\
\hline
\end{tabular}

$R=$ Revised dala.

Notes: - Monthly data are not adjusted for seasonal variations. - The U.S. import statistics rellect both government and nongovernment imports of merchandise from toreign countries into the U.S. customs territory, which comprises the 50 States, the District of Columbia, Puento Rico, and the Virgin Islands. See Note 5 at end of section. - Tolals may not equal sum of components due to irdependent rounding.

Sources: See end of section. 
Figure 1.6 Energy Consumption per Dollar of Gross Domestic Product

(Thousand Btu per 1987 Dollar)

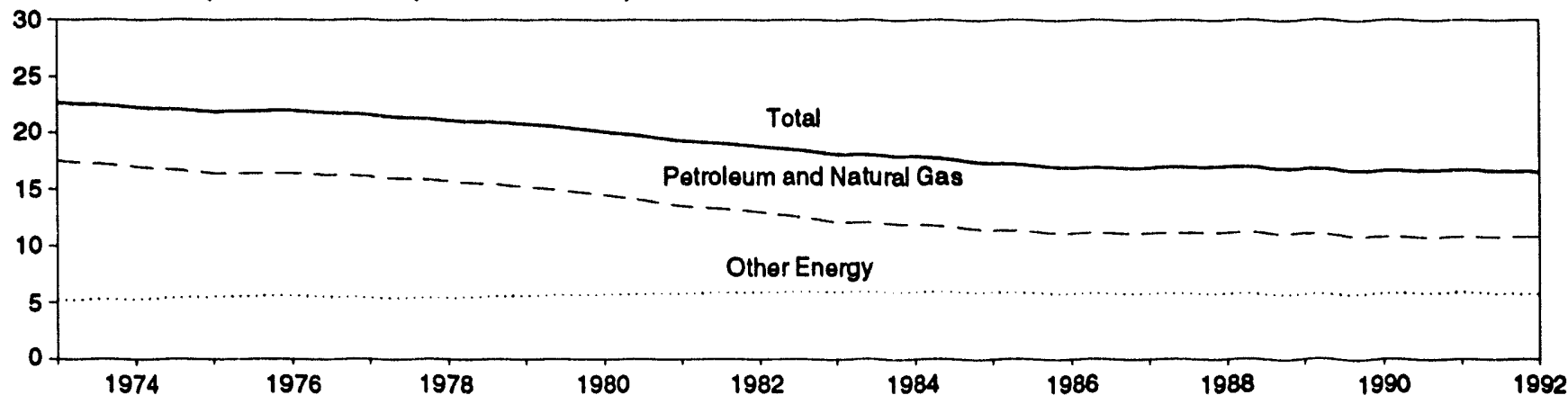

Source: Table 1.7.

Table 1.7 Energy Consumption per Dollar of Gross Domestic Product (Seasonally Adjusted at Annual Rates)

\begin{tabular}{|c|c|c|c|c|c|c|c|}
\hline & \multicolumn{3}{|c|}{ Energy Consumption } & \multirow{3}{*}{$\begin{array}{c}\begin{array}{c}\text { Gross } \\
\text { Domestle } \\
\text { Product } \\
\text { (GDP) }\end{array} \\
\begin{array}{c}\text { Trillion } \\
1987 \text { Dollars }\end{array} \\
\end{array}$} & \multicolumn{3}{|c|}{ Energy Consumption per Dollar of GDP } \\
\hline & $\begin{array}{c}\text { Petroloum } \\
\text { and } \\
\text { Natural Gas }\end{array}$ & $\begin{array}{l}\text { Other } \\
\text { Energy }\end{array}$ & Totala & & $\begin{array}{c}\text { Potroleum } \\
\text { and } \\
\text { Natural Gas }\end{array}$ & $\begin{array}{c}\text { Other } \\
\text { Energy }\end{array}$ & Total \\
\hline & \multicolumn{3}{|c|}{ Quadrillion Btu } & & \multicolumn{3}{|c|}{ Thousand Btu per 1987 Dollar } \\
\hline 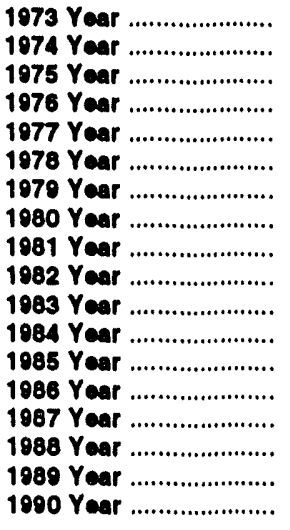 & $\begin{array}{l}\mathbf{5 7 . 3 5 2} \\
\mathbf{5 5 . 1 8 7} \\
\mathbf{5 2 . 6 7 8} \\
\mathbf{5 5 . 5 2 0} \\
\mathbf{5 7 . 0 5 3} \\
\mathbf{5 7 . 9 6 6} \\
\mathbf{5 7 . 7 8 9} \\
\mathbf{5 4 . 5 9 6} \\
\mathbf{5 1 . 8 5 9} \\
\mathbf{4 8 . 7 3 6} \\
\mathbf{4 7 . 4 1 1} \\
\mathbf{4 9 . 5 5 8} \\
\mathbf{4 8 . 7 5 6} \\
\mathbf{4 8 . 9 0 4} \\
\mathbf{5 0 . 6 0 9} \\
\mathbf{5 2 . 7 7 4} \\
\mathbf{5 3 . 5 9 5} \\
\mathbf{5 2 . 8 4 9}\end{array}$ & $\begin{array}{l}16.930 \\
17.356 \\
17.868 \\
18.842 \\
10.235 \\
20.123 \\
21.109 \\
21.359 \\
22.131 \\
22.112 \\
23.113 \\
24.586 \\
25.225 \\
25.393 \\
26.285 \\
27.444 \\
27.730 \\
28.416\end{array}$ & $\begin{array}{l}74.282 \\
72.543 \\
70.546 \\
74.362 \\
76.288 \\
78.089 \\
78.898 \\
75.955 \\
73.990 \\
70.848 \\
70.524 \\
74.144 \\
73.981 \\
74.287 \\
76.894 \\
80.218 \\
81.325 \\
81.265\end{array}$ & $\begin{array}{l}3.269 \\
3.248 \\
3.222 \\
3.381 \\
3.533 \\
3.704 \\
3.797 \\
3.776 \\
3.843 \\
3.760 \\
3.907 \\
4.149 \\
4.280 \\
4.405 \\
4.540 \\
4.710 \\
4.838 \\
4.897\end{array}$ & $\begin{array}{l}17.5 \\
17.0 \\
16.4 \\
16.4 \\
16.1 \\
15.7 \\
15.2 \\
14.5 \\
13.5 \\
13.0 \\
12.1 \\
11.0 \\
11.4 \\
11.1 \\
11.1 \\
11.2 \\
11.1 \\
10.8\end{array}$ & $\begin{array}{l}5.2 \\
5.3 \\
5.5 \\
5.6 \\
5.4 \\
5.4 \\
5.6 \\
5.7 \\
5.8 \\
5.0 \\
5.9 \\
5.0 \\
5.0 \\
5.8 \\
5.8 \\
5.6 \\
5.7 \\
5.8\end{array}$ & $\begin{array}{l}22.7 \\
22.3 \\
21.9 \\
22.0 \\
21.6 \\
21.1 \\
20.8 \\
20.1 \\
19.3 \\
18.8 \\
18.1 \\
17.0 \\
17.3 \\
16.0 \\
16.0 \\
17.0 \\
18.8 \\
18.6\end{array}$ \\
\hline $\begin{array}{l}19011^{\text {st }} \text { Quarter ............ } \\
2^{\text {nd }} \text { Quarter ........... } \\
3^{\text {rd }} \text { Quarter ............ } \\
4^{\text {th }} \text { Quarter ............ } \\
\text { Year ...................... }\end{array}$ & $\begin{array}{l}52.305 \\
51.934 \\
52.687 \\
52.869 \\
\mathbf{5 2 . 4 5 2}\end{array}$ & $\begin{array}{l}28.372 \\
29.116 \\
28.771 \\
28.399 \\
28.664\end{array}$ & $\begin{array}{l}80.677 \\
81.050 \\
81.458 \\
81.268 \\
81.116\end{array}$ & $\begin{array}{l}4.838 \\
4.856 \\
4.873 \\
4.880 \\
4.861\end{array}$ & $\begin{array}{l}10.8 \\
10.7 \\
10.8 \\
10.8 \\
10.8\end{array}$ & $\begin{array}{l}5.9 \\
6.0 \\
5.9 \\
5.8 \\
5.0\end{array}$ & $\begin{array}{l}16.7 \\
16.7 \\
16.7 \\
16.7 \\
16.7\end{array}$ \\
\hline $\begin{array}{r}19021^{\text {st }} \text { Quarter ............ } \\
2^{\text {nd }} \text { Quarter ........... } \\
3^{\text {rd }} \text { Quarter ............ } \\
4^{\text {th }} \text { Quarter ............ } \\
\text { Year ....................... }\end{array}$ & $\begin{array}{l}A_{53.705} \\
A_{53.987} \\
A_{52.819} \\
A_{54.073} \\
53.645\end{array}$ & $\begin{array}{r}P_{28.134} \\
P_{28.596} \\
P_{28.345} \\
29.077 \\
A_{28.539}\end{array}$ & $\begin{array}{l}{ }^{A} 81.839 \\
{ }^{R} 82.583 \\
A_{81.164} \\
{ }^{A} 83.150 \\
{ }^{A} 82.184\end{array}$ & $\begin{array}{l}4.922 \\
4.957 \\
4.998 \\
5.068 \\
4.986\end{array}$ & $\begin{array}{l}10.9 \\
10.9 \\
10.6 \\
10.7 \\
10.8\end{array}$ & $\begin{array}{l}5.7 \\
5.8 \\
5.7 \\
5.7 \\
5.7\end{array}$ & $\begin{array}{r}16.6 \\
\text { ค }_{16.7} \\
\text { ค } 16.2^{16.2} \\
16.4 \\
18.5\end{array}$ \\
\hline $\begin{array}{c}10031^{\text {st }} \text { Quarter ............ } \\
2^{\text {nd }} \text { Quarter .......... } \\
3^{\text {rd }} \text { Quarter ........... }\end{array}$ & $\begin{array}{l}P_{55.853} \\
P_{53.158} \\
P_{54.286}\end{array}$ & $\begin{array}{l}R_{29.525} \\
P_{29.990} \\
R_{29.454}\end{array}$ & $\begin{array}{l}R_{85.378} \\
R_{83.148} \\
R_{83.740}\end{array}$ & $\begin{array}{r}5.078 \\
5.102 \\
R_{5.138}\end{array}$ & $\begin{array}{l}11.0 \\
10.4 \\
10.6\end{array}$ & $\begin{array}{l}5.8 \\
5.9 \\
5.7\end{array}$ & $\begin{array}{l}16.8 \\
16.3 \\
16.3\end{array}$ \\
\hline
\end{tabular}

axcludes wood, waste, geothermal, wind, photovoltaic, and solar thermal energy, except for small amounts used by electric utilities to generate electricily for distribution.

$R=$ Revised data.

Notes: - Quarterty data are seasonally adjusted and shown at annual rates. - Geographic coverage is the $\mathbf{5 0}$ States and the District of Columbla. - Tolals may not equal sum of components due to independent rounding.
- Yearly data may not equal average of quarters due to seasonality adjustments and independent roundir $y$.

Sources: - Energy Consumption: Table 1.4. - Grose Domestle Product: 1073-1001-U.S. Department of Commerce, Bureau of Economic Analysis, Survey of Current Business, Seplember 1993, Table 2. 1092 forward-U.S. Department of Commerce, Bureau of Economic Analysis, United States Department of Commerce News, December 22, 1993, Table 2. 


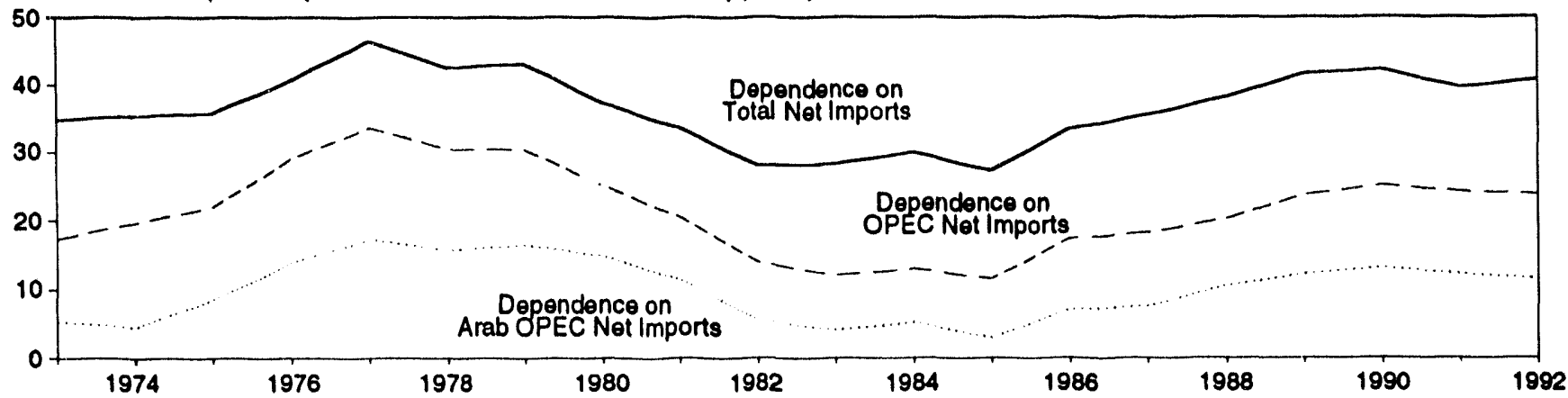

Source: Table 1.8

Table 1.8 U.S. Dependence on Petroleum Net Imports

\begin{tabular}{|c|c|c|c|c|c|c|c|}
\hline \multirow{3}{*}{ Annual Rate } & \multicolumn{3}{|c|}{ Not Importsa } & \multirow{3}{*}{$\begin{array}{l}\text { Potroleum } \\
\text { Products } \\
\text { Supplied }\end{array}$} & \multicolumn{3}{|c|}{$\begin{array}{l}\text { Not Imports as Percent of } \\
\text { U.S. Potroloum Products Supplled }\end{array}$} \\
\hline & $\begin{array}{c}\text { From Arab } \\
\text { OPEC }\end{array}$ & $\begin{array}{l}\text { From } \\
\text { OPECC }\end{array}$ & $\begin{array}{c}\text { From All } \\
\text { Countrles }\end{array}$ & & $\begin{array}{c}\text { From Arab } \\
\text { OPECb }\end{array}$ & $\begin{array}{l}\text { From } \\
\text { OPEC }\end{array}$ & $\begin{array}{c}\text { From All } \\
\text { Countries }\end{array}$ \\
\hline & \multicolumn{3}{|c|}{ Thousand Barrels per Day } & & \multicolumn{3}{|c|}{ Percent } \\
\hline 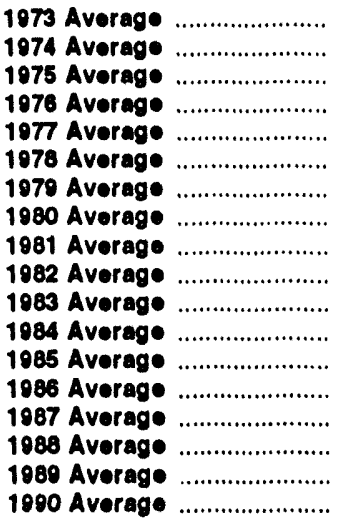 & $\begin{array}{r}914 \\
752 \\
1,382 \\
2,423 \\
3,164 \\
2,962 \\
3,054 \\
2,549 \\
1,844 \\
852 \\
630 \\
817 \\
470 \\
1,160 \\
1,272 \\
1,837 \\
2,128 \\
2,243\end{array}$ & $\begin{array}{l}2,991 \\
3,277 \\
3,599 \\
5,063 \\
6,190 \\
5,747 \\
5,633 \\
4,293 \\
3,315 \\
2,136 \\
1,843 \\
2,037 \\
1,821 \\
2,828 \\
3,053 \\
3,513 \\
4,124 \\
4,285\end{array}$ & $\begin{array}{l}6,025 \\
5,892 \\
5,846 \\
7,090 \\
8,565 \\
8,002 \\
7,985 \\
6,365 \\
5,401 \\
4,298 \\
4,312 \\
4,715 \\
4,286 \\
5,439 \\
5,014 \\
6,587 \\
7,202 \\
7,161\end{array}$ & $\begin{array}{l}17,308 \\
16,653 \\
16,322 \\
17,461 \\
18,431 \\
18,847 \\
18,513 \\
17,056 \\
16,058 \\
15,296 \\
15,231 \\
15,726 \\
15,726 \\
16,281 \\
16,665 \\
17,283 \\
17,325 \\
16,988\end{array}$ & $\begin{array}{r}5.3 \\
4.5 \\
8.5 \\
13.9 \\
17.3 \\
15.7 \\
16.5 \\
14.0 \\
11.5 \\
5.6 \\
4.1 \\
5.2 \\
3.0 \\
7.1 \\
7.6 \\
10.6 \\
12.3 \\
13.2\end{array}$ & $\begin{array}{l}17.3 \\
10.7 \\
22.0 \\
29.0 \\
33.6 \\
30.5 \\
30.4 \\
25.2 \\
20.6 \\
14.0 \\
12.1 \\
13.0 \\
11.6 \\
17.4 \\
18.3 \\
20.3 \\
23.8 \\
25.2\end{array}$ & $\begin{array}{l}34.8 \\
35.4 \\
35.8 \\
40.6 \\
46.5 \\
42.5 \\
43.1 \\
37.3 \\
33.6 \\
28.1 \\
28.3 \\
30.0 \\
27.3 \\
33.4 \\
35.5 \\
38.1 \\
41.6 \\
42.2\end{array}$ \\
\hline 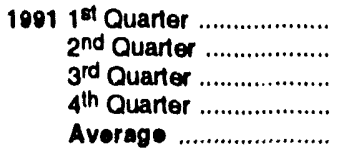 & $\begin{array}{l}1,978 \\
2,253 \\
2,026 \\
1,971 \\
2,057\end{array}$ & $\begin{array}{l}3,727 \\
4,301 \\
4,252 \\
3,974 \\
4,064\end{array}$ & $\begin{array}{l}5,686 \\
7,127 \\
7,224 \\
6,452 \\
6,626\end{array}$ & $\begin{array}{l}16,486 \\
16,400 \\
17,002 \\
16,959 \\
16,714\end{array}$ & $\begin{array}{l}12.0 \\
13.7 \\
11.9 \\
11.6 \\
12.3\end{array}$ & $\begin{array}{l}22.6 \\
26.2 \\
25.0 \\
23.4 \\
24.3\end{array}$ & $\begin{array}{l}34.5 \\
43.5 \\
42.5 \\
38.0 \\
39.6\end{array}$ \\
\hline 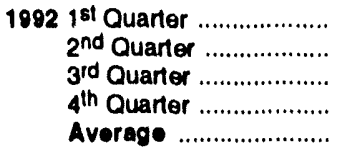 & $\begin{array}{l}2,052 \\
1,922 \\
1,910 \\
2,005 \\
1,972\end{array}$ & $\begin{array}{l}3,783 \\
4,056 \\
4,230 \\
4,210 \\
4,071\end{array}$ & $\begin{array}{l}6,239 \\
7,027 \\
7,451 \\
7,029 \\
6,936\end{array}$ & $\begin{array}{l}16,910 \\
16,740 \\
16,984 \\
17,493 \\
17,033\end{array}$ & $\begin{array}{l}12.1 \\
11.5 \\
11.2 \\
11.5 \\
11.6\end{array}$ & $\begin{array}{l}22.4 \\
24.2 \\
24.9 \\
24.1 \\
23.9\end{array}$ & $\begin{array}{l}36.9 \\
42.0 \\
43.9 \\
40.2 \\
40.7\end{array}$ \\
\hline 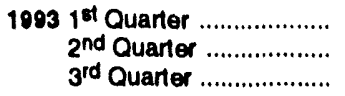 & $\begin{array}{l}2,025 \\
2,053 \\
1,907\end{array}$ & $\begin{array}{l}4,311 \\
4,352 \\
4,129\end{array}$ & $\begin{array}{l}7,038 \\
7,507 \\
7,750\end{array}$ & $\begin{array}{l}17,126 \\
16,678 \\
17,360\end{array}$ & $\begin{array}{l}11.8 \\
12.3 \\
11.0\end{array}$ & $\begin{array}{l}25.2 \\
26.1 \\
23.8\end{array}$ & $\begin{array}{l}41.1 \\
45.0 \\
44.6\end{array}$ \\
\hline
\end{tabular}

a "Net Imports" are imports minus exports. Imports from members of the Organization of Petroleum Exporting Countries (OPEC) exclude indirect imports, which are petroleum products primarily from Caribbean and West European areas and relined from crude oil produced by OPEC.

b The Arab members of OPEC are Algeria, Iraq, Kuwait, Libya, Qatar, Saudi Arabla, and the United Arab Emirates. Net imports from the Neutral Zone between Kuwalt and Saudi Arabia are included in net imports trom Arab OPEC.

c OPEC currently consists of Gabon, Indonesia, Iran, Nigeria, and Venezuela, as well as the Arab members.

Notes: - Beginning in October 1977, Strategic Petroleum Reserves are included. - Geographic coverage is the 50 States and the District of Columbia. - Annual averages may not equal average of quarters due to independent rounding.

Sources: - Imports: Tables 3.3a-3.3h. - Exports: 1973-1976-U.S. Department of the Interior, Bureau of Mines, Mineral Industry Surveys. 1077-1980-Energy Intormalion Administration (ElA), Energy Data Reports, "Petroleum Statement, Annual." 1081-1902-ElA, Petroleum Supply Annual. 1093 forward-EIA, Petroloum Supply Monthly. - Potroloum Products Supplled: Table 3.1a. 
Figure 1.8 Cost of Fuels to End Users in Constant (1982-84) Dollars

(Dollars per Million Btu)

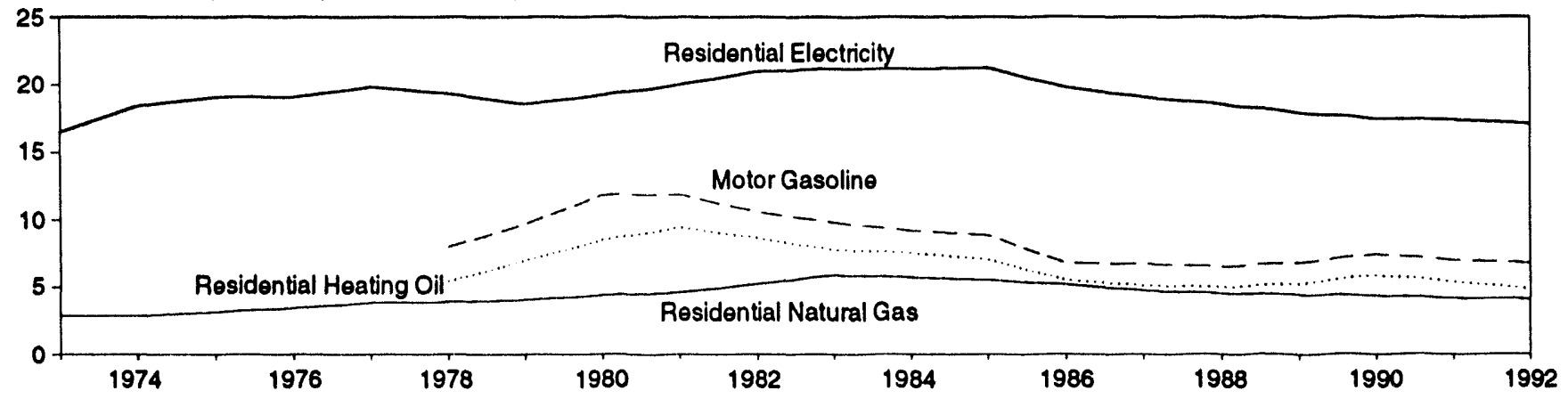

Source: Table 1.9.

Table 1.9 Cost of Fuels to End Users in Constant (1982-84) Dollars

\begin{tabular}{|c|c|c|c|c|c|c|c|c|}
\hline & \multicolumn{2}{|c|}{ Motor Gasollne } & \multicolumn{2}{|c|}{$\begin{array}{l}\text { Rosidental } \\
\text { Heating OII }\end{array}$} & \multicolumn{2}{|c|}{$\begin{array}{l}\text { Residential } \\
\text { Natural Ges } \\
\end{array}$} & \multicolumn{2}{|c|}{$\begin{array}{l}\text { Rosidontial } \\
\text { Eloctriclty }\end{array}$} \\
\hline & $\begin{array}{l}\text { Cents per } \\
\text { Gallon }\end{array}$ & $\begin{array}{l}\text { Dollars per } \\
\text { Million Btu }\end{array}$ & $\begin{array}{l}\text { Cents per } \\
\text { Gallon }\end{array}$ & $\begin{array}{l}\text { Dollars per } \\
\text { Million Blu }\end{array}$ & $\begin{array}{l}\text { Cents per } \\
\text { Thousand Cubic Feet }\end{array}$ & $\begin{array}{l}\text { Dollars per } \\
\text { Million Btu }\end{array}$ & $\begin{array}{l}\text { Cents per } \\
\text { Kilowatthour }\end{array}$ & $\begin{array}{l}\text { Dollars per } \\
\text { Million Btu }\end{array}$ \\
\hline 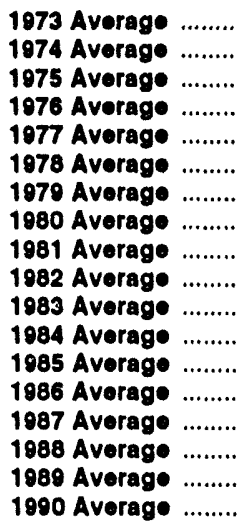 & $\begin{array}{l}\text { NA } \\
\text { NA } \\
\text { NA } \\
\text { NA } \\
\text { NA } \\
100.0 \\
121.5 \\
148.2 \\
148.8 \\
132.7 \\
123.0 \\
115.3 \\
111.2 \\
84.9 \\
84.2 \\
81.4 \\
85.5 \\
93.1\end{array}$ & $\begin{array}{l}\text { NA } \\
\text { NA } \\
\text { NA } \\
\text { NA } \\
\text { NA } \\
8.00 \\
9.71 \\
11.85 \\
11.90 \\
10.61 \\
9.83 \\
9.22 \\
8.89 \\
6.79 \\
6.74 \\
6.51 \\
6.83 \\
7.44\end{array}$ & $\begin{array}{l}\text { NA } \\
\text { NA } \\
\text { NA } \\
\text { NA } \\
\text { NA } \\
75.2 \\
97.0 \\
118.2 \\
131.4 \\
120.2 \\
108.2 \\
105.0 \\
97.9 \\
76.3 \\
70.7 \\
68.7 \\
72.6 \\
81.3\end{array}$ & $\begin{array}{l}\text { NA } \\
\text { NA } \\
\text { NA } \\
\text { NA } \\
\text { NA } \\
5.42 \\
6.99 \\
8.52 \\
9.47 \\
8.67 \\
7.80 \\
7.57 \\
7.06 \\
5.50 \\
5.10 \\
4.96 \\
5.23 \\
5.86\end{array}$ & $\begin{array}{l}290.5 \\
290.1 \\
317.8 \\
348.0 \\
387.8 \\
392.6 \\
410.5 \\
446.6 \\
471.9 \\
535.8 \\
608.4 \\
589.0 \\
568.8 \\
531.8 \\
487.7 \\
462.4 \\
454.8 \\
443.8\end{array}$ & $\begin{array}{l}2.85 \\
2.83 \\
3.12 \\
3.41 \\
3.81 \\
3.86 \\
4.03 \\
4.36 \\
4.60 \\
5.22 \\
5.90 \\
5.72 \\
5.52 \\
5.17 \\
4.73 \\
4.49 \\
4.41 \\
4.31\end{array}$ & $\begin{array}{l}5.6 \\
6.3 \\
6.3 \\
6.5 \\
6.5 \\
6.8 \\
6.8 \\
6.6 \\
6.3 \\
6.6 \\
6.8 \\
7.2 \\
7.2 \\
7.2 \\
7.2 \\
7.2 \\
5.8 \\
6.5 \\
6.3 \\
6.1 \\
6.0\end{array}$ & $\begin{array}{l}16.50 \\
18.43 \\
19.07 \\
19.06 \\
19.83 \\
19.33 \\
18.57 \\
19.21 \\
19.00 \\
20.96 \\
21.10 \\
21.16 \\
21.25 \\
19.70 \\
19.00 \\
18.58 \\
17.96 \\
17.49\end{array}$ \\
\hline $\begin{array}{r}10911^{\text {st }} \text { Quarter ..... } \\
2^{\text {nd }} \text { Quarter .... } \\
3^{\text {rd }} \text { Quarter .... } \\
4^{\text {th }} \text { Quarter .... } \\
\text { Average ........ }\end{array}$ & $\begin{array}{l}90.0 \\
88.1 \\
87.3 \\
86.1 \\
87.8\end{array}$ & $\begin{array}{l}7.19 \\
7.04 \\
6.98 \\
6.88 \\
7.02\end{array}$ & $\begin{array}{l}81.7 \\
68.5 \\
64.2 \\
69.7 \\
74.8\end{array}$ & $\begin{array}{l}5.89 \\
4.94 \\
4.63 \\
5.03 \\
5.39\end{array}$ & $\begin{array}{l}413.2 \\
470.5 \\
524.5 \\
416.8 \\
427.3\end{array}$ & $\begin{array}{l}4.01 \\
4.57 \\
5.09 \\
4.04 \\
4.14\end{array}$ & $\begin{array}{l}5.6 \\
6.0 \\
6.1 \\
5.8 \\
5.9\end{array}$ & $\begin{array}{l}16.52 \\
17.72 \\
18.01 \\
17.03 \\
17.43\end{array}$ \\
\hline $\begin{array}{r}19921^{\text {đd }} \text { Quarter ..... } \\
2^{\text {nd }} \text { Quarter .... } \\
3^{\text {1d }} \text { Quarter .... } \\
4^{\text {th }} \text { Quarter ..... } \\
\text { Average ........ }\end{array}$ & $\begin{array}{l}81.1 \\
85.3 \\
87.1 \\
85.6 \\
84.8\end{array}$ & $\begin{array}{l}6.49 \\
6.82 \\
6.96 \\
6.84 \\
6.78\end{array}$ & $\begin{array}{l}67.7 \\
66.0 \\
63.7 \\
66.5 \\
66.6\end{array}$ & $\begin{array}{l}4.88 \\
4.76 \\
4.59 \\
4.79 \\
4.80\end{array}$ & $\begin{array}{l}398.0 \\
443.5 \\
517.4 \\
429.2 \\
419.8\end{array}$ & $\begin{array}{l}3.86 \\
4.30 \\
5.02 \\
4.16 \\
4.07\end{array}$ & $\begin{array}{l}5.6 \\
5.9 \\
6.1 \\
5.8 \\
5.8\end{array}$ & $\begin{array}{l}16.48 \\
17.40 \\
17.89 \\
16.94 \\
17.13\end{array}$ \\
\hline $\begin{array}{c}19931^{\text {st }} \text { Quarter ..... } \\
2^{\text {nd }} \text { Quarter .... } \\
3^{\text {rd }} \text { Quarter ..... }\end{array}$ & $\begin{array}{l}81.9 \\
82.3 \\
80.3\end{array}$ & $\begin{array}{l}6.55 \\
6.58 \\
6.42\end{array}$ & $\begin{array}{r}66.2 \\
63.0 \\
R 58.7\end{array}$ & $\begin{array}{r}4.78 \\
4.54 \\
R_{4}^{4.23}\end{array}$ & $\begin{array}{l}397.6 \\
463.2 \\
544.9\end{array}$ & $\begin{array}{l}3.86 \\
4.49 \\
5.29\end{array}$ & $\begin{array}{l}5.5 \\
5.9 \\
6.0\end{array}$ & $\begin{array}{l}15.98 \\
17.28 \\
17.61\end{array}$ \\
\hline
\end{tabular}

$\mathrm{R}=\mathrm{R} \theta \mathrm{vised}$ data. $\mathrm{NA}=\mathrm{Not}$ available.

Notes: - Fuel costs are calculated by using the Urban Consumer Price Index (CPI) developed by the Bureau of Labor Statistics. See Note 6 at end of section. - Geographic coverage is the 50 States and the District of Columbia. - Annual averages may not equal average of quarters due to independent rounding.

Sources: - Annual Data: Annual prices in Tables 9.4 (All Types), 9.8c,
9.11, and 9.9 (Monthly Series), adjusted by the CPI. Q Quarterly Data: Simple averages of monthly prices in Tables 9.4 (All Types), 9.8c, 9.11, and 9.9 (Monthly Series), adjusted by the CPI. - CPI: 1073-1090-Economic Report of the President, February 1993. Table B-56. 1991 fonward-Council of Economic Advisers, Economic Indicators, December 1993, "Consumer Prices - All Urban Consumers." - Conversion Factors: Tables A1, A4, and A8. 
Figure 1.9 Passenger Car Efficiency

(Index, 1973 = 100)

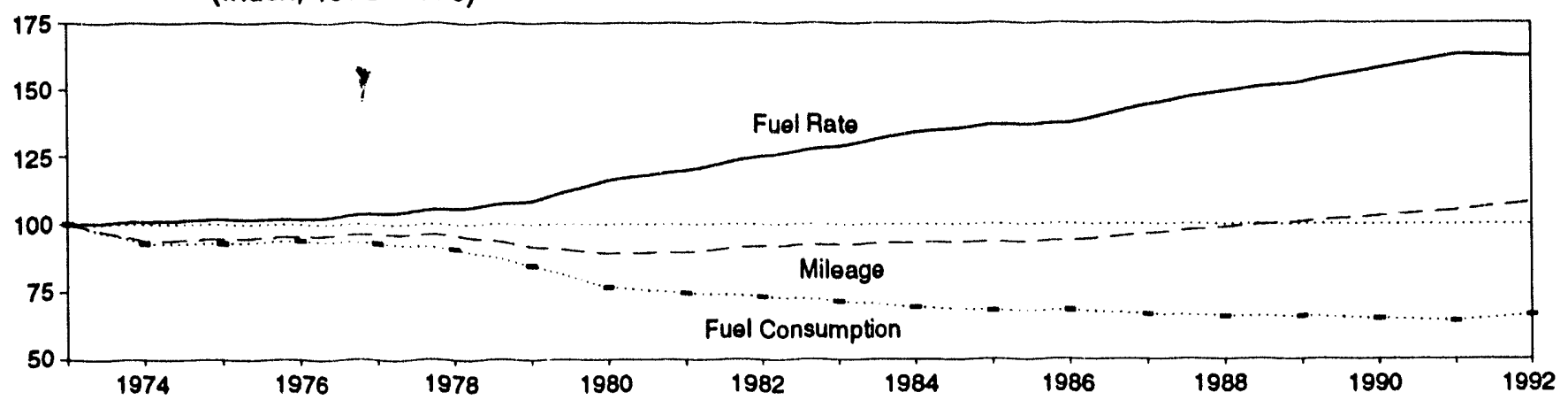

Source: Table 1.10

Table 1.10 Passenger Car Efficiency

\begin{tabular}{|c|c|c|c|c|c|c|}
\hline & \multicolumn{2}{|c|}{ Mlleage } & \multicolumn{2}{|c|}{ Fued Cunsumption } & \multicolumn{2}{|c|}{ Fuel Rato } \\
\hline & $\begin{array}{l}\text { Miles } \\
\text { per Car }\end{array}$ & $\begin{array}{c}\text { Index } \\
1973=100.0\end{array}$ & $\begin{array}{l}\text { Gallons } \\
\text { per Car }\end{array}$ & $\begin{array}{c}\text { Index } \\
1973=100.0\end{array}$ & $\begin{array}{c}\text { Miles } \\
\text { per Gallon }\end{array}$ & $\begin{array}{c}\text { Index } \\
1973=100.0\end{array}$ \\
\hline $\begin{array}{l}1973 \\
1974 \\
1975 \\
1976 \\
1077 \\
1978 \\
1979 \\
1980\end{array}$ & $\begin{array}{r}10,256 \\
9,606 \\
9,690 \\
9,785 \\
9,879 \\
9,835 \\
0,403 \\
0,141 \\
0,186 \\
9,428 \\
0,475 \\
0,558 \\
9,560 \\
9,608 \\
0,878 \\
10,121 \\
10,332 \\
10,548 \\
10,757 \\
11,063\end{array}$ & $\begin{array}{r}100.0 \\
93.7 \\
94.5 \\
95.4 \\
96.3 \\
95.9 \\
91.7 \\
89.1 \\
89.6 \\
91.9 \\
92.4 \\
93.2 \\
93.2 \\
93.7 \\
96.3 \\
98.7 \\
100.7 \\
102.8 \\
104.9 \\
107.9\end{array}$ & $\begin{array}{l}771 \\
716 \\
716 \\
723 \\
716 \\
701 \\
653 \\
591 \\
576 \\
566 \\
553 \\
536 \\
525 \\
526 \\
514 \\
509 \\
509 \\
502 \\
496 \\
512\end{array}$ & $\begin{array}{r}100.0 \\
92.0 \\
92.9 \\
93.8 \\
92.9 \\
90.9 \\
84.7 \\
76.7 \\
74.7 \\
73.4 \\
71.7 \\
69.5 \\
68.1 \\
68.2 \\
66.7 \\
66.0 \\
66.0 \\
65.1 \\
64.3 \\
66.4\end{array}$ & $\begin{array}{l}13.30 \\
13.42 \\
13.52 \\
13.53 \\
13.80 \\
14.04 \\
14.41 \\
15.46 \\
15.94 \\
16.65 \\
17.14 \\
17.83 \\
18.20 \\
18.27 \\
18.20 \\
19.87 \\
20.31 \\
21.02 \\
21.60 \\
21.60\end{array}$ & $\begin{array}{l}100.0 \\
100.9 \\
101.7 \\
101.7 \\
103.8 \\
105.6 \\
108.3 \\
116.2 \\
110.8 \\
125.2 \\
128.0 \\
134.1 \\
136.8 \\
137.4 \\
144.4 \\
149.4 \\
152.7 \\
158.0 \\
163.1 \\
162.4\end{array}$ \\
\hline
\end{tabular}

a Preliminary data.

Note: Geographic coverage is the 50 Stales and the District of Columbia.

Sources: Indices are prepared from slatistics published by the U.S.

Highway Statistics Division. - 1973-1985: Highway Statistics Summary to 1985, Table VM-201A. 1986 forward: Highway Statistics, annual, Table VM-1.

Department of Transportation, Federal Highway Administration, Federal 


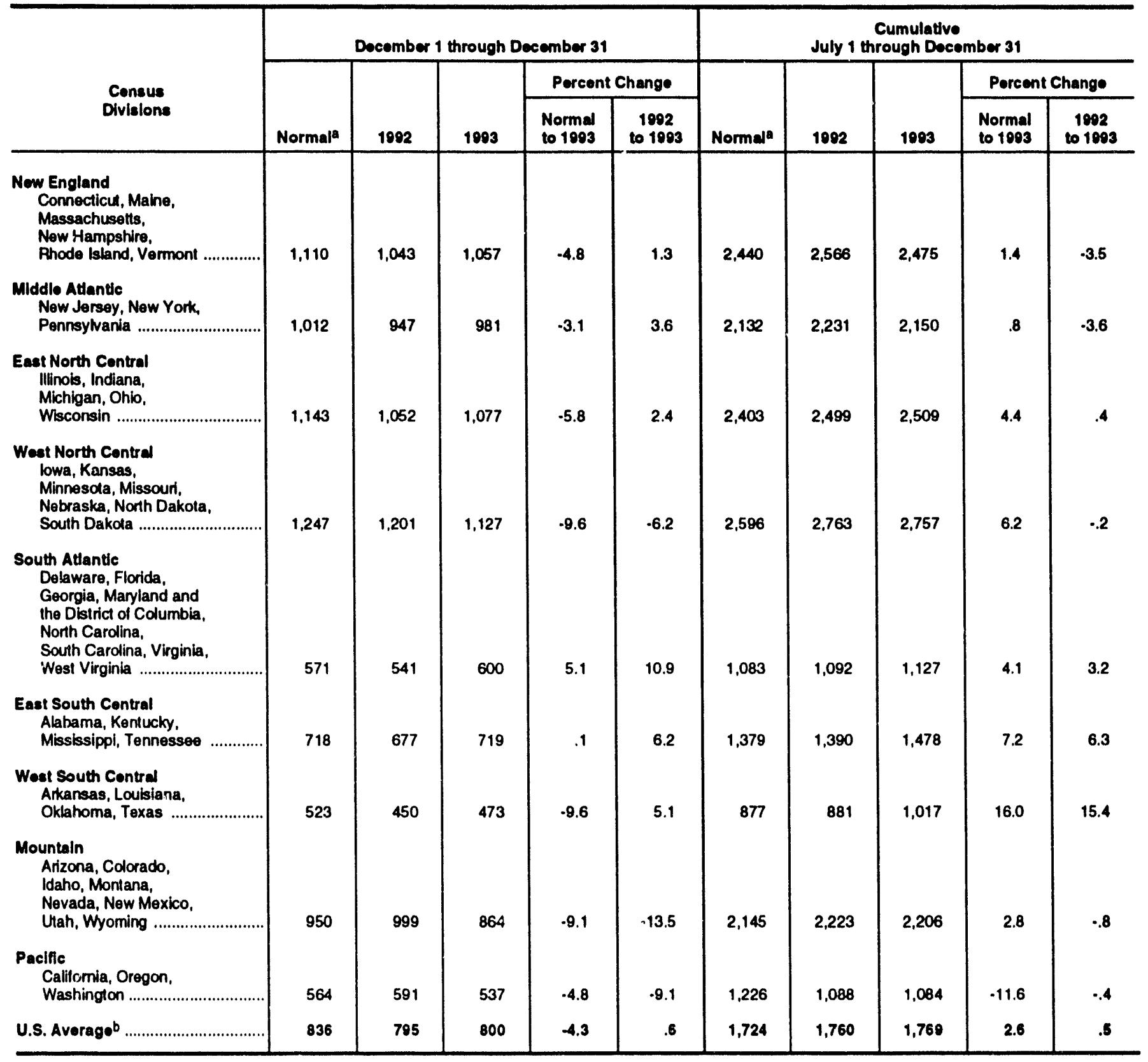

- "Normal" is based on calculations of data from 1861 through 1990.

bxcludes Alaska and Hawaii.

Source: Seo Nole 7 at end of section. 


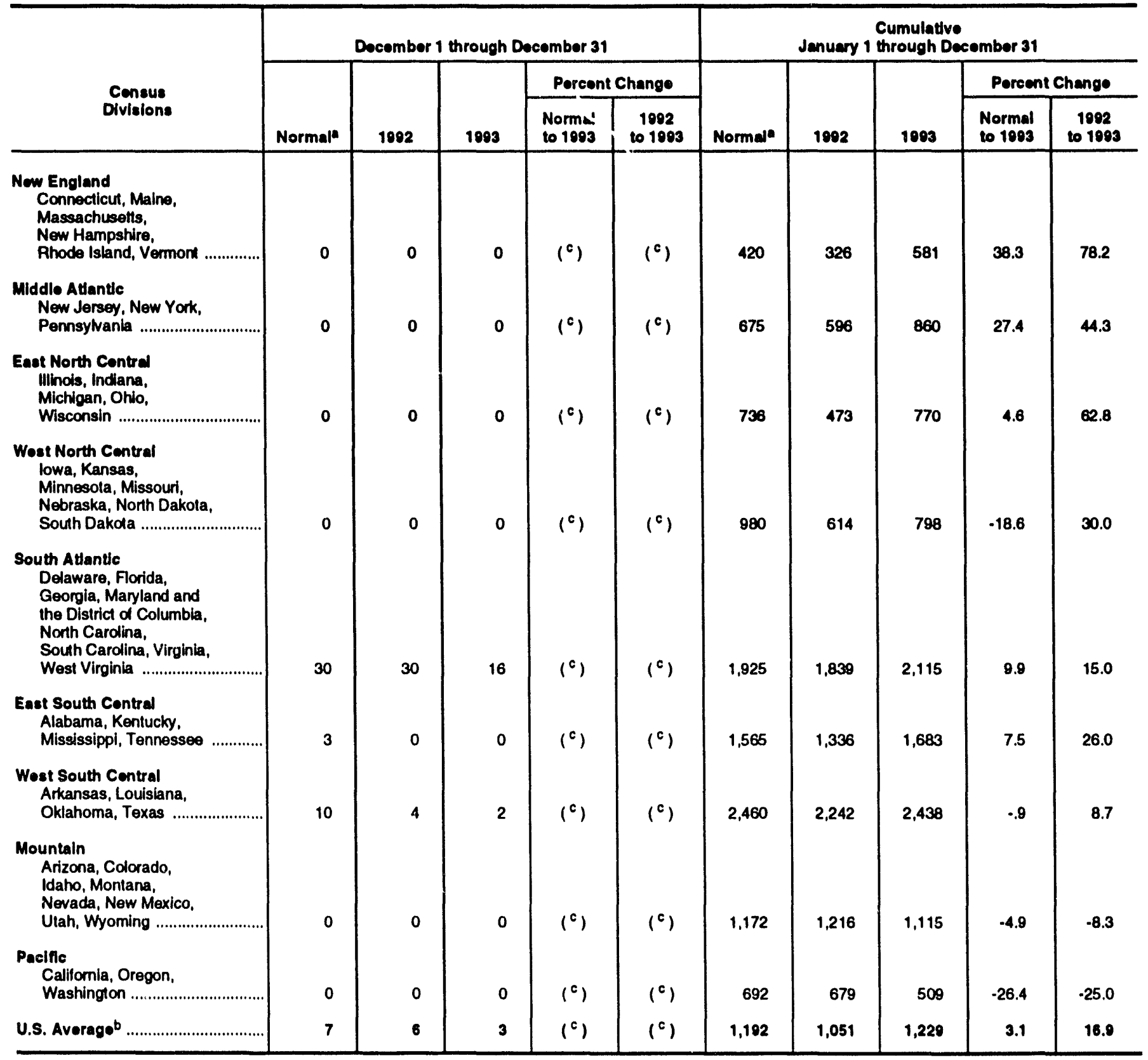

- "Normal" is based on calculations of data from 1961 through 1990.

incalculable.

b Exdudes Alaska and Hawaii.

Source: See Nole 7 at end of section.

c Percent change is nol meaninglul: normal is less than 100 or ratio is 


\section{Energy Summary Notes}

1. Energy Production: Production of energy includes production of coal, crude oil and lease condensate, natural gas plant liquids, naturai gas (dry), electric utility and industrial production of hydroelectric power, and electricity generated from nuclear power. Production also includes electricity generated for distribution from wood, waste, geothermal, wind, photovoltaic, and solar thernal energy but excludes other energy obtained from those sources because consistent historical data are not available. Approximate heat contents (Btu values) are derived by using the conversion factors provided in Appendix $\Lambda$.

2. Energy Consumption: Consumption of energy includes consumption of coal, natural gas (including supplemental gaseous fuels), petroleum products supplied, electric utility and industrial production of hydroelectric power, net imports of electricity (assumed to be hydroclectricity), net imports of coal coke, and electricity generated from nuclear power. Consumption also includes electricity generated for distribution from wood, waste, geothermal, wind, photovoltaic, and solar thermal energy but excludes other energy obtained from those sources because consistent historical data are not available. Approximate heat contents (Btu values) are derived by using the conversion factors provided in Appendix $\Lambda$.

3. Energy Imports: Energy imports include imports of coal, crude oil (including crude oil imported for the Strategic Petroleum Reserve), petroleum products, natural gas, electricity (assumed to be hydroclectricity), and coal coke. Approximate heat contents (Btu values) are derived by using the conversion factors provided in Appendix $\Lambda$. For further information on electricity, see "Note for imports and exports of electricity" under Note 8 of the Notes and Sources for the linergy Consumption Section.

4. Energy Exports: Energy exports include coal, crude oil, petroleum products, matural gas, electricity produced from hydroclectric power, and coal coke. Approximate heat contents (Btu values) are derived by using the conversion factors provided in $\Lambda$ ppendix $\Lambda$. For more information on electricity, see "Note for imports and exports of electricity" under Note 8 of the Notes and Sources for the Energy Consumption Section.

5. Merchandise Trade Value: Import datal presented are based on the customs value. That value dees not include insurance and freight and is consequently lower than the cost, insurance, and freight (CII) value, which is also reported by the Bureatu of the Census. All export data, and import data prior 10 1981, are on a free alongside ship (f.a.s.) hasis.

"Balance" is exports minus imports; a positive balance indicates a surplus trate value and a negative balance indicates a deficit trate value. "linergy" includes mineral fuels, lubricants, and related material. "NonEnergy Balance" and "Total Merchandise" include foreign exports (i.e., reexports) and nonmonetary gold and Department of Defense Grant-Aid shipments. The "Non-Energy Balance" is calculated by subtracting the "Energy" from the "Total Merchandise Balance."

"Imports" consist of government and nongovernment shipments of merchandise into the 50 States, the District of Columbia, Puerto Rico, the U.S. Virgin Islands, and the U.S. Foreign Trade Zones. They reflect the total arrival from foreign countries of merchandise that immediately entered consumption channels, warehouses, the Foreign Trade Zones, or the Strategic Petroleum Reserve. They exclude shipments between the United States, Puerto Rico, and U.S. possessions, shipments to U.S. Armed Forces and diplomatic missions abroad for their own use, U.S. goods returned to the United States by its Armed Forces, and in-transit shipments.

6. The Consumer Price Index: The values for the Consumer Price Index, All Urban Consumers, All Items, $1982-84=100$, are as follows:

$\begin{array}{lrlll}1973 & 44.4 & 1991 & \text { 1st Quarter } & 134.8 \\ 1974 & 49.3 & & \text { 2nd Quarter } & 135.6 \\ 1975 & 53.8 & & \text { 3rd Quarter } & 136.7 \\ 1976 & 56.9 & & 4 \text { hi Quarter } & 137.7 \\ 1977 & 60.6 & & \text { Year } & 136.2 \\ 1978 & 65.2 & 1992 & \text { 1st Quarter } & 138.7 \\ 1979 & 72.6 & & \text { 2nd Quarter } & 139.8 \\ 1980 & 82.4 & & \text { 3rd Quarter } & 140.9 \\ 1981 & 90.9 & & \text { 41h Quarter } & 141.9 \\ 1982 & 96.5 & & \text { Year } & 140.3 \\ 1983 & 99.6 & 1993 & \text { 1si Quarter } & 143.1 \\ 1984 & 103.9 & & \text { 2nd Quarter } & 144.2 \\ 1985 & 107.6 & \text { 3rd Quarter } & 144.8 \\ 1986 & 109.6 & & & \\ 1987 & 113.6 & & \end{array}$

7. Degree-Days: Degree-days are relative measurements of outdoor air temperature. Cooling degree-days are defined as deviations of the mean daily temperature at a siunpling station above a base temperature equal to $65^{\circ} \mathrm{F}$ by convention. Heating degree-days are deviations of the mean daily temperature below $65^{\circ} \mathrm{F}$. For example, if a weather station recorded a mean daily temperature of $78^{\circ} \mathrm{F}$, cooling degree-days for that station would be 13 (and heating degree-days, 0). A weather station recording a mean daily temperature of $40^{\circ} \mathrm{F}$ would report 25 heating degree-days (and 0 cooling degree-days).

There are several degree-day databases maintained by the National oceanic and Aunospheric Administration. The information published in the Monthly Energy Review (MER) is developed by the National Weather Service Climate Analysis Center, Canp Springs, MD. The data are available weekly with monthly summaries and are hased on inean daily temperatures recorded at 
about 200 major weather stations around the country. The temperature information recorded at those weather stations is used to calculate statewide degree-day averages based on population. The State figures are then aggregated into Census Divisions and into the national average. The population weights currently used represent resident State population data estimated for 1990 by the U.S. Department of Commerce, Bureau of the Census. The data shown in the MER are available sooner than the Historical Climatology Series 5-1 and 5-2 developed by the National Climatic Center, Asheville, NC, which compiles data from some 8,000 weather stations.

\section{Sources for Table 1.6}

U.S. Department of Commerce, Bureau of the Census, Foreign Trade Division:

- Petroleum Exports-1974-1987: "U.S. Exports," FT410, December issues. 1988: "Report on U.S. Merchandise Trade, 1988 Final Revisions." 1989: "Report on U.S. Merchandise Trade, 1989 Revisions." 1990: "U.S. Merchandise Trade, 1990 Final Report." 1991: "U.S. Merchandise Trade, 1991 Final Report," May 13, 1992. 1992: "U.S. Merchandise Trade, 1992 Final Report," May 12, 1993. 1993: "U.S. Merchandise Trade," FT900, monthly.

- Petroleum Imports-1974-1987: "U.S. Merchandise Trade," FT900, December issues, 1975-1988. 1988: "Report on U.S. Merchandise Trade, 1988 Final Revisions." 1989: "Report on U.S. Merchandise Trade, 1989 Revisions." 1990: "U.S. Merchandise
Trade, 1990 Final Report." 1991: "U.S. Merchandise Trade, 1991 Final Report," May 13, 1992, and "U.S. Merchandise Trade, October 1992," December 17, 1992, page 3. 1992: "U.S. Merchandise Trade, 1992 Final Report," May 12, 1993. 1993: "U.S. Merchandise Trade," FT900, monthly.

- Energy Exports and Imports-1974-1987: U.S. merchandise trade press releases and database printouts for adjustments. 1988: January-July, monthly FT900 supplement, 1989 issues. August-December, monthly FT900, 1989 issues. 1989: Monthly FT900, 1990 issues. 1990: "U.S. Merchandise Trade, 1990 Final Report." 1991: "U.S. Merchandise Trade, 1991 Final Report," May 13, 1992, and "U.S. Merchandise Trade, October 1992," December 17, 1992, page 3. 1992: "U.S. Merchandise Trade, 1992 Final Report," May 12, 1993. 1993: "U.S. Merchandise Trade," FT900, monthly.

- Total Merchandise-1974-1987: U.S. merchandise trade press releases and database printouts for adjustments. 1988: "Report on U.S. Merchandise Trade, 1988 Final Revisions," August 18, 1989. 1989: "Report on U.S. Merchandise Trade, 1989 Revisions," July 10, 1990. 1990: "U.S. Merchandise Trade, 1990 Final Report," May 10, 1991, and "U.S. Merchandise Trade, December 1992," February 18, 1993, page 3. 1991-1992: "U.S. Merchandise Trade, 1992 Final Report," May 12, 1993. 1993: "U.S. Merchandise Trade," FTO00, monthly.

- Petroleum Balance, Energy Balance, and Non-Energy Balance-Calculated by the Energy Information Administration. 


\section{Section 2. Energy Consumption}

U.S. total energy consumption in October 1993 was 6.7 quadrillion Btu. Petroleum products accounted for 43 percent ${ }^{1}$ of the energy consumed in October 1993, while coal accounted for 24 percent and natural gas accounted for 23 percent.

Residential and commercial sector consumption was 2.1 quadrillion Btu in October 1993, up 2 percent from the October 1992 level. The sector accounted for 32 percent of October 1993 total consumption, about the same share as in October 1992.

Industrial sector consumption was 2.6 quadrillion Btu in October 1993, up 1 percent from the October 1992 level. The industrial sector accounted for 40 percent of October 1993 total consumption, up 1 percentage point from its 39-percent share in October 1992.
Transportation sector consumption of energy was 1.9 quadrillion Btu in October 1993, down 1 percent from the October 1992 level. The sector accounted for 28 percent of October 1993 total consumption, down 1 percentage point from its 29-percent share in October 1992.

Electric utility consumption of energy totaled 2.4 quadrillion Btu in October 1993, up 1 percent from the October 1992 level. Coal contributed 57 percent of the energy consumed by electric utilities in October 1993, while nuclear electric power contributed 20 percent; natural gas 10 percent; hydroelectric power 9 percent; petroleum 3 percent; and geothermal, wood, waste, wind, photovoltaic, and solar thermal energy, about 1 percent.

\section{Table 2.1 Energy Consumption Summary for October 1993} (Quadrillion Btu)

\begin{tabular}{|c|c|c|c|c|c|c|}
\hline \multirow[b]{2}{*}{ Energy Source } & \multicolumn{4}{|c|}{ End-Use Sectore } & \multirow[b]{2}{*}{$\begin{array}{l}\text { Electrle } \\
\text { Utilltles }\end{array}$} & \multirow[b]{2}{*}{ Total } \\
\hline & $\begin{array}{c}\text { and } \\
\text { Commercial }\end{array}$ & Industrial & Transportation & Totala & & \\
\hline 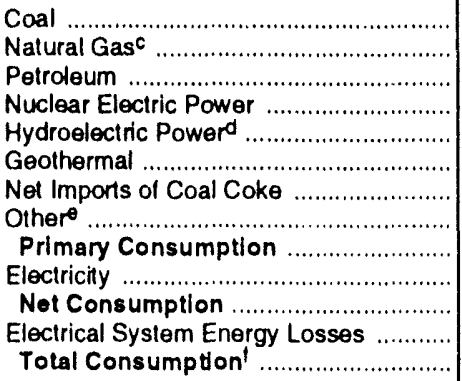 & $\begin{array}{r}0.010 \\
.437 \\
.176 \\
- \\
- \\
- \\
- \\
- \\
.623 \\
.494 \\
1.118 \\
1.006 \\
2.124\end{array}$ & $\begin{array}{r}0.217 \\
.779 \\
.774 \\
- \\
.002 \\
- \\
.001 \\
- \\
1.774 \\
.284 \\
2.058 \\
.579 \\
2.637\end{array}$ & $\begin{array}{r}\left({ }^{b}\right) \\
.045 \\
1.842 \\
- \\
- \\
- \\
- \\
- \\
1.887 \\
.001 \\
1.888 \\
.002 \\
1.891\end{array}$ & $\begin{array}{r}0.226 \\
1.262 \\
2.792 \\
- \\
.002 \\
- \\
.001 \\
- \\
4.284 \\
.780 \\
5.064 \\
1.588 \\
6.652\end{array}$ & $\begin{array}{r}1.349 \\
.238 \\
.080 \\
.477 \\
.208 \\
.013 \\
- \\
.002 \\
2.368 \\
- \\
- \\
- \\
-\end{array}$ & $\begin{array}{r}1.576 \\
1.501 \\
2.871 \\
.477 \\
.211 \\
.013 \\
.001 \\
.002 \\
6.652 \\
- \\
- \\
- \\
-\end{array}$ \\
\hline
\end{tabular}

a Totals for coal and natural gas may not equal sum of sectors due to the use of sector-specitic conversion tactors.

b Small amounts of coal consumed for Iransportation are reported as industrial sector consumption.

c Includes supplemental gaseous fuels. Transportation sector is pipeline luel only.

Includes net imports of electricity.

- "Other" is electricity generated lor distribution from wood, waste, wind, pholovoltaic, and solar thermal energy.

'Due to a lack of consistent hislorical dala, some renewable energy sources are not included. For example, in 1991, 3.3 quadrillion Btu of renewable energy consumed by U.S. electric utilities to generate electricity for distribution is included, but an estimated 3.4 quadrillion Btu of renewable energy used by other sectors is not included.

$-=$ Not applicable. $(s)=$ Less than +0.5 trillion Btu and greater than -0.5 trillion Btu.

Nole: Totals may not equal sum of components due to independent rounding.

Additional Notes and Sources: See Tables 2.2-2.6 and end of section.

\footnotetext{
'Percentage changes are based on numbers in the following tables.
} 
Figure 2.1 Energy Consumption by End-Use Sector

(Quadrillion Btu)

Consumption by End-Use Sector, 1973-1992

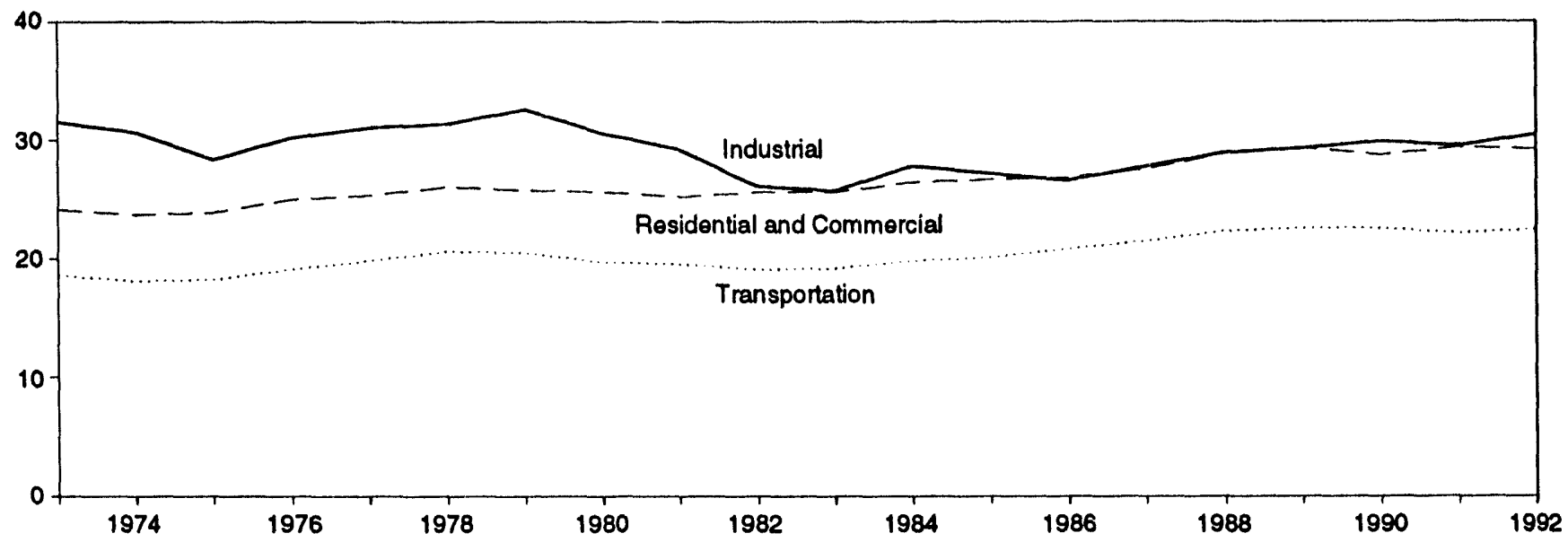

Consumption by End-Use Sector, Monthly

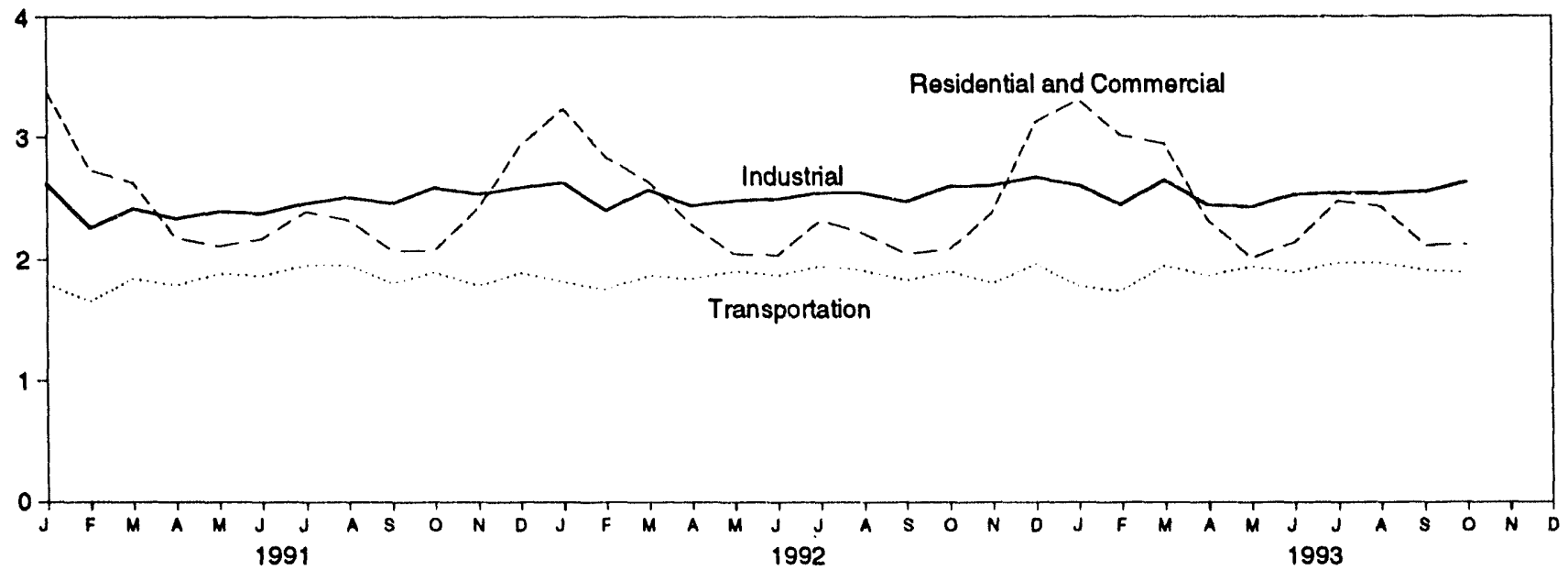

Consumption by End-Use Sector, October

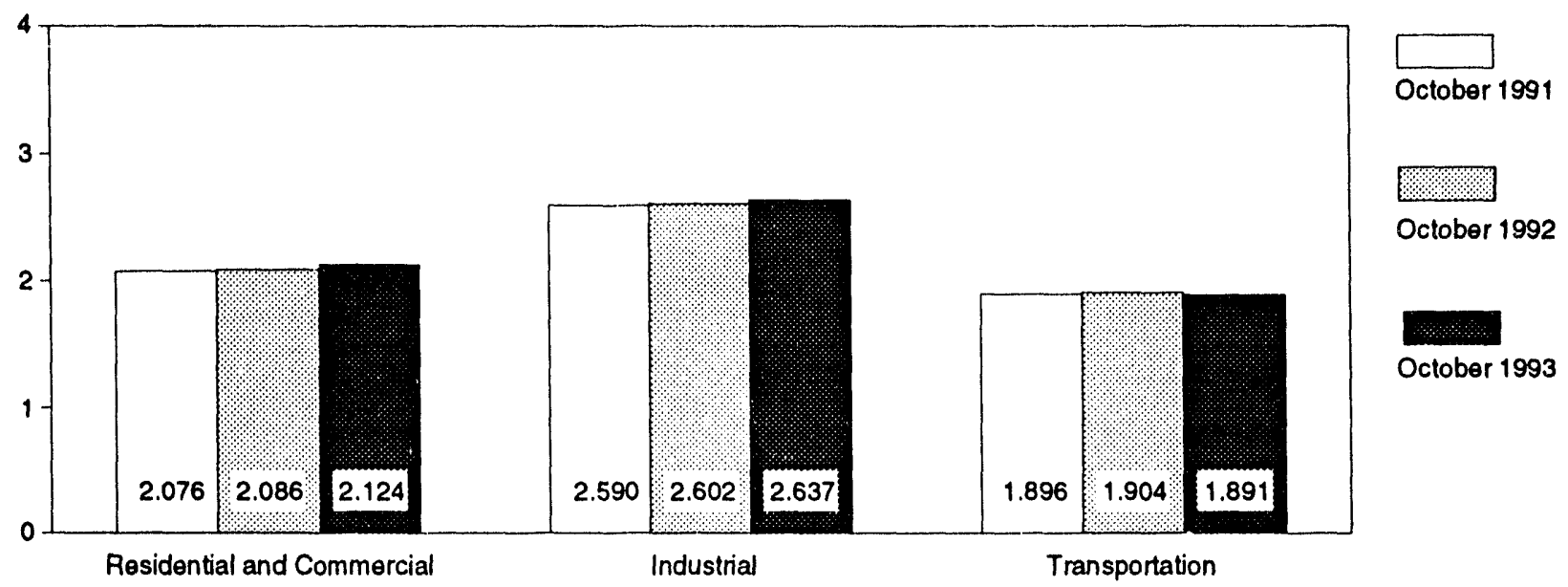

Note: Because vertical scales differ, graphs should not be compared.

Source: Table 2.2. 


\begin{tabular}{|c|c|c|c|c|c|c|c|c|}
\hline & \multicolumn{2}{|c|}{ Residential and Commercial } & \multicolumn{2}{|c|}{ Industrial } & \multicolumn{2}{|c|}{ Transportation } & \multirow[b]{2}{*}{ Not } & \multirow[b]{2}{*}{ Totala } \\
\hline & Not & Total & Not & Total & Not & Total & & \\
\hline 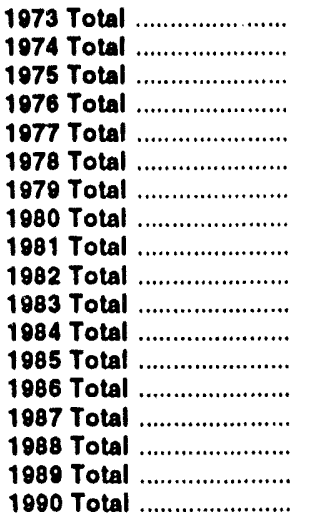 & $\begin{array}{l}15.766 \\
15.246 \\
15.200 \\
15.997 \\
15.828 \\
16.023 \\
15.709 \\
15.075 \\
14.541 \\
14.629 \\
14.395 \\
14.964 \\
14.839 \\
14.791 \\
15.146 \\
16.004 \\
16.261 \\
15.568\end{array}$ & $\begin{array}{l}24.143 \\
23.724 \\
23.900 \\
25.020 \\
25.387 \\
26.088 \\
25.809 \\
25.653 \\
25.243 \\
25.630 \\
25.630 \\
26.478 \\
26.704 \\
26.852 \\
27.621 \\
28.922 \\
29.402 \\
28.790\end{array}$ & $\begin{array}{l}25.917 \\
24.994 \\
22.737 \\
24.038 \\
24.593 \\
24.637 \\
25.679 \\
23.854 \\
22.533 \\
20.020 \\
10.401 \\
21.184 \\
20.520 \\
20.101 \\
21.116 \\
22.085 \\
22.272 \\
22.841\end{array}$ & $\begin{array}{l}31.528 \\
30.696 \\
28.401 \\
30.234 \\
31.075 \\
31.388 \\
32.615 \\
30.609 \\
29.238 \\
26.144 \\
25.756 \\
27.862 \\
27.213 \\
26.629 \\
27.828 \\
28.988 \\
28.355 \\
29.932\end{array}$ & $\begin{array}{l}18.584 \\
18.095 \\
18.210 \\
19.076 \\
19.794 \\
20.589 \\
20.447 \\
19.669 \\
19.480 \\
19.043 \\
19.109 \\
19.773 \\
20.036 \\
20.781 \\
21.410 \\
22.274 \\
22.530 \\
22.504\end{array}$ & $\begin{array}{l}18.605 \\
18.117 \\
18.244 \\
19.101 \\
19.810 \\
20.611 \\
20.472 \\
19.695 \\
19.507 \\
19.069 \\
19.135 \\
19.801 \\
20.067 \\
20.812 \\
21.448 \\
22.305 \\
22.561 \\
22.535\end{array}$ & $\begin{array}{l}60.274 \\
58.341 \\
56.157 \\
50.110 \\
60.223 \\
61.251 \\
61.836 \\
58.597 \\
56.556 \\
53.697 \\
52.007 \\
55.023 \\
55.391 \\
55.676 \\
57.678 \\
60.366 \\
61.070 \\
60.921\end{array}$ & $\begin{array}{l}74.282 \\
72.543 \\
70.546 \\
74.362 \\
76.288 \\
78.080 \\
78.898 \\
75.955 \\
73.990 \\
70.848 \\
70.524 \\
74.144 \\
73.981 \\
74.297 \\
76.894 \\
80.218 \\
81.325 \\
81.265\end{array}$ \\
\hline 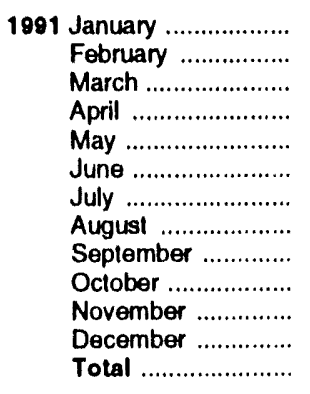 & $\begin{array}{r}2.141 \\
1.754 \\
1.585 \\
1.234 \\
1.024 \\
.972 \\
1.029 \\
1.002 \\
.982 \\
1.063 \\
1.406 \\
1.793 \\
15.986\end{array}$ & $\begin{array}{r}3.376 \\
2.729 \\
2.632 \\
2.179 \\
2.111 \\
2.171 \\
2.396 \\
2.327 \\
2.078 \\
2.076 \\
2.421 \\
2.928 \\
29.424\end{array}$ & $\begin{array}{r}2.048 \\
1.765 \\
1.856 \\
1.788 \\
1.757 \\
1.764 \\
1.822 \\
1.869 \\
1.906 \\
2.001 \\
1.960 \\
2.014 \\
22.549\end{array}$ & $\begin{array}{r}2.620 \\
2.261 \\
2.420 \\
2.339 \\
2.397 \\
2.381 \\
2.463 \\
2.511 \\
2.461 \\
2.590 \\
2.536 \\
2.591 \\
29.571\end{array}$ & $\begin{array}{r}1.795 \\
1.653 \\
1.842 \\
1.784 \\
1.882 \\
1.863 \\
1.952 \\
1.953 \\
1.802 \\
1.893 \\
1.783 \\
1.888 \\
22.090\end{array}$ & $\begin{array}{r}1.798 \\
1.655 \\
1.844 \\
1.786 \\
1.885 \\
1.866 \\
1.955 \\
1.956 \\
1.804 \\
1.896 \\
1.785 \\
1.891 \\
22.120\end{array}$ & $\begin{array}{r}5.984 \\
5.170 \\
5.280 \\
4.805 \\
4.663 \\
4.603 \\
4.808 \\
4.828 \\
4.690 \\
4.956 \\
5.146 \\
5.694 \\
60.626\end{array}$ & $\begin{array}{r}7.795 \\
6.643 \\
6.893 \\
6.302 \\
6.344 \\
6.421 \\
6.818 \\
6.798 \\
6.344 \\
6.561 \\
6.740 \\
7.408 \\
81.116\end{array}$ \\
\hline 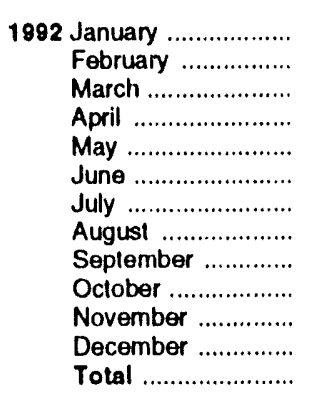 & $\begin{array}{r}2.040 \\
1.828 \\
1.610 \\
1.343 \\
1.060 \\
.943 \\
1.018 \\
.987 \\
.961 \\
1.096 \\
1.372 \\
1.919 \\
16.177\end{array}$ & 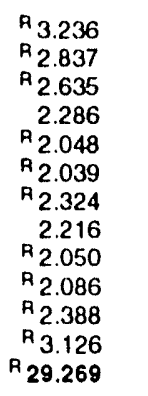 & $\begin{array}{r}2.060 \\
1.889 \\
1.997 \\
\text { ค } 1.895 \\
\text { म } 1.887 \\
1.864 \\
1.894 \\
\text { P } 1.922 \\
\text { म } 1895 \\
2.023 \\
2.014 \\
2.085 \\
\text { P3.425 }\end{array}$ & $\begin{array}{r}\mathrm{A}_{2} 2.630 \\
\mathrm{~A}_{2.405} \\
\mathrm{~A}_{2} .572 \\
\mathrm{~A}_{2.443} \\
2.485 \\
2.497 \\
2.549 \\
2.548 \\
\mathrm{~A}_{2} 2.476 \\
\mathrm{R}_{2} 2.602 \\
\mathrm{~A}_{2.609} \\
2.677 \\
\mathrm{~F}_{30.495}\end{array}$ & $\begin{array}{r}1.815 \\
1.750 \\
1.865 \\
1.838 \\
1.903 \\
1.866 \\
1.946 \\
1.907 \\
1.828 \\
1.902 \\
1.802 \\
1.963 \\
22.384\end{array}$ & $\begin{array}{r}1.817 \\
1.753 \\
1.868 \\
1.840 \\
1.906 \\
1.869 \\
1.948 \\
1.910 \\
1.830 \\
1.904 \\
1.804 \\
1.965 \\
22.414\end{array}$ & $\begin{array}{r}\mathrm{A}_{5} .913 \\
5.465 \\
5.470 \\
5.075 \\
4.850 \\
4.675 \\
\mathrm{P}_{4.862} \\
\mathrm{P}_{4.819} \\
4.687 \\
\mathrm{P}_{5.021} \\
5.187 \\
\mathrm{P}_{5.967} \\
\mathrm{R}_{61.892}\end{array}$ & 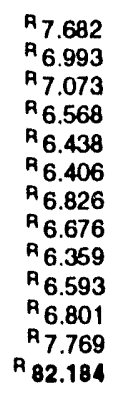 \\
\hline 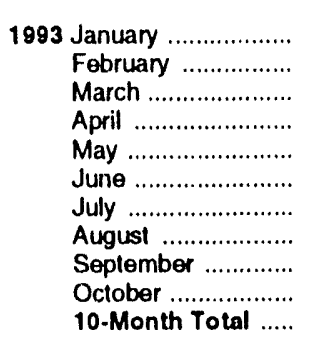 & $\begin{array}{r}2.099 \\
1.966 \\
1.853 \\
1.381 \\
1.022 \\
.979 \\
1.067 \\
R 1.046 \\
R 1.022 \\
1.118 \\
13.553\end{array}$ & $\begin{array}{r}R_{3.309} \\
R_{3} .016 \\
A_{2} .949 \\
A_{2} .319 \\
A_{2} .016 \\
A_{2} .143 \\
2.482 \\
R_{2} .437 \\
R_{2} .121 \\
2.124 \\
24.917\end{array}$ & $\begin{array}{r}R_{2} .037 \\
R_{1} .920 \\
2.032 \\
1.900 \\
1.821 \\
A_{1} 1.886 \\
R_{1} 1.893 \\
A_{1} 1.897 \\
A_{2} .011 \\
2.058 \\
19.506\end{array}$ & $\begin{array}{r}\mathrm{R}_{2.608} \\
\mathrm{~A}_{2} .453 \\
\mathrm{R}_{2} .652 \\
2.448 \\
\mathrm{~A}_{2.436} \\
2.533 \\
\mathrm{~A}_{2} .547 \\
\mathrm{R}_{2} .543 \\
\mathrm{~A}_{2.557} \\
2.637 \\
25.415\end{array}$ & $\begin{array}{r}1.776 \\
R 1.739 \\
\text { ค } 1.948 \\
1.865 \\
1.941 \\
1.891 \\
1.973 \\
1.969 \\
1.910 \\
1.888 \\
18.901\end{array}$ & $\begin{array}{r}1.778 \\
\text { ค } 1.742 \\
1.951 \\
1.868 \\
1.944 \\
1.894 \\
1.976 \\
1.972 \\
1.913 \\
1.891 \\
18.927\end{array}$ & $\begin{array}{r}R_{5} .912 \\
R_{5} 525 \\
A_{5.883} \\
A_{5} 5.144 \\
4.783 \\
P_{4.759} \\
R_{4.940} \\
R_{4.919} \\
A_{4.945} \\
5.064 \\
51.975\end{array}$ & $\begin{array}{r}R_{7.696} \\
R_{7.211} \\
R_{7.552} \\
R_{6.633} \\
R_{6.394} \\
6.573 \\
R_{7.011} \\
6.959 \\
6.593 \\
6.652 \\
69.274\end{array}$ \\
\hline $\begin{array}{l}1992 \text { 10-Month Total ..... } \\
1991 \text { 10-Month Total ..... }\end{array}$ & $\begin{array}{l}12.885 \\
12.787\end{array}$ & $\begin{array}{l}23.757 \\
24.076\end{array}$ & $\begin{array}{l}19.326 \\
18.576\end{array}$ & $\begin{array}{l}25.207 \\
24.444\end{array}$ & $\begin{array}{l}18.620 \\
18.419\end{array}$ & $\begin{array}{l}18.645 \\
18.444\end{array}$ & $\begin{array}{l}50.837 \\
49.786\end{array}$ & $\begin{array}{l}67.614 \\
66.968\end{array}$ \\
\hline
\end{tabular}

a Due to a lack of consistent historical data, some renewable energy sources are not included. For example, in 1991, 3.3 quadrillion Btu of renewable energy consumed by U.S. electric utilities to generate electricity for distribution is included, but an estimated 3.4 quadrillion Btu of renewable energy used by other sectors is not included.
$R=$ Revised data.

Notes: - Geographic coverage is the 50 States and the District of Columbia. - Tolals may not equal sum of components due to independent rourising and the use of sector-specitic conversion factors for natural gas and coal. Additional Notes and Sources: See end of section. 
Flgure 2.2 Residentlal and Commerclal Energy Consumption

(Quadrillion Btu)

Consumption by Major Sources, 1973-1992

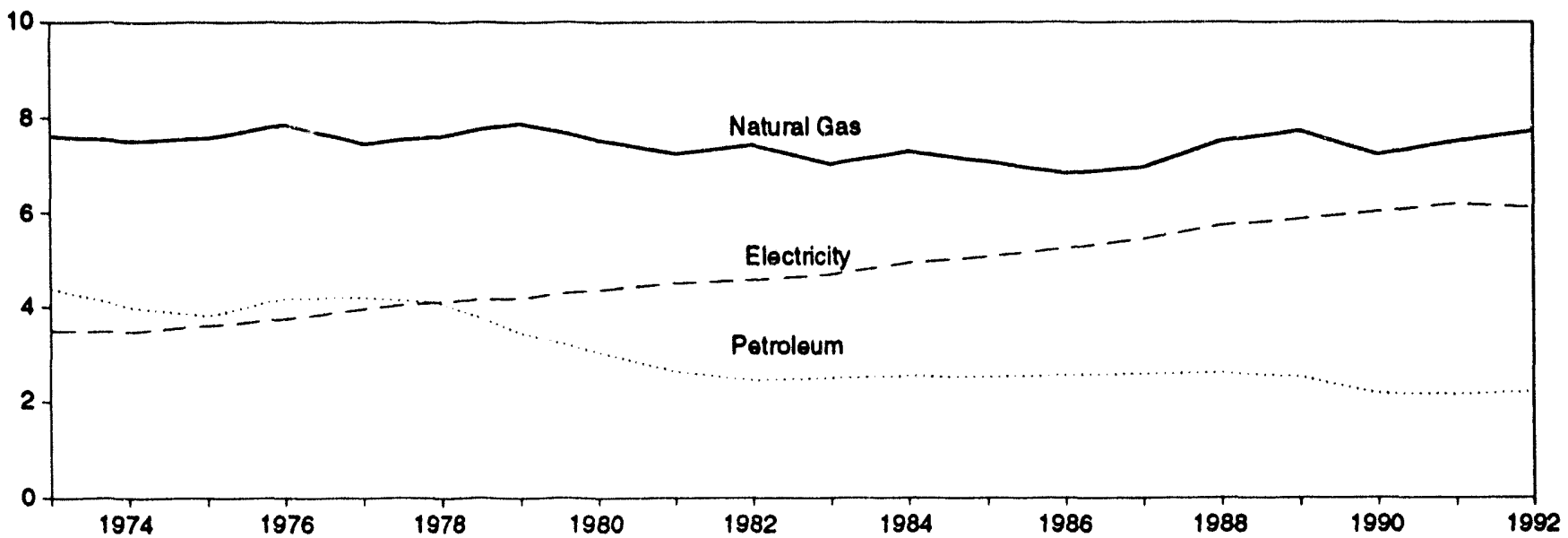

Consumption by Major Sources, Monthly

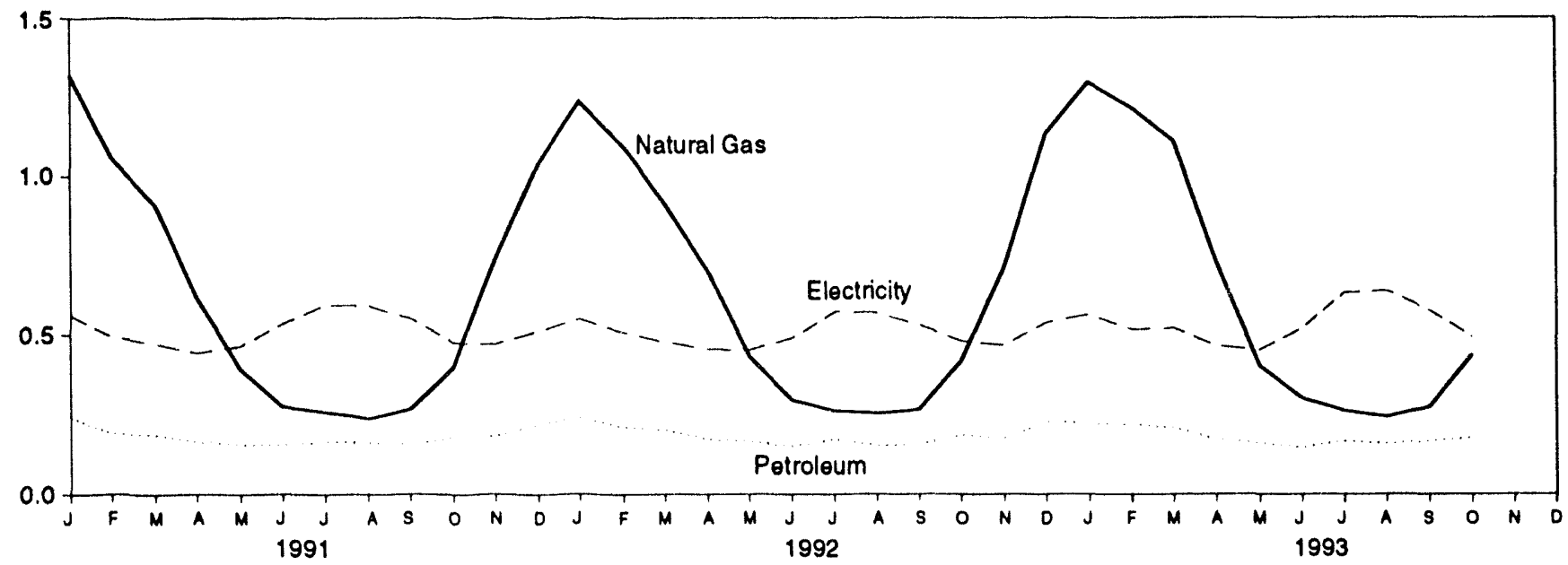

Tolal Consumption, January-October

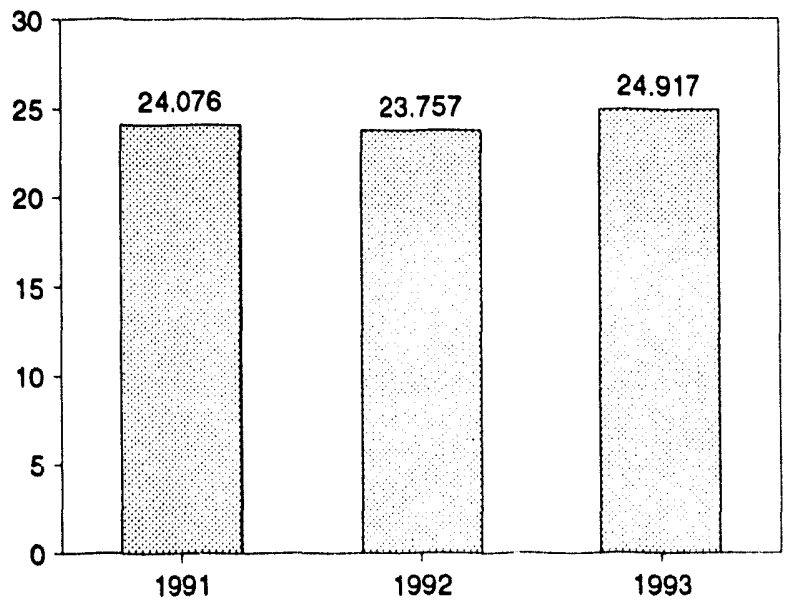

Consumption by Major Sources, October 1993

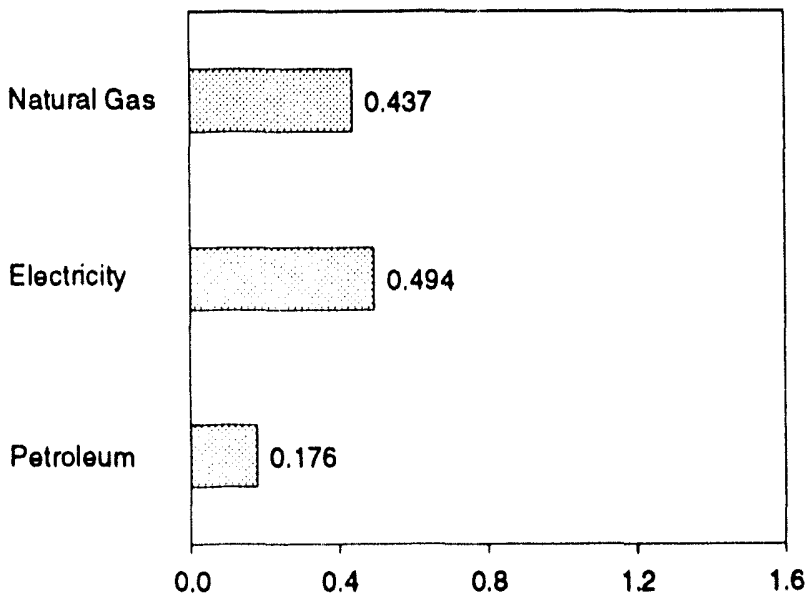

Nole: Because vertical scales ditfer, graphs should nol be compared. Source: Table 2.3. 
Table 2.3 Residential and Commercial Energy Consumption (Quadrillion Btu)

\begin{tabular}{|c|c|c|c|c|c|c|c|c|}
\hline & Coal & $\begin{array}{c}\text { Natural } \\
\text { Gasa }\end{array}$ & Potroleum & $\begin{array}{c}\text { Primary } \\
\text { Consumption }\end{array}$ & Electrlcity & $\begin{array}{c}\text { Not } \\
\text { Consumption }\end{array}$ & $\begin{array}{l}\text { Electrical } \\
\text { Bystem } \\
\text { Energy } \\
\text { Lossee }\end{array}$ & $\begin{array}{c}\text { Total } \\
\text { Conoumptionb }\end{array}$ \\
\hline 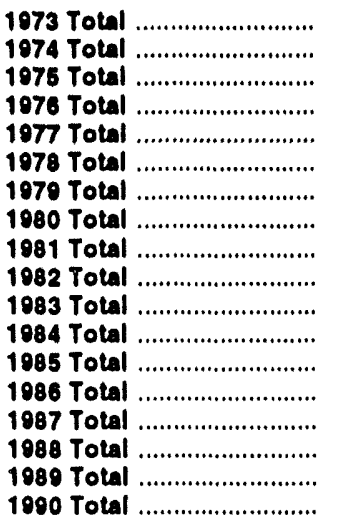 & $\begin{array}{l}0.254 \\
.257 \\
.200 \\
.203 \\
.205 \\
.214 \\
.187 \\
.145 \\
.167 \\
.187 \\
.182 \\
.209 \\
.176 \\
.176 \\
.162 \\
.168 \\
.146 \\
.156\end{array}$ & $\begin{array}{l}7.626 \\
7.618 \\
7.581 \\
7.868 \\
7.461 \\
7.624 \\
7.891 \\
7.540 \\
7.243 \\
7.427 \\
7.024 \\
7.292 \\
7.079 \\
6.825 \\
6.954 \\
7.513 \\
7.731 \\
7.225\end{array}$ & $\begin{array}{l}4.391 \\
3.996 \\
3.805 \\
4.181 \\
4.200 \\
4.070 \\
3.448 \\
3.035 \\
2.834 \\
2.449 \\
2.498 \\
2.535 \\
2.522 \\
2.555 \\
2.587 \\
2.600 \\
2.525 \\
2.173\end{array}$ & $\begin{array}{r}12.270 \\
11.771 \\
11.505 \\
12.250 \\
11.873 \\
11.008 \\
11.525 \\
10.721 \\
10.043 \\
10.063 \\
9.715 \\
10.036 \\
0.777 \\
9.556 \\
9.703 \\
10.280 \\
10.402 \\
9.553\end{array}$ & $\begin{array}{l}3.495 \\
3.475 \\
3.604 \\
3.747 \\
3.055 \\
4.116 \\
4.184 \\
4.355 \\
4.497 \\
4.586 \\
4.880 \\
4.028 \\
5.061 \\
5.235 \\
5.443 \\
5.724 \\
5.859 \\
6.015\end{array}$ & $\begin{array}{l}15.768 \\
18.246 \\
15.200 \\
15.097 \\
15.828 \\
16.023 \\
15.709 \\
15.075 \\
14.541 \\
14.620 \\
14.395 \\
14.064 \\
14.830 \\
14.791 \\
15.148 \\
18.004 \\
16.261 \\
15.568\end{array}$ & $\begin{array}{r}0.377 \\
8.478 \\
8.700 \\
9.023 \\
9.550 \\
10.065 \\
10.101 \\
10.578 \\
10.703 \\
11.001 \\
11.235 \\
11.514 \\
11.868 \\
12.061 \\
12.475 \\
12.018 \\
13.141 \\
13.221\end{array}$ & $\begin{array}{l}24.143 \\
23.724 \\
23.000 \\
25.020 \\
25.387 \\
28.088 \\
25.809 \\
25.853 \\
25.243 \\
25.630 \\
25.630 \\
26.476 \\
26.704 \\
26.852 \\
27.821 \\
28.022 \\
20.402 \\
28.700\end{array}$ \\
\hline 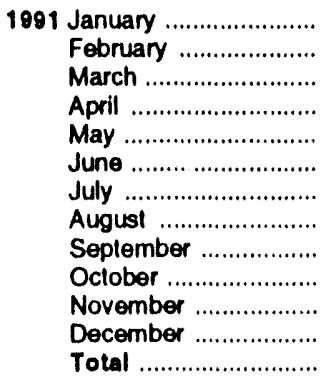 & $\begin{array}{l}.020 \\
.014 \\
.012 \\
.009 \\
.008 \\
.007 \\
.010 \\
.009 \\
.007 \\
.008 \\
.016 \\
.020 \\
.141\end{array}$ & $\begin{array}{r}1.317 \\
1.055 \\
.911 \\
.617 \\
.394 \\
.275 \\
.259 \\
.238 \\
.267 \\
.400 \\
.737 \\
1.040 \\
7.510\end{array}$ & $\begin{array}{l}.242 \\
.190 \\
.187 \\
.164 \\
.156 \\
.155 \\
.164 \\
.163 \\
.155 \\
.178 \\
.182 \\
.219 \\
2.154\end{array}$ & $\begin{array}{r}1.579 \\
1.259 \\
1.111 \\
.790 \\
.558 \\
.437 \\
.433 \\
.410 \\
.429 \\
.586 \\
.934 \\
1.279 \\
9.806\end{array}$ & $\begin{array}{l}.562 \\
.495 \\
.474 \\
.444 \\
.466 \\
.535 \\
.596 \\
.593 \\
.553 \\
.477 \\
.471 \\
.514 \\
6.180\end{array}$ & $\begin{array}{r}2.141 \\
1.754 \\
1.585 \\
1.234 \\
1.024 \\
.972 \\
1.029 \\
1.002 \\
.982 \\
1.063 \\
1.406 \\
1.793 \\
15.986\end{array}$ & $\begin{array}{r}1.236 \\
.975 \\
1.047 \\
.945 \\
1.088 \\
1.199 \\
1.367 \\
1.325 \\
1.096 \\
1.013 \\
1.015 \\
1.134 \\
13.438\end{array}$ & $\begin{array}{r}3.376 \\
2.729 \\
2.632 \\
2.179 \\
2.111 \\
2.171 \\
2.396 \\
2.327 \\
2.078 \\
2.076 \\
2.421 \\
2.928 \\
29.424\end{array}$ \\
\hline 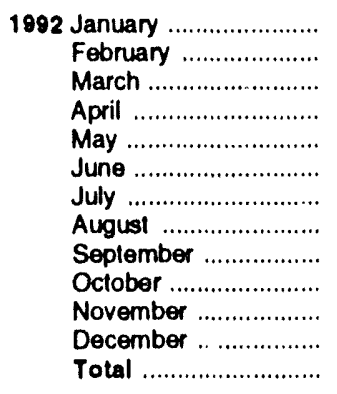 & $\begin{array}{r}.017 \\
\mathrm{R} .013 \\
.012 \\
.012 \\
.007 \\
.007 \\
.011 \\
.009 \\
.009 \\
\mathrm{R} .008 \\
.015 \\
.021 \\
\mathrm{R} \\
.142\end{array}$ & $\begin{array}{l}1.233 \\
1.095 \\
.916 \\
.703 \\
.434 \\
.296 \\
.262 \\
.254 \\
.266 \\
.419 \\
.714 \\
1.132 \\
7.726\end{array}$ & $\begin{array}{l}.240 \\
.211 \\
.202 \\
.172 \\
.165 \\
.150 \\
.172 \\
.153 \\
.155 \\
.186 \\
.175 \\
.227 \\
2.210\end{array}$ & $\begin{array}{r}1.490 \\
1.319 \\
1.131 \\
.887 \\
.607 \\
.453 \\
.445 \\
.417 \\
.429 \\
.614 \\
.904 \\
1.380 \\
10.078\end{array}$ & $\begin{array}{l}.550 \\
.509 \\
.479 \\
.456 \\
.453 \\
.490 \\
.573 \\
.570 \\
.532 \\
.482 \\
.468 \\
.539 \\
6.099\end{array}$ & $\begin{array}{r}2.040 \\
1.828 \\
1.610 \\
1.343 \\
1.060 \\
.943 \\
1.018 \\
.987 \\
.961 \\
1.096 \\
1.372 \\
1.919 \\
16.177\end{array}$ & 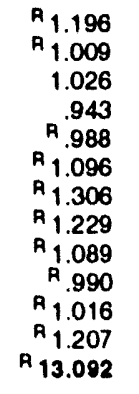 & $\begin{array}{r}A_{3.236} \\
A_{2} .837 \\
A_{2.635} \\
2.286 \\
A_{2} .048 \\
A_{2} 2.039 \\
A_{2.324} \\
2.216 \\
A_{2.050} \\
R_{2} 2.086 \\
A_{2.388} \\
A_{3.126} \\
A_{29.260}\end{array}$ \\
\hline 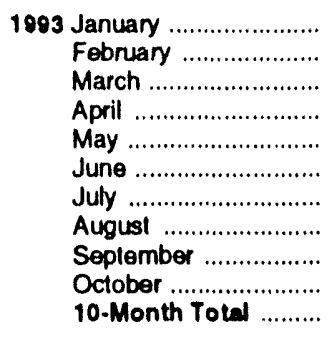 & $\begin{array}{r}.017 \\
.017 \\
.013 \\
.017 \\
.009 \\
.011 \\
\text { ค } 011 \\
\text { ค } .009 \\
\text { ค } .007 \\
.010 \\
.122\end{array}$ & $\begin{array}{r}1.294 \\
1.215 \\
1.110 \\
.729 \\
.402 \\
.300 \\
.261 \\
+.242 \\
.273 \\
.437 \\
6.264\end{array}$ & $\begin{array}{l}.223 \\
.218 \\
.208 \\
.170 \\
.159 \\
.147 \\
.165 \\
.157 \\
.165 \\
.176 \\
1.787\end{array}$ & $\begin{array}{r}1.534 \\
1.449 \\
1.332 \\
.916 \\
.570 \\
.458 \\
.436 \\
.408 \\
.408 \\
.445 \\
.623 \\
8.172\end{array}$ & $\begin{array}{l}.564 \\
.517 \\
.521 \\
.465 \\
.452 \\
.520 \\
.631 \\
.638 \\
.576 \\
.494 \\
5.380\end{array}$ & $\begin{array}{r}2.099 \\
1.966 \\
1.853 \\
1.381 \\
1.022 \\
.979 \\
1.067 \\
A_{1} 1.046 \\
P_{1.022} \\
1.118 \\
13.553\end{array}$ & $\begin{array}{r}{ }^{A} 1.210 \\
A_{1} 1.050 \\
A_{1} .096 \\
A_{1.938} \\
.994 \\
A_{1} .164 \\
A_{1.415} \\
A_{1} 1.391 \\
A_{1} 1.100 \\
1.006 \\
11.364\end{array}$ & $\begin{array}{r}A_{3.309} \\
A_{3.016} \\
A_{2.949} \\
A_{2.319} \\
R_{2.016} \\
A_{2.143} \\
2.482 \\
A_{2.437} \\
R_{2.121} \\
2.124 \\
24.917\end{array}$ \\
\hline $\begin{array}{l}109210-\text { Month Total ......... } \\
1091 \text { 10-Month Total ........ }\end{array}$ & $\begin{array}{l}.106 \\
.105\end{array}$ & $\begin{array}{l}5.879 \\
5.733\end{array}$ & $\begin{array}{l}1.808 \\
1.754\end{array}$ & $\begin{array}{l}7.793 \\
7.592\end{array}$ & $\begin{array}{l}5.093 \\
5.195\end{array}$ & $\begin{array}{l}12.885 \\
12.787\end{array}$ & $\begin{array}{l}10.872 \\
11.289\end{array}$ & $\begin{array}{l}23.757 \\
24.078\end{array}$ \\
\hline
\end{tabular}

\footnotetext{
- Includes supplemental gaseous fuels.

b Due to a lack of consistent historical data, some renewable energy sources are not included. For example, in 1991, an estimated 0.7 quadrillion Btu of renewable energy consumed by the U.S. residential and commercial sectors (primarity the residential sector) is not included.
}

$R=$ Revised data.

Noles: - Geographic coverage is the 50 States and the Distrid of Columbia. - Tolals may not equal sum of components due to independent rounding. Additional Noles and Sources: See end of section. 
Figure 2.3 Industrial Energy Consumption

(Quadrillion Btu)

Consumption by Major Sources, 1973-1992

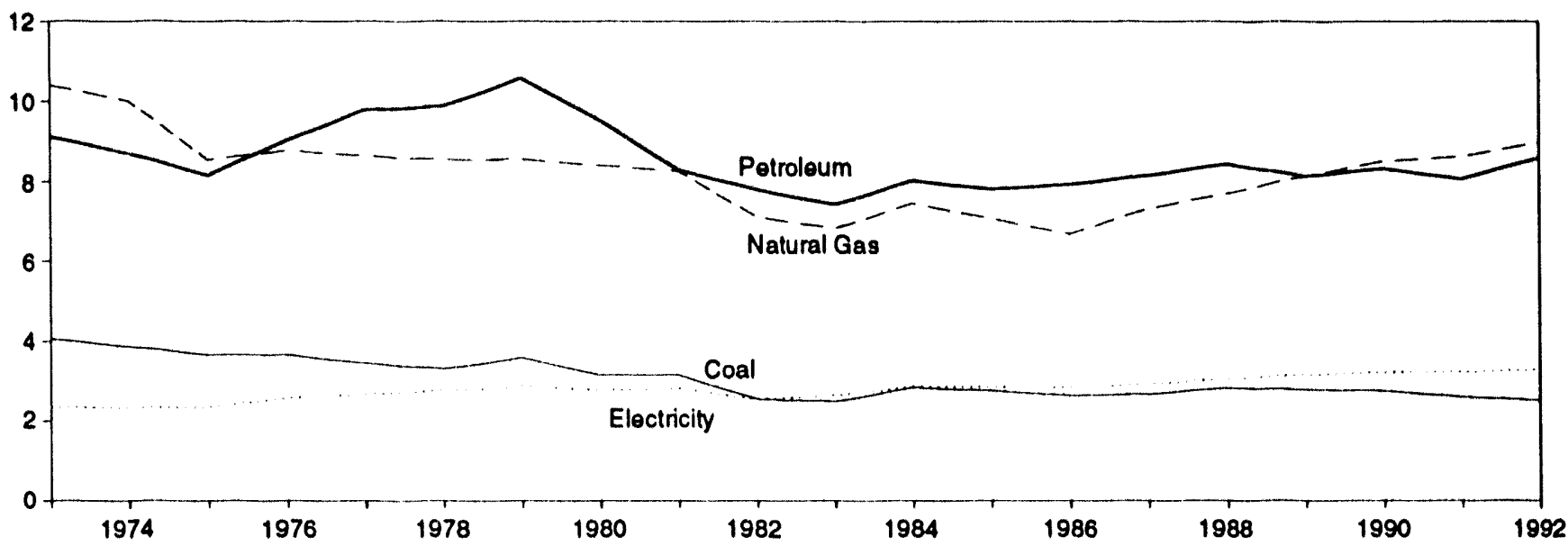

Consumption by Major Sources, Monthly

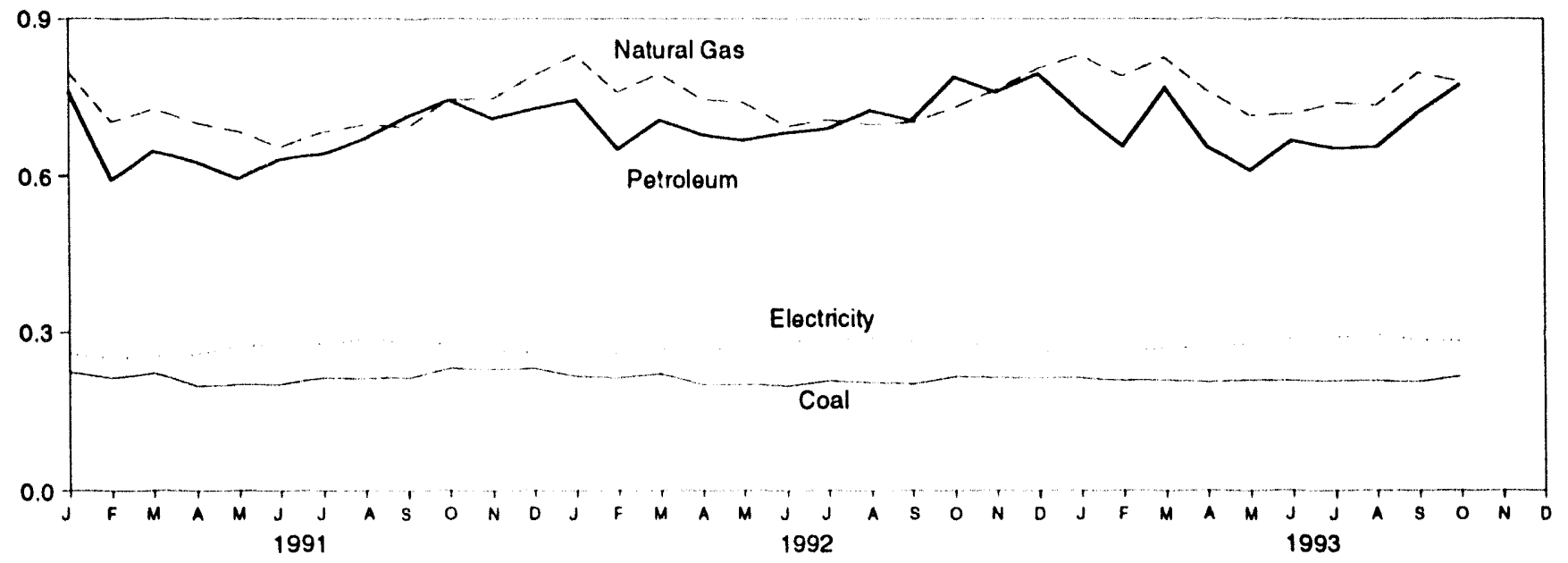

Total Consumption, January-October

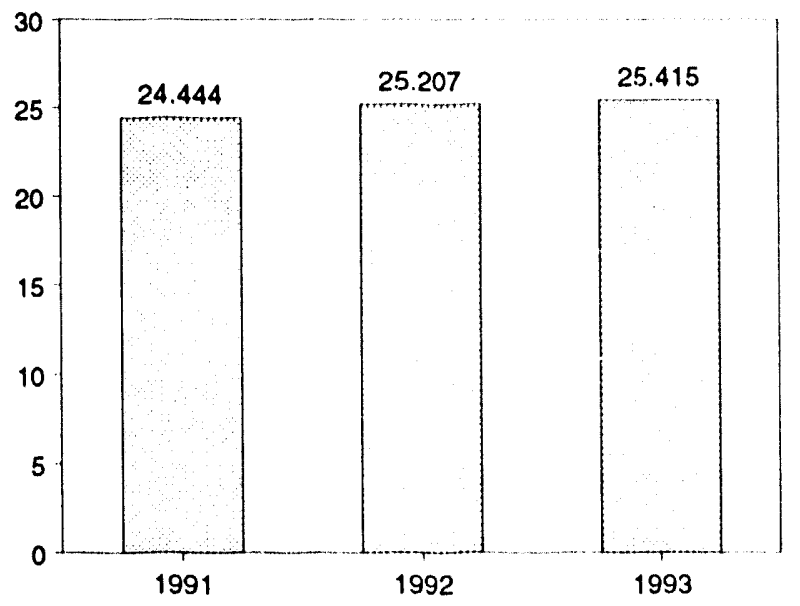

Consumption by Major Sources, October 1993

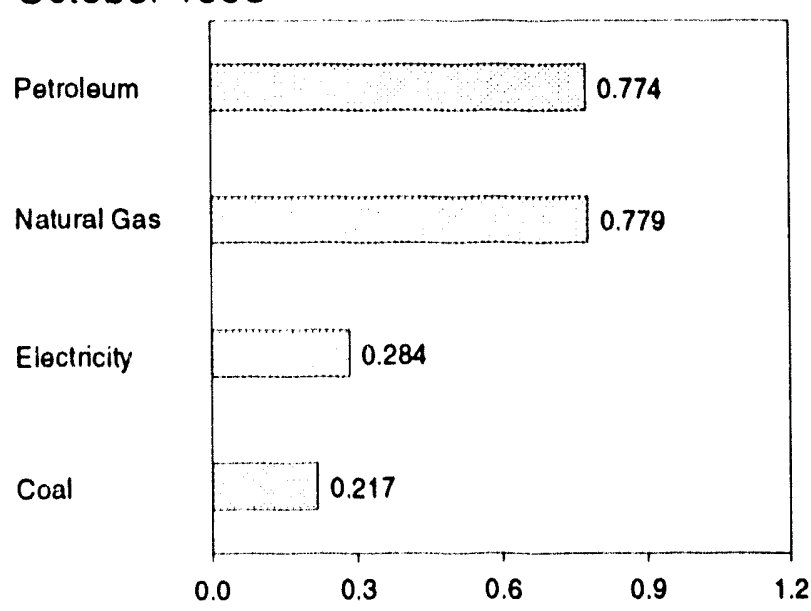

Note: Because vertical scales differ, graphs should not be compared. Source: Table 2.4. 
Table 2.4 Industrial Energy Consumption

(Quadrillion Btu)

\begin{tabular}{|c|c|c|c|c|c|c|c|c|c|c|}
\hline & Coal & $\begin{array}{c}\text { Natural } \\
\text { Gas }\end{array}$ & Potroleum & $\begin{array}{l}\text { Hydro- } \\
\text { electric } \\
\text { Power }\end{array}$ & $\begin{array}{c}\text { Not } \\
\text { Imports } \\
\text { of Coal } \\
\text { Coke }\end{array}$ & $\begin{array}{c}\text { Primary } \\
\text { Consumption }\end{array}$ & Electricity & $\begin{array}{c}\text { Nat } \\
\text { Consumption }\end{array}$ & $\begin{array}{c}\text { Eloctrical } \\
\text { Systom } \\
\text { Energy } \\
\text { Lossos }\end{array}$ & $\begin{array}{c}\text { Total } \\
\text { Consumptlon }\end{array}$ \\
\hline 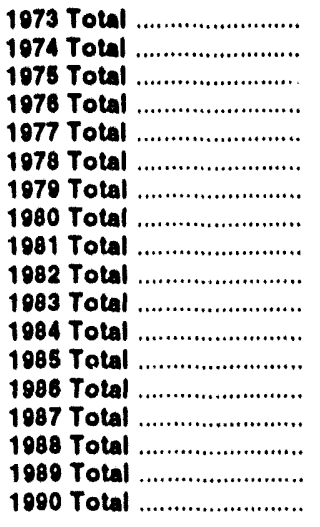 & $\begin{array}{l}4.057 \\
3.870 \\
3.667 \\
3.661 \\
3.454 \\
3.314 \\
3.593 \\
3.155 \\
3.157 \\
2.552 \\
2.490 \\
2.842 \\
2.760 \\
2.640 \\
2.673 \\
2.828 \\
2.787 \\
2.756\end{array}$ & $\begin{array}{r}10.388 \\
10.004 \\
8.532 \\
8.762 \\
8.635 \\
8.539 \\
8.549 \\
8.395 \\
8.257 \\
7.121 \\
6.826 \\
7.448 \\
7.080 \\
6.690 \\
7.323 \\
7.696 \\
8.131 \\
8.502\end{array}$ & $\begin{array}{r}9.104 \\
8.694 \\
8.146 \\
9.010 \\
9.774 \\
9.887 \\
10.568 \\
9.525 \\
8.285 \\
7.794 \\
7.420 \\
8.014 \\
7.805 \\
7.920 \\
8.158 \\
8.430 \\
8.133 \\
8.319\end{array}$ & $\begin{array}{l}0.035 \\
.033 \\
.032 \\
.033 \\
.033 \\
.032 \\
.034 \\
.033 \\
.033 \\
.033 \\
.033 \\
.033 \\
.033 \\
.033 \\
.033 \\
.033 \\
.033 \\
.033\end{array}$ & $\begin{array}{r}-0.007 \\
.056 \\
.014 \\
(8) \\
.015 \\
.125 \\
.063 \\
.035 \\
.016 \\
.022 \\
.016 \\
.011 \\
.013 \\
.017 \\
.009 \\
.040 \\
.030 \\
.005\end{array}$ & $\begin{array}{l}23.576 \\
22.857 \\
20.391 \\
21.485 \\
21.911 \\
21.876 \\
22.807 \\
21.073 \\
10.715 \\
17.470 \\
16.753 \\
18.325 \\
17.665 \\
17.267 \\
18.188 \\
19.026 \\
19.113 \\
10.615\end{array}$ & $\begin{array}{l}2.341 \\
2.337 \\
2.348 \\
2.573 \\
2.882 \\
2.761 \\
2.873 \\
2.781 \\
2.817 \\
2.542 \\
2.648 \\
2.850 \\
2.855 \\
2.834 \\
2.928 \\
3.059 \\
3.158 \\
3.226\end{array}$ & $\begin{array}{l}25.017 \\
24.094 \\
22.737 \\
24.038 \\
24.593 \\
24.537 \\
25.670 \\
23.854 \\
22.533 \\
20.020 \\
10.401 \\
21.184 \\
20.520 \\
20.101 \\
21.116 \\
22.085 \\
22.272 \\
22.841\end{array}$ & $\begin{array}{l}5.611 \\
6.701 \\
5.684 \\
6.198 \\
6.481 \\
6.751 \\
6.935 \\
6.755 \\
6.705 \\
6.124 \\
6.358 \\
6.670 \\
6.693 \\
6.529 \\
6.711 \\
6.003 \\
7.084 \\
7.001\end{array}$ & $\begin{array}{l}31.828 \\
30.090 \\
28.401 \\
30.234 \\
31.075 \\
31.388 \\
32.618 \\
30.600 \\
20.238 \\
26.144 \\
25.756 \\
27.862 \\
27.213 \\
26.028 \\
27.828 \\
28.988 \\
29.356 \\
29.932\end{array}$ \\
\hline 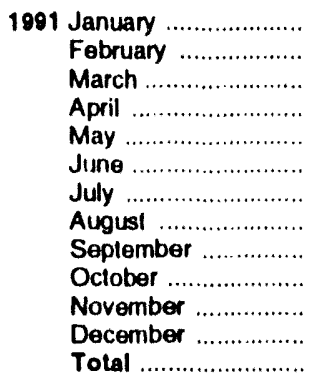 & $\begin{array}{r}.225 \\
.214 \\
.223 \\
.199 \\
.201 \\
.202 \\
.214 \\
.213 \\
.214 \\
.232 \\
.231 \\
.232 \\
2.601\end{array}$ & $\begin{array}{l}.798 \\
.703 \\
.727 \\
.701 \\
.684 \\
.654 \\
.683 \\
.697 \\
.692 \\
.745 \\
.747 \\
.790 \\
8.619\end{array}$ & $\begin{array}{l}.761 \\
.592 \\
.646 \\
.626 \\
.594 \\
.631 \\
.641 \\
.670 \\
.714 \\
.744 \\
.710 \\
.727 \\
8.057\end{array}$ & $\begin{array}{l}.003 \\
.003 \\
.003 \\
.003 \\
.003 \\
.003 \\
.003 \\
.002 \\
.002 \\
.002 \\
.002 \\
.002 \\
.033\end{array}$ & $\begin{array}{r}.001 \\
.001 \\
.002 \\
.001 \\
.001 \\
.001 \\
.003 \\
.002 \\
.004 \\
.001 \\
.001 \\
(s) \\
.009\end{array}$ & $\begin{array}{r}1.788 \\
1.513 \\
1.601 \\
1.529 \\
1.482 \\
1.489 \\
1.543 \\
1.581 \\
1.625 \\
1.723 \\
1.692 \\
1.752 \\
19.310\end{array}$ & $\begin{array}{l}.260 \\
.252 \\
.255 \\
.259 \\
.274 \\
275 \\
.274 \\
.287 \\
.280 \\
.278 \\
.267 \\
.262 \\
3.230\end{array}$ & $\begin{array}{r}2.048 \\
1.765 \\
1.856 \\
1.788 \\
1.757 \\
1.764 \\
1.822 \\
1.869 \\
1.906 \\
2.001 \\
1.960 \\
2.014 \\
22.549\end{array}$ & $\begin{array}{l}.572 \\
.496 \\
.564 \\
.550 \\
.640 \\
.617 \\
.641 \\
.642 \\
.556 \\
.589 \\
.576 \\
.577 \\
7.022\end{array}$ & $\begin{array}{r}2.620 \\
2.261 \\
2.420 \\
2.339 \\
2.397 \\
2.381 \\
2.463 \\
2.511 \\
2.461 \\
2.590 \\
2.536 \\
2.591 \\
29.571\end{array}$ \\
\hline 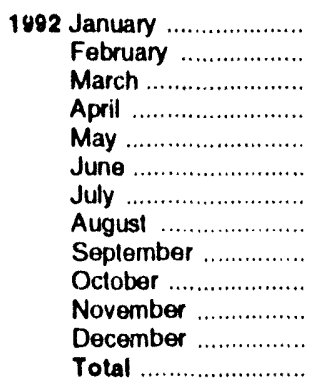 & $\begin{array}{r}.217 \\
.214 \\
.222 \\
.201 \\
.202 \\
.199 \\
\text { ค } .208 \\
\text { ค . } 206 \\
\text { ค . } 202 \\
\text { R .217 } \\
.214 \\
.214 \\
\text { ค }_{2.515}\end{array}$ & $\begin{array}{r}.830 \\
.759 \\
.795 \\
.746 \\
.740 \\
.694 \\
.706 \\
.698 \\
.701 \\
.730 \\
.763 \\
.805 \\
8.967\end{array}$ & $\begin{array}{l}.745 \\
.650 \\
.706 \\
.678 \\
.667 \\
.682 \\
.689 \\
.725 \\
.705 \\
.789 \\
.759 \\
.795 \\
8.589\end{array}$ & $\begin{array}{l}.003 \\
.003 \\
.003 \\
.003 \\
.003 \\
.003 \\
.003 \\
.002 \\
.002 \\
.002 \\
.002 \\
.002 \\
.033\end{array}$ & $\begin{array}{l}.004 \\
.003 \\
.003 \\
.003 \\
.001 \\
.003 \\
.001 \\
.001 \\
.001 \\
.002 \\
.001 \\
.005 \\
.027\end{array}$ & $\begin{array}{r}1.798 \\
1.629 \\
\mathrm{~A}_{1.728} \\
1.631 \\
1.614 \\
1.581 \\
1.607 \\
\mathrm{P}_{1.632} \\
\mathrm{~A}_{1.611} \\
1.741 \\
\mathrm{P} 1.739 \\
1.821 \\
\mathrm{~A}_{20.131}\end{array}$ & $\begin{array}{l}.262 \\
.260 \\
.269 \\
.265 \\
.274 \\
.283 \\
.287 \\
.290 \\
.284 \\
.282 \\
.274 \\
.264 \\
3.284\end{array}$ & $\begin{array}{r}2.060 \\
1.889 \\
1.997 \\
R_{1.895} \\
\mathrm{P}_{1.887} \\
1.864 \\
1.894 \\
\mathrm{P}_{1} 1.922 \\
\mathrm{P}_{1.895} \\
2.023 \\
2.014 \\
2.085 \\
\mathrm{~A}_{23.425}\end{array}$ & $\begin{array}{r}.570 \\
.517 \\
\mathrm{R} .575 \\
.548 \\
\mathrm{~A} .597 \\
.633 \\
.655 \\
\mathrm{~A} .625 \\
.581 \\
\mathrm{~A} .579 \\
\mathrm{~A} .595 \\
.592 \\
\mathrm{~A} 7.070\end{array}$ & $\begin{array}{r}A_{2.630} \\
A_{2.405} \\
A_{2} .572 \\
A_{2.443} \\
2.485 \\
2.497 \\
2.549 \\
2.548 \\
A_{2.476} \\
A_{2.602} \\
{ }_{2} 2.609 \\
2.677 \\
{ }^{2} 30.495\end{array}$ \\
\hline 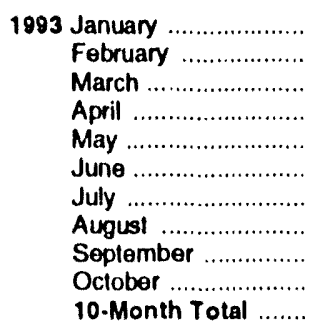 & $\begin{array}{r}.214 \\
\text { ค } 209 \\
.210 \\
\text { ค } .206 \\
.210 \\
.208 \\
\text { ค } .208 \\
.208 \\
\text { ค } .207 \\
.217 \\
2.098\end{array}$ & $\begin{array}{r}.830 \\
.790 \\
.826 \\
.762 \\
.715 \\
\text { ค } \\
.717 \\
.739 \\
\text { ค } .734 \\
\text { ค } .797 \\
.779 \\
7.688\end{array}$ & $\begin{array}{l}.720 \\
.656 \\
.768 \\
.654 \\
.610 \\
.666 \\
.652 \\
.654 \\
.721 \\
.774 \\
6.876\end{array}$ & $\begin{array}{l}.003 \\
.003 \\
.003 \\
.003 \\
.003 \\
.003 \\
.003 \\
.002 \\
.002 \\
.002 \\
.028\end{array}$ & $\begin{array}{r}.004 \\
(s) \\
.003 \\
.002 \\
.002 \\
.003 \\
(s) \\
.002 \\
.001 \\
.001 \\
.016\end{array}$ & 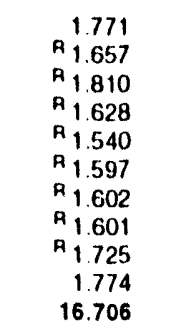 & $\begin{array}{l}266 \\
.263 \\
.271 \\
.272 \\
.280 \\
.289 \\
.291 \\
.296 \\
.286 \\
.284 \\
2.799\end{array}$ & $\begin{array}{r}{ }^{A} 2.037 \\
A_{1} .920 \\
2.082 \\
1.900 \\
1.821 \\
A_{1} 1.886 \\
A_{1} 1.893 \\
A_{1} 1.897 \\
A_{2} 2.011 \\
2.058 \\
19.506\end{array}$ & $\begin{array}{r}.571 \\
ค .533 \\
A .570 \\
.548 \\
.616 \\
.647 \\
.654 \\
.646 \\
.546 \\
.579 \\
5.909\end{array}$ & $\begin{array}{r}A_{2.608} \\
A_{2.453} \\
A_{2.6} 2 \\
2.448 \\
A_{2.436} \\
2.533 \\
A_{2.547} \\
A_{2} .543 \\
A_{2.557} \\
2.637 \\
25.415\end{array}$ \\
\hline $\begin{array}{l}1992 \text { 10-Month Total ....... } \\
1991 \text { 10-Month Total ....... }\end{array}$ & $\begin{array}{l}2.088 \\
2.137\end{array}$ & $\begin{array}{l}7.400 \\
7.083\end{array}$ & $\begin{array}{l}7.035 \\
6.620\end{array}$ & $\begin{array}{l}.028 \\
.028\end{array}$ & $\begin{array}{l}.021 \\
.007\end{array}$ & $\begin{array}{l}16.571 \\
15.875\end{array}$ & $\begin{array}{l}2.755 \\
2.701\end{array}$ & $\begin{array}{l}19.326 \\
18.576\end{array}$ & $\begin{array}{l}5.880 \\
5.868\end{array}$ & $\begin{array}{l}25.207 \\
24.444\end{array}$ \\
\hline
\end{tabular}

a Includes supplemental gaseous fuels.

b Due to a lack of consistent historical data, some renewable energy sources are not included. For example, in 1991, an estimaled 2.7 quadrillion Blu of renewable energy consumed by the U.S. industrial sector (primarity the pulp and paper industry) is not included
$R=$ Revised data. $(s)=$ Less than +0.5 trillion Blu and greater than $\mathbf{- 0 . 5}$ trillion Btu

Notes: Geographic coverage is the 50 States and the District of Columbia.

- Totals may not equal sum ol components due to independent rounding. Additional Noles and Sources: See end of section. 
Figure 2.4 Transportation Energy Consumptlon

(Quadrillion Btu)

Consumption by Major Sources, 1973-1992

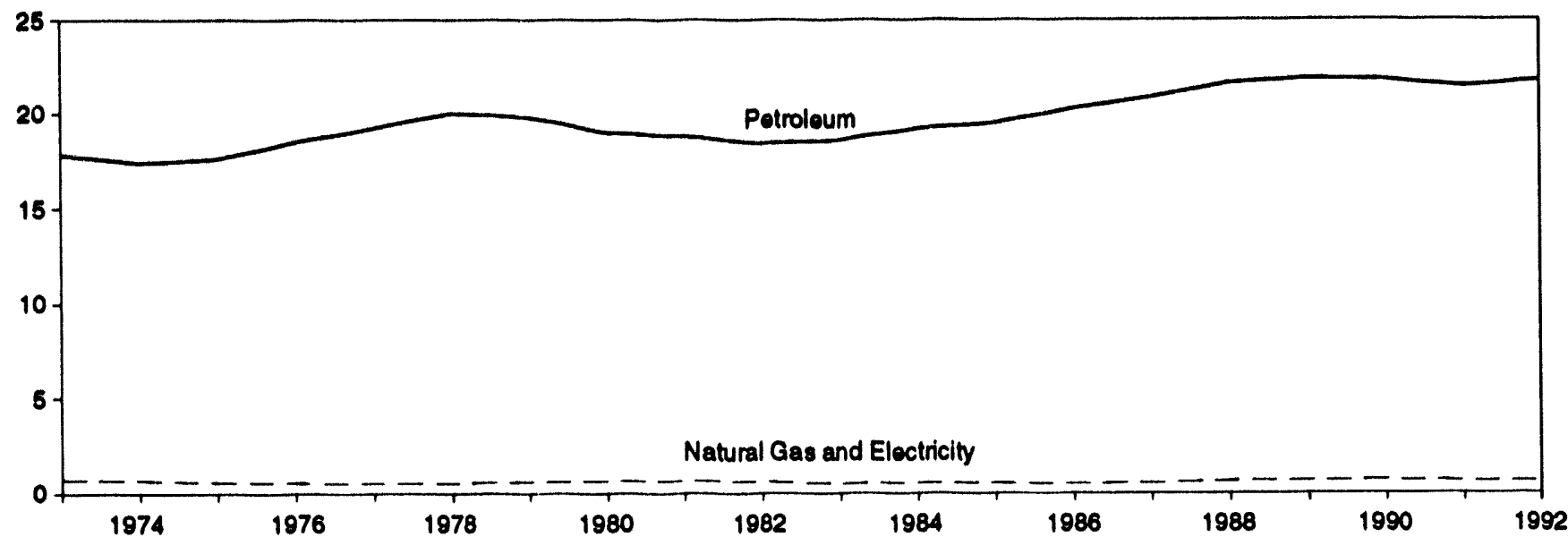

Consumption by Major Sources, Monthly

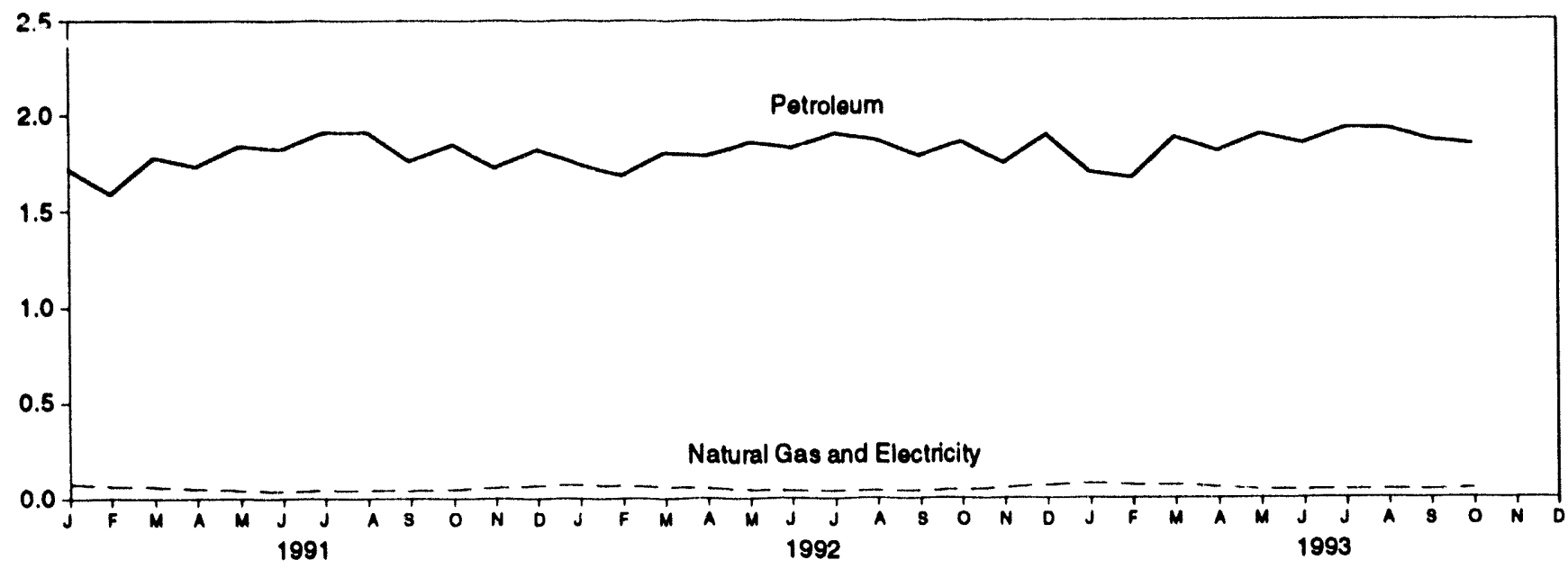

Total Consumption, January-October

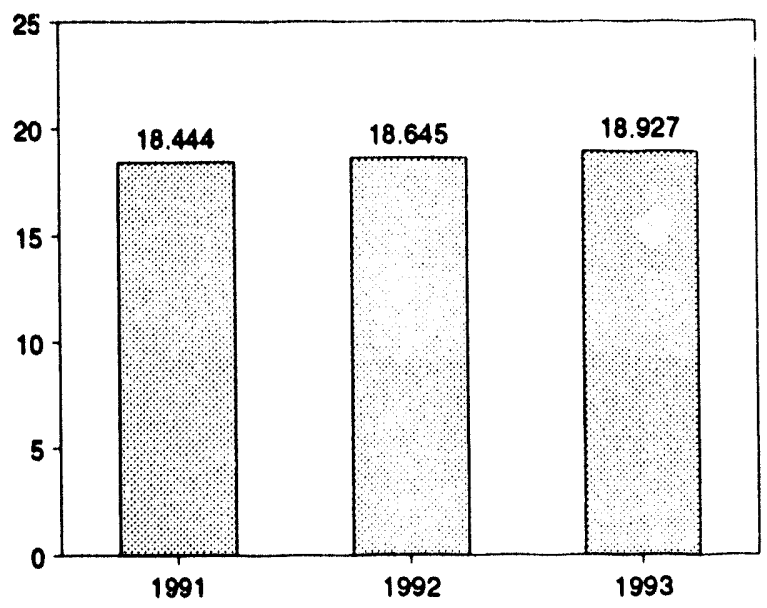

Total Consumption, Monthly

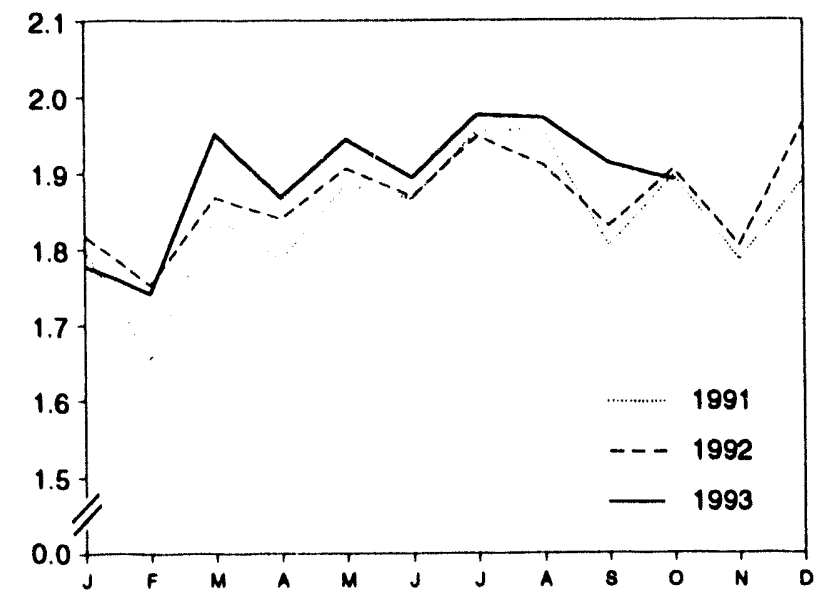

Note: Because venical scales difter, graphs should not be compared. 


\begin{tabular}{|c|c|c|c|c|c|c|c|c|}
\hline & Coal & $\begin{array}{c}\text { Natural } \\
\text { Gasa }\end{array}$ & Potroleum & $\begin{array}{c}\text { Primary } \\
\text { Consumption }\end{array}$ & Electrleity & $\begin{array}{c}\text { Not } \\
\text { Consumpton }\end{array}$ & $\begin{array}{l}\text { Electricel } \\
\text { Syotom } \\
\text { Energy } \\
\text { Losses }\end{array}$ & $\begin{array}{c}\text { Total } \\
\text { Consumption }\end{array}$ \\
\hline 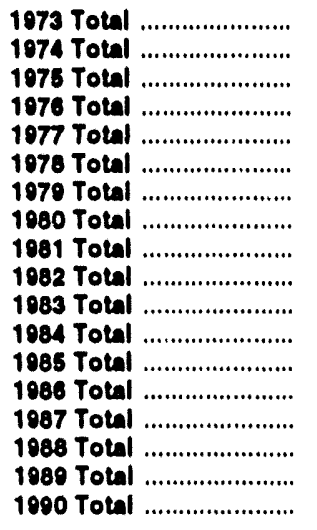 & 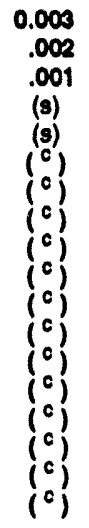 & $\begin{array}{r}0.743 \\
.686 \\
.895 \\
.859 \\
.543 \\
.539 \\
.612 \\
.850 \\
.658 \\
.612 \\
.505 \\
.545 \\
.510 \\
.499 \\
.535 \\
.632 \\
.649 \\
.680\end{array}$ & $\begin{array}{l}17.831 \\
17.390 \\
17.614 \\
18.508 \\
10.241 \\
20.041 \\
19.825 \\
19.008 \\
18.811 \\
18.420 \\
18.503 \\
19.216 \\
10.504 \\
20.269 \\
20.871 \\
21.629 \\
21.868 \\
21.810\end{array}$ & $\begin{array}{l}18.576 \\
18.086 \\
18.200 \\
10.085 \\
10.784 \\
20.580 \\
20.438 \\
19.658 \\
10.469 \\
10.092 \\
10.098 \\
10.761 \\
20.024 \\
20.768 \\
21.406 \\
22.260 \\
22.517 \\
22.400\end{array}$ & $\begin{array}{l}0.008 \\
.000 \\
.010 \\
.010 \\
.010 \\
.008 \\
.010 \\
.011 \\
.011 \\
.011 \\
.011 \\
.012 \\
.013 \\
.013 \\
.013 \\
.014 \\
.014 \\
.014\end{array}$ & $\begin{array}{l}18.584 \\
18.005 \\
18.219 \\
10.078 \\
10.704 \\
20.589 \\
20.447 \\
10.680 \\
19.480 \\
10.043 \\
10.100 \\
10.773 \\
20.038 \\
20.781 \\
21.410 \\
22.274 \\
22.530 \\
22.504\end{array}$ & $\begin{array}{l}0.020 \\
.022 \\
.025 \\
.025 \\
.025 \\
.022 \\
.025 \\
.026 \\
.026 \\
.026 \\
.026 \\
.028 \\
.030 \\
.031 \\
.029 \\
.031 \\
.031 \\
.031\end{array}$ & $\begin{array}{l}18.605 \\
18.117 \\
18.244 \\
19.101 \\
10.010 \\
20.611 \\
20.472 \\
19.098 \\
10.607 \\
10.080 \\
10.136 \\
10.801 \\
20.087 \\
20.812 \\
21.446 \\
22.306 \\
22.561 \\
22.536\end{array}$ \\
\hline 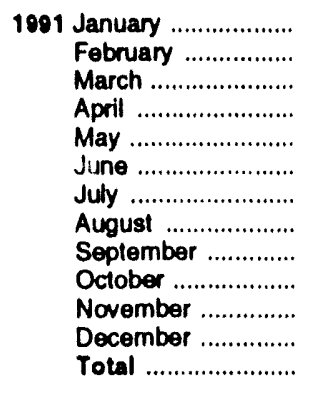 & $\begin{array}{l}\left(\begin{array}{l}c \\
c\end{array}\right. \\
\left(\begin{array}{l}c \\
c\end{array}\right. \\
(c) \\
(c) \\
(c) \\
(c) \\
(c) \\
(c) \\
(c)\end{array}$ & $\begin{array}{l}.076 \\
.063 \\
.060 \\
.050 \\
.043 \\
.038 \\
.041 \\
.041 \\
.040 \\
.046 \\
.055 \\
.066 \\
.620\end{array}$ & $\begin{array}{r}1.718 \\
1.588 \\
1.780 \\
1.732 \\
1.838 \\
1.823 \\
1.910 \\
1.911 \\
1.761 \\
1.846 \\
1.726 \\
1.821 \\
21.456\end{array}$ & $\begin{array}{r}1.794 \\
1.652 \\
1.840 \\
1.783 \\
1.881 \\
1.862 \\
1.951 \\
1.952 \\
1.800 \\
1.892 \\
1.782 \\
1.887 \\
22.076\end{array}$ & $\begin{array}{l}.001 \\
.001 \\
.001 \\
.001 \\
.001 \\
.001 \\
.001 \\
.001 \\
.001 \\
.001 \\
.001 \\
.001 \\
.014\end{array}$ & $\begin{array}{r}1.795 \\
1.653 \\
1.842 \\
1.784 \\
1.882 \\
1.863 \\
1.952 \\
1.953 \\
1.802 \\
1.893 \\
1.783 \\
1.888 \\
22.090\end{array}$ & $\begin{array}{l}.003 \\
.002 \\
.002 \\
.002 \\
.003 \\
.003 \\
.003 \\
.003 \\
.002 \\
.002 \\
.002 \\
.002 \\
.030\end{array}$ & $\begin{array}{l}1.788 \\
1.655 \\
1.844 \\
1.786 \\
1.885 \\
1.866 \\
1.855 \\
1.856 \\
1.804 \\
1.896 \\
1.785 \\
1.891 \\
22.120\end{array}$ \\
\hline 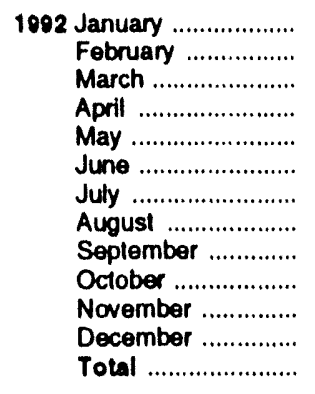 & $\begin{array}{l}\left(\begin{array}{l}c \\
c\end{array}\right) \\
(c) \\
(c)\end{array}$ & $\begin{array}{l}.070 \\
.064 \\
.060 \\
.052 \\
.044 \\
.039 \\
.040 \\
.039 \\
.038 \\
.042 \\
.052 \\
.066 \\
.606\end{array}$ & $\begin{array}{r}1.743 \\
1.685 \\
1.804 \\
1.785 \\
1.859 \\
1.826 \\
1.904 \\
1.867 \\
1.788 \\
1.859 \\
1.749 \\
1.895 \\
21.765\end{array}$ & $\begin{array}{l}1.813 \\
1.749 \\
1.864 \\
1.837 \\
1.902 \\
1.865 \\
1.944 \\
1.906 \\
1.826 \\
1.901 \\
1.801 \\
1.962 \\
22.371\end{array}$ & $\begin{array}{l}.001 \\
.001 \\
.001 \\
.001 \\
.001 \\
.001 \\
.001 \\
.001 \\
.001 \\
.001 \\
.001 \\
.001 \\
.014\end{array}$ & $\begin{array}{l}1.815 \\
1.750 \\
1.865 \\
1.838 \\
1.903 \\
1.866 \\
1.946 \\
1.907 \\
1.828 \\
1.902 \\
1.802 \\
1.963 \\
22.384\end{array}$ & $\begin{array}{l}.002 \\
.002 \\
.002 \\
.002 \\
.003 \\
.003 \\
.003 \\
.003 \\
.003 \\
.002 \\
.002 \\
.003 \\
.030\end{array}$ & $\begin{array}{l}1.817 \\
1.753 \\
1.868 \\
1.840 \\
1.906 \\
1.869 \\
1.848 \\
1.910 \\
1.830 \\
1.904 \\
1.804 \\
1.965 \\
22.414\end{array}$ \\
\hline 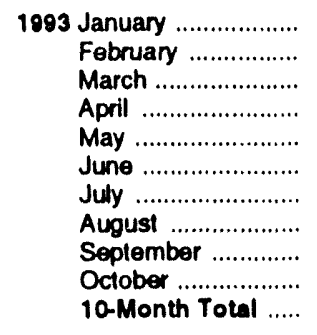 & $\begin{array}{l}(c) \\
(c) \\
(c) \\
(c) \\
(c) \\
(c) \\
(c) \\
(c) \\
(c)\end{array}$ & $\begin{array}{l}.075 \\
\mathrm{R} .067 \\
.066 \\
.054 \\
.042 \\
.040 \\
.042 \\
.042 \\
.041 \\
.045 \\
.514\end{array}$ & $\begin{array}{r}1.700 \\
1.671 \\
1.881 \\
1.810 \\
1.898 \\
1.850 \\
1.930 \\
1.926 \\
1.867 \\
1.842 \\
18.375\end{array}$ & $\begin{array}{r}1.775 \\
\text { R } 1.738 \\
1.947 \\
1.864 \\
1.940 \\
1.890 \\
1.972 \\
1.968 \\
1.909 \\
1.887 \\
18.889\end{array}$ & $\begin{array}{l}.001 \\
.001 \\
.001 \\
.001 \\
.001 \\
.001 \\
.001 \\
.001 \\
.001 \\
.001 \\
.012\end{array}$ & $\begin{array}{r}1.776 \\
R 1.739 \\
R 1.948 \\
1.865 \\
1.941 \\
1.891 \\
1.973 \\
1.969 \\
1.910 \\
1.888 \\
18.901\end{array}$ & $\begin{array}{l}.003 \\
.002 \\
.002 \\
.002 \\
.002 \\
.003 \\
.003 \\
.003 \\
.002 \\
.002 \\
.025\end{array}$ & $\begin{array}{r}1.778 \\
A_{1.742} \\
A_{1.951} \\
1.868 \\
1.944 \\
1.894 \\
1.976 \\
1.972 \\
1.913 \\
1.891 \\
18.927\end{array}$ \\
\hline $\begin{array}{l}1092 \text { 10-Month Total ..... } \\
1091 \text { 10-Month Total ..... }\end{array}$ & $\left(\begin{array}{l}c \\
(c)\end{array}\right.$ & $\begin{array}{l}.488 \\
.490\end{array}$ & $\begin{array}{l}18.121 \\
17.908\end{array}$ & $\begin{array}{l}18.608 \\
18.407\end{array}$ & $\begin{array}{l}.012 \\
.012\end{array}$ & $\begin{array}{l}18.620 \\
18.410\end{array}$ & $\begin{array}{l}.025 \\
.025\end{array}$ & $\begin{array}{l}18.645 \\
18.444\end{array}$ \\
\hline
\end{tabular}

- Pipeline fuel only, including supplemental gaseous fuels.

b Due to a lack of consistent historical data, some renewable energy sources are not included. For example, in 1991, an estimated 0.1 quadrillion Btu of renewable energy consumed by the U.S. Iransportation sector is not included.

c Since 1978, the small amounts of coal consumed for transportation are reported as industrial sector consumption

$R=$ Revised data. (s)=Less than 0.5 inilion Buu.

Notes: - Geographic coverage is the 50 States and the District of Columbia.

- Tolals may not equal sum of components due to independent rounding. Additional Noles and Sources: See end of section. 
Figure 2.5 Energy Input at Electric Utilities

(Quadrillion Btu)

Total Input, 1973-1992

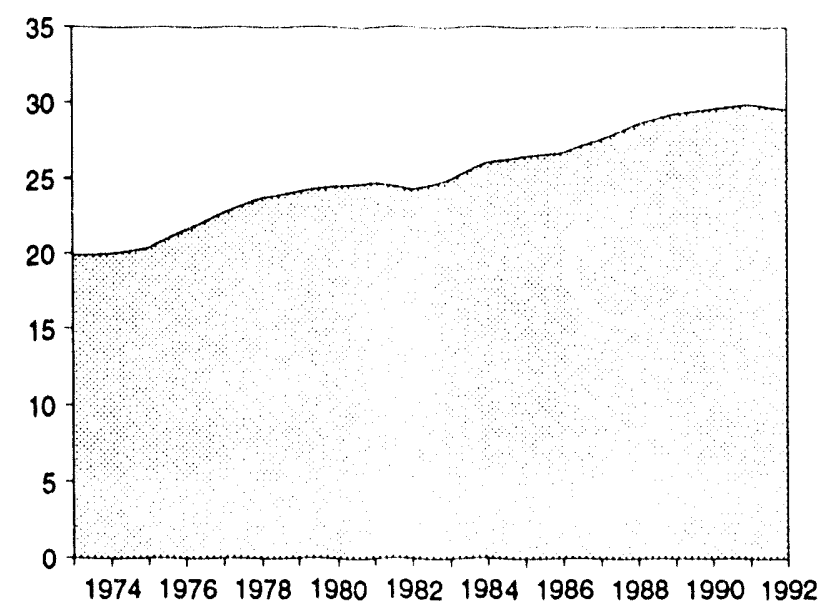

Input by Major Sources, 1973-1992

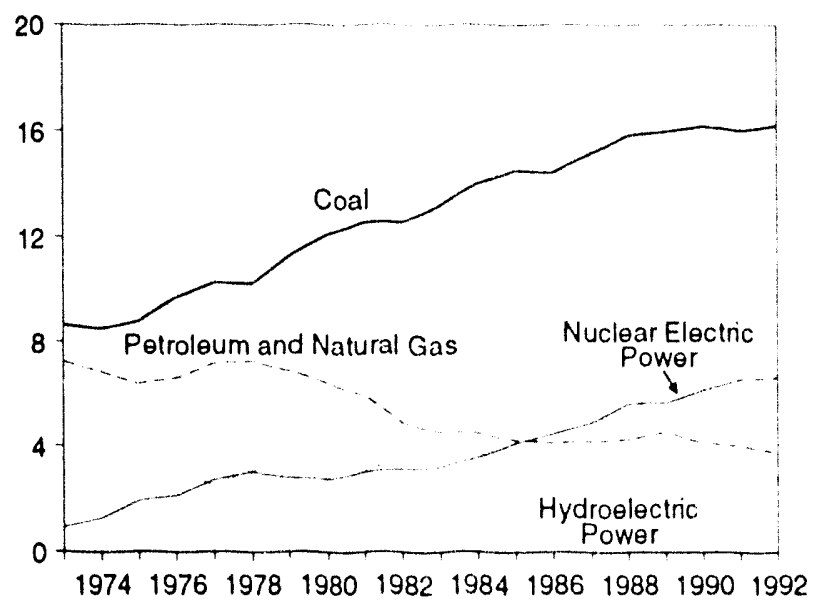

Total Input, January-October

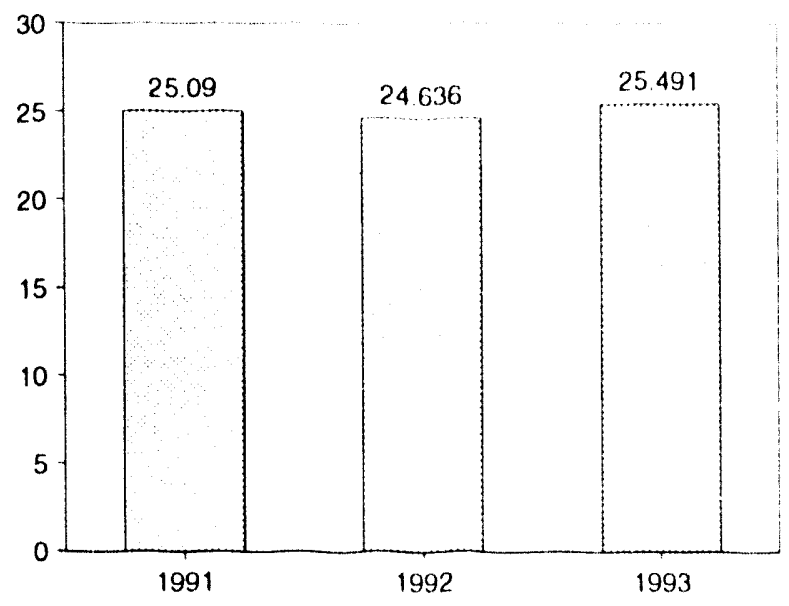

Total Input, Monthly

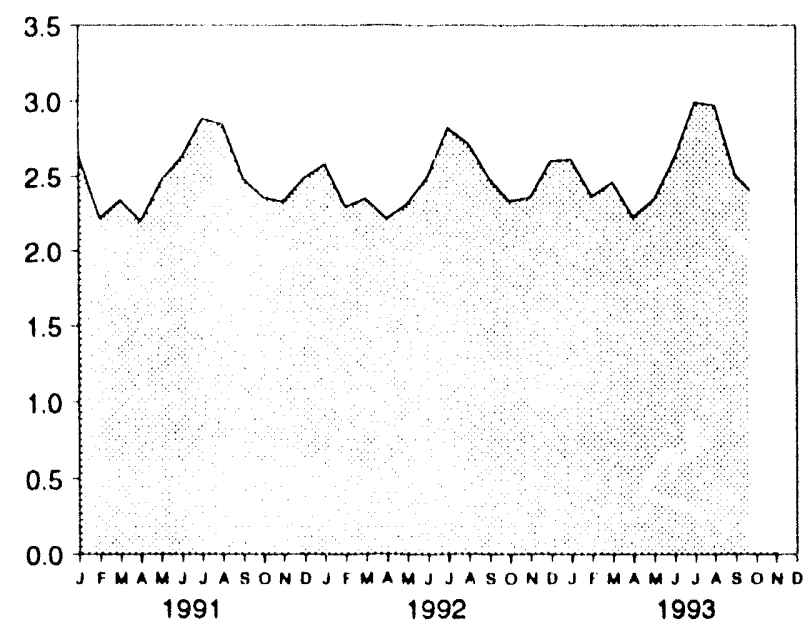

Input by Major Sources, Monthly

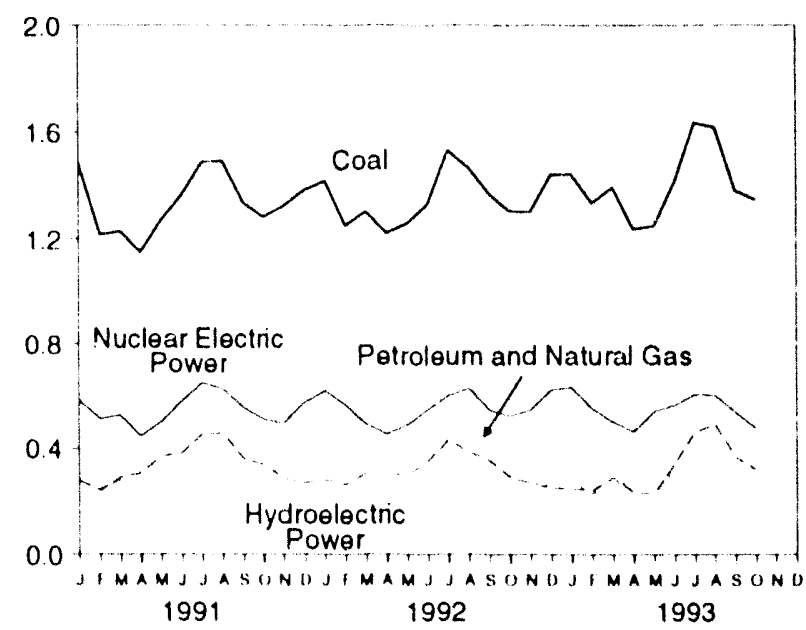

Input by Major Sources,

October 1993

Coal 1.349

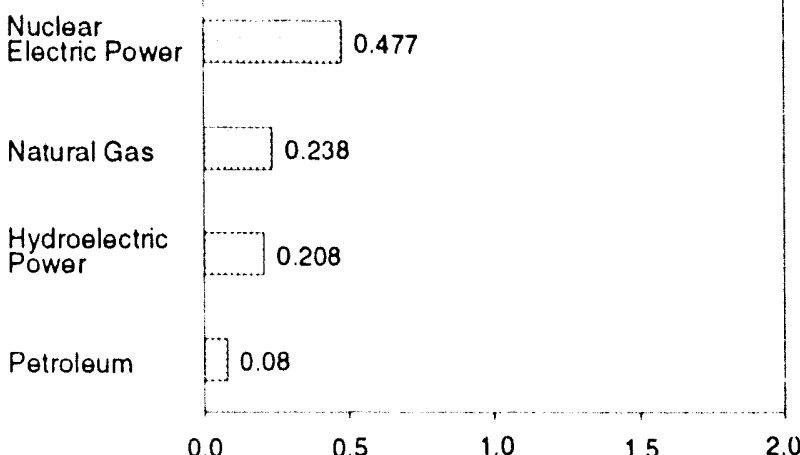

Nole: Because vertlcal scales difter, graphs should nol be compared Source: Table 2.6. 
Table 2.6 Energy Input at Electric Utilities (Quadrillion Btu)

\begin{tabular}{|c|c|c|c|c|c|c|c|c|}
\hline & Coal & $\begin{array}{c}\text { Natural } \\
\text { Gas }^{a}\end{array}$ & Petroloumb & $\begin{array}{l}\text { Nuclear } \\
\text { Electric } \\
\text { Power }\end{array}$ & $\begin{array}{l}\text { Hydro- } \\
\text { lectric } \\
\text { Powerc }\end{array}$ & $\begin{array}{l}\text { Geothermal } \\
\text { Energy }\end{array}$ & Otherd & Total \\
\hline 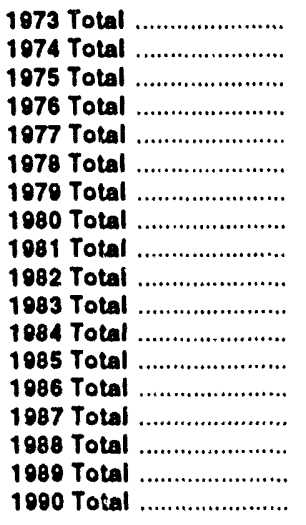 & $\begin{array}{r}8.658 \\
8.534 \\
8.786 \\
9.720 \\
10.262 \\
10.238 \\
11.260 \\
12.123 \\
12.583 \\
12.582 \\
13.213 \\
14.020 \\
14.542 \\
14.444 \\
15.173 \\
15.850 \\
15.988 \\
16.189\end{array}$ & $\begin{array}{l}3.748 \\
3.519 \\
3.240 \\
3.152 \\
3.284 \\
3.297 \\
3.613 \\
3.810 \\
3.768 \\
3.342 \\
2.993 \\
3.220 \\
3.160 \\
2.691 \\
2.935 \\
2.709 \\
2.871 \\
2.882\end{array}$ & $\begin{array}{l}3.515 \\
3.365 \\
3.166 \\
3.477 \\
3.901 \\
3.987 \\
3.283 \\
2.634 \\
2.202 \\
1.568 \\
1.544 \\
1.286 \\
1.090 \\
1.452 \\
1.257 \\
1.563 \\
1.685 \\
1.250\end{array}$ & $\begin{array}{l}0.910 \\
1.272 \\
1.900 \\
2.111 \\
2.702 \\
3.024 \\
2.776 \\
2.739 \\
3.008 \\
3.131 \\
3.203 \\
3.553 \\
4.149 \\
4.471 \\
4.906 \\
5.661 \\
5.677 \\
6.161\end{array}$ & $\begin{array}{l}2.975 \\
3.276 \\
3.187 \\
3.032 \\
2.482 \\
3.110 \\
3.107 \\
3.085 \\
3.072 \\
3.539 \\
3.866 \\
3.767 \\
3.365 \\
3.413 \\
3.084 \\
2.630 \\
2.848 \\
2.914\end{array}$ & $\begin{array}{l}0.043 \\
.053 \\
.070 \\
.078 \\
.077 \\
.064 \\
.084 \\
.110 \\
.123 \\
.105 \\
.120 \\
.165 \\
.198 \\
.210 \\
.229 \\
.217 \\
.197 \\
.181\end{array}$ & $\begin{array}{l}0.003 \\
.003 \\
.002 \\
.003 \\
.005 \\
.003 \\
.005 \\
.005 \\
.004 \\
.003 \\
.004 \\
.009 \\
.015 \\
.012 \\
.016 \\
.017 \\
.020 \\
.021\end{array}$ & $\begin{array}{l}19.852 \\
20.022 \\
20.350 \\
21.574 \\
22.713 \\
23.724 \\
24.128 \\
24.505 \\
24.760 \\
24.270 \\
24.056 \\
26.020 \\
26.519 \\
26.703 \\
27.600 \\
28.648 \\
29.286 \\
29.590\end{array}$ \\
\hline 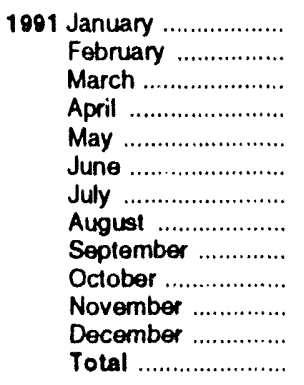 & $\begin{array}{r}1.482 \\
1.217 \\
1.230 \\
1.151 \\
1.271 \\
1.366 \\
1.491 \\
1.492 \\
1.337 \\
1.284 \\
1.324 \\
1.384 \\
16.028\end{array}$ & $\begin{array}{l}.177 \\
.150 \\
.198 \\
.221 \\
.255 \\
.266 \\
.338 \\
.335 \\
.269 \\
.270 \\
.203 \\
.174 \\
2.856\end{array}$ & $\begin{array}{l}.099 \\
.092 \\
.092 \\
.084 \\
.115 \\
.117 \\
.118 \\
.123 \\
.091 \\
.068 \\
.084 \\
.094 \\
1.178\end{array}$ & $\begin{array}{l}.584 \\
.514 \\
.528 \\
.447 \\
.502 \\
.582 \\
.652 \\
.628 \\
.557 \\
.512 \\
.497 \\
.576 \\
6.579\end{array}$ & $\begin{array}{l}.275 \\
.234 \\
.280 \\
.284 \\
.314 \\
.283 \\
.272 \\
.256 \\
.218 \\
.217 \\
.209 \\
.247 \\
3.083\end{array}$ & $\begin{array}{l}.015 \\
.013 \\
.015 \\
.013 \\
.014 \\
.014 \\
.014 \\
.014 \\
.013 \\
.014 \\
.015 \\
.015 \\
.170\end{array}$ & $\begin{array}{l}.002 \\
.002 \\
.002 \\
.002 \\
.002 \\
.002 \\
.002 \\
.002 \\
.002 \\
.002 \\
.002 \\
.002 \\
.021\end{array}$ & $\begin{array}{r}2.634 \\
2.221 \\
2.344 \\
2.201 \\
2.472 \\
2.631 \\
2.887 \\
2.851 \\
2.488 \\
2.361 \\
2.333 \\
2.492 \\
29.915\end{array}$ \\
\hline 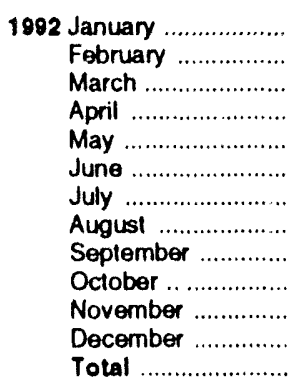 & 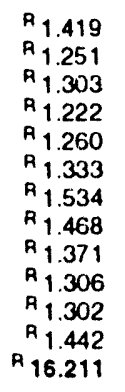 & $\begin{array}{l}.173 \\
.174 \\
.212 \\
.234 \\
.242 \\
.272 \\
.341 \\
.309 \\
.280 \\
.217 \\
.193 \\
179 \\
2.826\end{array}$ & $\begin{array}{l}.108 \\
.087 \\
.092 \\
.069 \\
.056 \\
.080 \\
.092 \\
.076 \\
.074 \\
.073 \\
.074 \\
.070 \\
.951\end{array}$ & $\begin{array}{l}.621 \\
.567 \\
.492 \\
.454 \\
.490 \\
.550 \\
.602 \\
.630 \\
.547 \\
.524 \\
.545 \\
.624 \\
6.646\end{array}$ & $\begin{array}{r}.243 \\
.204 \\
.235 \\
.220 \\
.252 \\
.255 \\
.240 \\
.218 \\
.202 \\
.201 \\
.228 \\
.274 \\
2.773\end{array}$ & $\begin{array}{l}.015 \\
.013 \\
.015 \\
.014 \\
.014 \\
.014 \\
.014 \\
.014 \\
.013 \\
.014 \\
.014 \\
.014 \\
.170\end{array}$ & $\begin{array}{l}.002 \\
.002 \\
.002 \\
.001 \\
.002 \\
.002 \\
.002 \\
.002 \\
.002 \\
.002 \\
.002 \\
.002 \\
.022\end{array}$ & 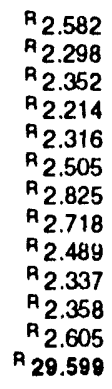 \\
\hline 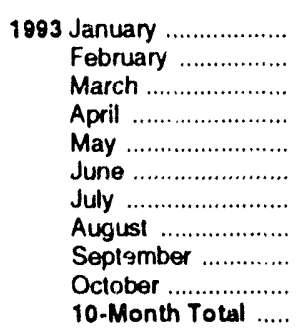 & $\begin{array}{l}A_{1} 1.445 \\
A_{1} .335 \\
A_{1} 1.394 \\
A_{1.238} \\
A_{1.249} \\
A_{1.416} \\
A_{1.636} \\
A_{1} 1.620 \\
A_{1.383} \\
1.349 \\
14.065\end{array}$ & $\begin{array}{l}.168 \\
.165 \\
.198 \\
.178 \\
.171 \\
.260 \\
.341 \\
.365 \\
.265 \\
.238 \\
2.348\end{array}$ & $\begin{array}{l}.077 \\
.074 \\
.090 \\
.055 \\
.056 \\
.083 \\
.121 \\
.126 \\
.102 \\
.080 \\
.865\end{array}$ & $\begin{array}{l}.634 \\
.551 \\
.501 \\
.464 \\
.541 \\
.565 \\
.607 \\
.604 \\
.537 \\
.477 \\
5.481\end{array}$ & $\begin{array}{l}.276 \\
.227 \\
.263 \\
.276 \\
.314 \\
.287 \\
.275 \\
.245 \\
.210 \\
.208 \\
2.582\end{array}$ & $\begin{array}{l}.014 \\
.013 \\
.014 \\
.014 \\
.012 \\
.012 \\
.014 \\
.014 \\
.013 \\
.013 \\
.133\end{array}$ & $\begin{array}{l}.002 \\
.002 \\
.002 \\
.002 \\
.001 \\
.001 \\
.001 \\
.002 \\
.002 \\
.002 \\
.017\end{array}$ & $\begin{array}{r}A_{2.616} \\
A_{2.367} \\
A_{2.462} \\
R_{2.226} \\
A_{2.345} \\
A_{2} .625 \\
A_{2} .994 \\
R_{2} .975 \\
R_{2.512} \\
2.368 \\
25.491\end{array}$ \\
\hline $\begin{array}{l}109210 \text {-Month Total ..... } \\
1991 \text { 10-Month Total ..... }\end{array}$ & $\begin{array}{l}13.468 \\
13.320\end{array}$ & $\begin{array}{l}2.454 \\
2.479\end{array}$ & $\begin{array}{r}.807 \\
1.000\end{array}$ & $\begin{array}{l}5.477 \\
5.506\end{array}$ & $\begin{array}{l}2.271 \\
2.627\end{array}$ & $\begin{array}{l}.142 \\
.140\end{array}$ & $\begin{array}{l}.018 \\
.017\end{array}$ & $\begin{array}{l}24.636 \\
25.090\end{array}$ \\
\hline
\end{tabular}

a Includes supplemental gaseous tuels.

b Petrolesum products reported as "oil consumed in steam plants" through 1979 and "heavy oil" from 1980 lorward, which are assumed to be residual fuel oil; petroleum products reported as "oil consumed in gas lurbine and internal combustion engine plants" through 1979 and "light oil" from 1980 forward, which are assumed to be clislillale fuel oil, kerosene, and petroteum coke. c Includes net imports of electricity.

d "Other" is electricity generated for distribution from wood, wasle, wind, pholovollaic, and solar thermal energy.

$R=$ Revised dala.

Noles: - Geographic coverage is the 50 States and the Distrid of Columbia.

- Tolals may not equal sum of components due to independent rounding. Additional Notes and Sources: See end of section. 


\section{Energy Consumption Notes and Sources}

The data in this section of the Monthly Energy Review $(M E R)$ are obtained initially from a group of energy-related surveys, typically called "supply surveys," conducted by the Energy Informatio 1 Administration (EIA). Supply surveys are those sur reys directed to suppliers and marketers of specific energy sources. They measure the quantities of specific energy sources produced, or the quantities supplied to the market, or both. The data obtained from the EIA's supply surveys are integrated to yield the summary consumption statistics published in this section (and in Section 1) of the MER. Users of the EIA's energy consumption statistics should be aware of a second group of energy-related surveys, typically called "consumption surveys." Consumption surveys gather information on the types of energy consumed by end users of energy, along with the characteristics of those end users that can be associated with energy use. For example, the Manufacturing Energy Consumption Survey belongs to the consumption survey group because it collects information direclly from end users (the manufacturing establishments). There are important differences between the supply and consumption surveys that need to be taken into account in any analysis that uses both data sources. For information on those differences, see Energy Consumption by End-Use Sector, A Comparison of Measures by Consumption and Supply Surveys, DOE/EIA-0533, Energy Information Administration, Washington, DC, April 6, 1990. The numbered notes that follow elahorate on essential information in Seciion 2.

1. Total Energy Consumed: Total energy consumed includes coal, natural gas (including supplemental gaseous fucls), petroleum products supplied, electric utility and industrial generation of hydroelectric power, net imports of electricity generated from hydroelectric power, and electricity generated from nuclear power. Total energy consumed also includes electricity generated from wood, waste, geothermal, wind, photovoltaic, and solar thermal energy but excludes other energy obtained from those sources because consistent historical data are not available.

2. Economic Sectors: Energy use is assigned to the major economic sectors according to the following guidelines as closely as possible:

- Residential-All private residences, whether occupied or vacant, owned or rented, including single-family homes, multifamily housing units, and mobile homes. Secondary homes, such as summer homes, are also included. Institutional housing, such as school dormitories, hospitals, and military barracks, generally are not included in the residential sector; they are included in the commercial sector.

- Commercial-Business establishments that are not engaged in transportation or in manufacturing or other types of industrial activity (agriculture, mining, or construction). Commercial establishments include hotels, motels, restaurants, wholesale businesses, retail stores, laundries, and other service enterprises; religious and nonprofit organizations; health, social, and educational institutions; and Federal, State, and local governments. Street lights, pumps, bridges, and public services are also included if the establishment opera $\cdots$; them is considered commercial.

- Industrial-Manufacturing industries, which make up the largest part of the sector, along with mining, construction, agriculture, fisheries, and forestry. Establish:nents in the sector range from steel mills to small farms to companies assembling electronic components.

- Transportation-Private and public vehicles that move people and commodities. Included are automobiles, trucks, buses, motorcycles, railroads and railways (including streetcars), aircraft, ships, barges, and natural gas pipelines.

- Electric Utility-Privately and publicly owned establishınents that generate, transmit, distribute, and sell electricity primarily for use by the public and meet the definition of an electric utility. Nonutility power producers are not included in the electric utility sector.

Although the end-use allocations are made according to these aggregations as closely as possible, some data are collected by using different classifications. For example, data on agricultural use of natural gas are collected and reported in the commercial sector, rather than in the industrial sector. Since agricultural use of natural gas cannot be identified separately, it is included in the commercial sector in this report. Another example is master-metered condominiums and apartments, and buildings with a combination of residential and commercial units. In many cases, the metering and billing practices cause residential energy usage of electricity, natural gas, or lucl oil to be included in the commercial sector. No arljustments for these discrepancies were made.

3. Conversion Factors: See the conversion factors listed in Appendix $\Lambda$.

4. Coal: Coal is anthracite, bituminous coal (including subbituminous coal), and lignite. Sources:

- 1973-September 1977: U.S. Deparument of the Interior (DOI), Bureau of Mines (BOM), Minerals Yearbook and Minerals Industry Surveys.

- Electric Utilities-October 1977 forward: Energy Information Administration (EIA), Form EIA-759 (formerly Form FPC-4), "Monthly Power Plant Report."

- Other Industrial-October 1977-December 1979: EIA, Form EIA-3, "Monthly Coal Consumption Report - Manufacturing Plants"; January 1980 for- 
ward: EIA, Form EIA-3, "Quarterly Coal Consumption Report - Manufacturing Plants," and Form EIA-6, "Coal Distribution Report."

- Coke Plants-October 1977-December 1980: EIA, Form EIA-5/5A, "Coke and Coal Chemicals - Monthly/Annual"; January 1981-December 1984: EIA, Form EIA-5/5A, "Coke Plant Report Quarterly/Annual Supplement"; January 1985 forward: EIA, Form EIA-5/5A, "Coke Plant Report," quarterly.

- Residential and Commercial-October 1977. December 1979: EIA, Form EIA-2, "Monthly Coal Report, Retail Dealers - Upper Lake Docks"; January 1980 forward: EIA, Form EIA-6, "Coal Distribution Report."

5. Natural Gas: Natural gas consumption by end use is based on data presented in Table 4.3 of this report. For Section 2 calculations, lease and plant fuel consumption are added to industrial deliveries, and pipeline fuel represents transportation use of natural gas. Values in $\mathrm{Btu}$ are derived by using the conversion factors provided in $\Lambda$ ppendix $A$. Sources:

- 1973-1975: DOI, BOM, Minerals Yearbook, "Natural Gas" chapter.

- 1976-1978: EIA, "Energy Data Reports," Natural Gas, Annual.

- 1979: EIA, Natural Gas Production and Consumption 1979.

- 1980-1992: EIA, Natural Gas Annual.

- 1993: EIA, Natural Gas Monthly.

- Electric Utilities-1973-1976: Form FPC.4, "Monthly Power Plant Report"; 1977-1981: Federal Energy Regulatory Commission (FERC), Form FPC-4, "Monthly Power Plant Report"; 1982 forward: EIA, Form EIA-759, "Monthly Power Plant Report."

- American Gas Association, "Monthly Gas Utility Statistical Report," residential and commercial monthly sales data for 1973-1979, which are used to estimate monthly consumption values from EIA annual consumption values.

6. Petroleum: Petroleum consumption by end use is the sum of all individual petroleum products estimated to be consumed in each end-use sector. First, total consumption by product is determined. Petroleum consumption in this section of the Monthly Energy Review $(M E R)$ is the series called "petroleum products supplied" in Section 3. Sources for petroleum products supplied by individual products are:

- 1973-1975: DOI, BOM, Mineral Industry Surveys, "Petroleum Statement, Annual."

- 1976-1980: EIA, Energy Data Reports, "Petroleum Statement, Annual."

- 1981-1991: ElA, Petroleum Supply Annual.

- 1992 and 1993: EI^, Petroleum Supply Monthly.
Specific petroleum products' end-use allocation procedures follow:

- Aviation Gasoline-All product supplied is assigned to the transportation sector.

- Asphalt-All product supplied is assigned to the industrial sector.

- Distillate Fuel-Product supplied is assigned to electric utilities and non-electric utilities as follows:

\section{Electric Utilities, All Periods.}

Monthly and annual consumption for 1973-1979 is assumed to be the amount of oil (minus small amounts of kerosene and kerosene-type jet fuel deliveries) reported as consumed in internal combustion and gas turbine engine plants. From January 1980 , electric utility consumption of distillate fuel is assumed to be the petroleum products reported as "light oil" (minus small amounts of kerosene deliveries through 1982) consumed at electric utilities.

Sources: 1973-September 1977: FPC, Form FPC4, "Monthly Power Plant Report"; October 19771981: FERC, Form FPC-4, "Monthly Power Plant Report"; 1982 forward: EIA, Form EIA-759, "Monthly Power Plant Report."

Sectors Other Than Electric Utilities, Annual Estimates Through 1991.

The aggregate non-electric utility use of distillate fuel is total distillate fuel supplied minus the electric utility consumption. The non-electric utility annual consumption totals are allocated to the individual non-electric utility sectors (residential, commercial, industrial, and transportation) in proportion to the share of "adjusted sales" of each end-use sector, as reported in EIA's Fuel Oil and Kerosene Sales (Sales) report series (DOE/EIA0535 ), which is based primarily on data collected by Form EIA-821, previously Form EIA-172. "Adjusted sales" are sales that have been adjusted at the PAD district level to equal EIA volume estimates of petroleum products supplied in the U.S. market. Following are notes on the individual sector groupings:

- Since 1979 , the residential sector adjusted sales total is utirectly from the Sales reports. Prior to 1979, each year's sales subtotal of the heating plus industrial category is split into residential, commercial, and industrial (including farm) in proportion to the 1979 shares.

- Since 1979, the commercial sector adjusted sales total is directly from the Sales reports. Prior to 1979 , each year's sales subtotal of the heating plus industrial category is split into residential, commer- 
cial, and industrial (including farm) in proportion to the 1979 shares.

- Since 1979, the industrial sector adjusted sales total is the sum of the adjusted sales for industrial, farm, oil company, off-highway, diesel, and all other uses. Prior to 1979, each year's sales subtotal of the heating plus industrial category is split into residential, commercial, and industrial (including farm) in proportion to the 1979 shares, and this estimated industrial portion is added to oil company, off-highway diesel, and all other uses.

- The transportation sector adjusted sales total is the sum of the adjusted sales for railroad, vessel bunkering, on-highway diesel, and military uses for all years.

\section{Sectors Other Than Electric Utilities, Monthly Es- timates Through 1991.}

- Residential and commercial monthly consumption is estimated by allocating the annual estimates described above into months in proportion to each month's share of the year's sales of No. 2 heating oil as reported in the "Monthly Report of lleating Oil Sales" by the Ethyl Corporation from 19731980 and the American Petroleum Institute for 1981 and 1982, and the EIA, Form EIA-782A, "Refiners'/Gas Plant ()perators' Monthly Petroleum Product Sales Report," No. 2 ruel (Oil Sales to End Users and for Resale, since 1983.

- The transportation highway use portion is allocated into the months in proportion to each month's share of the year's total sales for highway use as reported by the Federal Ilighway Administration's Table Ml-25, "Private and Commercial llighway Use of Special Fuels by Months." The remaining transportation use of distillate fuel (i.e., for railroads, vessel bunkering, and military use) is evenly distributed over the months, adjusted for the number of days per month.

- Industrial monhly estimates are made by subtracting the residential and commercial, transportation, and electric utility sector estimates from each month's total distillate fucl supplice.

\section{Sectors Other Than Electric Utilities, 1992 and 1993}

Each month's non-clectric utility consumption subtotal is disaggregated into the major end-use sectors in proportion to the shares each sector held of the non-electric utility subtotal in the same month in 1991.

- Jet Fuel-Through 1982, small amounts of kerosene-type jet fuel were consumed by electric utilities. Kerosene-type jet fucl deliveries to electric utilities as reported on the form FERC423 (formerly Form I:P(-423) were used as estimates of this consumption. All remaining jet fuel (kerosene-type and naphtha-type) is consumed by the transportation sector.

- Kerosene-Total product supplied monthly is allocated to the major end-use sectors in proportion to annual sales grouped into end-use sectors from EIA's Fuel Oil and Kerosene Sales (Sales) reports (based primarily on data collected by Form EIA-821, previously Form EI $\Lambda-172$ ), as follows:

- Residential deliveries are directly from the Sales reports for 1979-1991. Sales for 1991 are used as estimates for succeeding periods. Prior to 1979, each year's sales category called "heating" is split into residential, commercial, and industrial in proportion to the 1979 shares.

- Commercial sales are directly from the Sales reports for 1979-1991. Sales for 1991 are used as estimates for succeeding periods. Prior to 1979 , each year's sales category called "heating" is split into residential, commercial, and industrial in proportion to the 1979 shares.

- Industrial sales are direclly from the Sales reports for 1979-1991. Sales for 1991 are used as estimates for succeeding periods. Prior to 1979, each year's sales catcgory called "heating" is split into residential, commercial and industrial in proportion to the 1979 shares, and this estimated industrial (including farm) portion is added to all other uses.

- Liquefied Petroleum Gases (IPC)-The annual shares of LPG's total consumption that are estimated to be consumed by each end-use sector are applied to each month's total LPG consumption (i.e., product supplied) to create monthly end-use consumption estimates. The annual enduse shares are calculated in the following manner:

- Sales of LPG to the residential and commercial sector are converted from thousand gallons per year to thousand barrels per year and are assumed to be the annual consumption of LPC $i$ by the sector.

- The quantity of LPG sold each year for consumption in internal combustion engines is allocated between the transportation and industrial sectors on the basis of data for special fuels used on highways published by the U.S. Department of Transportation, Federal Highway Administration, in Highway Statistics. The allocations of L.PG sold for internal combustion engine use to the transportation sector range from a high of 67 percent in 1981 to a low of 37 percent in 1987.

- LPG consumed annually by the industrial sector is estimated as the difference between I PG total supplied and the estimated consumption of LPG by the sum of the residential and commercial sector and the transportation sector. The industrial sector includes $L . P C$ used by chemical plants as raw materials or solvents and used in the production of 
synthetic rubber; refinery fuel use; use as synthetic natural gas feedstock and use in secondary recovery projects; all farm use; LPG sold to gas utility companies for distribution through the mains; and a portion of the use of LPG as an internal combustion engine fuel.

The sources of the annual sales data for creating annual end-use shares are:

- 1973-1982: EIA's "Sales of Liquefied Petroleum Gases and Ethane" reports, based primarily on data collected by Form EIA-174.

- 1983: End-use consumption estimates for 1983 are based on 1982 end-use consumption because the collection of data under Form EIA-174 was discontinued after data year 1982.

- 1984-1991: American Petroleum Institute (API), "Sales of Natural Gas Liquids and Liquefied Refinery Cases," which is based on an LPG sales survey jointly sponsored by $\mathrm{API}$, the Gas Processors Association, and the National Liquefied Petrolcum Gas Association.

- 1992 and 1993: The 1991 source is used to estimate succeeding periods.

- Lubricants-Total product supplied is allocated to the industrial and transportation sectors for all months according to proportions developed from annual sales of lubricants to the two sectors from U.S. Department of Commerce, Bureau of the Census, Current Industrial Reports, "Sales of Lubricating and Industrial Oils and Greases." The 1973 shares are applied to 1973 and 1974; the 1975 shares are applied to 1975 and 1976; and the 1977 shares are applied to 1977 forward.

- Motor Gasoline-Total product supplied monthly is allocated to the major end-use sectors in proportion to aggregations of annual sales categories created on the basis of the U.S. Deparunent of Transportation, Federal Ilighway Administration, Highway Statistics, Tables MF-21, MF-24, and MF-25, as follows:

- Commercial sales are the sum of sales for public non-highway use and miscellaneous and unclassified uses.

- Industrial sales are the sum of sales for agriculture, construction, and industrial and commercial use as classified in the Highway Statistics.

- Transportation sales are the sum of sales for highway use (minus the sales of special fuels, which are primarily diesel fuel and are accounted for in the transportation sector of distillate fuel) and sales for marine use.

- Petroleum Coke-The portion consumed by electric utilities is from form EIA-75\%, "Monthly
Power Plant Report" (formerly Form FPC-4). The remaining petrolcum coke is assigned to the industrial sector.

- Residual Fuel-Product supplied is assigned to electric utilities and non-electric utilities as follows:

\section{Electric Utilities, All Periods.}

Monthly and annual consumption for 1973-1979 is assumed to be the amount of oil reported as consumed in sleam-electric power plants. From January 1980 forward, electric utility consumption of residual fuel is assumed to be the petroleum products reported as heavy oil consumed at electric utilities.

Sources: 1973-September 1977: Form FPC-4, "Monthly Power Plant Report"; October 19771981: FERC, Form FPC-4, "Monthly Power Plant Report"; 1982 forward: EIA, Form EIA-759, "Monthly Power Plant Report."

Sectors Other Than Electric Utilities, Annual Estimates Through 1991.

The aggregate non-electric utility use of residual fuel is total residual fuel supplied minus the electric utility consumption. The non-electric utility annual totals are allocated into the individual non-electric utility sectors in proportion to the amount of residual fuel sold to end users, grouped into sectors from EIA's Fuel Oil and Kerosene Sales (Sales) reports (based primarily on data collected by Form EIA-821, previously Form EIA-172), as follows:

- Since 1979, commercial sales data are directly from the Sales reports. Prior to 1979, each year's sales subtotal of the heating plus industrial category is split into commercial and industrial in proportion to the 1979 shares.

- Since 1979, industrial sales data are the sum of sales for industrial, oil company, and all other uses. Prior to 1979, each year's sales subtotal of the heating plus industrial category is split into commercial and industrial in proportion to the 1979 shares, and this estimated industrial portion is added to oil company and all other uses.

- Transportation sales are the sum of sales for railroad, vessel bunkering, and military uses for all years.

Sectors Other Than Electric Utilities, Monthly Estimates Through 1991.

- Commercial sector monthly consumption is estimated by allocating the annual commercial sector estimates described above into months in proportion to each month's share of the year's sales of No. 2 fuel oil as reported in the "Monthly Report 
of Heating Oil Sales" by the Ethyl Corporation for 1973-1980 and the American Petroleum Institute for 1981 and 1982, and the EIA, Form EIA-782A, "Refiners'/Gas Plant Operators' Monthly Petroleum Product Sales Report," No. 2 Fuel Oil Sales to End Users and for Resale, since 1983.

- Transportation monthly estimates a*e made by evenly distributing the annual sector estimate over the months, adjusting for the number of days per month.

- Industrial monthly estimates are made by subtracting the commercial, transportation, and electric utility sector estimates from each month's total residual fuel supplied.

\section{Sectors Other Than Electric Utilities, 1992 and 1993}

Each month's non-electric utility consumption subtotal is disaggregated into the major end-use sectors in proportion to the shares each sector held of the non-electric utility subtotal in the same month in 1991.

- Road Oil-All product supplied is assigned to the industrial sector.

- All Other Petroleum Products-The product supplied of all remaining petroleum products is assigned to the industrial sector.

7. Nuclear Electric Power and Wood, Waste, Geothermal, Wind, Photovoltaic, and Solar Thermal Energy Sources Connected to Electric Utility Distribution Systems: Sources:

- 1973-1976: FPC, Form FPC-4, "Monthly Power Plant Report."

- 1977-1981: FERC, Form FPC-4, "Monthly Power Plant Report."

- 1982 forward: EIA, Form EIA-759, "Monthly Power Plant Report."

8. Hydroelectric Power: Includes electricity generated by hydroelectric power at electric utilities, small amounts in the industrial sector, and net imports of electricity, which are assumed to be generated by hydroelectric power and are included in the electric utilities sector.

Sources for electric utilities sector:

- 1973-1976: FPC, Form FPC-4, "Monthly Power Plant Report."

- 1977-1981: FERC, Form FPC-4, "Monthly Power Plant Report."

- 1982 forward: EIA, Form EIA-759, "Monthly Power Plant Report."
Sources for industrial sector:

- 1973-1978: FPC, Form FPC-4, "Monthly Power Plant Report," for plants with generating capacity exceeding 10 megawatts, and FPC, Form FPC12C, "Industrial Electric Generating Capacity," for all other plants.

- 1979: FPC, Form FPC-4, "Monthly Power Plant Report," for plants with gencrating capacity exceeding 10 megawatts and EIA estimates for all other plants.

- 1980 forward: Annual generation estimated by EIA as the average generation over the 6-year period of 1974-1979; monthly generation estimated to be in proportion to each month's hydroelectricity generation in the electric utility industry in 1980.

\section{Sources for imports and exports of electricity:}

- 1973-September 1977: Unpublished Federal Power Commission data.

- October 1977-1980: Unpublished Economic Regulatory Administration (ERA) data.

- 1981: DOE, Office of Energy Emergency Operations, "Report on Electric Energy Exchanges with Canada and Mexico for Calendar Year 1981," April 1982 (revised June 1982).

- 1982 and 1983: DOE, ERA, Electricity Exchanges Across International Borders.

- 1984-1986: DOE, ERA, Electricity Transactions Across International Borders.

- 1987 and 1988: DOE, ERA, Form ERA-781R, "Annual Report of International Electrical Export/Import Data."

- 1989-1991: DOE, Assistant Secretary for Fossil Energy, Form FE-781-R, "Annual Report of International Electrical Expor/Import Data."

- 1992 forward: EIA estimates based on preliminary data from the National Energy Board of Canada and DOE, Assistant Secretary for Fossil Energy.

9. Net Imports of Coal Coke: Net imports means imports minus exports, and a minus sign indicates that exports are greater than imports. Sources:

- 1973-1975: DOI, BOM, Minerals Yearbook, "Coke and Coal Chemicals" chapter.

- 1976-1980: EIA, Energy Data Report, "Coke and Coal Chemicals" annual.

- 1981: EIA, Energy Data Report, "Coke Plant Report," quarterly.

- 1982 forward: EIA, Quarterly Coal Report.

10. Electricity: End-use consumption of electricity is based on Table 7.2 sales data. "Other," which is primarily for use in government buildings, is added to the commercial sector, except for approximately 4 per- 
cent used by railroads and railways and attributed to the transportation sector. For 1973-1983 and 1992 forward, "Monthly Series" data are used directly. For 19841991, monthly estimates are created by dividing each month's "Monthly Series" value by the "Monthly Series" total for the year and multiplying by the "Annual Series" value for the year. Kilowatthours are converted to Btu at the rate of 3,412 Btu per kilowatthour. See Table 7.2 for sources of the electricity sales data.

11. Electrical System Energy Losses: Electrical system energy losses are calculated as the difference between total energy input at electric utilities and the total energy content of electricity sold to end-use consumers. Most of those losses occur at stean-electric power plants (conventional and nuclear) in the conversion of heat energy into mechanical energy to turn electric generators. The loss is a thermodynamically necessary feature of the steam-electric cycle. Part of the energy input-10-output losses is a result of imputing fossil energy equivalent inputs for hydroelectric and other energy sources, since there is no generally accepted practice for measuring those thermal conversion rates. In addition to conversion losses, other losses include power plant use of electricity, transmission and distribution of electricity from power plants to end-use consumers (also called "line losses"), and unaccounted for electricity. Total losses are allocated to the end-use sectors in proportion to each sector's share of total electricity sales. Overall, approximately 67 percent of total energy input is lost in conversion; of electricity generated, approximately 5 percent is lost in plant use and 9 percent is lost in transmission and distribution. Calculated electrical system energy losses may be less than actual losses, because primary consumption does not include the energy equivalent of utility purchases of electricity from non-electric utilities and from Canada and Mexico, although they are included in electricity sales. 


\section{Section 3. Petroleum}

Total petroleum imports ${ }^{2}$ averaged 8.3 million barrels per day in December 1993,5 percent $^{3}$ lower than the previous month's rate but 5 percent higher than the December 1992 rate.

In December 1993, 17.7 million barrels per day of petroleum products were supplied for domestic use, 1 percent lower than the December 1992 rate. Motor gasoline accounted for 43 percent of the total; distillate fuel oil, 19 percent; and residual fuel oil, 6 percent.

Motor gasoline supplied during December 1993 averaged 7.7 million barrels per day, 1 percent higher than the previous month's rate and 3 percent higher than the December 1992 rate. Total motor gasoline stocks were 226 million barrels at the end of December 1993, 6 million barrels above the stock level in the previous month and 10 million barrels above the level 1 year earlier.
Distillate fuel oil supplied during December 1993 averaged 3.4 million barrels per day, 7 percent higher than the previous month's rate and 3 percent higher than the December 1992 rate. Distillate fuel oil ending stocks for December 1993 were 144 million barrels, 6 million barrels helow the stock level in the previous month but 3 million barrels above the stock level 1 year earlier.

Residual fuel oil supplied in December 1993 averaged 1.0 million barrels per day, 4 percent lower than the previous month's rate and 21 percent lower than the December 1992 rate. Residual fuel oil stocks measured 45 million barrels at the end of December 1993, 4 million barrels below the stock level in the previous month but 2 million barrels above the stock level 1 year carlier.

Estimates (except of crude production) for the most current month are based on Energy Information Administration (EIA) weekly data and will be revised to conform with data from the EIA Petroleum Reporting System as available. For the most recent month, crude production is an EIA estimate based on historical and provisional data through September 1993.

\footnotetext{
${ }^{2}$ Tolal import dala Include imports into the Strategic Petroleum Reserve.

${ }^{3}$ Percentage changes are based on numbers shown in the lollowing lables.
} 
Table 3.1a Petroleum Overview: Field Production, Stock Change, Petroleum Products Supplied, and Ending Stocks

\begin{tabular}{|c|c|c|c|c|c|c|c|}
\hline & \multicolumn{3}{|c|}{ Flold Production } & \multicolumn{2}{|c|}{ Stock Changea } & \multirow[b]{2}{*}{$\begin{array}{l}\text { Petroloum } \\
\text { Products } \\
\text { Supplled }\end{array}$} & \multirow{2}{*}{$\begin{array}{l}\text { Ending Stockb } \\
\text { Crude Olld and } \\
\text { Potroloum } \\
\text { Product }\end{array}$} \\
\hline & $\begin{array}{c}\text { Total } \\
\text { Domest } \mathrm{c}^{\mathrm{c}}\end{array}$ & $\begin{array}{c}\text { Crude } \\
\text { Oll }\end{array}$ & $\begin{array}{c}\text { Natural } \\
\text { Gas Plant } \\
\text { Production }\end{array}$ & $\begin{array}{c}\text { Crude } \\
\text { Olld }\end{array}$ & $\begin{array}{c}\text { Potroleum } \\
\text { Products }\end{array}$ & & \\
\hline & \multicolumn{6}{|c|}{ Thousand Barrels per Day } & Million Barrels \\
\hline 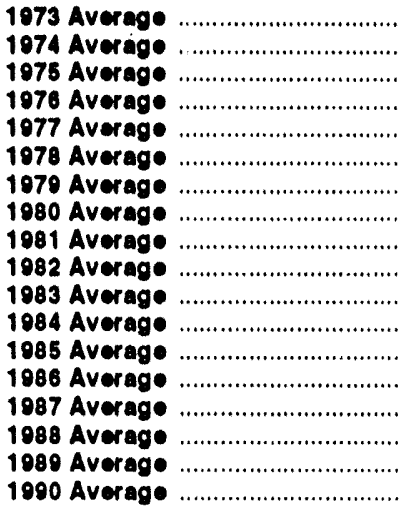 & $\begin{array}{r}10,978 \\
10,498 \\
10,045 \\
0,774 \\
9,913 \\
10,328 \\
10,179 \\
10,214 \\
10,230 \\
10,252 \\
10,299 \\
10,554 \\
10,636 \\
10,289 \\
10,008 \\
9,818 \\
9,219 \\
8,994\end{array}$ & $\begin{array}{l}9,208 \\
8,774 \\
8,375 \\
8,132 \\
8,245 \\
8,707 \\
8,552 \\
8,597 \\
8,572 \\
8,640 \\
8,688 \\
8,870 \\
8,971 \\
8,680 \\
8,349 \\
8,140 \\
7,613 \\
7,355\end{array}$ & $\begin{array}{l}1,738 \\
1,688 \\
1,633 \\
1,604 \\
1,618 \\
1,567 \\
1,584 \\
1,573 \\
1,609 \\
1,550 \\
1,559 \\
1,630 \\
1,609 \\
1,551 \\
1,595 \\
1,625 \\
1,546 \\
1,559\end{array}$ & $\begin{array}{r}-11 \\
62 \\
-17 \\
30 \\
170 \\
78 \\
148 \\
08 \\
0290 \\
138 \\
0214 \\
190 \\
50 \\
78 \\
128 \\
1 \\
86 \\
-35\end{array}$ & $\begin{array}{r}146 \\
117 \\
015 \\
-08 \\
378 \\
-172 \\
25 \\
42 \\
\cdot .130 \\
-283 \\
-234 \\
81 \\
-153 \\
124 \\
-87 \\
-29 \\
-129 \\
142\end{array}$ & $\begin{array}{l}17,308 \\
16,653 \\
16,322 \\
17,461 \\
18,431 \\
18,847 \\
18,513 \\
17,056 \\
16,058 \\
15,208 \\
15,231 \\
15,726 \\
15,726 \\
16,281 \\
16,665 \\
17,283 \\
17,325 \\
16,088\end{array}$ & $\begin{array}{r}1,008 \\
\bullet 1,074 \\
1,133 \\
1,112 \\
1,312 \\
1,278 \\
1,341 \\
1,392 \\
1,484 \\
1,430 \\
1,454 \\
1,556 \\
1,510 \\
1,593 \\
1,607 \\
1,597 \\
1,581 \\
1,621\end{array}$ \\
\hline 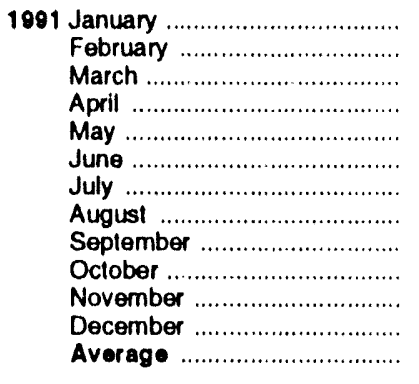 & $\begin{array}{l}9,255 \\
9,424 \\
9,301 \\
9,262 \\
9,157 \\
9,032 \\
9,056 \\
9,027 \\
9,088 \\
9,212 \\
9,129 \\
9,089 \\
9,168\end{array}$ & $\begin{array}{l}7,500 \\
7,637 \\
7,546 \\
7,509 \\
7,409 \\
7,320 \\
7,347 \\
7,316 \\
7,368 \\
7,437 \\
7,328 \\
7,299 \\
7,417\end{array}$ & $\begin{array}{l}1,647 \\
1,695 \\
1,683 \\
1,665 \\
1,657 \\
1,627 \\
1,622 \\
1,627 \\
1,623 \\
1,686 \\
1,697 \\
1,686 \\
1,659\end{array}$ & $\begin{array}{r}-71 \\
231 \\
.239 \\
50 \\
566 \\
.299 \\
.153 \\
103 \\
-156 \\
51 \\
43 \\
-611 \\
-42\end{array}$ & $\begin{array}{r}-1.027 \\
.704 \\
-268 \\
628 \\
988 \\
546 \\
199 \\
316 \\
653 \\
.659 \\
62 \\
.365 \\
.22\end{array}$ & $\begin{array}{l}16,893 \\
16,339 \\
16,212 \\
16,139 \\
16,189 \\
16,878 \\
16,971 \\
17,183 \\
16,848 \\
16,996 \\
16,730 \\
17,145 \\
16,714\end{array}$ & $\begin{array}{l}1,587 \\
1,573 \\
1,558 \\
1,578 \\
1,626 \\
1,634 \\
1,635 \\
1,648 \\
1,663 \\
1,644 \\
1,647 \\
1,617 \\
1,617\end{array}$ \\
\hline 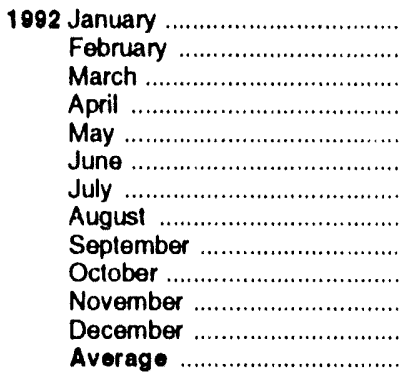 & $\begin{array}{l}9,176 \\
9,175 \\
9,123 \\
9,072 \\
8,949 \\
8,968 \\
8,961 \\
8,678 \\
8,843 \\
9,025 \\
8,975 \\
9,019 \\
8,996\end{array}$ & $\begin{array}{l}7,361 \\
7,389 \\
7,348 \\
7,293 \\
7,169 \\
7,167 \\
7,131 \\
6,922 \\
7,030 \\
7,126 \\
7,024 \\
7,103 \\
7,171\end{array}$ & $\begin{array}{l}1,688 \\
1,696 \\
1,694 \\
1,693 \\
1,695 \\
1,701 \\
1,683 \\
1,638 \\
1,660 \\
1,722 \\
1,754 \\
1,744 \\
1,697\end{array}$ & $\begin{array}{r}540 \\
171 \\
.250 \\
315 \\
-144 \\
-581 \\
244 \\
-124 \\
-160 \\
411 \\
-227 \\
-212 \\
-1\end{array}$ & $\begin{array}{r}.757 \\
.951 \\
.291 \\
92 \\
770 \\
604 \\
290 \\
161 \\
653 \\
.258 \\
77 \\
-1,203 \\
-68\end{array}$ & $\begin{array}{l}17,012 \\
16,893 \\
16,825 \\
16,764 \\
16,485 \\
16,978 \\
17,143 \\
16,929 \\
16,876 \\
17,448 \\
17,091 \\
17,928 \\
17,033\end{array}$ & $\begin{array}{r}1,610 \\
1,588 \\
1,571 \\
1,583 \\
1,602 \\
1,603 \\
1,620 \\
1,621 \\
1,636 \\
1,640 \\
1,636 \\
\theta_{1}, 592 \\
\theta_{1}, 592\end{array}$ \\
\hline 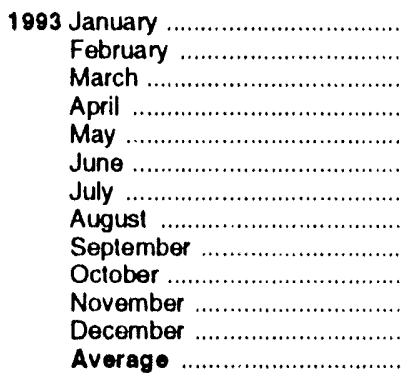 & $\begin{array}{l}E_{89,257} \\
E_{8,948} \\
E_{9,009} \\
E_{8,904} \\
E_{8,775} \\
E_{8,697} \\
E_{8,599} \\
E_{8,691} \\
E_{8,670} \\
E_{8,847} \\
\text { AE }_{8,823} \\
E_{8,880} \\
E_{8,841}\end{array}$ & $\begin{array}{l}E_{7,008} \\
E_{6,957} \\
E_{6,976} \\
E_{6,897} \\
E_{6,833} \\
E_{6,756} \\
E_{6,654} \\
E_{6,732} \\
E_{6,711} \\
E_{6,816} \\
\text { PE }_{6,888} \\
P E_{6,886} \\
P_{6,842}\end{array}$ & $\begin{array}{r}1,728 \\
1,761 \\
1,799 \\
1,790 \\
1,719 \\
1,738 \\
1,723 \\
1,732 \\
1,717 \\
1,765 \\
\text { R } 1,674 \\
\text { E } 1,740 \\
\text { E. } 1,741\end{array}$ & $\begin{array}{r}264 \\
219 \\
246 \\
537 \\
133 \\
-15 \\
41 \\
.524 \\
.439 \\
333 \\
\text { A } 251 \\
\text { E } 93 \\
\text { E } 94\end{array}$ & $\begin{array}{r}0370 \\
-799 \\
.619 \\
388 \\
897 \\
586 \\
542 \\
386 \\
7 \\
420 \\
A_{-286} \\
E_{-446} \\
E_{127}\end{array}$ & $\begin{array}{r}16,320 \\
17,397 \\
17,688 \\
16,673 \\
16,340 \\
17,032 \\
17,208 \\
17,176 \\
17,709 \\
17,230 \\
\text { A } 17,688 \\
\text { E } 17,721 \\
\text { E } 17,179\end{array}$ & $\begin{array}{r}1,611 \\
1,595 \\
1,584 \\
1,611 \\
1,643 \\
1,660 \\
1,678 \\
1,674 \\
1,661 \\
1,685 \\
A_{1} 1,684 \\
E_{1,669} \\
\varepsilon_{1,669}\end{array}$ \\
\hline
\end{tabular}

a A negative number indicates a decrease in stocks and a positive number indicates an increase.

b Stocks are totals as of end of period.

c Includes crude oil, natural gas plant liquids, and other liquids.

d Includes stocks located in the Strategic Petroleum Reserve.

- See Note 4 at end of section.

See Note 6 at end of section.

- Beginning in 1993, includes fuel ethanol blended into finished motor gasoline and oxygenate production from merchant MTBE (methyl tertiary butyl ether) plants.

PE=Preliminary estimate. $R=$ Revised data. $\quad N A=$ Not available. $E=$ Estimate.

Notes: - Crude oil includes lease condensate. - Geographic coverage is the 50 States and the District of Columbia.

Sources: - 1973-1980: Energy Intormation Administration (EIA), Petroleum Supply Monthly, February 1993, Table S1. • 1981 forward: EIA, Petroleum Supply Monthly, January 1994, Table S1. 
Table 3.1b Petroleum Overview: Imports, Exports, and Net Imports

\begin{tabular}{|c|c|c|c|c|c|c|c|}
\hline & \multicolumn{3}{|c|}{ Imports } & \multicolumn{3}{|c|}{ Exports } & \multirow[b]{2}{*}{$\begin{array}{c}\text { Not } \\
\text { Importeb }\end{array}$} \\
\hline & Total & $\begin{array}{c}\text { Crude } \\
\text { Oll* }\end{array}$ & $\begin{array}{c}\text { Potroleum } \\
\text { Products }\end{array}$ & Total & $\begin{array}{c}\text { Crudo } \\
\text { Oll }\end{array}$ & $\begin{array}{l}\text { Potroloum } \\
\text { Producte }\end{array}$ & \\
\hline & \multicolumn{7}{|c|}{ Thousand Barrels per Day } \\
\hline 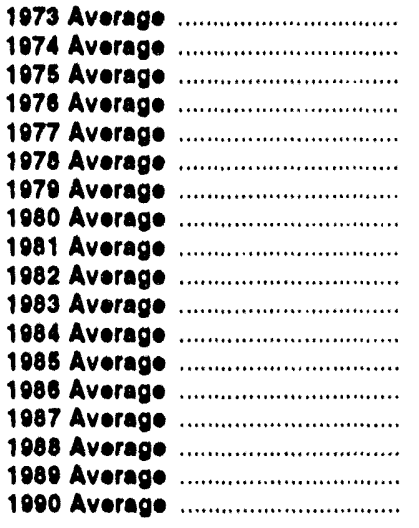 & $\begin{array}{l}6,256 \\
6,112 \\
6,056 \\
7,313 \\
8,807 \\
8,363 \\
8,456 \\
6,909 \\
5,996 \\
5,113 \\
5,051 \\
5,437 \\
5,067 \\
6,224 \\
6,678 \\
7,402 \\
8,061 \\
8,018\end{array}$ & $\begin{array}{l}3,244 \\
3,477 \\
4,105 \\
5,287 \\
6,615 \\
6,358 \\
6,510 \\
5,263 \\
4,396 \\
3,488 \\
3,329 \\
3,428 \\
3,201 \\
4,178 \\
4,674 \\
5,107 \\
5,843 \\
8,804\end{array}$ & $\begin{array}{l}3,012 \\
2,635 \\
1,051 \\
2,026 \\
2,193 \\
2,008 \\
1,937 \\
1,646 \\
1,590 \\
1,625 \\
1,722 \\
2,011 \\
1,666 \\
2,045 \\
2,004 \\
2,205 \\
2,217 \\
2,123\end{array}$ & $\begin{array}{r}231 \\
221 \\
200 \\
223 \\
243 \\
382 \\
0471 \\
544 \\
505 \\
815 \\
730 \\
722 \\
781 \\
785 \\
784 \\
818 \\
850 \\
857\end{array}$ & $\begin{array}{r}2 \\
3 \\
6 \\
8 \\
50 \\
158 \\
238 \\
287 \\
228 \\
238 \\
164 \\
181 \\
204 \\
154 \\
151 \\
158 \\
142 \\
109\end{array}$ & $\begin{array}{l}220 \\
218 \\
204 \\
218 \\
103 \\
204 \\
0238 \\
256 \\
367 \\
570 \\
578 \\
641 \\
577 \\
631 \\
613 \\
681 \\
717 \\
740\end{array}$ & 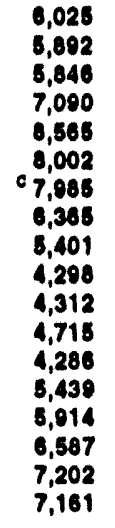 \\
\hline 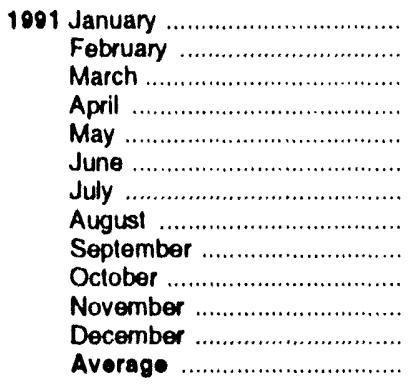 & $\begin{array}{l}7,103 \\
6,865 \\
6,646 \\
7.418 \\
8,518 \\
8,245 \\
7.755 \\
8,670 \\
7,826 \\
7.467 \\
7.615 \\
7.337 \\
7,627\end{array}$ & $\begin{array}{l}5,296 \\
5,485 \\
5,166 \\
5,529 \\
6,363 \\
6,334 \\
5,955 \\
6,645 \\
5,812 \\
5,683 \\
5,528 \\
5,565 \\
5,782\end{array}$ & $\begin{array}{l}1,808 \\
1,380 \\
1,480 \\
1,888 \\
2,155 \\
1,911 \\
1,801 \\
2,025 \\
2,015 \\
1,784 \\
2,087 \\
1,772 \\
1,844\end{array}$ & $\begin{array}{r}1.199 \\
1.441 \\
944 \\
737 \\
1.149 \\
921 \\
963 \\
837 \\
785 \\
918 \\
926 \\
1.213 \\
1,001\end{array}$ & $\begin{array}{r}50 \\
152 \\
137 \\
162 \\
165 \\
78 \\
139 \\
55 \\
109 \\
92 \\
126 \\
133 \\
116\end{array}$ & $\begin{array}{r}1.149 \\
1,288 \\
807 \\
575 \\
984 \\
843 \\
824 \\
783 \\
676 \\
826 \\
800 \\
1.081 \\
885\end{array}$ & $\begin{array}{l}5,904 \\
5,424 \\
5,702 \\
6,680 \\
7,369 \\
7,323 \\
6,793 \\
7,832 \\
7,042 \\
6,550 \\
6,690 \\
6,124 \\
6,626\end{array}$ \\
\hline 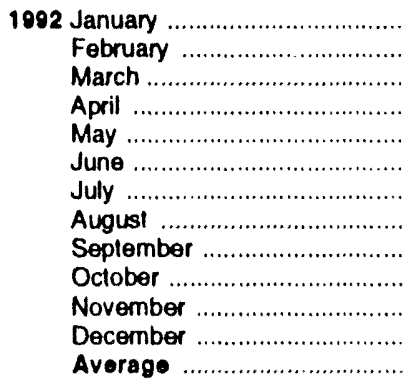 & $\begin{array}{l}7,712 \\
6,827 \\
7,068 \\
8,092 \\
7,823 \\
7,946 \\
8,479 \\
8,260 \\
8,178 \\
8,505 \\
7,872 \\
7,839 \\
7,888\end{array}$ & $\begin{array}{l}5,956 \\
5,079 \\
5,321 \\
6,127 \\
6,060 \\
6,171 \\
6,796 \\
6,457 \\
6,218 \\
6,696 \\
6,121 \\
5,937 \\
6,083\end{array}$ & $\begin{array}{l}1,756 \\
1.748 \\
1,747 \\
1,966 \\
1,763 \\
1,775 \\
1,683 \\
1,803 \\
1,960 \\
1,810 \\
1,751 \\
1,901 \\
1,805\end{array}$ & $\begin{array}{r}1.144 \\
852 \\
912 \\
937 \\
885 \\
957 \\
929 \\
789 \\
848 \\
902 \\
995 \\
1.237 \\
950\end{array}$ & $\begin{array}{r}118 \\
22 \\
105 \\
23 \\
106 \\
107 \\
53 \\
133 \\
68 \\
106 \\
111 \\
107 \\
89\end{array}$ & $\begin{array}{r}1,026 \\
829 \\
807 \\
914 \\
779 \\
850 \\
876 \\
657 \\
780 \\
796 \\
885 \\
1,130 \\
861\end{array}$ & $\begin{array}{l}6,568 \\
5,975 \\
6,156 \\
7,155 \\
6,939 \\
6,989 \\
7,550 \\
7,470 \\
7,330 \\
7,603 \\
6,877 \\
6,602 \\
6,938\end{array}$ \\
\hline 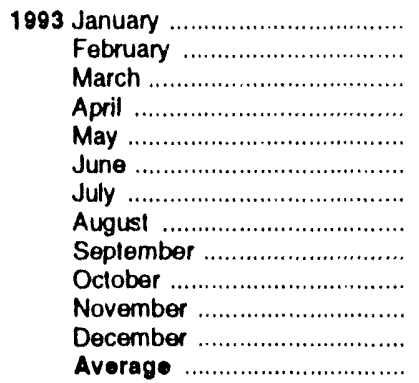 & $\begin{array}{r}7,964 \\
7,930 \\
8,342 \\
8,485 \\
8,348 \\
8,745 \\
9,145 \\
8,360 \\
8,476 \\
9,147 \\
R_{8,725} \\
E_{8,259} \\
E_{8,497}\end{array}$ & $\begin{array}{r}6,292 \\
6,156 \\
6,513 \\
6,698 \\
6,549 \\
7,175 \\
7,262 \\
6,614 \\
6,558 \\
7,181 \\
\text { P }_{6,892} \\
\text { E }_{6,667} \\
\text { E }_{6,716}\end{array}$ & $\begin{array}{l}1,672 \\
1,775 \\
1,829 \\
1,787 \\
1,799 \\
1,569 \\
1,883 \\
1,746 \\
1,918 \\
1,966 \\
\text { P } 1,833 \\
\text { E } 1,592 \\
1,781\end{array}$ & $\begin{array}{r}1,135 \\
1,033 \\
970 \\
1,067 \\
1,082 \\
899 \\
1,013 \\
823 \\
902 \\
889 \\
\text { A } 965 \\
\text { E } 870 \\
\text { E } 970\end{array}$ & $\begin{array}{r}129 \\
166 \\
139 \\
73 \\
112 \\
150 \\
62 \\
55 \\
107 \\
62 \\
\text { A }_{67} \\
\text { E } 117 \\
\text { E } 103\end{array}$ & $\begin{array}{r}1,006 \\
867 \\
831 \\
994 \\
970 \\
750 \\
950 \\
768 \\
796 \\
827 \\
\text { P }_{898} \\
E_{754} \\
E_{868}\end{array}$ & $\begin{array}{r}6,830 \\
6,897 \\
7,373 \\
7,418 \\
7,266 \\
7,845 \\
8,132 \\
7,537 \\
7,574 \\
8,258 \\
R 7,760 \\
\text { E } 7,389 \\
\text { E } 7,527\end{array}$ \\
\hline
\end{tabular}

a Includes crude oil for storage in the Strategic Petroleum Reserve.

b Net imports equals imports minus exports.

c See Nole 6 at end of section.

$R=$ Revised dala. E=Estimate.

Notes: - Geographic coverage is the 50 States and the District of Columbia.

- Totals may not equal sum of components due to independent rounding

Sources: - 1973-1080: Energy Information Administration (EIA). Petroleum Supply Monthly, February 1993, Table S1. - 1981 forward: EIA, Petroloum Supply Monthly, January 1994, Table S1. 


\section{Flgure 3.1 Petroleum Overvlew \\ (Million Barrels per Day)}

\section{Overview, January-December}

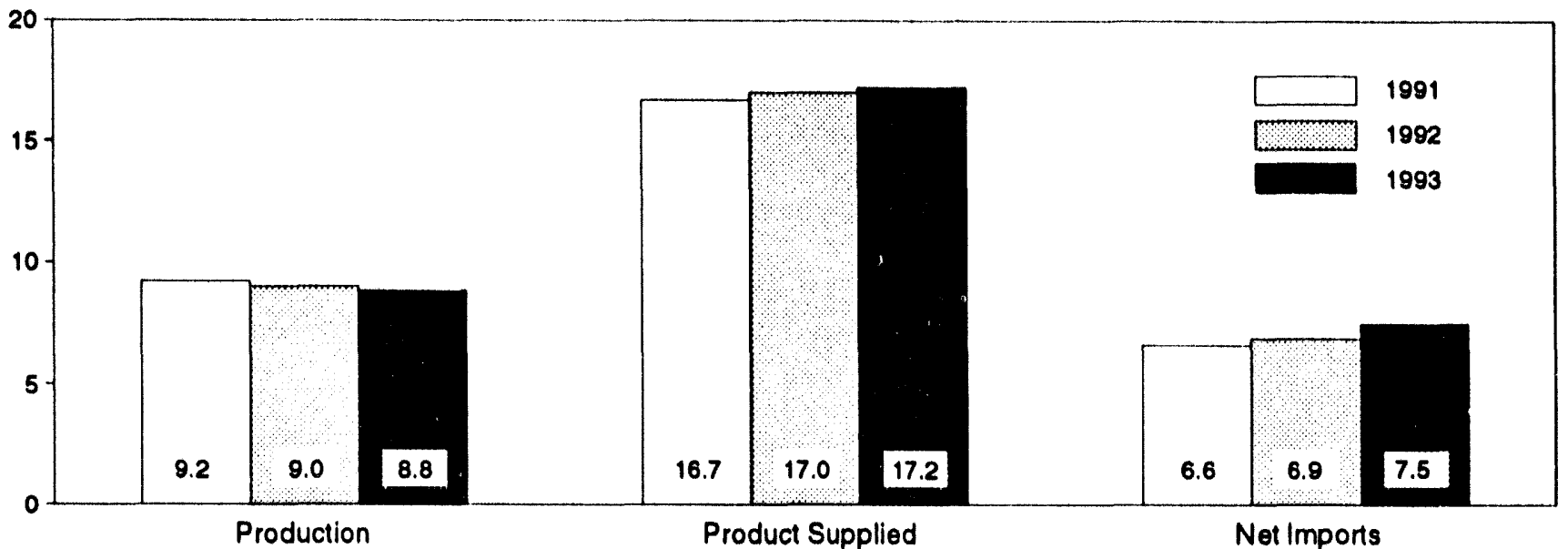

Overview, 1973-1993

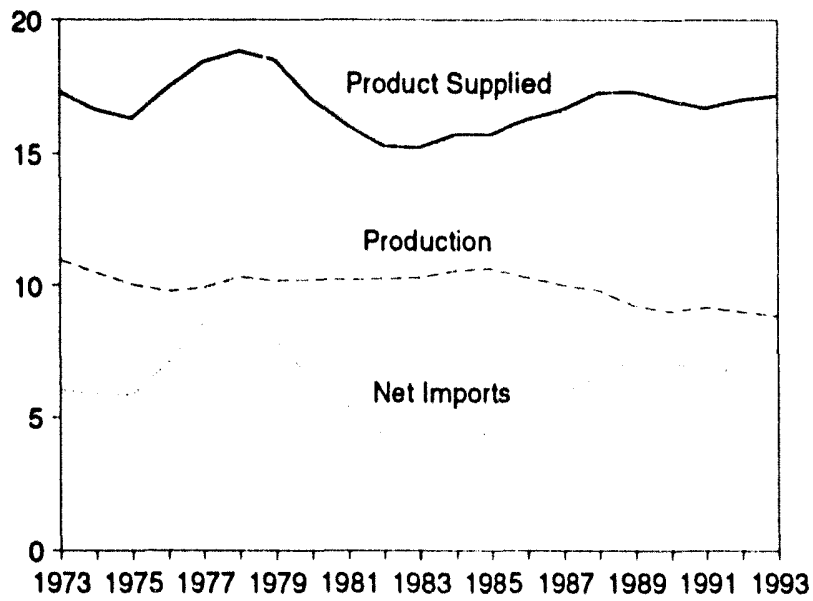

Crude Oil Production, 1973-1993

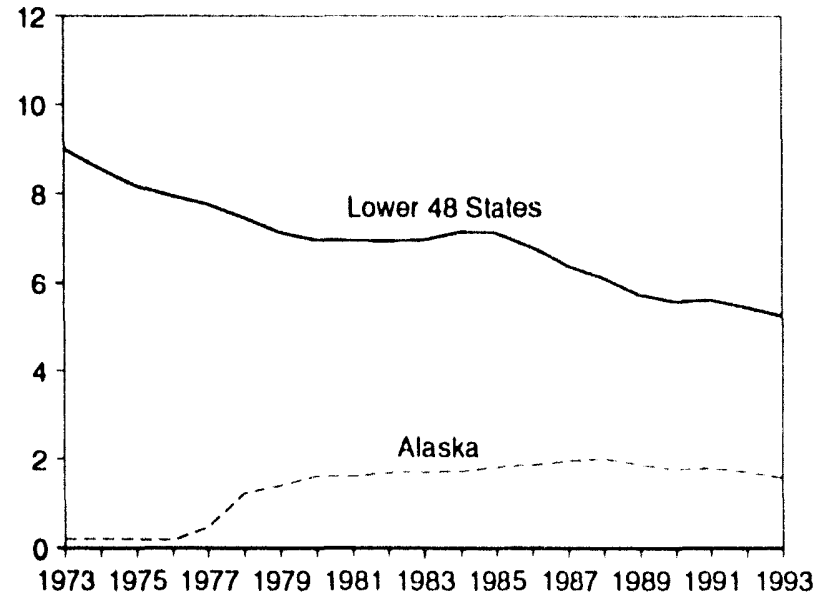

Production, 1973-1993

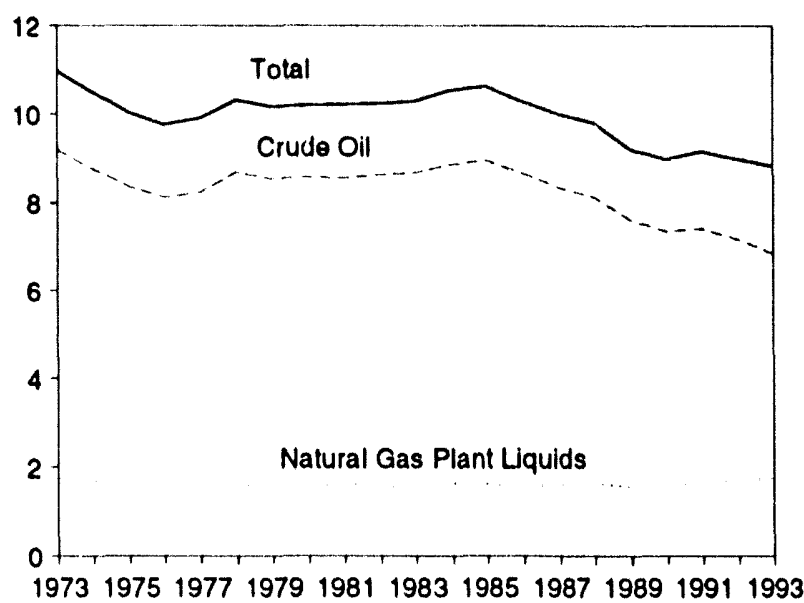

Total Production, Monthly

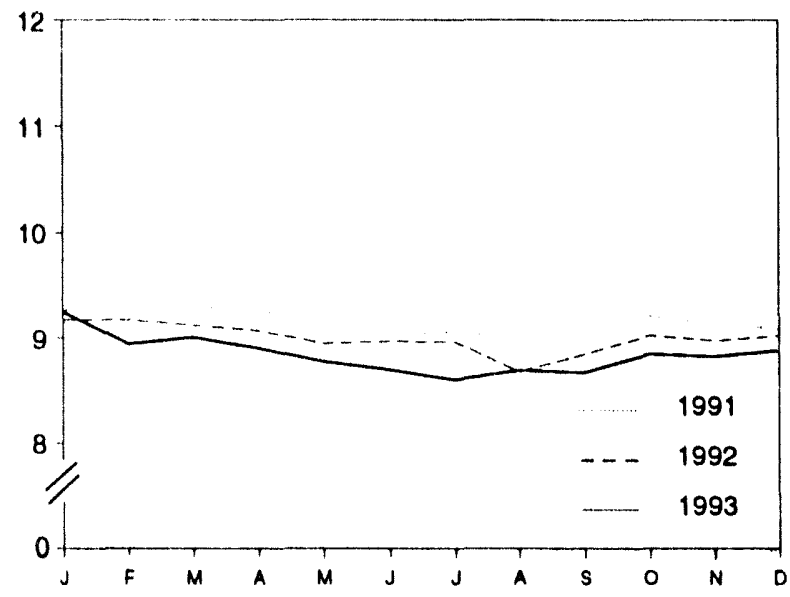

Note: Because vertical scales differ, graphs should nol be compared

Sources: Tables 3.1a, 3.1b, and 3.2a 
Figure 3.1 Petroleum Overview (Continued)

(Million Barrels per Day, Except as Noted)

Product Supplied, 1973-1993

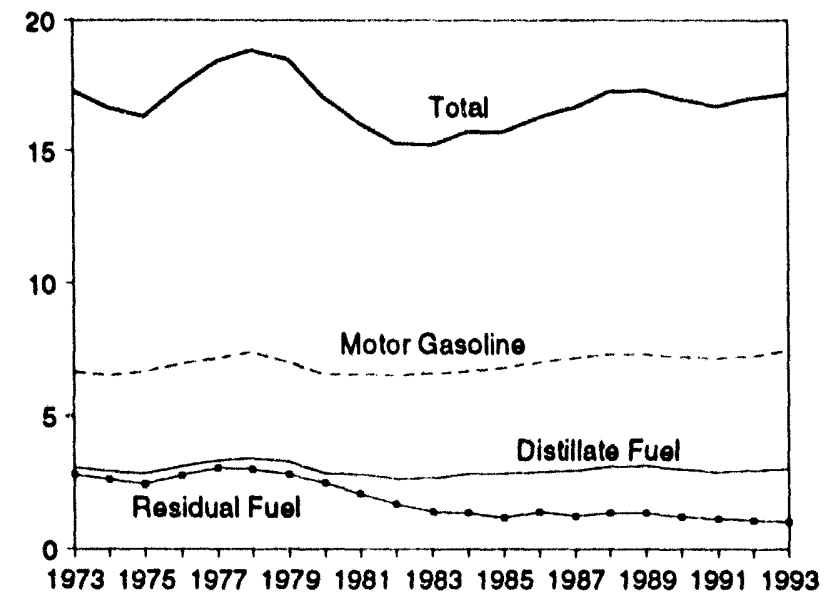

Total Product Supplied, Monthly

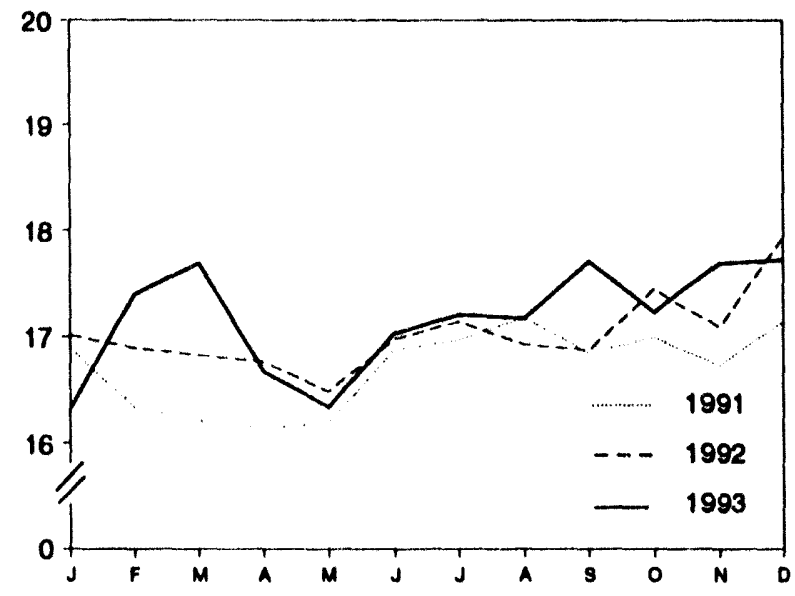

Imports from Selected Countries, November 1993

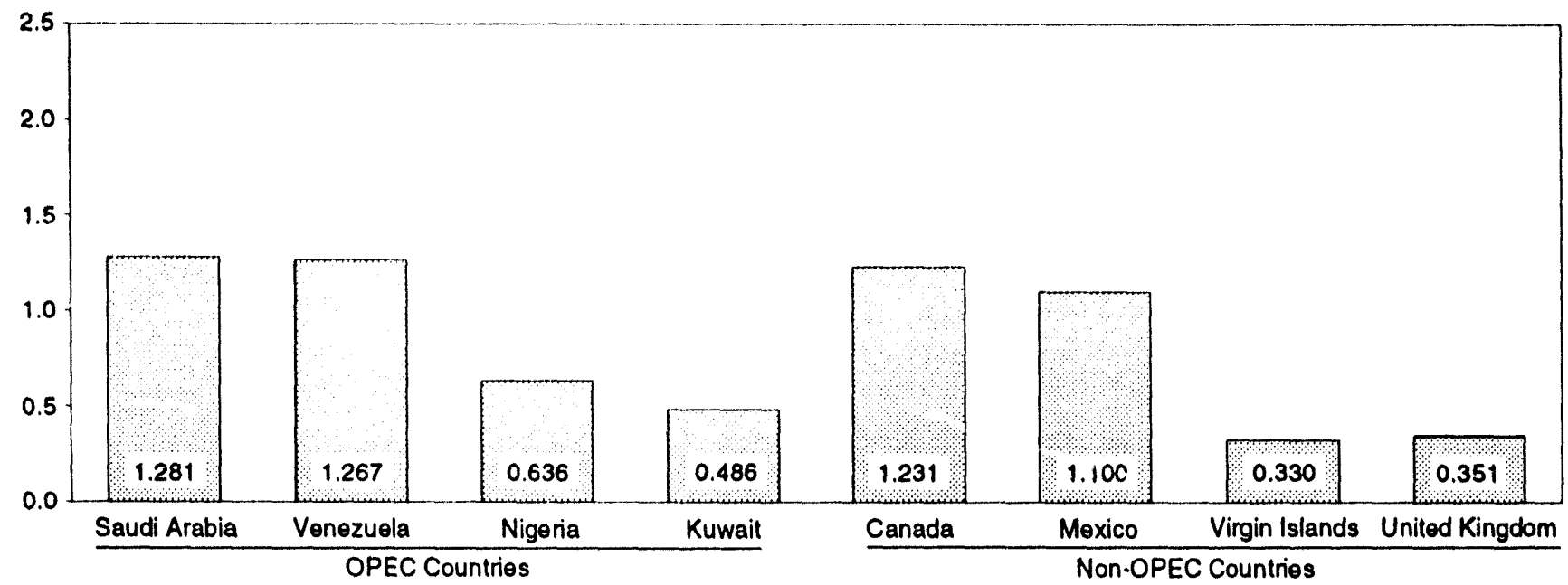

Stocks, End of Year, 1973-1993

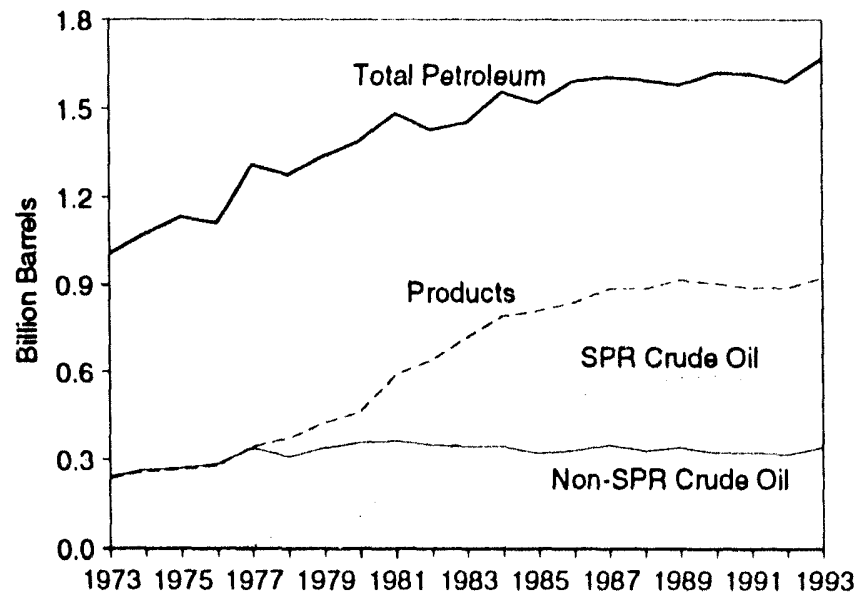

Note: OPEC = Organization of Petroleum Exponing Countries.

Note: Because vertical scales differ, graphs should not be compared

Total Petroleum Stocks, End of Month

Sources: Tables 3.1a, 3.2b, 3.3a, 3.3b, 3.3d-3.3h, 3.4, 3.5, and 3.6.

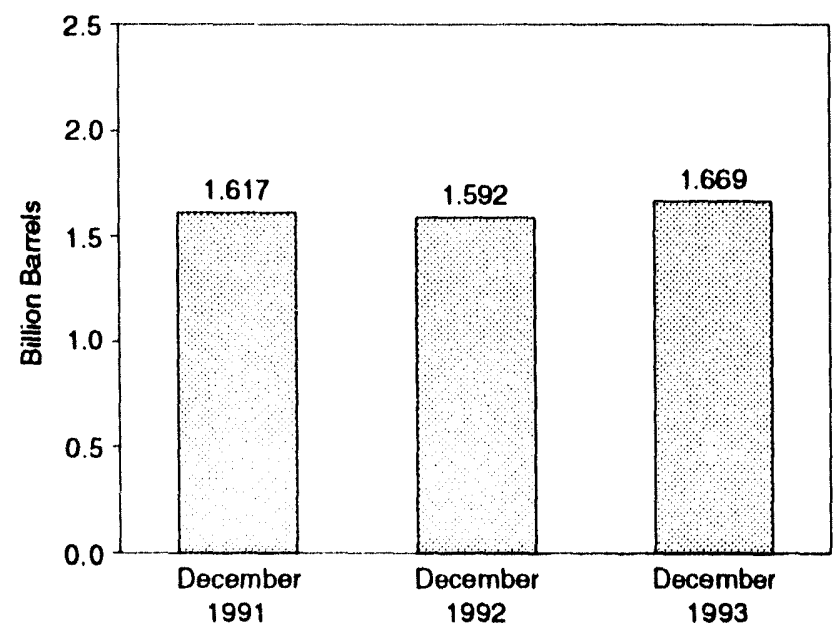

Note: SPR = Strategic Petroleum Reserve. 


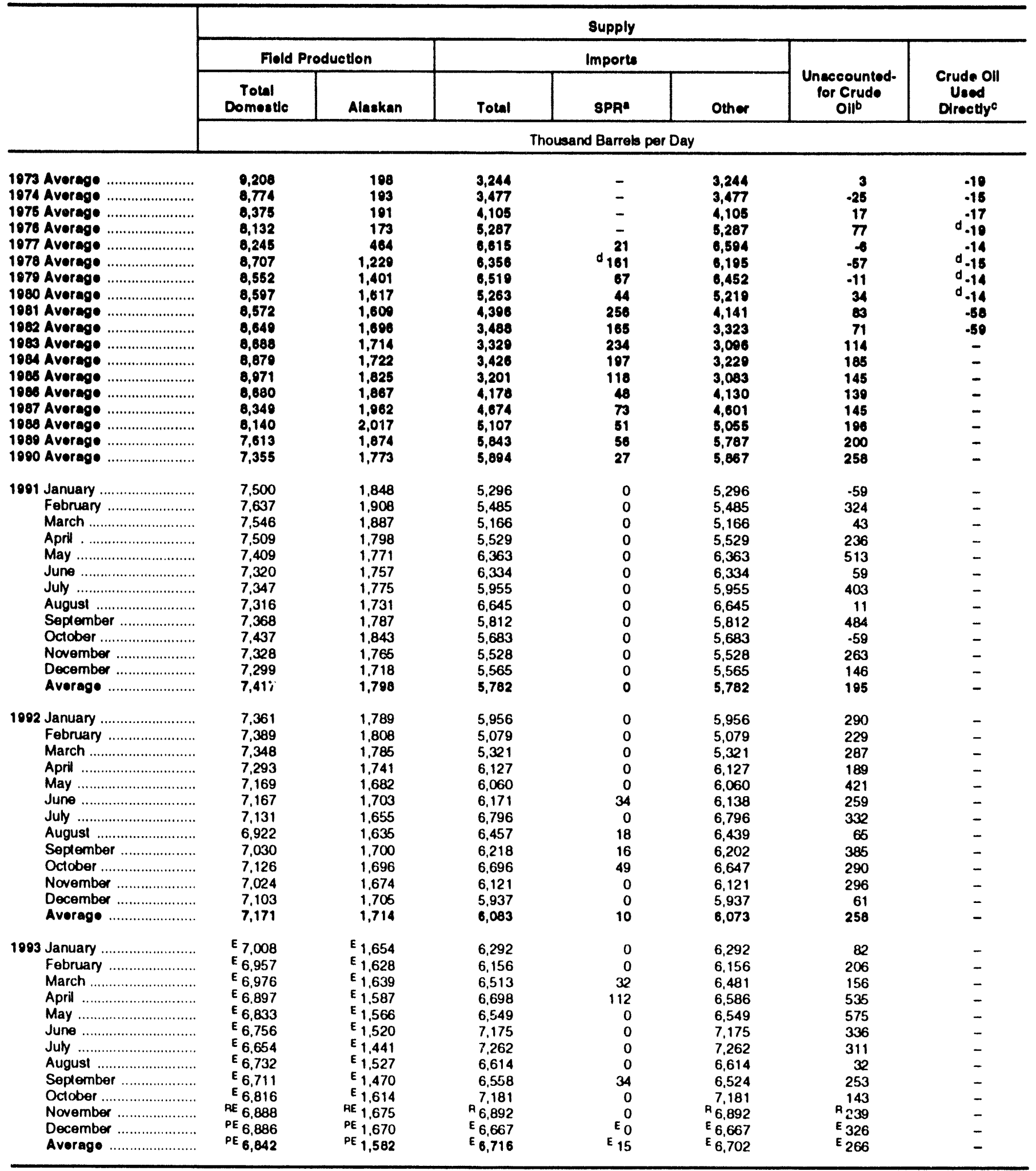

atrategic Petroleum Reserve.

b A balancing item.

C Beginning in January 1983, crude oil used directly as luel is shown as product supplied.

d See Nole 6 at end of section.

$P E=$ Preliminary estimate. $A=$ Revised data. $-=$ Not applicable. $E=E s t i m a t e$.
Notes: - Crude oil includes lease condensale. - Geographic coverage is the 50 States and the District of Columbia. - Totals may not equal sum of components due to independent rounding.

Sources: - 1973-1980: Energy Intormation Adminisiration (EIA), Petroleum Supply Monthly, February 1993, Table S2. - 1981 forward: EIA, Petroleum Supply Monthly, January 1994, Table S2. 
Table 3.2b Crude Oil Supply and Disposition: Disposition and Ending Stocks

\begin{tabular}{|c|c|c|c|c|c|c|c|c|c|}
\hline & \multicolumn{6}{|c|}{ Disposition } & \multicolumn{3}{|c|}{ Endling stockes } \\
\hline & \multirow{2}{*}{$\begin{array}{l}\text { Crude } \\
\text { Losses }\end{array}$} & \multicolumn{2}{|c|}{ 8tock Changeb } & \multirow{2}{*}{$\begin{array}{l}\text { Refinery } \\
\text { Inputs }\end{array}$} & \multirow[b]{2}{*}{ Exporto } & \multirow{2}{*}{$\begin{array}{l}\text { Product } \\
\text { Supplledd }\end{array}$} & \multirow[b]{2}{*}{ Total } & \multirow[b]{2}{*}{ SPRc } & \multirow{2}{*}{$\begin{array}{l}\text { Othor } \\
\text { Primary }\end{array}$} \\
\hline & & SPRC & Other & & & & & & \\
\hline & \multicolumn{6}{|c|}{ Thousand Barrels per Day } & \multicolumn{3}{|c|}{ Million Barreda } \\
\hline 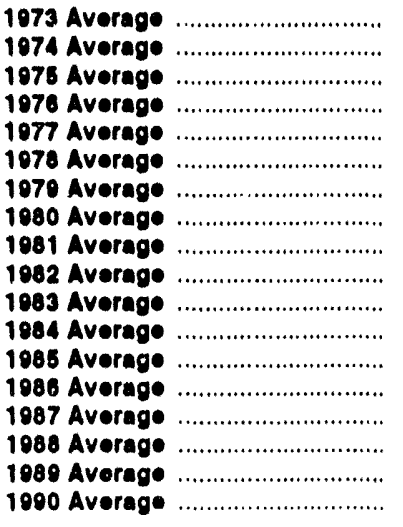 & $\begin{array}{r}13 \\
13 \\
13 \\
14 \\
16 \\
16 \\
16 \\
14 \\
5 \\
3 \\
2 \\
2 \\
1 \\
(s) \\
(s) \\
(s) \\
(s) \\
(s)\end{array}$ & $\begin{array}{r}- \\
- \\
- \\
- \\
20 \\
163 \\
67 \\
45 \\
338 \\
174 \\
234 \\
195 \\
117 \\
50 \\
80 \\
52 \\
58 \\
16\end{array}$ & $\begin{array}{r}-11 \\
62 \\
17 \\
30 \\
150 \\
-94 \\
01 \\
52 \\
1-46 \\
-38 \\
0.20 \\
4 \\
-67 \\
28 \\
40 \\
-51 \\
30 \\
-51\end{array}$ & $\begin{array}{l}12,431 \\
12,133 \\
12,442 \\
13,416 \\
14,602 \\
14,739 \\
14,648 \\
13,481 \\
12,470 \\
11,774 \\
11,686 \\
12,044 \\
12,002 \\
12,718 \\
12,854 \\
13,246 \\
13,401 \\
13,409\end{array}$ & $\begin{array}{r}2 \\
3 \\
6 \\
8 \\
80 \\
188 \\
235 \\
287 \\
228 \\
230 \\
164 \\
181 \\
204 \\
154 \\
151 \\
155 \\
142 \\
100\end{array}$ & $\begin{array}{l}- \\
- \\
- \\
- \\
- \\
- \\
- \\
- \\
- \\
60 \\
64 \\
60 \\
40 \\
34 \\
40 \\
20 \\
24\end{array}$ & $\begin{array}{r}242 \\
268 \\
271 \\
288 \\
348 \\
376 \\
430 \\
1488 \\
804 \\
0844 \\
723 \\
708 \\
814 \\
843 \\
890 \\
890 \\
821 \\
908\end{array}$ & $\begin{array}{r}- \\
- \\
- \\
- \\
7 \\
67 \\
91 \\
108 \\
230 \\
294 \\
370 \\
451 \\
493 \\
512 \\
541 \\
800 \\
580 \\
508\end{array}$ & $\begin{array}{r}242 \\
248 \\
271 \\
288 \\
340 \\
300 \\
330 \\
1388 \\
363 \\
0350 \\
344 \\
345 \\
321 \\
331 \\
340 \\
330 \\
341 \\
323\end{array}$ \\
\hline 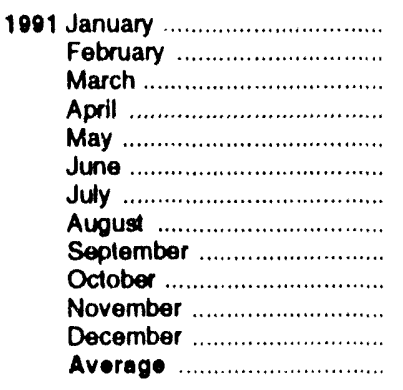 & $\begin{array}{c}0 \\
0 \\
(s) \\
(s) \\
(s) \\
(s) \\
0 \\
0 \\
0 \\
(s) \\
(s) \\
0 \\
(s)\end{array}$ & $\begin{array}{r}0 \\
-147 \\
-422 \\
0 \\
0 \\
(s) \\
(s) \\
(s) \\
0 \\
(s) \\
(s) \\
(s) \\
-47\end{array}$ & $\begin{array}{r}-71 \\
379 \\
183 \\
50 \\
566 \\
-299 \\
-153 \\
103 \\
-156 \\
51 \\
43 \\
-611 \\
5\end{array}$ & $\begin{array}{l}12,735 \\
13,046 \\
12,839 \\
13,042 \\
13,539 \\
13,918 \\
13,703 \\
13,800 \\
13,694 \\
12,896 \\
12,929 \\
13,465 \\
13,301\end{array}$ & $\begin{array}{r}50 \\
152 \\
137 \\
162 \\
165 \\
78 \\
139 \\
55 \\
109 \\
92 \\
126 \\
133 \\
116\end{array}$ & $\begin{array}{l}23 \\
17 \\
18 \\
21 \\
15 \\
16 \\
15 \\
13 \\
16 \\
22 \\
22 \\
23 \\
18\end{array}$ & $\begin{array}{l}906 \\
913 \\
905 \\
907 \\
924 \\
915 \\
911 \\
914 \\
909 \\
911 \\
912 \\
893 \\
893\end{array}$ & $\begin{array}{l}586 \\
582 \\
568 \\
568 \\
568 \\
568 \\
569 \\
569 \\
569 \\
569 \\
569 \\
569 \\
569\end{array}$ & $\begin{array}{l}320 \\
331 \\
337 \\
338 \\
356 \\
347 \\
342 \\
345 \\
341 \\
342 \\
344 \\
325 \\
325\end{array}$ \\
\hline 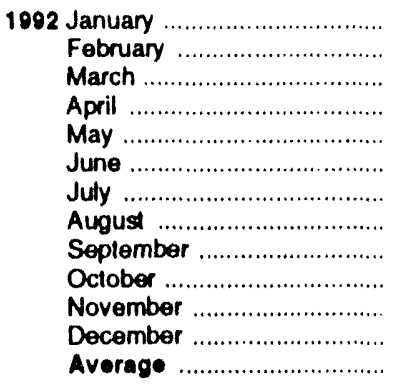 & $\begin{array}{c}0 \\
(s) \\
(s) \\
0 \\
0 \\
(s) \\
0 \\
(s) \\
0 \\
(s) \\
(s) \\
(s) \\
0\end{array}$ & $\begin{array}{c}(s) \\
0 \\
(s) \\
0 \\
(s) \\
34 \\
(s) \\
20 \\
43 \\
69 \\
15 \\
22 \\
17\end{array}$ & $\begin{array}{r}540 \\
171 \\
.250 \\
315 \\
.145 \\
.615 \\
244 \\
.144 \\
.204 \\
342 \\
.243 \\
.234 \\
.18\end{array}$ & $\begin{array}{l}12,923 \\
12,486 \\
13,083 \\
13,260 \\
13,679 \\
14,059 \\
13,953 \\
13,426 \\
13,714 \\
13,584 \\
13,547 \\
13,194 \\
13,411\end{array}$ & $\begin{array}{r}118 \\
22 \\
105 \\
23 \\
106 \\
107 \\
53 \\
133 \\
68 \\
106 \\
111 \\
107 \\
89\end{array}$ & $\begin{array}{r}26 \\
17 \\
18 \\
11 \\
10 \\
12 \\
9 \\
8 \\
11 \\
10 \\
10 \\
12 \\
13\end{array}$ & $\begin{array}{l}910 \\
915 \\
907 \\
917 \\
912 \\
895 \\
902 \\
898 \\
893 \\
906 \\
899 \\
893 \\
893\end{array}$ & $\begin{array}{l}569 \\
569 \\
569 \\
569 \\
569 \\
570 \\
570 \\
570 \\
571 \\
574 \\
574 \\
575 \\
575\end{array}$ & $\begin{array}{l}341 \\
346 \\
339 \\
348 \\
344 \\
325 \\
333 \\
328 \\
322 \\
333 \\
325 \\
318 \\
318\end{array}$ \\
\hline 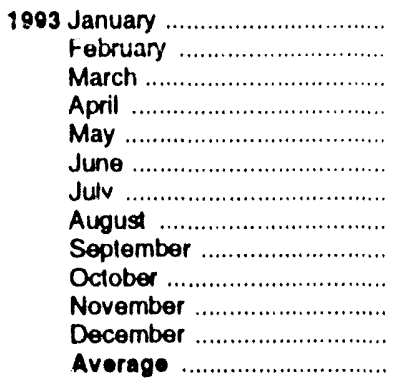 & $\begin{array}{c}\text { (s) } \\
(\mathbf{s}) \\
0 \\
(\mathbf{s}) \\
0 \\
0 \\
0 \\
0 \\
(\mathbf{s}) \\
0 \\
0 \\
\mathrm{E} \\
0 \\
\text { (s) }\end{array}$ & $\begin{array}{r}19 \\
18 \\
58 \\
136 \\
13 \\
21 \\
19 \\
24 \\
52 \\
19 \\
\text { R } 18 \\
\text { E } 9 \\
\text { E }\end{array}$ & $\begin{array}{r}245 \\
202 \\
188 \\
401 \\
120 \\
.37 \\
22 \\
.548 \\
.491 \\
314 \\
R_{233} \\
E_{84} \\
E_{60}\end{array}$ & $\begin{array}{l}12,980 \\
12,923 \\
13,249 \\
13,512 \\
13,701 \\
14,125 \\
14,114 \\
13,839 \\
13,845 \\
13,733 \\
\text { A } 13,689 \\
13,660 \\
\text { E } 13,618\end{array}$ & $\begin{array}{r}129 \\
166 \\
139 \\
73 \\
112 \\
150 \\
62 \\
55 \\
107 \\
62 \\
\text { P } 67 \\
\text { E } 117 \\
\text { E } 103\end{array}$ & $\begin{array}{r}10 \\
10 \\
11 \\
9 \\
10 \\
8 \\
9 \\
8 \\
8 \\
9 \\
12 \\
A_{13} \\
E_{10} \\
E_{10}\end{array}$ & $\begin{array}{r}901 \\
907 \\
915 \\
931 \\
935 \\
935 \\
936 \\
920 \\
906 \\
917 \\
\text { P }_{924} \\
\text { E }_{928} \\
\text { E }_{928}\end{array}$ & $\begin{array}{r}575 \\
576 \\
578 \\
582 \\
582 \\
583 \\
583 \\
584 \\
586 \\
586 \\
587 \\
\text { E } 587 \\
\text { E } 587\end{array}$ & $\begin{array}{l}326 \\
331 \\
337 \\
349 \\
353 \\
352 \\
352 \\
335 \\
321 \\
330 \\
\text { A } 337 \\
E_{341} \\
\text { E } 341\end{array}$ \\
\hline
\end{tabular}

Stocks are tolats as of end of period.

b A negative number indicates a decrease in slocks and a positive number indicates an increase.

c Strategic Petroleum Reserve.

d Beginning in January 1983, crude oil used direclly as fuel is shown as product supplied.

- Soe Nole 6 al end of section.

1 Stocks of Alaskan crude oil in transit are included from January 1981 forward. See Nole 5 at end of section.
- See Note 4 at end of section.

$\mathrm{R}=$ Revised data. - =Not applicable. E=Estimate. (s) =L Less than +500 barrels per day and grealer than .500 barrels per day.

Noles: - Crude oil includes lease condensale. - Geographic coverage is the 50 States and the Distric of Columbia. - Tolals may not equal sum of components due to independent rourding.

Sources: - 1073-1980: Energy Inlormation Administration (EL). Petroleum Supply Monthy. February 1993, Table S2. - 1981 forwerd: EIA, Petroleum Supply Monthly, January 1994, Table S2. 
Table 3.3a Petroleum Imports: Algeria, Iraq, Kuwait, and Libya (Thousand Barrels per Day)

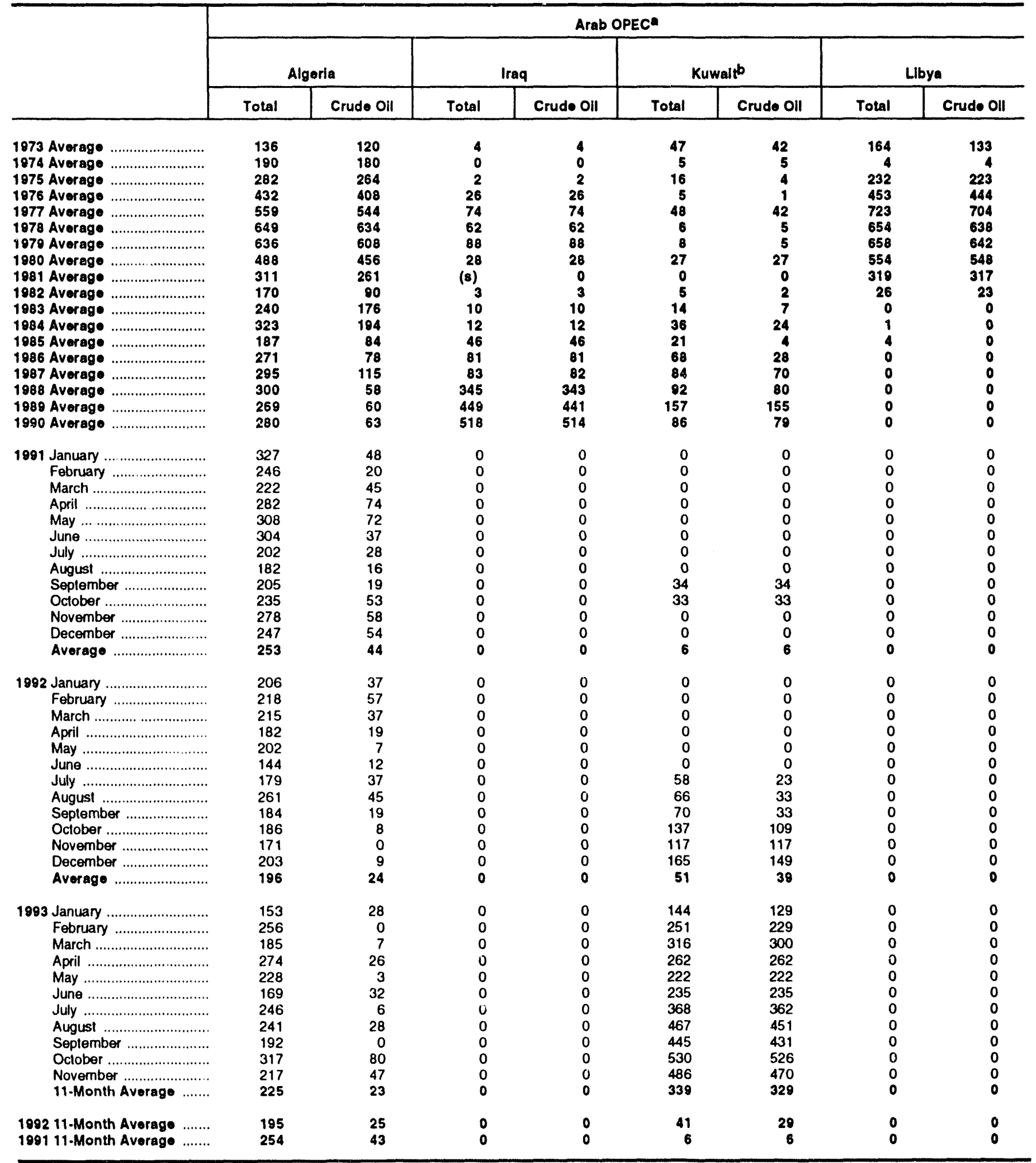

a Excludes petroleum imported into the United States indirectly from members of the Organization of Petroleum Exporting Countries (OPEC), primarily trom Caribbean and West European areas, as petroleum products that were refined from crude oil produced by OPEC.

Imports trom the Neutral Zone between Kuwait and Saudi Arabia are included in Saudi Arabia.

(s)=Less than 500 barrels per day
Notes: - Beginning in October 1977. Stralegic Petroleum Reserve imports are included. - Geographic coverage is the 50 States and the District of Columbia.

Sources: - 1973-1880: Energy Information Administration (EIA), Petroleum Supply Monthly, February 1993, Table S3. - 1981 forward: EIA, Petroleum Supph Monthly, January 1994, Table S3. 
Table 3.3b Petroleum Imports: Qatar, Saudi Arabia, U.A.E., and Total Arab OPEC (Thousand Barrels per Day)

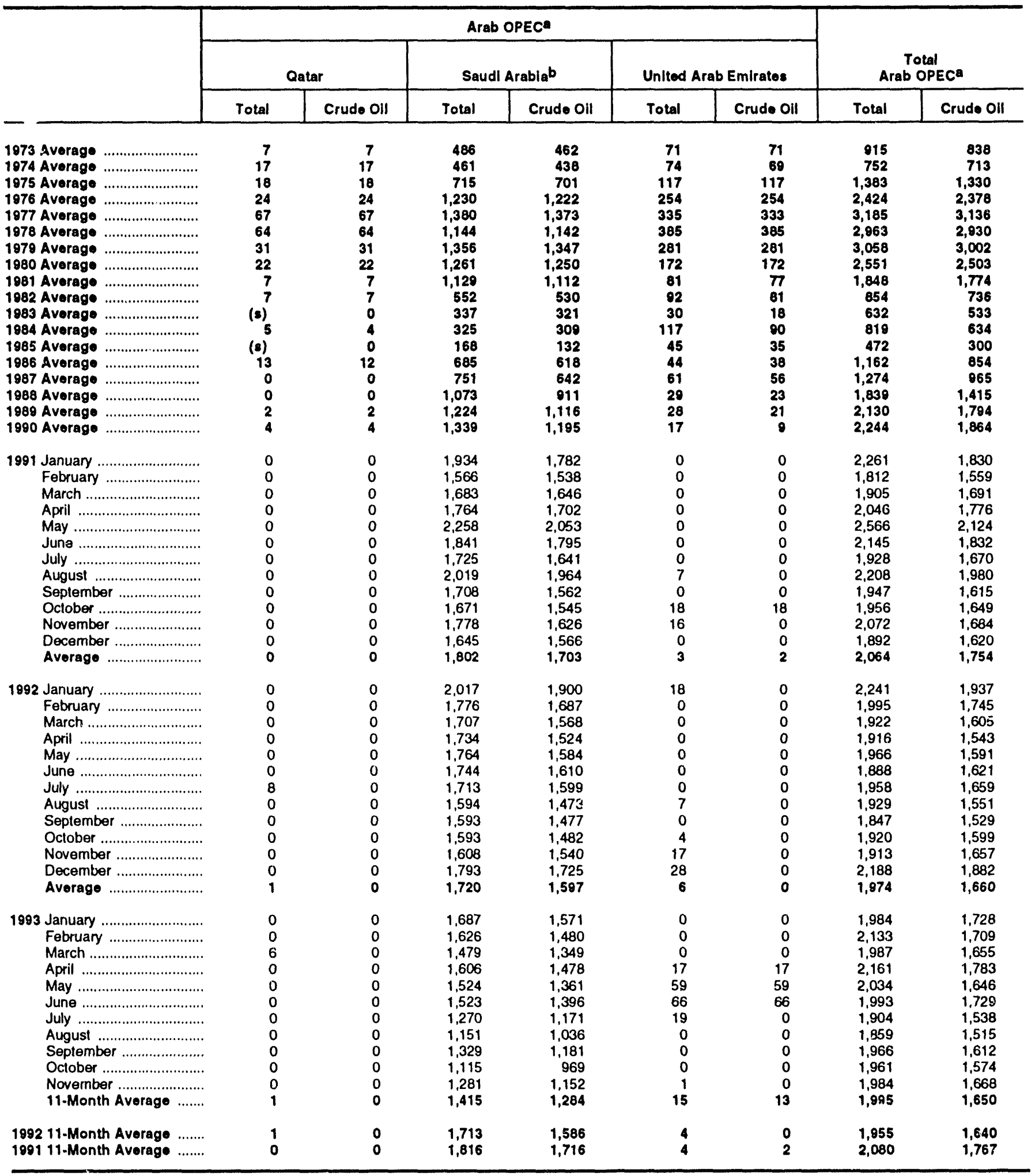

a Excludes petroleum imported into the United States indirectly from members of the Organization of Petroleum Exporting Countries (OPEC), primarily from Caribbean and West European areas, as petroleum products that were refined trom crude oil produced by OPEC.

b Imports from the Neutral Zone between Kuwait and Saudi Arabia are included in Saudi Arabia.

(s)=Less than 500 barrels per day.
Notes: - Beginning in October 1977, Stratogic Petroleum Reserve imports are included. - Geographic coverage is the 50 States and the District of Columbia. - Totals may not equal sum of components due to independent rounding.

Sources: - 1973-1980: Energy Information Administration (EIA), Petroleum Supply Monthly, February 1993, Table S3. - 1981 forward: EIA, Petroleum Supply Monthly, January 1994, Table S3. 
Table 3.3c Petroleum Imports: Ecuador, Gabon, Indonesia, and Iran (Thousand Barrels per Day)

\begin{tabular}{|c|c|c|c|c|c|c|c|c|}
\hline & \multicolumn{8}{|c|}{ Non-Arab OPECa } \\
\hline & \multicolumn{2}{|c|}{ Ecuadorb } & \multicolumn{2}{|c|}{ Gabon } & \multicolumn{2}{|c|}{ Indonesla } & \multicolumn{2}{|c|}{ Iran } \\
\hline & Total & Crude Oll & Total & Crude Oll & Total & Crude Oll & Total & Crude Oll \\
\hline 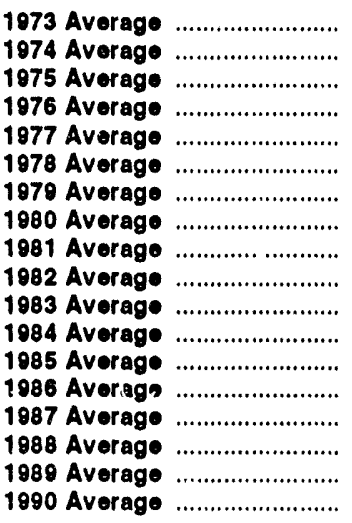 & $\begin{array}{l}48 \\
42 \\
57 \\
51 \\
57 \\
54 \\
42 \\
27 \\
48 \\
42 \\
61 \\
55 \\
67 \\
77 \\
29 \\
47 \\
89 \\
48\end{array}$ & $\begin{array}{l}47 \\
42 \\
57 \\
51 \\
55 \\
38 \\
30 \\
17 \\
38 \\
32 \\
56 \\
47 \\
56 \\
64 \\
23 \\
33 \\
80 \\
38\end{array}$ & $\begin{array}{l}0 \\
23 \\
27 \\
28 \\
42 \\
41 \\
42 \\
26 \\
35 \\
40 \\
50 \\
58 \\
52 \\
26 \\
35 \\
16 \\
50 \\
64\end{array}$ & $\begin{array}{r}0 \\
23 \\
27 \\
26 \\
35 \\
38 \\
42 \\
25 \\
35 \\
40 \\
50 \\
57 \\
51 \\
25 \\
35 \\
15 \\
40 \\
64\end{array}$ & $\begin{array}{l}213 \\
300 \\
390 \\
539 \\
541 \\
573 \\
420 \\
348 \\
366 \\
248 \\
338 \\
343 \\
314 \\
318 \\
285 \\
205 \\
183 \\
114\end{array}$ & $\begin{array}{r}200 \\
284 \\
379 \\
537 \\
507 \\
533 \\
380 \\
314 \\
318 \\
226 \\
315 \\
304 \\
292 \\
297 \\
262 \\
186 \\
158 \\
98\end{array}$ & $\begin{array}{r}223 \\
460 \\
280 \\
298 \\
535 \\
555 \\
304 \\
0 \\
0 \\
35 \\
48 \\
10 \\
27 \\
19 \\
98 \\
c \\
(8) \\
0 \\
0\end{array}$ & $\begin{array}{r}216 \\
463 \\
278 \\
298 \\
530 \\
554 \\
297 \\
8 \\
0 \\
35 \\
48 \\
10 \\
27 \\
10 \\
98 \\
c \quad(8) \\
0 \\
0\end{array}$ \\
\hline 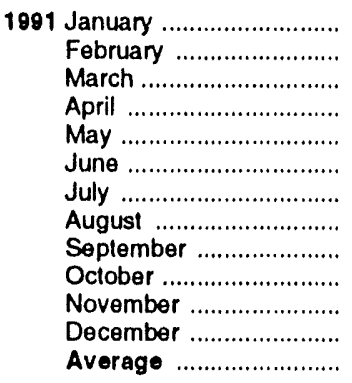 & $\begin{array}{r}18 \\
66 \\
67 \\
35 \\
109 \\
129 \\
62 \\
112 \\
31 \\
30 \\
55 \\
41 \\
63\end{array}$ & $\begin{array}{r}6 \\
55 \\
58 \\
24 \\
103 \\
126 \\
47 \\
93 \\
25 \\
24 \\
48 \\
23 \\
53\end{array}$ & $\begin{array}{r}41 \\
95 \\
29 \\
72 \\
96 \\
70 \\
137 \\
56 \\
91 \\
137 \\
91 \\
91 \\
84\end{array}$ & $\begin{array}{r}41 \\
95 \\
29 \\
72 \\
96 \\
70 \\
137 \\
56 \\
91 \\
137 \\
91 \\
91 \\
84\end{array}$ & $\begin{array}{r}70 \\
162 \\
93 \\
69 \\
97 \\
187 \\
88 \\
93 \\
83 \\
118 \\
120 \\
163 \\
111\end{array}$ & $\begin{array}{r}70 \\
153 \\
93 \\
69 \\
97 \\
187 \\
88 \\
87 \\
64 \\
91 \\
96 \\
134 \\
102\end{array}$ & $\begin{array}{r}0 \\
0 \\
0 \\
0 \\
0 \\
0 \\
81 \\
48 \\
152 \\
43 \\
64 \\
0 \\
32\end{array}$ & $\begin{array}{r}0 \\
0 \\
0 \\
0 \\
0 \\
0 \\
81 \\
48 \\
152 \\
43 \\
64 \\
0 \\
32\end{array}$ \\
\hline 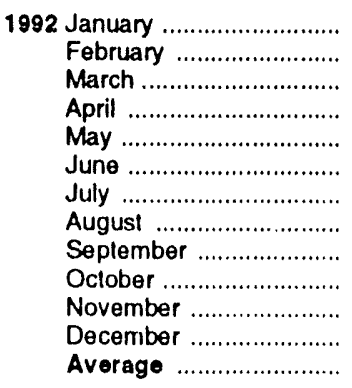 & $\begin{array}{r}56 \\
61 \\
26 \\
53 \\
51 \\
105 \\
111 \\
99 \\
97 \\
42 \\
53 \\
24 \\
65\end{array}$ & $\begin{array}{r}56 \\
48 \\
26 \\
46 \\
51 \\
101 \\
111 \\
93 \\
97 \\
36 \\
53 \\
24 \\
62\end{array}$ & $\begin{array}{r}91 \\
105 \\
25 \\
186 \\
135 \\
129 \\
143 \\
108 \\
165 \\
167 \\
114 \\
120 \\
124\end{array}$ & $\begin{array}{r}91 \\
105 \\
25 \\
186 \\
135 \\
129 \\
143 \\
108 \\
158 \\
167 \\
114 \\
120 \\
123\end{array}$ & $\begin{array}{r}125 \\
39 \\
85 \\
54 \\
155 \\
109 \\
65 \\
91 \\
57 \\
54 \\
36 \\
60 \\
78\end{array}$ & $\begin{array}{r}117 \\
39 \\
83 \\
49 \\
133 \\
102 \\
65 \\
85 \\
38 \\
43 \\
23 \\
60 \\
70\end{array}$ & $\begin{array}{l}0 \\
0 \\
0 \\
0 \\
0 \\
0 \\
0 \\
0 \\
0 \\
0 \\
0 \\
0 \\
0\end{array}$ & $\begin{array}{l}0 \\
0 \\
0 \\
0 \\
0 \\
0 \\
0 \\
0 \\
0 \\
0 \\
0 \\
0 \\
0\end{array}$ \\
\hline 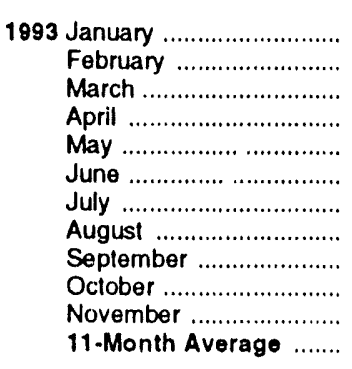 & $\begin{array}{l}\left(\begin{array}{l}b \\
b \\
b\end{array}\right) \\
\left(\begin{array}{l}b \\
b\end{array}\right) \\
\left(\begin{array}{l}b \\
b \\
(b\end{array}\right) \\
\left(\begin{array}{l}b \\
b\end{array}\right) \\
\left(\begin{array}{l}b \\
b\end{array}\right) \\
\left(\begin{array}{l}b \\
b\end{array}\right)\end{array}$ & $\begin{array}{l}\left(\begin{array}{l}b \\
b\end{array}\right) \\
(b) \\
b \\
(b) \\
(b) \\
(b) \\
b \\
\left(\begin{array}{l}b \\
b\end{array}\right) \\
\left(\begin{array}{l}b \\
b\end{array}\right) \\
(b)\end{array}$ & $\begin{array}{r}90 \\
88 \\
126 \\
127 \\
169 \\
107 \\
168 \\
152 \\
211 \\
242 \\
143 \\
148\end{array}$ & $\begin{array}{r}89 \\
88 \\
123 \\
127 \\
169 \\
107 \\
166 \\
152 \\
211 \\
242 \\
136 \\
147\end{array}$ & $\begin{array}{r}37 \\
52 \\
67 \\
76 \\
82 \\
97 \\
55 \\
95 \\
51 \\
131 \\
74 \\
74\end{array}$ & $\begin{array}{l}37 \\
51 \\
64 \\
76 \\
82 \\
67 \\
55 \\
80 \\
40 \\
82 \\
34 \\
61\end{array}$ & $\begin{array}{l}0 \\
0 \\
0 \\
0 \\
0 \\
0 \\
0 \\
0 \\
0 \\
0 \\
0 \\
0\end{array}$ & $\begin{array}{l}0 \\
0 \\
0 \\
0 \\
0 \\
0 \\
0 \\
0 \\
0 \\
0 \\
0 \\
0\end{array}$ \\
\hline $\begin{array}{l}1992 \text { 11-Month Average ....... } \\
1991 \text { 11-Month Average ....... }\end{array}$ & $\begin{array}{l}69 \\
65\end{array}$ & $\begin{array}{l}65 \\
55\end{array}$ & $\begin{array}{r}124 \\
83\end{array}$ & $\begin{array}{r}123 \\
83\end{array}$ & $\begin{array}{r}80 \\
107\end{array}$ & $\begin{array}{l}71 \\
99\end{array}$ & $\begin{array}{r}0 \\
35\end{array}$ & $\begin{array}{r}0 \\
35\end{array}$ \\
\hline
\end{tabular}

a Excludes petroleum imported into the United States indirectly from members of the Organization of Petroleum Exporting Countries (OPEC), primarily from Caribbean and West European areas, as petroleum producls that were relined from crude oll produced by OPEC.

Ecuador withdrew from OPEC on December 31, 1992. As of January 1993, imports from Ecuador appear on Table 3.31 under "Non-OPEC."

C A small amount of Iranian crude oil entered the United States in January 1988 trom the Virgin Islands. The oil originated in Iran and was exported to the Virgin Islands prior to the signing of Execulive Order 12613 on October
$29,1987$.

(s)=Less than 500 barrels per day.

Notes: - Beginning in October 1977, Strategic Petroleum Reserve imports are included. - Geographlc coverage is the 50 States and the Distrlet of Columbia.

Sources: - 1973-1980: Energy Information Administration (EIA), Petroleum Supply Monthly, February 1993, Table S3. • 1981 forward: EIA, Petroleum Supply Monthly, January 1994, Table S3. 
Table 3.3d Petroleum Imports: Nigeria, Venezuela, Total Non-Arab OPEC, and Total OPEC

(Thousand Barrels per Day)

\begin{tabular}{|c|c|c|c|c|c|c|c|c|}
\hline & \multicolumn{4}{|c|}{ Non-Arab OPECa } & \multirow{2}{*}{\multicolumn{2}{|c|}{$\begin{array}{c}\text { Total } \\
\text { Non-Arab OPECa,b }\end{array}$}} & \multirow{2}{*}{\multicolumn{2}{|c|}{$\begin{array}{c}\text { Total } \\
\text { OPECa,b }\end{array}$}} \\
\hline & \multicolumn{2}{|c|}{ Nigeria } & \multicolumn{2}{|c|}{ Venezuela } & & & & \\
\hline & Total & Crude Oil & Total & Crude Oil & Total & Crude Oll & Total & Crude Oil \\
\hline 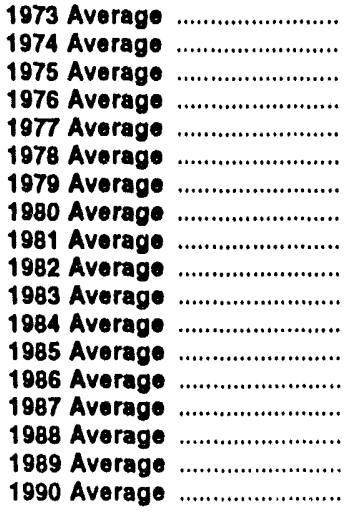 & $\begin{array}{r}459 \\
713 \\
762 \\
1,025 \\
1,143 \\
919 \\
1,080 \\
857 \\
620 \\
514 \\
302 \\
216 \\
293 \\
440 \\
535 \\
618 \\
815 \\
800\end{array}$ & $\begin{array}{r}448 \\
697 \\
746 \\
1,014 \\
1,130 \\
910 \\
1,069 \\
841 \\
611 \\
510 \\
301 \\
207 \\
280 \\
437 \\
529 \\
607 \\
800 \\
784\end{array}$ & $\begin{array}{r}1,135 \\
979 \\
702 \\
700 \\
690 \\
646 \\
690 \\
481 \\
406 \\
412 \\
422 \\
548 \\
605 \\
793 \\
804 \\
794 \\
873 \\
1,025\end{array}$ & $\begin{array}{l}344 \\
319 \\
395 \\
241 \\
250 \\
181 \\
293 \\
156 \\
147 \\
155 \\
164 \\
253 \\
306 \\
416 \\
488 \\
439 \\
495 \\
666\end{array}$ & $\begin{array}{l}2,078 \\
2,527 \\
2,219 \\
2,642 \\
3,008 \\
2,788 \\
2,579 \\
1,749 \\
1,476 \\
1,291 \\
1,231 \\
1,230 \\
1,358 \\
1,674 \\
1,787 \\
1,681 \\
2,010 \\
2,052\end{array}$ & $\begin{array}{r}1,257 \\
1,827 \\
1,882 \\
2,167 \\
2,507 \\
2,254 \\
2,110 \\
1,361 \\
1,149 \\
998 \\
944 \\
878 \\
1,012 \\
1,259 \\
1,435 \\
1,281 \\
1,582 \\
1,650\end{array}$ & $\begin{array}{l}2,993 \\
3,280 \\
3,601 \\
5,066 \\
6,193 \\
5,751 \\
5,637 \\
4,300 \\
3,323 \\
2,146 \\
1,862 \\
2,049 \\
1,830 \\
2,837 \\
3,060 \\
3,520 \\
4,140 \\
4,296\end{array}$ & $\begin{array}{l}2,095 \\
2,540 \\
3,211 \\
4,545 \\
5,643 \\
5,184 \\
5,112 \\
3,864 \\
2,922 \\
1,734 \\
1,477 \\
1,512 \\
1,312 \\
2,113 \\
2,400 \\
2,696 \\
3,376 \\
3,514\end{array}$ \\
\hline 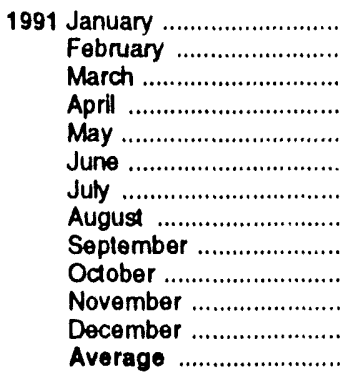 & $\begin{array}{r}504 \\
721 \\
531 \\
677 \\
860 \\
832 \\
833 \\
1,016 \\
489 \\
651 \\
704 \\
617 \\
703\end{array}$ & $\begin{array}{l}481 \\
717 \\
531 \\
649 \\
838 \\
827 \\
817 \\
983 \\
467 \\
623 \\
674 \\
593 \\
683\end{array}$ & $\begin{array}{r}1,005 \\
959 \\
998 \\
845 \\
997 \\
1,135 \\
1,102 \\
1,070 \\
1,163 \\
1,087 \\
1,065 \\
987 \\
1,035\end{array}$ & $\begin{array}{l}673 \\
686 \\
631 \\
470 \\
581 \\
705 \\
683 \\
701 \\
790 \\
777 \\
671 \\
655 \\
658\end{array}$ & $\begin{array}{l}1,637 \\
2,003 \\
1,718 \\
1,698 \\
2,158 \\
2,354 \\
2,304 \\
2,394 \\
2,009 \\
2,067 \\
2,099 \\
1,899 \\
2,028\end{array}$ & $\begin{array}{l}1,271 \\
1,705 \\
1,342 \\
1,283 \\
1,715 \\
1,915 \\
1,855 \\
1,966 \\
1,589 \\
1,694 \\
1,644 \\
1,496 \\
1,622\end{array}$ & $\begin{array}{l}3,898 \\
3,815 \\
3,623 \\
3,744 \\
4,724 \\
4,498 \\
4,232 \\
4,602 \\
3,956 \\
4,023 \\
4,171 \\
3,791 \\
4,092\end{array}$ & $\begin{array}{l}3,101 \\
3,264 \\
3,033 \\
3,059 \\
3,839 \\
3,747 \\
3,525 \\
3,946 \\
3,204 \\
3,343 \\
3,328 \\
3,116 \\
3,377\end{array}$ \\
\hline 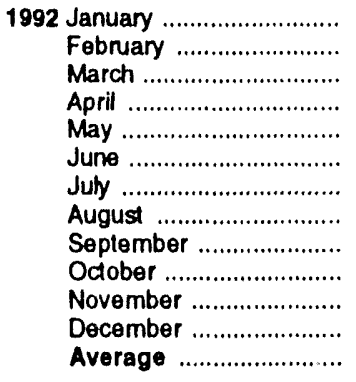 & $\begin{array}{l}593 \\
322 \\
441 \\
798 \\
773 \\
740 \\
900 \\
815 \\
774 \\
827 \\
626 \\
549 \\
681\end{array}$ & $\begin{array}{l}566 \\
303 \\
409 \\
788 \\
773 \\
740 \\
883 \\
795 \\
754 \\
813 \\
608 \\
532 \\
665\end{array}$ & $\begin{array}{l}1,119 \\
1,028 \\
1,106 \\
1,079 \\
1,038 \\
1,059 \\
1,163 \\
1,102 \\
1,333 \\
1,497 \\
1,343 \\
1,164 \\
1,170\end{array}$ & $\begin{array}{r}787 \\
655 \\
793 \\
722 \\
745 \\
738 \\
912 \\
841 \\
953 \\
1,073 \\
921 \\
763 \\
826\end{array}$ & $\begin{array}{l}1,984 \\
1,555 \\
1,684 \\
2,169 \\
2,152 \\
2,141 \\
2,382 \\
2,215 \\
2,426 \\
2,587 \\
2,173 \\
1,917 \\
2,117\end{array}$ & $\begin{array}{l}1,617 \\
1,150 \\
1,336 \\
1,791 \\
1,837 \\
1,809 \\
2,114 \\
1,922 \\
2,001 \\
2,133 \\
1,719 \\
1,499 \\
1,746\end{array}$ & $\begin{array}{l}4,224 \\
3,549 \\
3,606 \\
4,085 \\
4,118 \\
4,029 \\
4,339 \\
4,144 \\
4,274 \\
4,507 \\
4,086 \\
4,105 \\
4,092\end{array}$ & $\begin{array}{l}3,554 \\
2,895 \\
2,941 \\
3,334 \\
3,428 \\
3,430 \\
3,772 \\
3,473 \\
3,531 \\
3,732 \\
3,376 \\
3,381 \\
3,406\end{array}$ \\
\hline 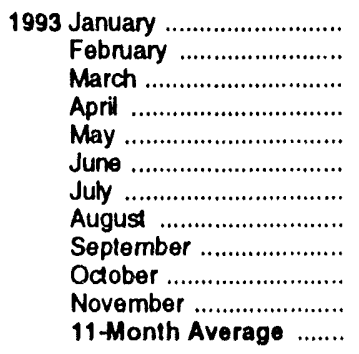 & $\begin{array}{l}729 \\
927 \\
928 \\
892 \\
741 \\
848 \\
893 \\
562 \\
514 \\
603 \\
636 \\
751\end{array}$ & $\begin{array}{l}729 \\
913 \\
892 \\
871 \\
723 \\
827 \\
888 \\
549 \\
496 \\
593 \\
612 \\
734\end{array}$ & $\begin{array}{l}1,385 \\
1,290 \\
1,208 \\
1,297 \\
1,226 \\
1,277 \\
1,384 \\
1,375 \\
1,243 \\
1,267 \\
1,267 \\
1,293\end{array}$ & $\begin{array}{r}1,038 \\
925 \\
817 \\
1,006 \\
954 \\
992 \\
1,068 \\
1,135 \\
1,033 \\
993 \\
1,073 \\
1,003\end{array}$ & $\begin{array}{r}\text { b } 2,241 \\
2,358 \\
2,330 \\
2,392 \\
2,219 \\
2,329 \\
2,500 \\
2,183 \\
2,018 \\
2,242 \\
2,120 \\
2,266\end{array}$ & $\begin{array}{r}\text { b } 1,892 \\
1,976 \\
1,897 \\
2,080 \\
1,929 \\
1,992 \\
2,177 \\
1,915 \\
1,779 \\
1,910 \\
1,855 \\
1,946\end{array}$ & $\begin{array}{r}4,225 \\
4,491 \\
4,317 \\
4,553 \\
4,253 \\
4,321 \\
4,404 \\
4,043 \\
3,984 \\
4,203 \\
4,104 \\
4,262\end{array}$ & $\begin{array}{r}\text { b } 3,620 \\
3,685 \\
3,552 \\
3,863 \\
3,574 \\
3,721 \\
3,715 \\
3,431 \\
3,391 \\
3,484 \\
3,523 \\
3,595\end{array}$ \\
\hline $\begin{array}{l}199211 \text {-Month Average ....... } \\
199111 \text {-Month Average ....... }\end{array}$ & $\begin{array}{l}693 \\
711\end{array}$ & $\begin{array}{l}677 \\
692\end{array}$ & $\begin{array}{l}1,170 \\
1,039\end{array}$ & $\begin{array}{l}832 \\
670\end{array}$ & $\begin{array}{l}2,136 \\
2,040\end{array}$ & $\begin{array}{l}1,769 \\
1,634\end{array}$ & $\begin{array}{l}4,090 \\
4,120\end{array}$ & $\begin{array}{l}3,409 \\
3,401\end{array}$ \\
\hline
\end{tabular}

a Excludes petroleum imported into the United States indirectly from members of the Organization of Petroleum Exporting Countries (OPEC). primarily from Caribbean and West European areas, as petroleum products that were refined from crude oil produced by OPEC.

As of January 1993, excludes petroleum imported from Ecuador, which withdrew from OPEC on December 31, 1992.

Noles: - Beginning in October 1977, Strategic Petroleum Reserve imports are included. - Geographic coverage is the $\mathbf{5 0}$ States and the Distrid of Columbia. - Tolals may not equal sum of components due 10 independent rounding.

Sources: - 1973-1980: Energy Information Administration (ElA), Petroleum Supply Monthly, February 1993, Table S3. • 1981 forward: EIA, Petroleum Supply Monthly, January 1994, Table S3. 
Table 3.3e Petroleum Imports: Angola, Australia, Bahama Islands, Brazil, Canada, and China

(Thousand Barrels per Day)

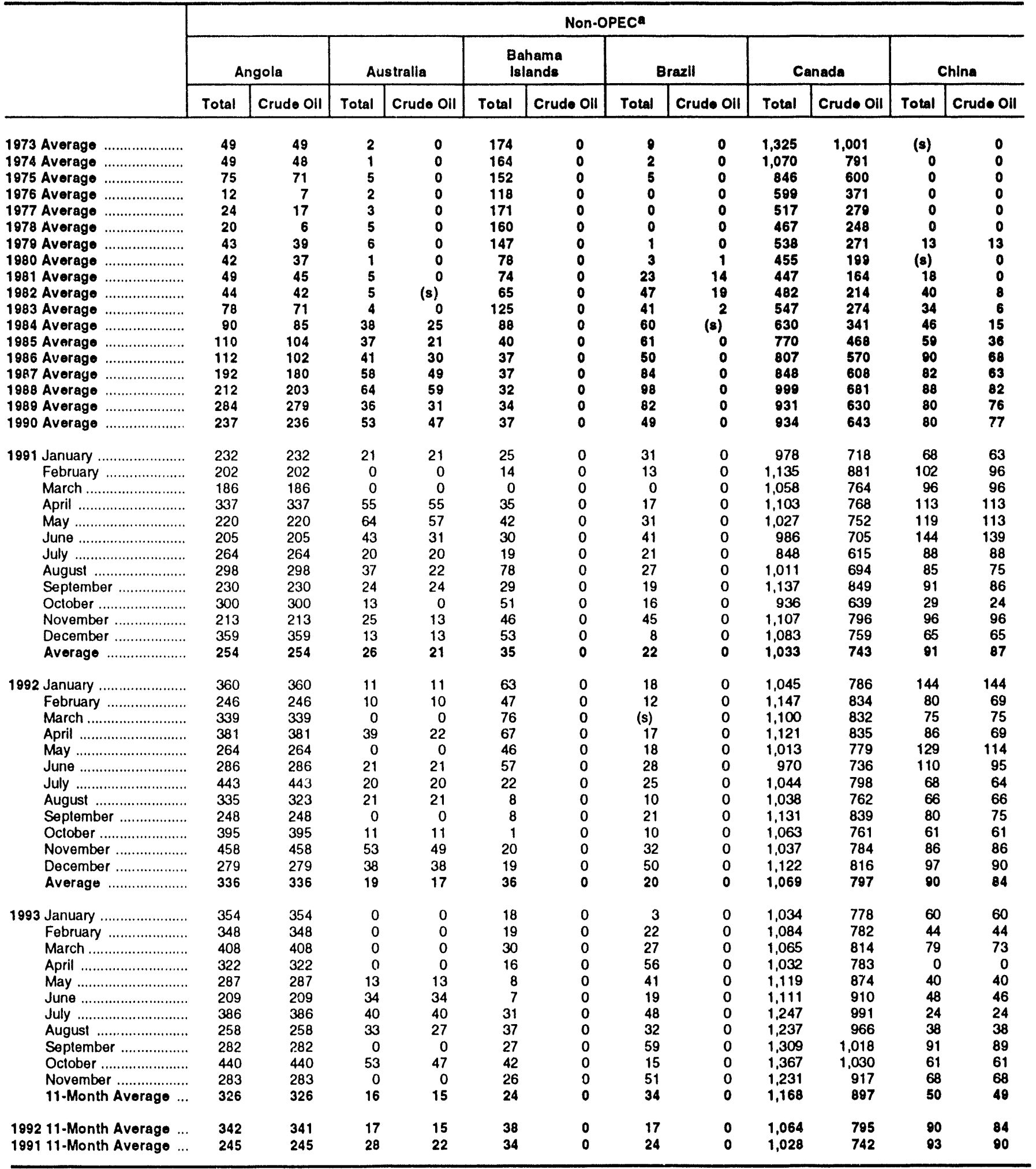

a Includes petroleum imported into the United States indirectly from members of the Organization of Pelroleum Exporting Countries (OPEC), primarily Irom Caribbean and West European areas, as petroleum products that were refined from crude oil produced by OPEC.

(s)=Less than 500 barrels per day.

Noles: - Beginning in October 1977, Strategic Petroleum Reserve imports are included. - Geographic coverage is the 50 States and the District of Columbia.

Sources: - 1973-1980: Energy Information Administration (ELA), Petroleum Supply Monthly, February 1993, Table S3. - 1981 forward: EIA, Petroleum Supply Monthly, January 1994, Table S3. 
Table 3.3f Petroleum Imports: Colombia, Ecuador, Italy, Malaysia, Mexico, and Netherlands

(Thousand Barrels per Day)

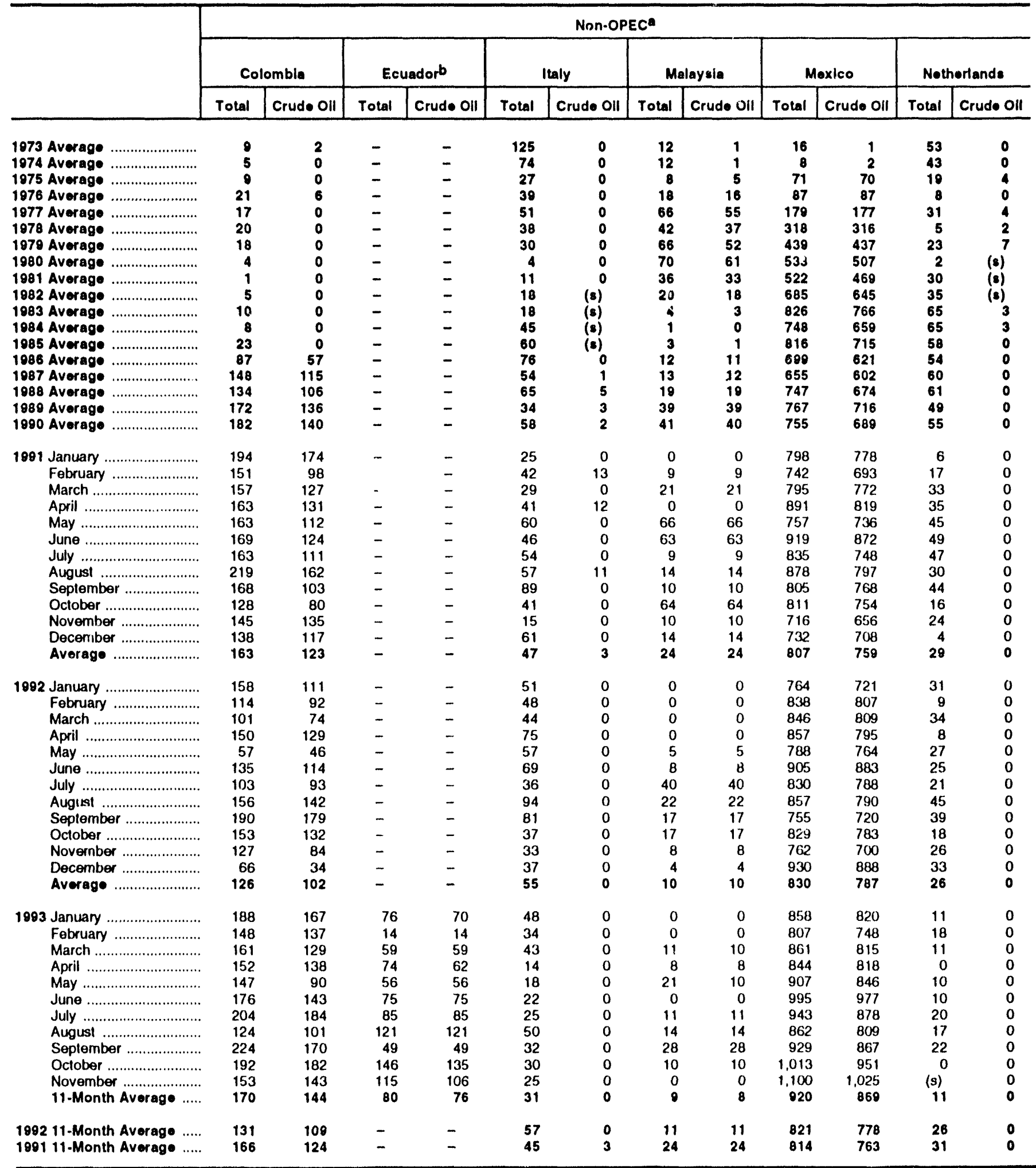

a Includes petroleum imported into the United States indirectly from members of the Organization of Petroleum Exponing Countries (OPEC). primarily Irom Caribbean and West European areas, as pelroleum products that were refined from crude oil produced by OPEC.

b Through 1992, Ecuador was a member of OPEC. See Table 3.3c.

- =Not applicable. (s)=Less than 500 barrels per day.
Notes: - Beginning in October 1977. Stralegic Putriteum Reserve imports are included. - Geographic coverage is the 50 States and the District of Columbia.

Sources: - 1973-1980: Energy Inlormation Administration (EIA), Petroleum Supply Monthly, February 1993, Table S3. - 1981 forward: EIA, Petroloum Supply Monthly, January 1994, Table S3. 
Table 3.3g Petroleum Imports: Netherlands Antilles, Norway, Puerto Rico, Russia, Spain, and Trinidad and Tobago

(Thousand Barrels per Day)

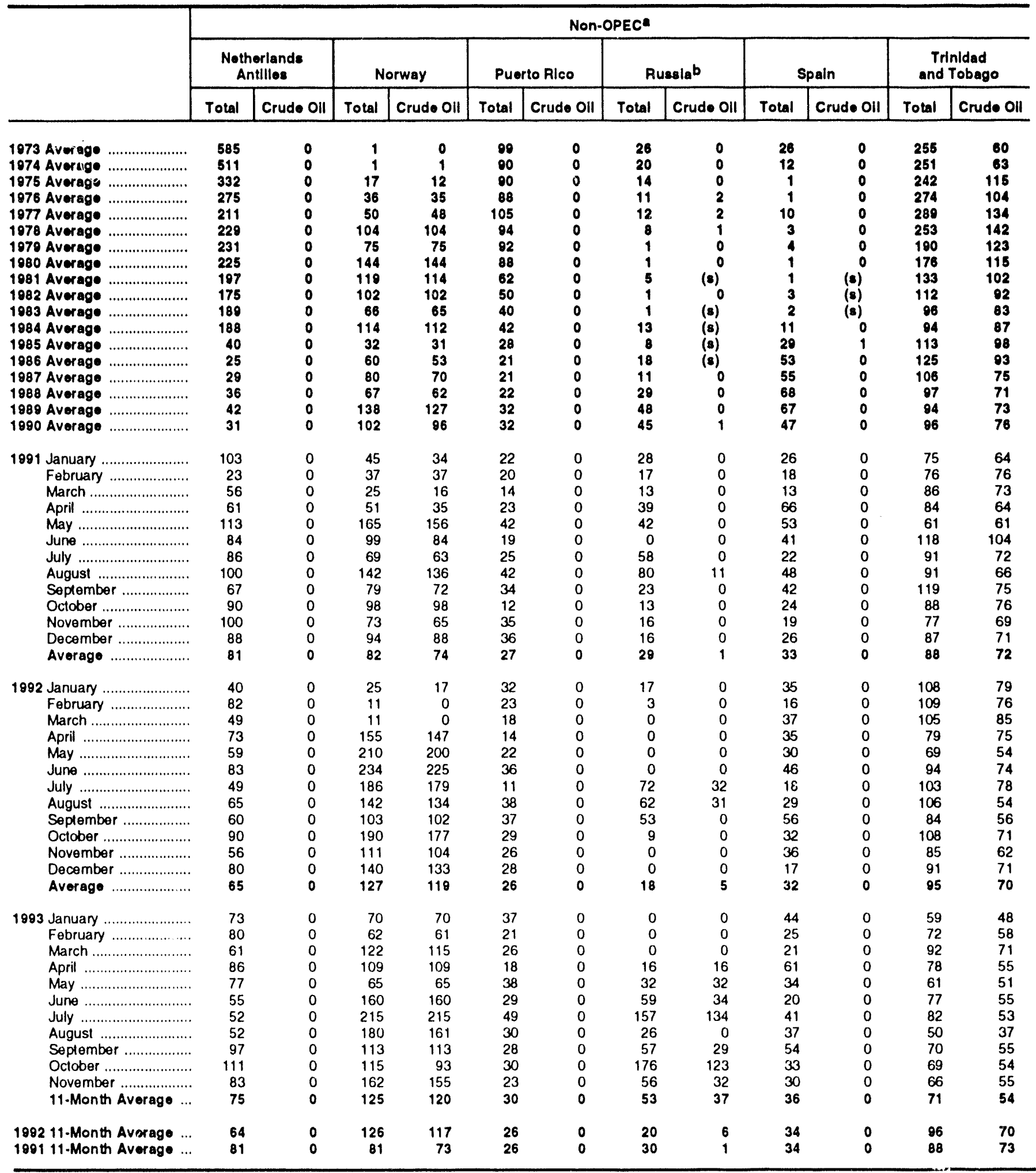

a Includes petroleum imported into the United States indirectly from members of the Organization of Petroleum Exporting Countries (OPEC), primarily trom Caribbean and West European areas, as petroleum products that were relined from crude oil produced by OPEC.

Imports trom other States in the former U.S.S.R. may be included in imports Irom Russia for the years 1973 through 1992.

(s)=Less than 500 barrels per day.
Noles: - Beginning in October 1977, Strategic Petroleum Reserve imports are included. - Geographic coverage is the 50 States and the District of Columbia.

Sources: - 1973-1980: Energy Information Administration (EIA), Petroleum Supply Monthly, February 1993, Table S3. • 1981 forward: EIA Petroleum Supply Monthly, January 1994, Table S3. 
Table 3.3h Petroleum Imports: United KIngdom, Virgin Islands, Other Non-OPEC, Total Non-OPEC, and Total Imports

(Thousand Barrels per Day)

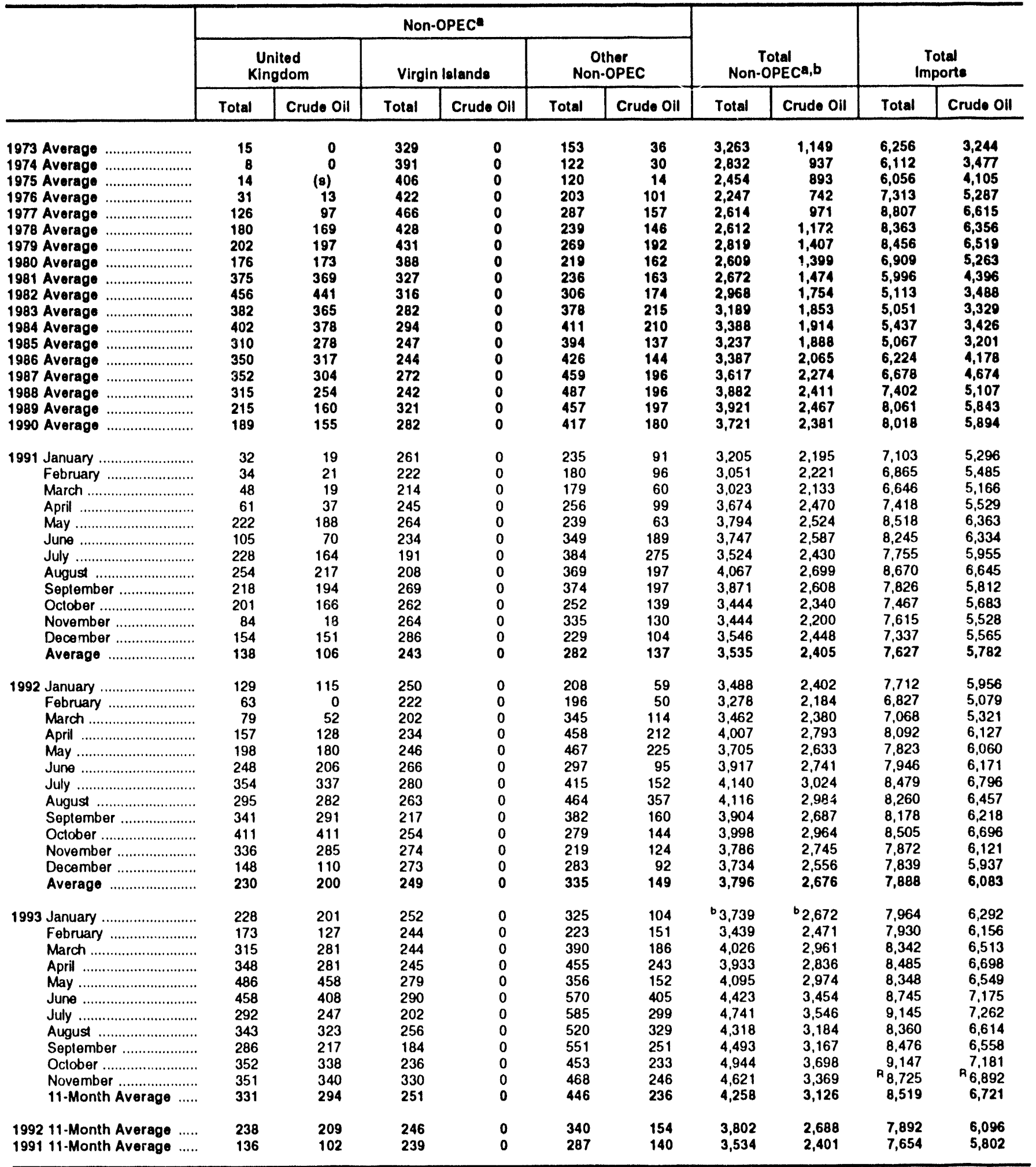

a Includes petroleum imported into the United States indirectly from members of the Organization of Petroleum Exporting Counlries (OPEC), primarily Irom Caribbean and West European areas, as petroleum products that were refined from crude oll produced by OPEC.

b As of January 1993, includes petroleum imported from Ecuador, which withdrew Irom OPEC on December 31, 1992.

$\mathrm{R}=$ Revised data. (s)=Less than 500 barrels per day.
Noles: - Beginning in October 1977, Strategic Petroleum Reserve imports are included. - Geographic coverage is the 50 States and the District of Columbia. - Totals may not equal sum of components due to independent roundirig.

Sources: - 1973-1980: Energy Information Administration (EIA), Petroleum Supply Monthy, February 1993, Table S3. - 1981 forward: ElA, Petroloum Supply Monthly, January 1994, Table S3. 
Figure 3.2 Finished Motor Gasoline

- (Million Barrels per Day, Except as Noted)

Overview, 1973-1993

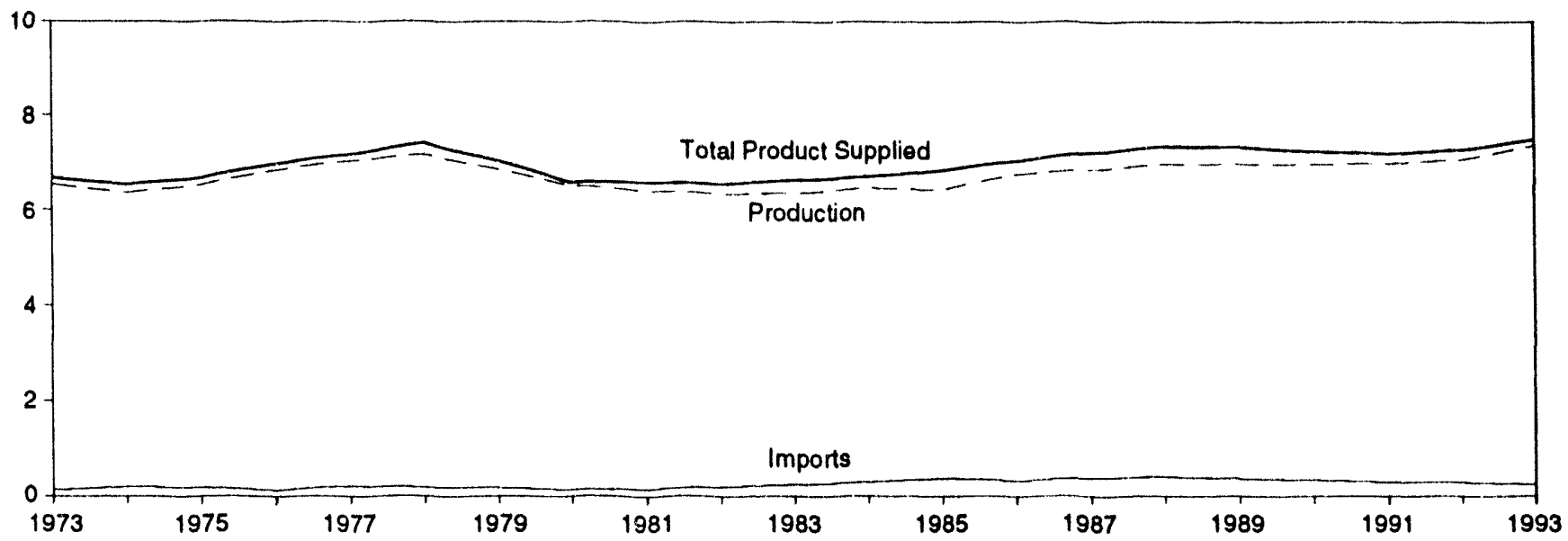

Overview, Monthly

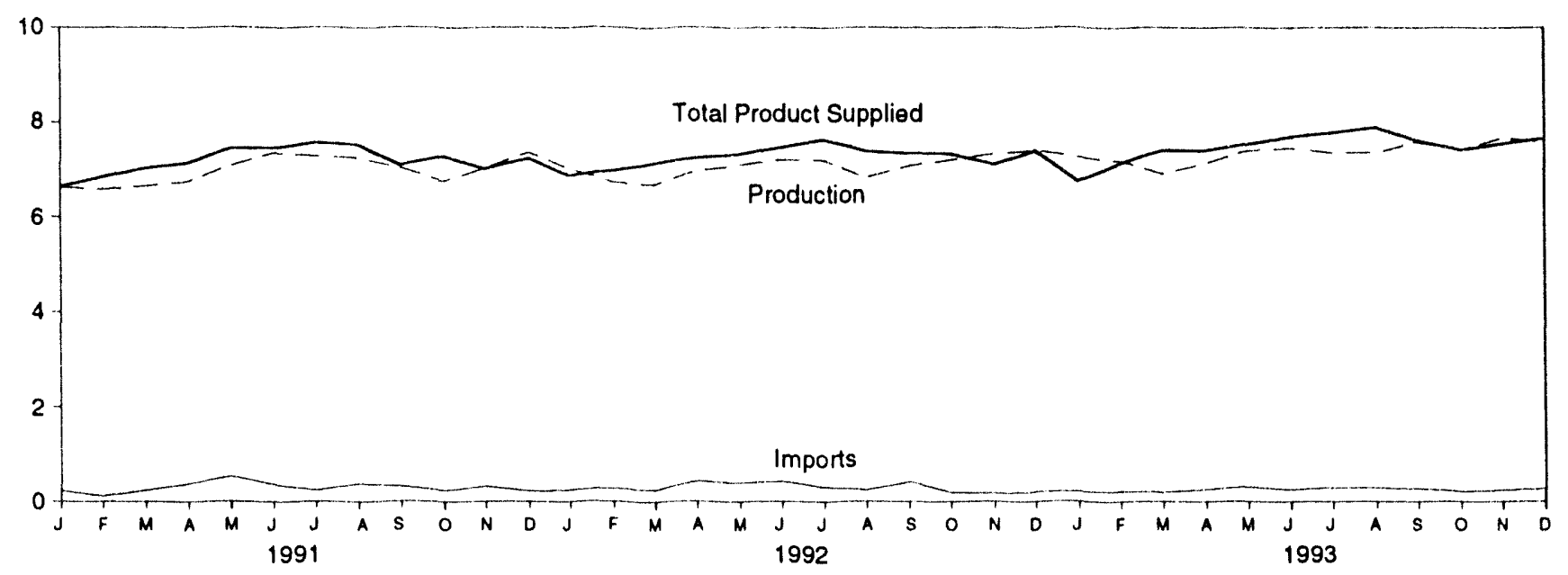

Total Product Supplied, January-December

Total Stocks, End of Month
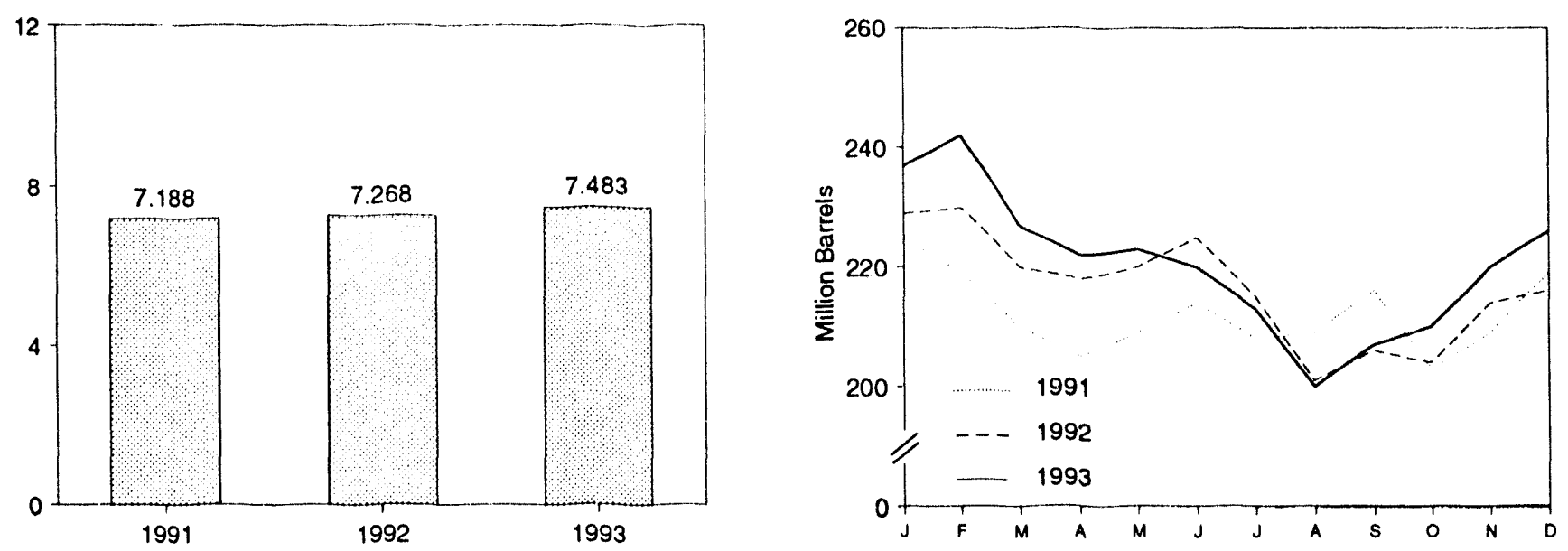

Nole: Because vertical scales differ, graphs should not be compared. Source: Table 3.4 . 
Table 3.4 Finished Motor Gasoline Supply and Disposition

\begin{tabular}{|c|c|c|c|c|c|c|c|c|}
\hline & \multicolumn{2}{|c|}{ Supply } & \multicolumn{3}{|c|}{ Disposition } & \multicolumn{2}{|c|}{$\begin{array}{l}\text { Motor Gesoline } \\
\text { Ending Stocke }\end{array}$} & \multirow{2}{*}{$\begin{array}{c}\text { Oxygonatee } \\
\text { Ending } \\
\text { Stocke }\end{array}$} \\
\hline & $\begin{array}{c}\text { Total } \\
\text { Production }\end{array}$ & Importsb & $\begin{array}{c}\text { Stock } \\
\text { Changeb,c }\end{array}$ & Exports & $\begin{array}{l}\text { Product } \\
\text { Supplied }\end{array}$ & Totald & Finished & \\
\hline & \multicolumn{5}{|c|}{ Thousand Barrels per Day } & \multicolumn{3}{|c|}{ Million Barrels } \\
\hline 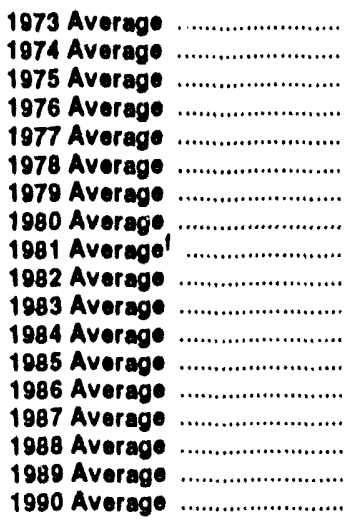 & $\begin{array}{l}6,535 \\
6,360 \\
6,520 \\
6,841 \\
7,033 \\
7,169 \\
6,852 \\
6,506 \\
6,405 \\
6,338 \\
6,340 \\
6,453 \\
6,419 \\
6,752 \\
6,841 \\
6,956 \\
6,963 \\
6,959\end{array}$ & $\begin{array}{l}134 \\
204 \\
184 \\
131 \\
217 \\
190 \\
181 \\
140 \\
157 \\
197 \\
247 \\
299 \\
381 \\
326 \\
384 \\
405 \\
369 \\
342\end{array}$ & $\begin{array}{r}-9 \\
24 \\
028 \\
-10 \\
72 \\
-54 \\
-2 \\
66 \\
0.28 \\
-25 \\
-45 \\
54 \\
-41 \\
11 \\
-15 \\
3 \\
-35 \\
10\end{array}$ & $\begin{array}{r}4 \\
2 \\
2 \\
3 \\
2 \\
1 \\
18) \\
1 \\
2 \\
20 \\
10 \\
6 \\
10 \\
33 \\
35 \\
22 \\
39 \\
55\end{array}$ & $\begin{array}{l}6,674 \\
6,537 \\
6,675 \\
6,978 \\
7,177 \\
7,412 \\
7,034 \\
6,579 \\
6,588 \\
6,539 \\
6,622 \\
6,693 \\
6,831 \\
7,034 \\
7,206 \\
7,336 \\
7,328 \\
7,235\end{array}$ & $\begin{array}{r}209 \\
-218 \\
235 \\
231 \\
258 \\
238 \\
237 \\
-261 \\
253 \\
0235 \\
222 \\
243 \\
223 \\
233 \\
226 \\
228 \\
213 \\
220\end{array}$ & $\begin{array}{l}\text { NA } \\
\text { NA } \\
\text { NA } \\
\text { NA } \\
\text { NA } \\
\text { NA } \\
\text { NA } \\
\text { NA } \\
203 \\
0194 \\
186 \\
205 \\
190 \\
194 \\
189 \\
190 \\
177 \\
181\end{array}$ & $\begin{array}{l}\text { NA } \\
\text { NA } \\
\text { NA } \\
\text { NA } \\
\text { NA } \\
\text { NA } \\
\text { NA } \\
\text { NA } \\
\text { NA } \\
N A \\
N A \\
N A \\
N A \\
N A \\
N A \\
N A \\
\text { NA } \\
\text { NA }\end{array}$ \\
\hline 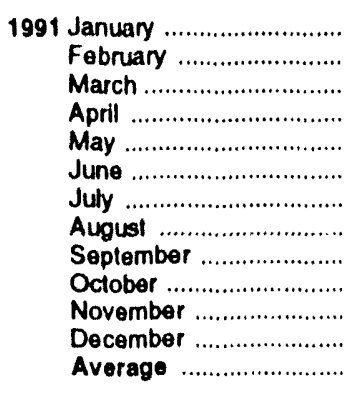 & $\begin{array}{l}6,629 \\
6,573 \\
6,643 \\
6,742 \\
7,063 \\
7,351 \\
7,274 \\
7,247 \\
7,030 \\
6,749 \\
7,018 \\
7,354 \\
6,975\end{array}$ & $\begin{array}{l}228 \\
115 \\
235 \\
381 \\
528 \\
364 \\
232 \\
385 \\
312 \\
236 \\
322 \\
216 \\
297\end{array}$ & $\begin{array}{r}162 \\
-252 \\
-236 \\
.67 \\
95 \\
160 \\
177 \\
-177 \\
7 \\
195 \\
.354 \\
228 \\
267 \\
3\end{array}$ & $\begin{array}{r}50 \\
102 \\
97 \\
53 \\
59 \\
99 \\
122 \\
98 \\
63 \\
58 \\
58 \\
104 \\
79 \\
82\end{array}$ & $\begin{array}{l}6,645 \\
6,838 \\
7,017 \\
7,137 \\
7,437 \\
7,456 \\
7,561 \\
7,528 \\
7,083 \\
7,281 \\
7,008 \\
7,224 \\
7,188\end{array}$ & $\begin{array}{l}225 \\
219 \\
210 \\
205 \\
209 \\
214 \\
208 \\
209 \\
216 \\
203 \\
209 \\
219 \\
219\end{array}$ & $\begin{array}{l}186 \\
179 \\
171 \\
169 \\
172 \\
177 \\
172 \\
172 \\
178 \\
167 \\
173 \\
182 \\
182\end{array}$ & $\begin{array}{l}\text { NA } \\
\text { NA } \\
\text { NA } \\
\text { NA } \\
\text { NA } \\
\text { NA } \\
\text { NA } \\
\text { NA } \\
\text { NA } \\
\text { NA } \\
\text { NA } \\
\text { NA } \\
\text { NA }\end{array}$ \\
\hline 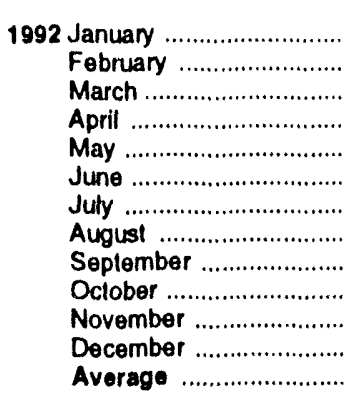 & $\begin{array}{l}7,013 \\
6,726 \\
6,683 \\
6,954 \\
7,092 \\
7,198 \\
7,195 \\
6,817 \\
7,071 \\
7,198 \\
7,323 \\
7,411 \\
7,058\end{array}$ & $\begin{array}{l}246 \\
275 \\
247 \\
428 \\
392 \\
424 \\
303 \\
240 \\
418 \\
193 \\
170 \\
202 \\
294\end{array}$ & $\begin{array}{r}304 \\
.22 \\
.278 \\
54 \\
74 \\
76 \\
.249 \\
.446 \\
60 \\
.41 \\
318 \\
32 \\
.11\end{array}$ & $\begin{array}{r}87 \\
59 \\
71 \\
90 \\
82 \\
86 \\
108 \\
123 \\
85 \\
94 \\
74 \\
184 \\
96\end{array}$ & $\begin{array}{l}6,869 \\
6,963 \\
7,137 \\
7,238 \\
7,328 \\
7,460 \\
7,639 \\
7,380 \\
7,344 \\
7,338 \\
7,102 \\
7,396 \\
7,268\end{array}$ & $\begin{array}{l}229 \\
230 \\
220 \\
218 \\
220 \\
225 \\
215 \\
201 \\
206 \\
204 \\
214 \\
216 \\
216\end{array}$ & $\begin{array}{l}191 \\
191 \\
182 \\
183 \\
186 \\
188 \\
180 \\
167 \\
168 \\
167 \\
177 \\
178 \\
178\end{array}$ & $\begin{array}{l}\text { NA } \\
\text { NA } \\
\text { NA } \\
\text { NA } \\
\text { NA } \\
\text { NA } \\
\text { NA } \\
\text { NA } \\
\text { NA } \\
\text { NA } \\
\text { NA } \\
\text { NA } \\
\text { NA }\end{array}$ \\
\hline 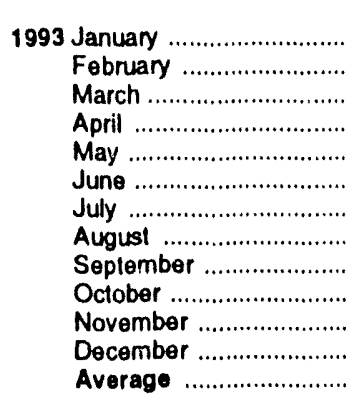 & $\begin{array}{r}97,254 \\
7,172 \\
6,897 \\
7,123 \\
7,394 \\
7,447 \\
7,344 \\
7,344 \\
7,583 \\
7,409 \\
R 7,664 \\
\text { E } 7,577 \\
\text { E,351 }\end{array}$ & $\begin{array}{r}204 \\
216 \\
198 \\
253 \\
308 \\
251 \\
292 \\
283 \\
269 \\
210 \\
210 \\
R_{237} \\
E_{267} \\
E_{249}\end{array}$ & $\begin{array}{r}571 \\
160 \\
-411 \\
-137 \\
80 \\
-75 \\
-242 \\
-336 \\
154 \\
127 \\
R_{237} \\
E_{122} \\
E_{20}\end{array}$ & $\begin{array}{r}142 \\
99 \\
109 \\
111 \\
90 \\
81 \\
100 \\
77 \\
85 \\
80 \\
8123 \\
E^{2} \\
\text { E } 72 \\
97\end{array}$ & $\begin{array}{r}96,746 \\
7,129 \\
7,397 \\
7,401 \\
7,531 \\
7,692 \\
7,777 \\
7,885 \\
7,612 \\
7,411 \\
R 7,541 \\
E_{7,650} \\
E_{7,483}\end{array}$ & $\begin{array}{r}237 \\
242 \\
227 \\
222 \\
223 \\
220 \\
213 \\
200 \\
207 \\
210 \\
R_{220} \\
E_{226} \\
\text { E } 226_{22}\end{array}$ & $\begin{array}{l}195 \\
200 \\
187 \\
183 \\
185 \\
183 \\
176 \\
165 \\
170 \\
174 \\
A_{181} \\
E_{186} \\
E_{186}\end{array}$ & $\begin{array}{l}n_{14} \\
13 \\
14 \\
15 \\
17 \\
18 \\
20 \\
21 \\
20 \\
17 \\
15 \\
\text { NA } \\
\text { NA }\end{array}$ \\
\hline
\end{tabular}

- Stocks are tolals as of end of periud.

b From 1981 fonward, blending components are excluded.

c A negative number indicates a decrease in stocks and a positive number indicates an increase.

Inciudes motor gasoline blending components, but excludes oxygenales, which are reported separately.

- See Nole 4 at end of section.

1 See Nole 2 at end of section.

- Beginning in 1993, motor gasoline production and product supplied include blending of fuel ethanol and an adjustment to correct for the imbalance of molor gasoline blending components. See Note 2 al end of section.

h See Nole 1 at end of section.

$R=$ Revised data. $N A=\mathrm{Nol}$ available. E=Estimale. (s)=Less than 500 barrels per day.

Note: Geographic coverage is the 50 States and the Distrid of Columbia.

Sources: 1973-1980: Energy Information Administration (ELA), Pelroleum Supply Monthly, Februany 1993, Table S4. - 1981 forward: ElA, Petroleum Supply Monthy, January 1994, Table S4. 
Figure 3.3 Distillate Fuel

(Million Barrels per Day, Except as Noted)

Overview, 1973-1993

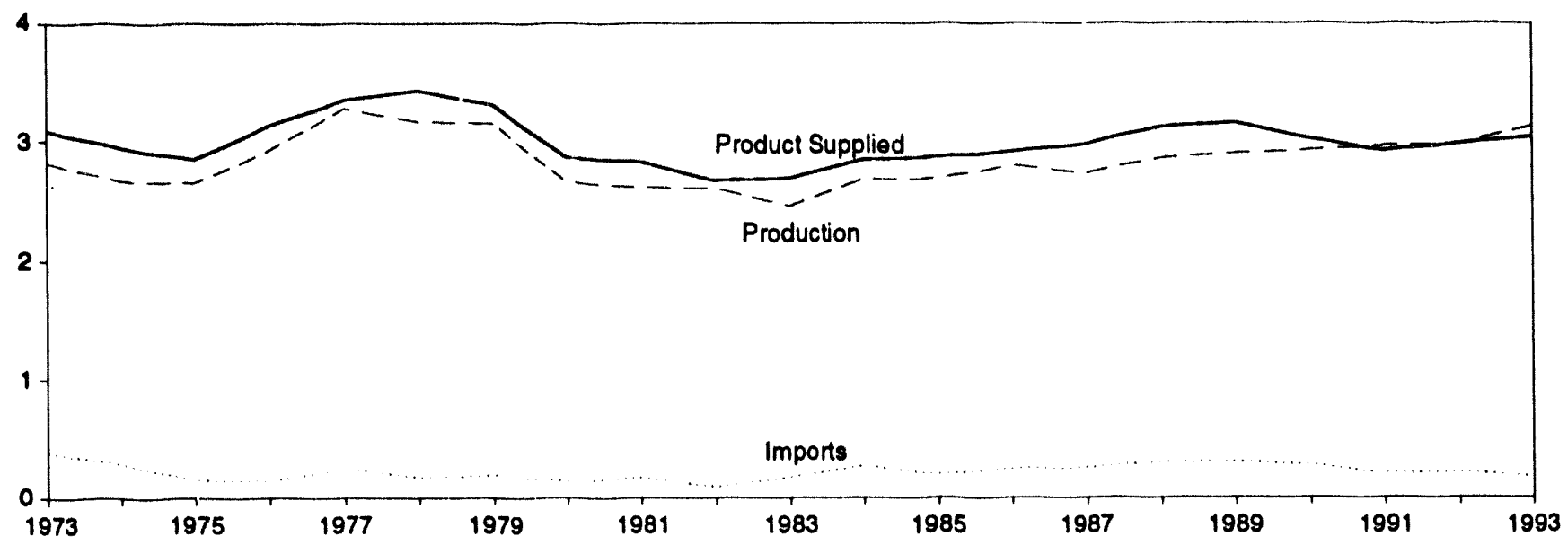

Overview, Monthly

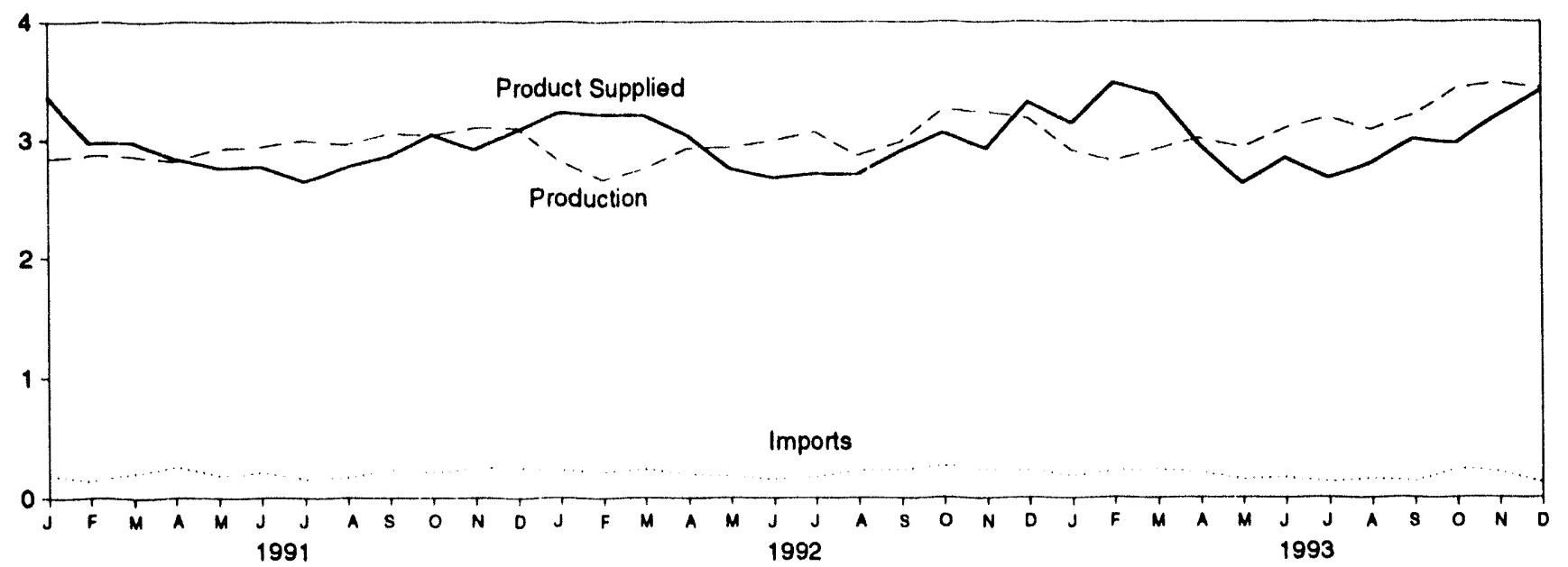

Product Supplied, January-December

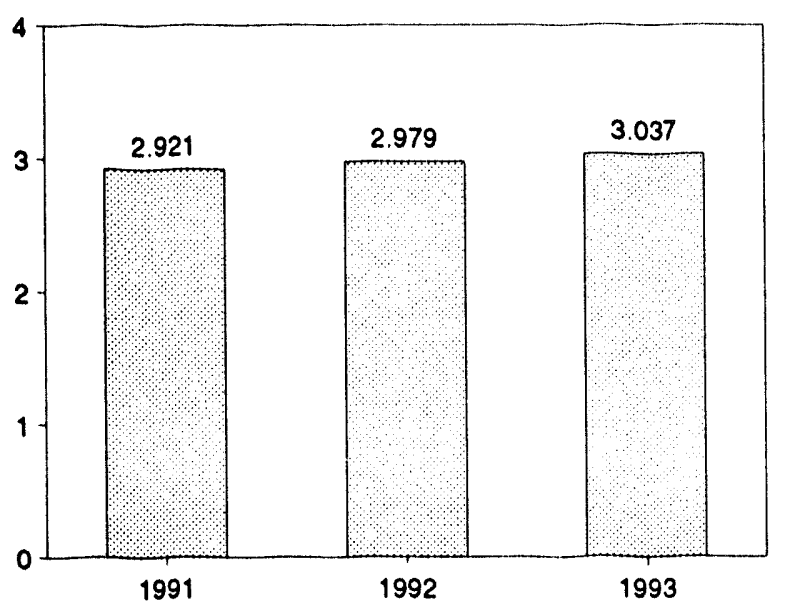

Stocks, End of Month

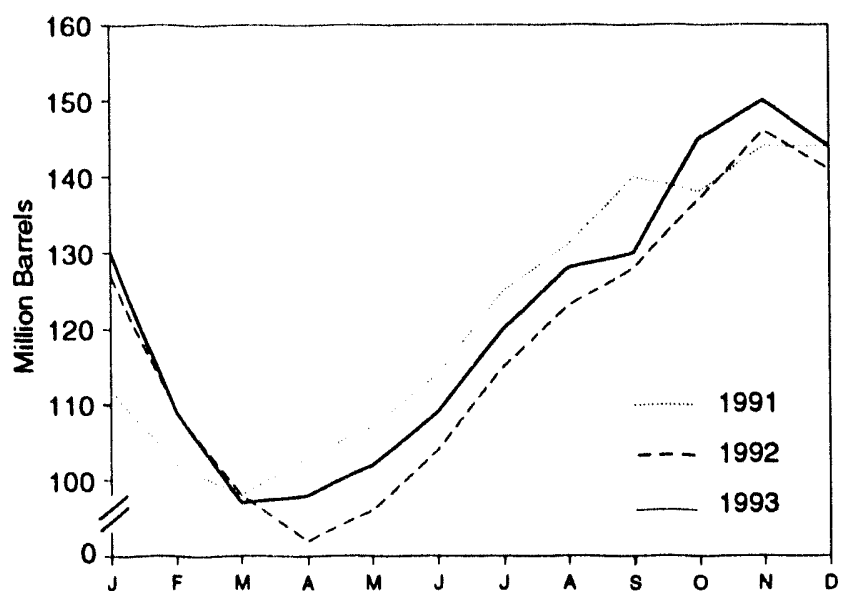

Source: Table 3.5 . 
Table 3.5 Distlllate Fuel OII Supply and Disposition

\begin{tabular}{|c|c|c|c|c|c|c|c|c|c|}
\hline & \multicolumn{3}{|c|}{ Supply } & \multicolumn{3}{|c|}{ Dlsposition } & \multicolumn{3}{|c|}{ Ending stocke } \\
\hline & \multirow[b]{2}{*}{$\begin{array}{c}\text { Tolal } \\
\text { Production } \\
\end{array}$} & \multirow[b]{2}{*}{ Importe } & \multirow[b]{2}{*}{$\begin{array}{l}\text { Crude Oll } \\
\text { Ueed } \\
\text { Directlyb }\end{array}$} & \multirow[b]{2}{*}{$\begin{array}{l}\text { Stock } \\
\text { Changec }\end{array}$} & \multirow[b]{2}{*}{ Exporte } & \multirow[b]{2}{*}{$\begin{array}{l}\text { Product } \\
\text { Suppliedb }\end{array}$} & \multirow[b]{2}{*}{ Total } & \multicolumn{2}{|c|}{ Sulfur Content } \\
\hline & & & & & & & & $\begin{array}{l}0.05 \text { Percent } \\
\text { or Lesed }\end{array}$ & $\begin{array}{l}\text { Grester Then } \\
0.05 \text { Percent }\end{array}$ \\
\hline & \multicolumn{6}{|c|}{ Thousand Barrels per Day } & \multicolumn{3}{|c|}{ Million Barreb } \\
\hline 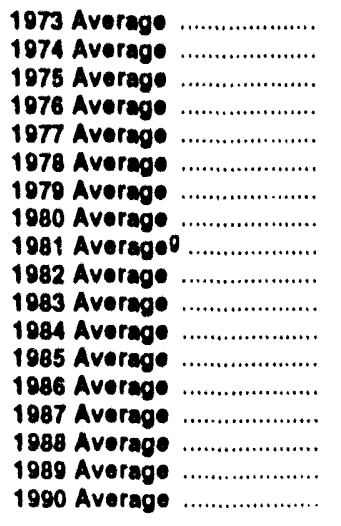 & $\begin{array}{l}2,822 \\
2,669 \\
2,654 \\
2,924 \\
3,278 \\
3,167 \\
3,153 \\
2,662 \\
2,613 \\
2,606 \\
2,456 \\
2,681 \\
2,687 \\
2,798 \\
2,731 \\
2,859 \\
2,899 \\
2,925\end{array}$ & $\begin{array}{r}392 \\
289 \\
155 \\
146 \\
250 \\
173 \\
193 \\
142 \\
173 \\
93 \\
174 \\
272 \\
200 \\
247 \\
255 \\
302 \\
306 \\
278\end{array}$ & $\begin{array}{r}2 \\
2 \\
2 \\
1 \\
1 \\
1 \\
1 \\
1 \\
10 \\
10 \\
- \\
- \\
- \\
- \\
- \\
- \\
- \\
-\end{array}$ & $\begin{array}{r}115 \\
110 \\
.1 .41 \\
-62 \\
176 \\
.03 \\
34 \\
-64 \\
1.38 \\
-35 \\
1.124 \\
57 \\
-48 \\
31 \\
-56 \\
-30 \\
-49 \\
73\end{array}$ & $\begin{array}{r}8 \\
2 \\
1 \\
1 \\
1 \\
3 \\
3 \\
3 \\
5 \\
74 \\
64 \\
51 \\
67 \\
100 \\
66 \\
69 \\
97 \\
109\end{array}$ & $\begin{array}{l}3,092 \\
2,948 \\
2,851 \\
3,133 \\
3,352 \\
3,432 \\
3,311 \\
2,866 \\
2,820 \\
2,671 \\
2,690 \\
2,845 \\
2,868 \\
2,914 \\
2,976 \\
3,122 \\
3,157 \\
3,021\end{array}$ & $\begin{array}{r}196 \\
1200 \\
209 \\
186 \\
250 \\
216 \\
229 \\
1205 \\
192 \\
1179 \\
140 \\
161 \\
144 \\
155 \\
134 \\
124 \\
106 \\
132\end{array}$ & $\begin{array}{l}\text { NA } \\
\text { NA } \\
\text { NA } \\
\text { NA } \\
\text { NA } \\
\text { NA } \\
N A \\
N A \\
N A \\
N A \\
N A \\
N A \\
N A \\
N A \\
\text { NA } \\
\text { NA } \\
\text { NA } \\
\text { NA }\end{array}$ & $\begin{array}{l}\text { NA } \\
\text { NA } \\
\text { NA } \\
\text { NA } \\
\text { NA } \\
\text { NA } \\
\text { NA } \\
\text { NA } \\
\text { NA } \\
\text { NA } \\
\text { NA } \\
\text { NA } \\
\text { NA } \\
\text { NA } \\
\text { NA } \\
\text { NA } \\
\text { NA } \\
\text { NA }\end{array}$ \\
\hline 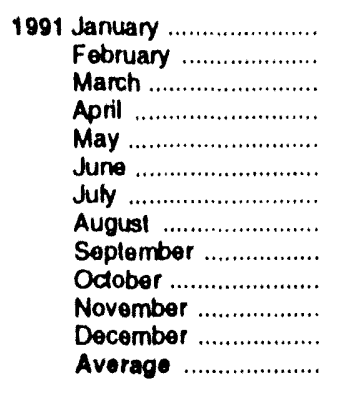 & $\begin{array}{l}2,845 \\
2,870 \\
2,865 \\
2,819 \\
2,929 \\
2,941 \\
2,998 \\
2,961 \\
3,055 \\
3,040 \\
3,103 \\
3,107 \\
2,962\end{array}$ & $\begin{array}{l}192 \\
139 \\
206 \\
258 \\
186 \\
209 \\
155 \\
168 \\
237 \\
207 \\
249 \\
252 \\
205\end{array}$ & $\begin{array}{l}- \\
\overline{-} \\
- \\
- \\
- \\
- \\
- \\
- \\
- \\
-\end{array}$ & $\begin{array}{r}.662 \\
.359 \\
-112 \\
156 \\
132 \\
225 \\
356 \\
214 \\
291 \\
-59 \\
206 \\
-30 \\
31\end{array}$ & $\begin{array}{r}332 \\
393 \\
198 \\
81 \\
218 \\
150 \\
149 \\
144 \\
136 \\
259 \\
224 \\
302 \\
215\end{array}$ & $\begin{array}{l}3,367 \\
2,976 \\
2,984 \\
2,839 \\
2,765 \\
2,775 \\
2,648 \\
2,770 \\
2,865 \\
3,047 \\
2,921 \\
3,087 \\
2,921\end{array}$ & $\begin{array}{r}112 \\
102 \\
98 \\
103 \\
107 \\
114 \\
125 \\
131 \\
140 \\
138 \\
144 \\
144 \\
144\end{array}$ & $\begin{array}{l}\text { NA } \\
\text { NA } \\
\text { NA } \\
\text { NA } \\
\text { NA } \\
\text { NA } \\
\text { NA } \\
\text { NA } \\
\text { NA } \\
\text { NA } \\
\text { NA } \\
\text { NA } \\
\text { NA }\end{array}$ & $\begin{array}{l}\text { NA } \\
\text { NA } \\
\text { NA } \\
\text { NA } \\
\text { NA } \\
\text { NA } \\
\text { NA } \\
\text { NA } \\
\text { NA } \\
\text { NA } \\
\text { NA } \\
\text { NA }\end{array}$ \\
\hline 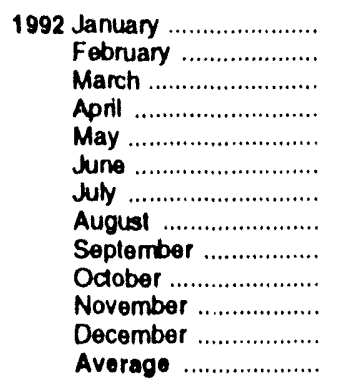 & $\begin{array}{l}2,818 \\
2,661 \\
2,749 \\
2,930 \\
2,933 \\
2,995 \\
3,067 \\
2,865 \\
2,983 \\
3,251 \\
3,240 \\
3,179 \\
2,974\end{array}$ & $\begin{array}{l}232 \\
217 \\
238 \\
202 \\
179 \\
157 \\
172 \\
229 \\
237 \\
263 \\
236 \\
229 \\
216\end{array}$ & $\begin{array}{l}- \\
- \\
- \\
- \\
- \\
- \\
- \\
- \\
- \\
- \\
-\end{array}$ & $\begin{array}{r}.541 \\
-618 \\
.358 \\
.185 \\
139 \\
268 \\
328 \\
262 \\
168 \\
290 \\
316 \\
-183 \\
8\end{array}$ & $\begin{array}{l}360 \\
278 \\
138 \\
278 \\
222 \\
205 \\
201 \\
127 \\
145 \\
169 \\
230 \\
276 \\
219\end{array}$ & $\begin{array}{l}3,231 \\
3,219 \\
3,207 \\
3,039 \\
2,753 \\
2,679 \\
2,710 \\
2,705 \\
2,908 \\
3,056 \\
2,929 \\
3,316 \\
2,979\end{array}$ & $\begin{array}{r}127 \\
109 \\
98 \\
92 \\
96 \\
104 \\
115 \\
123 \\
128 \\
137 \\
146 \\
141 \\
141\end{array}$ & $\begin{array}{l}\text { NA } \\
\text { NA } \\
N A \\
N A \\
N A \\
N A \\
N A \\
N A \\
N A \\
N A \\
N A \\
N A \\
N A\end{array}$ & $\begin{array}{l}N A \\
N A \\
N A \\
N A \\
N A \\
N A \\
N A \\
N A \\
N A \\
N A \\
N A \\
N A \\
N A\end{array}$ \\
\hline 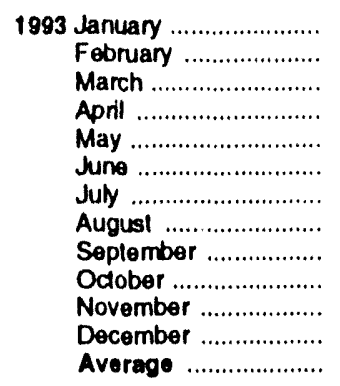 & $\begin{array}{l}2,909 \\
2,813 \\
2,918 \\
3,010 \\
2,930 \\
3,095 \\
3,185 \\
3,084 \\
3,206 \\
3,435 \\
\text { ค } 3,478 \\
\text { E }_{3,439} \\
\text { E } 3,127\end{array}$ & $\begin{array}{l}182 \\
224 \\
235 \\
209 \\
153 \\
168 \\
130 \\
159 \\
137 \\
242 \\
\text { A }_{214} \\
E_{125} \\
\text { E } 181\end{array}$ & $\begin{array}{l}- \\
- \\
- \\
- \\
- \\
- \\
- \\
- \\
-\end{array}$ & $\begin{array}{r}.336 \\
.742 \\
-386 \\
30 \\
104 \\
263 \\
348 \\
249 \\
80 \\
467 \\
156 \\
E_{-30} \\
E_{22}\end{array}$ & $\begin{array}{l}287 \\
301 \\
154 \\
241 \\
355 \\
158 \\
298 \\
197 \\
262 \\
241 \\
\text { A }_{330} \\
E_{175} \\
E_{250}\end{array}$ & $\begin{array}{r}3,141 \\
3,478 \\
3,386 \\
2,949 \\
2,624 \\
2,843 \\
2,669 \\
2,797 \\
3,001 \\
2,968 \\
\text { A } 3,206 \\
\text { E } 3,420 \\
\text { E } 3,037\end{array}$ & $\begin{array}{r}130 \\
109 \\
97 \\
98 \\
102 \\
109 \\
120 \\
128 \\
130 \\
145 \\
P_{150} \\
\text { E } 144 \\
\text { E } 144\end{array}$ & $\begin{array}{r}9_{22} \\
16 \\
12 \\
13 \\
14 \\
17 \\
23 \\
45 \\
47 \\
55 \\
R_{64} \\
63 \\
63\end{array}$ & $\begin{array}{r}9108 \\
84 \\
85 \\
86 \\
87 \\
92 \\
97 \\
83 \\
84 \\
90 \\
85 \\
81 \\
81\end{array}$ \\
\hline
\end{tabular}

- Slocks are lolals as of end of period.

b Beginning in January 1983, crude oil used directly as distillate fuel oil is reported as crude oil product supplied on Table $3.2 \mathrm{~b}$ rather than as distillate fuel oil product supplied.

- A negative number indicates a decrease in stocks and a positive number indicales an increase.

d By woight.

- See Nole 6 at end of section.

1 Seo Note 4 at end of section.
9 See Note 3 al end of section.

$R=$ Revised dala. NA=Nol available. $-=$ Nol applicable. $E=E$ Estimate.

Notes: - Geographic coverage is the 50 Stales and the Disirict of Columbia. - Tolals may not equal sum of components due to independent rounding.

Sources: - 1973-1980: Enorgy Information Administralion (ELA). Petroloum Supply Monthly, Fobruary 1993, Table S5. • 1981 forward: EIA, Petroleum Supply Monthly, January 1994, Table S5. 
Figure 3.4 Residual Fuel

(Million Barrels per Day, Except as Noted)

Overview, 1973-1993

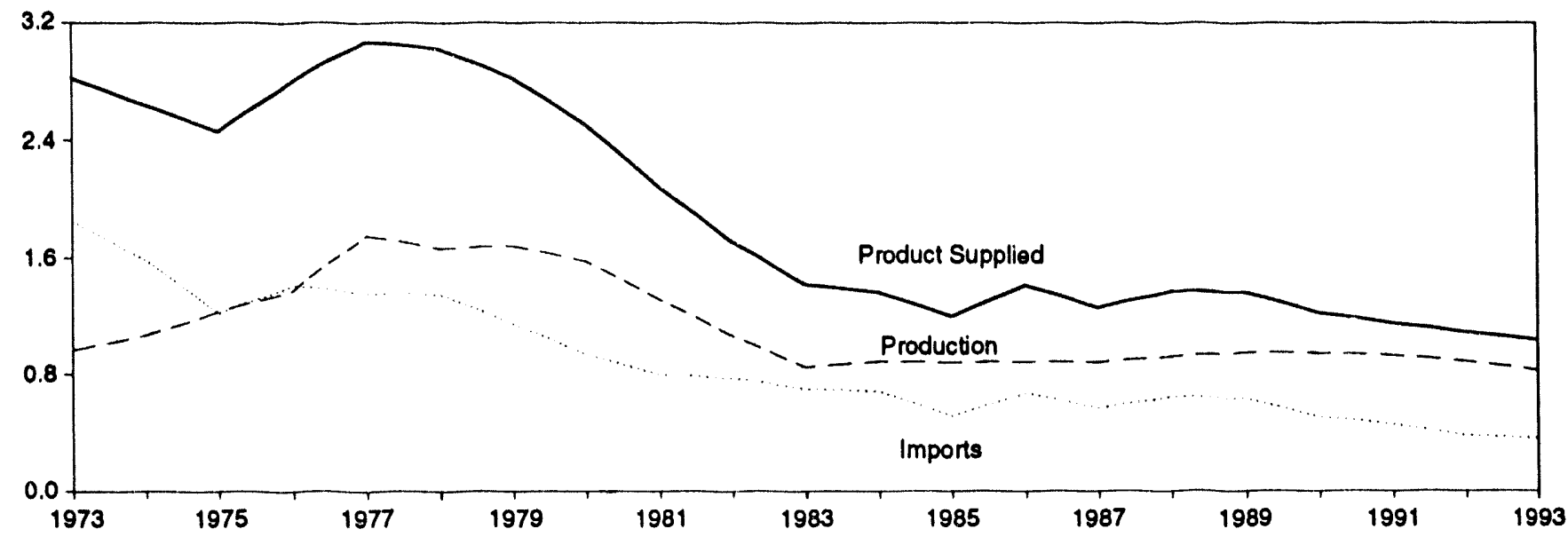

Overview, Monthly

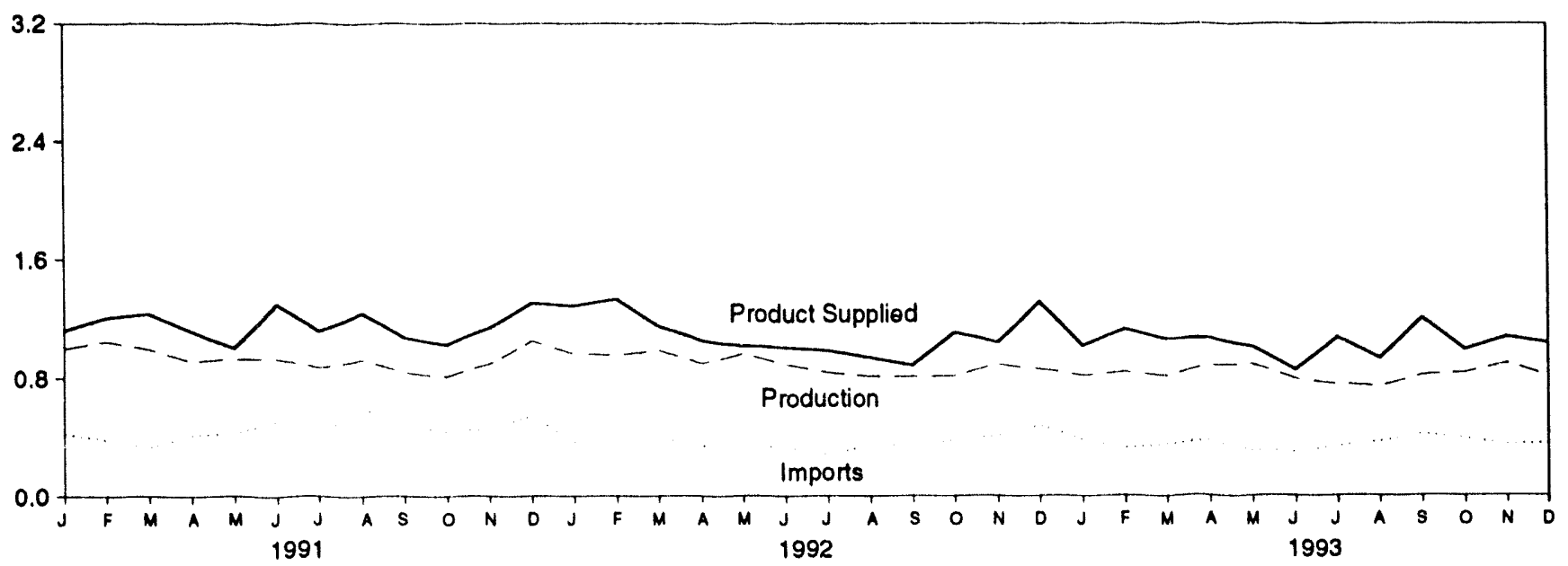

Product Supplied, January-December

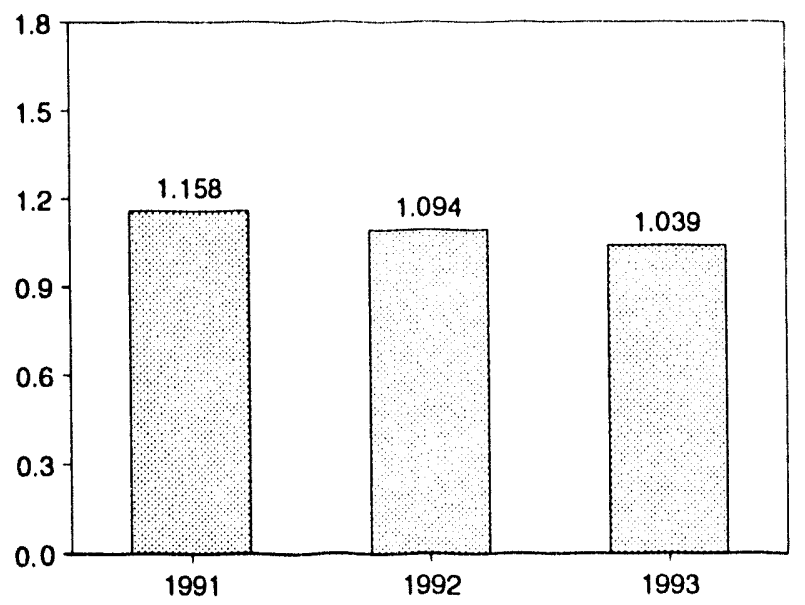

Stocks, End of Month

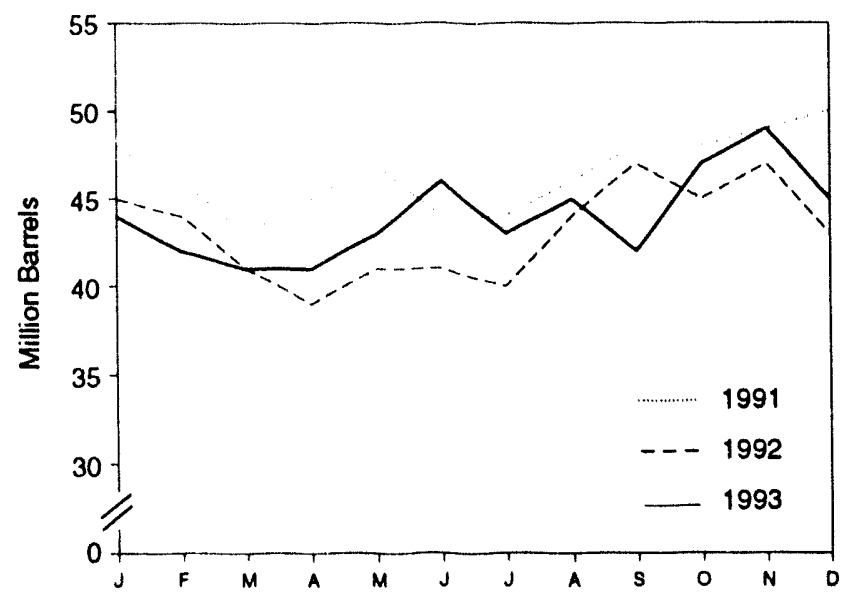

Nole: Because vertical scales differ, graphs should nol be compared. Source: Table 3.6. 
Table 3.6 Residual Fuel OII Supply and Disposition

\begin{tabular}{|c|c|c|c|c|c|c|c|}
\hline & \multicolumn{3}{|c|}{ Supply } & \multicolumn{3}{|c|}{ Dieposition } & \multirow{3}{*}{$\begin{array}{c}\begin{array}{c}\text { Ending } \\
\text { Stockse }\end{array} \\
\text { Million Barrots }\end{array}$} \\
\hline & $\begin{array}{c}\text { Total } \\
\text { Production }\end{array}$ & Imports & $\begin{array}{c}\text { Crude Oll } \\
\text { Used } \\
\text { Directly }\end{array}$ & $\begin{array}{c}\text { Stock } \\
\text { Changeb }\end{array}$ & Exports & $\begin{array}{l}\text { Product } \\
\text { Supplied }\end{array}$ & \\
\hline & \multicolumn{6}{|c|}{ Thousand Barrels per Day } & \\
\hline 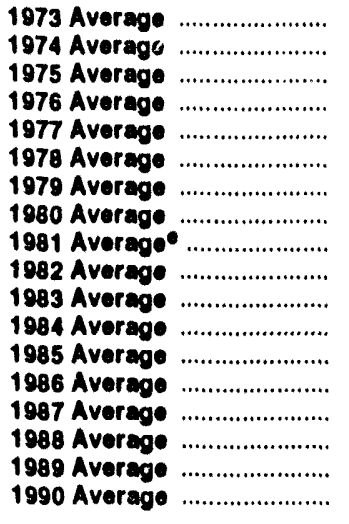 & $\begin{array}{r}971 \\
1,070 \\
1,235 \\
1,377 \\
1,754 \\
1,667 \\
1,687 \\
1,580 \\
1,321 \\
1,070 \\
852 \\
891 \\
882 \\
889 \\
885 \\
926 \\
954 \\
950\end{array}$ & $\begin{array}{l}1,853 \\
1,587 \\
1,223 \\
1,413 \\
1,359 \\
1,355 \\
1,151 \\
839 \\
800 \\
776 \\
699 \\
681 \\
510 \\
669 \\
565 \\
644 \\
629 \\
504\end{array}$ & $\begin{array}{l}17 \\
13 \\
15 \\
17 \\
13 \\
13 \\
12 \\
12 \\
48 \\
48 \\
- \\
- \\
- \\
- \\
- \\
- \\
- \\
-\end{array}$ & $\begin{array}{r}-5 \\
17 \\
d-2 \\
-5 \\
48 \\
1 \\
15 \\
-10 \\
d-37 \\
-32 \\
d-55 \\
12 \\
-7 \\
-8 \\
(8) \\
-8 \\
-2 \\
13\end{array}$ & $\begin{array}{r}23 \\
14 \\
15 \\
12 \\
6 \\
13 \\
9 \\
33 \\
118 \\
209 \\
185 \\
190 \\
197 \\
147 \\
186 \\
200 \\
215 \\
211\end{array}$ & $\begin{array}{l}2,822 \\
2,639 \\
2,462 \\
2,801 \\
3,071 \\
3,023 \\
2,826 \\
2,508 \\
2,088 \\
1,716 \\
1,421 \\
1,369 \\
1,202 \\
1,418 \\
1,264 \\
1,378 \\
1,370 \\
1,229\end{array}$ & $\begin{array}{r}53 \\
d_{60} \\
74 \\
72 \\
60 \\
80 \\
96 \\
d 92 \\
78 \\
d 66 \\
49 \\
53 \\
50 \\
47 \\
47 \\
45 \\
44 \\
49\end{array}$ \\
\hline 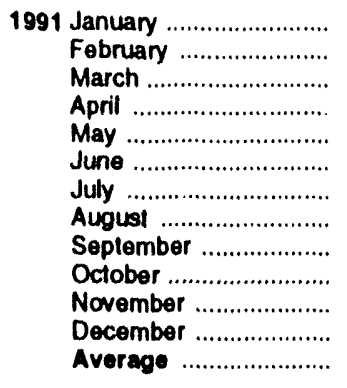 & $\begin{array}{r}1,001 \\
1,050 \\
995 \\
916 \\
929 \\
933 \\
871 \\
925 \\
838 \\
814 \\
896 \\
1,051 \\
934\end{array}$ & $\begin{array}{l}425 \\
384 \\
332 \\
416 \\
425 \\
512 \\
420 \\
599 \\
481 \\
438 \\
455 \\
547 \\
453\end{array}$ & $\begin{array}{l}- \\
- \\
- \\
- \\
- \\
- \\
- \\
- \\
- \\
-\end{array}$ & $\begin{array}{r}-19 \\
.76 \\
.85 \\
68 \\
50 \\
-103 \\
-1 \\
68 \\
78 \\
6 \\
24 \\
28 \\
4\end{array}$ & $\begin{array}{l}320 \\
299 \\
178 \\
145 \\
300 \\
245 \\
176 \\
216 \\
168 \\
217 \\
189 \\
264 \\
226\end{array}$ & $\begin{array}{l}1,124 \\
1,211 \\
1,234 \\
1,119 \\
1,003 \\
1,303 \\
1,117 \\
1,240 \\
1,074 \\
1,029 \\
1,139 \\
1,307 \\
1,158\end{array}$ & $\begin{array}{l}48 \\
46 \\
43 \\
45 \\
47 \\
44 \\
44 \\
46 \\
48 \\
48 \\
49 \\
50 \\
50\end{array}$ \\
\hline 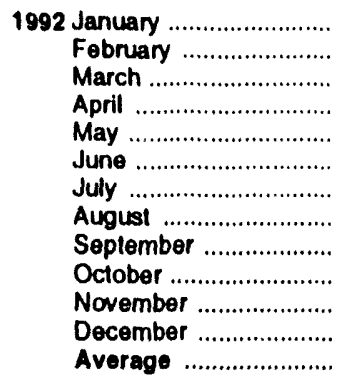 & $\begin{array}{l}965 \\
957 \\
990 \\
900 \\
964 \\
894 \\
838 \\
815 \\
810 \\
818 \\
895 \\
862 \\
892\end{array}$ & $\begin{array}{l}364 \\
498 \\
397 \\
342 \\
328 \\
334 \\
280 \\
347 \\
349 \\
376 \\
411 \\
481 \\
375\end{array}$ & $\begin{array}{l}- \\
- \\
- \\
- \\
- \\
- \\
- \\
- \\
- \\
-\end{array}$ & $\begin{array}{r}-144 \\
.55 \\
.77 \\
.78 \\
67 \\
.11 \\
.37 \\
125 \\
123 \\
.72 \\
49 \\
.127 \\
-20\end{array}$ & $\begin{array}{r}184 \\
176 \\
310 \\
265 \\
207 \\
230 \\
169 \\
96 \\
149 \\
156 \\
216 \\
158 \\
193\end{array}$ & $\begin{array}{r}1,289 \\
1,334 \\
1,154 \\
1,055 \\
1,019 \\
1,009 \\
986 \\
941 \\
887 \\
1,110 \\
1,041 \\
1,312 \\
1,094\end{array}$ & $\begin{array}{l}45 \\
44 \\
41 \\
39 \\
41 \\
41 \\
40 \\
44 \\
47 \\
45 \\
47 \\
43 \\
43\end{array}$ \\
\hline 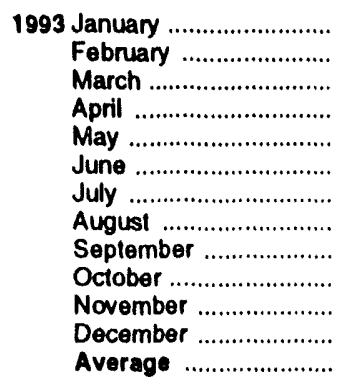 & $\begin{array}{l}820 \\
841 \\
819 \\
887 \\
896 \\
797 \\
760 \\
745 \\
822 \\
839 \\
R_{901} \\
E_{818} \\
E_{828}\end{array}$ & $\begin{array}{r}383 \\
325 \\
352 \\
377 \\
308 \\
299 \\
337 \\
370 \\
420 \\
391 \\
\text { A }_{347} \\
E_{358} \\
E_{356}\end{array}$ & $\begin{array}{l}- \\
- \\
- \\
- \\
- \\
- \\
- \\
- \\
- \\
- \\
-\end{array}$ & $\begin{array}{r}49 \\
.75 \\
-46 \\
24 \\
53 \\
92 \\
.101 \\
61 \\
.73 \\
141 \\
R_{85} \\
E_{-31} \\
E_{15}\end{array}$ & $\begin{array}{r}133 \\
113 \\
152 \\
169 \\
137 \\
147 \\
122 \\
120 \\
110 \\
94 \\
R_{86} \\
E_{169} \\
E_{129}\end{array}$ & $\begin{array}{r}1,020 \\
1,128 \\
1,065 \\
1,070 \\
1,014 \\
857 \\
1,075 \\
935 \\
1,205 \\
995 \\
R_{1,077} \\
E_{1,038} \\
E_{1,039}\end{array}$ & $\begin{array}{l}44 \\
42 \\
41 \\
41 \\
43 \\
46 \\
43 \\
45 \\
42 \\
47 \\
A_{49} \\
E_{45} \\
E_{45}\end{array}$ \\
\hline
\end{tabular}

- Beginning in January 1983, crude oil used directly as residual fuel oil is reported as crude oll product supplied on Table $3.2 \mathrm{~b}$ rather than as residual fuel oil product supplied.

A negative number indicates a decrease in stocks and a positive number indicates an increase.

c Slocks are lotals as of end of period.

- See Nole 4 al end de section.
- See Note 3 at end of section.

$R=$ Revised data. $-=$ Not applicable. E=Estimate. (s)=Less than +500 barrels per day and grealer than -500 barrels per day.

Note: Geographic coverage is the $\mathbf{5 0}$ States and the District of Columbia.

Sources: - 1973-1980: Energy Information Administration (ElA), Petroleum Supply Monthly, February 1993, Tablo S6. - 1981 forward: ElA, Petroleum Supply Monthy, Januany 1994, Table S6. 
Figure 3.5 Jet Fuel

(Million Barrels per Day, Except as Noted)

Total Jet Fuel Overview, 1973-1993

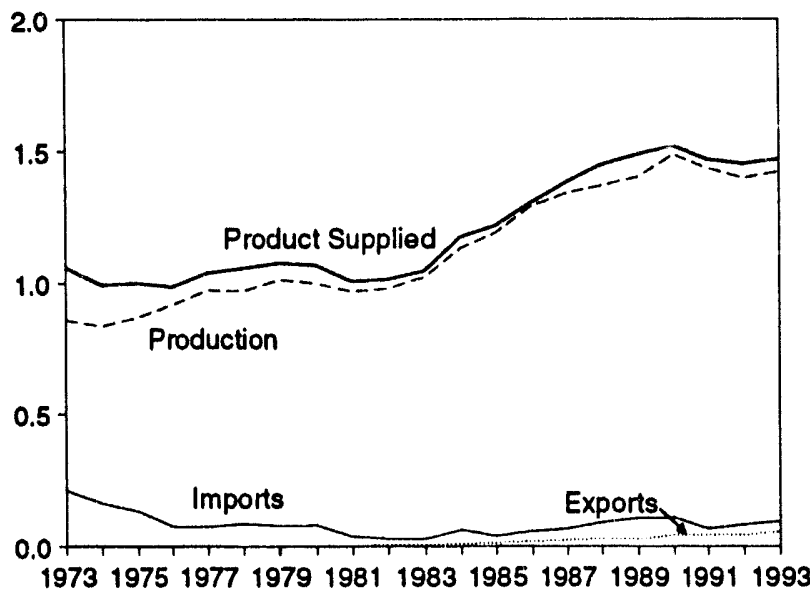

Product Supplied by Type, 1973-1993

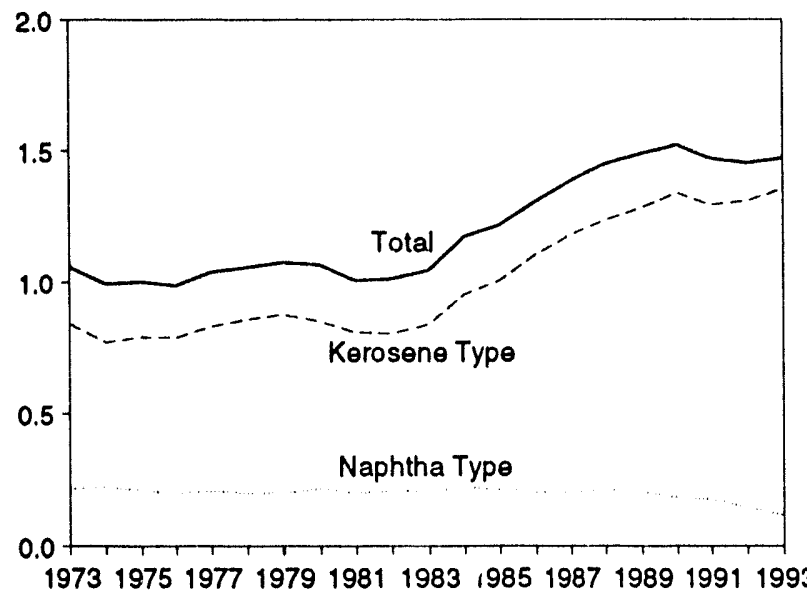

Total Product Supplied, January-December

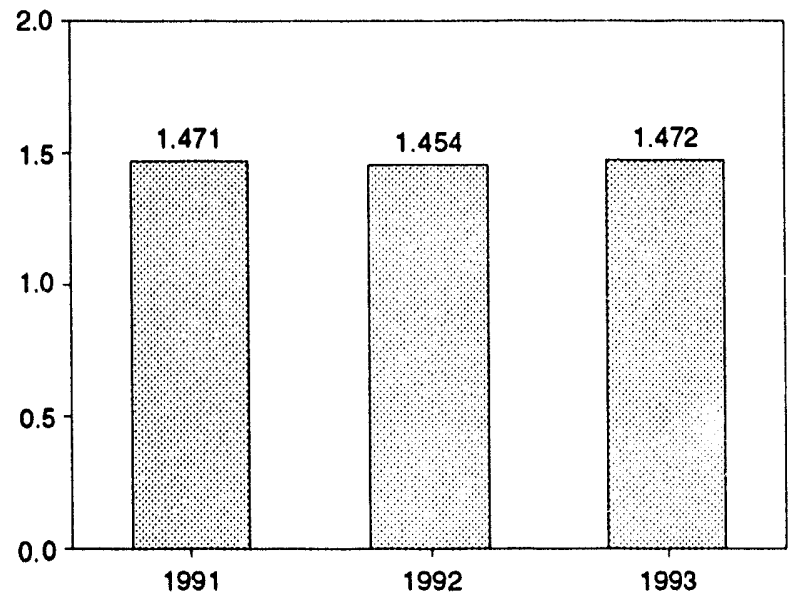

Total Jet Fuel Overview, Monthly

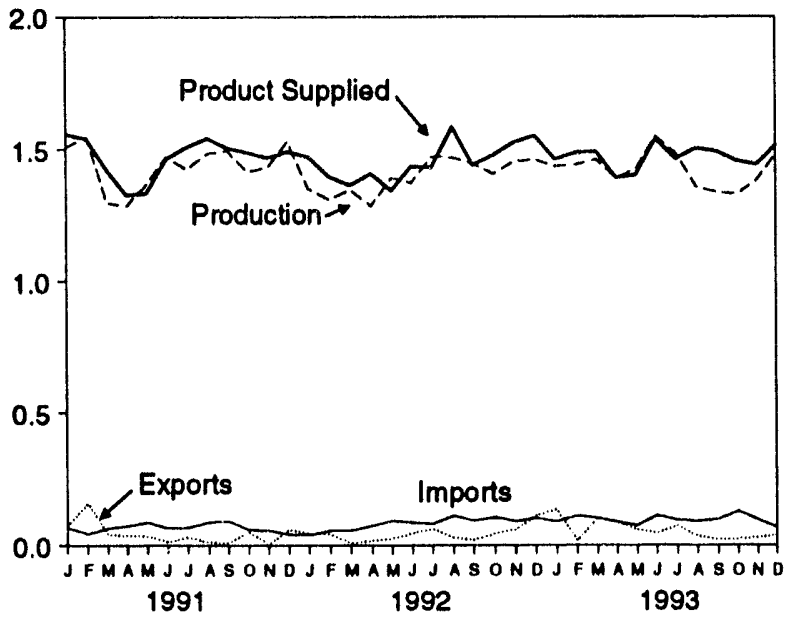

Product Supplied by Type, Monthly

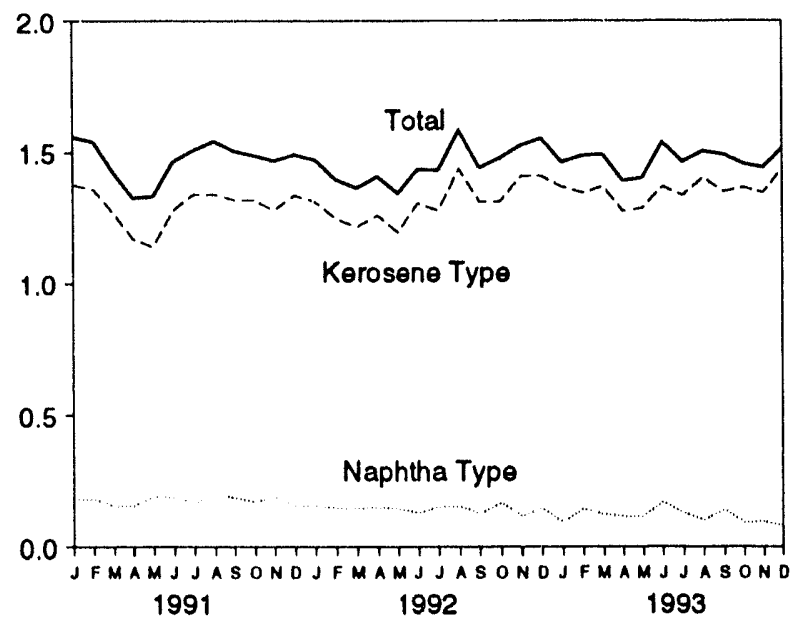

Total Stocks, End of Month

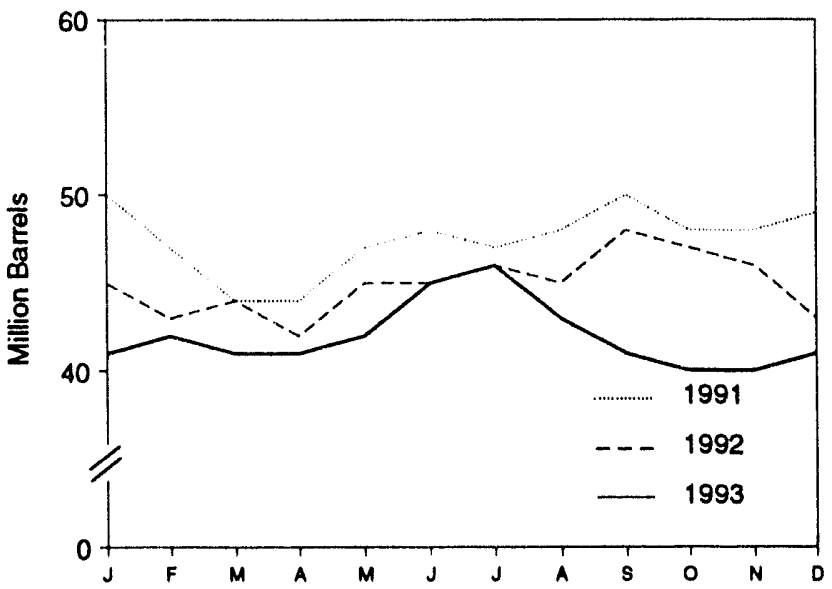

Source: Table 3.7 
Table 3.7 Jet Fuel Supply and Disposition

\begin{tabular}{|c|c|c|c|c|c|c|c|c|c|}
\hline & \multicolumn{3}{|c|}{ Supply } & \multicolumn{4}{|c|}{ Disposition } & & \\
\hline & \multicolumn{2}{|c|}{ Production } & \multirow[b]{2}{*}{ Imports } & \multirow{2}{*}{$\begin{array}{c}\text { Slock } \\
\text { Changeb }\end{array}$} & \multirow[b]{2}{*}{ Exports } & \multicolumn{2}{|c|}{ Product Supplied } & \multicolumn{2}{|c|}{ Ending Stocke" } \\
\hline & Total & Kerosene Type & & & & Total & Kerosene Type & Total & Koroesen Type \\
\hline & \multicolumn{7}{|c|}{ Thousand Barrels per Day } & \multicolumn{2}{|c|}{ Million Barrels } \\
\hline $\begin{array}{l}1973 \text { Average } \\
1974 \text { Average }\end{array}$ & $\begin{array}{r}859 \\
836 \\
871 \\
918 \\
973 \\
970 \\
1,012 \\
999 \\
968 \\
978 \\
1,022 \\
1,132 \\
1,189 \\
1,293 \\
1,343 \\
1,370 \\
1,403 \\
1,488\end{array}$ & $\begin{array}{r}679 \\
641 \\
691 \\
731 \\
787 \\
791 \\
835 \\
811 \\
775 \\
778 \\
817 \\
919 \\
983 \\
1,097 \\
1,138 \\
1,164 \\
1,197 \\
1,311\end{array}$ & $\begin{array}{r}212 \\
163 \\
133 \\
76 \\
75 \\
86 \\
78 \\
80 \\
38 \\
29 \\
29 \\
62 \\
39 \\
57 \\
67 \\
90 \\
106 \\
108\end{array}$ & $\begin{array}{r}8 \\
2 \\
c 2 \\
5 \\
7 \\
-2 \\
13 \\
10 \\
c-4 \\
-12 \\
6 \\
(8) \\
9 \\
-4 \\
25 \\
(8) \\
-17 \\
-8 \\
31\end{array}$ & $\begin{array}{r}4 \\
3 \\
2 \\
2 \\
2 \\
1 \\
1 \\
1 \\
2 \\
6 \\
6 \\
9 \\
13 \\
18 \\
24 \\
28 \\
27 \\
43\end{array}$ & $\begin{array}{r}1,050 \\
903 \\
1,001 \\
887 \\
1,039 \\
1,057 \\
1,076 \\
1,068 \\
1,007 \\
1,013 \\
1,046 \\
1,175 \\
1,218 \\
1,307 \\
1,385 \\
1,440 \\
1,480 \\
1,522\end{array}$ & $\begin{array}{r}842 \\
771 \\
791 \\
789 \\
831 \\
858 \\
876 \\
851 \\
809 \\
804 \\
839 \\
953 \\
1,005 \\
1,105 \\
1,181 \\
1,236 \\
1,284 \\
1,340\end{array}$ & $\begin{array}{r}20 \\
629 \\
30 \\
32 \\
35 \\
34 \\
39 \\
042 \\
41 \\
637 \\
39 \\
42 \\
40 \\
50 \\
50 \\
44 \\
41 \\
52\end{array}$ & $\begin{array}{r}23 \\
c_{24} \\
25 \\
26 \\
28 \\
28 \\
33 \\
636 \\
34 \\
c^{31} \\
32 \\
35 \\
34 \\
43 \\
42 \\
38 \\
34 \\
46\end{array}$ \\
\hline 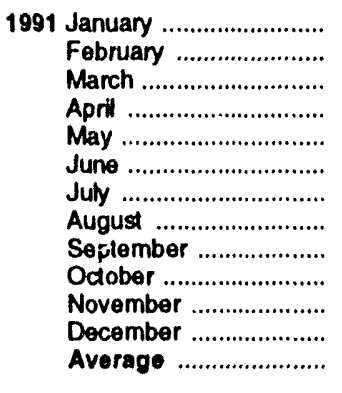 & $\begin{array}{l}1,509 \\
1,548 \\
1,299 \\
1,286 \\
1,367 \\
1,473 \\
1,426 \\
1,486 \\
1,495 \\
1,415 \\
1,433 \\
1,530 \\
1,438\end{array}$ & $\begin{array}{l}1,354 \\
1,384 \\
1,157 \\
1,135 \\
1,191 \\
1,300 \\
1,255 \\
1,316 \\
1,322 \\
1,253 \\
1,276 \\
1,357 \\
1,274\end{array}$ & $\begin{array}{l}67 \\
44 \\
65 \\
73 \\
87 \\
64 \\
67 \\
88 \\
92 \\
59 \\
56 \\
42 \\
67\end{array}$ & $\begin{array}{r}-55 \\
-108 \\
-99 \\
-8 \\
85 \\
58 \\
-47 \\
21 \\
71 \\
-66 \\
15 \\
22 \\
-9\end{array}$ & $\begin{array}{r}73 \\
159 \\
40 \\
38 \\
35 \\
13 \\
31 \\
14 \\
11 \\
50 \\
5 \\
59 \\
43\end{array}$ & $\begin{array}{l}1,559 \\
1,541 \\
1,423 \\
1,329 \\
1,334 \\
1,465 \\
1,509 \\
1,543 \\
1,506 \\
1,489 \\
1,469 \\
1,492 \\
1,471\end{array}$ & $\begin{array}{l}1,378 \\
1,360 \\
1,270 \\
1,173 \\
1,143 \\
1,280 \\
1,343 \\
1,343 \\
1,321 \\
1,319 \\
1,282 \\
1,338 \\
1,296\end{array}$ & $\begin{array}{l}50 \\
47 \\
44 \\
44 \\
47 \\
48 \\
47 \\
48 \\
50 \\
48 \\
48 \\
49 \\
49\end{array}$ & $\begin{array}{l}44 \\
41 \\
38 \\
38 \\
41 \\
43 \\
41 \\
42 \\
45 \\
43 \\
44 \\
44 \\
44\end{array}$ \\
\hline 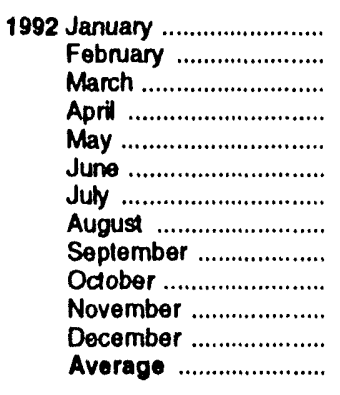 & $\begin{array}{l}1,352 \\
1,311 \\
1,347 \\
1,286 \\
1,393 \\
1,374 \\
1,473 \\
1,471 \\
1,448 \\
1,408 \\
1,456 \\
1,462 \\
1,399\end{array}$ & $\begin{array}{l}1,200 \\
1,164 \\
1,215 \\
1,131 \\
1,214 \\
1,234 \\
1,328 \\
1,339 \\
1,296 \\
1,265 \\
1,319 \\
1,336 \\
1,254\end{array}$ & $\begin{array}{r}39 \\
56 \\
56 \\
74 \\
93 \\
86 \\
81 \\
111 \\
93 \\
105 \\
90 \\
102 \\
82\end{array}$ & $\begin{array}{r}-127 \\
-73 \\
31 \\
-68 \\
114 \\
-21 \\
59 \\
-32 \\
78 \\
-12 \\
-41 \\
-101 \\
-16\end{array}$ & $\begin{array}{r}44 \\
42 \\
7 \\
18 \\
26 \\
45 \\
62 \\
28 \\
20 \\
44 \\
59 \\
112 \\
43\end{array}$ & $\begin{array}{l}1,473 \\
1,398 \\
1,365 \\
1,409 \\
1,346 \\
1,436 \\
1,433 \\
1,585 \\
1,442 \\
1,480 \\
1,528 \\
1,553 \\
1,454\end{array}$ & $\begin{array}{l}1,314 \\
1,250 \\
1,218 \\
1,262 \\
1,198 \\
1,308 \\
1,280 \\
1,438 \\
1,313 \\
1,315 \\
1,411 \\
1,410 \\
1,310\end{array}$ & $\begin{array}{l}45 \\
43 \\
44 \\
42 \\
45 \\
45 \\
46 \\
45 \\
48 \\
47 \\
46 \\
43 \\
43\end{array}$ & $\begin{array}{l}40 \\
38 \\
39 \\
37 \\
40 \\
39 \\
42 \\
41 \\
43 \\
43 \\
41 \\
39 \\
39\end{array}$ \\
\hline 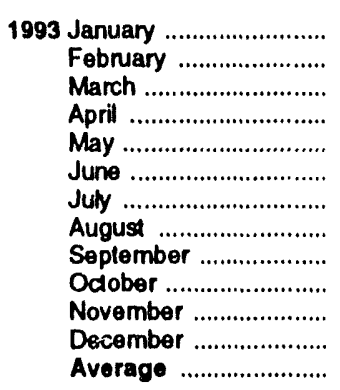 & $\begin{array}{r}1,437 \\
1,442 \\
1,463 \\
1,390 \\
1,426 \\
1,549 \\
1,485 \\
1,358 \\
1,339 \\
1,330 \\
\text { A }_{1,383} \\
E_{1,482} \\
E_{1,424}\end{array}$ & $\begin{array}{r}1,306 \\
1,318 \\
1,332 \\
1,262 \\
1,300 \\
1,409 \\
1,359 \\
1,257 \\
1,242 \\
1,242 \\
R_{1,298} \\
E_{1,417} \\
E_{1,312}\end{array}$ & $\begin{array}{r}89 \\
110 \\
102 \\
88 \\
75 \\
111 \\
94 \\
91 \\
97 \\
127 \\
{ }_{96} \\
E_{68} \\
E_{95}\end{array}$ & $\begin{array}{r}-73 \\
46 \\
-29 \\
-4 \\
37 \\
78 \\
41 \\
-91 \\
-78 \\
-24 \\
{ }^{R} 6 \\
E_{-5} \\
E_{-6}\end{array}$ & $\begin{array}{r}134 \\
17 \\
101 \\
88 \\
60 \\
45 \\
73 \\
34 \\
21 \\
23 \\
\text { P }_{29} \\
E_{39} \\
E_{56}\end{array}$ & $\begin{array}{r}1,464 \\
1,488 \\
1,493 \\
1,393 \\
1,404 \\
1,538 \\
1,465 \\
1,506 \\
1,493 \\
1,457 \\
A_{1,443} \\
E_{1,516} \\
E_{1,472}\end{array}$ & $\begin{array}{r}1,371 \\
1,346 \\
1,371 \\
1,278 \\
1,289 \\
1,370 \\
1,337 \\
1,405 \\
1,352 \\
1,367 \\
\text { P }_{1,347} \\
\text { E } 1,438_{1,36} \\
\text { E } 1,356^{2}\end{array}$ & $\begin{array}{l}41 \\
42 \\
41 \\
41 \\
42 \\
45 \\
46 \\
43 \\
41 \\
40 \\
\mathrm{~A}_{40} \\
\mathrm{E}_{41} \\
\mathrm{E}_{41}\end{array}$ & $\begin{array}{r}36 \\
38 \\
37 \\
37 \\
38 \\
41 \\
42 \\
39 \\
38 \\
37 \\
\text { R }_{37} \\
\text { E }_{39} \\
\text { E }_{39}\end{array}$ \\
\hline
\end{tabular}

- Slocks are tolaks as of end of period.

b A negalive number indicales a decrease in stocks and a positive number indicates an increase.

c See Nole 4 al end of section.

$R=$ Revised data. E=Estimate. (s)=Less than +500 barreis per day and

grealer than -500 barreks per day

Note: Geographic coverage is the 50 States and the District of Columbla.

Sources: - 1973-1980: Energy Intormation Administration (ELA)

Petroleum Supply Monthly, Fobruary 1993, Table S7. • 1981 forward: E.IA Petroloum Supply Monthly, January 1994, Table S7. 
Figure 3.6 Liquefied Petroleum Gases

(Million Barrels per Day, Except as Noted)

Overview, 1973-1992

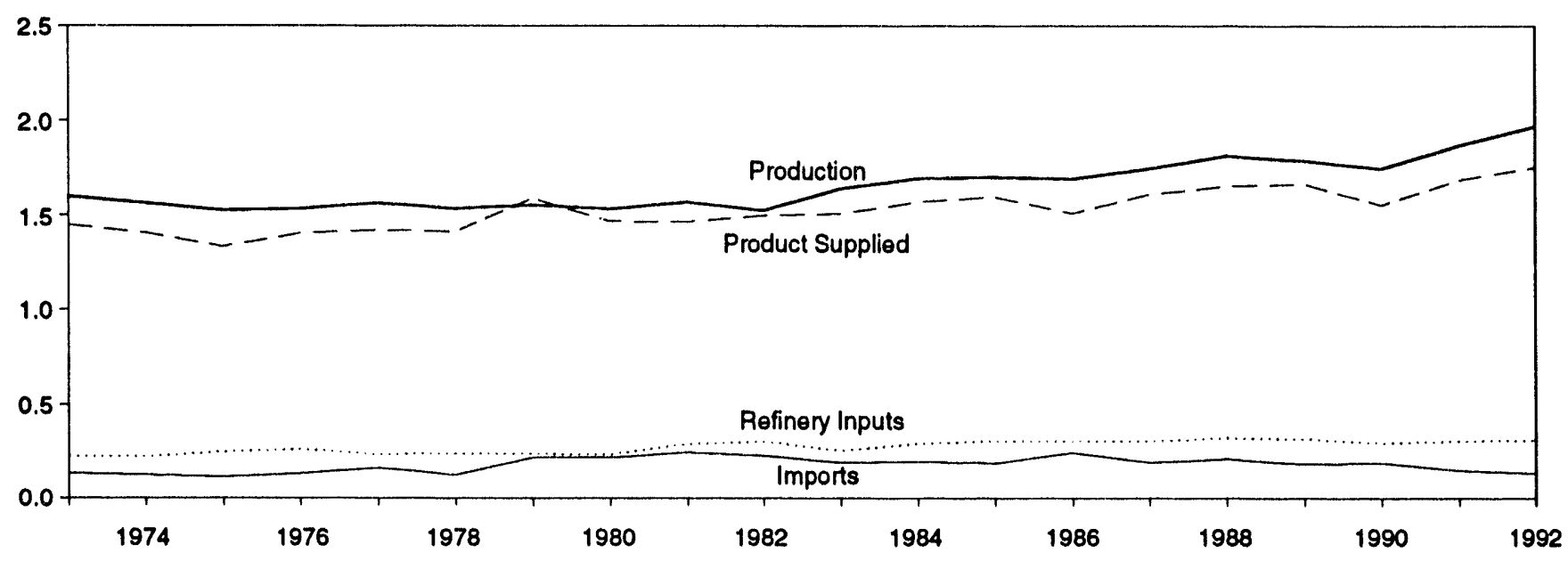

Overview, Monthly

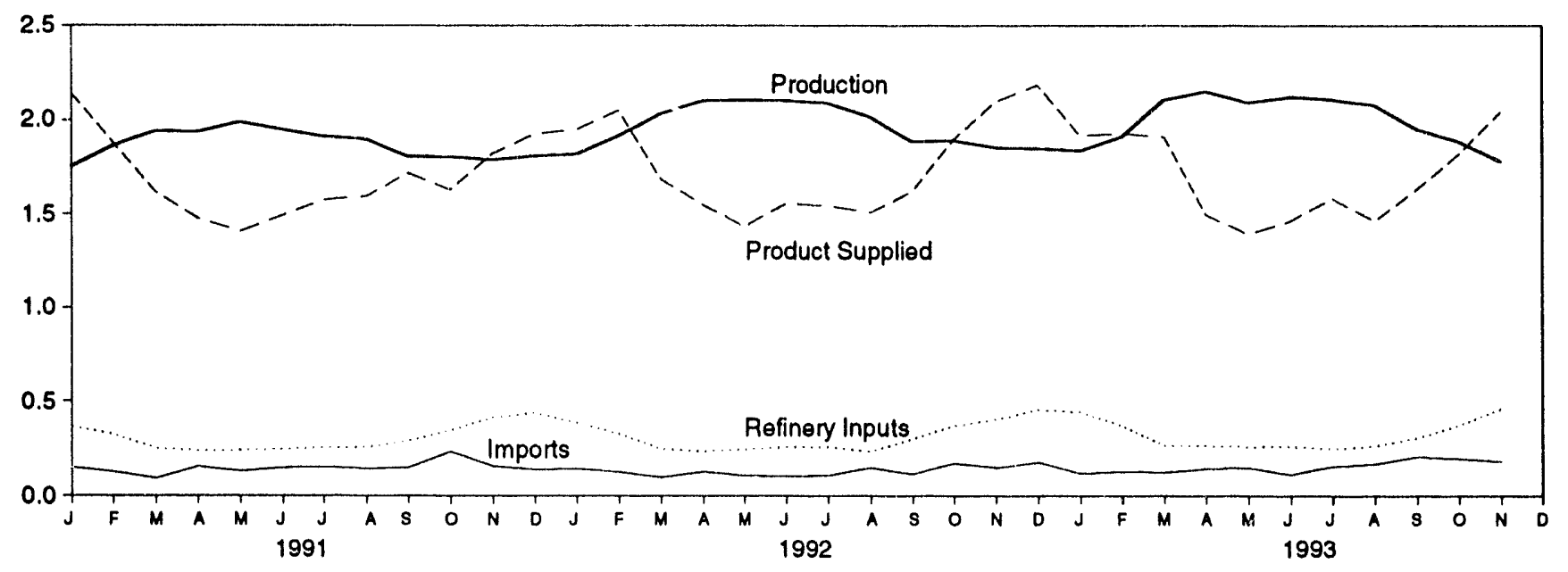

Product Supplied, January-November

Stocks, End of Month
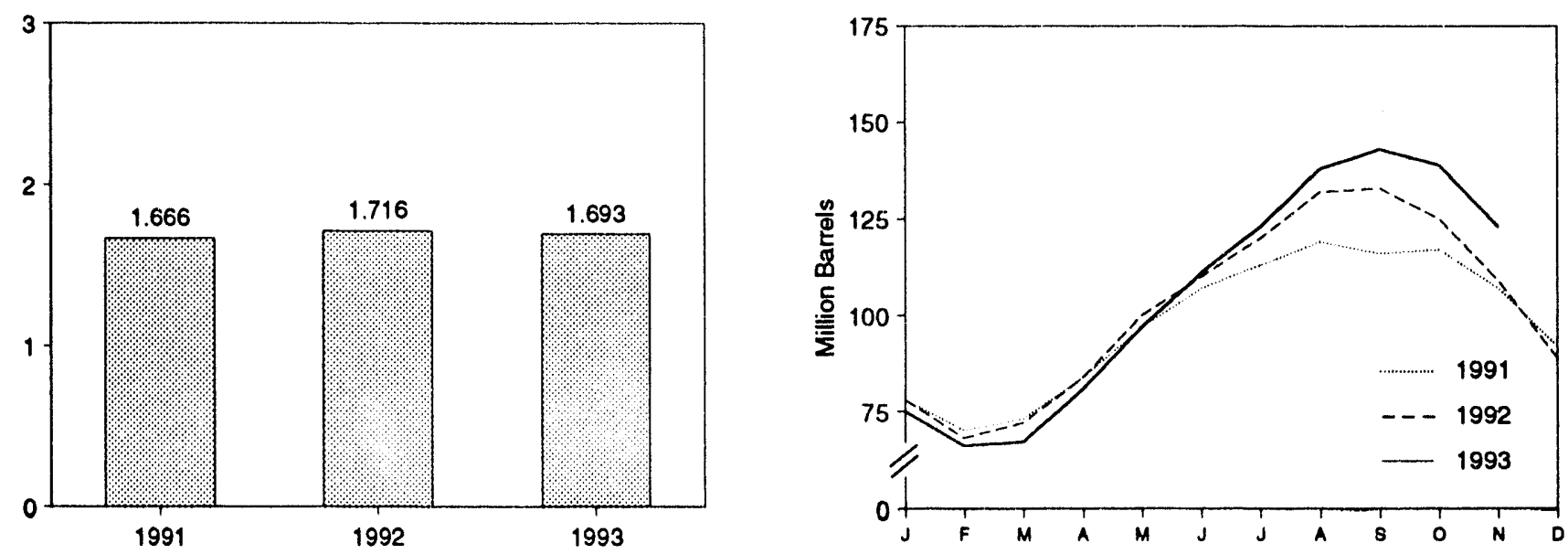

Note: Because vertical scales differ, graphs should not be compared. Sourco: Table 3.8 . 
Table 3.8 Liquefied Petroleum Gases Supply and Disposition

\begin{tabular}{|c|c|c|c|c|c|c|c|}
\hline & \multicolumn{2}{|c|}{ Supply } & \multicolumn{4}{|c|}{ Disposition } & \multirow{3}{*}{$\frac{\begin{array}{c}\text { Ending } \\
\text { Stocks }\end{array}}{\text { Millon Barrels }}$} \\
\hline & $\begin{array}{c}\text { Total } \\
\text { Production }\end{array}$ & Imports & $\begin{array}{l}\text { Stock } \\
\text { Changea }\end{array}$ & $\begin{array}{l}\text { Rofinery } \\
\text { Inpute }\end{array}$ & Exporte & $\begin{array}{l}\text { Product } \\
\text { Supplied }\end{array}$ & \\
\hline & \multicolumn{6}{|c|}{ Thousand Barrels per Day } & \\
\hline 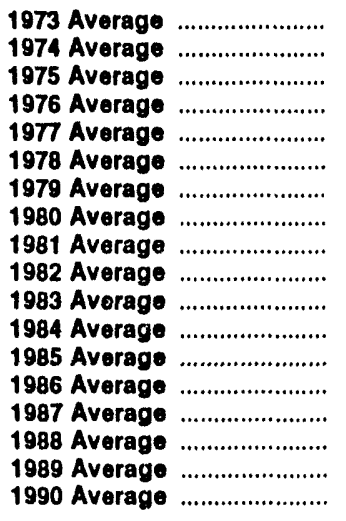 & $\begin{array}{r}1,600 \\
1,565 \\
1,527 \\
1,535 \\
1,566 \\
1,537 \\
1,556 \\
1,535 \\
1,571 \\
1,527 \\
1,642 \\
1,697 \\
1,704 \\
1,695 \\
1,748 \\
1,817 \\
1,791 \\
1,749\end{array}$ & $\begin{array}{l}132 \\
123 \\
112 \\
130 \\
161 \\
123 \\
217 \\
216 \\
244 \\
226 \\
190 \\
195 \\
187 \\
242 \\
190 \\
209 \\
181 \\
188\end{array}$ & $\begin{array}{r}35 \\
38 \\
c 35 \\
-24 \\
55 \\
-12 \\
c-70 \\
27 \\
c 18 \\
-111 \\
c-4 \\
c-19 \\
-75 \\
80 \\
-15 \\
1 \\
-47 \\
48\end{array}$ & $\begin{array}{l}220 \\
220 \\
246 \\
260 \\
233 \\
239 \\
236 \\
233 \\
289 \\
300 \\
253 \\
291 \\
304 \\
302 \\
304 \\
321 \\
315 \\
293\end{array}$ & $\begin{array}{l}27 \\
25 \\
26 \\
25 \\
18 \\
20 \\
15 \\
21 \\
42 \\
65 \\
73 \\
48 \\
62 \\
42 \\
38 \\
49 \\
35 \\
40\end{array}$ & $\begin{array}{l}1,449 \\
1,406 \\
1,333 \\
1,404 \\
1,422 \\
1,413 \\
1,592 \\
1,469 \\
1,466 \\
1,499 \\
1,509 \\
1,572 \\
1,599 \\
1,512 \\
1,612 \\
1,656 \\
1,668 \\
1,556\end{array}$ & $\begin{array}{r}99 \\
c 113 \\
125 \\
116 \\
136 \\
c 132 \\
111 \\
c 120 \\
135 \\
c 94 \\
c 101 \\
101 \\
74 \\
103 \\
97 \\
97 \\
80 \\
98\end{array}$ \\
\hline 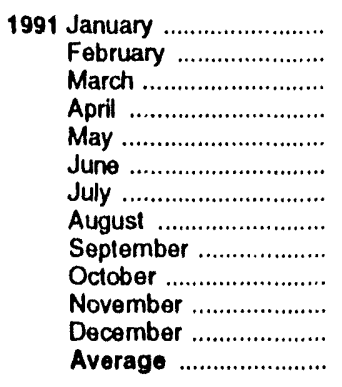 & $\begin{array}{l}1,753 \\
1,865 \\
1,942 \\
1,937 \\
1,989 \\
1,949 \\
1,913 \\
1,899 \\
1,806 \\
1,805 \\
1,789 \\
1,810 \\
1,871\end{array}$ & $\begin{array}{r}148 \\
126 \\
91 \\
154 \\
129 \\
148 \\
151 \\
143 \\
147 \\
233 \\
156 \\
139 \\
147\end{array}$ & $\begin{array}{r}-658 \\
-271 \\
113 \\
346 \\
428 \\
328 \\
211 \\
175 \\
-84 \\
33 \\
-330 \\
-488 \\
-15\end{array}$ & $\begin{array}{l}364 \\
322 \\
249 \\
237 \\
239 \\
245 \\
253 \\
255 \\
288 \\
345 \\
413 \\
437 \\
304\end{array}$ & $\begin{array}{l}56 \\
60 \\
56 \\
31 \\
45 \\
32 \\
24 \\
18 \\
31 \\
31 \\
40 \\
73 \\
41\end{array}$ & $\begin{array}{l}2,139 \\
1,880 \\
1,615 \\
1,477 \\
1,407 \\
1,492 \\
1,575 \\
1,594 \\
1,718 \\
1,629 \\
1,821 \\
1,927 \\
1,689\end{array}$ & $\begin{array}{r}78 \\
70 \\
73 \\
84 \\
97 \\
107 \\
113 \\
119 \\
116 \\
117 \\
107 \\
92 \\
92\end{array}$ \\
\hline 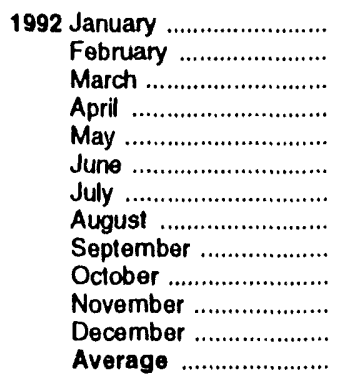 & $\begin{array}{l}1,820 \\
1,917 \\
2,033 \\
2,102 \\
2,106 \\
2,102 \\
2,090 \\
2,016 \\
1,886 \\
1,892 \\
1,854 \\
1,849 \\
1,972\end{array}$ & $\begin{array}{r}142 \\
126 \\
97 \\
127 \\
106 \\
104 \\
106 \\
148 \\
114 \\
171 \\
148 \\
176 \\
131\end{array}$ & $\begin{array}{r}-452 \\
-365 \\
153 \\
401 \\
489 \\
334 \\
345 \\
369 \\
37 \\
-242 \\
-541 \\
-660 \\
-10\end{array}$ & $\begin{array}{l}384 \\
326 \\
247 \\
233 \\
245 \\
257 \\
255 \\
233 \\
299 \\
369 \\
403 \\
453 \\
309\end{array}$ & $\begin{array}{l}80 \\
33 \\
43 \\
45 \\
44 \\
59 \\
52 \\
55 \\
45 \\
39 \\
43 \\
49 \\
49\end{array}$ & $\begin{array}{l}1,950 \\
2,051 \\
1,687 \\
1,549 \\
1,433 \\
1,556 \\
1,544 \\
1,507 \\
1,620 \\
1,898 \\
2,097 \\
2,184 \\
1,755\end{array}$ & $\begin{array}{r}78 \\
68 \\
72 \\
84 \\
100 \\
110 \\
120 \\
132 \\
133 \\
125 \\
109 \\
89 \\
89\end{array}$ \\
\hline 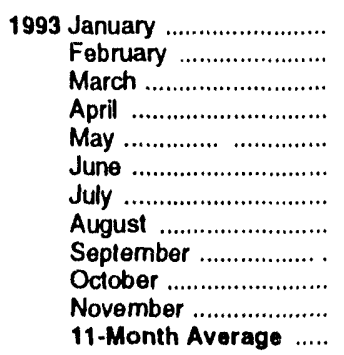 & $\begin{array}{l}1,837 \\
1,912 \\
2,106 \\
2,151 \\
2,031 \\
2,122 \\
2,108 \\
2,078 \\
1,952 \\
1,887 \\
1,781 \\
2,003\end{array}$ & $\begin{array}{l}117 \\
128 \\
123 \\
142 \\
148 \\
111 \\
155 \\
167 \\
206 \\
195 \\
180 \\
152\end{array}$ & $\begin{array}{r}-441 \\
-310 \\
9 \\
466 \\
538 \\
469 \\
380 \\
475 \\
188 \\
-129 \\
-560 \\
102\end{array}$ & $\begin{array}{l}440 \\
367 \\
263 \\
263 \\
258 \\
260 \\
246 \\
263 \\
304 \\
372 \\
458 \\
317\end{array}$ & $\begin{array}{l}39 \\
55 \\
47 \\
69 \\
50 \\
41 \\
54 \\
45 \\
35 \\
21 \\
21 \\
43\end{array}$ & $\begin{array}{l}1,917 \\
1,928 \\
1,910 \\
1,495 \\
1,393 \\
1,463 \\
1,583 \\
1,462 \\
1,632 \\
1,819 \\
2,042 \\
1,693\end{array}$ & $\begin{array}{r}75 \\
66 \\
67 \\
81 \\
97 \\
111 \\
123 \\
138 \\
143 \\
139 \\
123 \\
123\end{array}$ \\
\hline $\begin{array}{l}1992 \text { 11-Month Average ..... } \\
1991 \text { 11-Month Average ..... }\end{array}$ & $\begin{array}{l}1,984 \\
1,877\end{array}$ & $\begin{array}{l}126 \\
148\end{array}$ & $\begin{array}{l}50 \\
29\end{array}$ & $\begin{array}{l}295 \\
291\end{array}$ & $\begin{array}{l}49 \\
39\end{array}$ & $\begin{array}{l}1,716 \\
1,666\end{array}$ & $\begin{array}{l}109 \\
107\end{array}$ \\
\hline
\end{tabular}

a negative number indicates a decrease in stocks and a positive number indicates an increase.

b Stocks are totals as of end of period.

c See Note 4 at end of section.

d See Note 6 at end of section.

Notes: - Llquefied petroleum gases include ethane, ethylene, propane,

propylene, normal butane, butylene, isobutane and isobutylene. - Geographic coverage is the 50 States and the District of Columbia.

Sounces: - 1973-1980: Energy Information Administration (EIA), Petroleum Supply Monthly, February 1993, Table S8. • 1981 forward: EIA, Petroleum Supply Monthly, January 1994, Table S9. 
Figure 3.7 Propane and Propylene

(Million Barrels per Day, Except as Noted)

Overview, 1973-1992

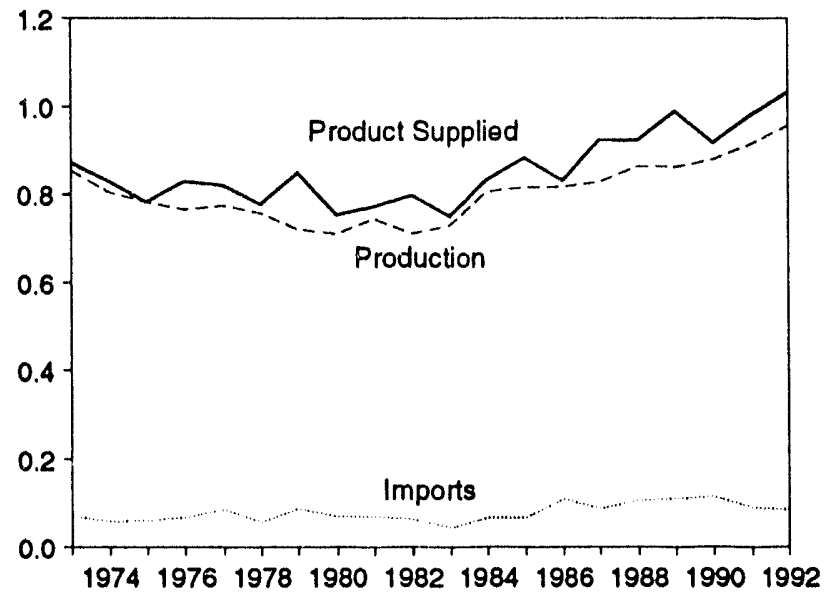

Product Supplied, Monthly

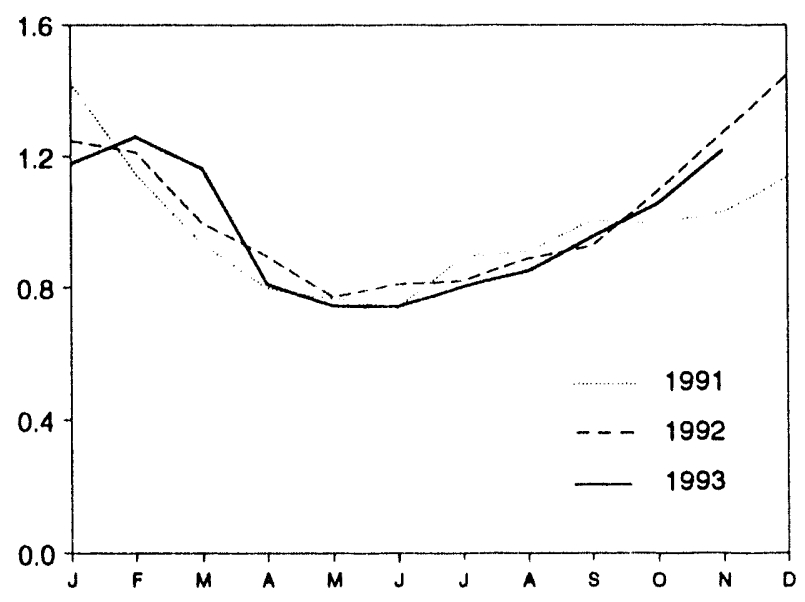

Stocks, End of Month

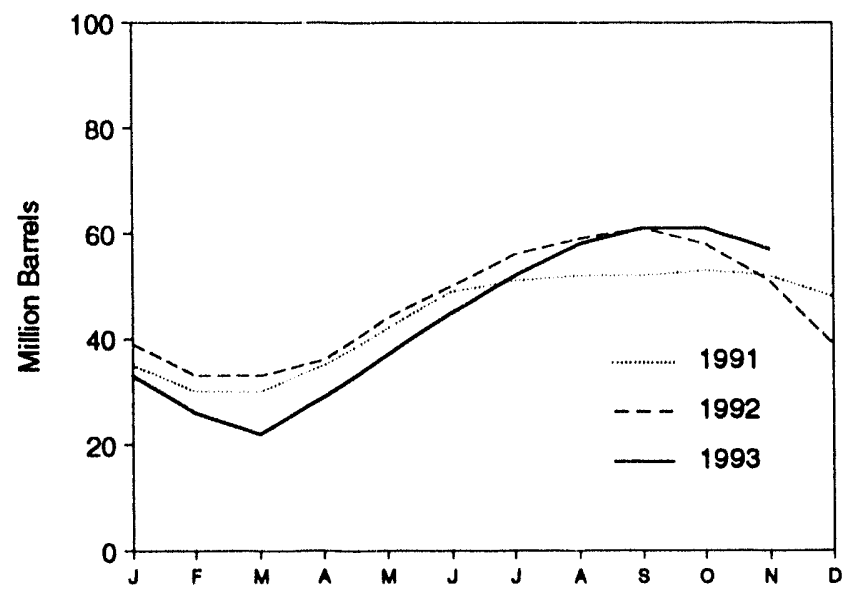

Product Supplied, January-November

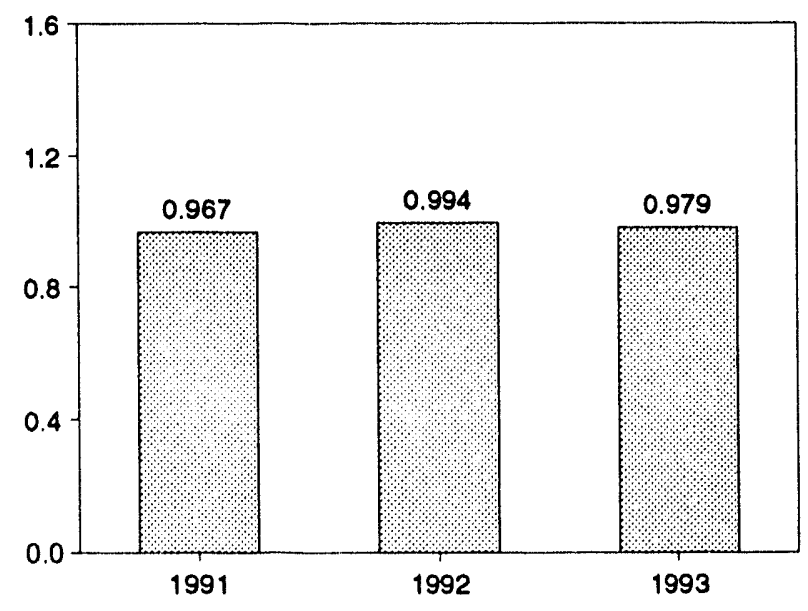

Share of Liquefied Petroleum Gases, November

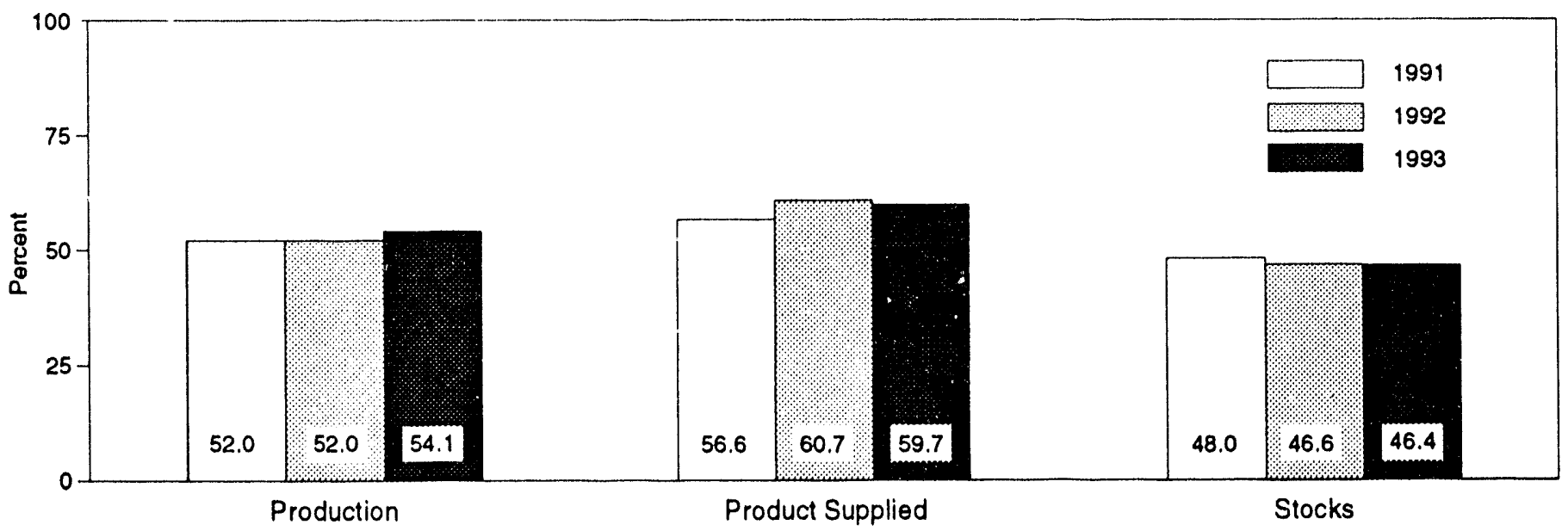

Note: Because vertical scales differ, graphs should not be compared.

Sources: Table 3.9 and, for calculation of shares, data prlor to rounding for publication in Tables 3.8 and 3.9 . 
Table 3.9 Propane and Propylene Supply and Disposition (A Subset of Table 3.8)

\begin{tabular}{|c|c|c|c|c|c|c|c|}
\hline & \multicolumn{2}{|c|}{ Supply } & \multicolumn{4}{|c|}{ Disposition } & \multirow{3}{*}{$\frac{\begin{array}{c}\text { Ending } \\
\text { Stocke }\end{array}}{\text { Million Barrels }}$} \\
\hline & $\begin{array}{c}\text { Total } \\
\text { Production }\end{array}$ & Imports & $\begin{array}{c}\text { Stock } \\
\text { Changea }\end{array}$ & $\begin{array}{c}\text { Refinery } \\
\text { Inputs }\end{array}$ & Exports & $\begin{array}{l}\text { Producls } \\
\text { Supplied } \\
\end{array}$ & \\
\hline & \multicolumn{6}{|c|}{ Thousand Barrels per Day } & \\
\hline $\begin{array}{l}1973 \text { Average } \\
1974 \text { Average } \\
1975 \text { Average } \\
1976 \text { Average } \\
1977 \text { Average } \\
1978 \text { Average } \\
1979 \text { Average } \\
1980 \text { Average } \\
1981 \text { Average } \\
1982 \text { Average } \\
1983 \text { Average } \\
1984 \text { Average } \\
1985 \text { Average } \\
1986 \text { Average } \\
1987 \text { Average } \\
1988 \text { Average } \\
1989 \text { Average } \\
1990 \text { Average }\end{array}$ & $\begin{array}{l}854 \\
805 \\
783 \\
766 \\
775 \\
758 \\
721 \\
711 \\
745 \\
711 \\
730 \\
806 \\
816 \\
817 \\
828 \\
863 \\
862 \\
878\end{array}$ & $\begin{array}{r}71 \\
59 \\
60 \\
68 \\
86 \\
57 \\
88 \\
69 \\
70 \\
63 \\
44 \\
67 \\
67 \\
110 \\
88 \\
106 \\
111 \\
115\end{array}$ & $\begin{array}{r}30 \\
11 \\
36 \\
-22 \\
21 \\
15 \\
c-61 \\
4 \\
6.18 \\
-59 \\
c-24 \\
67 \\
-50 \\
64 \\
-41 \\
7 \\
-52 \\
48\end{array}$ & $\begin{array}{r}8 \\
9 \\
11 \\
12 \\
10 \\
13 \\
14 \\
12 \\
5 \\
4 \\
1 \\
4 \\
3 \\
4 \\
8 \\
8 \\
11 \\
(8)\end{array}$ & $\begin{array}{r}15 \\
14 \\
13 \\
13 \\
10 \\
9 \\
8 \\
10 \\
18 \\
31 \\
43 \\
30 \\
48 \\
28 \\
24 \\
31 \\
24 \\
28\end{array}$ & $\begin{array}{l}872 \\
830 \\
783 \\
830 \\
821 \\
778 \\
849 \\
754 \\
773 \\
798 \\
751 \\
833 \\
883 \\
831 \\
924 \\
923 \\
990 \\
917\end{array}$ & $\begin{array}{r}65 \\
69 \\
82 \\
74 \\
81 \\
897 \\
64 \\
64 \\
65 \\
76 \\
654 \\
648 \\
58 \\
39 \\
63 \\
48 \\
50 \\
32 \\
49\end{array}$ \\
\hline 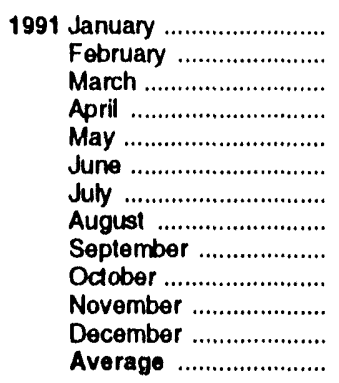 & $\begin{array}{l}920 \\
923 \\
912 \\
900 \\
922 \\
906 \\
901 \\
891 \\
905 \\
902 \\
930 \\
964 \\
915\end{array}$ & $\begin{array}{r}105 \\
90 \\
56 \\
101 \\
90 \\
81 \\
91 \\
73 \\
92 \\
146 \\
82 \\
86 \\
91\end{array}$ & $\begin{array}{r}-449 \\
-174 \\
.10 \\
179 \\
214 \\
223 \\
81 \\
40 \\
-22 \\
35 \\
-37 \\
-128 \\
-3\end{array}$ & $\begin{array}{r}0 \\
0 \\
0 \\
0 \\
0 \\
0 \\
0 \\
0 \\
0 \\
0 \\
0 \\
(s) \\
\text { (s) }\end{array}$ & $\begin{array}{l}51 \\
40 \\
45 \\
25 \\
31 \\
22 \\
15 \\
13 \\
14 \\
18 \\
20 \\
38 \\
28\end{array}$ & $\begin{array}{r}1,422 \\
1,147 \\
933 \\
798 \\
767 \\
741 \\
895 \\
910 \\
1,006 \\
995 \\
1,030 \\
1,139 \\
982\end{array}$ & $\begin{array}{l}35 \\
30 \\
30 \\
35 \\
42 \\
49 \\
51 \\
52 \\
52 \\
53 \\
52 \\
48 \\
48\end{array}$ \\
\hline 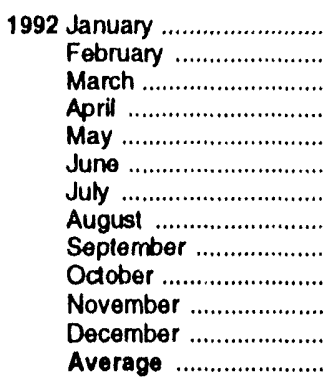 & $\begin{array}{l}949 \\
955 \\
940 \\
961 \\
977 \\
978 \\
964 \\
946 \\
931 \\
333 \\
964 \\
977 \\
956\end{array}$ & $\begin{array}{r}90 \\
86 \\
68 \\
80 \\
72 \\
66 \\
68 \\
85 \\
71 \\
104 \\
99 \\
131 \\
85\end{array}$ & $\begin{array}{r}-282 \\
-200 \\
-15 \\
120 \\
253 \\
206 \\
176 \\
117 \\
51 \\
-88 \\
-243 \\
-385 \\
-24\end{array}$ & $\begin{array}{l}\text { (s) } \\
(\mathrm{s}) \\
(\mathrm{s}) \\
0 \\
(\mathrm{~s}) \\
(\mathrm{s}) \\
(\mathrm{s}) \\
(\mathrm{s}) \\
(\mathrm{s}) \\
(\mathrm{s}) \\
0 \\
0 \\
(\mathrm{~s})\end{array}$ & $\begin{array}{l}72 \\
27 \\
26 \\
24 \\
23 \\
27 \\
35 \\
25 \\
25 \\
30 \\
33 \\
45 \\
33\end{array}$ & $\begin{array}{r}1,249 \\
1,214 \\
997 \\
896 \\
773 \\
811 \\
821 \\
889 \\
927 \\
1,095 \\
1,273 \\
1,448 \\
1,032\end{array}$ & $\begin{array}{l}39 \\
33 \\
33 \\
36 \\
44 \\
50 \\
56 \\
59 \\
61 \\
58 \\
51 \\
39 \\
39\end{array}$ \\
\hline 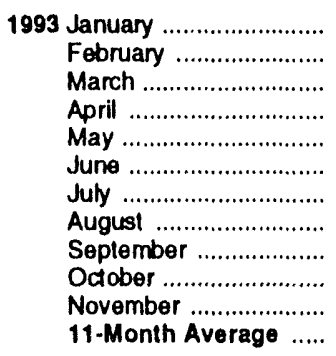 & $\begin{array}{l}965 \\
959 \\
971 \\
973 \\
942 \\
958 \\
956 \\
945 \\
956 \\
953 \\
964 \\
958\end{array}$ & $\begin{array}{r}72 \\
78 \\
85 \\
112 \\
96 \\
75 \\
105 \\
116 \\
132 \\
107 \\
138 \\
101\end{array}$ & $\begin{array}{r}-173 \\
-261 \\
-140 \\
233 \\
262 \\
266 \\
232 \\
184 \\
116 \\
-10 \\
.136 \\
54\end{array}$ & $\begin{array}{r}1 \\
(s) \\
(s) \\
(s) \\
0 \\
0 \\
0 \\
0 \\
0 \\
0 \\
0 \\
(8)\end{array}$ & $\begin{array}{l}31 \\
37 \\
32 \\
40 \\
30 \\
23 \\
26 \\
27 \\
17 \\
13 \\
17 \\
27\end{array}$ & $\begin{array}{r}1,179 \\
1,261 \\
1,165 \\
812 \\
746 \\
744 \\
804 \\
851 \\
955 \\
1,057 \\
1,220 \\
979\end{array}$ & $\begin{array}{l}33 \\
26 \\
22 \\
29 \\
37 \\
45 \\
52 \\
58 \\
61 \\
61 \\
57 \\
57\end{array}$ \\
\hline $\begin{array}{l}1992 \text { 11-Month Average ..... } \\
1991 \text { 11-Month Average ..... }\end{array}$ & $\begin{array}{l}954 \\
910\end{array}$ & $\begin{array}{l}81 \\
92\end{array}$ & $\begin{array}{r}10 \\
8\end{array}$ & $\begin{array}{r}\text { (s) } \\
0\end{array}$ & $\begin{array}{l}32 \\
27\end{array}$ & $\begin{array}{l}994 \\
967\end{array}$ & $\begin{array}{l}51 \\
52\end{array}$ \\
\hline
\end{tabular}

a negative number indicates a decrease in stocks and a positive number indicates an increase.

Stocks are totals as of end of period.

c See Note 4 at end of section.

(s)=Less than 500 barrels per day.

Note: Geographic coverage is the 50 States and the District of Columbia.
Sources: - 1973 through 1975: U.S. Department of the Interior, Bureau of Mines, Mineral Industry Surveys, "Petroleum Statement, Annual." - 1976 through 1980: Energy Intormation Administration (EIA), Energy Data Peports, Petroleum Statement, Annual." - 1981 forward: ElA, Petroleum Supply Monthly, January 1994, Table S8. 
Table 3.10 Other Petroleum Products Supply and Disposition

\begin{tabular}{|c|c|c|c|c|c|c|c|}
\hline & \multicolumn{2}{|c|}{ Supply } & \multicolumn{4}{|c|}{ Disposition } & \multirow{3}{*}{$\begin{array}{c}\begin{array}{c}\text { Ending } \\
\text { Stocks }\end{array} \\
\text { Million Barrels }\end{array}$} \\
\hline & $\begin{array}{c}\text { Total } \\
\text { Production }\end{array}$ & Imports & $\begin{array}{c}\text { Slock } \\
\text { Changea }\end{array}$ & $\begin{array}{l}\text { Refinery } \\
\text { Inputs }\end{array}$ & Exports & $\begin{array}{l}\text { Products } \\
\text { Supplied }\end{array}$ & \\
\hline & \multicolumn{6}{|c|}{ Thousand Barrels per Day } & \\
\hline 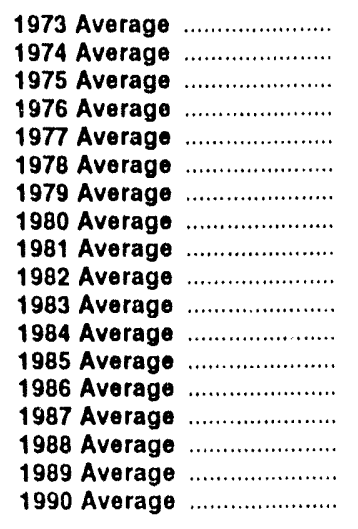 & $\begin{array}{l}2,833 \\
2,722 \\
2,547 \\
2,725 \\
2,939 \\
3,076 \\
3,141 \\
2,957 \\
2,771 \\
2,475 \\
2,437 \\
2,500 \\
2,532 \\
2,704 \\
2,737 \\
2,773 \\
2,771 \\
2,842\end{array}$ & $\begin{array}{r}290 \\
269 \\
144 \\
129 \\
130 \\
80 \\
116 \\
130 \\
188 \\
305 \\
382 \\
503 \\
550 \\
504 \\
543 \\
645 \\
627 \\
705\end{array}$ & $\begin{array}{r}1 \\
25 \\
c-6 \\
(8) \\
20 \\
-12 \\
24 \\
15 \\
c-42 \\
-68 \\
c-6 \\
c-32 \\
22 \\
-15 \\
-1 \\
22 \\
12 \\
-32\end{array}$ & $\begin{array}{l}750 \\
665 \\
537 \\
524 \\
514 \\
492 \\
352 \\
310 \\
723 \\
787 \\
712 \\
791 \\
886 \\
888 \\
829 \\
799 \\
797 \\
887\end{array}$ & $\begin{array}{l}162 \\
172 \\
158 \\
172 \\
164 \\
165 \\
208 \\
197 \\
197 \\
205 \\
236 \\
236 \\
227 \\
291 \\
264 \\
294 \\
305 \\
289\end{array}$ & $\begin{array}{r}2,211 \\
2,129 \\
2,001 \\
2,158 \\
2,371 \\
2,511 \\
2,673 \\
2,566 \\
2,081 \\
d 1,857 \\
1,877 \\
2,007 \\
1,947 \\
2,045 \\
2,187 \\
2,303 \\
2,285 \\
2,402\end{array}$ & $\begin{array}{r}179 \\
c 188 \\
188 \\
188 \\
195 \\
191 \\
200 \\
c 205 \\
241 \\
c 216 \\
c 217 \\
198 \\
206 \\
201 \\
200 \\
208 \\
213 \\
201\end{array}$ \\
\hline 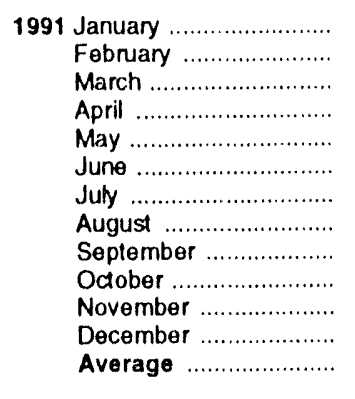 & $\begin{array}{l}2,653 \\
2,668 \\
2,576 \\
2,724 \\
2,853 \\
3,030 \\
3,029 \\
2,993 \\
3,010 \\
2,824 \\
2,750 \\
2,797 \\
2,826\end{array}$ & $\begin{array}{l}748 \\
573 \\
551 \\
607 \\
800 \\
615 \\
776 \\
642 \\
746 \\
611 \\
850 \\
577 \\
675\end{array}$ & $\begin{array}{r}204 \\
363 \\
151 \\
133 \\
198 \\
-123 \\
-143 \\
-169 \\
101 \\
-218 \\
-81 \\
-163 \\
18\end{array}$ & $\begin{array}{r}844 \\
726 \\
819 \\
753 \\
900 \\
1,092 \\
1,081 \\
1,013 \\
802 \\
944 \\
1,093 \\
1,147 \\
936\end{array}$ & $\begin{array}{l}317 \\
275 \\
239 \\
228 \\
327 \\
304 \\
321 \\
296 \\
267 \\
211 \\
238 \\
304 \\
277\end{array}$ & $\begin{array}{l}2,036 \\
1,876 \\
1,919 \\
2,217 \\
2,228 \\
2,372 \\
2,545 \\
2,496 \\
2,586 \\
2,498 \\
2,349 \\
2,085 \\
2,269\end{array}$ & $\begin{array}{l}207 \\
217 \\
222 \\
226 \\
232 \\
228 \\
224 \\
219 \\
222 \\
215 \\
213 \\
208 \\
208\end{array}$ \\
\hline 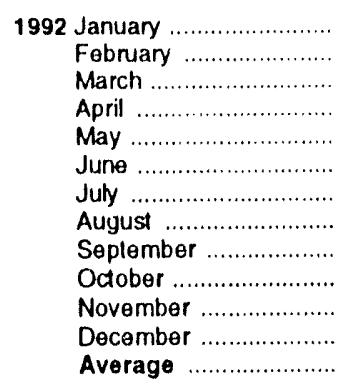 & $\begin{array}{l}2,702 \\
2,642 \\
2,752 \\
2,900 \\
2,929 \\
3,126 \\
3,207 \\
3,068 \\
3,114 \\
2,923 \\
2,915 \\
2,853 \\
2,928\end{array}$ & $\begin{array}{l}734 \\
575 \\
713 \\
793 \\
565 \\
669 \\
740 \\
729 \\
748 \\
701 \\
697 \\
711 \\
707\end{array}$ & $\begin{array}{r}203 \\
183 \\
238 \\
-31 \\
-113 \\
-42 \\
-156 \\
-116 \\
188 \\
-182 \\
-24 \\
-165 \\
-3\end{array}$ & $\begin{array}{r}787 \\
883 \\
730 \\
1,043 \\
910 \\
787 \\
996 \\
884 \\
675 \\
954 \\
989 \\
1,223 \\
906\end{array}$ & $\begin{array}{l}272 \\
240 \\
239 \\
217 \\
199 \\
225 \\
284 \\
227 \\
336 \\
295 \\
264 \\
352 \\
263\end{array}$ & $\begin{array}{l}2,175 \\
1,911 \\
2,258 \\
2,464 \\
2,598 \\
2,826 \\
2,822 \\
2,802 \\
2,663 \\
2,557 \\
2,383 \\
2,154 \\
2,470\end{array}$ & $\begin{array}{l}214 \\
219 \\
227 \\
226 \\
222 \\
221 \\
216 \\
212 \\
218 \\
212 \\
212 \\
c_{2} 207 \\
c_{207}\end{array}$ \\
\hline 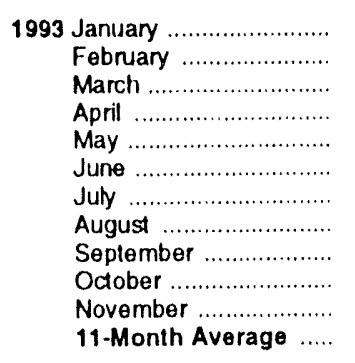 & $\begin{array}{l}\text { e } 3,026 \\
2,815 \\
2,866 \\
2,862 \\
2,899 \\
3,022 \\
3,116 \\
3,094 \\
3,016 \\
3,108 \\
2,978 \\
2,984\end{array}$ & $\begin{array}{l}698 \\
773 \\
818 \\
719 \\
808 \\
630 \\
875 \\
676 \\
789 \\
802 \\
760 \\
759\end{array}$ & $\begin{array}{r}c_{600} \\
122 \\
243 \\
9 \\
85 \\
-240 \\
116 \\
27 \\
-265 \\
-164 \\
-210 \\
31\end{array}$ & $\begin{array}{r}829 \\
949 \\
747 \\
900 \\
979 \\
981 \\
945 \\
865 \\
1,031 \\
1,138 \\
1,274 \\
966\end{array}$ & $\begin{array}{r}{ }^{2} 271 \\
282 \\
269 \\
315 \\
278 \\
278 \\
302 \\
295 \\
282 \\
369 \\
309 \\
296\end{array}$ & $\begin{array}{r}2,023 \\
2,235 \\
2,425 \\
2,357 \\
2,364 \\
2,632 \\
2,628 \\
2,583 \\
2,757 \\
2,567 \\
2,365 \\
2,450\end{array}$ & $\begin{array}{l}225 \\
228 \\
236 \\
236 \\
239 \\
231 \\
235 \\
236 \\
228 \\
223 \\
217 \\
217\end{array}$ \\
\hline $\begin{array}{l}199211 \text {-Month Average } \ldots . . \\
199111 \text {-Month Average } \ldots . .\end{array}$ & $\begin{array}{l}2,935 \\
2,829\end{array}$ & $\begin{array}{l}706 \\
684\end{array}$ & $\begin{array}{l}12 \\
35\end{array}$ & $\begin{array}{l}876 \\
917\end{array}$ & $\begin{array}{l}254 \\
275\end{array}$ & $\begin{array}{l}2,499 \\
2,286\end{array}$ & $\begin{array}{l}212 \\
213\end{array}$ \\
\hline
\end{tabular}

- A negative number indirates a decrease in stocks and a posilive number indicates an increase

b Stocks are tolals as of end of period.

c See Note 4 at end of section.

d See Nole 6 at end of section.

- Beginning in 1993, other petroleum products production, exports, and products supplied include an adjustment to oxygenates and motor gasoline blending components.

(s) $=$ Less than +500 barrels per day and greater than -500 barrels per day
Notes: - Other petroleum products include pentanes plus, other hydrocarbons and oxygenates, untinished oils, gasoline blending components, and all finished petroleum products except tinished motor gasoline, distillate fuel oil, residual fuel oil, jel fuel, and liquefied petroleum gases. - Geographic coverage is the 50 States and the District of Columbia.

Sources: - 1973-1980: Energy Intormation Administration (EIA), Petroleum Supply Monthly, February 1993, Table S9. - 1981 fonward: EIA, Petroleum Supply Monthly, January 1994, Table S10. 


\section{Petroleum Notes}

1. The Energy Information Administration (EIA) uses a number of sources and methods to maintain the survey respondent lists. On a regular basis, survey managers review such industry publications as the Oil and (ias Journal and Oil Daily for information on facilities or companies starting up or closing down operations. Those sources are augmented by articles in newspapers, letters from respondents indicating changes in status, and information received from survey systems.

To supplement routine frames maintenance and to provide more thorough coverage, a comprehensive frames investigation is conducted every 3 years. This investigation results in the reassessment and recompilation of the complete frame for each survey. The effort also includes the evaluation of the impact of potential frame changes on the historical time series of data published from these respondents. The results of this frume study are usually implemented in January to provide a full year under the same frame.

In 1991, the EIA conducted a frane identifier survey of companies that produce, blend, store, or import oxygenates. A summary of the results from the identification survey was published in the Weekly Petroleum Status Report dated February 12, 1992, and in the February 1992 issue of the Petroleum Supply Monthly. In order to continue to provide relevant information about U.S. and regional gasoline supply, the I:IA conducted a second frame identifier survey of those companies during 1992. As a result, numerous respondents were added to the monthly surveys effective in January 1993. See Explanatory Note 7 in the Petroleum Supply Monthly.

2. Motor Gasoline: Beginning in January 1981, the EIA expanded its universe to include non-refinery blenders and separated blending components from finished motor gasoline as a reporting category. Also, survey forms were modified to describe refinery operations more accurately.

Beginning with the reporting of January 1993 data, the EIA made adjusuments to the product supplied series for finished motor gasoline. It was recognized that motor gasoline statistics published by the BIA through 1992 were underreported because the reporting system was (1) not collecting all fuel ethanol blending, and (2) there was a misreporting of inotor gasoline blending components that were blended into finished gasoline. The adjustments are incorporated into EIA's data beginning in January 1993. To facilitate data analysis across the 1992-1993 period, EIA has prepared a table of 1992 data adjusted according to the 1993 basis. See Petroleum Supply Monthly, March 1903, Table II3.

3. Distillate and Residual Fuel (Oils: The requirement to report crude oil in pipelines or burned on leases as either distillate or residual fuel oil has been eliminated.
Prior to January 1981, the refinery input of unfinished oils typically exceeded the available supply of unfinished oils. That discrepancy was assumed to be due to the redesignation of distillate and residual fuel oils received as such but used as unfinished oil inputs by the receiving refinery. The imbalance between supply and disposition of unfinished oils would then be subtracted from the production of distillate and residual fuel oils. Two-thirds of that difference was subtracted from distillate and one-third from residual. Beginning in January 1981, the ElA modified its survey forms 10 account for redesignated product and discontinued the alove-mentioned adjustment.

Beginning in January 1093, the end-of-month stocks of distillate fuel oil are split int() I wo sulfur calcegories (0.05 pereent sulfur or less and greater than 0.(0) pereent sulfur) to meet Environmental Protection Agency requirements effective in ()etober 1992. For further details, see the EIA, Petroleum Supply Monthly.

4. New Stock Basis: In January 1975, 1979, 1981, and 1983, numerous respondents were added to bulk terminal and pipeline surveys, affecting subsequent stocks reported and stock change calculations. Using the expanded coverage (new basis), the end-of-year stocks, in million barrels, would have been:

- Crude ()il: 1982-045 (lotal) and 351 (O)ther Primary).

- Crude ()il and Petrolcum Products: 1974-1,121; 1980-1,425; and 1982-1,461.

- Motor (iasoline: 1974-225; 1980 -263; 1982244 ('Total) and 202 (länished).

- Distillate fucl ()il: 1974-224; 1980-205; and $1982-186$.

- Residual fuel ()il: 1974-75; 1980-01; and $1982-69$

- Jet fuel: 1974-30 (Totial) and 24 (Kerosene Type); $1980-42$ (Total) and 36 (Kerosene Type); and 1982-39) (Total) and 32 (Kerosene Type).

- I.jquefied Petroleum (iases: 1974-113; 1978 136; 1980-128; and 1982-1(1)2.

- Propane and Propylene: 1978-80; 1980-69; and $1982-57$.

- Other Petroleum Products: 1974-190; 1980207 ; and $1982-219$.

Stock change calculations beginning in 1975, 1979, 1981 , and 1983 were made by using new basis stock levels.

In January 1984, changes were made in the reporting of natural gas liquids. As a result, unfractionated stream, which was formerly included in the "()ther Petroleum Products Supply and I)isposition" table, is now reported on a component basis (ethane, propane, normal hutane, isobutane, and pentanes plus). Most of these stocks now appear in the "licquefied Petroleum (iases Supply and 
Disposition" table. This change affects stocks reported and stock change calculations in each table. Under the new basis, end-of-year 1983 stocks, in million barrels, would have been:

- Liquefied Petroleum Gases: 1983-108.

- Propane and Propylene: 1983-55.

- Other Petroleum Products: 1983-210.

In January 1993, changes were made in the monthly surveys to begin collecting bulk terminal and pipeline stocks of oxygenates. This change affected stocks reported and stock change calculations. However, a new basis stock level was not calculated for 1992 end-of-year stocks.
5. Stocks of Alaskan Crude Oil: Stocks of Alaskan Crude oil in transit were included for the first time in January 1981. The major impact of this change is on the reporting of stock change calculations. Using the expanded coverage (new basis), 1980 end-of-year stocks, in million barrels, would have been 488 (Total) and 380 (Other Primary).

6. Data Discrepancies: Due to differences internal to EIA data processing systems, some small discrepancies exist between data in the Monthly Energy Review (MER) and the Petroleum Supply Annual (PSA) and Petroleum Supply Monthly (PSM). The data that have discrepancies are footnoted in Section 3 tables and summarized here.

\begin{tabular}{lllrr} 
Table & \multicolumn{1}{c}{ Data Series } & $\begin{array}{c}\text { Year } \\
\text { Average }\end{array}$ & $\begin{array}{c}\text { MER } \\
\text { Data }\end{array}$ & $\begin{array}{r}\text { PSA and PSM } \\
\text { Data }\end{array}$ \\
\hline $3.1 \mathrm{a}$ & Natural Gas Plant Production & 1976 & 1,604 & 1,603 \\
$3.1 \mathrm{~b}$ & Exports, Total & 1979 & 471 & 472 \\
$3.1 \mathrm{~b}$ & Exports, Petroleum Products & 1979 & 236 & 237 \\
$3.1 \mathrm{~b}$ & Net Imports & 1979 & 7,985 & 7,984 \\
$3.2 \mathrm{a}$ & Crude Used Directly & 1976 & -19 & -18 \\
$3.2 \mathrm{a}$ & Imports, SPR & 1978 & 161 & 162 \\
$3.2 \mathrm{a}$ & Crude Used Directly & 1978 & -15 & -14 \\
$3.2 \mathrm{a}$ & Crude Used Direculy & 1979 & -14 & -13 \\
$3.2 \mathrm{a}$ & Crude Used Directly & 1980 & -14 & -13 \\
$3.2 \mathrm{~b}$ & Crude Losses & 1976 & 14 & 15 \\
$3.2 \mathrm{~b}$ & Crude Losses & 1980 & 14 & 15 \\
3.5 & Stock Change & 1974 & 10 & 9 \\
3.5 & Stock Change & 1975 & -41 & -40 \\
3.8 & Total Production & 1982 & 1,527 & 1,525 \\
3.10 & Products Supplied & 1982 & 1,857 & 1,856 \\
\hline
\end{tabular}




\section{Section 4. Natural Gas}

Total dry natural gas production in the United States during November 1993 was an estimated 1.5 trillion cubic feet, 2 percent ${ }^{4}$ higher than production during the previous November.

Consumption of natural and supplemental gas in November 1993 was 1.7 trillion cubic feet, 3 percent above the level in November 1992.

Deliveries to residential consumers in October 1993 (latest date for which data are available) were 252 billion cubic feet, 5 percent higher than the previous October's deliveries. Total deliveries to industrial consumers during October 1993 were 653 billion cubic feet, 7 percent more than the previous October's level.

Imports of natural gas in November 1993 were 182 billion cubic feet, 13 percent lower than imports in the previous November.

Stocks of working gas ${ }^{5}$ in underground natural gas storage reservoirs at the end of November 1993 totaled 2.8 trillion cubic feet, 9 percent below the level of stocks available 1 year earlier. Net withdrawals from storage during November 1993 were 204 billion cubic feet, 13 percent above the amount of withdrawals during the previous November. 
Figure 4.1 Natural Gas

(Trillion Cubic Feet)

Overview, 1973-1992

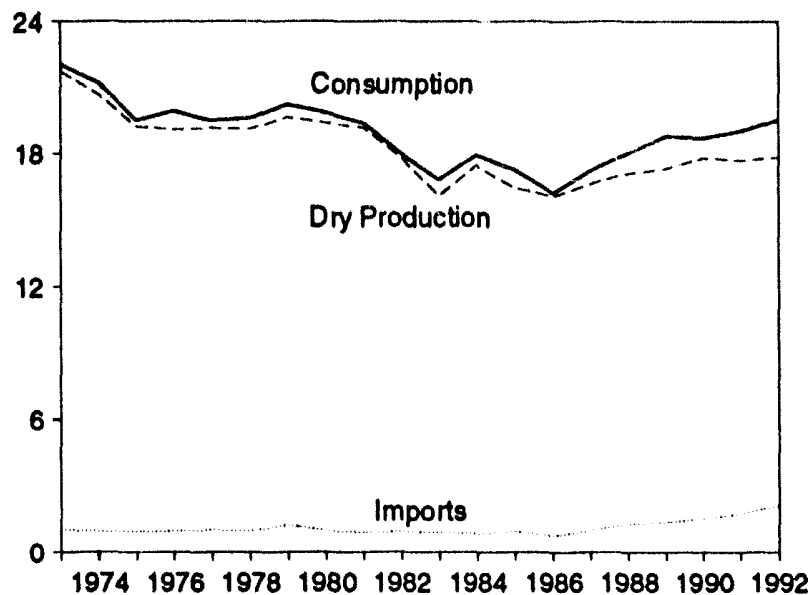

Consumption by Sector, 1973-1992

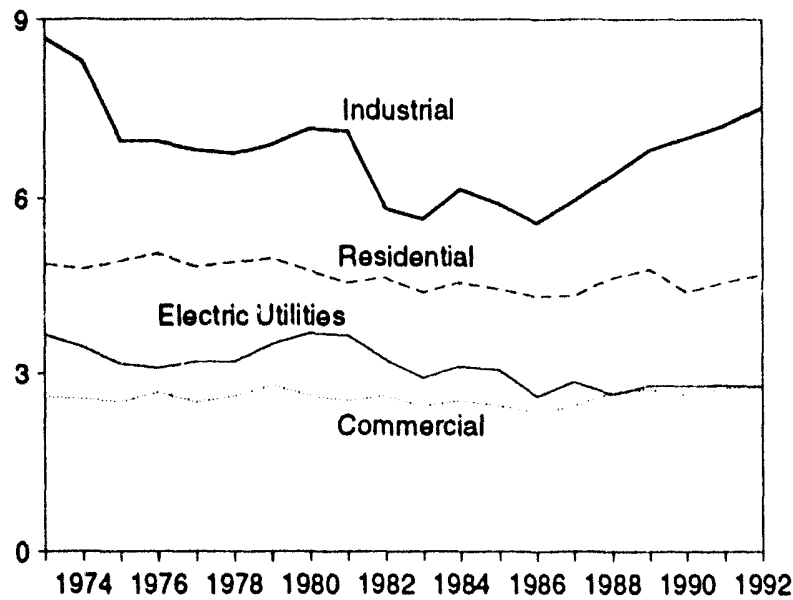

Underground Storage, End of Year, 1973-1992

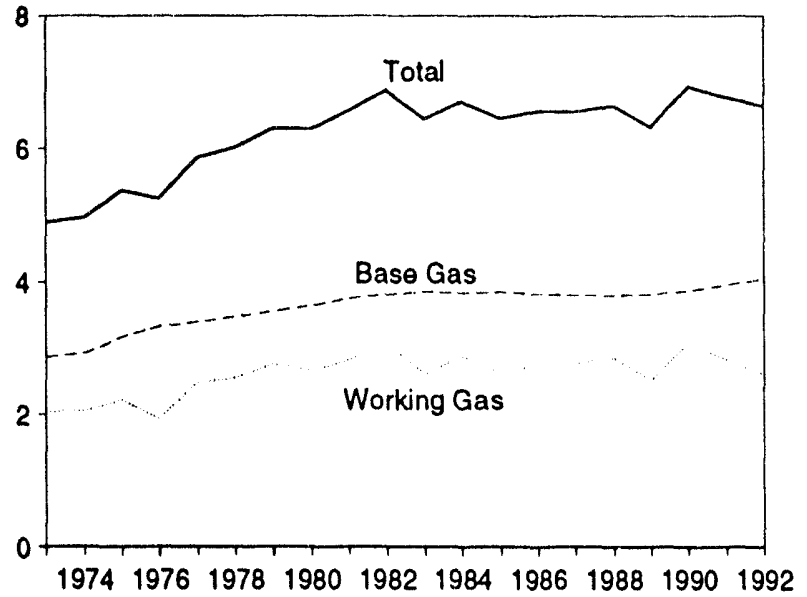

Overview, Monthly

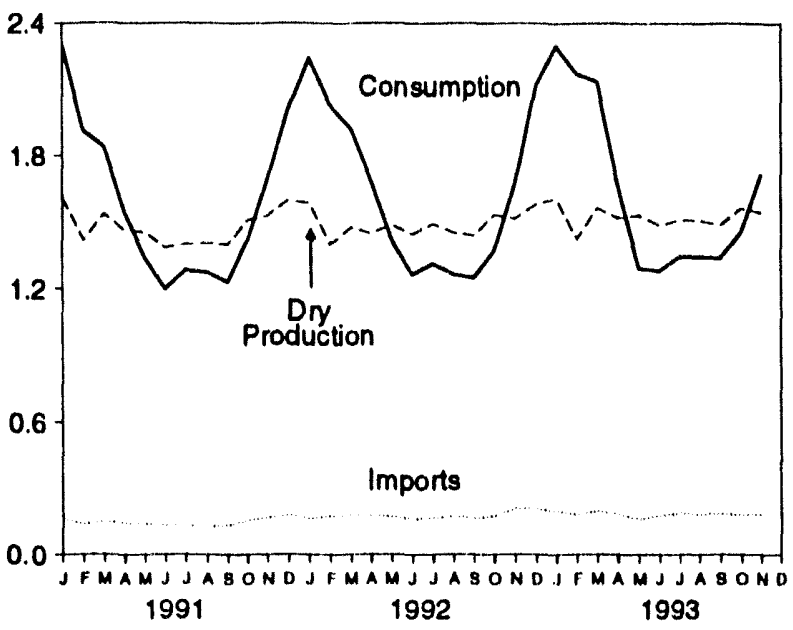

Consumption by Sector, Monthly

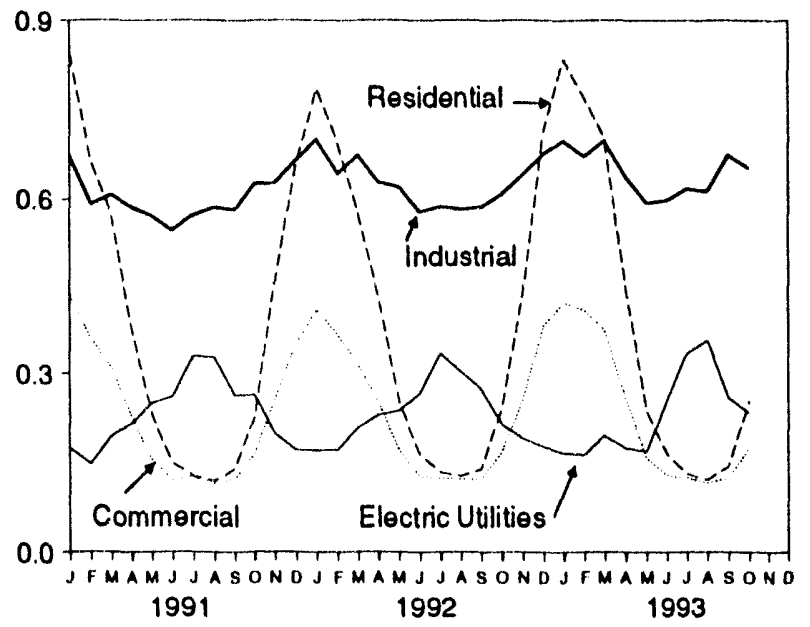

Underground Storage, End of Month

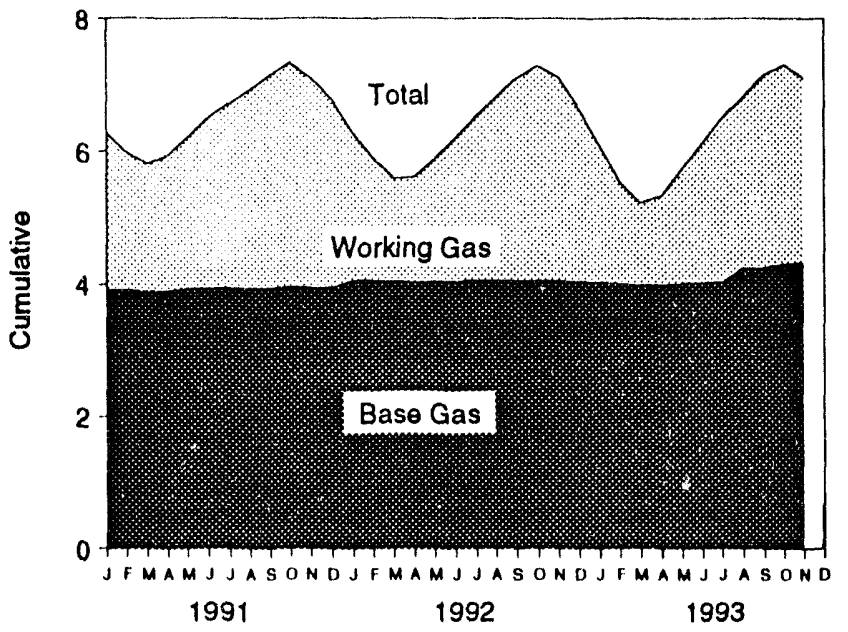

Note: Because vertical scales ditfer, graphs should not be compared Sources: Tables $4.2,4.4$, and 4.5 . 
Table 4.1 Natural Gas Production

(Billion Cubic Feet)

\begin{tabular}{|c|c|c|c|c|c|c|c|}
\hline & $\begin{array}{c}\text { Grose } \\
\text { Withdrawalsa }\end{array}$ & Pepressuringb & $\begin{array}{l}\text { Nonhydro- } \\
\text { carbon Cases } \\
\text { Aomovedc }\end{array}$ & $\begin{array}{l}\text { Vented } \\
\text { and } \\
\text { Flaredd }\end{array}$ & $\begin{array}{l}\text { Merkoted } \\
\text { Productlon } \\
\text { (Wot) }\end{array}$ & $\begin{array}{l}\text { Extrection } \\
\text { Loes }\end{array}$ & $\begin{array}{c}\text { Total } \\
\text { Dry Gen } \\
\text { Productiong }\end{array}$ \\
\hline 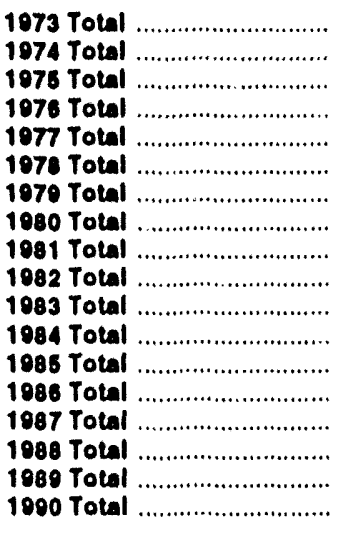 & $\begin{array}{l}24,067 \\
22,850 \\
21,104 \\
20,044 \\
21,007 \\
21,309 \\
21,083 \\
21,870 \\
21,587 \\
20,272 \\
18,659 \\
20,287 \\
19,607 \\
19,131 \\
20,140 \\
20,099 \\
21,074 \\
21,523\end{array}$ & $\begin{array}{r}1,171 \\
1,080 \\
861 \\
859 \\
035 \\
1,181 \\
1,248 \\
1,365 \\
1,312 \\
1,388 \\
1,458 \\
1,630 \\
1,015 \\
1,838 \\
2,208 \\
2,478 \\
2,475 \\
2,489\end{array}$ & $\begin{array}{l}\text { NA } \\
\text { NA } \\
\text { NA } \\
\text { NA } \\
\text { NA } \\
\text { NA } \\
109 \\
222 \\
208 \\
222 \\
224 \\
328 \\
337 \\
378 \\
460 \\
362 \\
280\end{array}$ & $\begin{array}{r}248 \\
169 \\
134 \\
132 \\
137 \\
153 \\
187 \\
128 \\
98 \\
93 \\
95 \\
108 \\
95 \\
98 \\
124 \\
143 \\
142 \\
160\end{array}$ & $\begin{array}{r}h_{22,648} \\
h_{21,801} \\
h_{20,100} \\
h_{10,052} \\
h_{20,025} \\
h_{10,074} \\
h_{20,471} \\
20,100 \\
10,058 \\
18,882 \\
16,894 \\
18,304 \\
17,270 \\
16,850 \\
17,433 \\
17,918 \\
18,095 \\
18,894\end{array}$ & $\begin{array}{l}917 \\
987 \\
872 \\
884 \\
963 \\
852 \\
808 \\
777 \\
778 \\
762 \\
790 \\
838 \\
816 \\
800 \\
812 \\
816 \\
785 \\
784\end{array}$ & $\begin{array}{l}h_{21,731} \\
h_{20,713} \\
h_{10,236} \\
h_{10,001} \\
h_{10,163} \\
h_{10,122} \\
h_{10,083} \\
10,403 \\
19,181 \\
17,820 \\
16,004 \\
17,468 \\
18,464 \\
18,080 \\
16,621 \\
17,103 \\
17,311 \\
17,810\end{array}$ \\
\hline 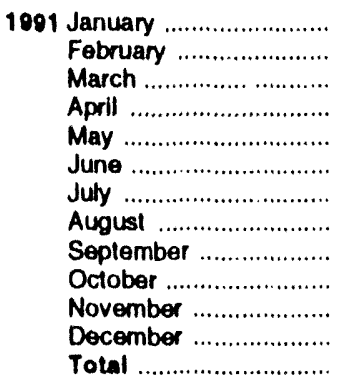 & $\begin{array}{r}1,958 \\
1,738 \\
1,889 \\
1,800 \\
1,786 \\
1,713 \\
1,740 \\
1,741 \\
1,716 \\
1,864 \\
1,864 \\
1,942 \\
21,750\end{array}$ & $\begin{array}{r}235 \\
221 \\
245 \\
234 \\
227 \\
226 \\
236 \\
231 \\
214 \\
245 \\
226 \\
231 \\
2,772\end{array}$ & $\begin{array}{r}24 \\
22 \\
24 \\
21 \\
23 \\
22 \\
23 \\
23 \\
24 \\
23 \\
23 \\
24 \\
276\end{array}$ & $\begin{array}{r}13 \\
12 \\
13 \\
14 \\
15 \\
14 \\
16 \\
15 \\
14 \\
15 \\
15 \\
15 \\
170\end{array}$ & $\begin{array}{r}1,686 \\
1,483 \\
1,607 \\
1,531 \\
1,522 \\
1,451 \\
1,465 \\
1,471 \\
1,464 \\
1,580 \\
1,600 \\
1,673 \\
18,532\end{array}$ & $\begin{array}{r}76 \\
67 \\
72 \\
69 \\
69 \\
65 \\
66 \\
66 \\
66 \\
71 \\
72 \\
75 \\
835\end{array}$ & $\begin{array}{l}1,610 \\
1,417 \\
1,535 \\
1,462 \\
1,453 \\
1,385 \\
1,399 \\
1,405 \\
1,398 \\
1,509 \\
1,528 \\
1,597 \\
17,698\end{array}$ \\
\hline 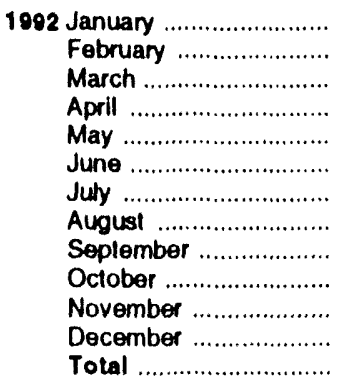 & $\begin{array}{r}1,952 \\
1,748 \\
1,837 \\
1,801 \\
1,842 \\
1,800 \\
1,842 \\
1,799 \\
1,786 \\
1,899 \\
1,871 \\
1,956 \\
22,132\end{array}$ & $\begin{array}{r}251 \\
247 \\
254 \\
246 \\
248 \\
246 \\
238 \\
237 \\
242 \\
253 \\
246 \\
263 \\
2,973\end{array}$ & $\begin{array}{r}24 \\
22 \\
22 \\
24 \\
24 \\
23 \\
24 \\
24 \\
21 \\
25 \\
23 \\
24 \\
280\end{array}$ & $\begin{array}{r}14 \\
13 \\
14 \\
13 \\
12 \\
15 \\
16 \\
15 \\
15 \\
13 \\
14 \\
14 \\
168\end{array}$ & $\begin{array}{r}1,663 \\
1,467 \\
1,547 \\
1,518 \\
1,557 \\
1,515 \\
1,564 \\
1,522 \\
1,508 \\
1,608 \\
1,588 \\
1,656 \\
18,712\end{array}$ & $\begin{array}{l}77 \\
68 \\
72 \\
71 \\
73 \\
71 \\
73 \\
71 \\
70 \\
75 \\
74 \\
77 \\
872\end{array}$ & $\begin{array}{r}1,586 \\
1,398 \\
1,475 \\
1,447 \\
1,485 \\
1,444 \\
1,491 \\
1,451 \\
1,437 \\
1,533 \\
1,514 \\
1,578 \\
17,840\end{array}$ \\
\hline 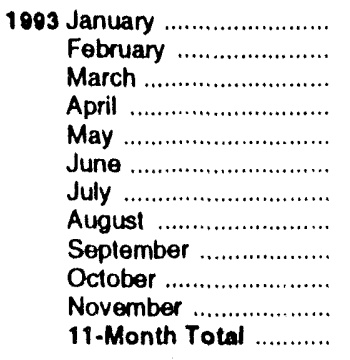 & $\begin{array}{r}1,991 \\
\text { P }_{1,773} \\
1,940 \\
1,885 \\
1,901 \\
1,835 \\
\text { P }_{1,867} \\
\text { P }_{1,865} \\
\text { P }_{1,847} \\
\text { E }_{1,933} \\
\text { E }_{1,913} \\
\text { E }_{20,750}\end{array}$ & $\begin{array}{r}270 \\
246 \\
266 \\
256 \\
261 \\
242 \\
248 \\
R_{248} \\
{ }_{2} 255 \\
E_{257} \\
E_{257} 257 \\
E_{2,807}\end{array}$ & $\begin{array}{r}22 \\
21 \\
21 \\
22 \\
21 \\
21 \\
22 \\
R_{22} \\
21 \\
E_{22} \\
E_{22} \\
E_{237}\end{array}$ & $\begin{array}{r}15 \\
14 \\
14 \\
16 \\
15 \\
15 \\
15 \\
15 \\
14 \\
\text { E } 15 \\
\text { E } 15 \\
\text { E } 161\end{array}$ & $\begin{array}{r}1,684 \\
A_{1,492} \\
A_{1,639} \\
1,592 \\
1,605 \\
1,557 \\
A_{1,583} \\
A_{1,580} \\
A_{1,557} \\
E_{1,638} \\
E_{1,618} \\
E_{17,546}\end{array}$ & $\begin{array}{r}78 \\
70 \\
76 \\
74 \\
75 \\
73 \\
74 \\
74 \\
73 \\
\text { E } 76 \\
\text { E } 75 \\
\text { E } 818\end{array}$ & $\begin{array}{r}1,606 \\
A 1,423 \\
1,563 \\
1,518 \\
1,530 \\
1,484 \\
1,509 \\
A 1,507 \\
A 1,485 \\
E_{1,562} \\
E_{1,543} \\
E_{16,728}\end{array}$ \\
\hline $\begin{array}{l}109211 \text {-Month Total .......... } \\
1091 \text { 11-Month Total ........... }\end{array}$ & $\begin{array}{l}20,176 \\
19,808\end{array}$ & $\begin{array}{l}2,710 \\
2,541\end{array}$ & $\begin{array}{l}257 \\
252\end{array}$ & $\begin{array}{l}154 \\
155\end{array}$ & $\begin{array}{l}17,056 \\
16,860\end{array}$ & $\begin{array}{l}795 \\
750\end{array}$ & $\begin{array}{l}16,261 \\
16,100\end{array}$ \\
\hline
\end{tabular}

- Gas whihdrawn from gas and oil wells

b The injection of natural gas into oil and gas formations for pressure maintenance and cycling purposes.

c See Nole 1 at end of section.

d Vented: Natural gas released into the air on the base site or at processing plants. Flared: Nalural gas burned in llares on the base site or at gas processing plants.

"Gross Withdrawals" minus "Repressuring," "Nonhydrocarbon Gases Removed," and "Vented and Flared." See Nole 2 at end of section.
1 See Note 3 at end of section.

g "Markeled Production (Wel)" minus "Extraction Loss."

h May include unknown quantities of nonhydrocarbon gases.

$\mathrm{R}=$ Revised data. $\mathrm{NA}=\mathrm{Nol}$ available. $E=$ Estimate.

Notes: - Geographic coverage is the 50 States and the Disirict of Columbla

- Tolals may nol equal sum of componerts due to independent rounding.

Sources: - 1073-1086: Energy Intormation Administration (EIA), Naturas Gas Annual 1991, Table 95. - 1987 forward: ElA, Natural Gas Monthly, January 1994, Table 1. 
Table 4.2 Natural Gas Supply and Disposition

(Billion Cubic Feet)

\begin{tabular}{|c|c|c|c|c|c|c|c|c|c|}
\hline & \multicolumn{5}{|c|}{ Supply } & \multirow[b]{2}{*}{$\begin{array}{c}\text { Total } \\
\text { Supply/ } \\
\text { Dlspositiond }\end{array}$} & \multicolumn{3}{|c|}{ Dleposition } \\
\hline & $\begin{array}{c}\text { Total } \\
\text { Dry Gas } \\
\text { Production }\end{array}$ & $\begin{array}{c}\text { Withdrawals } \\
\text { from } \\
\text { Storagoa }\end{array}$ & $\begin{array}{c}\text { Supplemental } \\
\text { Gaseous } \\
\text { Fuels }\end{array}$ & Importec & $\begin{array}{l}\text { Balancing } \\
\text { Itom }^{b}\end{array}$ & & $\begin{array}{l}\text { Additions } \\
\text { to } \\
\text { Storage }\end{array}$ & Exportec & Consumption ${ }^{b}$ \\
\hline 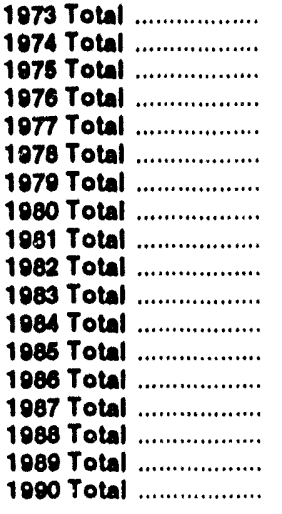 & $\begin{array}{l}21,731 \\
20,713 \\
10,236 \\
19,008 \\
10,163 \\
10,122 \\
19,663 \\
19,403 \\
19,181 \\
17,820 \\
16,004 \\
17,466 \\
16,454 \\
16,050 \\
16,621 \\
17,103 \\
17,311 \\
17,810\end{array}$ & $\begin{array}{l}1,533 \\
1,701 \\
1,760 \\
1,921 \\
1,750 \\
2,158 \\
2,047 \\
1,972 \\
1,930 \\
2,164 \\
2,270 \\
2,098 \\
2,397 \\
1,837 \\
1,905 \\
2,270 \\
2,854 \\
1,988\end{array}$ & $\begin{array}{l}\text { NA } \\
\text { NA } \\
\text { NA } \\
\text { NA } \\
\text { NA } \\
\text { NA } \\
\text { NA } \\
155 \\
176 \\
145 \\
132 \\
110 \\
126 \\
113 \\
101 \\
101 \\
107 \\
123\end{array}$ & $\begin{array}{r}1,033 \\
950 \\
953 \\
964 \\
1,011 \\
966 \\
1,253 \\
985 \\
904 \\
933 \\
918 \\
843 \\
950 \\
750 \\
993 \\
1,294 \\
1,382 \\
1,532\end{array}$ & $\begin{array}{r}-106 \\
-280 \\
-235 \\
-216 \\
-41 \\
-287 \\
-372 \\
-640 \\
-500 \\
-537 \\
1.703 \\
-217 \\
-428 \\
-493 \\
-444 \\
-453 \\
-218 \\
-140\end{array}$ & $\begin{array}{l}24,101 \\
23,084 \\
21,714 \\
21,767 \\
21,883 \\
21,058 \\
22,501 \\
21,875 \\
21,601 \\
20,525 \\
18,712 \\
20,300 \\
19,490 \\
18,266 \\
19,176 \\
20,315 \\
21,435 \\
21,302\end{array}$ & $\begin{array}{l}1,974 \\
1,784 \\
2,104 \\
1,758 \\
2,307 \\
2,278 \\
2,295 \\
1,940 \\
2,228 \\
2,472 \\
1,822 \\
2,298 \\
2,163 \\
1,984 \\
1,911 \\
2,211 \\
2,528 \\
2,490\end{array}$ & $\begin{array}{r}77 \\
77 \\
73 \\
65 \\
56 \\
53 \\
56 \\
40 \\
50 \\
52 \\
55 \\
55 \\
55 \\
61 \\
54 \\
74 \\
107 \\
86\end{array}$ & $\begin{array}{l}22,010 \\
21,223 \\
10,838 \\
10,018 \\
10,521 \\
10,027 \\
20,241 \\
10,877 \\
10,404 \\
18,001 \\
16,036 \\
17,051 \\
17,281 \\
18,221 \\
17,211 \\
18,000 \\
18,801 \\
18,716\end{array}$ \\
\hline 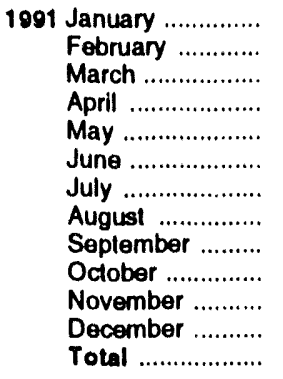 & $\begin{array}{r}1,610 \\
1,417 \\
1,535 \\
1,462 \\
1,453 \\
1,385 \\
1,399 \\
1,405 \\
1,398 \\
1,509 \\
1,528 \\
1,597 \\
17,698\end{array}$ & $\begin{array}{r}682 \\
409 \\
297 \\
104 \\
58 \\
42 \\
75 \\
82 \\
78 \\
103 \\
360 \\
461 \\
2,752\end{array}$ & $\begin{array}{r}12 \\
10 \\
11 \\
9 \\
9 \\
8 \\
9 \\
9 \\
8 \\
10 \\
9 \\
11 \\
113\end{array}$ & $\begin{array}{r}163 \\
138 \\
151 \\
144 \\
141 \\
133 \\
135 \\
127 \\
134 \\
157 \\
169 \\
181 \\
1,773\end{array}$ & $\begin{array}{r}-44 \\
62 \\
.15 \\
65 \\
13 \\
.37 \\
.28 \\
.48 \\
.72 \\
.88 \\
.209 \\
.98 \\
.500\end{array}$ & $\begin{array}{r}2,423 \\
2,035 \\
1,979 \\
1,785 \\
1,675 \\
1,531 \\
1,590 \\
1,574 \\
1,545 \\
1,691 \\
1,856 \\
2,151 \\
21,836\end{array}$ & $\begin{array}{r}115 \\
112 \\
129 \\
234 \\
331 \\
326 \\
299 \\
290 \\
304 \\
258 \\
150 \\
125 \\
2,672\end{array}$ & $\begin{array}{r}10 \\
11 \\
10 \\
9 \\
8 \\
7 \\
8 \\
10 \\
11 \\
14 \\
15 \\
18 \\
129\end{array}$ & $\begin{array}{r}2,299 \\
1,912 \\
1,840 \\
1,542 \\
1,337 \\
1,199 \\
1,283 \\
1,274 \\
1,231 \\
1,419 \\
1,691 \\
2,009 \\
10,035\end{array}$ \\
\hline 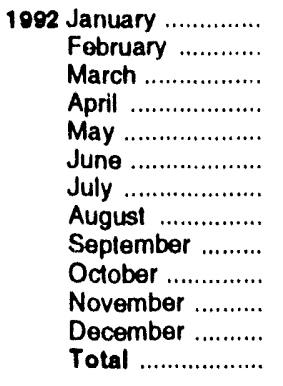 & $\begin{array}{r}1,586 \\
1,398 \\
1,475 \\
1,447 \\
1,485 \\
1,444 \\
1,491 \\
1,451 \\
1,437 \\
1,533 \\
1,514 \\
1,579 \\
17,640\end{array}$ & $\begin{array}{r}624 \\
463 \\
397 \\
142 \\
44 \\
35 \\
42 \\
46 \\
40 \\
70 \\
282 \\
587 \\
2,772\end{array}$ & $\begin{array}{r}12 \\
11 \\
11 \\
10 \\
9 \\
8 \\
8 \\
8 \\
8 \\
10 \\
11 \\
12 \\
118\end{array}$ & $\begin{array}{r}165 \\
175 \\
180 \\
176 \\
174 \\
162 \\
167 \\
175 \\
166 \\
176 \\
210 \\
209 \\
2,138\end{array}$ & $\begin{array}{r}-71 \\
42 \\
.42 \\
89 \\
68 \\
16 \\
-8 \\
.19 \\
.24 \\
.130 \\
.239 \\
.191 \\
-508\end{array}$ & $\begin{array}{r}2,315 \\
2,089 \\
2,022 \\
1,864 \\
1,780 \\
1,666 \\
1,700 \\
1,662 \\
1,629 \\
1,659 \\
1,778 \\
2,195 \\
22,360\end{array}$ & $\begin{array}{r}60 \\
45 \\
74 \\
161 \\
344 \\
384 \\
373 \\
380 \\
362 \\
271 \\
88 \\
58 \\
2,590\end{array}$ & $\begin{array}{r}16 \\
14 \\
23 \\
18 \\
19 \\
18 \\
16 \\
18 \\
18 \\
19 \\
19 \\
19 \\
216\end{array}$ & $\begin{array}{r}2,239 \\
2,031 \\
1,926 \\
1,685 \\
1,418 \\
1,264 \\
1,311 \\
1,264 \\
1,249 \\
1,368 \\
1,672 \\
2,119 \\
18,544\end{array}$ \\
\hline 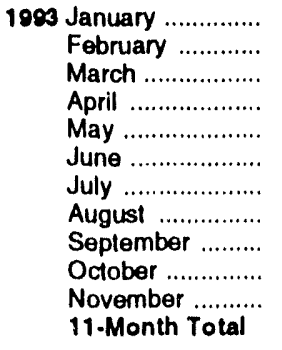 & $\begin{array}{r}1,606 \\
A_{1,423} \\
1,563 \\
1,518 \\
1,530 \\
1,484 \\
1,509 \\
R_{1}, 507 \\
R_{1,485} \\
E_{1} 1,562 \\
E_{1,543} \\
E_{16,728}\end{array}$ & $\begin{array}{r}605 \\
578 \\
381 \\
111 \\
25 \\
43 \\
48 \\
98 \\
25 \\
97 \\
315 \\
2,327\end{array}$ & $\begin{array}{r}13 \\
12 \\
12 \\
10 \\
8 \\
10 \\
9 \\
9 \\
9 \\
10 \\
12 \\
114\end{array}$ & $\begin{array}{r}198 \\
183 \\
199 \\
185 \\
160 \\
178 \\
190 \\
184 \\
188 \\
183 \\
182 \\
2,031\end{array}$ & 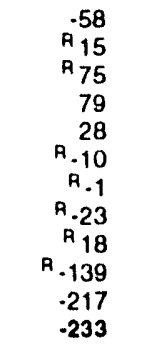 & $\begin{array}{r}2,364 \\
R_{2}, 210 \\
R_{2,230} \\
1,904 \\
1,751 \\
R_{1,706} \\
1,755 \\
1,774 \\
R_{1,725} \\
\text { म }_{1,714} \\
1,834 \\
20,967\end{array}$ & $\begin{array}{r}50 \\
27 \\
78 \\
219 \\
447 \\
416 \\
398 \\
419 \\
378 \\
247 \\
110 \\
2,787\end{array}$ & $\begin{array}{r}18 \\
13 \\
17 \\
12 \\
12 \\
11 \\
14 \\
11 \\
11 \\
10 \\
10 \\
137\end{array}$ & $\begin{array}{r}2,297 \\
R_{2,171} \\
R_{2,136} \\
1,673 \\
1,291 \\
R_{1,280} \\
1,343 \\
1,344 \\
R_{1,336} \\
R_{1,457} \\
1,714 \\
18,043\end{array}$ \\
\hline $\begin{array}{l}199211-\text { Month Total } \\
199111 \text {-Month Total }\end{array}$ & $\begin{array}{l}16,261 \\
16,100\end{array}$ & $\begin{array}{l}2,186 \\
2,291\end{array}$ & $\begin{array}{l}106 \\
102\end{array}$ & $\begin{array}{l}1,928 \\
1,593\end{array}$ & $\begin{array}{l}.316 \\
.401\end{array}$ & $\begin{array}{l}20,165 \\
18,685\end{array}$ & $\begin{array}{l}2,541 \\
2,547\end{array}$ & $\begin{array}{l}198 \\
111\end{array}$ & $\begin{array}{l}17,426 \\
17,026\end{array}$ \\
\hline
\end{tabular}

a Data for 1980-1992 include underground storage and fiquelied natural gas storage. All other data include underground storage only. Computation procedures are discussed in Nole 8 at end of section.

b See Noles at end of section.

c See Table 4.3.

- Data for 1978 forward do not include in-transit receipts and deliveries.

- May include unknown quantities of nonhydrocarbon gases

1 Seo Note 7 at end of section.

$R=$ Revised data. $N A=N o l$ available. $E=$ Estimate.

Notes: • Geographic coverage is the 50 Stales and the District of Columbia.

- Totals may not equal sum of components due to independent rounding.
Sources: - 1973-1986: Total Dry Gas Production-Energy Information Administration (EIA) Natural Gas Annual 1991, Table 95. Withdrawals from Storage, 1973-1975 and 1980-1986-ElA, Natural Gas Annual 1991, Table 96. Withdrawals from Storage, 1976-1972-ElA, Natural Gas Production and Consumption 1979, Table 1. Supplemental Gaseous Fuole, 1980-1986-ElA, Natural Gas Annual 1990, Volume 2, Table 12. Imports, Additions to Storage, Exports, and Consumption-EIA, Natural Gas Annual 1991. Table 96. Total Supply/Disposition-Sum of disposition items. Balancing Item-Tolal supply/disposition minus all other supply items. - 1987 forward: ElA, Natural Gas Monthly, January 1994, Table 2. 
Table 4.3 Natural Gas Trade by Country

(Billion Cubic Feet)

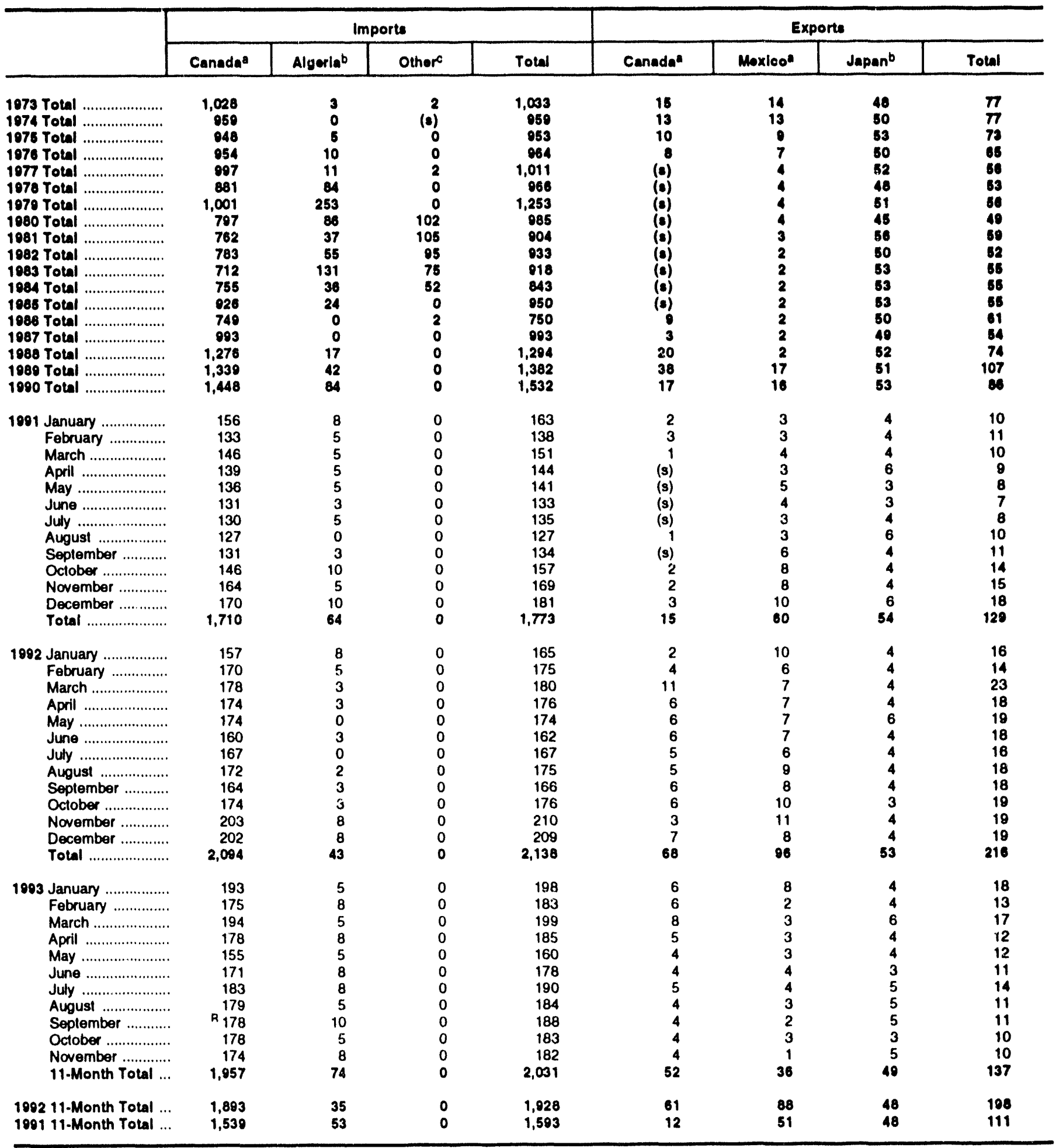

- By pipeline, except for very small amounts of liquefied natural gas imported from Canada in 1973, 1977 and 1981. See Note 5 at end of section.

b As liquelied natural gas.

c For 1973-1984, imports are from Mexico; for 1986, imports are from Indonesia.

$R=$ Revised data. (s)=Less than 500 million cubic feet.
Notes: - See Nole 5 al end of section. - Geographic coverege is the 50 States and the District of Columbia. - Totals may not equal sum of components due to independent rounding.

Source: Energy Information Administration, Natural Gas Monthly, Janusary 1994. Tables 5 and 6. 
Table 4.4 Natural Gas Consumption by End-Use Sector

(Billion Cubic Feet)

\begin{tabular}{|c|c|c|c|c|c|c|c|c|}
\hline & \multirow[b]{2}{*}{$\begin{array}{l}\text { Lease and } \\
\text { Plant Fuel }\end{array}$} & \multirow[b]{2}{*}{$\begin{array}{l}\text { Pipeline } \\
\text { Fuela }\end{array}$} & \multicolumn{5}{|c|}{ Delivered to Consumers } & \multirow[b]{2}{*}{$\begin{array}{c}\text { Total } \\
\text { Consumption }\end{array}$} \\
\hline & & & Residential & Commercial & Industrial & $\begin{array}{l}\text { Electric } \\
\text { Utilities }\end{array}$ & Total & \\
\hline 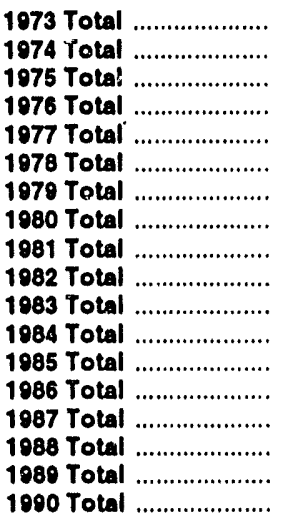 & $\begin{array}{r}1,486 \\
1,477 \\
1,396 \\
1,634 \\
1,659 \\
1,648 \\
1,499 \\
1,026 \\
928 \\
1,109 \\
978 \\
1,077 \\
966 \\
923 \\
1,149 \\
1,096 \\
1,070 \\
1,236\end{array}$ & $\begin{array}{l}728 \\
669 \\
583 \\
548 \\
533 \\
530 \\
601 \\
635 \\
642 \\
596 \\
490 \\
529 \\
504 \\
485 \\
519 \\
614 \\
629 \\
660\end{array}$ & $\begin{array}{l}4,879 \\
4,786 \\
4,924 \\
5,051 \\
4,821 \\
4,903 \\
4,965 \\
4,752 \\
4,546 \\
4,633 \\
4,381 \\
4,555 \\
4,433 \\
4,314 \\
4,315 \\
4,630 \\
4,781 \\
4,391\end{array}$ & $\begin{array}{l}2,597 \\
2,556 \\
2,508 \\
2,668 \\
2,501 \\
2,601 \\
2,786 \\
2,611 \\
2,520 \\
2,606 \\
2,433 \\
2,524 \\
2,432 \\
2,318 \\
2,430 \\
2,670 \\
2,718 \\
2,623\end{array}$ & $\begin{array}{l}8,689 \\
8,292 \\
6,968 \\
6,964 \\
6,815 \\
6,757 \\
6,899 \\
7,172 \\
7,128 \\
5,831 \\
5,643 \\
6,154 \\
5,901 \\
5,579 \\
5,953 \\
6,383 \\
6,816 \\
7,018\end{array}$ & $\begin{array}{l}3,660 \\
3,443 \\
3,158 \\
3,081 \\
3,191 \\
3,188 \\
3,491 \\
3,682 \\
3,640 \\
3,226 \\
2,911 \\
3,111 \\
3,044 \\
2,602 \\
2,844 \\
2,636 \\
2,787 \\
2,707\end{array}$ & $\begin{array}{c}19,825 \\
19,077 \\
17,558 \\
17,764 \\
17,329 \\
17: \cdots \\
18 \\
17 \\
13 \\
15,2 \\
16,5 ; \\
15,811 \\
14,814 \\
15,542 \\
16,320 \\
17,102 \\
16,820\end{array}$ & $\begin{array}{r}22,049 \\
21,223 \\
10,538 \\
10,946 \\
19,521 \\
11+\cdots \\
\\
\vdots \\
\therefore \\
17,051 \\
17,281 \\
16,221 \\
17,211 \\
18,030 \\
18,801 \\
18,716\end{array}$ \\
\hline 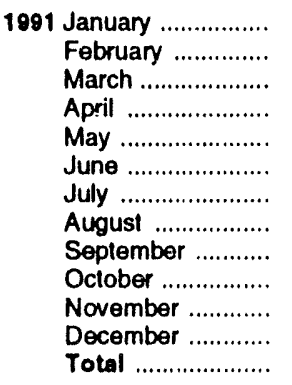 & $\begin{array}{r}102 \\
90 \\
98 \\
93 \\
93 \\
89 \\
90 \\
90 \\
89 \\
97 \\
97 \\
101 \\
1,128\end{array}$ & $\begin{array}{r}74 \\
61 \\
58 \\
49 \\
42 \\
37 \\
40 \\
40 \\
38 \\
44 \\
54 \\
64 \\
601\end{array}$ & $\begin{array}{r}844 \\
664 \\
573 \\
373 \\
229 \\
148 \\
126 \\
118 \\
138 \\
225 \\
459 \\
658 \\
4,556\end{array}$ & $\begin{array}{r}434 \\
359 \\
310 \\
225 \\
154 \\
119 \\
125 \\
113 \\
121 \\
163 \\
256 \\
350 \\
2,729\end{array}$ & $\begin{array}{r}672 \\
591 \\
607 \\
586 \\
571 \\
546 \\
572 \\
586 \\
582 \\
626 \\
627 \\
665 \\
7,231\end{array}$ & $\begin{array}{l}173 \\
146 \\
193 \\
216 \\
249 \\
260 \\
330 \\
328 \\
263 \\
263 \\
198 \\
170 \\
2,789\end{array}$ & $\begin{array}{r}2,123 \\
1,761 \\
1,683 \\
1,400 \\
1,202 \\
1,073 \\
1,153 \\
1,144 \\
1,103 \\
1,278 \\
1,540 \\
1,843 \\
17,305\end{array}$ & $\begin{array}{r}2,299 \\
1,912 \\
1,840 \\
1,542 \\
1,337 \\
1,199 \\
1,283 \\
1,274 \\
1,231 \\
1,419 \\
1,691 \\
2,009 \\
19,035\end{array}$ \\
\hline 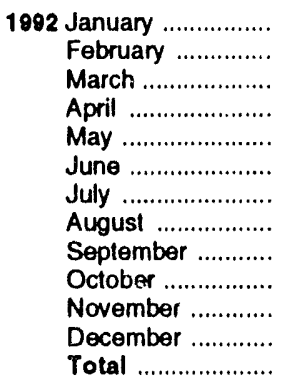 & $\begin{array}{r}104 \\
92 \\
97 \\
95 \\
97 \\
95 \\
98 \\
95 \\
94 \\
101 \\
99 \\
104 \\
1,171\end{array}$ & $\begin{array}{r}68 \\
62 \\
58 \\
51 \\
42 \\
37 \\
39 \\
37 \\
37 \\
41 \\
50 \\
64 \\
588\end{array}$ & $\begin{array}{l}786 \\
696 \\
574 \\
431 \\
251 \\
162 \\
132 \\
126 \\
13 i \\
241 \\
437 \\
717 \\
4,690\end{array}$ & $\begin{array}{r}410 \\
366 \\
315 \\
? \\
\\
\\
\\
121 \\
166 \\
256 \\
381 \\
2,803\end{array}$ & $\begin{array}{r}701 \\
644 \\
674 \\
628 \\
620 \\
578 \\
587 \\
582 \\
586 \\
608 \\
641 \\
677 \\
7,527\end{array}$ & $\begin{array}{r}169 \\
170 \\
208 \\
229 \\
236 \\
266 \\
334 \\
303 \\
274 \\
213 \\
189 \\
176 \\
2,766\end{array}$ & $\begin{array}{r}2,067 \\
1,876 \\
1,770 \\
1,539 \\
1,278 \\
1,132 \\
1,175 \\
1,131 \\
1,117 \\
1,227 \\
1,523 \\
1,951 \\
17,786\end{array}$ & $\begin{array}{r}2,239 \\
2,031 \\
1,926 \\
1,685 \\
1,418 \\
1,264 \\
1,311 \\
1,264 \\
1,249 \\
1,368 \\
1,672 \\
2,119 \\
10,544\end{array}$ \\
\hline 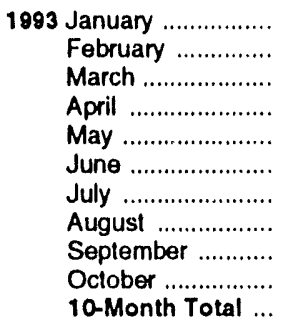 & $\begin{array}{r}105 \\
R_{93} \\
103 \\
100 \\
100 \\
97 \\
99 \\
99 \\
R_{97} \\
103 \\
997\end{array}$ & $\begin{array}{r}73 \\
R 65 \\
R_{64} \\
53 \\
41 \\
38 \\
40 \\
40 \\
40 \\
44 \\
499\end{array}$ & $\begin{array}{l}834 \\
770 \\
703 \\
450 \\
234 \\
164 \\
130 \\
120 \\
142 \\
252 \\
3,798\end{array}$ & $\begin{array}{r}421 \\
408 \\
374 \\
257 \\
156 \\
127 \\
123 \\
115 \\
123 \\
172 \\
2,277\end{array}$ & $\begin{array}{r}699 \\
672 \\
699 \\
639 \\
593 \\
R \quad 598 \\
618 \\
R \\
613 \\
675 \\
653 \\
6,460\end{array}$ & $\begin{array}{r}164 \\
162 \\
194 \\
174 \\
167 \\
255 \\
333 \\
357 \\
259 \\
233 \\
2,298\end{array}$ & $\begin{array}{r}2,119 \\
2,012 \\
1,969 \\
1,521 \\
1,150 \\
R 1,144 \\
1,204 \\
R 1,205 \\
1,198 \\
1,311 \\
14,833\end{array}$ & $\begin{array}{r}2,297 \\
A_{2,17 i} \\
A_{2,136} \\
1,673 \\
1,291 \\
A_{1,280} \\
1,343 \\
1,344 \\
A_{1,336} \\
1,457 \\
16,329\end{array}$ \\
\hline $\begin{array}{l}199210 \text {-Month Total ... } \\
1981 \text { 10-Month Total ... }\end{array}$ & $\begin{array}{l}968 \\
931\end{array}$ & $\begin{array}{l}473 \\
484\end{array}$ & $\begin{array}{l}3,536 \\
3,438\end{array}$ & $\begin{array}{l}2,166 \\
2,123\end{array}$ & $\begin{array}{l}6,209 \\
5,939\end{array}$ & $\begin{array}{l}2,401 \\
2,421\end{array}$ & $\begin{array}{l}14,312 \\
13,921\end{array}$ & $\begin{array}{l}15,753 \\
15,336\end{array}$ \\
\hline
\end{tabular}

a Natural gas consumed in the operation of pipelines, primarily in compressors.

$R=$ Revised data.

Notes: - Natural gas includes supplemental gaseous fuels. - Geographic coverage is the 50 States and the District of Columbia. - Totals may not equal sumı of components due to independent rounding

Sources: - 1973-1986: Energy Information Administration (EIA), Natural Gas Annual 1991, Table 97. - 1987 forward: ElA, Natural Gas Monthly, January 1994, Table 3. 
Table 4.5 Natural Gas in Underground Storage

(Volumes in Billion Cubic Feet)

\begin{tabular}{|c|c|c|c|c|c|c|c|c|}
\hline & \multicolumn{3}{|c|}{$\begin{array}{l}\text { Natural Gas in } \\
\text { Underground Storage, } \\
\text { End of Perlod }\end{array}$} & \multicolumn{2}{|c|}{$\begin{array}{c}\text { Change In Working Gas } \\
\text { from Same Perlod } \\
\text { Provious Year }\end{array}$} & \multicolumn{3}{|c|}{ Storage Activity } \\
\hline & Base Gas & Working Gas & Totala & Volume & Percent & Injections ${ }^{b}$ & Withdrawaleb & Nor \\
\hline 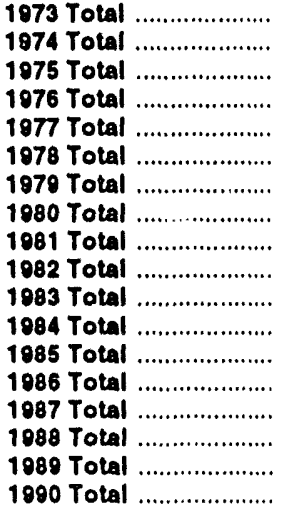 & $\begin{array}{l}2,864 \\
2,812 \\
3,162 \\
3,323 \\
3,391 \\
3,473 \\
3,553 \\
3,642 \\
3,752 \\
3,808 \\
3,847 \\
3,830 \\
3,842 \\
3,810 \\
3,792 \\
3,800 \\
3,812 \\
3,868\end{array}$ & $\begin{array}{l}2,034 \\
2,050 \\
2,212 \\
1,026 \\
2,475 \\
2,547 \\
2,753 \\
2,655 \\
2,817 \\
3,071 \\
2,595 \\
2,876 \\
2,607 \\
2,749 \\
2,756 \\
2,850 \\
2,513 \\
3,068\end{array}$ & $\begin{array}{l}4,898 \\
4,962 \\
5,374 \\
5,250 \\
5,866 \\
6,020 \\
6,306 \\
6,297 \\
6,569 \\
6,870 \\
6,442 \\
6,706 \\
6,448 \\
6,567 \\
6,548 \\
6,650 \\
6,325 \\
6,936\end{array}$ & $\begin{array}{r}305 \\
16 \\
162 \\
-286 \\
549 \\
72 \\
207 \\
-99 \\
162 \\
255 \\
-476 \\
281 \\
-270 \\
142 \\
7 \\
84 \\
-337 \\
555\end{array}$ & $\begin{array}{r}17.6 \\
.8 \\
7.9 \\
-12.9 \\
28.5 \\
2.8 \\
8.1 \\
-3.6 \\
6.1 \\
0.0 \\
-15.5 \\
10.8 \\
-9.4 \\
5.5 \\
.3 \\
3.4 \\
-11.8 \\
22.1\end{array}$ & $\begin{array}{l}1,974 \\
1,784 \\
2,104 \\
1,756 \\
2,307 \\
2,278 \\
2,295 \\
1,896 \\
2,180 \\
2,398 \\
1,700 \\
2,252 \\
2,128 \\
1,952 \\
1,887 \\
2,174 \\
2,491 \\
2,433\end{array}$ & $\begin{array}{l}1,533 \\
1,701 \\
1,760 \\
1,821 \\
1,750 \\
2,158 \\
2,047 \\
1,910 \\
1,887 \\
2,094 \\
2,142 \\
2,064 \\
2,359 \\
1,812 \\
1,881 \\
2,244 \\
2,804 \\
1,934\end{array}$ & $\begin{array}{r}442 \\
84 \\
344 \\
-165 \\
557 \\
120 \\
248 \\
-14 \\
293 \\
306 \\
-442 \\
188 \\
-231 \\
140 \\
6 \\
-69 \\
-313 \\
409\end{array}$ \\
\hline 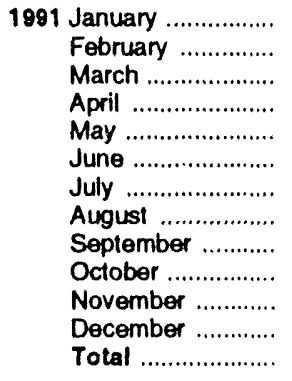 & $\begin{array}{l}3,911 \\
3,908 \\
3,895 \\
3,898 \\
3,931 \\
3,939 \\
3,942 \\
3,949 \\
3,950 \\
3,961 \\
3,952 \\
3,954 \\
3,954\end{array}$ & $\begin{array}{l}2,362 \\
2,063 \\
1,912 \\
2,037 \\
2,273 \\
2,553 \\
2,771 \\
2,978 \\
3,201 \\
3,369 \\
3,148 \\
2,824 \\
2,824\end{array}$ & $\begin{array}{l}6,273 \\
5,972 \\
5,806 \\
5,935 \\
6,204 \\
6,492 \\
6,713 \\
6,927 \\
7,151 \\
7,330 \\
7,100 \\
6,778 \\
6,778\end{array}$ & $\begin{array}{r}92 \\
59 \\
37 \\
91 \\
93 \\
68 \\
-20 \\
-93 \\
-120 \\
-98 \\
-324 \\
-244 \\
-244\end{array}$ & $\begin{array}{l}4.1 \\
3.0 \\
2.0 \\
4.7 \\
4.3 \\
2.7 \\
-.7 \\
-3.0 \\
-3.6 \\
-2.8 \\
-9.3 \\
-8.0 \\
-8.0\end{array}$ & $\begin{array}{r}115 \\
112 \\
129 \\
228 \\
319 \\
314 \\
290 \\
282 \\
294 \\
251 \\
150 \\
125 \\
2,608\end{array}$ & $\begin{array}{r}660 \\
397 \\
291 \\
104 \\
58 \\
42 \\
75 \\
82 \\
78 \\
103 \\
352 \\
448 \\
2,689\end{array}$ & $\begin{array}{r}-545 \\
-285 \\
-162 \\
124 \\
261 \\
272 \\
214 \\
200 \\
216 \\
148 \\
-202 \\
-323 \\
-80\end{array}$ \\
\hline 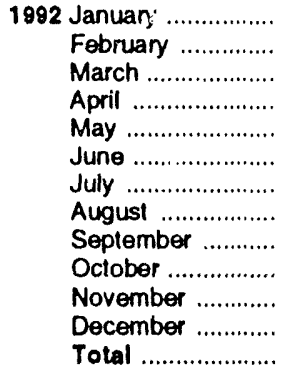 & $\begin{array}{l}4,061 \\
4,057 \\
4,046 \\
4,038 \\
4,044 \\
4,050 \\
4,064 \\
4,062 \\
4,061 \\
4,065 \\
4,061 \\
4,044 \\
4,044\end{array}$ & $\begin{array}{l}2,216 \\
1,837 \\
1,545 \\
1,573 \\
1,848 \\
2,153 \\
2,460 \\
2,761 \\
3,044 \\
3,223 \\
3,054 \\
2,597 \\
2,597\end{array}$ & $\begin{array}{l}6,277 \\
5,894 \\
5,591 \\
5,611 \\
5,892 \\
6,203 \\
6,524 \\
6,823 \\
7,105 \\
7,288 \\
7,115 \\
6,641 \\
6,641\end{array}$ & $\begin{array}{l}-146 \\
-226 \\
-367 \\
-463 \\
.425 \\
-400 \\
-311 \\
-217 \\
-157 \\
-146 \\
.94 \\
-227 \\
-227\end{array}$ & $\begin{array}{r}-6.2 \\
-10.9 \\
-19.2 \\
-22.8 \\
-18.7 \\
-15.7 \\
-11.2 \\
-7.3 \\
-4.9 \\
-4.3 \\
-3.0 \\
-8.0 \\
-8.0\end{array}$ & $\begin{array}{r}68 \\
52 \\
81 \\
167 \\
330 \\
366 \\
357 \\
364 \\
346 \\
264 \\
95 \\
65 \\
2,555\end{array}$ & $\begin{array}{r}591 \\
441 \\
381 \\
150 \\
53 \\
43 \\
50 \\
54 \\
48 \\
78 \\
276 \\
557 \\
2,724\end{array}$ & $\begin{array}{r}-524 \\
-389 \\
-301 \\
18 \\
277 \\
323 \\
307 \\
309 \\
298 \\
186 \\
-181 \\
-491 \\
-168\end{array}$ \\
\hline 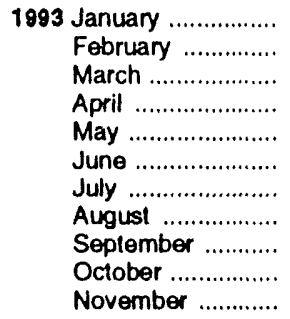 & $\begin{array}{l}4,040 \\
4,014 \\
3,993 \\
3,999 \\
4,017 \\
4,029 \\
4,030 \\
4,254 \\
4,254 \\
4,314 \\
4,323\end{array}$ & $\begin{array}{l}2,045 \\
1,519 \\
1,237 \\
1,335 \\
1,738 \\
2,100 \\
2,465 \\
2,566 \\
2,901 \\
2,992 \\
2,781\end{array}$ & $\begin{array}{l}6,086 \\
5,532 \\
5,230 \\
5,334 \\
5,755 \\
6,128 \\
6,495 \\
6,820 \\
7,155 \\
7,305 \\
7,104\end{array}$ & $\begin{array}{r}-170 \\
-319 \\
-308 \\
-238 \\
-111 \\
-53 \\
5 \\
-195 \\
-143 \\
-232 \\
-273\end{array}$ & $\begin{array}{r}-7.7 \\
-17.3 \\
-19.9 \\
-15.1 \\
-6.0 \\
-2.5 \\
.2 \\
-7.1 \\
-4.7 \\
-7.2 \\
-8.9\end{array}$ & $\begin{array}{r}50 \\
27 \\
78 \\
219 \\
447 \\
416 \\
398 \\
419 \\
378 \\
247 \\
110\end{array}$ & $\begin{array}{r}605 \\
578 \\
381 \\
111 \\
25 \\
43 \\
48 \\
98 \\
25 \\
97 \\
315\end{array}$ & $\begin{array}{r}.556 \\
.552 \\
-304 \\
108 \\
423 \\
372 \\
350 \\
321 \\
352 \\
150 \\
-204\end{array}$ \\
\hline
\end{tabular}

a Total underground storage capacity at the end of earh calendar year (in billion cubic feel): 1975--6,280 (first year for which data are available); 1976-6,544; 1977-66,678; 1978-6,890; 1979-.6,929; 1980--7,434; $1981 .-7,805 ; \quad 1982 .-7,915 ; \quad 1983 .-7,985 ; \quad 1984-.8,043 ; \quad 1985 \cdot-8,087$ 1986- $-8,145 ; 1987,1988$, and $1989 \cdot-8,124 ; 1990-8,125 ; 1991 \cdot .7,993$; and 1992-.7,932. Current capacity remains at 7,932.

bor 1980-1991, data differ from those shown on Table 4.2, which includes liquelied natural gas storage for that period.

c Positive numbers indicate injections are greater than withdrawals Negative numbers indicate withdrawals are greater than injections. Net injections or withdrawals may not equal the difference between applicable ending stocks. See Note 8 at end of section.

Notes: - Geographic coverage is the 50 States and the District of Columbia.

- Tolals may not equal sum of components due to independent rounding.

Sources: - Storage Activity: 1973-1975-Energy Information
Administration (E|A), Natural Gas Annual 1990, Volume 2, Table 9. 1976-1979-ElA, Natural Gas Production and Consumption 1979, Table 1. 1980-1986-EIA, Nalural Gas Annual 1990, Volume 2, Table 11. 1087 forward-EIA, Natural Gas Monthy, January 1994, Table 13. - Other Data: 1873 and 1974 -American Gas Association (AGA), Gas Facts, 1972 Data, Table 57, Gas Facts, 1973 Data, Table 57, and Gas Facts, 1974 Data, Table 40. 1975 and 1976-Federal Energy Administration (FEA). Form FEA.G318-M.O. "Underground Gas Storage Repont" and Federal Power Commission (FPC), Form FPC-8, "Underground Gas Storage Report." 1977 and 1978-EIA, Form FEA-G318-M-0, "Underground Gas Slorage Report, and Federal Energy Regulatory Commission (FERC), Form FERC-8, "Underground Gas Storage Repont." 1979-1986-EIA, Form ElA-191, "Underground Gas Storage Report," and FERC, Form FERC-8, "Underground Gas Storage Report." 1887 forward-EIA, Natural Gas Monthy, January 1994, Table 13. 


\section{Natural Gas Notes}

1. Nonhydrocarbon Gases Removed: Annual data on nonhydrocarbon gases removed from marketed production-carbon dioxide, helium, hydrogen sulfide, and nitrogen-are from the Energy Information Administration (EIA) Natural Gas Annual (NGA) 1991. Data are not available for periods prior to 1980. Monthly data are reported by three States and computed for six States. Monthly data are preliminary until after publication of the EIA NGA. Differences between annual data published in the EIA NGA and the sum of the preliminary monthly data (January-December) are allocated proportionally to the months to create final monthly data. For further information on methods of estimating preliminary monthly data, see the EIA Natural Gas Monthly $(N G M)$.

\section{Production.}

- Annual data: Final annual data are from the EIA $N G A$.

- Estimated monthly data: Data for the two most recent months presented are estimated. Some of the data for earlier months are also estimated or computed. For a discussion of computation and estimation procedures, see the EIA NGM.

- Preliminary monthly data: Monthly data are considered preliminary until after publication of the EIA NGA. Preliminary monthly data are gathered from reports to the Interstate Oil Compact Commission and the U.S. Minerals Management Service. Volumetric data are converted, as necessary, to a standard $14.73 \mathrm{psi}$ pressure base. Unless there are major changes, data are not revised until after publication of the EIA NGA.

- Final monthly data: Differences between annual data in the EIA $N G A$ and the sum of preliminary monthly data (January-December) are allocated proportionally to the months to create final monthly data.

3. Extraction Loss: Extraction loss is the reduction in volume of natural gas resulting from the removal of natural gas liquid constituents at natural gas processing plants.

Annual data for extraction loss are from the EIA $N G A$, where they are estimated on the basis of the type and quantity of liquid products extracted from the gas stream and the calculated volume of such products at standard conditions. For a detailed explanation of the calculations used to derive estimated extraction losses, see the EIA $N G A$.

Preliminary monthly data are estimated on the basis of extraction loss as an annual percentage of marketed production. This percentage is applied to each month's marketed production to estimate monthly extraction loss.

Monthly data are revised and considered final after the publication of the EIA $N G A$. Final monthly data are estimated by allocating annual extraction loss data to the months on the basis of total natural gas marketed production data from the EIA NGA.

4. Supplemental Gaseous Fuels: Any gaseous substance that, introduced into or commingled with natural gas, increases the volume available for disposition. Such substances include, but are not limited to, propane-air, refinery gas, coke oven gas, still gas, manufactured gas, biomass gas, or air or inert gases added for Btu stabilization.

Annual data beginning with 1980 are from the EIA NGA. Unknown quantities of supplemental gaseous fuels are included in consumption data for 1979 and earlier years.

Monthly data are considered preliminary until after the publication of the EIA NGA. Monthly estimates are based on the annual ratio of supplemental gaseous fuels to the sum of dry gas production, net imports, and net withdrawals from storage. The ratio is applied to the monthly sum of the three elements to compute a monthly suppleinental gaseous fuels figure.

5. Imports and Exports: The United States imports natural gas via pipeline from Canada. Prior to 1985, it also imported natural gas via pipeline from Mexico. Liquefied natural gas (LNG) arrives via tanker from Algeria. One shipment of LNG was received from Indonesia in December 1986. Very small amounts of LNG arrived from Canada in 1973 (667 million cubic feet), 1977 (572 million cubic feet), and 1981 (6 million cubic feet). The United States exports natural gas via pipeline to Canada and Mexico and LNG via tanker to Japan.

Annual and final monthly data are from the annual Form FPC-14, "Annual Report for Irrporters and Exporters of Natural Gas," which requires data to be reported by month for the calendar year.

Preliminary monthly data are EIA estimates. For a discussion of estimation procedures, see the EIA NGM. Preliminary data are revised after the publication of the EIA U.S. Imports and Exports of Natural Gas.

6. Consumption: Consumption includes pipeline fuel use, lease and plant fuel use, and deliveries to consuming sectors.

Final data are from the EIA NGA. Monthly data are considered preliminary until after publication of the EIA $N G A$. For more detailed information on the methods of 
estimating preliminary and final monthly data, see the EIA NGM.

7. Balancing Item: The balancing item for natural gas represents the difference between the sum of the components of natural gas supply and the sum of components of natural gas disposition. The differences may be due to quantities lost or to the effects of data reporting problems. Reporting problems include differences due to the net result of conversions of flow data metered at varying temperature and pressure bases and converted to a standard temperature and pressure base; the effect of variations in company accounting and billing practices; differences between billing cycle and calendar period time frames; and imbalances resulting from the merger of data reporting systems which vary in scope, format, definitions, and type of respondents.

The increase of 0.2 trillion cubic feet (Tcf) in the "Balancing Item" category in 1983, followed by a decline of 0.5 Tcf in 1984, reflected unusually large differences resulting from the use of the annual billing cycle (essentially December 15 through the following December 14) consumption data in conjunction with calendar year supply data. Record cold temperatures during the last half of December 1983 resulted in a reported 0.3 Tcf increase in net withdrawals from underground storage for peak shaving as compared with the same period in 1982 , but the effect of this cold weather was reflected primarily in 1984 consumption data. For underground storage data, see Table F2 in the May 1985 NGM, which was published in July 1985.

8. Natural Gas Storage: Gas in storage at the end of a reporting period may not equal the quantity derived by adding or subtracting net injections or withdrawals from the quantity in storage at the end of the previous period. The difference is due to changes in the quantity of native gas included in the base gas and/or losses in base gas due to migration from storage reservoirs.

Monthly underground storage data are collected from the Forms FERC-8 (interstate data) and EIA-191 (intrastate data). Beginning in January 1991, all data are collected on the revised Form EIA-191. Injection and withdrawal data from the FERC-8/EIA-191 survey are adjusted to correspond to data from Form EIA-176 following publication of the EIA NGA.

The final monthly and annual storage and withdrawal data for 1980-1989 include both underground and liquefied natural gas (LNG) storage. Annual data on LNG additions and withdrawals are from Form EIA176. Monthly data are estimated by computing the ratio of each month's underground storage additions and withdrawals to annual underground storage additions and withdrawals and applying the ratio to the annual LNG data. 


\section{Section 5. Oil and Gas Resource Development}

A total of 84 seismic exploration crews were active in December 1993, 13 more crews than were active a year earlier. Of the total, 66 were land crews and 18 were aboard marine vessels. The number of land crews increased by 8 and the number of operating marine vessels increased by 5 vessels from the December 1992 count.

The December 1993 rotary rig count of 857 was 1 percent lower than the count in the previous month and 7 percent lower than the count in December 1992. Of the total number of rigs in operation, 754 were onshore and 103 were offshore. The number of onshore rigs was down 13 percent from the number in December 1992 , but the number of offshore rigs was up 75 percent.
Total footage drilled in December 1993 was 10.0 million feet, up 2 percent from footage drilled in November 1993 but down 18 percent from that drilled in December 1992.

The estimated number of exploratory and development oil and gas wells drilled during December 1993 was $1,263,2$ percent lower than the number drilled in November 1993 and 30 percent lower than the number drilled in December 1992. The estimated number of oil wells drilled was 561 and the estimated number of gas wells was 702,29 percent lower and 30 percent lower, respectively, from the December 1992 levels. The estimated number of dry holes drilled in December 1993 was 546,11 percent lower than the number drilled in both November 1993 and December 1992.

\section{Figure 5.1 Oil and Gas Resource Development Indicators}

\section{Crews Engaged in Exploration}

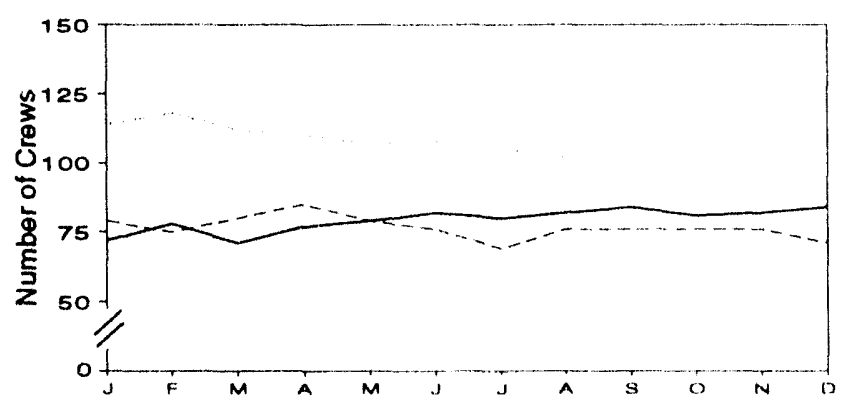

Wells Drilled

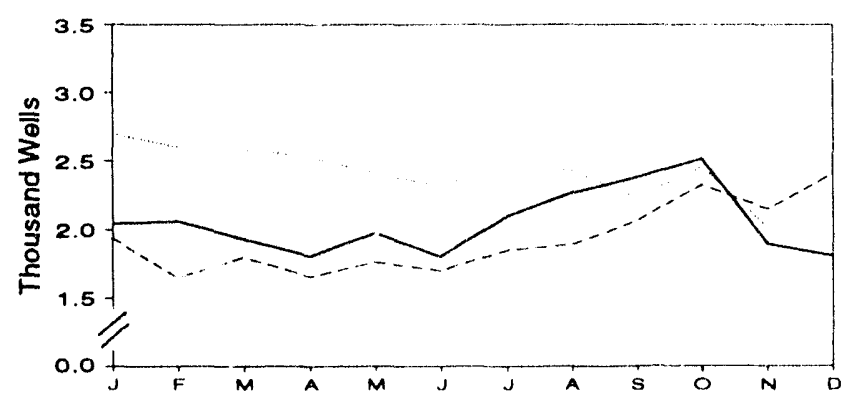

Rotary Rigs in Operation

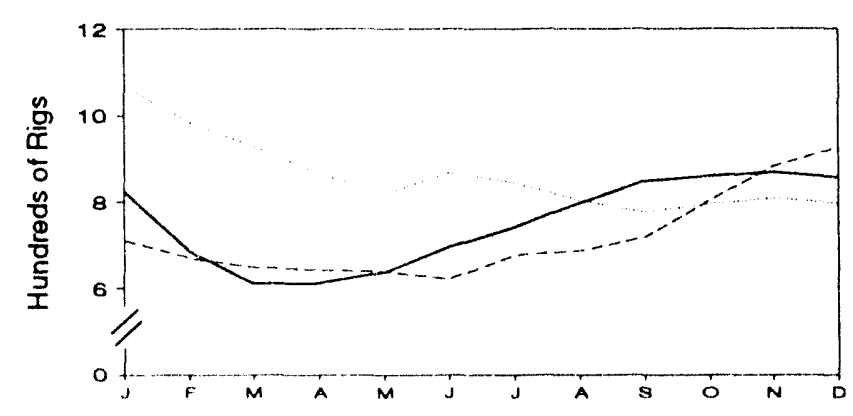

Footage Drilled

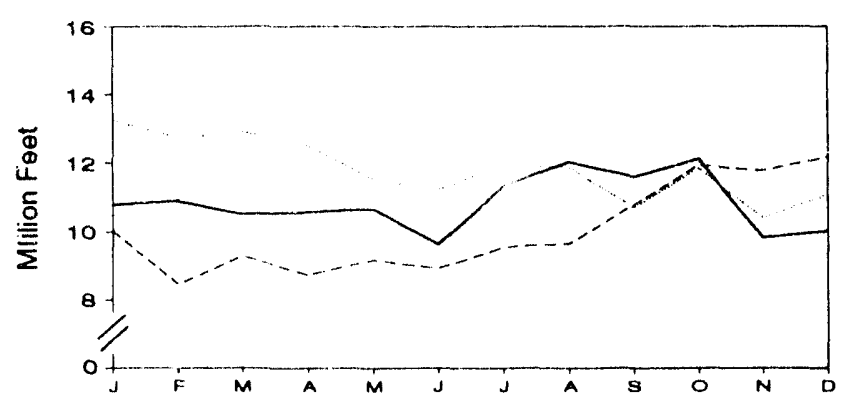


Table 5.1 Oil and Gas Drilling Activity Measurements

\begin{tabular}{|c|c|c|c|c|c|c|c|c|c|c|}
\hline & \multicolumn{3}{|c|}{$\begin{array}{l}\text { Crows Engaged in } \\
\text { Seismic Exploration }\end{array}$} & \multicolumn{5}{|c|}{ Rotary Rigs in Operattona } & \multirow{4}{*}{\begin{tabular}{c|}
$\begin{array}{c}\text { Total } \\
\text { Footage } \\
\text { Drilledc }\end{array}$ \\
housand Foet
\end{tabular}} & \multirow{4}{*}{$\frac{\begin{array}{c}\text { Actvo } \\
\text { Well Servicing } \\
\text { Units }\end{array}}{\text { Number }}$} \\
\hline & & & & By $s$ & Sito & & & & & \\
\hline & Offshore & Onshore & Total & Offshore & Onshore & Oll & Gas & Total & & \\
\hline & \multicolumn{3}{|c|}{ Monthly Average } & \multicolumn{5}{|c|}{ Weokly Average } & & \\
\hline 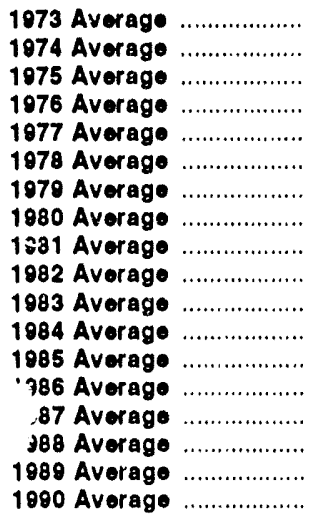 & $\begin{array}{l}23 \\
31 \\
30 \\
25 \\
27 \\
25 \\
30 \\
37 \\
44 \\
57 \\
47 \\
49 \\
45 \\
24 \\
24 \\
29 \\
23 \\
23\end{array}$ & $\begin{array}{l}227 \\
274 \\
254 \\
237 \\
281 \\
327 \\
370 \\
493 \\
637 \\
531 \\
426 \\
445 \\
333 \\
176 \\
153 \\
153 \\
109 \\
102\end{array}$ & $\begin{array}{l}250 \\
305 \\
284 \\
262 \\
308 \\
352 \\
400 \\
530 \\
681 \\
588 \\
473 \\
494 \\
378 \\
200 \\
177 \\
182 \\
132 \\
125\end{array}$ & $\begin{array}{r}84 \\
94 \\
106 \\
128 \\
167 \\
185 \\
207 \\
231 \\
256 \\
243 \\
199 \\
213 \\
206 \\
98 \\
95 \\
123 \\
105 \\
108\end{array}$ & $\begin{array}{r}1,110 \\
1,378 \\
1,554 \\
1,529 \\
1,834 \\
2,074 \\
1,870 \\
2,678 \\
3,714 \\
2,862 \\
2,033 \\
2,215 \\
1,774 \\
865 \\
841 \\
813 \\
764 \\
802\end{array}$ & $\begin{array}{l}\text { NA } \\
\text { NA } \\
\text { NA } \\
\text { NA } \\
\text { NA } \\
\text { NA } \\
\text { NA } \\
\text { NA } \\
\text { NA } \\
\text { NA } \\
\text { NA } \\
\text { NA } \\
\text { NA } \\
\text { NA } \\
\text { NA } \\
554 \\
453 \\
532\end{array}$ & $\begin{array}{l}\text { NA } \\
\text { NA } \\
\text { NA } \\
\text { NA } \\
\text { NA } \\
\text { NA } \\
\text { NA } \\
\text { NA } \\
\text { NA } \\
\text { NA } \\
\text { NA } \\
\text { NA } \\
\text { NA } \\
\text { NA } \\
\text { NA } \\
354 \\
401 \\
464\end{array}$ & $\begin{array}{r}1,104 \\
1,472 \\
1,660 \\
1,658 \\
2,001 \\
2,259 \\
2,177 \\
2,909 \\
3,970 \\
3,105 \\
2,232 \\
2,428 \\
1,980 \\
964 \\
936 \\
936 \\
869 \\
1,010\end{array}$ & $\begin{array}{l}139,427 \\
153,791 \\
181,046 \\
187,291 \\
215,696 \\
238,388 \\
243,686 \\
312,303 \\
408,842 \\
378,437 \\
318,585 \\
370,730 \\
312,569 \\
177,486 \\
161,226 \\
153,340 \\
133,383 \\
149,378\end{array}$ & $\begin{array}{c}\text { NA } \\
\text { NA } \\
\text { NA } \\
2,601 \\
2,828 \\
2,988 \\
3,399 \\
4,089 \\
4,850 \\
4,248 \\
3,732 \\
4,663 \\
4,716 \\
3,036 \\
3,060 \\
3,341 \\
3,391 \\
3,658\end{array}$ \\
\hline 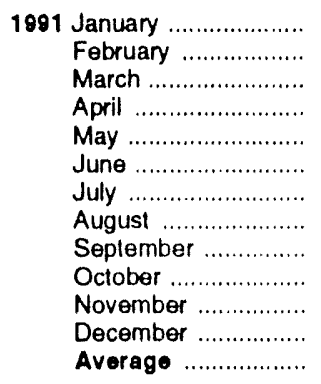 & $\begin{array}{l}22 \\
21 \\
24 \\
23 \\
22 \\
21 \\
16 \\
15 \\
14 \\
15 \\
18 \\
19 \\
19\end{array}$ & $\begin{array}{l}92 \\
97 \\
88 \\
87 \\
85 \\
87 \\
89 \\
87 \\
84 \\
81 \\
73 \\
66 \\
85\end{array}$ & $\begin{array}{r}114 \\
118 \\
112 \\
110 \\
107 \\
108 \\
105 \\
102 \\
98 \\
96 \\
91 \\
85 \\
104\end{array}$ & $\begin{array}{l}91 \\
88 \\
81 \\
95 \\
98 \\
93 \\
80 \\
68 \\
71 \\
68 \\
72 \\
65 \\
81\end{array}$ & $\begin{array}{l}977 \\
896 \\
848 \\
770 \\
721 \\
774 \\
764 \\
735 \\
704 \\
727 \\
736 \\
731 \\
779\end{array}$ & $\begin{array}{l}633 \\
564 \\
520 \\
469 \\
430 \\
483 \\
472 \\
451 \\
433 \\
433 \\
457 \\
469 \\
482\end{array}$ & $\begin{array}{l}413 \\
405 \\
389 \\
374 \\
354 \\
342 \\
332 \\
326 \\
314 \\
330 \\
328 \\
308 \\
351\end{array}$ & $\begin{array}{r}1,068 \\
984 \\
929 \\
865 \\
819 \\
867 \\
844 \\
803 \\
775 \\
795 \\
808 \\
796 \\
860\end{array}$ & $\begin{array}{r}13,243 \\
12,738 \\
12,905 \\
12,490 \\
11,514 \\
11,214 \\
11,940 \\
11,861 \\
10,669 \\
11,830 \\
10,395 \\
R 11,049 \\
R 141,848\end{array}$ & $\begin{array}{l}3,579 \\
3,512 \\
3,444 \\
3,416 \\
3,394 \\
3,363 \\
3,369 \\
3,257 \\
3,208 \\
3,138 \\
3,113 \\
3,183 \\
3,331\end{array}$ \\
\hline 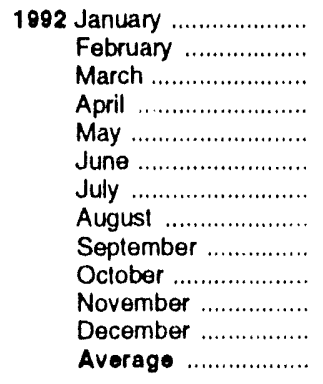 & $\begin{array}{r}18 \\
13 \\
13 \\
13 \\
13 \\
12 \\
9 \\
9 \\
10 \\
10 \\
15 \\
13 \\
12\end{array}$ & $\begin{array}{l}61 \\
62 \\
67 \\
72 \\
66 \\
64 \\
60 \\
67 \\
66 \\
66 \\
61 \\
58 \\
64\end{array}$ & $\begin{array}{l}79 \\
75 \\
80 \\
85 \\
79 \\
76 \\
69 \\
76 \\
76 \\
76 \\
76 \\
71 \\
76\end{array}$ & $\begin{array}{l}56 \\
51 \\
54 \\
55 \\
47 \\
44 \\
48 \\
51 \\
45 \\
53 \\
60 \\
59 \\
52\end{array}$ & $\begin{array}{l}654 \\
618 \\
594 \\
587 \\
591 \\
577 \\
628 \\
635 \\
672 \\
750 \\
822 \\
867 \\
669\end{array}$ & $\begin{array}{l}400 \\
378 \\
381 \\
370 \\
358 \\
343 \\
349 \\
334 \\
345 \\
392 \\
418 \\
397 \\
373\end{array}$ & $\begin{array}{l}294 \\
277 \\
250 \\
251 \\
260 \\
260 \\
310 \\
331 \\
356 \\
399 \\
451 \\
509 \\
331\end{array}$ & $\begin{array}{l}710 \\
669 \\
648 \\
642 \\
638 \\
621 \\
676 \\
686 \\
717 \\
803 \\
882 \\
926 \\
721\end{array}$ & $\begin{array}{r}10,017 \\
8,456 \\
9,289 \\
8,726 \\
9,158 \\
8,915 \\
9,529 \\
9,635 \\
10,748 \\
11,925 \\
11,764 \\
R 12,167 \\
R_{120,329}\end{array}$ & $\begin{array}{l}2,912 \\
2,704 \\
2,592 \\
2,727 \\
2,264 \\
2,369 \\
2,492 \\
2,630 \\
2,825 \\
3,076 \\
2,977 \\
3,218 \\
2,732\end{array}$ \\
\hline 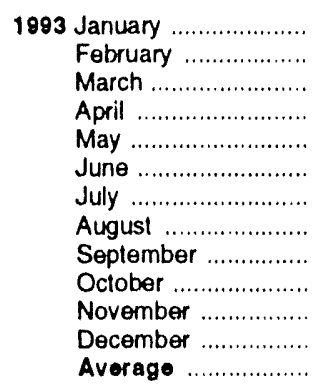 & $\begin{array}{l}17 \\
15 \\
16 \\
14 \\
15 \\
17 \\
15 \\
16 \\
18 \\
15 \\
17 \\
18 \\
16\end{array}$ & $\begin{array}{l}55 \\
63 \\
55 \\
63 \\
64 \\
65 \\
65 \\
66 \\
66 \\
66 \\
65 \\
66 \\
63\end{array}$ & $\begin{array}{l}72 \\
78 \\
71 \\
77 \\
79 \\
82 \\
80 \\
82 \\
84 \\
81 \\
82 \\
84 \\
79\end{array}$ & $\begin{array}{r}72 \\
69 \\
62 \\
69 \\
73 \\
83 \\
85 \\
87 \\
89 \\
93 \\
99 \\
103 \\
82\end{array}$ & $\begin{array}{l}752 \\
615 \\
549 \\
543 \\
564 \\
612 \\
656 \\
710 \\
759 \\
767 \\
769 \\
754 \\
672\end{array}$ & $\begin{array}{l}335 \\
311 \\
315 \\
320 \\
323 \\
350 \\
368 \\
397 \\
418 \\
441 \\
453 \\
425 \\
373\end{array}$ & $\begin{array}{l}454 \\
334 \\
268 \\
270 \\
294 \\
327 \\
360 \\
390 \\
421 \\
411 \\
408 \\
426 \\
364\end{array}$ & $\begin{array}{l}824 \\
684 \\
611 \\
612 \\
637 \\
695 \\
741 \\
797 \\
848 \\
860 \\
868 \\
857 \\
754\end{array}$ & $\begin{array}{r}10,784 \\
10,891 \\
10,501 \\
10,553 \\
10,644 \\
R 9,620 \\
11,308 \\
12,023 \\
11,575 \\
12,110 \\
9,810 \\
9,995 \\
129,814\end{array}$ & $\begin{array}{r}2,807 \\
2,899 \\
2,829 \\
2,703 \\
2,848 \\
3,087 \\
3,178 \\
3,423 \\
3,341 \\
3,519 \\
R_{3,604} \\
\text { E }_{3,600} \\
\text { E }_{3,153}\end{array}$ \\
\hline
\end{tabular}

a Monthly data are averages of 4. or 5.week reporting periods, not calendar months. Annual data are averages of 52. or 53-week reporting periods, not calendar years

$b$ Sum of oil, gas, and miscellaneous other rigs, which is not shown.

- Values shown are totals.

See Glossary.

$\mathrm{R}=$ Revised data. $\mathrm{NA}=\mathrm{Not}$ available. $E=$ Estimale.

Note: Geographic coverage is the 50 States and the District of Columbia.
Sources: - Crows Engagod In Solsmle Exploration: Sociely of Exploration Geophysicists, Tulsa, Oklahoma, Monthly Seismic Crew Count. - Rotary Rigs in Operation: Baker Hughes, Inc., Houston, Texas, Rolary Rigs Running--by State. - Total Footage Drllled: Energy Information Administration computations, which are based on well reports submitted to the American Petroleum Institute by the Petroleum Information Corporation. Denver, Colorado. - Actlve Well Servicing Units: American Association of Oilwell Servicing Contractors, Dallas, Texas, Well Servicing. 


\begin{tabular}{|c|c|c|c|c|c|c|c|c|c|c|c|c|}
\hline & \multicolumn{4}{|c|}{ Exploratory } & \multicolumn{4}{|c|}{ Dovolopment } & \multicolumn{4}{|c|}{ Total } \\
\hline & Oll & Gas & Dry & Total & Oil & Gas & Dry & Total & Oil & Gas & Dry & Total \\
\hline 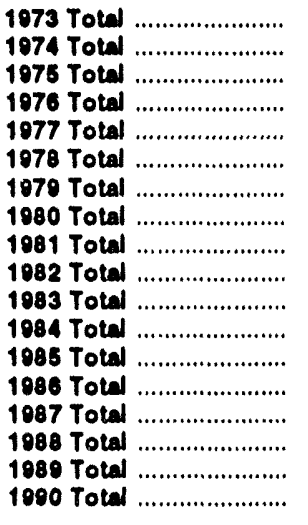 & $\begin{array}{r}654 \\
870 \\
991 \\
1,100 \\
1,183 \\
1,191 \\
1,335 \\
1,781 \\
2,667 \\
2,470 \\
2,113 \\
2,335 \\
1,870 \\
988 \\
859 \\
792 \\
580 \\
617\end{array}$ & $\begin{array}{r}1,079 \\
1,205 \\
1,263 \\
1,362 \\
1,562 \\
1,792 \\
1,920 \\
2,094 \\
2,533 \\
2,168 \\
1,660 \\
1,590 \\
1,282 \\
733 \\
673 \\
663 \\
652 \\
570\end{array}$ & $\begin{array}{r}6,038 \\
6,894 \\
7,207 \\
6,854 \\
7,402 \\
8,054 \\
7,478 \\
9,035 \\
12,297 \\
11,346 \\
10,271 \\
11,482 \\
9,445 \\
5,511 \\
5,179 \\
4,766 \\
4,001 \\
3,782\end{array}$ & $\begin{array}{r}7,771 \\
8,969 \\
0,461 \\
9,316 \\
10,147 \\
11,037 \\
10,733 \\
12,010 \\
17,497 \\
15,984 \\
14,044 \\
15,416 \\
12,606 \\
7,232 \\
6,711 \\
6,221 \\
5,233 \\
4,878\end{array}$ & $\begin{array}{r}9,597 \\
12,794 \\
15,888 \\
16,507 \\
17,517 \\
17,874 \\
19,368 \\
30,497 \\
40,176 \\
36,672 \\
35,086 \\
40,250 \\
33,142 \\
17,713 \\
15,327 \\
12,530 \\
9,750 \\
11,533\end{array}$ & $\begin{array}{r}5,896 \\
5,965 \\
6,907 \\
8,076 \\
10,557 \\
12,613 \\
13,250 \\
15,120 \\
17,374 \\
16,776 \\
12,896 \\
15,413 \\
12,970 \\
7,402 \\
7,084 \\
7,575 \\
8,573 \\
9,861\end{array}$ & $\begin{array}{r}4,428 \\
5,311 \\
6,529 \\
6,951 \\
7,634 \\
8,537 \\
8,560 \\
11,302 \\
14,987 \\
15,036 \\
14,065 \\
14,315 \\
11,763 \\
7,255 \\
6,302 \\
5,476 \\
4,490 \\
A 4,832\end{array}$ & $\begin{array}{r}19,821 \\
24,070 \\
29,424 \\
31,624 \\
35,708 \\
39,024 \\
41,178 \\
56,028 \\
72,537 \\
68,484 \\
62,047 \\
69,978 \\
57,875 \\
32,370 \\
28,713 \\
25,581 \\
22,822 \\
R 26,226\end{array}$ & $\begin{array}{l}10,251 \\
13,664 \\
16,970 \\
17,697 \\
18,700 \\
10,065 \\
20,703 \\
32,278 \\
42,843 \\
30,142 \\
37,109 \\
42,585 \\
35,021 \\
18,701 \\
16,186 \\
13,322 \\
10,330 \\
12,150\end{array}$ & $\begin{array}{r}6,975 \\
7,170 \\
8,170 \\
9,438 \\
12,119 \\
14,405 \\
15,170 \\
17,223 \\
19,907 \\
18,944 \\
14,556 \\
17,012 \\
14,252 \\
8,135 \\
7,757 \\
8,238 \\
9,225 \\
10,440\end{array}$ & $\begin{array}{r}10,466 \\
12,205 \\
13,736 \\
13,805 \\
15,036 \\
16,501 \\
16,038 \\
20,337 \\
27,284 \\
26,382 \\
24,336 \\
25,797 \\
21,208 \\
12,766 \\
11,481 \\
10,242 \\
8,491 \\
R 8,614\end{array}$ & $\begin{array}{r}27,692 \\
33,030 \\
38,885 \\
40,940 \\
45,855 \\
50,061 \\
51,011 \\
69,838 \\
90,034 \\
84,468 \\
76,001 \\
85,394 \\
70,481 \\
39,602 \\
35,424 \\
31,802 \\
28,055 \\
R_{31,204}\end{array}$ \\
\hline 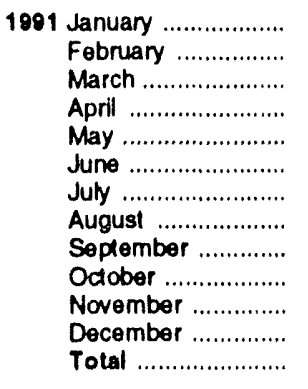 & $\begin{array}{r}56 \\
47 \\
53 \\
55 \\
39 \\
51 \\
56 \\
48 \\
39 \\
32 \\
25 \\
43 \\
544\end{array}$ & $\begin{array}{r}46 \\
47 \\
32 \\
36 \\
34 \\
42 \\
36 \\
37 \\
30 \\
45 \\
35 \\
43 \\
463\end{array}$ & $\begin{array}{r}247 \\
271 \\
267 \\
279 \\
263 \\
251 \\
301 \\
309 \\
255 \\
286 \\
302 \\
272 \\
2,303\end{array}$ & $\begin{array}{r}349 \\
365 \\
352 \\
370 \\
336 \\
344 \\
393 \\
394 \\
324 \\
363 \\
362 \\
R 358 \\
4,310\end{array}$ & $\begin{array}{r}1,166 \\
1,173 \\
1,098 \\
1,063 \\
996 \\
878 \\
903 \\
921 \\
816 \\
911 \\
725 \\
R 714 \\
R 11,364\end{array}$ & $\begin{array}{r}834 \\
681 \\
753 \\
704 \\
692 \\
727 \\
775 \\
755 \\
716 \\
767 \\
571 \\
692 \\
8,667\end{array}$ & $\begin{array}{r}352 \\
382 \\
379 \\
392 \\
387 \\
365 \\
401 \\
357 \\
374 \\
413 \\
357 \\
\text { P } 368 \\
4,527\end{array}$ & $\begin{array}{r}2,352 \\
2,236 \\
2,230 \\
2,159 \\
2,075 \\
1,970 \\
2,079 \\
2,033 \\
1,906 \\
2,091 \\
1,653 \\
R 1,774 \\
R 24,558\end{array}$ & $\begin{array}{r}1,222 \\
1,220 \\
1.151 \\
1,118 \\
1,035 \\
929 \\
959 \\
969 \\
855 \\
943 \\
750 \\
\text { P } 757 \\
\text { ค } 11,908\end{array}$ & $\begin{array}{r}880 \\
728 \\
785 \\
740 \\
726 \\
769 \\
811 \\
792 \\
746 \\
812 \\
606 \\
735 \\
9,130\end{array}$ & $\begin{array}{r}599 \\
653 \\
646 \\
671 \\
650 \\
616 \\
702 \\
666 \\
629 \\
699 \\
659 \\
\text { R } 640 \\
7,830\end{array}$ & $\begin{array}{r}2,701 \\
2,601 \\
2,582 \\
2,529 \\
2,411 \\
2,314 \\
2,472 \\
2,427 \\
2,230 \\
2,454 \\
2,015 \\
R 2,132 \\
R 28,868\end{array}$ \\
\hline 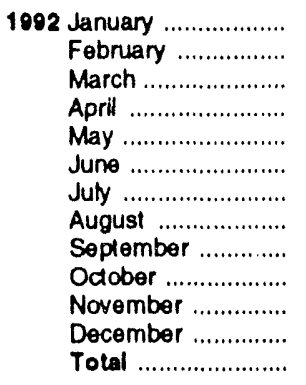 & $\begin{array}{r}46 \\
34 \\
38 \\
32 \\
35 \\
41 \\
43 \\
42 \\
36 \\
28 \\
38 \\
43 \\
456\end{array}$ & $\begin{array}{r}32 \\
30 \\
30 \\
22 \\
22 \\
32 \\
30 \\
32 \\
R_{23} \\
35 \\
30 \\
33 \\
R_{351}\end{array}$ & $\begin{array}{r}218 \\
167 \\
205 \\
233 \\
225 \\
209 \\
256 \\
241 \\
222 \\
205 \\
165 \\
225 \\
2,571\end{array}$ & $\begin{array}{r}296 \\
231 \\
273 \\
287 \\
282 \\
282 \\
329 \\
315 \\
R 281 \\
268 \\
233 \\
301 \\
R 3,378\end{array}$ & $\begin{array}{r}740 \\
590 \\
721 \\
656 \\
636 \\
626 \\
664 \\
617 \\
785 \\
750 \\
690 \\
8743 \\
{ }^{\circ} 8,218\end{array}$ & $\begin{array}{r}586 \\
553 \\
482 \\
415 \\
470 \\
462 \\
543 \\
600 \\
R 659 \\
948 \\
893 \\
R 973 \\
R 7,584\end{array}$ & $\begin{array}{l}317 \\
273 \\
320 \\
297 \\
374 \\
330 \\
312 \\
357 \\
339 \\
358 \\
331 \\
391 \\
3,989\end{array}$ & $\begin{array}{r}1,643 \\
1,416 \\
1,523 \\
1,368 \\
1,480 \\
1,418 \\
1,519 \\
1,574 \\
1,783 \\
2,056 \\
1,914 \\
R_{2,107} \\
R_{19,801}\end{array}$ & $\begin{array}{r}786 \\
624 \\
759 \\
688 \\
671 \\
667 \\
707 \\
659 \\
821 \\
77 J \\
728 \\
\text { ค } 786 \\
\text { P }_{B, 674}\end{array}$ & $\begin{array}{r}618 \\
583 \\
512 \\
437 \\
492 \\
494 \\
573 \\
632 \\
682 \\
983 \\
923 \\
\text { ค } 1,006 \\
7,935\end{array}$ & $\begin{array}{r}535 \\
440 \\
525 \\
530 \\
599 \\
539 \\
568 \\
598 \\
561 \\
563 \\
496 \\
616 \\
6,570\end{array}$ & $\begin{array}{r}1,939 \\
1,647 \\
1,796 \\
1,655 \\
1,762 \\
1,700 \\
1,848 \\
1,889 \\
2,064 \\
2,324 \\
2,147 \\
{ }^{2} 2,408 \\
{ }_{2} 2,179\end{array}$ \\
\hline 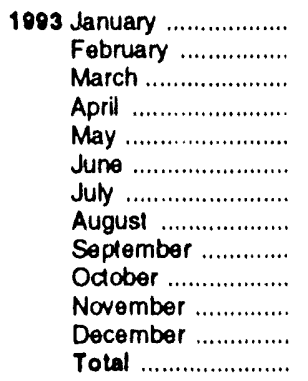 & $\begin{array}{r}41 \\
32 \\
23 \\
41 \\
36 \\
35 \\
34 \\
20 \\
28 \\
32 \\
24 \\
25 \\
371\end{array}$ & $\begin{array}{r}35 \\
42 \\
28 \\
28 \\
33 \\
R 31 \\
26 \\
36 \\
29 \\
36 \\
28 \\
29 \\
381\end{array}$ & $\begin{array}{r}162 \\
171 \\
175 \\
205 \\
176 \\
193 \\
254 \\
226 \\
253 \\
278 \\
214 \\
193 \\
2,500\end{array}$ & $\begin{array}{r}238 \\
245 \\
226 \\
274 \\
245 \\
\text { R } 259 \\
314 \\
282 \\
\text { R } 310 \\
346 \\
266 \\
247 \\
3,252\end{array}$ & $\begin{array}{r}614 \\
551 \\
593 \\
562 \\
588 \\
R_{611} \\
706 \\
665 \\
R 797 \\
818 \\
582 \\
536 \\
7,623\end{array}$ & $\begin{array}{r}.02 \\
917 \\
875 \\
614 \\
679 \\
{ }^{2} 558 \\
549 \\
937 \\
838 \\
840 \\
650 \\
673 \\
0,032\end{array}$ & $\begin{array}{r}290 \\
346 \\
236 \\
355 \\
462 \\
R 374 \\
527 \\
381 \\
435 \\
511 \\
397 \\
353 \\
4,667\end{array}$ & $\begin{array}{r}1,806 \\
1,814 \\
1,704 \\
1,531 \\
1,729 \\
R 1,543 \\
1,782 \\
1,983 \\
R 2,070 \\
2,169 \\
1,629 \\
1,562 \\
21,322\end{array}$ & $\begin{array}{r}655 \\
583 \\
616 \\
603 \\
624 \\
R \quad 646 \\
740 \\
685 \\
825 \\
850 \\
606 \\
561 \\
7,994\end{array}$ & $\begin{array}{r}937 \\
959 \\
903 \\
642 \\
712 \\
\mathrm{R} 589 \\
575 \\
973 \\
867 \\
876 \\
678 \\
702 \\
9,413\end{array}$ & $\begin{array}{r}452 \\
517 \\
411 \\
560 \\
638 \\
R 567 \\
781 \\
607 \\
688 \\
789 \\
611 \\
546 \\
7,167\end{array}$ & $\begin{array}{r}2,044 \\
2,059 \\
1,930 \\
1,805 \\
1,974 \\
R 1,802 \\
2,096 \\
2,265 \\
2,380 \\
2,515 \\
1,895 \\
1,809 \\
24,574\end{array}$ \\
\hline
\end{tabular}

Px=Revised data.

Noles: - Service wells, stratigraphic tests, and core tests are excluded.

- Geographic coverage is the 50 States and the District of Columbia. - Due to the method of estimation, dala shown on this page are frequently revised.
See end of section.

Sources: Energy information Administration computations, which are based on well reports submitted to the American Petroleum Institule by the Petroleum Intormation Corporation, Denver, Colorado. 


\section{Oil and Gas Resource Development Notes}

Three well types are considered in the Monthly Energy Review (MER) drilling statistics: "completed for oil," "completed for gas," and "dry hole." Wells that productively encounter both crude oil and natural gas are categorized as "completed for oil." Both development wells and exploratory wells (new field wildcats, new pool tests, and extension tests) are included in the statistics. All other classes of wells drilled in connection with the search for producible hydrocarbons are excluded.

Prior to the March $1985 M E R$, drilling statistics consisted of completion data for the above types and classes of wells as reported to the American Petroleum Institute (API) during a given month. Due to time lags between the date of well completion and the date of completion reporting to the $\mathrm{API}$, as-reported well completions proved to be an inaccurate indicator of drilling activity.
During 1982, for example, as-reported well completions rose, while the number of actual completions fell. Consequently, the drilling statistics published since the March 1985 MER are Energy Information Administration-generated (EIA) estimates produced by statistically imputing will counts and footage based on the partial data available from the API.

Estimates for a given month are first published in the $M E R$ for that month. Revisions of the "oil," "gas," and "dry" components are made in the 6th, 12th, and 24th subsequent months, as newly reported data allow refinement of the estimates. Unscheduled revisions may also occur when the latest estimate differs by more than 15 percent during the first 5 months, more than 10 percent during the next 6 months, or more than 2 percent thereafter through 5 years. After 5 years, the reported API data are published in lieu of EIA-generated estimates. Additional information about the EIA estimation methodology may be found in "Estimating Well Completions," the feature article published in the March 1985 MER. 


\section{Section 6. Coal}

Coal production in November 1993 totaled 80 million short tons, 1 percent ${ }^{6}$ lower than coal production in November 1992.

Electric utility coal consumption in October 1993 totaled 65 million short tons, 3 percent higher than the consumption level in October 1992.
Electric utility coal stocks were 115 million short tons at the end of October 1993, down from 157 million short tons at the end of October 1992.

Coal exports in October 1993 totaled 6 million short tons, 13 percent lower than exports in October 1992. Coal imports in October 1993 totaled 1 million short tons, more than double the amount of coal imported in October 1992.

\footnotetext{
"Percentage changes are based on unrounded data.
} 
Figure 6.1 Coal

(Million Short Tuns)

Overview, 1973-1992

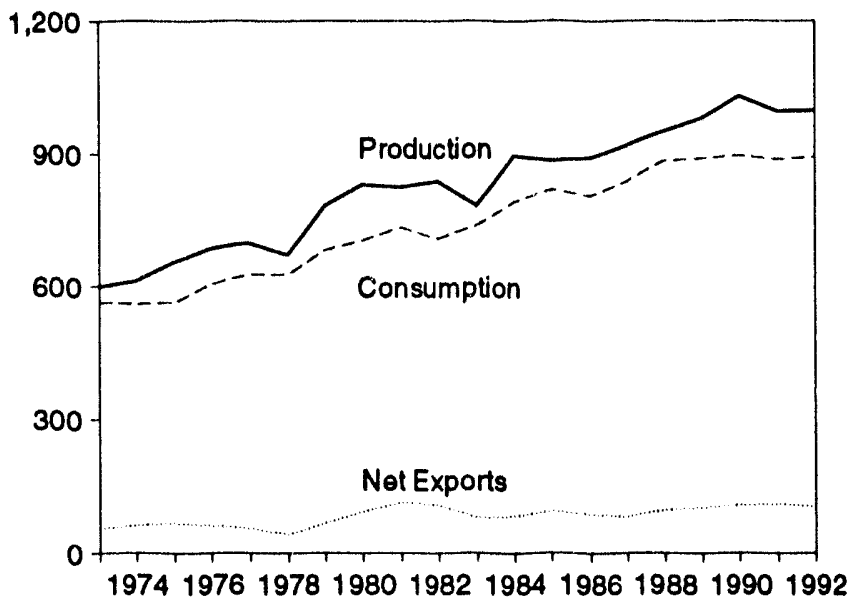

Consumption by Sector, 1973-1992

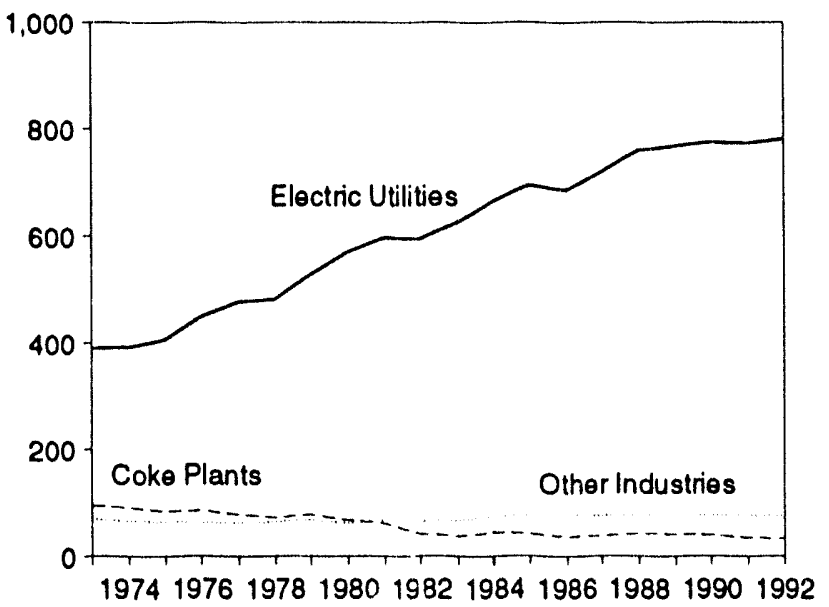

Stocks, End of Year, 1973-1992

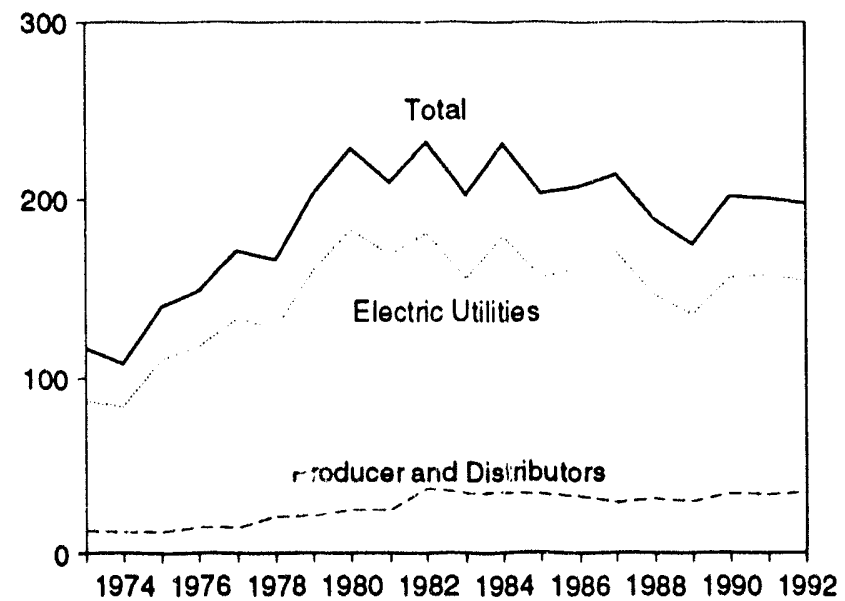

Overview, Monthly

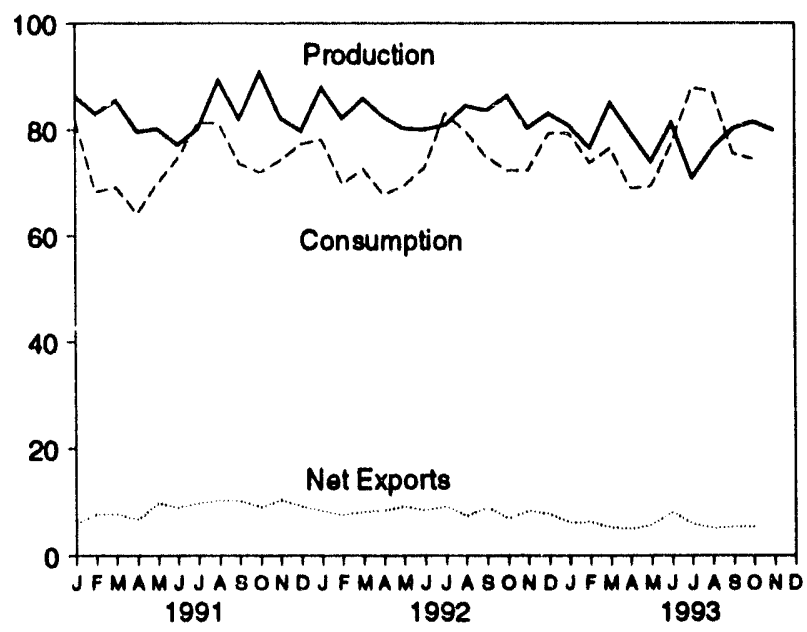

Consumption by Electric Utilities, Monthly

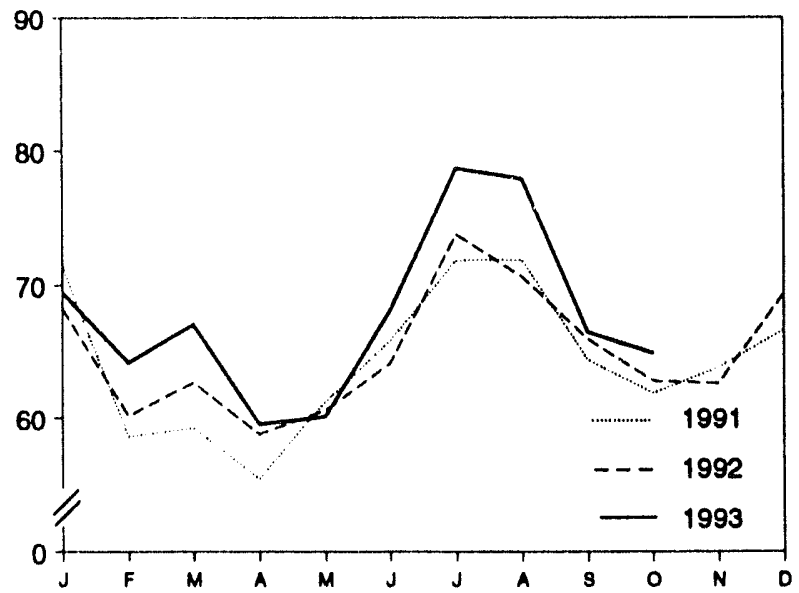

Stocks at Electric Utilities, End of Month

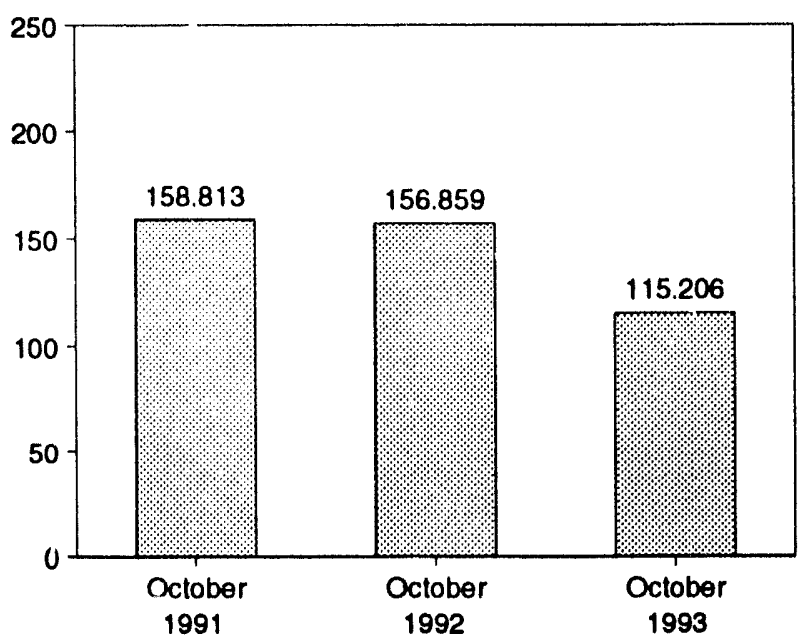

Note: Because vertical scales differ, graphs should not be compared. Sources: Tables 6.1, 6.2, and 6.3. 
Table 6.1 Coal Overview

(Thousand Short Tons)

\begin{tabular}{|c|c|c|c|c|c|}
\hline & Production & Consumption & Imports & Exports & Stocksb \\
\hline 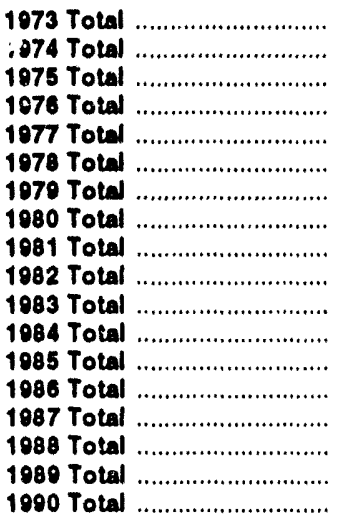 & $\begin{array}{r}598,568 \\
610,023 \\
654,641 \\
684,913 \\
697,205 \\
670,164 \\
781,134 \\
829,700 \\
823,775 \\
c 838,111 \\
782,091 \\
895,921 \\
883,638 \\
890,315 \\
818,762 \\
950,265 \\
980,729 \\
1,029,076\end{array}$ & $\begin{array}{l}562,584 \\
558,402 \\
562,640 \\
603,700 \\
625,291 \\
625,225 \\
680,524 \\
c 702,729 \\
c 732,628 \\
c 706,910 \\
c 736,671 \\
791,296 \\
818,049 \\
804,231 \\
836,841 \\
883,642 \\
889,689 \\
895,480\end{array}$ & $\begin{array}{r}127 \\
2,080 \\
940 \\
1,203 \\
1,647 \\
2,953 \\
2,050 \\
1,194 \\
1,043 \\
742 \\
1,271 \\
1,286 \\
1,952 \\
2,212 \\
1,747 \\
2,134 \\
2,851 \\
2,699\end{array}$ & $\begin{array}{r}53,587 \\
60,661 \\
66,309 \\
60,021 \\
54,312 \\
40,714 \\
66,042 \\
91,742 \\
112,541 \\
106,277 \\
77,772 \\
81,483 \\
92,680 \\
85,518 \\
79,607 \\
95,023 \\
100,815 \\
105,804\end{array}$ & $\begin{array}{r}116,865 \\
107,057 \\
140,158 \\
148,659 \\
171,323 \\
166,246 \\
202,472 \\
228,407 \\
209,423 \\
c 232,037 \\
c 202,585 \\
231,300 \\
203,367 \\
207,310 \\
213,780 \\
188,831 \\
175,087 \\
201,620\end{array}$ \\
\hline 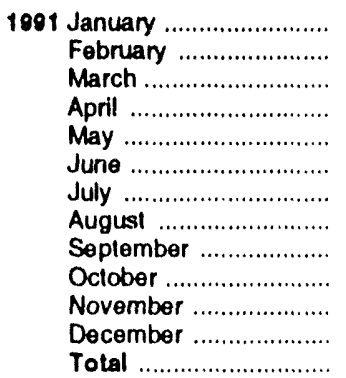 & $\begin{array}{r}86,261 \\
83,036 \\
85,450 \\
79,633 \\
80,190 \\
77,182 \\
80,151 \\
89,321 \\
81,966 \\
90,821 \\
82,194 \\
79,779 \\
995,984\end{array}$ & $\begin{array}{r}81,738 \\
68,282 \\
69,188 \\
64,184 \\
69,981 \\
74,592 \\
81,221 \\
81,196 \\
73,676 \\
72,018 \\
74,239 \\
77,305 \\
887,621\end{array}$ & $\begin{array}{l}263 \\
429 \\
246 \\
198 \\
248 \\
284 \\
348 \\
248 \\
387 \\
214 \\
298 \\
225 \\
3,390\end{array}$ & $\begin{array}{r}6,214 \\
8,127 \\
7,977 \\
6,917 \\
10,018 \\
9,278 \\
10,099 \\
10,541 \\
10,557 \\
9,244 \\
10,602 \\
9,393 \\
108,969\end{array}$ & $\begin{array}{l}199,927 \\
206,312 \\
213,647 \\
218,443 \\
219,221 \\
214,716 \\
204,378 \\
199,237 \\
197,488 \\
202,136 \\
201,670 \\
200,682 \\
200,682\end{array}$ \\
\hline 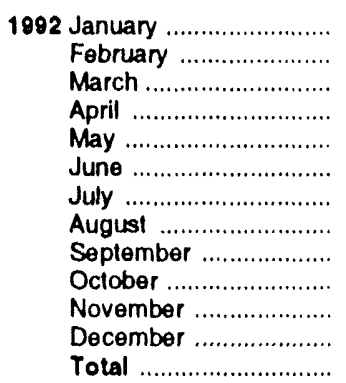 & $\begin{array}{r}87,948 \\
82,139 \\
85,869 \\
82,449 \\
80,250 \\
80,036 \\
80,862 \\
84,537 \\
83,657 \\
86,364 \\
80,335 \\
83,100 \\
997,545\end{array}$ & $\begin{array}{r}78,162 \\
69,837 \\
72,595 \\
67,802 \\
69,430 \\
72,804 \\
83,074 \\
79,736 \\
74,888 \\
72,405 \\
72,329 \\
79,359 \\
892,421\end{array}$ & $\begin{array}{l}272 \\
213 \\
193 \\
239 \\
339 \\
466 \\
362 \\
197 \\
323 \\
471 \\
377 \\
351 \\
3,803\end{array}$ & $\begin{array}{r}8,590 \\
7,759 \\
8,383 \\
8,616 \\
9,483 \\
9,911 \\
9,572 \\
7,605 \\
9,304 \\
7,443 \\
8,718 \\
8,134 \\
102,516\end{array}$ & $\begin{array}{l}200,325 \\
204,716 \\
208,485 \\
211,429 \\
214,714 \\
213,783 \\
202,271 \\
198,710 \\
197,076 \\
200,971 \\
201,683 \\
197,685 \\
107,685\end{array}$ \\
\hline 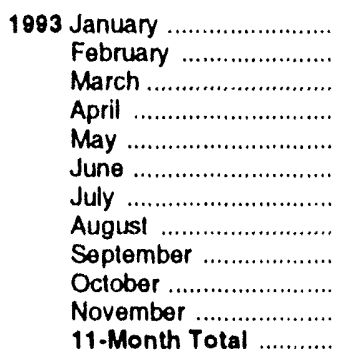 & $\begin{array}{r}80,780 \\
76,608 \\
85,072 \\
79,504 \\
74,063 \\
81,307 \\
\text { R } 70,994 \\
R 76,485 \\
R 80,237 \\
81,525 \\
79,912 \\
866,488\end{array}$ & $\begin{array}{c}79,309 \\
73,834 \\
76,552 \\
69,032 \\
69,362 \\
77,408 \\
887,970 \\
887,166 \\
\text { R } 75,576 \\
74,522 \\
\text { NA } \\
\text { NA }\end{array}$ & $\begin{array}{r}344 \\
454 \\
415 \\
281 \\
298 \\
514 \\
643 \\
747 \\
753 \\
1.054 \\
\text { NA } \\
\text { NA }\end{array}$ & $\begin{array}{l}6,506 \\
6,715 \\
5,648 \\
5,268 \\
6,060 \\
8,619 \\
6,573 \\
5,830 \\
6,120 \\
6,485 \\
\text { NA } \\
\text { NA }\end{array}$ & $\begin{array}{c}195,074 \\
191,990 \\
190,977 \\
194,014 \\
195,001 \\
189,344 \\
\text { A } 167,968 \\
\text { R } 152,778 \\
\text { A } 148,980 \\
150,834 \\
\text { NA } \\
\text { NA }\end{array}$ \\
\hline $\begin{array}{l}199211 \text {-Month Total .......... } \\
1991 \text { 11-Month Total .......... }\end{array}$ & $\begin{array}{l}914,445 \\
816,205\end{array}$ & $\begin{array}{r}:, 062 \\
0,0,316\end{array}$ & $\begin{array}{l}3,452 \\
3,164\end{array}$ & $\begin{array}{l}94,383 \\
99,575\end{array}$ & $\begin{array}{l}201,683 \\
201,670\end{array}$ \\
\hline
\end{tabular}

a Includes Puerto Rico.

b Slocks held by electric utilities, coke plants, general industry, and coal producers and distributors at end of period. Slocks held at retail dealers for consumption by the residential and commercial sector are excluded.

c See Note 6 al end of section.

$R=$ Revised data. NA=Nol available. $E=$ Estimate.

Noles: - Geographic coverage is the 50 Slates and the District of Columbia. - Data through 1991 are linal. Subsequent data are preliminary. - Totals may not equal sum of components due to independent rounding
- For methodology used to calculate production, consumption, and stocks, see Notes 1, 2, and 3 al end of section.

Sources: - Production: 1973-September 1977-U.S. Department of the Interior, Bureau of Mines. Minerals Yearbook and Minerals Industry Surveys. October 1877 forward-Energy Intormation Administration, Weekly Coal Production. - Consumption: Table 6.2. - Imports and Exports: U.S. Department of Commerce, Bureau of the Census, Monthly Reports IM-145 (Imports) and EM-522 (Exports). - Stocks: Table 6.3. 


\begin{tabular}{|c|c|c|c|c|c|}
\hline & \multirow[b]{2}{*}{$\begin{array}{c}\text { Residentlal } \\
\text { and } \\
\text { Commerclal }\end{array}$} & \multicolumn{2}{|c|}{ Industrial } & \multirow[b]{2}{*}{$\begin{array}{l}\text { Electrie } \\
\text { Utilitles }\end{array}$} & \multirow[b]{2}{*}{ Total } \\
\hline & & $\begin{array}{l}\text { Coko } \\
\text { Plants }\end{array}$ & $\begin{array}{c}\text { Other Industrial } \\
\text { Including } \\
\text { Tranxportatlon }\end{array}$ & & \\
\hline 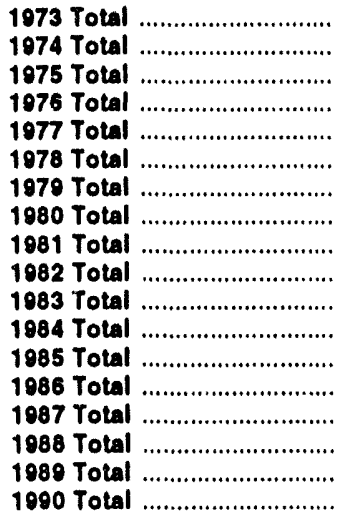 & $\begin{array}{r}11,117 \\
11,417 \\
9,410 \\
8,916 \\
8,954 \\
9,511 \\
8,388 \\
96,452 \\
97,422 \\
8,240 \\
8,448 \\
9,130 \\
7,779 \\
7,667 \\
6,914 \\
7,130 \\
6,167 \\
6,724\end{array}$ & $\begin{array}{r}94,101 \\
90,191 \\
83,598 \\
84,704 \\
77,730 \\
71,394 \\
77,368 \\
66,657 \\
a 61,015 \\
40,908 \\
37,033 \\
44,022 \\
41,056 \\
35,924 \\
36,057 \\
41,888 \\
40,508 \\
38,877\end{array}$ & $\begin{array}{l}68,154 \\
64,983 \\
63,670 \\
61,790 \\
61,472 \\
63,085 \\
67,717 \\
60,347 \\
67,385 \\
964,096 \\
965,079 \\
73,745 \\
75,372 \\
75,583 \\
75,175 \\
76,252 \\
76,134 \\
76,330\end{array}$ & $\begin{array}{l}389,212 \\
391,811 \\
405,962 \\
448,371 \\
477,128 \\
481,235 \\
527,051 \\
569,274 \\
596,797 \\
593,666 \\
625,211 \\
664,399 \\
693,841 \\
685,056 \\
717,804 \\
758,372 \\
766,888 \\
773,549\end{array}$ & $\begin{array}{r}562,584 \\
558,402 \\
562,640 \\
803,700 \\
625,201 \\
625,225 \\
680,524 \\
702,720 \\
732,628 \\
706,910 \\
736,671 \\
701,298 \\
818,040 \\
804,231 \\
836,041 \\
883,642 \\
889,699 \\
805,480\end{array}$ \\
\hline 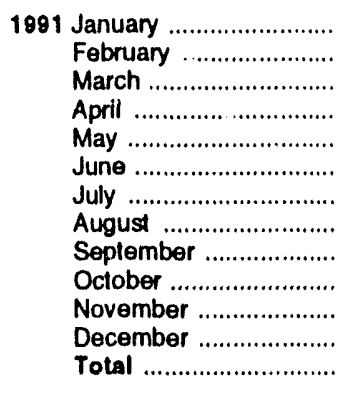 & $\begin{array}{r}862 \\
605 \\
541 \\
403 \\
330 \\
322 \\
427 \\
386 \\
319 \\
353 \\
677 \\
868 \\
6,094\end{array}$ & $\begin{array}{r}2,928 \\
2,479 \\
2,883 \\
2,675 \\
2,710 \\
2,690 \\
2,929 \\
2,916 \\
2,932 \\
2,902 \\
2,896 \\
2,913 \\
33,854\end{array}$ & $\begin{array}{r}6,541 \\
6,584 \\
6,492 \\
5,663 \\
5,713 \\
5,763 \\
6,014 \\
6,011 \\
6,026 \\
6,880 \\
6,852 \\
6,865 \\
75,405\end{array}$ & $\begin{array}{r}71,406 \\
58,614 \\
59,272 \\
55,443 \\
61,228 \\
65,817 \\
71,852 \\
71,884 \\
64,397 \\
61,883 \\
63,814 \\
66,659 \\
772,268\end{array}$ & $\begin{array}{r}81,738 \\
68,282 \\
69,188 \\
64,184 \\
69,981 \\
74,592 \\
81,221 \\
81,196 \\
73,676 \\
72,018 \\
74,239 \\
77,305 \\
887,621\end{array}$ \\
\hline 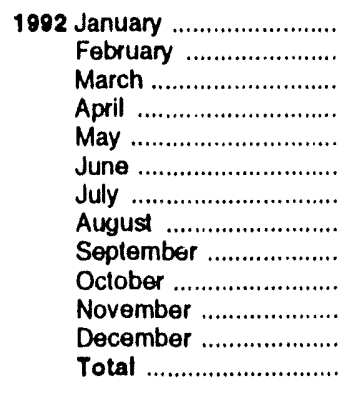 & $\begin{array}{r}735 \\
582 \\
526 \\
532 \\
321 \\
296 \\
474 \\
393 \\
368 \\
367 \\
642 \\
916 \\
6,153\end{array}$ & $\begin{array}{r}2,783 \\
2,656 \\
2,901 \\
2,723 \\
2,757 \\
2,617 \\
2,802 \\
2,773 \\
2,625 \\
2,586 \\
2,562 \\
2,581 \\
32,366\end{array}$ & $\begin{array}{r}6,379 \\
6,416 \\
6,464 \\
5,754 \\
5,762 \\
5,769 \\
5,983 \\
5,933 \\
5,927 \\
6,645 \\
6,513 \\
6,497 \\
74,042\end{array}$ & $\begin{array}{r}68,264 \\
60,183 \\
62,705 \\
58,794 \\
60,591 \\
64,122 \\
73,815 \\
70,637 \\
65,967 \\
62,806 \\
62,612 \\
69,365 \\
779,860\end{array}$ & $\begin{array}{r}78,162 \\
69,837 \\
72,595 \\
67,802 \\
69,430 \\
72,804 \\
83,074 \\
79,736 \\
74,888 \\
72,405 \\
72,329 \\
79,359 \\
892,421\end{array}$ \\
\hline 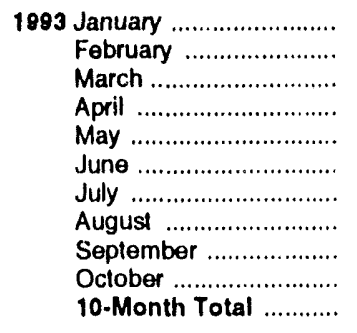 & $\begin{array}{r}747 \\
725 \\
580 \\
721 \\
380 \\
492 \\
R_{457} \\
\mathrm{R}_{411} \\
\mathrm{R}^{310} \\
438 \\
\mathbf{5 , 2 6 1}\end{array}$ & $\begin{array}{r}2,674 \\
2,468 \\
2,640 \\
2,578 \\
2,719 \\
2,588 \\
R 2,678 \\
R 2,664 \\
R 2,618 \\
2,779 \\
26,408\end{array}$ & $\begin{array}{r}6,397 \\
6,440 \\
6,259 \\
6,168 \\
6,162 \\
6,215 \\
R 6,128 \\
{ }^{R} 6,159 \\
{ }^{R} 6,143 \\
6,396 \\
62,467\end{array}$ & $\begin{array}{r}69,490 \\
6.1,201 \\
67,073 \\
59,563 \\
60,102 \\
68,113 \\
78,708 \\
77,932 \\
66,504 \\
64,909 \\
676,595\end{array}$ & $\begin{array}{r}79,309 \\
73,834 \\
76,552 \\
69,032 \\
69,362 \\
77,408 \\
87,970 \\
877,166 \\
875,576 \\
74,522 \\
770,731\end{array}$ \\
\hline $\begin{array}{l}1992 \text { 10-Month Total ........... } \\
1991 \text { 10-Month Total .......... }\end{array}$ & $\begin{array}{l}4,595 \\
4,549\end{array}$ & $\begin{array}{l}27,223 \\
28,044\end{array}$ & $\begin{array}{l}61,032 \\
61,689\end{array}$ & $\begin{array}{l}647,883 \\
641,795\end{array}$ & $\begin{array}{l}740,734 \\
736,077\end{array}$ \\
\hline
\end{tabular}

a See Note 6 at end of section.

$R=$ Revised data. $E=$ Estimate.

Note: - For sector-specific reporting and estimating intormation, see Nole 2 at end of section. - Geographic coverage is the 50 States and the District of Columbia. - Data through 1991 are tinal. Subsequent data are preliminary. - Totats may not equal sum of components due to independent rounding.

Sources: - Residential and Commercial: 1973-1976-U.S. Department of the Interior (DOI). Bureau of Mines (BOM), Minerals Yearbook. January-September $1977-D O I$, BOM, Form 6-1400, "Monthly Coal Report, Retail Dealers-Upper Lake Docks." October 1977-1979-Energy Information Administration (EIA), Form EIA-2, "Monthly Coal Report, Retail Dealers-Upper Lake Docks." 1980 forward-EIA, Form EIA-6, "Coal Distribution Report. - Coke Plants: 1973-September 1977-DOI,
BOM, Minerals Yearbook and Minerals Industry Surveys. October 1977-1980-EIA, Form EIA-5/5A, "Coke and Coal Chemicals: Monthly/Annual." 1881-1984-EIA, Form EIA-5/5A, "Coke Plant Report-Quarterly/Annual Supplement." 1985 forward-EIA, Form EIA-5, "Coke Plant Report," quarterly. - Other Industrial: 1973-September 1977-DOI, BOM, Minerals Yearbook and Minerals Industry Surveys. October 1977-1979-ElA, Form ElA-3, "Monthly Coal Consumption Report-Manutacluring Planis." 1980 forward-EIA, Form EIA-3, "Quarterty Coal Consumption Report-Manufacturing Plants," and Form EIA-6, "Coal Distribution Report." - Electric Utilities: 1973-September 1977-DOI, BOM, Minerals Yearbook and Minerals Industry Surveys. October 1077 forward-EIA, Form EIA-759 (formerly Form FPC-4), "Monthly Power Plant Report." 
Table 6.3 Coal Stocks, End of Period

(Thousand Short Tons)

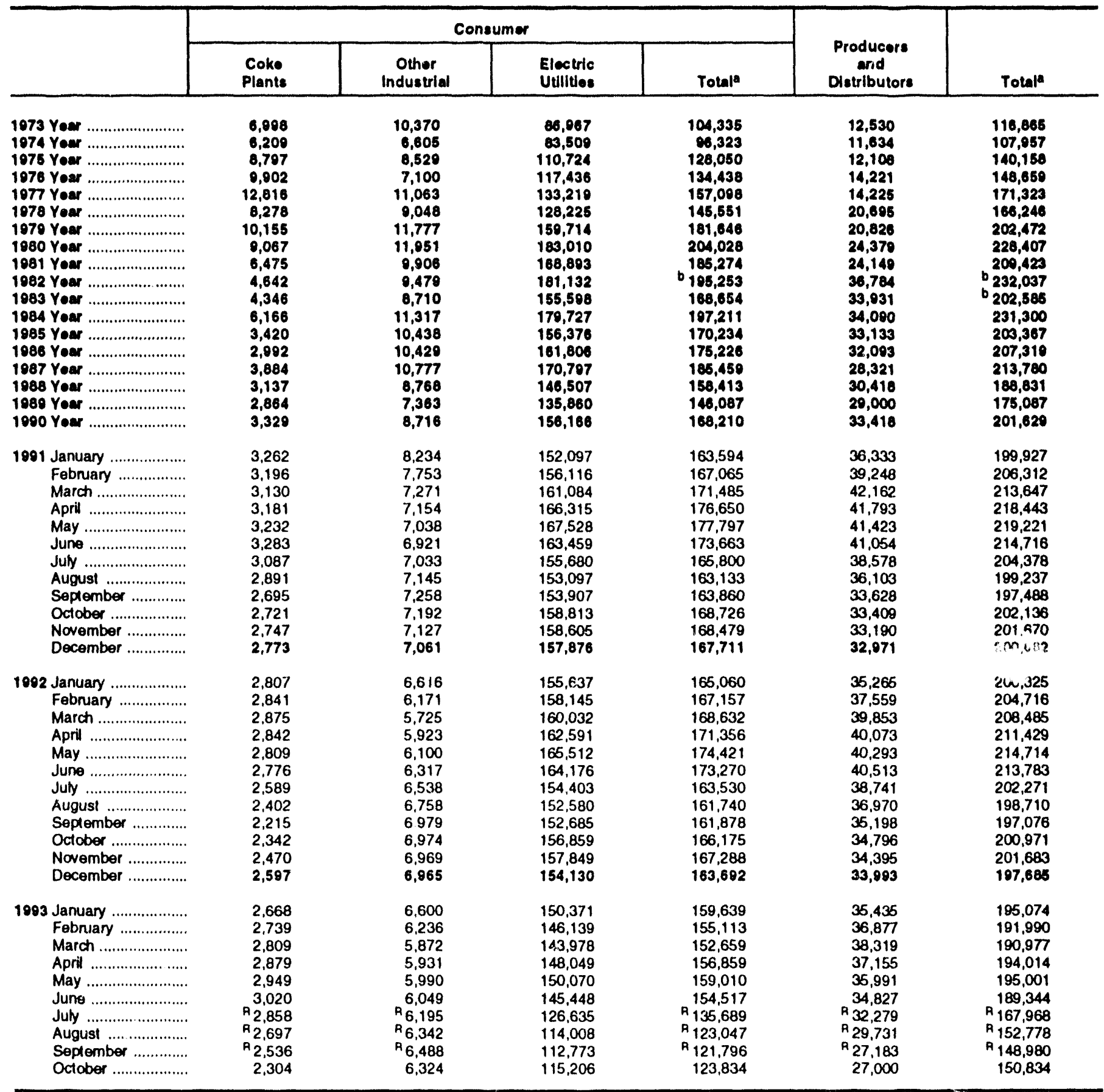

a Excludes stocks held at retail dealers for consumption by the residential and commercial sector.

b See NCle 6 at end of section.

$R=$ Pevised data. $E=$ Estimate.

Notes: - For sector-specilic reporting and estimating information, see Note 3 at end of section. - Geographic coverage is the 50 States and the District of Columbia. - Data through 1991 are final. Subsequent data are preliminary. - Totals may nol equal sum of components due to independent rounding.

Sources: - Coke Plants: 1973-Soptomber 1977-U.S. Department of the Interior (DOI), Bureau of Mines (BOM), Minerals Yearbook and Minerals Industry Surveys. October 1977-1080-Energy Inlormation Administration
(EIA), Form EIA-5/5A, "Coke and Coal Chemicals-Monthly/Annual." 1981-1984-EIA, Form EIA.5/5A, "Coke Plant Repont-Quarterly/Annual Supplement." 1985 forward-EIA, Form EIA-5, "Coke Plant Report, quarterty. - Other Industrlal: 1973-September 1077-DOI, BOM, Minerals Yearbook and Minerals Indusiry Surveys. October 1977-1979-EIA, Form ElA-3, "Monthly Coal Consumption Report-Manufacturing Plants." 1080 forward-EIA. Form EIA-3, Quartsily Coal Consumption ReportManufacturing Plants," and Form ElA-6, "Coal Distribution Report." - Eloctric Utilitios: 1973-Soptomber 1977-DOI, BOM, Minerals Yearbook and Minerals industry Sunvers. October 1977 forward-Elis, Form ElA.759 (formerly Form FPC.4), "Monthly Power Plant Report." - Producere and Distributore: EIA, Form EIA-6, "Coal Distribution Repon:" 


\section{Coal Notes}

1. Production: Preliminary monthly estimates of national coal production are the sum of weekly estimates developed by the Energy Information Administration(EIA) and published in the Weekly Coal Production report. When a week extends into a new month, production is allocated on a daily basis and added to the appropriate month. Weekly estimates are based on Association of American Railroads data showing the number of railcars loaded with coal during the week by Class I and certain other railroads. This number is converted into tons of coal by lia by using the average number of tons of coal per railcar loaded reported in the most recent "Quarterly Freight Commodity Statistics" from the Interstate Commerce Commission. If an average coal tonnage per railcar loaded is not available for a specific railroad, the national average is used. To derive the estimate of total weekly production, the total rail tonnage for the week is divided by the ratio of quarterly production shipped by rail and total quarterly production. Data for the corresponding quarter of previous years are used to derive this ratio. This method insures that the seasonal variations are preserved in the production estimates.

When preliminary quarterly data become available, the monthly and weekly estimates are addusted to conform to the quarterly figure. The adjustment procedure uses State-level production data and is explained in EI $\Lambda$ 's Quarterly Coal Report. Initial estimates of annual production published in January of the following year are based on preliminary production data covering the first 9 months (three quarters) and weekly/monthly estimates for the fourth quarter. The fourth quarter estimates may or may not he revised when preliminary data become available in March of the following year, depending on the magnitude of the difference between the estimates and the preliminary data. In any event. all quarterly, monthly, and weekly production figures are adjusted to conform to the final annual production data published in the Monthly Energy Review in the fall of the following year.

2. Consumption: Coal consumption data are reported by major end-use sector. Estimated data for the most recent months (designated by an "I:") are derived from forecasted values shown in the EIA Short-Term Energy Outlook (DOE/EIA-0202) table titled "Supply and Disposition of Coal: Mid World Oil Price Case." The monthly estimates are one-third of the quarterly values shown in the then current issue of the publication, regularly released in February, May, August, and November. The estimates are revised quarterly as collected data become available from the data sources. Sector-specific information follows.

- Residential and Commercial-Prior to 1980, monthly consumption estimates for the residential and commercial sector were derived by using reported data to modify baseline figures developed by the Bureau of Mines. From 1980-1987, month- ly estimates were derived by proportioning reported quarterly data by using the ratios of monthly-to-quarterly consumption data in 1979, the last year in which monthly data were reported on Form EIA-2. During 1981 and 1982, the estimates were also modified to reflect air temperature degree-days. Quarterly consumption data were directly from reported data and were defined as distribution to the residential and commercial sector as reported by coal producers and distributors on Form EIA-6. Beginning in January 1988, monthly residential and commercial consumption estimates are derived from reported quarterly data by using wonthly national average population weighted heating/cooling degree-days obtained from the National Oceanic and Atmospheric Administration. The monthly ratios are the monthly national sum of heating and cooling degree-days as a proportion of the quarterly national sum. Quarterly consumption data are directly from reported data.

- Coke Plants-Prior to 1980, monthly coke plant consumption data were taken directly from reported data. From 1980-1987, coke plant consumption estimates were derived by proportioning reported quarterly data by using the ratios of monthly-t()-quarterly consumption data in 1979 , the last year in which inonthly data were reported. Beginning in January 1988, monthly coke plant consumption estimates are derived from the reported quarterly data by using monthly ratios of raw steel production data from the American Iron and Steel Institute. The ratios are the monthly raw steel production from open hearth and basic oxygen process furnaces as a proportion of the quarterly production from those kinds of furnaces.

- Other Industrial-Prior to 1978, monthly consumption data for the other industrial sector (i.e., all industrial users minus coke plants) were derived by using reported data to modify baseline consumption tigures from the most recent Bureau of the Census Annual Survey of Manufactures or Census of Manufactures. For 1978 and 1979 monthly estimates were derived from data reported on Forms EIA-3 and EIA-6. From 1980-1987, monthly figures were estimated by proportioning quarterly data by using the ratios of monthly-toquarterly consumption data in 1979, the last year in which monthly data were reported on Form EIA-3. Quarterly consumption data were derived by adding beginning stocks at manufacturing plants to current receipts and subtracting ending stocks at manufacturing plants. In this calculation, current receipts were the greater of either reported receipts from manufacturing plants (Form EIA-3) or reported shipments to the other industrial sector (Form FiA-6), thereby eisuring that agriculture, forestry, fishing, mining, and construction consumption data were included where appropriate. Starting in January 1988, monthly consumption for the other industrial sector is estimated from reported quarterly data by using 


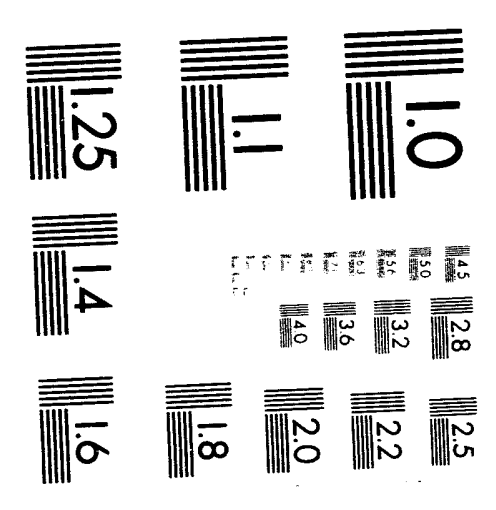



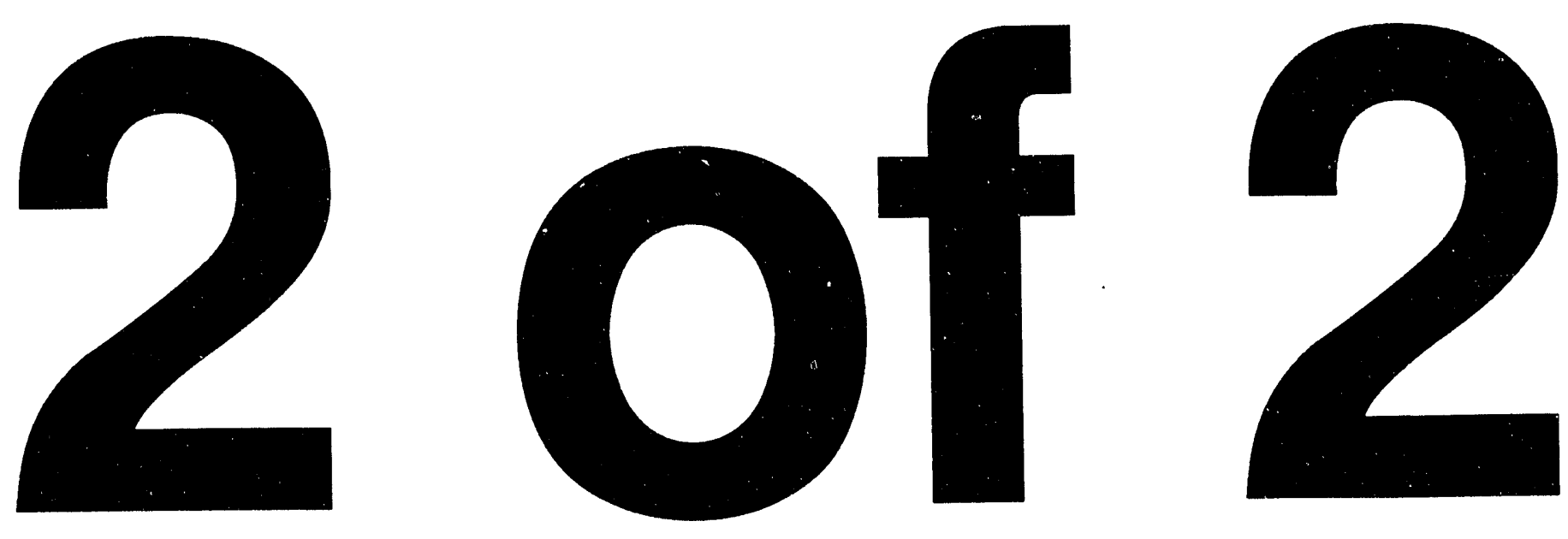
ratios derived from industrial production indices published by the Board of Governors of the Federal Reserve System. Indices for six major industry groups are used as the basis for calculating the ratios: foods, Standard Industrial Classification (SIC) 20; paper and products, SIC 26; chemicals and products, SIC 28; petroleum products, SIC 29; clay, glass, and stone products, SIC 32; and primary metals, SIC 33. The monthly ratios are computed as the monthly sum of the weighted indices as a proportion of the quarterly sum of the weighted indices by using the 1977 proportion as the weights.

- Electric Utilities-Monthly consumption data for electric utility plants are directly from reported data.

3. Stocks: Coal stocks data are reported by major enduse sector. Estimated data for the most recent months (designated by an "E") are derived from forecasted values shown in the EIA Short-Term Energy Outlook (DOE/EIA-0202) table titled "Supply and Disposition of Coal: Mid World Oil Price Case." The monthly estimates are one-third of the quarterly values shown in the then current issue of the publication, regularly released in February, May, August, and November. The estimates are revised quarterly as collected data become available from the data sources. Sector-specific information follows.

- Coke Plants-Prior to 1980 , monthly stocks at coke plants were taken directly from reported data. From 1980 forward, coke plant stocks are estimated by using one-third of the current quarterly change to indicate the monthly change in stocks. Quarterly stocks are directly from data reported on Form EIA-5.
- Other Industrial-Prior to 1978 , stocks for the other industrial sector were derived by using reported data to modify baseline figures from a one-time Bureau of Mines survey of consumers. For 1978-1982, monthly estimates were derived by judgmentally proportioning reported quarterly data based on representative seasonal patterns of supply and demand. From 1983 forward, other industrial coal stocks are estimated as indicated above for coke plants. Quarterly stocks are taken directly from data reported on Form EIA-3 and therefore include only manufacturing industries; data for agriculture, forestry, fishing, mining, and construction stocks are not available.

- Electric Utilities-Monthly stocks data at electric utility plants are taken directly from reported data.

- Producers and Distributors-Quarterly stocks at producers and distributors are taken directly from reported data. Monthly data are estimated by using one-third of the current quarterly change to indicate the monthly change in stocks.

4. Imports and Exports: All coal import and export figures are taken directly from data reported monthly by the Bureau of the Census.

5. Additional Information: EIA's Quarterly Coal Report provides additional information about coal data and estimation procedures.

6. Data Discrepancies: Due to differences internal to EIA data processing systems, some small discrepancies exist between data in the Monthly Energy Review (MER) and the Quarterly Coal Report (QCR). The data that have discrepancies are footnoted in Section 6 tables and summarized here.

\begin{tabular}{llcrr} 
Table & \multicolumn{1}{c}{ Data Series } & Year & $\begin{array}{r}\text { MER } \\
\text { Data }\end{array}$ & $\begin{array}{r}\text { QCR } \\
\text { Data }\end{array}$ \\
\hline 6.1 & Consumption & 1980 & 702,729 & 702,730 \\
6.1 & Consumption & 1981 & 732,628 & 732,627 \\
6.1 & Production & 1982 & 838,111 & 838,112 \\
6.1 & Consumption & 1982 & 706,910 & 706,911 \\
6.1 & Stocks & 1982 & 232,037 & 232,038 \\
6.1 & Consumption & 1983 & 736,671 & 736,672 \\
6.1 & Stocks & 1983 & 202,585 & 202,584 \\
6.2 & Residential and Commercial & 1980 & 6,452 & 6,451 \\
6.2 & Total & 1980 & 702,729 & 702,730 \\
6.2 & Residential and Commercial & 1981 & 7,422 & 7,421 \\
6.2 & Coke Plants & 1981 & 61,015 & 61,014 \\
6.2 & Total & 1981 & 732,628 & 732,627 \\
6.2 & Other Industrial & 1982 & 64,096 & 64,097 \\
6.2 & Total & 1982 & 706,910 & 706,911 \\
6.2 & Other Industrial & 1983 & 65,979 & 65,980 \\
6.2 & Total & 1983 & 736,671 & 736,672 \\
6.3 & Consumer, Total & 1982 & 195,253 & 195,254 \\
6.3 & Total & 1982 & 232,037 & 232,038 \\
6.3 & Total & 1983 & 202,585 & 202,584 \\
\hline
\end{tabular}




\section{Section 7. Electricity}

During October 1993, electric utilities generated 224 billion kilowatthours of electricity, 1 percent $^{7}$ more than in October 1992. Coal-fired generation totaled 131 billion kilowatthours, 2 percent more than in October 1992. Nuclear generation totaled 44 billion kilowatthours, 9 percent below the level 1 year earlier. Natural gas-fired generation was 23 billion kilowatthours, 12 percent higher than the October 1992 level. Hydroelectric generation totaled 17 billion kilowatthours, 3 percent above the October 1992 level. Petroleum-fired generation totaled 8 billion kilowatthours, 11 percent above the level 1 year earlier.

Sales of electricity to all ultimate consumers in the United States in October were 229 billion kilowatthours, 2 percent more than sales during October 1992. Sales to industrial consumers totaled 83 billion kilowathours in October 1993, 1 percent above the level a year ago. Sales to residential consumers during October 1993 were 72 billion kilowatthours, 3 percent above the level of sales during the previous year. Commercial sales were 65 billion kilowatthours, 2 percent above the level of commercial sales 1 year earlier. In October 1993, other sales totaled 8 billion kilowathours, 6 percent above the October 1992 level.

Electric utility consumption of coal during October 1993 was 65 million short tons, 3 percent above consumption in October 1992. Petroleum consumption (excluding petroleum coke) during October 1993 was 12 million barrels, 9 percent above the October 1992 level. During October 1993, electric utilities consumed 233 billion cubic feet of natural gas, 10 percent above the October 1992 consumption level.

On October 31, 1993, electric utility stocks of all types of coal totaled 115 million short tons, 27 percent below the level on October 31,1992 . Stocks of petroleum (excluding petroleum coke) on October 31, 1993, totaled 61 million barrels, 10 percent below the level on October 31, 1992.

'Percentage changes are based on numbers shown in the following tables. 
Figure 7.1 Electric Utility Net Generation of Electricity

(Billion Kilowatthours)

Net Generation by Source, 1973-1992

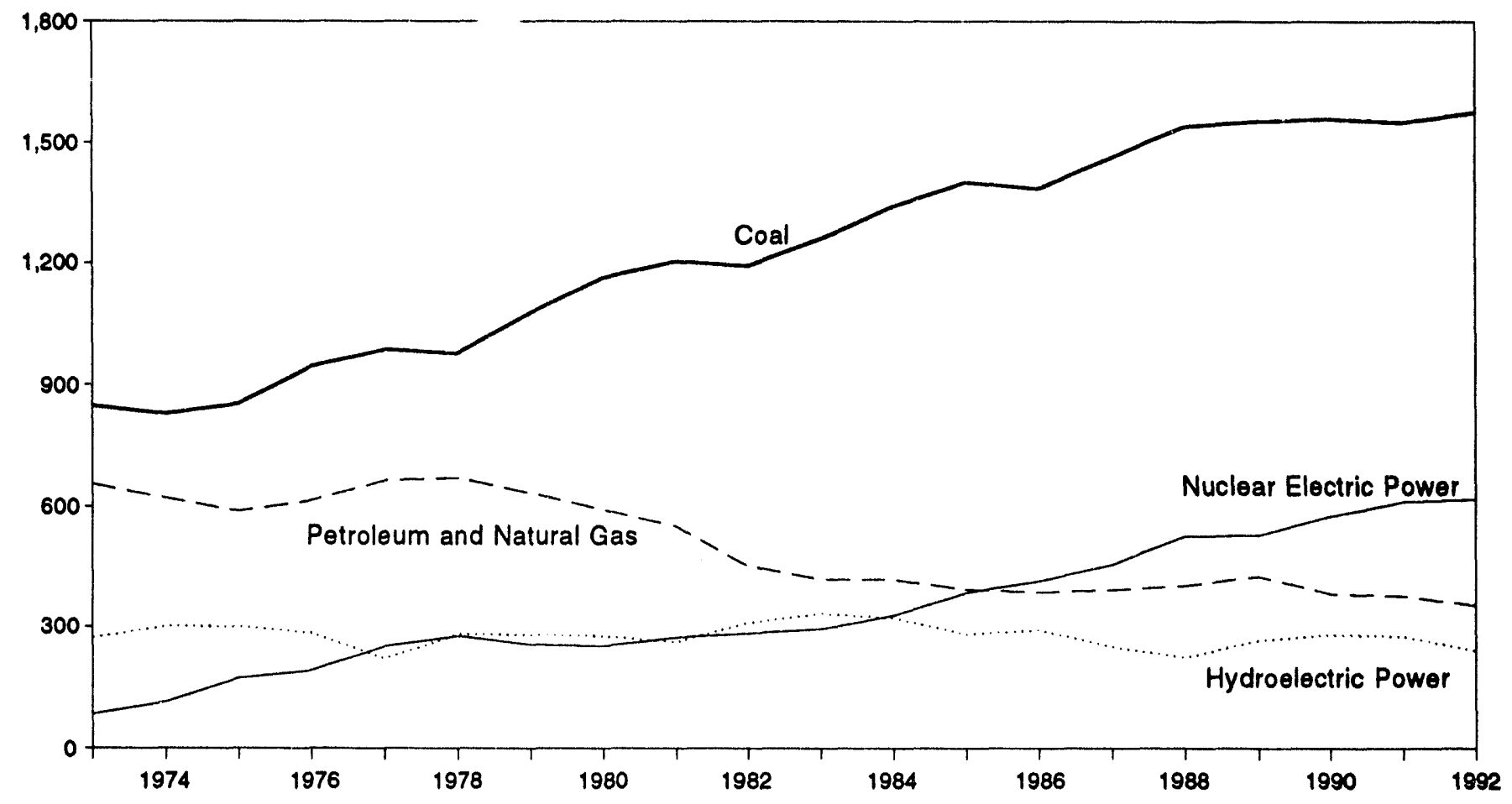

Net Generation, January-October

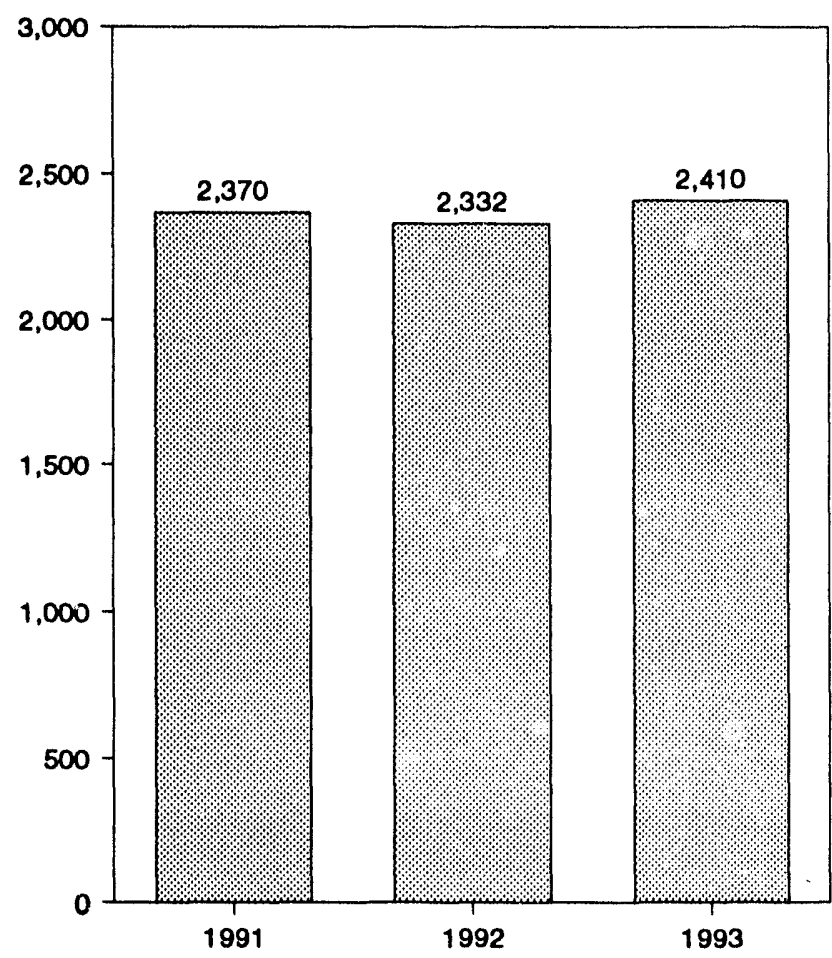

Net Generation by Source, October 1993

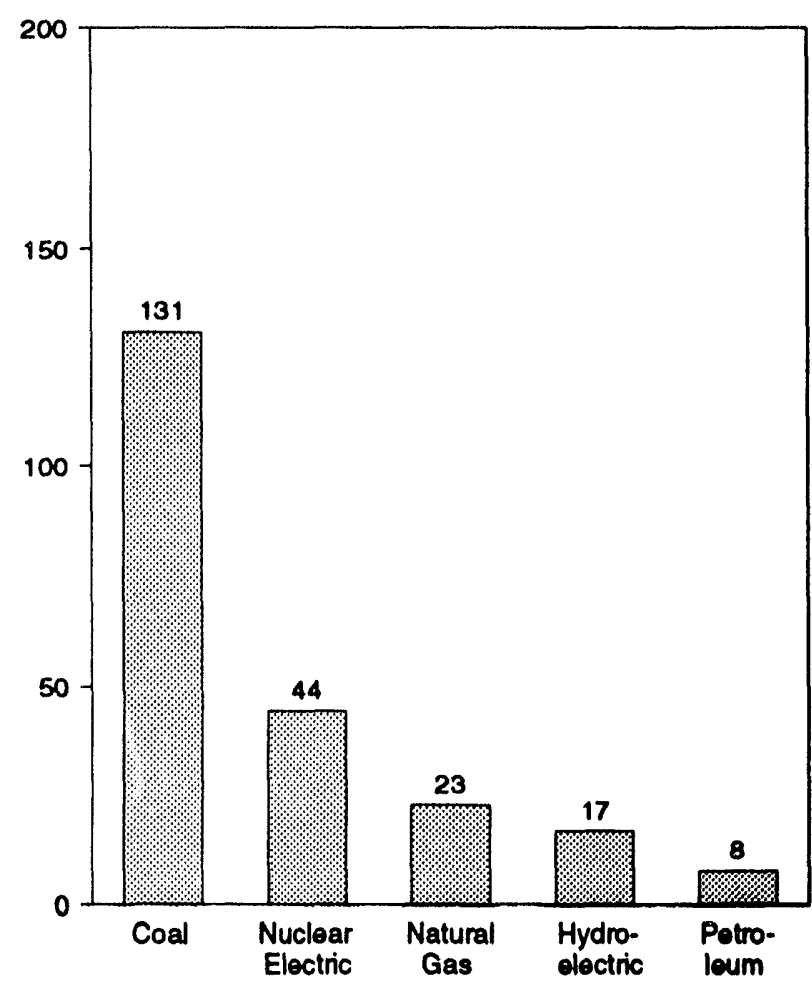

Nole: Bocause vertical scales differ, graphs should not be compared. Source: Table 7.1. 


\begin{tabular}{|c|c|c|c|c|c|c|c|c|}
\hline & Coal & $\begin{array}{c}\text { Natural } \\
\text { Gas }\end{array}$ & Petroleum ${ }^{b}$ & $\begin{array}{l}\text { Nuclear } \\
\text { Electric } \\
\text { Power }\end{array}$ & $\begin{array}{l}\text { Hydro- } \\
\text { Eloctric } \\
\text { Power }\end{array}$ & $\begin{array}{l}\text { Geothermal } \\
\text { Energy }\end{array}$ & Otherc & Total \\
\hline 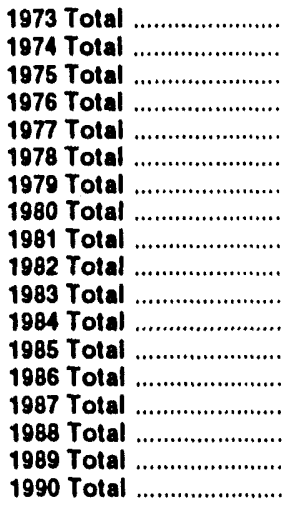 & $\begin{array}{r}847,651 \\
828,433 \\
852,786 \\
944,391 \\
985,219 \\
975,742 \\
1,075,037 \\
1,161,562 \\
1,203,203 \\
1,192,004 \\
1,259,424 \\
1,341,681 \\
1,402,128 \\
1,385,831 \\
1,463,781 \\
1,540,653 \\
1,553,661 \\
1,559,606\end{array}$ & $\begin{array}{l}340,858 \\
320,065 \\
299,778 \\
294,624 \\
305,505 \\
305,391 \\
329,485 \\
346,240 \\
345,777 \\
305,260 \\
274,098 \\
297,394 \\
291,946 \\
248,508 \\
272,621 \\
252,801 \\
266,598 \\
264,089\end{array}$ & $\begin{array}{l}314,343 \\
300,931 \\
289,095 \\
319,988 \\
358,179 \\
365,060 \\
303,525 \\
245,994 \\
206,421 \\
146,797 \\
144,499 \\
119,808 \\
100,202 \\
136,585 \\
118,493 \\
148,900 \\
158,318 \\
117,017\end{array}$ & $\begin{array}{r}83,479 \\
113,976 \\
172,505 \\
191,104 \\
250,883 \\
276,403 \\
255,155 \\
251,116 \\
272,674 \\
282,773 \\
293,677 \\
327,634 \\
383,691 \\
414,038 \\
455,270 \\
526,973 \\
529,355 \\
576,862\end{array}$ & $\begin{array}{l}272,083 \\
301,032 \\
300,047 \\
283,707 \\
220,475 \\
280,419 \\
279,783 \\
276,021 \\
260,684 \\
309,213 \\
332,130 \\
321,150 \\
281,149 \\
290,844 \\
249,695 \\
222,940 \\
265,063 \\
279,926\end{array}$ & $\begin{array}{r}1,966 \\
2,453 \\
3,246 \\
3,616 \\
3,582 \\
2,978 \\
3,889 \\
5,073 \\
5,686 \\
4,843 \\
6,075 \\
7,741 \\
9,325 \\
10,308 \\
10,775 \\
10,300 \\
9,342 \\
8,581\end{array}$ & $\begin{array}{r}328 \\
251 \\
191 \\
266 \\
481 \\
338 \\
498 \\
433 \\
368 \\
321 \\
381 \\
898 \\
1,399 \\
1,195 \\
1,491 \\
1,684 \\
1,968 \\
2,070\end{array}$ & $\begin{array}{l}1,860,710 \\
1,867,140 \\
1,917,649 \\
2,037,696 \\
2,124,323 \\
2,206,331 \\
2,247,372 \\
2,286,439 \\
2,294,812 \\
2,241,211 \\
2,310,285 \\
2,416,304 \\
2,469,841 \\
2,487,310 \\
2,572,127 \\
2,704,250 \\
2,784,304 \\
2,808,151\end{array}$ \\
\hline 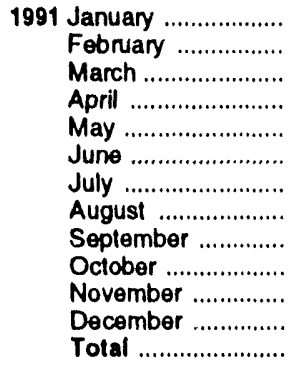 & $\begin{array}{r}141,945 \\
117,867 \\
118,366 \\
112,418 \\
123,906 \\
131,964 \\
143,997 \\
144,194 \\
129,141 \\
125,523 \\
129,125 \\
132,721 \\
1,551,167\end{array}$ & $\begin{array}{r}16,348 \\
13,723 \\
18,446 \\
20,504 \\
23,455 \\
24,417 \\
31,145 \\
30,970 \\
24,966 \\
25,390 \\
18,990 \\
15,819 \\
264,172\end{array}$ & $\begin{array}{r}9,222 \\
8,689 \\
8,785 \\
7,984 \\
10,995 \\
11,159 \\
11,010 \\
11,866 \\
8,646 \\
6,483 \\
7,784 \\
8,841 \\
111,463\end{array}$ & $\begin{array}{r}54,369 \\
47,863 \\
49,121 \\
41,631 \\
46,755 \\
54,208 \\
60,735 \\
58,473 \\
51,874 \\
47,653 \\
46,295 \\
53,589 \\
612,565\end{array}$ & $\begin{array}{r}25,676 \\
21,915 \\
25,820 \\
25,687 \\
28,455 \\
25,830 \\
24,250 \\
21,747 \\
18,428 \\
17,538 \\
18,300 \\
21,873 \\
275,519\end{array}$ & $\begin{array}{r}704 \\
614 \\
701 \\
629 \\
644 \\
686 \\
686 \\
679 \\
637 \\
673 \\
704 \\
729 \\
8,087\end{array}$ & $\begin{array}{r}192 \\
149 \\
162 \\
151 \\
164 \\
162 \\
153 \\
186 \\
193 \\
171 \\
179 \\
187 \\
2,050\end{array}$ & $\begin{array}{r}248,455 \\
210,821 \\
221,400 \\
209,004 \\
234,373 \\
248,427 \\
271,976 \\
268,115 \\
233,885 \\
223,430 \\
221,377 \\
233,760 \\
2,825,023\end{array}$ \\
\hline 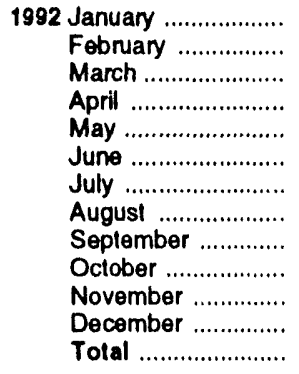 & $\begin{array}{r}137,327 \\
121,732 \\
127,678 \\
119,909 \\
123,768 \\
129,607 \\
149,028 \\
141,900 \\
133,239 \\
127,940 \\
125,535 \\
138,234 \\
1,575,895\end{array}$ & $\begin{array}{r}16,178 \\
16,165 \\
19,906 \\
21,913 \\
22,689 \\
24,997 \\
31,950 \\
28,778 \\
26,099 \\
20,420 \\
18,031 \\
16,744 \\
263,872\end{array}$ & $\begin{array}{r}10,202 \\
8,296 \\
8,809 \\
6,505 \\
5,156 \\
7,508 \\
8,540 \\
6,923 \\
6,841 \\
6,908 \\
6,838 \\
6,390 \\
88,916\end{array}$ & $\begin{array}{r}57,849 \\
52,804 \\
45,835 \\
42,268 \\
45,627 \\
51,185 \\
56,049 \\
58,656 \\
50,919 \\
48,784 \\
50,726 \\
58,075 \\
618,776\end{array}$ & $\begin{array}{r}21,502 \\
17,966 \\
21,566 \\
19,454 \\
22,285 \\
22,698 \\
19,711 \\
18,062 \\
16,838 \\
16,375 \\
19,294 \\
23,808 \\
239,559\end{array}$ & $\begin{array}{r}711 \\
626 \\
713 \\
645 \\
683 \\
675 \\
685 \\
690 \\
642 \\
677 \\
675 \\
682 \\
8,104\end{array}$ & $\begin{array}{r}202 \\
172 \\
158 \\
143 \\
147 \\
170 \\
184 \\
195 \\
183 \\
185 \\
165 \\
192 \\
2,096\end{array}$ & $\begin{array}{r}243,970 \\
217,761 \\
224,665 \\
210,837 \\
220,355 \\
236,842 \\
266,148 \\
255,203 \\
234,760 \\
221,289 \\
221,263 \\
244,126 \\
2,797,219\end{array}$ \\
\hline 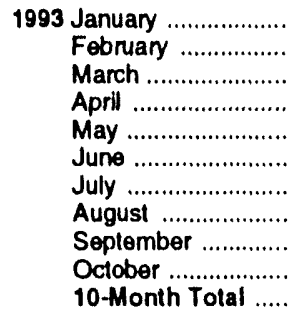 & $\begin{array}{r}138,357 \\
130,078 \\
136,280 \\
120,325 \\
120,878 \\
137,464 \\
158,380 \\
156,193 \\
133,856 \\
130,926 \\
1,362,736\end{array}$ & $\begin{array}{r}15,811 \\
15,773 \\
18,740 \\
16,591 \\
15,843 \\
24,391 \\
31,684 \\
34,262 \\
25,020 \\
22,906 \\
221,022\end{array}$ & $\begin{array}{r}7,226 \\
6,950 \\
8,569 \\
5,205 \\
5,268 \\
7,819 \\
11,341 \\
11,978 \\
9,759 \\
7,659 \\
81,774\end{array}$ & $\begin{array}{l}59,076 \\
51,319 \\
46,606 \\
43,199 \\
50,367 \\
52,620 \\
56,502 \\
56,209 \\
49,989 \\
44,434 \\
510,321\end{array}$ & $\begin{array}{r}24,474 \\
19,743 \\
23,583 \\
25,171 \\
29,323 \\
26,606 \\
23,575 \\
19,685 \\
17,089 \\
16,899 \\
226,149\end{array}$ & $\begin{array}{r}651 \\
633 \\
659 \\
654 \\
582 \\
586 \\
643 \\
653 \\
630 \\
625 \\
6,316\end{array}$ & $\begin{array}{r}202 \\
167 \\
193 \\
148 \\
135 \\
139 \\
144 \\
167 \\
173 \\
174 \\
1,642\end{array}$ & $\begin{array}{r}245,797 \\
224,663 \\
234,630 \\
211,292 \\
222,396 \\
249,625 \\
282,270 \\
279,147 \\
236,516 \\
223,622 \\
2,409,960\end{array}$ \\
\hline $\begin{array}{l}1992 \text { 10-Month Total ..... } \\
1991 \text { 10-Month Total ..... }\end{array}$ & $\begin{array}{l}1,312,126 \\
1,289,321\end{array}$ & $\begin{array}{l}229,096 \\
229,363\end{array}$ & $\begin{array}{l}75,688 \\
94,838\end{array}$ & $\begin{array}{l}509,975 \\
512,680\end{array}$ & $\begin{array}{l}196,458 \\
235,346\end{array}$ & $\begin{array}{l}6,747 \\
6,654\end{array}$ & $\begin{array}{l}1,740 \\
1,684\end{array}$ & $\begin{array}{l}2,331,830 \\
2,369,886\end{array}$ \\
\hline
\end{tabular}

- Includes supplemental gaseous fuel.

Includes fuel oil nos. 1, 2, 4, 5, and 6, crude oil, kerosene, and petroleum coke.

"Other" is electricity produced from wood, waste, wind, photovoltaic, and solar thermal energy sources connected to electric utility distribution systems.

Notes: - Geographic coverage is the 50 States and the District of Columbia.

- Totals may not equal sum ol components due to independent rounding.

Sources: - 1973-September 1977: Federal Power Commission. Form

FPC-4, "Monthly Power Plant Repont" - October 1977-1979: Federal

Energy Regulatory Commission (FERC), Form FPC-4, "Monthly Power Plant
Report." - 1980: Energy Information Administration (ElA), Electric Powel Monthly, March 1991, Table 4, and (for geothermal energy and other) FERC, Form FPC-4, "Monthly Power Plant Report." 1981: EIA, Electric Powel Monthly, March 1992. Table 4, and (for geothermal energy and other) FERC, Form FPC.4, "Monthly Power Plant Report." 1982 and 1991 monthly data: ElA, Electric Power Monthly, March 1993, Table 4, and (for geotherma energy and other) EIA, Form ElA-759, "Monthly Power Plant Repon." • 1983 forward (except 199 i monthly data): ElA, Electric Power Monthly, January 1994, Table 4, and (for geothermal energy and other) EIA, Form EIA-759, "Monthly Power Plant Repont." 
Figure 7.2 Electricity Sales

(Billion Kilowatthours)

Total Sales, January-October

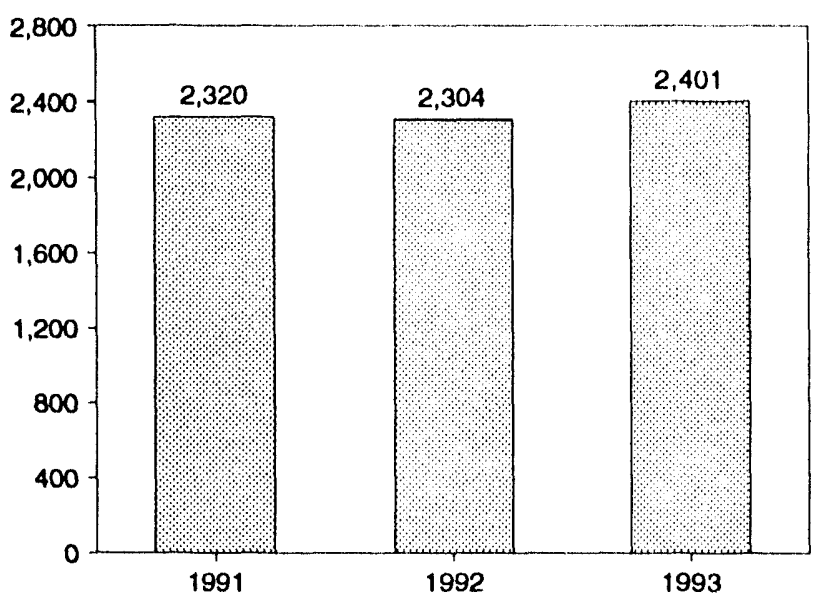

Total Sales, Monthly

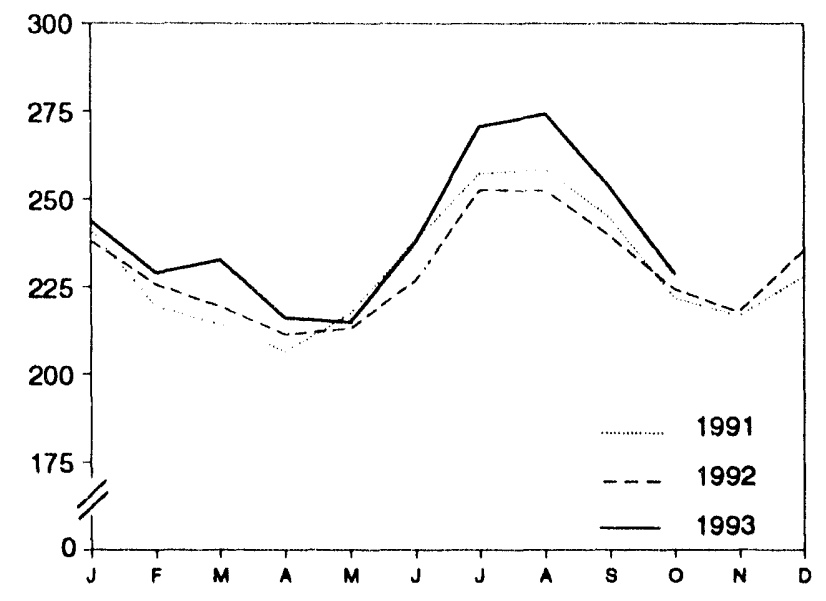

\section{Sales by Sector, Monthly}

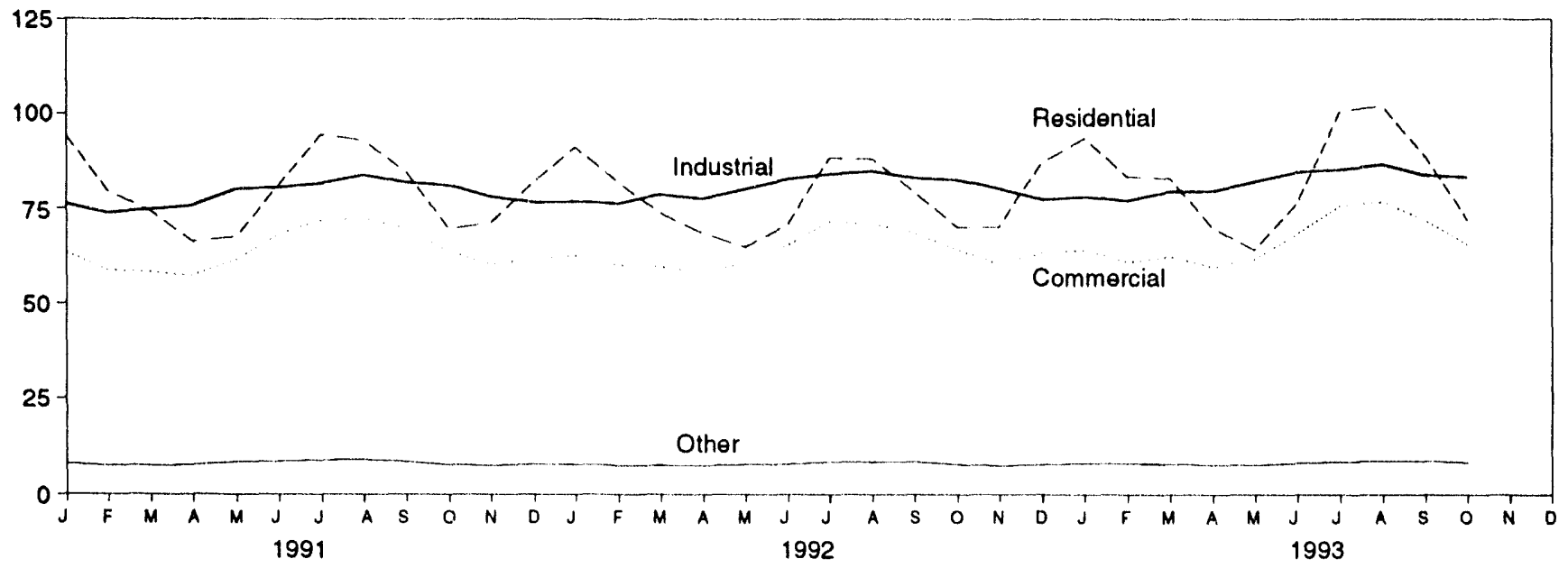

Sales by Sector, 1973-1992

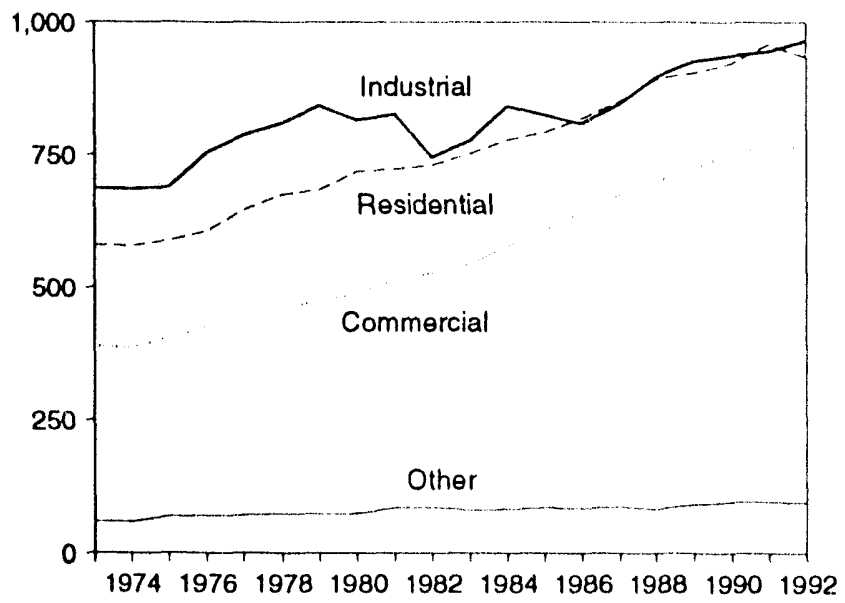

Sales by Sector, October 1993

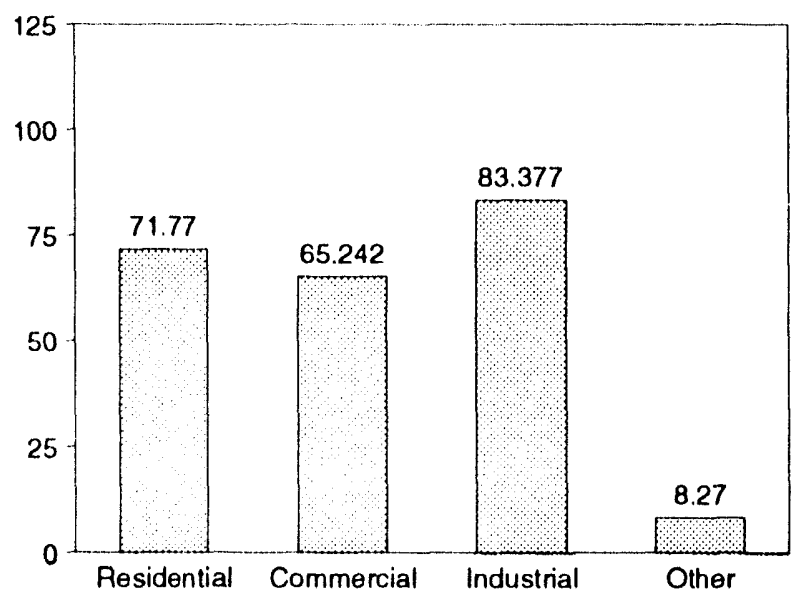

Note: Because ventical scales differ, graphs should not be compared. Source: Table 7.2, Monthly Serles. 
(Million Kilowatthours)

\begin{tabular}{|c|c|c|c|c|c|c|c|c|c|c|}
\hline & \multicolumn{2}{|c|}{ Residential } & \multicolumn{2}{|c|}{ Commercial } & \multicolumn{2}{|c|}{ Industrial } & \multicolumn{2}{|c|}{ Other ${ }^{a}$} & \multicolumn{2}{|c|}{ Total } \\
\hline & $\begin{array}{l}\text { Monthly } \\
\text { Series }\end{array}$ & $\begin{array}{l}\text { Annual } \\
\text { Series }\end{array}$ & $\begin{array}{c}\text { Monthly } \\
\text { Series }\end{array}$ & $\begin{array}{l}\text { Annual } \\
\text { Series }\end{array}$ & $\begin{array}{c}\text { Monthly } \\
\text { Series }\end{array}$ & $\begin{array}{l}\text { Annual } \\
\text { Series }\end{array}$ & $\begin{array}{l}\text { Monthly } \\
\text { Series }\end{array}$ & $\begin{array}{l}\text { Annual } \\
\text { Series }\end{array}$ & $\begin{array}{l}\text { Monthly } \\
\text { Series b }\end{array}$ & $\begin{array}{l}\text { Annual } \\
\text { Series }\end{array}$ \\
\hline 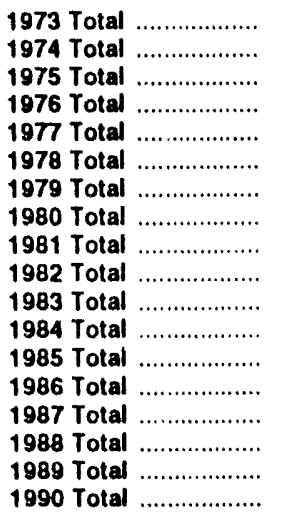 & $\begin{array}{l}579,231 \\
578,184 \\
588,140 \\
606,452 \\
645,239 \\
674,466 \\
682,819 \\
717,495 \\
722,265 \\
729,520 \\
750,948 \\
777,654 \\
790,977 \\
817,663 \\
849,613 \\
892,125 \\
903,979 \\
921,473\end{array}$ & $\begin{array}{l}\text { NA } \\
\text { NA } \\
\text { NA } \\
\text { NA } \\
\text { NA } \\
\text { NA } \\
\text { NA } \\
\text { NA } \\
\text { NA } \\
\text { NA } \\
\text { NA } \\
780,092 \\
793,934 \\
819,088 \\
850,410 \\
892,866 \\
905,525 \\
924,019\end{array}$ & $\begin{array}{l}388,266 \\
384,826 \\
403,049 \\
425,094 \\
446,514 \\
461,163 \\
473,307 \\
488,155 \\
514,338 \\
526,397 \\
543,788 \\
578,281 \\
608,968 \\
641,469 \\
673,707 \\
697,711 \\
725,229 \\
750,835\end{array}$ & $\begin{array}{l}\text { NA } \\
\text { NA } \\
\text { NA } \\
\text { NA } \\
\text { NA } \\
\text { NA } \\
\text { NA } \\
\text { NA } \\
\text { NA } \\
\text { NA } \\
\text { NA } \\
582,621 \\
605,989 \\
630,520 \\
660,433 \\
699,100 \\
725,861 \\
751,027\end{array}$ & $\begin{array}{l}686,085 \\
684,875 \\
687,680 \\
754,069 \\
786,037 \\
809,078 \\
841,903 \\
815,067 \\
825,743 \\
744,949 \\
775,999 \\
840,588 \\
824,523 \\
808,292 \\
845,266 \\
895,751 \\
926,376 \\
836,428\end{array}$ & $\begin{array}{c}\text { NA } \\
\text { NA } \\
\text { NA } \\
\text { NA } \\
\text { NA } \\
\text { NA } \\
\text { NA } \\
\text { NA } \\
\text { NA } \\
\text { NA } \\
\text { NA } \\
837,836 \\
836,772 \\
830,531 \\
858,233 \\
896,498 \\
925,659 \\
945,522\end{array}$ & $\begin{array}{l}59,326 \\
58,039 \\
68,222 \\
69,631 \\
70,571 \\
73,215 \\
73,070 \\
73,732 \\
84,756 \\
85,575 \\
80,219 \\
81,849 \\
85,075 \\
83,409 \\
86,854 \\
82,362 \\
91,066 \\
95,936\end{array}$ & $\begin{array}{c}\text { NA } \\
\text { NA } \\
\text { NA } \\
\text { NA } \\
\text { NA } \\
\text { NA } \\
\text { NA } \\
\text { NA } \\
\text { NA } \\
\text { NA } \\
\text { NA } \\
85,248 \\
87,279 \\
88,615 \\
88,196 \\
89,598 \\
89,765 \\
91,988\end{array}$ & $\begin{array}{l}1,712,909 \\
1,705,924 \\
1,747,091 \\
1,855,246 \\
1,948,361 \\
2,017,922 \\
2,071,099 \\
2,094,449 \\
2,147,103 \\
2,086,441 \\
2,150,955 \\
2,278,372 \\
2,309,543 \\
2,350,835 \\
2,455,440 \\
2,567,949 \\
2,646,651 \\
2,704,672\end{array}$ & $\begin{array}{c}\text { NA } \\
\text { NA } \\
\text { NA } \\
\text { NA } \\
\text { NA } \\
\text { NA } \\
\text { NA } \\
\text { NA } \\
\text { NA } \\
\text { NA } \\
\text { NA } \\
2,285,796 \\
2,323,974 \\
2,368,753 \\
2,457,272 \\
2,578,062 \\
2,546,809 \\
2,712,555\end{array}$ \\
\hline 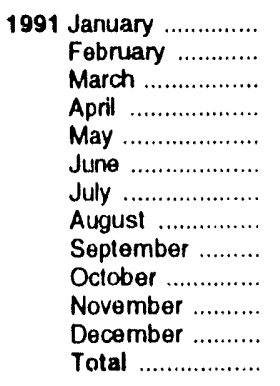 & $\begin{array}{r}94,144 \\
79,676 \\
74,078 \\
66,079 \\
67,450 \\
81,116 \\
94,738 \\
93,127 \\
84,696 \\
69,422 \\
71,114 \\
82,160 \\
957,801\end{array}$ & $\begin{array}{l}- \\
- \\
- \\
- \\
- \\
- \\
- \\
- \\
- \\
- \\
- \\
- \\
955,417\end{array}$ & $\begin{array}{r}63,336 \\
58,582 \\
58,157 \\
57,155 \\
61,434 \\
67,991 \\
71,872 \\
72,360 \\
69,501 \\
63,439 \\
60,133 \\
61,516 \\
765,476\end{array}$ & $\begin{array}{l}- \\
- \\
- \\
- \\
- \\
- \\
- \\
- \\
- \\
- \\
- \\
- \\
765,664\end{array}$ & $\begin{array}{r}76,111 \\
73,715 \\
74,720 \\
75,706 \\
80,236 \\
80,569 \\
81,700 \\
83,974 \\
81,967 \\
81,209 \\
78,176 \\
76,601 \\
944,684\end{array}$ & $\begin{array}{c}- \\
- \\
- \\
- \\
- \\
- \\
- \\
- \\
- \\
- \\
946,583\end{array}$ & $\begin{array}{r}7,905 \\
7,424 \\
7,459 \\
7,600 \\
8,378 \\
8,502 \\
8,877 \\
8,986 \\
8,476 \\
7,654 \\
7,463 \\
7,790 \\
36,513\end{array}$ & $\begin{array}{c}- \\
- \\
- \\
- \\
- \\
- \\
- \\
- \\
- \\
- \\
94,339\end{array}$ & $\begin{array}{r}241,497 \\
219,397 \\
214,414 \\
206,541 \\
217,498 \\
238,177 \\
257,187 \\
258,447 \\
244,639 \\
221,723 \\
216,886 \\
228,068 \\
2,764,474\end{array}$ & $\begin{array}{c}- \\
- \\
- \\
- \\
- \\
- \\
- \\
- \\
- \\
2,762,003\end{array}$ \\
\hline 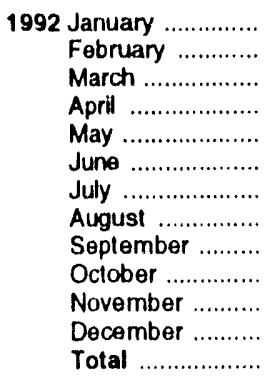 & $\begin{array}{r}91,310 \\
82,022 \\
73,635 \\
68,322 \\
64,662 \\
70,745 \\
88,510 \\
88,251 \\
79,400 \\
69,838 \\
69,970 \\
87,378 \\
934,044\end{array}$ & $\begin{array}{l}- \\
- \\
- \\
- \\
- \\
- \\
- \\
- \\
- \\
- \\
\text { NA }\end{array}$ & $\begin{array}{r}62,441 \\
59,876 \\
59,574 \\
58,081 \\
60,559 \\
65,209 \\
71,445 \\
70,844 \\
68,437 \\
63,985 \\
60,131 \\
63,082 \\
763,664\end{array}$ & $\begin{array}{l}- \\
- \\
- \\
- \\
- \\
- \\
- \\
- \\
- \\
- \\
\text { NA }\end{array}$ & $\begin{array}{r}76,760 \\
76,312 \\
78,741 \\
77,607 \\
80,191 \\
82,900 \\
84,195 \\
85,013 \\
83,182 \\
82,678 \\
80,421 \\
77,358 \\
965,356\end{array}$ & $\begin{array}{l}- \\
- \\
- \\
- \\
- \\
- \\
- \\
- \\
- \\
- \\
\text { NA }\end{array}$ & $\begin{array}{r}7,725 \\
7,507 \\
7,542 \\
7,448 \\
7,767 \\
7,901 \\
8,392 \\
8,327 \\
8,441 \\
7,766 \\
7,462 \\
7,725 \\
94,003\end{array}$ & $\begin{array}{l}- \\
- \\
- \\
- \\
- \\
- \\
- \\
- \\
- \\
- \\
\text { NA }\end{array}$ & $\begin{array}{r}238,235 \\
225,717 \\
219,491 \\
211,458 \\
213,179 \\
226,755 \\
252,541 \\
252,435 \\
239,460 \\
224,267 \\
217,984 \\
235,543 \\
2,757,067\end{array}$ & $\begin{array}{l}- \\
- \\
- \\
- \\
- \\
- \\
- \\
- \\
- \\
- \\
\text { NA }\end{array}$ \\
\hline 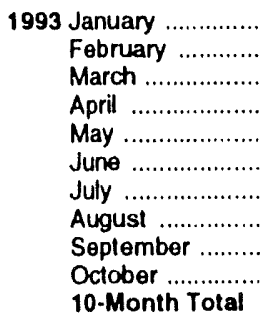 & $\begin{array}{r}93,739 \\
83,416 \\
83,023 \\
69,668 \\
63,852 \\
76,584 \\
101,023 \\
102,214 \\
88,884 \\
71,770 \\
834,174\end{array}$ & $\begin{array}{l}- \\
- \\
- \\
- \\
- \\
- \\
- \\
- \\
-\end{array}$ & $\begin{array}{r}63,930 \\
60,624 \\
62,169 \\
59,389 \\
61,420 \\
68,171 \\
75,704 \\
76,551 \\
71,708 \\
65,242 \\
654,909\end{array}$ & $\begin{array}{l}- \\
- \\
- \\
- \\
- \\
- \\
- \\
-\end{array}$ & $\begin{array}{r}78,074 \\
77,017 \\
79,504 \\
79,593 \\
82,100 \\
84,768 \\
85,370 \\
86,832 \\
83,839 \\
83,377 \\
820,476\end{array}$ & $\begin{array}{l}- \\
- \\
- \\
- \\
- \\
- \\
- \\
- \\
- \\
-\end{array}$ & $\begin{array}{r}8,113 \\
7,940 \\
7,919 \\
7,588 \\
7,602 \\
8,138 \\
8,457 \\
8,609 \\
8,699 \\
8,270 \\
81,335\end{array}$ & $\begin{array}{l}- \\
- \\
- \\
- \\
- \\
- \\
- \\
- \\
-\end{array}$ & $\begin{array}{r}243,856 \\
228,997 \\
232,615 \\
216,238 \\
214,975 \\
237,662 \\
270,555 \\
274,206 \\
253,130 \\
228,660 \\
2,400,894\end{array}$ & $\begin{array}{l}- \\
- \\
- \\
- \\
- \\
- \\
- \\
- \\
-\end{array}$ \\
\hline $\begin{array}{l}199210 \text {-Month Total } \\
1991 \text { 10-Month Total }\end{array}$ & $\begin{array}{l}776,696 \\
804,527\end{array}$ & - & $\begin{array}{l}640,451 \\
643,827\end{array}$ & - & $\begin{array}{l}807,577 \\
789,907\end{array}$ & - & $\begin{array}{l}78,816 \\
81,260\end{array}$ & - & $\begin{array}{l}2,303,539 \\
2,319,520\end{array}$ & - \\
\hline
\end{tabular}

a "Other" is public street and highway lighting, other sales to public authorities, sales to railroads and railways, and interdepartmental sales.

b Annual totals are the sums of the monthly values

NA $=$ Not available. $-=$ Not applicable

Notes: - Geographic coverage is the 50 States and the District of Columbia.

- Totals may not equal sum of components due to independent rounding.

Sources: - 1973-September 1977: Federal Power Commission, Form FPC-5, "Monthly Statement of Electric Operating Revenue and Income."
October 1977-1979: Federal Energy Regulatory Commission, Form FERC-5, "Electric Operating Revenue and Income." - 1980: Energy Information Administration (EIA), Electric Power Monthly, March 1991, Table 51. 1981: ElA, Electric Power Monthly, March 1992, Table 51. 1982 and 1991 monthly data: EIA, Electric Power Monthly, March 1993, Table 51. 1983 forward (except 1991 monthly data): ElA, Electric Powel Monthly, January 1994, Table 51. 
Fuels Consumed, 1973-1992

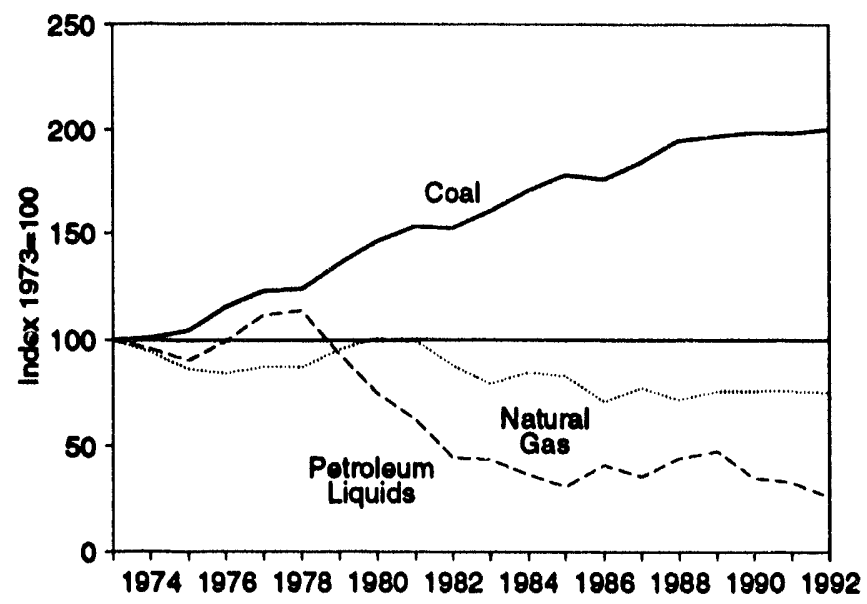

Petroleum Liquids Consumed, Monthly

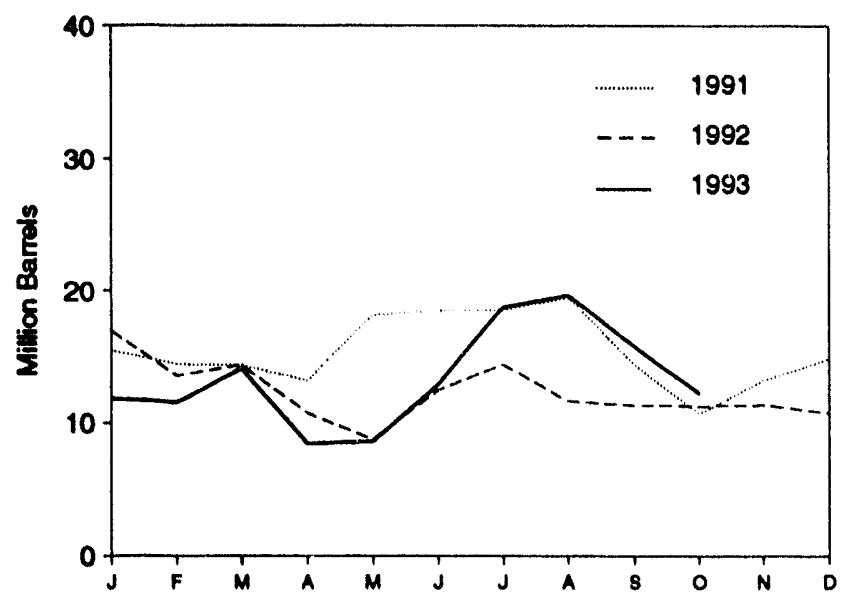

Coal Stocks, End of Month

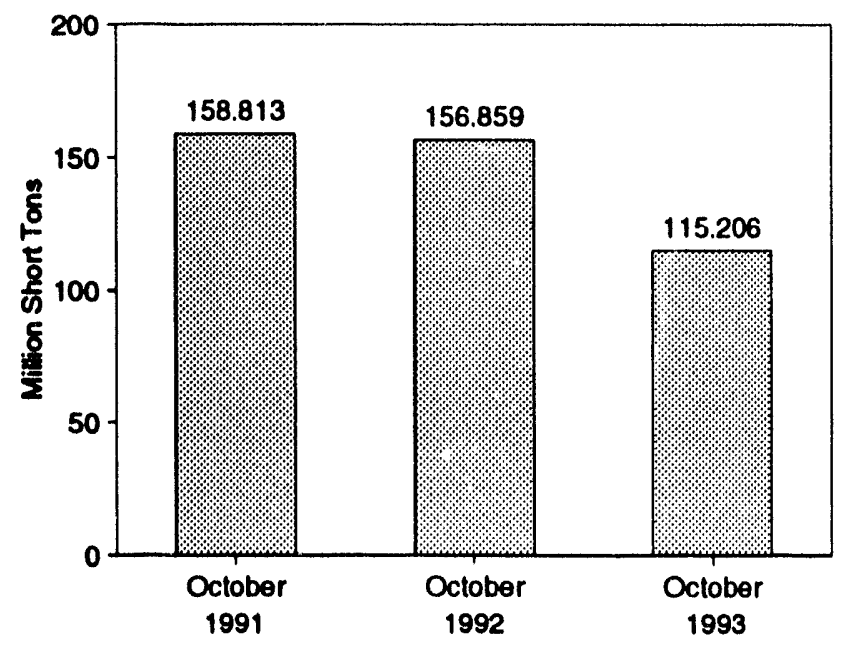

Coal Consumed, Monthly

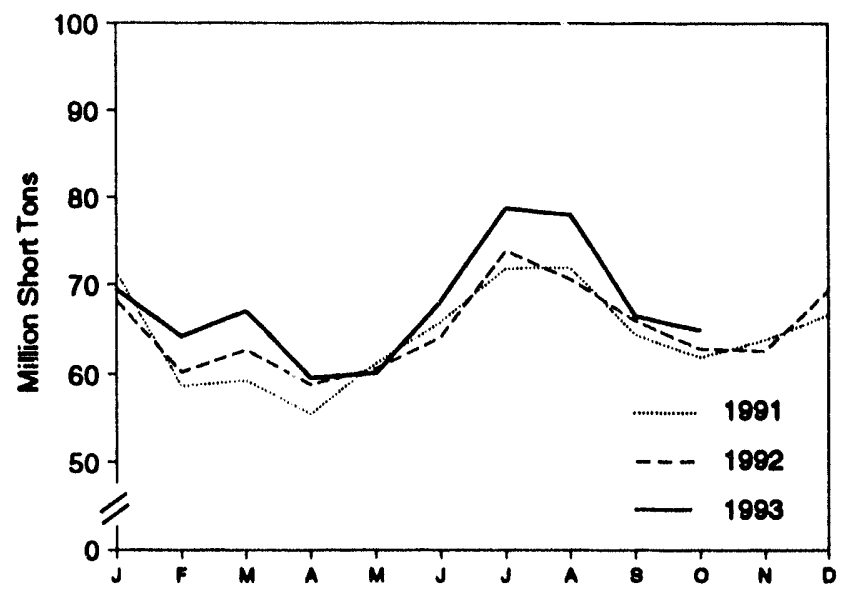

Natural Gas Consumed, Monthly

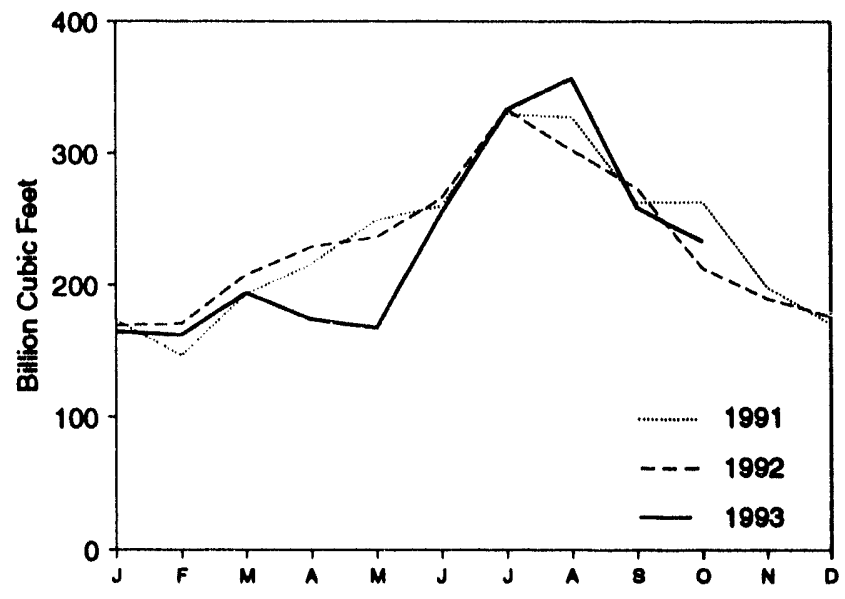

Petroleum Liquids Stocks, End of Month

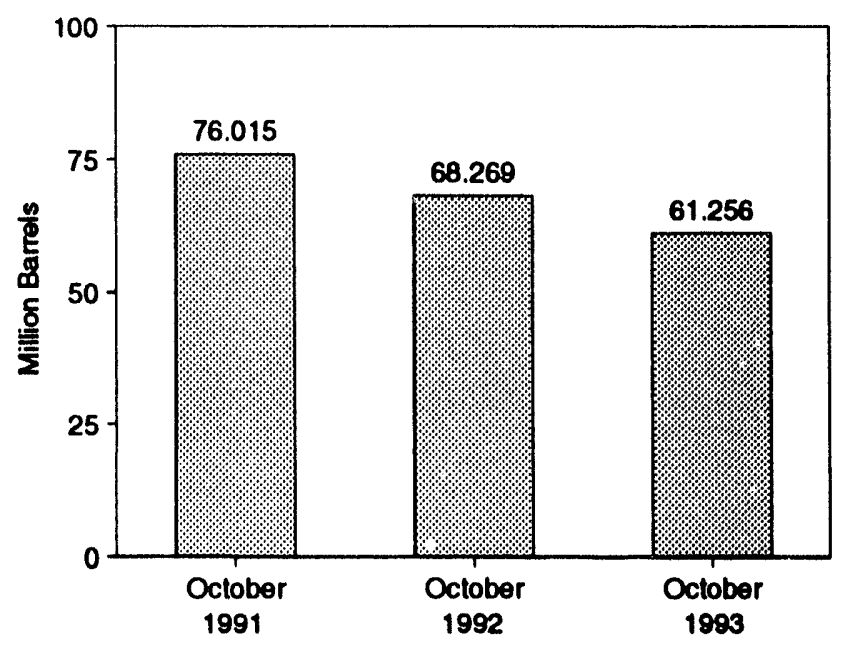

Note: Because vertical scales difter, graphs should not be compared. Sources: Tables 7.3 and 7.4 . 


\begin{tabular}{|c|c|c|c|c|c|c|c|c|c|c|c|}
\hline & \multicolumn{4}{|c|}{ Coal } & \multicolumn{6}{|c|}{ Potroloum } & \multirow[b]{3}{*}{$\begin{array}{c}\text { Natural } \\
\text { Gas }^{d}\end{array}$} \\
\hline & \multirow[b]{2}{*}{$\begin{array}{l}\text { Anthra- } \\
\text { clto }\end{array}$} & \multirow[b]{2}{*}{$\begin{array}{c}\text { Bituminous } \\
\text { Coal }\end{array}$} & \multirow[b]{2}{*}{ Lignite } & \multirow[b]{2}{*}{ Total } & \multicolumn{2}{|c|}{$\begin{array}{c}\text { By Type } \\
\text { of Petroloum }\end{array}$} & \multicolumn{2}{|c|}{$\begin{array}{c}\text { By Prime } \\
\text { Mover Type }\end{array}$} & \multirow[b]{2}{*}{$\begin{array}{c}\text { Total } \\
\text { Ulquids }\end{array}$} & \multirow[b]{2}{*}{$\begin{array}{c}\text { Potroleum } \\
\text { Coke }\end{array}$} & \\
\hline & & & & & $\begin{array}{c}\text { Heavy } \\
\text { Olla }\end{array}$ & $\begin{array}{c}\text { Light } \\
\text { olib }\end{array}$ & $\begin{array}{l}\text { Steam } \\
\text { Plants } \\
\end{array}$ & GT/ICC & & & \\
\hline & \multicolumn{4}{|c|}{ Thousand Short Tons } & \multicolumn{5}{|c|}{ Thousand Barrels } & $\begin{array}{l}\text { Thousand } \\
\text { Short Tons }\end{array}$ & $\begin{array}{c}\text { Million } \\
\text { Cubic Fee }\end{array}$ \\
\hline 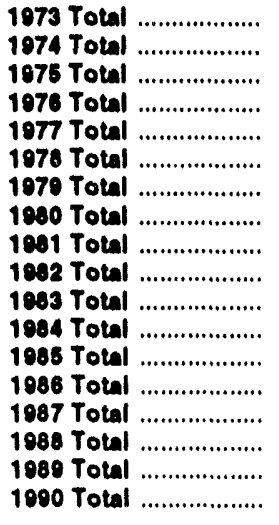 & $\begin{array}{r}1,443 \\
1,498 \\
1,480 \\
1,350 \\
1,425 \\
1,064 \\
1,046 \\
1,951 \\
1,221 \\
1,076 \\
1,038 \\
1,070 \\
1,033 \\
829 \\
972 \\
1,063 \\
1,049 \\
1,031\end{array}$ & $\begin{array}{l}376,075 \\
378,643 \\
388,523 \\
425,205 \\
451,051 \\
448,763 \\
488,120 \\
526,680 \\
550,784 \\
543,346 \\
570,108 \\
606,330 \\
631,885 \\
616,134 \\
647,824 \\
681,048 \\
688,504 \\
694,317\end{array}$ & $\begin{array}{l}10,794 \\
11,670 \\
15,960 \\
21,817 \\
24,650 \\
31,407 \\
37,876 \\
41,642 \\
44,702 \\
40,245 \\
54,067 \\
56,090 \\
60,023 \\
68,093 \\
69,098 \\
76,260 \\
77,335 \\
78,201\end{array}$ & $\begin{array}{l}389,212 \\
391,811 \\
405,962 \\
448,371 \\
477,126 \\
481,235 \\
527,051 \\
569,274 \\
506,797 \\
503,666 \\
625,211 \\
664,390 \\
693,841 \\
685,056 \\
717,894 \\
758,372 \\
766,888 \\
773,549\end{array}$ & $\begin{array}{c}\text { NA } \\
\text { NA } \\
\text { NA } \\
\text { NA } \\
\text { NA } \\
\text { NA } \\
\text { NA } \\
391,163 \\
329,798 \\
234,434 \\
228,984 \\
189,289 \\
158,779 \\
216,156 \\
184,011 \\
229,327 \\
241,960 \\
181,231\end{array}$ & $\begin{array}{c}\text { NA } \\
\text { NA } \\
\text { NA } \\
\text { NA } \\
\text { NA } \\
\text { NA } \\
\text { NA } \\
29,051 \\
21,313 \\
15,337 \\
16,512 \\
15,190 \\
14,635 \\
14,326 \\
15,367 \\
18,769 \\
25,491 \\
14,823\end{array}$ & $\begin{array}{l}513,100 \\
483,146 \\
467,221 \\
514,077 \\
574,869 \\
588,310 \\
402,606 \\
401,863 \\
330,680 \\
243,537 \\
237,845 \\
197,050 \\
166,842 \\
222,500 \\
190,818 \\
235,817 \\
250,315 \\
187,531\end{array}$ & $\begin{array}{r}47,058 \\
53,128 \\
38,907 \\
41,843 \\
48,837 \\
47,520 \\
30,691 \\
18,351 \\
11,431 \\
6,234 \\
7,652 \\
7,429 \\
6,572 \\
7,983 \\
8,560 \\
12,279 \\
17,136 \\
8,523\end{array}$ & $\begin{array}{l}560,248 \\
536,274 \\
506,128 \\
555,920 \\
623,705 \\
635,830 \\
523,297 \\
420,214 \\
351,111 \\
249,771 \\
245,497 \\
204,479 \\
173,414 \\
230,482 \\
199,378 \\
248,096 \\
267,451 \\
196,054\end{array}$ & $\begin{array}{r}507 \\
625 \\
70 \\
68 \\
98 \\
398 \\
268 \\
179 \\
139 \\
140 \\
261 \\
252 \\
231 \\
313 \\
348 \\
409 \\
517 \\
819\end{array}$ & $\begin{array}{l}3,660,172 \\
3,443,428 \\
3,157,660 \\
3,080,868 \\
3,101,200 \\
3,188,363 \\
3,490,523 \\
3,681,595 \\
3,640,154 \\
3,225,518 \\
2,010,767 \\
3,111,312 \\
3,044,083 \\
2,602,370 \\
2,844,051 \\
2,635,613 \\
2,787,012 \\
2,787,332\end{array}$ \\
\hline 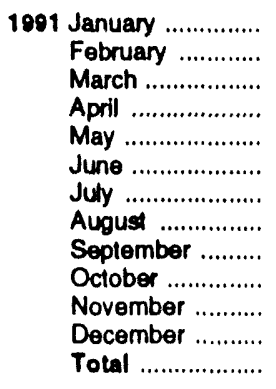 & $\begin{array}{r}74 \\
68 \\
93 \\
92 \\
73 \\
72 \\
101 \\
90 \\
90 \\
86 \\
79 \\
77 \\
994\end{array}$ & $\begin{array}{r}63,779 \\
52,090 \\
52,924 \\
50,131 \\
55,229 \\
58,455 \\
64,202 \\
64,280 \\
57,474 \\
55,586 \\
57,662 \\
59,462 \\
691,275\end{array}$ & $\begin{array}{r}7,553 \\
6,456 \\
6,255 \\
5,219 \\
5,926 \\
7,290 \\
7,548 \\
7,514 \\
6,833 \\
6,212 \\
6,073 \\
7,120 \\
79,899\end{array}$ & $\begin{array}{r}71,406 \\
58,614 \\
59,272 \\
55,443 \\
61,228 \\
65,817 \\
71,852 \\
71,884 \\
64,397 \\
61,883 \\
63,814 \\
66,659 \\
772,268\end{array}$ & $\begin{array}{r}14,264 \\
13,595 \\
13,513 \\
12,142 \\
16,312 \\
17,325 \\
17,289 \\
18,041 \\
13,209 \\
9,791 \\
12,020 \\
13,656 \\
171,157\end{array}$ & $\begin{array}{r}1,187 \\
804 \\
828 \\
1,019 \\
1,814 \\
1,122 \\
1,218 \\
1,380 \\
1,165 \\
902 \\
1,146 \\
1,143 \\
13,729\end{array}$ & $\begin{array}{r}14,911 \\
14,021 \\
13,999 \\
12,641 \\
16,919 \\
17,845 \\
17,737 \\
18,500 \\
13,634 \\
10,289 \\
12,575 \\
14,214 \\
177,286\end{array}$ & $\begin{array}{r}541 \\
377 \\
341 \\
519 \\
1,208 \\
602 \\
770 \\
921 \\
740 \\
403 \\
591 \\
586 \\
7,600\end{array}$ & $\begin{array}{r}15,452 \\
14,398 \\
14,340 \\
13,161 \\
18,126 \\
18,447 \\
18,507 \\
19,421 \\
14,374 \\
10,693 \\
13,166 \\
14,800 \\
184,866\end{array}$ & $\begin{array}{r}74 \\
57 \\
73 \\
72 \\
66 \\
50 \\
61 \\
56 \\
52 \\
50 \\
52 \\
59 \\
722\end{array}$ & $\begin{array}{r}173,138 \\
146,266 \\
192,899 \\
215,659 \\
249,454 \\
260,153 \\
329,861 \\
327,621 \\
262,825 \\
263,376 \\
197,831 \\
169,931 \\
2,789,014\end{array}$ \\
\hline 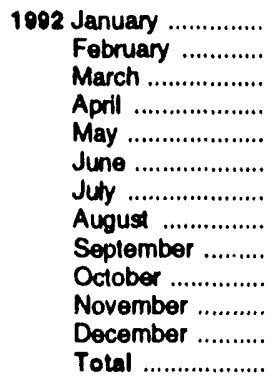 & $\begin{array}{r}80 \\
80 \\
93 \\
73 \\
69 \\
84 \\
90 \\
84 \\
83 \\
85 \\
74 \\
93 \\
986\end{array}$ & $\begin{array}{r}60,881 \\
53,687 \\
56,243 \\
53,314 \\
54,664 \\
57,179 \\
66,318 \\
62,937 \\
58,899 \\
56,366 \\
56,186 \\
61,951 \\
698,626\end{array}$ & $\begin{array}{r}7,304 \\
6,415 \\
6,368 \\
5,407 \\
5,858 \\
6,859 \\
7,407 \\
7,616 \\
6,985 \\
6,356 \\
6,352 \\
7,321 \\
80,248\end{array}$ & $\begin{array}{r}68,264 \\
60,183 \\
62,705 \\
58,794 \\
60,591 \\
64,122 \\
73,815 \\
70,637 \\
65,967 \\
62,806 \\
62,612 \\
69,365 \\
779,660\end{array}$ & $\begin{array}{r}15,811 \\
12,730 \\
13,492 \\
9,929 \\
7,910 \\
11,372 \\
12,939 \\
10,607 \\
10,456 \\
10,454 \\
10,330 \\
9,749 \\
135,779\end{array}$ & $\begin{array}{r}1,103 \\
806 \\
843 \\
811 \\
843 \\
1,077 \\
1,428 \\
1,011 \\
849 \\
792 \\
1,004 \\
989 \\
11,556\end{array}$ & $\begin{array}{r}16,332 \\
13,093 \\
13,932 \\
10,335 \\
8,385 \\
11,881 \\
13,392 \\
11,067 \\
10,820 \\
10,867 \\
10,803 \\
10,256 \\
141,163\end{array}$ & $\begin{array}{r}582 \\
444 \\
404 \\
404 \\
367 \\
568 \\
974 \\
551 \\
485 \\
379 \\
531 \\
482 \\
6,172\end{array}$ & $\begin{array}{r}16,915 \\
13,536 \\
14,336 \\
10,740 \\
8,752 \\
12,449 \\
14,367 \\
11,619 \\
11,305 \\
11,246 \\
11,333 \\
10,737 \\
147,335\end{array}$ & $\begin{array}{r}71 \\
76 \\
83 \\
66 \\
50 \\
66 \\
72 \\
116 \\
98 \\
103 \\
93 \\
105 \\
999\end{array}$ & $\begin{array}{r}169,125 \\
170,293 \\
207,656 \\
229,012 \\
236,316 \\
265,882 \\
333,567 \\
302,544 \\
273,670 \\
212,640 \\
189,296 \\
175,608 \\
2,765,608\end{array}$ \\
\hline 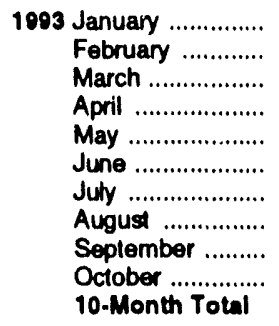 & $\begin{array}{r}79 \\
88 \\
101 \\
84 \\
81 \\
80 \\
73 \\
67 \\
60 \\
64 \\
778\end{array}$ & $\begin{array}{r}61,793 \\
57,682 \\
60,969 \\
53,722 \\
53,450 \\
61,085 \\
71,124 \\
70,241 \\
60,154 \\
59,094 \\
609,316\end{array}$ & $\begin{array}{r}7,617 \\
6,431 \\
6,002 \\
5,757 \\
6,570 \\
6,948 \\
7,511 \\
7,624 \\
6,289 \\
5,752 \\
66,502\end{array}$ & $\begin{array}{l}69,490 \\
64,201 \\
67,073 \\
59,563 \\
60,102 \\
68,113 \\
78,708 \\
77,932 \\
66,504 \\
64,909 \\
676,595\end{array}$ & $\begin{array}{r}10,804 \\
10,591 \\
12,784 \\
7,629 \\
7,722 \\
11,756 \\
16,896 \\
18,044 \\
14,730 \\
11,324 \\
122,281\end{array}$ & $\begin{array}{r}1,011 \\
934 \\
1,277 \\
819 \\
867 \\
1,113 \\
1,815 \\
1,570 \\
1,030 \\
897 \\
11,334\end{array}$ & $\begin{array}{r}11,265 \\
11,023 \\
13,313 \\
8,094 \\
8,198 \\
12,249 \\
17,406 \\
18,515 \\
15,111 \\
11,777 \\
126,951\end{array}$ & $\begin{array}{r}550 \\
502 \\
748 \\
354 \\
392 \\
621 \\
1,305 \\
1,099 \\
649 \\
444 \\
6,664\end{array}$ & $\begin{array}{r}11,815 \\
11,525 \\
14,062 \\
8,448 \\
8,590 \\
12,870 \\
18,711 \\
19,614 \\
15,760 \\
12,221 \\
133,615\end{array}$ & $\begin{array}{r}92 \\
81 \\
87 \\
79 \\
86 \\
98 \\
125 \\
112 \\
129 \\
112 \\
999\end{array}$ & $\begin{array}{r}164,400 \\
161,778 \\
193,795 \\
173,709 \\
167,146 \\
254,601 \\
333,405 \\
356,695 \\
258,812 \\
233,192 \\
2,297,532\end{array}$ \\
\hline $\begin{array}{l}1002 \text { 10-Month Total } \\
1901 \text { 10-Month Total }\end{array}$ & $\begin{array}{l}820 \\
830\end{array}$ & $\begin{array}{l}580,489 \\
574,151\end{array}$ & $\begin{array}{l}66,575 \\
66,806\end{array}$ & $\begin{array}{l}647,883 \\
641,795\end{array}$ & $\begin{array}{l}115,701 \\
145,480\end{array}$ & $\begin{array}{r}9,564 \\
11,439\end{array}$ & $\begin{array}{l}120,105 \\
150,497\end{array}$ & $\begin{array}{l}5,160 \\
6,422\end{array}$ & $\begin{array}{l}125,264 \\
156,920\end{array}$ & $\begin{array}{l}801 \\
611\end{array}$ & $\begin{array}{l}2,400,704 \\
2,421,253\end{array}$ \\
\hline
\end{tabular}

- Heavy oll includes fuel oil nos. 4, 5, and 6, and residual fuel oils

b Light oil includes fuel oil nos. 1 and 2, kerosene, and jet fuel.

c $\mathrm{GT/L}=$ Gas turbine and internal combustion plants.

d Includes supplemental gaseous fuels.
$\mathrm{NA}=\mathrm{Nol}$ available

Notes: - Geographic coverage is the 50 States and the District of Columbla.

- Totals may not equal sum of components due to independent rounding.

Sources: See end of section. 
Table 7.4 Electric Utility Stocks of Coal and Petroleum, End of Period

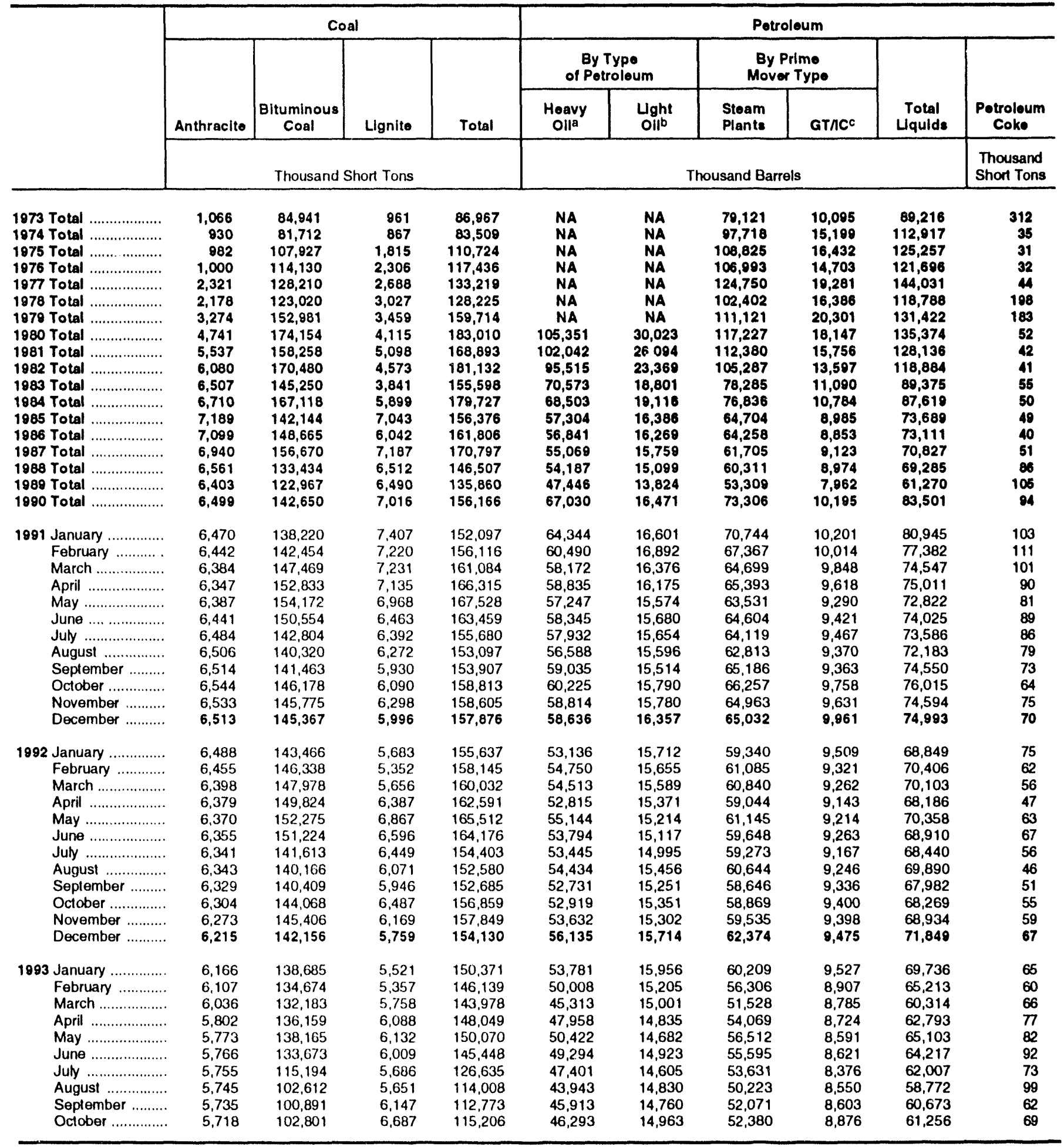

a Heavy oil includes fuel oil nos, 4,5, and 6, and residual fuel oils.

b Light oil includes fuel oil nos. 1 and 2, kerosene, and jet fuel.

c $\mathrm{GT} / \mathrm{KC}=$ Gas lurbine and internal combustion plants

$N A=$ Not available.

Notes: - Geographic coverage is the 50 States and the District of Columbia

- Totals may not equal sum of components due to independent rounding.

Sources: - Prime Mover Typo Data: 1973-September 1977-Federal

Power Commission (FPC). Form FPC.4, "Monthly Power Plant Repont."

October 1977-1981-Federal Energy Regulatory Commission (FERC). Form
FPC-4, "Monthly Power Plant Report." 1982 forward-Energy Information Administration (EIA), Form EIA.759, "Monthly Power Plant Report." - All Other Data: 1973-September 1977-FPC, Form FPC-4, "Monthly Power Plant Report." October 1977-1979-FERC, Form FPC-4, "Monthly Power Plant Report." 1980-ElA, Electric Power Monthly, March 1991, Table 28. 1981-ElA, Electric Power Monthy, March 1992. Table 28. 1982 and 1991 monthly data-EIA, Electric Power Monthly, March 1993, Table 28. 1983 lorward (oxcept 1001 monthly data) -EIA, Electric Power Monthly, January 1994, Table 28. 


\section{Sources for Table 7.3}

- Prime Mover Type Data: 1973-September 1977Federal Power Commission (FPC), Form FPC-4, "Monthly Power Plant Report." October 1977-1981Federal Energy Regulatory Commission (FERC), Form FPC-4, "Monthly Power Plant Report." 1982 forward-Energy Information Administration (EIA), Form EIA-759, "Monthly Power Plant Report."
- All Other Data: 1973-September 1977-FPC, Form FPC-4, "Monthly Power Plant Report." October 1977-1979-FERC, Form FPC-4, "Monthly Power Plant Report." 1980-EIA, Electric Power Monthly, March 1991, Table 17. 1981-EIA, Electric Power Monthly, March 1992, Table 17. 1982 and 1991 monthly data-EIA, Electric Power Monthly, March 1993, Table 17. 1983 forward (except 1991 monthly data)-ElA, Electric Power Monthly, January 1994, Table 17. 


\section{Section 8. Nuclear Energy}

In October 1993, U.S. nuclear generating units produced a total of 44 net terawatthours (billion kilowatthours) of electricity, 9 percent ${ }^{8}$ less than in October 1992. Nuclear units generated at an average capacity factor of 60.2 percent, 6 percentage points lower than in October 1992. Nuclear power supplied 19.9 percent of the total electric utility-generated electricity in October 1993, compared with 22.0 percent in October 1992.

No low- or full power licenses for nuclear power plants were issued by the Nuclear Regulatory Commission during October 1993.

On October 31, 1993, there were 109 operable nuclear generating units in the United States, with a collective net summer capability of 99.0 million kilowatts of electricity. Of the 109 operable units, 31 units generated at less than 25 percent of capacity because of maintenance, refueling, or repair outage, and 19 of the 31 units generated no electricity during the month.

Two operable units, Browns Ferry 1 and 3, have been shut down since March 1985. Each unit had a capacity of 1,065 megawatts electric.

As of October 31, there were 116 domestic nuclear generating units in all stages of construction and operation. The aggregate net design capacity of operable units was 101.1 million kilowatts, and the design capacity of units under construction was $\mathbf{8 . 5}$ million kilowatts, for a total design capacity of $\mathbf{1 0 9 . 6}$ million kilowatts. 
Figure 8.1 Nuclear Power Plant Operations

Operable Units, End of Year, 1973-1992

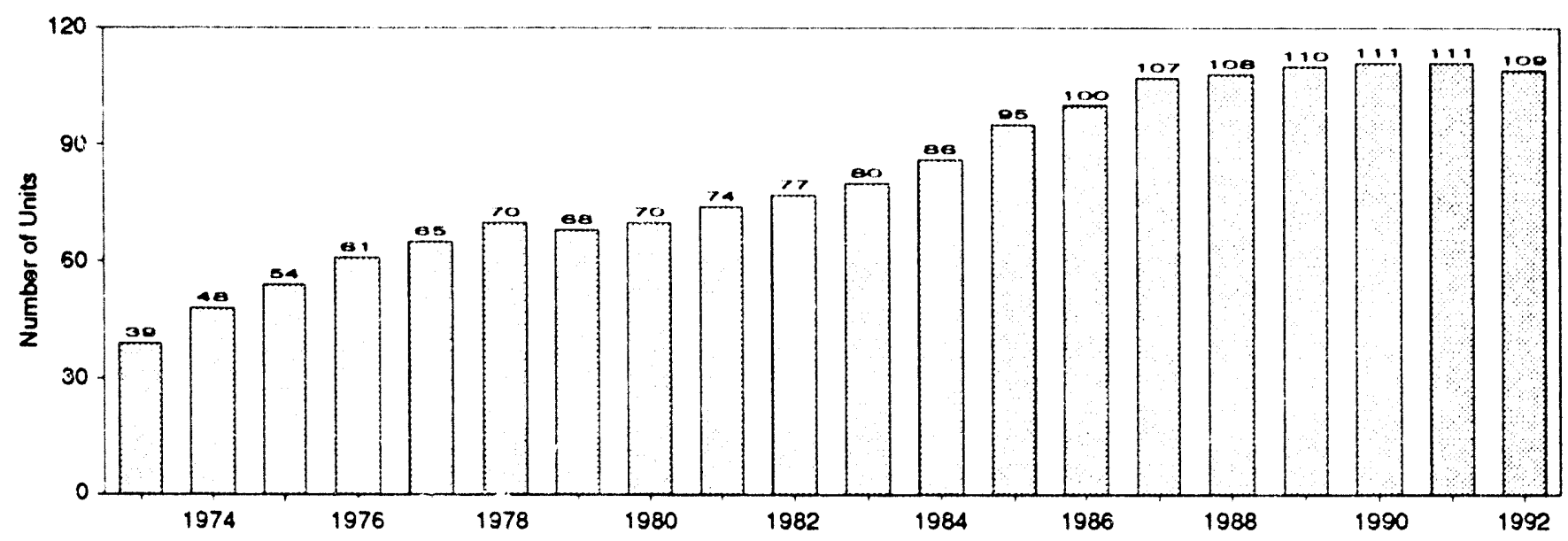

Net Generation of Electricity, 1973-1992

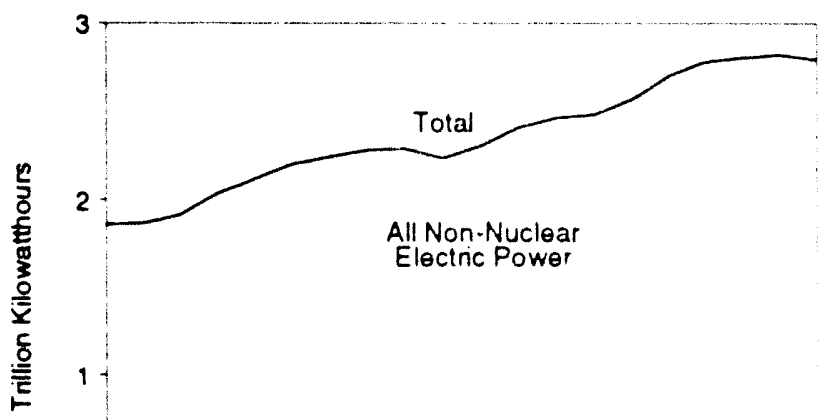

Nuclear Electric Power

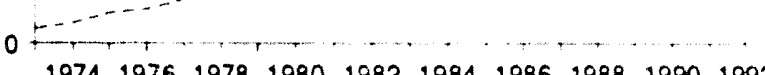

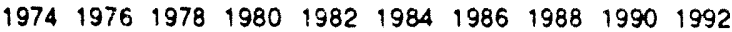

Nuclear Electricity Net Generation

80

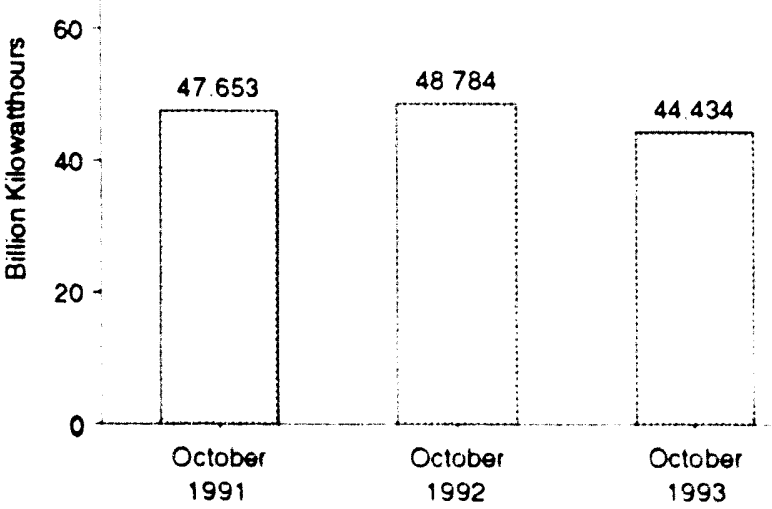

Nuclear Portion of Domestic Electricity Net Generation 30 .

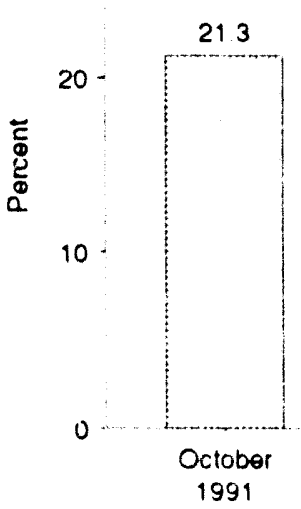

Capacity Factor, Monthly
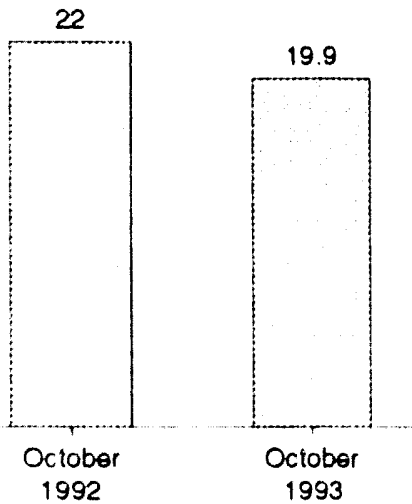

Note Because vertical scales ditler. graphs should not be compared Sources: Tabies 71 and 81 
Table 8.1 Nuclear Power Plant Operations

\begin{tabular}{|c|c|c|c|c|c|}
\hline & $\begin{array}{l}\text { Operable } \\
\text { Units } a, b\end{array}$ & $\begin{array}{c}\text { Nuclear } \\
\text { Electricity } \\
\text { Net } \\
\text { Generation }\end{array}$ & $\begin{array}{c}\text { Nuclear } \\
\text { Portion of } \\
\text { Domestic } \\
\text { Electricity } \\
\text { Net Generation }\end{array}$ & $\begin{array}{c}\text { Not } \\
\text { Summer } \\
\text { Capablity } \\
\text { of Operable } \\
\text { Unitsa,c }\end{array}$ & $\begin{array}{l}\text { Capacity } \\
\text { Factord }\end{array}$ \\
\hline & Number & $\begin{array}{l}\text { Million } \\
\text { Kilowalthours }\end{array}$ & Percent & $\begin{array}{l}\text { Million } \\
\text { Kilowatts }\end{array}$ & Percent \\
\hline 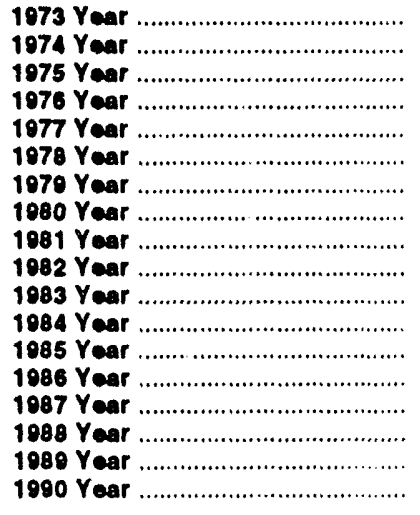 & $\begin{array}{r}39 \\
48 \\
54 \\
61 \\
65 \\
70 \\
68 \\
70 \\
74 \\
77 \\
80 \\
86 \\
95 \\
100 \\
107 \\
108 \\
110 \\
111\end{array}$ & $\begin{array}{r}83,478 \\
113,876 \\
172,505 \\
191,104 \\
250,883 \\
276,403 \\
255,155 \\
251,116 \\
272,674 \\
282,773 \\
283,677 \\
327,634 \\
383,691 \\
414,038 \\
455,270 \\
526,973 \\
529,355 \\
576,862\end{array}$ & $\begin{array}{r}4.5 \\
6.1 \\
9.0 \\
9.4 \\
11.8 \\
12.5 \\
11.4 \\
11.0 \\
11.9 \\
12.6 \\
12.7 \\
13.6 \\
15.5 \\
16.6 \\
17.7 \\
19.5 \\
19.0 \\
20.5\end{array}$ & $\begin{array}{l}22.683 \\
31.867 \\
37.267 \\
43.822 \\
46.303 \\
50.824 \\
49.747 \\
51.810 \\
56.042 \\
60.035 \\
63.009 \\
69.652 \\
79.397 \\
85.241 \\
93.583 \\
94.695 \\
98.161 \\
99.624\end{array}$ & $\begin{array}{l}53.5 \\
47.8 \\
55.0 \\
54.7 \\
63.3 \\
64.5 \\
58.4 \\
56.3 \\
58.2 \\
56.6 \\
54.4 \\
56.3 \\
58.0 \\
56.0 \\
57.4 \\
63.5 \\
62.2 \\
66.0\end{array}$ \\
\hline 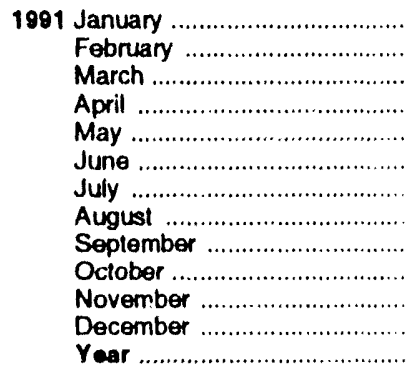 & $\begin{array}{l}111 \\
111 \\
111 \\
111 \\
111 \\
111 \\
111 \\
111 \\
111 \\
111 \\
111 \\
111 \\
111\end{array}$ & $\begin{array}{r}54,369 \\
47,863 \\
49,121 \\
41,631 \\
46,755 \\
54,208 \\
60,735 \\
58,473 \\
51,874 \\
47,653 \\
46,295 \\
53,589 \\
612,565\end{array}$ & $\begin{array}{l}21.9 \\
22.7 \\
22.2 \\
19.9 \\
19.9 \\
21.8 \\
22.3 \\
21.8 \\
22.2 \\
21.3 \\
20.9 \\
22.9 \\
21.7\end{array}$ & $\begin{array}{l}99.624 \\
99.624 \\
99.624 \\
99.624 \\
99.624 \\
99.624 \\
99.589 \\
99.589 \\
99.589 \\
99.589 \\
99.589 \\
99.589 \\
99.589\end{array}$ & $\begin{array}{l}73.4 \\
71.5 \\
66.3 \\
58.1 \\
63.1 \\
75.6 \\
82.0 \\
78.9 \\
72.3 \\
64.2 \\
64.6 \\
72.3 \\
70.2\end{array}$ \\
\hline 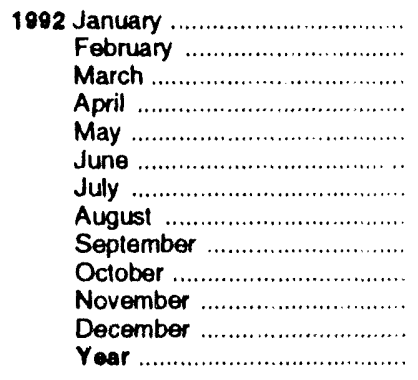 & $\begin{array}{l}111 \\
110 \\
110 \\
110 \\
110 \\
110 \\
110 \\
110 \\
110 \\
110 \\
110 \\
109 \\
109\end{array}$ & $\begin{array}{r}57,849 \\
52,804 \\
45,835 \\
42,268 \\
45,627 \\
51,185 \\
56,049 \\
58,656 \\
50,919 \\
48,784 \\
50,726 \\
58,075 \\
618,776\end{array}$ & $\begin{array}{l}23.7 \\
24.2 \\
20.4 \\
20.0 \\
20.7 \\
21.6 \\
21.1 \\
23.0 \\
21.7 \\
22.0 \\
22.9 \\
23.8 \\
22.1\end{array}$ & $\begin{array}{l}94.589 \\
99.422 \\
99.422 \\
99.422 \\
99.422 \\
99.422 \\
99.422 \\
99.422 \\
99.422 \\
99.422 \\
99.422 \\
98.986 \\
98.986\end{array}$ & $\begin{array}{l}78.1 \\
76.3 \\
62.0 \\
59.1 \\
61.7 \\
71.5 \\
75.8 \\
79.3 \\
71.1 \\
65.9 \\
70.9 \\
78.9 \\
70.9\end{array}$ \\
\hline 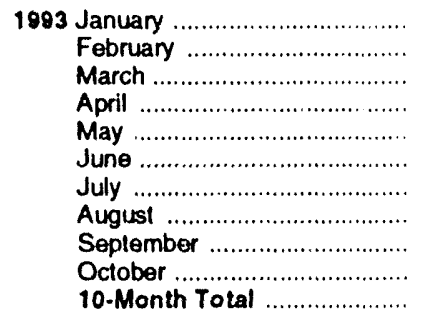 & $\begin{array}{l}108 \\
108 \\
108 \\
109 \\
109 \\
109 \\
109 \\
109 \\
109 \\
109 \\
109\end{array}$ & $\begin{array}{r}59,076 \\
51,319 \\
46,606 \\
43,199 \\
50,367 \\
52,620 \\
56,502 \\
56,209 \\
49,989 \\
44,434 \\
510,321\end{array}$ & $\begin{array}{l}24.0 \\
22.8 \\
19.9 \\
20.4 \\
22.6 \\
21.1 \\
20.0 \\
20.1 \\
21.1 \\
19.9 \\
21.2\end{array}$ & $\begin{array}{l}97.882 \\
97.882 \\
97.882 \\
99.032 \\
99.032 \\
99.032 \\
99.031 \\
99.031 \\
99.031 \\
99.031 \\
99.031\end{array}$ & $\begin{array}{l}81.1 \\
78.0 \\
64.0 \\
60.7 \\
68.4 \\
73.8 \\
76.7 \\
76.3 \\
70.1 \\
60.2 \\
70.9\end{array}$ \\
\hline 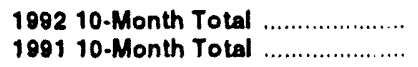 & $\begin{array}{l}110 \\
111\end{array}$ & $\begin{array}{l}5(8,975 \\
512,680\end{array}$ & $\begin{array}{l}21.9 \\
21.6\end{array}$ & $\begin{array}{l}99.422 \\
99.589\end{array}$ & $\begin{array}{l}70.1 \\
70.5\end{array}$ \\
\hline
\end{tabular}

At end a period.

b See Note 1 at end of section.

c For the delinition of "Net Summer Capability," see Note 3 at end of section.

f For an explanation of the method of calculating the capacity factor, see Note 4 at end of section.

Notes: - Geographic coverage is the 50 States and the District of Columbia

- Nuclear electricity net generation tolals may not equal sum of components due to independent rounding.

Sources: - Operable Units: 1973-1982-U.S. Department of Energy (DOE), Otlice of Nuclear Programs, "U.S. Central Station Nuclear Electric

Generating Units: Significant Milestones. 1983 forward-Nuclear Regulatory Commission (NRC), "Licensed Operating Reactors" (NUREG-0020). - Nuclear Electricity Net Generation: Table 7.1. - Nuclear Portion of Domestic Electricity Net Generation: Calculated from dala in Table 7.1. - Net Summer Capability of Operable Units: 1973-1982-Compiled from various sources, primarily DOE, Otilce of Nuclear Reactor Programs, "U.S. Ceniral Station Nuclear Electric Generating Units: Significant Milestones." 1983 forward-Energy Information Administration (EIA). Form ElA-860, "Annual Electric Generation Report," and monthly updates as appropriate. - Capacity Factor: EIA, Otfice of Coal, Nuclear. Electric and Alternale Fuels. 
Table 8.2 Nuclear Generating Units, End of Period

\begin{tabular}{|c|c|c|c|c|c|c|c|c|}
\hline & \multicolumn{2}{|c|}{$\begin{array}{l}\text { Licensed } \\
\text { for Operation }\end{array}$} & \multicolumn{2}{|c|}{$\begin{array}{c}\text { Construction } \\
\text { Permite }\end{array}$} & \multirow[b]{2}{*}{ On Order } & \multirow[b]{2}{*}{ Announced } & \multirow[b]{2}{*}{ Total } & \multirow{3}{*}{$\frac{\begin{array}{c}\text { Total } \\
\text { Dosign } \\
\text { Capacity }\end{array}}{\begin{array}{c}\text { Million } \\
\text { Kllowatts }\end{array}}$} \\
\hline & Operablea & In Startupb & Grantod & Pending & & & & \\
\hline & \multicolumn{7}{|c|}{ Number of Units } & \\
\hline 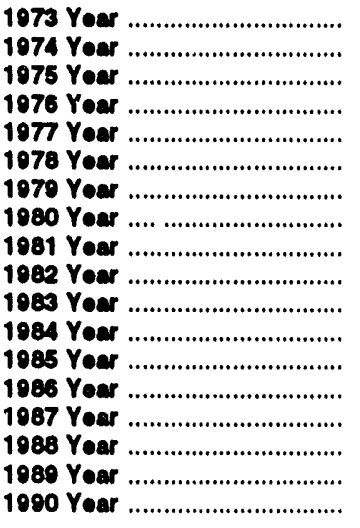 & $\begin{array}{r}39 \\
48 \\
54 \\
61 \\
65 \\
70 \\
68 \\
70 \\
74 \\
77 \\
80 \\
86 \\
95 \\
100 \\
107 \\
108 \\
110 \\
111\end{array}$ & $\begin{array}{l}2 \\
5 \\
2 \\
1 \\
2 \\
0 \\
0 \\
1 \\
0 \\
2 \\
3 \\
6 \\
3 \\
7 \\
4 \\
3 \\
1 \\
0\end{array}$ & $\begin{array}{r}57 \\
62 \\
69 \\
71 \\
78 \\
88 \\
90 \\
82 \\
76 \\
60 \\
53 \\
38 \\
30 \\
19 \\
14 \\
12 \\
10 \\
8\end{array}$ & $\begin{array}{l}52 \\
75 \\
69 \\
63 \\
49 \\
32 \\
24 \\
12 \\
11 \\
3 \\
0 \\
0 \\
0 \\
0 \\
0 \\
0 \\
0 \\
0\end{array}$ & $\begin{array}{r}49 \\
30 \\
14 \\
16 \\
13 \\
5 \\
3 \\
3 \\
2 \\
2 \\
2 \\
2 \\
2 \\
2 \\
2 \\
0 \\
0 \\
0\end{array}$ & $\begin{array}{l}0 \\
6 \\
5 \\
2 \\
2 \\
0 \\
0 \\
0 \\
0 \\
0 \\
0 \\
0 \\
0 \\
0 \\
0 \\
0 \\
0 \\
0\end{array}$ & $\begin{array}{l}208 \\
226 \\
213 \\
214 \\
209 \\
105 \\
185 \\
168 \\
163 \\
144 \\
138 \\
132 \\
130 \\
128 \\
127 \\
123 \\
121 \\
110\end{array}$ & $\begin{array}{l}108 \\
223 \\
212 \\
211 \\
203 \\
191 \\
180 \\
162 \\
157 \\
134 \\
120 \\
123 \\
121 \\
110 \\
110 \\
115 \\
113 \\
111\end{array}$ \\
\hline 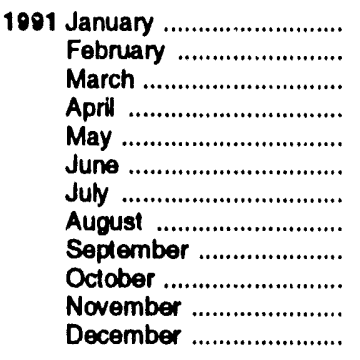 & $\begin{array}{l}111 \\
111 \\
111 \\
111 \\
111 \\
111 \\
111 \\
111 \\
111 \\
111 \\
111 \\
111\end{array}$ & $\begin{array}{l}0 \\
0 \\
0 \\
0 \\
0 \\
0 \\
0 \\
0 \\
0 \\
0 \\
0 \\
0\end{array}$ & $\begin{array}{l}8 \\
8 \\
8 \\
8 \\
8 \\
8 \\
8 \\
8 \\
8 \\
8 \\
8 \\
8\end{array}$ & $\begin{array}{l}0 \\
0 \\
0 \\
0 \\
0 \\
0 \\
0 \\
0 \\
0 \\
0 \\
0 \\
0\end{array}$ & $\begin{array}{l}0 \\
0 \\
0 \\
0 \\
0 \\
0 \\
0 \\
0 \\
0 \\
0 \\
0 \\
0\end{array}$ & $\begin{array}{l}0 \\
0 \\
0 \\
0 \\
0 \\
0 \\
0 \\
0 \\
0 \\
0 \\
0 \\
0\end{array}$ & $\begin{array}{l}119 \\
119 \\
119 \\
119 \\
119 \\
119 \\
119 \\
119 \\
119 \\
119 \\
119 \\
119\end{array}$ & $\begin{array}{l}111 \\
111 \\
111 \\
111 \\
111 \\
111 \\
111 \\
111 \\
111 \\
111 \\
111 \\
111\end{array}$ \\
\hline 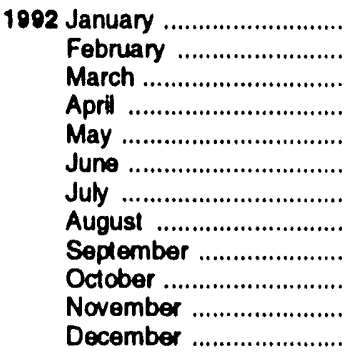 & $\begin{array}{l}111 \\
110 \\
110 \\
110 \\
110 \\
110 \\
110 \\
110 \\
110 \\
110 \\
110 \\
100\end{array}$ & $\begin{array}{l}0 \\
0 \\
0 \\
0 \\
0 \\
0 \\
0 \\
0 \\
0 \\
0 \\
0 \\
0\end{array}$ & $\begin{array}{l}8 \\
8 \\
8 \\
8 \\
8 \\
8 \\
8 \\
8 \\
8 \\
8 \\
8 \\
8\end{array}$ & $\begin{array}{l}0 \\
0 \\
0 \\
0 \\
0 \\
0 \\
0 \\
0 \\
0 \\
0 \\
0 \\
0\end{array}$ & $\begin{array}{l}0 \\
0 \\
0 \\
0 \\
0 \\
0 \\
0 \\
0 \\
0 \\
0 \\
0 \\
0\end{array}$ & $\begin{array}{l}0 \\
0 \\
0 \\
0 \\
0 \\
0 \\
0 \\
0 \\
0 \\
0 \\
0 \\
0\end{array}$ & $\begin{array}{l}119 \\
118 \\
118 \\
118 \\
118 \\
118 \\
118 \\
118 \\
118 \\
118 \\
118 \\
117\end{array}$ & $\begin{array}{l}111 \\
111 \\
111 \\
111 \\
111 \\
111 \\
111 \\
111 \\
111 \\
111 \\
111 \\
111\end{array}$ \\
\hline 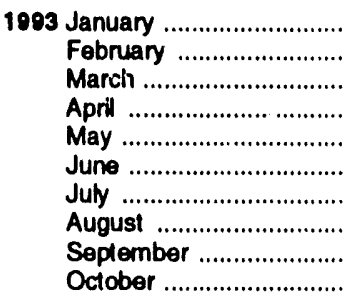 & $\begin{array}{l}108 \\
108 \\
108 \\
109 \\
109 \\
109 \\
109 \\
109 \\
109 \\
109\end{array}$ & $\begin{array}{l}0 \\
1 \\
1 \\
0 \\
0 \\
0 \\
0 \\
0 \\
0 \\
0\end{array}$ & $\begin{array}{l}8 \\
7 \\
7 \\
7 \\
7 \\
7 \\
7 \\
7 \\
7 \\
7\end{array}$ & $\begin{array}{l}0 \\
0 \\
0 \\
0 \\
0 \\
0 \\
0 \\
0 \\
0 \\
0\end{array}$ & $\begin{array}{l}0 \\
0 \\
0 \\
0 \\
0 \\
0 \\
0 \\
0 \\
0 \\
0\end{array}$ & $\begin{array}{l}0 \\
0 \\
0 \\
0 \\
0 \\
0 \\
0 \\
0 \\
0 \\
0\end{array}$ & $\begin{array}{l}116 \\
116 \\
116 \\
116 \\
116 \\
116 \\
116 \\
116 \\
116 \\
116\end{array}$ & $\begin{array}{l}110 \\
110 \\
110 \\
110 \\
110 \\
110 \\
110 \\
110 \\
110 \\
110\end{array}$ \\
\hline
\end{tabular}

- See Note 1 al end of section.

b See Nole 2 at end of section.

c Net design electrical rating (DER) is used because many of the units were canceled prior to being assigned a net summer capability. See Note 3 at end of section.

Note: Geographic coverage is the 50 States and the District of Columbia.

Sources: - Licensed for Operation: 1973-1982-U.S. Department of Energy (DOE), Ottice of Nuclear Programs, "U.S. Central Station Nuclear Electric Generating Units: Significant Milestones." 1983 forward-Nuclear Regulatory Commission (NRC). "Licensed Operating Reactors" (NUREG-0020). - Constructlon Permite, On Order, and Announced: 1073-1082-Compiled from various sources, primarily DOE, Office of Nuclear Reactor Programs, "U.S. Central Station Nuclear Electric Generating Units: Signilicant Milestones"; Energy Information Administration (EIA). Oflice of Coal, Nuclear, Electric and Alternate Fuels (CNEAF). "Nuclear Sleam-Electric
Units That Have Been in Operation as of 1957-1989"; EIA, CNEAF. "Nuclear Plant Cancellations: Causes, Costs, and Consequences"; and Uility Data Institute, Inc., "U.S. Nuclear Plant Statistics, 1987." 1083 forward-NRC, "Summary Information Repor" (NUREG-0871); NAC, "Licensed Operating Reactors" (NUREG-0020); and various joumals. - Total Design Capacity: 1973-1982-Compiled from various sources, primarily DOE, Oflice of Nuchisar Reactor Programs, "U.S. Central Station Nuclear Electric Generating Units: Significant Milestones"; EIA, CNEAF, "Nuclear Steam-Electric Units That Have Been in Operation as of 1957-1987"; EIA, CNEAF, "Monthly Repont for Electric Utilities-Power Generation"; EIA, CNEAF, "Nudear Plant Cancellations: Causes, Costs, and Consequences"; and Utility Data Inethute, Inc., "U.S. Nuclear Plant Statistics, 1987." 1983 forward-NRC, "Summary Information Report" (NUREG-0871): NRC, "Licensed Operating Reactors" (NUREG-0020); and EIA, Form EIA-860, "Annual Electric Generator Repont." 


\section{Nuclear Energy Notes}

1. Operable Units: Nuclear generating units that have been issued a full-power license by the Nuclear Regulatory Commission (NRC).

Exceptions: The Shippingport (60 megawatts (MW)) and the Hanford-N (840 MW) nuclear units were included in the operable units until 1982 and 1988, respectively. The Shippingport unit was excluded from the operable category during March 1974-August 1977 due to a major core modification outage. Hanford-N, an unlicensed unit used for defense material production, was included in the operable category because power was produced as by-product and sold commercially. Three Mile Island $2(880 \mathrm{MW})$ experienced a major accident in 1979 and, although that unit still retains its operating license and site cleanup continues, there is no plan to restart it. Therefore, it has not been included in the operable category since March 1979. Although Shoreham received a full-power license in April 1989, the unit is not currently scheduled to operate and, therefore, has not been included in the operable category. Rancho Seco $(873 \mathrm{MW}$ ) was shut down by the Sacramento Municipal Utility District (SMUD) in June 1989 following a referendum on its continued operation. Because there are currently no plans to operate it as a nuclear unit, it is no longer included as an operable unit but is identified as a unit shut down for an extended period. As soon as SMUD and the NRC formalize the plant's official retirement, it will be noted as such in this report. The Department of Energy-operated Experimental Breeder Reactor 2 unit is not a commercial reactor and is therefore not included in the operable category.

In addition, nine units have been retired and therefore removed from the operable category. Those units are: Peach Bottom 1 (40 MW) and Indian Point 1 (265 MW), both retired in 1974; Humboldt Bay (65 MW), officially retired in 1976; Dresden 1 (200 MW), retired in August 1979; LaCrosse (51 MW), retired in May 1987; Fort Saint Vrain (217 MW), retired in August 1989; Yankee Rowe 1 (185 MW), retired in February 1992; San Onofre $1(436 \mathrm{MW})$, retired in December 1992; and Trojan $(1,104 \mathrm{MW})$, retired in January 1993.

2. In Startup: The period of time between a nuclear generating unit's initial fuel loading date and the issuance of its full-power license. During that period, the unit is undergoing low-power testing and the maximum level of operation is 5 percent of the unit's besign thermal rating.

3. Capacity: Nuclear generating units may have more than one type of net capacity rating, including the following:

(a) Net Summer Capability-The steady hourly output that generating equipment is expected to supply to system load, exclusive of auxiliary power, as demonstrats: $d$ by test at the time of summer peak demand. Auxiliary power of a typical nuclear power plant is about 5 percent of gross generation.

(b) Net Design Capacity or Net Design Electrical Rating (DER)-The nominal net electrical output of a unit, specified by the utility and used for plant design.

4. Monthly Capacity Factors: The monthly capacity factors are computed as the actual monthly generation divided by the maximum possible generation for that month. The maximum possible generation is the number of hours in the month inultiplied by the net summer capability at the end of the month. That fraction is then multiplied by 100 to obtain a percentage. Annual capacity factors are averages of the monthly values for that year. 


\section{Section 9. Energy Prices}

Crude Oil. The average price of domestic crude oil purchased at the wellhead was $\$ 13.80$ per barrel in October 1993, 20 percent below the level in October 1992. The refiner acquisition cost of imported crude oil in October 1993 was $\$ 15.48$ per barrel, 20 percent below the October 1992 level. The average cost of domestic crude oil in October 1993 was $\$ 16.09,18$ percent less than the October 1992 average.

Motor Gasoline. The national city average retail price of unleaded regular gasoline at all types of stations was $\$ 1.11$ per gallon in November 1993,4 percent lower than the price in November 1992. The price of unleaded premium gasoline averaged $\$ 1.31$ per gallon in November 1993, 3 percent lower than the price in November 1992.

Residual Fuel Oil. The average price, excluding taxes, of residual fuel oil sold to end users in October 1993 was 32 cents per gallon, 1 percent higher than the previous month's price and 19 percent lower than the October 1992 average. The average resale price, excluding taxes, of residual fuel oil in October 1993 was 28 cents per gallon, 6 percent above the September 1993 average but 24 percent below the price 1 year earlier.

Aviation Fuel. The average price, excluding taxes, of aviation gasoline sold to end users in October 1993 was 98 cents per gallon, slightly lower than the previous month's price and 6 percent lower than the October 1992 price. The average price, excluding taxes, of kerosene-type jet fuel sold to end users in October 1993 was 61 cents per gallon, 8 percent higher than the previous month's average price but 8 percent lower than the October 1992 average price.

No. 2 Distillate Fuel Oil. The October 1993 national average price, excluding taxes, of heating oil sold to residential customers was 89 cents per gallon, 4 percent higher than the September 1993 price but 5 percent lower than the October 1992 price. The average price of No. 2 fuel oil sold to all end users was 63 cents per gallon in October 1993, 11 percent higher than the
September 1993 price but 7 percent lower than the October 1992 price.

Electricity. The average price of electricity sold to all ultimate consumers in the United States in October 1993 was 7.2 cents per kilowatthour, 4 percent above the October 1992 mean price. The price of electricity sold to residential consumers in Octobber 1993 averaged 8.8 cents per kilowatthour, 4 percent above the October 1992 price. The price of electricity sold to commercial consumers averaged 8.1 cents per kilowatthour in October 1993, 3 percent above the October 1992 price. The price of electricity sold to other consumers was 7.3 cents per kilowatthour, 6 percent above the October 1992 price. The price of electricity sold to industrial users in October 1993 averaged 5.0 cents per kilowatthour, 2 percent above the price 1 year earlier.

Beginning with January 1986, there were new series of national average price estimates based on a statistically derived sample of both publicly and privately owned electric utilities. Previously, average price estimates were derived from selected privately owned electric utilities and were not national averages.

Natural Gas. The estimated average wellhead price of natural gas for October 1993 was $\$ 1.99$ per thousand cubic feet, 16 percent below the Octoher 1992 price.

The average price of natural gas delivered to electric utility plants was $\$ 2.69$ per thousand cubic feet in September 1993 (latest date for which data are available), 7 percent above the September 1992 price. The average price of natural gas used by residential consumers in October 1993 was $\$ 6.75$ per thousand cubic fect, 4 percent above the October 1992 price. The average price of natural gas used by commercial consumers in October 1993 was $\$ 5.12$ per thousand cubic feet, 4 percent higher than the October 1992 price. The average price of natural gas used by industrial consumers in October 1993 was $\$ 2.88$ per thousand cubic feet, 10 percent below the October 1992 price. 
Crude Oil Prices, 1973-1992

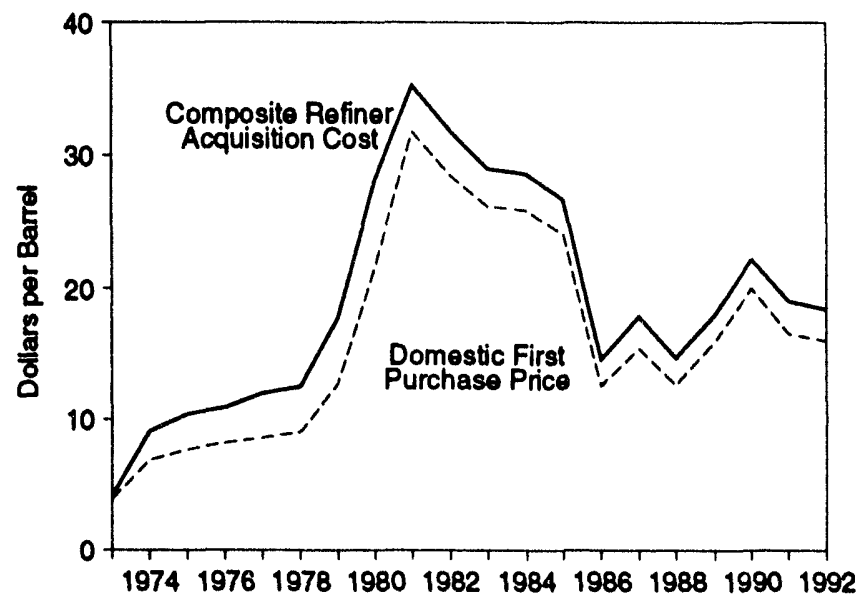

Composite Refiner Acquisition Cost, Monthly

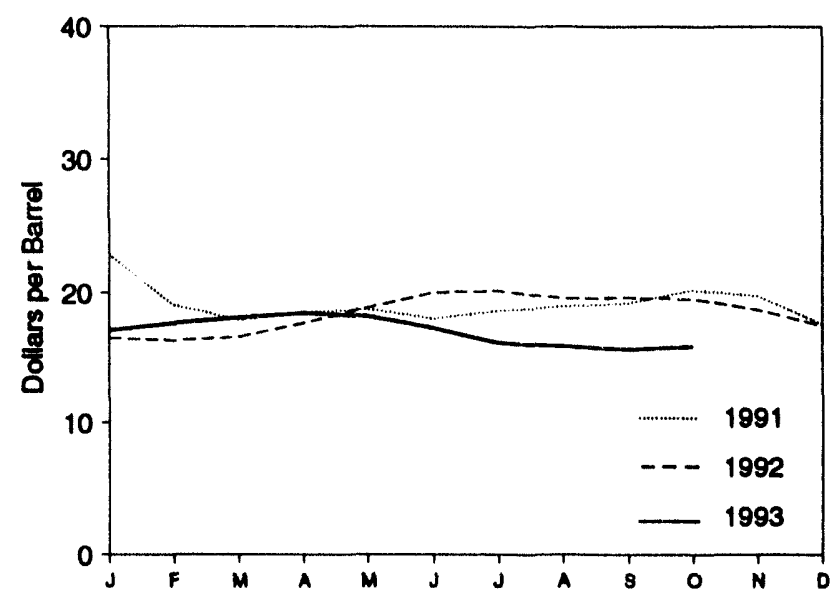

Refiner Prices to End Users: Motor Gasoline, Diesel Fuel, and Jet Fuel, Monthly

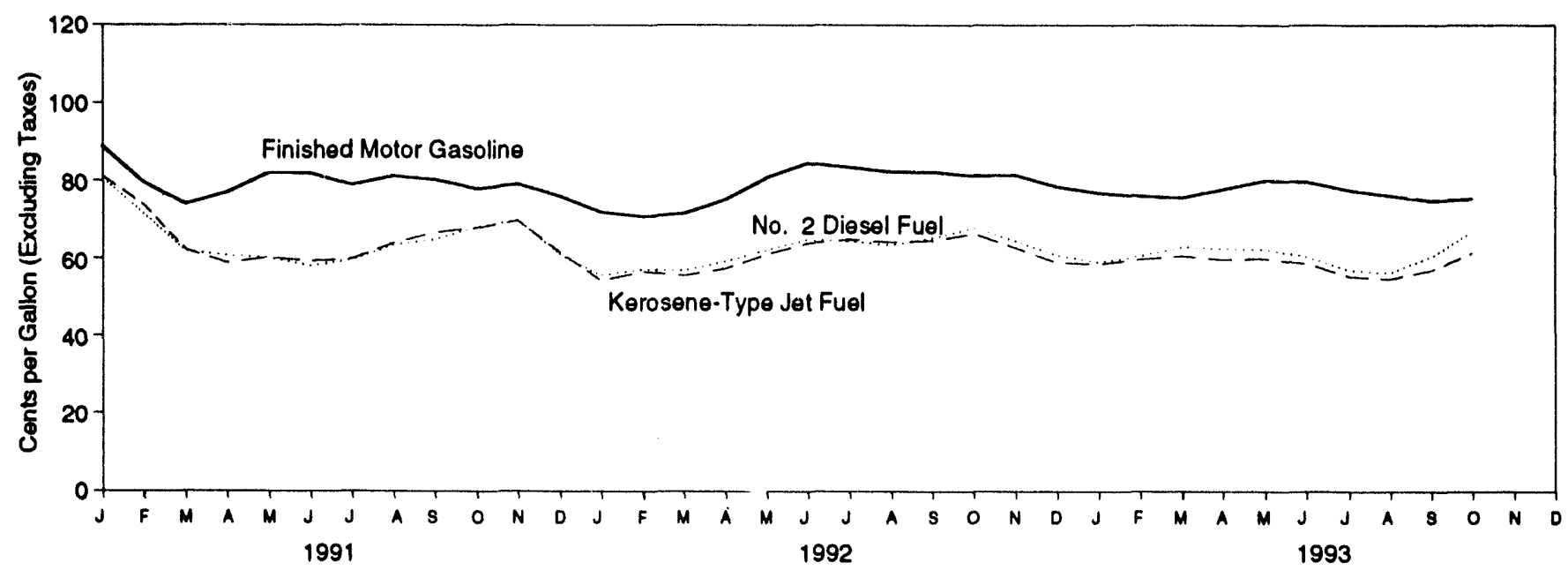

Refiner Prices to End Users: No. 2 Fuel Oil, Propane, and Residual Fuel, Monthly

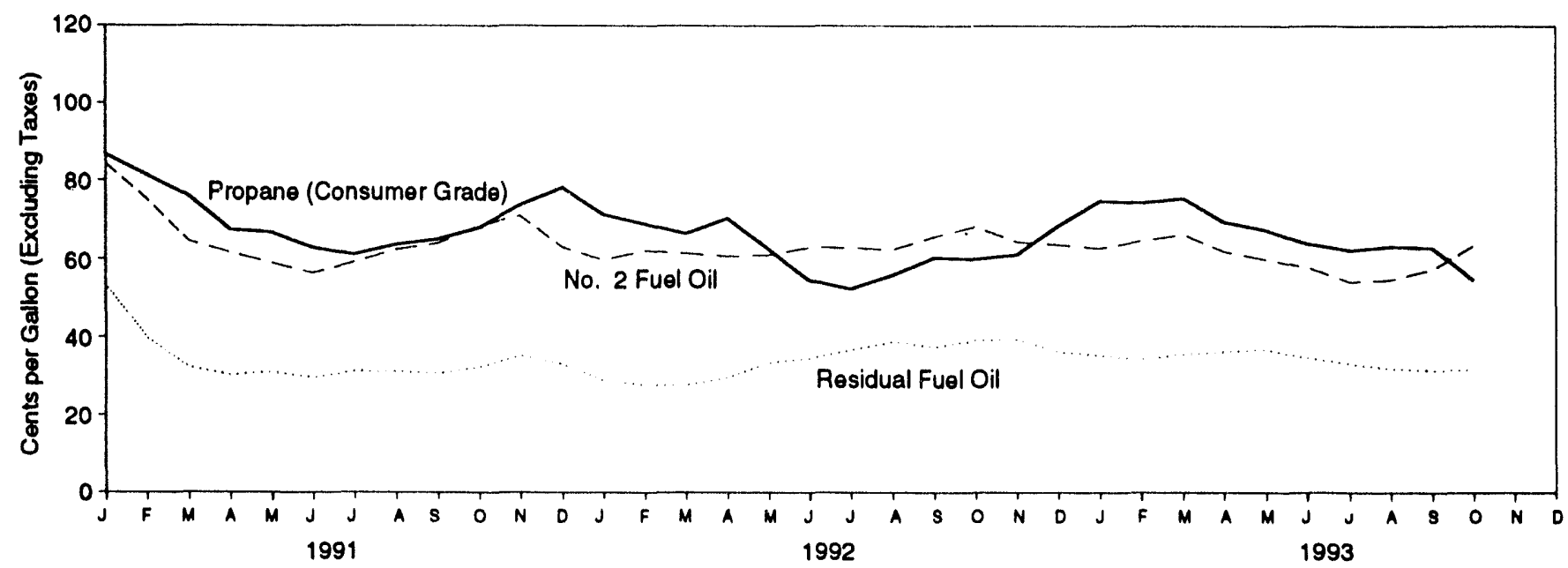

Sources: Tables 9.1, 9.5, and 9.7. 
(Dollars per Barrel)

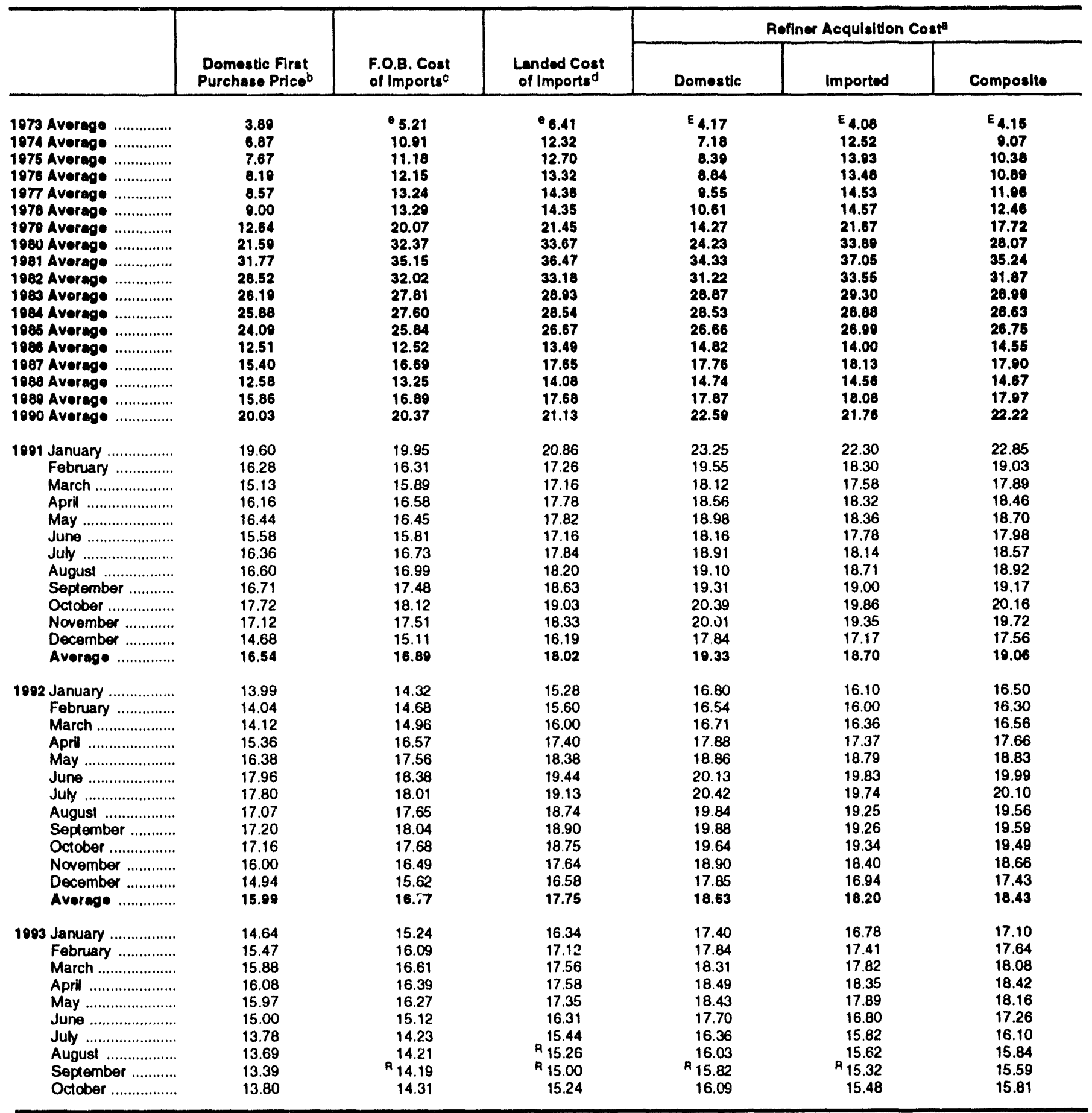

- See Note 4 at end of section.

b See Nole 1 at end ol section.

c See Note 2 at end of section.

- See Note 3 al end of section.

- Based on October, November, and December data only.

$R=$ Revised dala. E=Estimate.

Notes: - Geographic coverage is the 50 States, the District of Columbia,
Puento Rico, the Virgin Islands, and all U.S. Territories and Possessions. - Values for Domestic First Purchase Price and Refiner Acquisition Cost for the current month and for F.O.B. and Landed Costs of Imports for the current 2 months are preliminary. F.O.B. and landed costs through 1980 rellect the period of reporting; prices after 1980 rellect the period of loading Annual averages are the averages of the monthly prices, weighted by volume. Sources: 560 end of section. 


\begin{tabular}{|c|c|c|c|c|c|c|c|c|c|c|c|}
\hline & Algerla & Indonesia & Iran & Mexico & Nigerla & $\begin{array}{l}\text { Saudi } \\
\text { Arabla }\end{array}$ & $\begin{array}{c}\text { United } \\
\text { Kingdom }\end{array}$ & Venezuela & $\begin{array}{c}\text { Other } \\
\text { Countrles }\end{array}$ & $\begin{array}{c}\text { Arab } \\
\text { OPECa }\end{array}$ & $\begin{array}{l}\text { Total } \\
\text { OPECb }\end{array}$ \\
\hline 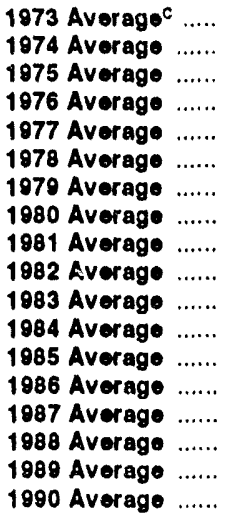 & $\begin{array}{r}7.23 \\
13.23 \\
11.83 \\
13.05 \\
14.35 \\
14.12 \\
20.53 \\
36.67 \\
39.08 \\
34.20 \\
30.09 \\
28.34 \\
26.89 \\
13.62 \\
16.79 \\
W \\
W \\
W\end{array}$ & $\begin{array}{r}5.67 \\
11.99 \\
12.55 \\
12.76 \\
13.57 \\
13.61 \\
19.03 \\
32.17 \\
35.62 \\
35.11 \\
29.92 \\
29.13 \\
27.12 \\
13.19 \\
17.40 \\
13.81 \\
17.01 \\
21.29\end{array}$ & $\begin{array}{l}4.24 \\
10.85 \\
10.81 \\
11.61 \\
12.68 \\
12.65 \\
22.93 \\
N A \\
\text { (d) } \\
30.97 \\
28.39 \\
27.42 \\
W \\
W \\
W \\
\text { (d) } \\
\text { (d) } \\
\text { (d) }\end{array}$ & $\begin{array}{l}\text { NA } \\
W \\
11.44 \\
12.22 \\
13.42 \\
13.24 \\
20.27 \\
31.06 \\
33.01 \\
28.08 \\
25.20 \\
26.39 \\
25.33 \\
11.84 \\
16.36 \\
12.18 \\
15.96 \\
19.26\end{array}$ & $\begin{array}{r}7.81 \\
12.44 \\
11.82 \\
13.08 \\
14.44 \\
14.05 \\
21.69 \\
35.93 \\
38.31 \\
35.13 \\
29.81 \\
29.51 \\
28.04 \\
14.35 \\
18.47 \\
15.16 \\
18.31 \\
22.46\end{array}$ & $\begin{array}{r}3.25 \\
10.17 \\
10.87 \\
11.62 \\
12.38 \\
12.70 \\
17.28 \\
28.17 \\
32.60 \\
33.73 \\
27.53 \\
27.67 \\
22.04 \\
11.36 \\
15.12 \\
12.16 \\
16.29 \\
20.36\end{array}$ & $\begin{array}{c}N A \\
N A \\
N A \\
W \\
14.11 \\
13.82 \\
21.70 \\
34.36 \\
36.06 \\
33.42 \\
29.81 \\
28.87 \\
27.64 \\
13.84 \\
18.28 \\
14.80 \\
17.89 \\
23.43\end{array}$ & $\begin{array}{r}5.39 \\
10.71 \\
11.04 \\
11.39 \\
12.63 \\
12.38 \\
16.90 \\
24.81 \\
28.95 \\
23.74 \\
21.48 \\
24.23 \\
23.64 \\
10.82 \\
15.08 \\
12.96 \\
16.09 \\
18.55\end{array}$ & $\begin{array}{r}4.84 \\
10.02 \\
10.86 \\
11.92 \\
13.19 \\
13.35 \\
21.10 \\
34.34 \\
36.69 \\
31.86 \\
27.96 \\
27.79 \\
26.12 \\
13.32 \\
17.11 \\
13.45 \\
17.12 \\
10.88\end{array}$ & $\begin{array}{r}4.06 \\
10.06 \\
11.18 \\
12.06 \\
13.13 \\
13.28 \\
10.27 \\
31.57 \\
34.70 \\
33.84 \\
28.28 \\
27.79 \\
24.34 \\
11.58 \\
15.80 \\
12.57 \\
16.72 \\
18.84\end{array}$ & $\begin{array}{r}5.43 \\
11.33 \\
11.34 \\
12.23 \\
13.20 \\
13.31 \\
10.88 \\
32.21 \\
35.17 \\
33.48 \\
28.46 \\
27.70 \\
25.67 \\
12.21 \\
16.43 \\
13.43 \\
17.06 \\
20.40\end{array}$ \\
\hline $\begin{array}{l}1891 \text { January ........ } \\
\text { February ...... } \\
\text { March .......... } \\
\text { April ............ } \\
\text { May .............. } \\
\text { June ............ } \\
\text { July ............. } \\
\text { August ........ } \\
\text { September .... } \\
\text { October ........ } \\
\text { November .... } \\
\text { December .... } \\
\text { Averege ...... }\end{array}$ & $\begin{array}{l}W \\
W \\
W \\
W \\
W \\
W \\
W \\
W \\
W \\
W \\
W \\
W \\
W\end{array}$ & $\begin{array}{c}W \\
20.82 \\
W \\
16.85 \\
W \\
16.77 \\
W \\
W \\
W \\
18.50 \\
W \\
W \\
18.69\end{array}$ & 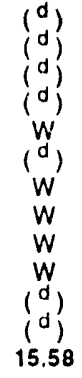 & $\begin{array}{l}19.39 \\
13.62 \\
13.59 \\
15.34 \\
15.24 \\
14.68 \\
15.24 \\
15.34 \\
15.40 \\
16.91 \\
16.30 \\
13.47 \\
15.37\end{array}$ & $\begin{array}{l}24.68 \\
20.48 \\
19.44 \\
19.12 \\
19.35 \\
18.38 \\
19.44 \\
20.20 \\
21.10 \\
22.55 \\
21.63 \\
18.99 \\
20.29\end{array}$ & $\begin{array}{c}12.69 \\
14.06 \\
W \\
15.14 \\
15.15 \\
14.54 \\
W \\
16.35 \\
15.85 \\
14.61 \\
13.33 \\
12.72 \\
14.62\end{array}$ & $\begin{array}{c}W \\
W \\
24.50 \\
W \\
W \\
W \\
19.45 \\
W \\
20.24 \\
W \\
21.67 \\
W \\
20.81\end{array}$ & $\begin{array}{l}17.04 \\
14.50 \\
14.90 \\
15.38 \\
14.68 \\
13.62 \\
14.85 \\
14.64 \\
15.53 \\
16.44 \\
14.77 \\
12.62 \\
14.91\end{array}$ & $\begin{array}{l}21.24 \\
17.12 \\
16.18 \\
16.90 \\
16.95 \\
16.33 \\
17.41 \\
17.82 \\
18.79 \\
19.42 \\
18.97 \\
16.57 \\
17.79\end{array}$ & $\begin{array}{l}16.04 \\
14.56 \\
15.24 \\
15.72 \\
15.71 \\
15.29 \\
15.86 \\
16.81 \\
16.76 \\
15.76 \\
15.02 \\
14.32 \\
15.59\end{array}$ & $\begin{array}{l}19.45 \\
16.73 \\
16.48 \\
16.88 \\
16.71 \\
16.04 \\
16.86 \\
17.23 \\
17.57 \\
18.12 \\
17.03 \\
15.03 \\
16.90\end{array}$ \\
\hline $\begin{array}{l}1992 \text { January ........ } \\
\text { February ...... } \\
\text { March .......... } \\
\text { April ............ } \\
\text { May .............. } \\
\text { June ............ } \\
\text { July ............. } \\
\text { August ......... } \\
\text { September .... } \\
\text { October ........ } \\
\text { November .... } \\
\text { December .... } \\
\text { Averag॰ ...... }\end{array}$ & $\begin{array}{l}W \\
W \\
(d) \\
W \\
W \\
W \\
W \\
W \\
\left(\begin{array}{l}d \\
d\end{array}\right) \\
\left(\begin{array}{l}d \\
d\end{array}\right) \\
W \\
W\end{array}$ & $\begin{array}{l}W \\
W \\
W \\
16.23 \\
W \\
W \\
W \\
W \\
W \\
W \\
W \\
W \\
17.06\end{array}$ & $\begin{array}{l}\left(\begin{array}{l}d \\
d \\
d\end{array}\right) \\
d \\
(d) \\
\left(\begin{array}{l}d \\
d\end{array}\right) \\
\left(\begin{array}{l}d \\
d\end{array}\right) \\
\left(\begin{array}{l}d \\
d\end{array}\right) \\
\left(\begin{array}{l}d \\
d\end{array}\right) \\
\left(\begin{array}{l}d \\
d\end{array}\right)\end{array}$ & $\begin{array}{l}12.45 \\
12.40 \\
12.68 \\
14.11 \\
16.05 \\
17.09 \\
16.88 \\
16.36 \\
16.88 \\
16.90 \\
15.78 \\
14.79 \\
15.26\end{array}$ & $\begin{array}{l}18.58 \\
18.28 \\
18.10 \\
19.59 \\
20.47 \\
21.42 \\
20.83 \\
20.33 \\
20.84 \\
20.76 \\
20.00 \\
18.42 \\
19.98\end{array}$ & $\begin{array}{c}W \\
14.61 \\
14.87 \\
W \\
17.61 \\
W \\
17.60 \\
W \\
16.69 \\
W \\
14.62 \\
15.62 \\
15.85\end{array}$ & 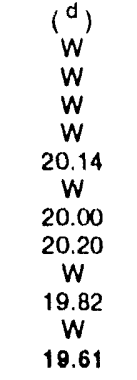 & $\begin{array}{l}12.32 \\
12.53 \\
12.45 \\
14.38 \\
15.03 \\
15.33 \\
15.10 \\
15.38 \\
16.21 \\
15.40 \\
13.82 \\
13.38 \\
14.38\end{array}$ & $\begin{array}{l}15.44 \\
16.04 \\
16.01 \\
17.10 \\
18.35 \\
19.20 \\
18.74 \\
18.43 \\
18.65 \\
18.70 \\
17.57 \\
16.13 \\
17.65\end{array}$ & $\begin{array}{l}14.07 \\
15.35 \\
15.20 \\
17.26 \\
18.13 \\
17.95 \\
18.20 \\
17.99 \\
17.11 \\
15.89 \\
15.12 \\
15.91 \\
16.50\end{array}$ & $\begin{array}{l}14.50 \\
15.04 \\
15.28 \\
17.25 \\
17.83 \\
18.44 \\
18.09 \\
17.69 \\
18.01 \\
17.42 \\
15.97 \\
15.60 \\
16.87\end{array}$ \\
\hline $\begin{array}{c}1993 \text { January ........ } \\
\text { February ...... } \\
\text { March ........... } \\
\text { April ............ } \\
\text { May ............. } \\
\text { June ............. } \\
\text { July ............. } \\
\text { August ........ } \\
\text { September ... } \\
\text { October ........ }\end{array}$ & $\begin{array}{l}\left(\begin{array}{l}d \\
d\end{array}\right) \\
\left(\begin{array}{l}w \\
w\end{array}\right. \\
\left(\begin{array}{l}d \\
d\end{array}\right) \\
\left(\begin{array}{l}d \\
d\end{array}\right) \\
w \\
\left(\begin{array}{l}d \\
w\end{array}\right) \\
w\end{array}$ & $\begin{array}{l}W \\
W \\
W \\
W \\
19.14 \\
W \\
16.48 \\
17.74 \\
W \\
W\end{array}$ & $\begin{array}{l}\left(\begin{array}{l}d \\
d\end{array}\right) \\
\left(\begin{array}{l}d \\
d\end{array}\right) \\
\left(\begin{array}{l}d \\
d\end{array}\right) \\
\left(\begin{array}{l}d \\
d\end{array}\right) \\
\left(\begin{array}{l}d \\
d\end{array}\right) \\
\left(\begin{array}{l}d \\
d\end{array}\right)\end{array}$ & $\begin{array}{r}14.14 \\
14.64 \\
15.17 \\
15.04 \\
15.15 \\
14.06 \\
13.09 \\
13.20 \\
R 13.50 \\
13.72\end{array}$ & $\begin{array}{r}17.95 \\
19.06 \\
19.33 \\
19.19 \\
18.92 \\
18.01 \\
17.46 \\
17.42 \\
\mathrm{~A} 16.72 \\
17.03\end{array}$ & $\begin{array}{l}15.55 \\
16.17 \\
16.45 \\
16.03 \\
14.54 \\
W \\
W \\
W \\
W \\
12.91\end{array}$ & $\begin{array}{r}18.29 \\
18.13 \\
18.51 \\
18.36 \\
18.29 \\
17.15 \\
16.07 \\
16.73 \\
A 16.06 \\
16.31\end{array}$ & $\begin{array}{l}12.99 \\
13.68 \\
14.22 \\
14.52 \\
13.89 \\
12.47 \\
11.96 \\
12.56 \\
12.72 \\
12.16\end{array}$ & $\begin{array}{r}15.17 \\
16.51 \\
16.85 \\
16.90 \\
16.73 \\
15.89 \\
14.96 \\
14.68 \\
14.29 \\
14.82\end{array}$ & $\begin{array}{l}15.60 \\
16.39 \\
16.83 \\
16.24 \\
15.03 \\
14.29 \\
13.56 \\
14.40 \\
13.97 \\
14.06\end{array}$ & $\begin{array}{l}15.62 \\
16.49 \\
16.92 \\
16.59 \\
16.32 \\
14.94 \\
14.18 \\
14.24 \\
14.37 \\
14.21\end{array}$ \\
\hline
\end{tabular}

a The Arab members of OPEC are Algeria, Iraq, Kuwait, Libya, Qatar, Saudi Arabia, and the United Arab Emirates.

b Current members of OPEC are Gabon, Indonesia, Iran, Nigeria, and Venezuela, as well as the Arab members. Prior to 1993. Ecuador was also a member. The cost of imports from the Neutral Zone between Kuwait and Saudi Arabia is included in the cost of imports from "Total OPEC."

c Based on October, November, and December data only.

d No data reported.

$\mathrm{R}=$ Revised data. $N A=$ Not available. $W=$ Value withheld to avoid disclosure of individual company data.

Notes: - The Free on Board (F.O.B.) cost at the country of origin excludes all cosis related to insurance and transportation. See Note 2 at end of section. - Values for the current 2 months are preliminary. - Prices through
1980 reflect the period of reporting; prices after 1980 reflect the period of loading. - Annual averages are averages of the monthly prices, including prices not published, weighted by volume. - Cargoes that are purchased on a "netback" basis, or under similar contractual arrangements whereby the actual purchase price is not established at the time the crude oil is acquired for importation into the United States, are not included in the published data until the actual prices have been delermined and reported.

Sources: - October 1973-Septomber 1077: Federal Energy Administration, Form FEA-F701-M-0 "Transter Pricing Report." - October 1977-December 1977: Energy Information Administration (EIA), Form FEA-F701-M-0, "Transter Pricing Report." - 1978 forward: EIA, Petroloum Marketing Monthly, January 1994, Table 21. 
Table 9.3 Landed Costs of Crude Oil Imports from Selected Countries

(Dollars per Barrel)

\begin{tabular}{|c|c|c|c|c|c|c|c|c|c|c|c|c|}
\hline & Algerla & Canada & Indonesia & Iran & Mexico & Nigerla & $\begin{array}{l}\text { Saudl } \\
\text { Arabla }\end{array}$ & $\begin{array}{c}\text { United } \\
\text { Kingdom }\end{array}$ & Venezuela & $\begin{array}{c}\text { Other } \\
\text { Countries }\end{array}$ & $\begin{array}{l}\text { Arab } \\
\text { OPECa }\end{array}$ & $\begin{array}{l}\text { Total } \\
\text { OPECb }\end{array}$ \\
\hline 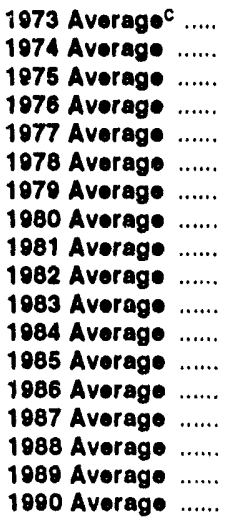 & $\begin{array}{r}8.39 \\
13.87 \\
12.86 \\
13.00 \\
15.24 \\
14.93 \\
21.88 \\
37.92 \\
40.46 \\
35.35 \\
31.26 \\
29.06 \\
27.51 \\
14.82 \\
17.87 \\
W \\
19.13 \\
W\end{array}$ & $\begin{array}{r}5.33 \\
11.48 \\
12.84 \\
13.36 \\
14.13 \\
14.41 \\
20.22 \\
30.11 \\
32.32 \\
27.15 \\
25.63 \\
26.56 \\
25.71 \\
13.43 \\
17.04 \\
13.50 \\
16.81 \\
20.48\end{array}$ & $\begin{array}{r}7.22 \\
13.20 \\
13.83 \\
13.85 \\
14.65 \\
14.65 \\
20.63 \\
33.92 \\
37.31 \\
36.70 \\
31.57 \\
30.87 \\
28.67 \\
14.63 \\
18.49 \\
15.15 \\
18.35 \\
22.50\end{array}$ & $\begin{array}{r}6.48 \\
12.48 \\
12.51 \\
12.86 \\
13.86 \\
13.89 \\
24.21 \\
N A \\
\text { d) } \\
32.46 \\
29.81 \\
28.70 \\
25.79 \\
12.38 \\
18.28 \\
W \\
\text { (d) } \\
\text { (d) }\end{array}$ & $\begin{array}{c}\text { NA } \\
W \\
12.61 \\
12.64 \\
13.82 \\
13.56 \\
20.77 \\
31.77 \\
33.70 \\
28.63 \\
25.78 \\
26.85 \\
25.63 \\
12.17 \\
16.69 \\
12.58 \\
16.35 \\
10.64\end{array}$ & $\begin{array}{r}9.08 \\
13.16 \\
12.70 \\
13.81 \\
15.29 \\
14.88 \\
22.87 \\
37.15 \\
39.66 \\
36.16 \\
30.85 \\
30.36 \\
28.96 \\
15.29 \\
19.32 \\
15.88 \\
19.19 \\
23.33\end{array}$ & $\begin{array}{r}5.37 \\
11.63 \\
12.50 \\
13.06 \\
13.69 \\
13.94 \\
18.95 \\
29.80 \\
34.20 \\
34.90 \\
29.27 \\
29.20 \\
24.72 \\
12.84 \\
16.81 \\
13.37 \\
17.34 \\
21.82\end{array}$ & $\begin{array}{c}N A \\
N A \\
N A \\
W \\
14.83 \\
14.53 \\
22.07 \\
35.68 \\
37.29 \\
34.25 \\
30.87 \\
28.45 \\
28.36 \\
14.63 \\
18.78 \\
15.82 \\
18.74 \\
22.65\end{array}$ & $\begin{array}{r}5.99 \\
11.25 \\
12.36 \\
11.89 \\
13.11 \\
12.84 \\
17.65 \\
25.02 \\
29.91 \\
24.93 \\
22.94 \\
25.19 \\
24.43 \\
11.52 \\
15.76 \\
13.66 \\
16.78 \\
20.31\end{array}$ & $\begin{array}{r}6.99 \\
12.93 \\
12.66 \\
13.36 \\
14.56 \\
14.58 \\
22.86 \\
36.15 \\
38.54 \\
34.03 \\
29.68 \\
28.21 \\
27.33 \\
14.25 \\
18.30 \\
14.45 \\
18.08 \\
20.52\end{array}$ & $\begin{array}{r}5.92 \\
12.39 \\
12.71 \\
13.31 \\
14.30 \\
14.36 \\
20.79 \\
32.97 \\
36.22 \\
35.15 \\
29.87 \\
29.10 \\
25.90 \\
13.14 \\
17.32 \\
13.60 \\
17.41 \\
20.64\end{array}$ & $\begin{array}{r}6.85 \\
12.49 \\
12.70 \\
13.32 \\
14.35 \\
14.34 \\
21.29 \\
33.56 \\
36.60 \\
34.81 \\
29.84 \\
29.06 \\
26.86 \\
13.46 \\
17.64 \\
14.18 \\
17.78 \\
21.23\end{array}$ \\
\hline $\begin{array}{l}1991 \text { January ........ } \\
\text { February ...... } \\
\text { March ........... } \\
\text { April ............ } \\
\text { May ............. } \\
\text { June ............ } \\
\text { July .............. } \\
\text { August ........ } \\
\text { September .... } \\
\text { October ........ } \\
\text { November .... } \\
\text { December .... } \\
\text { Average ...... }\end{array}$ & $\begin{array}{l}W \\
W \\
W \\
W \\
W \\
W \\
W \\
W \\
W \\
W \\
W \\
W \\
W\end{array}$ & $\begin{array}{l}20.81 \\
17.05 \\
15.20 \\
16.26 \\
16.28 \\
16.19 \\
17.14 \\
17.61 \\
17.84 \\
18.38 \\
17.53 \\
15.87 \\
17.16\end{array}$ & $\begin{array}{c}W \\
22.61 \\
20.03 \\
18.85 \\
W \\
18.25 \\
17.76 \\
W \\
W \\
19.85 \\
21.05 \\
W \\
20.20\end{array}$ & 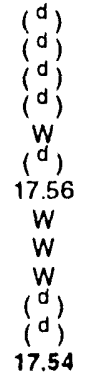 & $\begin{array}{l}19.98 \\
14.23 \\
14.15 \\
15.85 \\
15.81 \\
15.20 \\
15.89 \\
15.78 \\
15.82 \\
17.34 \\
16.53 \\
13.96 \\
15.89\end{array}$ & $\begin{array}{l}26.00 \\
21.66 \\
20.60 \\
20.31 \\
20.50 \\
19.79 \\
20.73 \\
21.29 \\
22.13 \\
23.68 \\
22.71 \\
19.96 \\
21.39\end{array}$ & $\begin{array}{l}18.53 \\
16.18 \\
17.08 \\
17.54 \\
17.34 \\
16.85 \\
17.48 \\
18.04 \\
18.19 \\
17.62 \\
16.46 \\
15.03 \\
17.22\end{array}$ & $\begin{array}{l}W \\
W \\
25.77 \\
20.56 \\
20.21 \\
19.35 \\
20.47 \\
20.71 \\
21.16 \\
22.07 \\
22.71 \\
20.29 \\
21.37\end{array}$ & $\begin{array}{l}18.35 \\
15.76 \\
16.18 \\
16.35 \\
15.74 \\
14.61 \\
15.92 \\
15.64 \\
16.44 \\
17.26 \\
15.66 \\
13.46 \\
15.92\end{array}$ & $\begin{array}{l}24.08 \\
19.42 \\
18.59 \\
18.77 \\
19.53 \\
18.38 \\
18.82 \\
19.30 \\
20.35 \\
20.91 \\
21.04 \\
18.67 \\
19.73\end{array}$ & $\begin{array}{l}18.94 \\
16.29 \\
17.23 \\
17.65 \\
17.49 \\
17.01 \\
17.61 \\
18.17 \\
18.42 \\
17.97 \\
16.90 \\
15.49 \\
17.45\end{array}$ & $\begin{array}{l}20.16 \\
17.43 \\
17.88 \\
18.17 \\
17.98 \\
17.32 \\
17.96 \\
18.40 \\
18.70 \\
19.03 \\
17.95 \\
15.94 \\
18.08\end{array}$ \\
\hline $\begin{array}{l}1992 \text { January ........ } \\
\text { February ...... } \\
\text { March .......... } \\
\text { April ............ } \\
\text { May .............. } \\
\text { June ............ } \\
\text { Juty .............. } \\
\text { August ........ } \\
\text { September ... } \\
\text { October ........ } \\
\text { November .... } \\
\text { December .... } \\
\text { Average ...... }\end{array}$ & 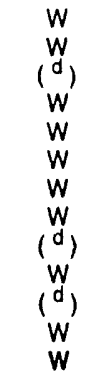 & $\begin{array}{l}14.83 \\
15.57 \\
15.68 \\
16.42 \\
17.35 \\
18.40 \\
18.50 \\
18.28 \\
18.35 \\
18.35 \\
17.26 \\
15.85 \\
17.04\end{array}$ & $\begin{array}{c}W \\
W \\
W \\
17.76 \\
17.66 \\
19.60 \\
21.06 \\
21.26 \\
W \\
W \\
W \\
W \\
18.76\end{array}$ & $\begin{array}{l}\left(\begin{array}{l}d \\
d \\
d\end{array}\right) \\
\left(\begin{array}{l}\text { a } \\
d\end{array}\right) \\
\left(\begin{array}{l}d \\
d\end{array}\right) \\
\left(\begin{array}{l}d \\
d\end{array}\right) \\
\left(\begin{array}{l}d \\
d\end{array}\right) \\
\left(\begin{array}{l}d \\
d\end{array}\right) \\
\left(\begin{array}{l}d \\
d\end{array}\right)\end{array}$ & $\begin{array}{l}13.02 \\
12.78 \\
13.06 \\
14.40 \\
16.39 \\
17.41 \\
17.20 \\
16.74 \\
17.34 \\
17.26 \\
16.18 \\
15.12 \\
15.60\end{array}$ & $\begin{array}{l}19.34 \\
19.10 \\
19.05 \\
20.32 \\
21.25 \\
22.11 \\
21.49 \\
21.05 \\
21.57 \\
21.60 \\
20.79 \\
19.32 \\
20.78\end{array}$ & $\begin{array}{l}14.81 \\
15.61 \\
16.05 \\
18.01 \\
18.62 \\
19.49 \\
19.00 \\
18.45 \\
18.45 \\
17.96 \\
17.02 \\
16.64 \\
17.48\end{array}$ & $\begin{array}{c}W \\
W \\
18.83 \\
18.97 \\
19.99 \\
20.85 \\
21.45 \\
21.37 \\
20.72 \\
21.17 \\
21.00 \\
19.46 \\
20.63\end{array}$ & $\begin{array}{l}13.20 \\
13.47 \\
13.41 \\
15.06 \\
15.73 \\
16.01 \\
15.78 \\
16.10 \\
16.89 \\
16.14 \\
14.51 \\
14.07 \\
15.13\end{array}$ & $\begin{array}{l}17.46 \\
17.64 \\
17.44 \\
18.10 \\
19.58 \\
20.93 \\
20.49 \\
20.10 \\
20.12 \\
20.09 \\
19.25 \\
17.80 \\
18.25\end{array}$ & $\begin{array}{l}15.16 \\
15.85 \\
16.14 \\
18.11 \\
18.80 \\
19.60 \\
19.15 \\
18.79 \\
18.51 \\
18.08 \\
17.05 \\
16.69 \\
17.63\end{array}$ & $\begin{array}{l}15.38 \\
15.87 \\
16.29 \\
18.07 \\
18.65 \\
19.57 \\
19.06 \\
18.70 \\
18.83 \\
18.56 \\
17.28 \\
16.62 \\
17.81\end{array}$ \\
\hline $\begin{array}{c}1893 \text { January ........ } \\
\text { February ...... } \\
\text { March .......... } \\
\text { April ............ } \\
\text { May ............. } \\
\text { June ............. } \\
\text { July ............. } \\
\text { August ........ } \\
\text { September ... } \\
\text { October ........ }\end{array}$ & $\begin{array}{l}\left(\begin{array}{l}d \\
d\end{array}\right) \\
w \\
w \\
w \\
w \\
\left(\begin{array}{l}d \\
w\end{array}\right) \\
w \\
\left(\begin{array}{l}d \\
w\end{array}\right) \\
w\end{array}$ & $\begin{array}{r}15.27 \\
15.84 \\
16.48 \\
16.79 \\
16.82 \\
16.25 \\
15.30 \\
R 14.94 \\
14.56 \\
15.13\end{array}$ & $\begin{array}{l}W \\
W \\
W \\
19.89 \\
20.57 \\
W \\
17.86 \\
19.28 \\
W \\
W\end{array}$ & $\begin{array}{l}\left(\begin{array}{l}d \\
d \\
d\end{array}\right) \\
\left(\begin{array}{l}0 \\
d \\
d\end{array}\right) \\
\left(\begin{array}{l}d \\
d\end{array}\right) \\
\left(\begin{array}{l}d \\
d\end{array}\right) \\
\left(\begin{array}{l}d \\
d\end{array}\right) \\
\left(\begin{array}{l}d\end{array}\right)\end{array}$ & $\begin{array}{r}14.50 \\
14.98 \\
15.50 \\
15.55 \\
15.57 \\
14.50 \\
13.44 \\
\text { H } 13.66 \\
\text { F } 13.81 \\
14.06\end{array}$ & $\begin{array}{r}18.96 \\
19.92 \\
20.25 \\
20.18 \\
19.79 \\
18.93 \\
18.31 \\
18.08 \\
R 17.62 \\
17.97\end{array}$ & $\begin{array}{r}16.36 \\
17.29 \\
17.56 \\
17.56 \\
16.64 \\
15.72 \\
14.94 \\
P 15.11 \\
P 14.67 \\
14.96\end{array}$ & $\begin{array}{r}19.12 \\
19.28 \\
19.43 \\
19.32 \\
19.33 \\
18.67 \\
17.51 \\
17.56 \\
R 17.04 \\
16.82\end{array}$ & $\begin{array}{r}14.07 \\
14.60 \\
15.14 \\
15.54 \\
14.91 \\
13.53 \\
12.92 \\
13.32 \\
13.46 \\
12.98\end{array}$ & $\begin{array}{r}17.21 \\
18.17 \\
18.43 \\
18.48 \\
18.41 \\
17.44 \\
16.44 \\
\text { A } 16.01 \\
15.55 \\
15.77\end{array}$ & $\begin{array}{r}16.39 \\
17.29 \\
17.63 \\
17.55 \\
16.79 \\
15.86 \\
14.96 \\
R 15.11 \\
\text { R } 14.59 \\
14.98\end{array}$ & $\begin{array}{r}16.64 \\
17.43 \\
17.83 \\
17.77 \\
17.30 \\
16.03 \\
15.30 \\
15.24 \\
P 14.98 \\
15.15\end{array}$ \\
\hline
\end{tabular}

a The Arab members of OPEC are Algeria, Iraq, Kuwail, Libya, Qatar, Saudi Arabia, and the United Arab Emirates.

b Current inembers of OPEC are Gabon, Indonesia, Iran, Nigeria, and Venezuela, as well as the Arab members. Prior to 1993, Ecuador was also a member. The cost of imports from the Neutral Zone between Kuwait and Saudi Arabia is included in the cost of imports from "Total OPEC."

c Based on October, November, and December data only

d No data reported.

$R=$ Revised data. $N A=N o t$ available. $W=V$ alue withheld to avoid disclosure of individual company data.

Noles: - See Note 3 at end of section. Values for the current 2 months are preliminary. - Prices through 1980 reflect the period of reporting; prices since then reflect the perion of loading. - Annual averages are averages of the monthly prices, iricluding prices not published, weighted by volume. - Cargoes that are purchased on a "netback" basis, or under similar contraclual arrangements whereby the actual purchase price is not established at the time the crude oil is acquired for importation into the United States, are not included in the published data until the actual prices have been delermined and reported.

Sources: - October 1973-September 1977: Federal Energy Administration, Form FEA-F701-M-0, "Transler Pricing Report." - October 1977. December 1977: Energy Information Administration (EIA). Form FEA.F701-M.0. "Transler Pricing Report." 1078 forward: ElA, Petroloum Marketing Monthly, January 1994, Table 22. 
Table 9.4 Motor Gasoline Retail Prices, U.S. City Average

(Cents per Gallon, Including Taxes)

\begin{tabular}{|c|c|c|c|c|}
\hline & $\begin{array}{l}\text { Leaded } \\
\text { Regular }\end{array}$ & $\begin{array}{c}\text { Unleaded } \\
\text { Regular }\end{array}$ & $\begin{array}{l}\text { Unleaded } \\
\text { Promlum }\end{array}$ & All Types: \\
\hline 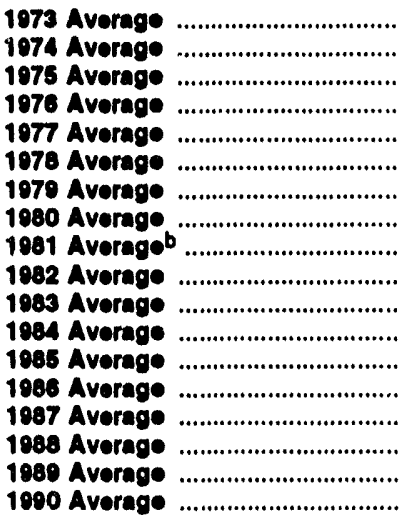 & \begin{tabular}{r|}
38.8 \\
53.2 \\
56.7 \\
59.0 \\
62.2 \\
62.6 \\
85.7 \\
119.1 \\
131.1 \\
122.2 \\
115.7 \\
112.9 \\
111.5 \\
85.7 \\
89.7 \\
89.9 \\
90.8 \\
114.0
\end{tabular} & $\begin{array}{r}N A \\
N A \\
N A \\
61.4 \\
65.6 \\
67.0 \\
90.3 \\
124.5 \\
137.8 \\
129.6 \\
124.1 \\
121.2 \\
120.2 \\
92.7 \\
94.8 \\
94.6 \\
102.1 \\
116.4\end{array}$ & $\begin{array}{l}\text { NA } \\
\text { NA } \\
\text { NA } \\
\text { NA } \\
\text { NA } \\
\text { NA } \\
\text { NA } \\
\text { NA } \\
\text { c } 147.0 \\
141.5 \\
138.3 \\
136.8 \\
134.0 \\
108.5 \\
109.3 \\
110.7 \\
119.7 \\
134.0\end{array}$ & $\begin{array}{r}N A \\
N A \\
N A \\
N A \\
N A \\
65.2 \\
88.2 \\
122.1 \\
135.3 \\
128.1 \\
122.6 \\
110.8 \\
119.6 \\
93.1 \\
95.7 \\
96.3 \\
106.0 \\
121.7\end{array}$ \\
\hline 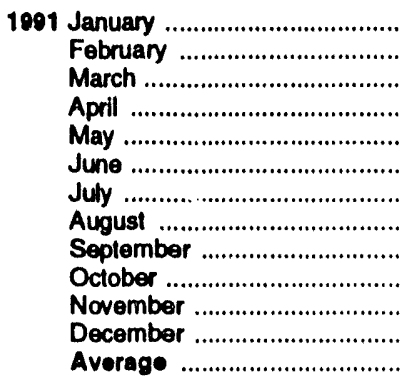 & $\begin{array}{l}124.6 \\
113.7 \\
104.7 \\
106.2 \\
\text { NA } \\
\text { NA } \\
\text { NA } \\
\text { NA } \\
\text { NA } \\
\text { NA } \\
\text { NA } \\
\text { NA } \\
\text { NA }\end{array}$ & $\begin{array}{l}124.7 \\
114.3 \\
108.2 \\
110.4 \\
115.6 \\
116.0 \\
112.7 \\
114.0 \\
114.3 \\
112.2 \\
113.4 \\
112.3 \\
114.0\end{array}$ & $\begin{array}{l}143.1 \\
132.1 \\
126.4 \\
128.1 \\
133.1 \\
133.8 \\
131.3 \\
131.8 \\
132.4 \\
130.7 \\
131.8 \\
130.9 \\
132.1\end{array}$ & $\begin{array}{l}130.4 \\
119.8 \\
113.8 \\
115.9 \\
120.9 \\
121.4 \\
118.5 \\
119.6 \\
119.9 \\
118.0 \\
119.3 \\
118.2 \\
118.6\end{array}$ \\
\hline 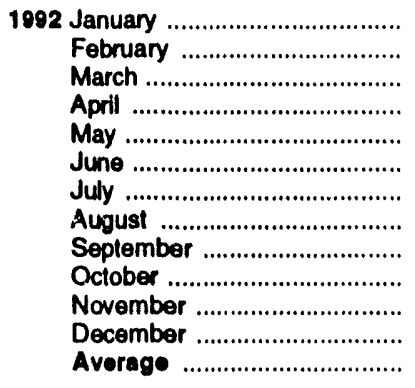 & $\begin{array}{l}\text { NA } \\
\text { NA } \\
\text { NA } \\
\text { NA } \\
\text { NA } \\
\text { NA } \\
\text { NA } \\
\text { NA } \\
\text { NA } \\
\text { NA } \\
\text { NA } \\
\text { NA } \\
\text { NA }\end{array}$ & $\begin{array}{l}107.3 \\
105.4 \\
105.8 \\
107.9 \\
113.6 \\
117.9 \\
117.5 \\
115.8 \\
115.8 \\
115.4 \\
115.9 \\
113.6 \\
112.7\end{array}$ & $\begin{array}{l}126.7 \\
124.8 \\
125.0 \\
126.8 \\
131.7 \\
135.9 \\
136.3 \\
134.8 \\
134.6 \\
134.5 \\
135.1 \\
133.0 \\
131.6\end{array}$ & $\begin{array}{l}113.5 \\
111.7 \\
112.2 \\
114.3 \\
119.7 \\
123.9 \\
123.8 \\
122.1 \\
122.2 \\
121.9 \\
122.3 \\
120.1 \\
119.0\end{array}$ \\
\hline 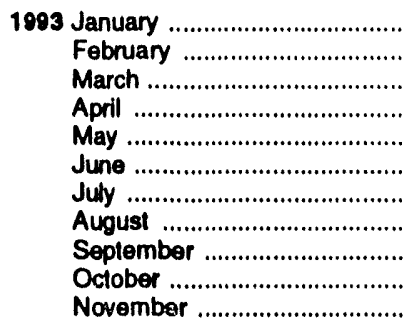 & $\begin{array}{l}\text { NA } \\
\text { NA } \\
\text { NA } \\
\text { NA } \\
\text { NA } \\
\text { NA } \\
\text { NA } \\
\text { NA } \\
\text { NA } \\
\text { NA } \\
\text { NA }\end{array}$ & $\begin{array}{l}111.7 \\
110.8 \\
109.8 \\
111.2 \\
112.9 \\
113.0 \\
110.9 \\
109.7 \\
108.5 \\
112.7 \\
111.3\end{array}$ & $\begin{array}{l}131.3 \\
130.1 \\
129.4 \\
130.4 \\
131.9 \\
132.1 \\
130.5 \\
129.4 \\
128.2 \\
132.3 \\
130.5\end{array}$ & $\begin{array}{l}118.2 \\
117.2 \\
116.3 \\
117.5 \\
119.3 \\
119.4 \\
117.4 \\
116.3 \\
115.1 \\
119.3 \\
117.8\end{array}$ \\
\hline
\end{tabular}

- Also includes types of moter gasoline nol shown separately.

b In September 1981, the Bureau of Labor Statistics changed the weights used in the calculation of average motor gasoline prices. From September 1881 fonward, gasohol is included in the average for all types, and unleaded premium is weighted more heavily.

Ceptember through December data only.

NA=Not available.

Notes: - See Note 5 at end of section. - Geographic coverage for
1973-1977 is 56 urban areas. Geographic coverage for 1978 fonward is 85 urban areas.

Sources: - Monthly Data: U.S. Department of Labor, Bureau of Labor Statistics, Consumer Prices: Energy. - Annual Data: 1073-Platt's Oil Price Handbook and Oilmanac, 1974, 51st Edition. 1074 torward-calculated by the Energy Intormation Administration as the simple averages of monthly data. 
Table 9.5 Refiner Prices of Residual Fuel Oil (Cents per Gallon, Excluding Taxes)

\begin{tabular}{|c|c|c|c|c|c|c|}
\hline & \multicolumn{2}{|c|}{$\begin{array}{c}\text { Residual Fuel Oll } \\
\text { Sulfur Content Lose } \\
\text { Than or Equal to } 1 \text { Percent }\end{array}$} & \multicolumn{2}{|c|}{$\begin{array}{l}\text { Residual Fuel Oll } \\
\text { Sulfur Content } \\
\text { Greater Than } 1 \text { Percent }\end{array}$} & \multicolumn{2}{|c|}{ Average } \\
\hline & $\begin{array}{c}\text { Sales for } \\
\text { Resale }\end{array}$ & $\begin{array}{l}\text { Sales to } \\
\text { End Users }\end{array}$ & $\begin{array}{c}\text { Sales for } \\
\text { Resale }\end{array}$ & $\begin{array}{l}\text { Sales to } \\
\text { End Users }\end{array}$ & $\begin{array}{l}\text { Sales for } \\
\text { Resale }\end{array}$ & $\begin{array}{l}\text { Sales to } \\
\text { End Users }\end{array}$ \\
\hline 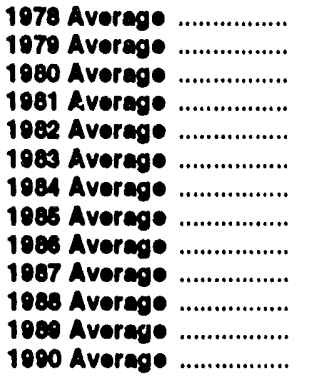 & $\begin{array}{l}29.3 \\
45.0 \\
80.8 \\
74.8 \\
69.5 \\
64.3 \\
68.5 \\
61.0 \\
32.8 \\
41.2 \\
33.3 \\
40.7 \\
47.2\end{array}$ & $\begin{array}{l}31.4 \\
46.8 \\
67.5 \\
82.0 \\
74.7 \\
69.5 \\
72.0 \\
64.4 \\
37.2 \\
44.7 \\
37.2 \\
43.6 \\
50.5\end{array}$ & $\begin{array}{l}24.5 \\
36.6 \\
47.9 \\
62.2 \\
57.2 \\
50.1 \\
63.9 \\
56.0 \\
28.0 \\
36.2 \\
27.1 \\
33.1 \\
37.2\end{array}$ & $\begin{array}{l}27.5 \\
38.0 \\
52.3 \\
67.3 \\
61.1 \\
61.1 \\
65.0 \\
58.2 \\
31.7 \\
30.6 \\
30.0 \\
34.4 \\
40.0\end{array}$ & $\begin{array}{l}26.3 \\
39.9 \\
52.8 \\
66.3 \\
61.2 \\
60.9 \\
65.4 \\
57.7 \\
30.5 \\
38.5 \\
30.0 \\
36.0 \\
41.3\end{array}$ & $\begin{array}{l}29.8 \\
43.6 \\
60.7 \\
75.6 \\
67.6 \\
65.1 \\
68.7 \\
61.0 \\
34.3 \\
42.3 \\
33.4 \\
38.6 \\
44.4\end{array}$ \\
\hline 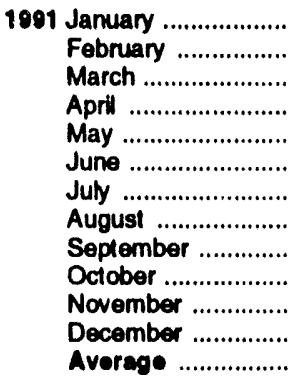 & $\begin{array}{l}52.1 \\
36.5 \\
36.0 \\
33.6 \\
36.6 \\
32.1 \\
32.6 \\
33.4 \\
33.7 \\
34.1 \\
36.6 \\
34.8 \\
36.4\end{array}$ & $\begin{array}{l}59.8 \\
44.4 \\
38.3 \\
37.8 \\
36.6 \\
35.3 \\
36.4 \\
36.8 \\
36.8 \\
38.5 \\
40.8 \\
40.0 \\
40.2\end{array}$ & $\begin{array}{l}49.2 \\
32.0 \\
24.2 \\
25.8 \\
27.7 \\
28.6 \\
27.4 \\
25.9 \\
25.4 \\
27.6 \\
27.9 \\
26.1 \\
29.2\end{array}$ & $\begin{array}{l}49.7 \\
37.1 \\
28.2 \\
27.0 \\
27.6 \\
26.9 \\
28.2 \\
27.7 \\
27.3 \\
29.7 \\
31.8 \\
28.8 \\
30.6\end{array}$ & $\begin{array}{l}50.2 \\
33.4 \\
28.2 \\
28.7 \\
30.3 \\
29.7 \\
28.8 \\
27.9 \\
27.9 \\
29.5 \\
30.7 \\
28.9 \\
31.4\end{array}$ & $\begin{array}{l}53.4 \\
39.8 \\
32.3 \\
30.2 \\
31.0 \\
29.5 \\
31.2 \\
31.1 \\
30.6 \\
32.3 \\
35.1 \\
33.1 \\
34.0\end{array}$ \\
\hline 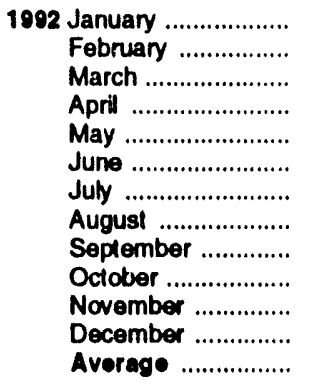 & $\begin{array}{l}30.3 \\
32.7 \\
30.8 \\
31.6 \\
33.1 \\
35.9 \\
38.0 \\
37.7 \\
37.9 \\
41.4 \\
39.2 \\
35.9 \\
35.4\end{array}$ & $\begin{array}{l}35.7 \\
36.2 \\
34.8 \\
35.3 \\
37.2 \\
38.8 \\
41.4 \\
42.1 \\
42.0 \\
44.7 \\
42.8 \\
40.2 \\
38.9\end{array}$ & $\begin{array}{l}21.1 \\
20.9 \\
21.1 \\
25.2 \\
29.1 \\
30.7 \\
33.3 \\
33.2 \\
32.9 \\
35.5 \\
33.8 \\
28.1 \\
28.4\end{array}$ & $\begin{array}{l}24.7 \\
23.6 \\
24.4 \\
27.5 \\
32.0 \\
33.1 \\
34.9 \\
37.0 \\
35.3 \\
37.3 \\
37.6 \\
33.4 \\
31.3\end{array}$ & $\begin{array}{l}24.4 \\
25.6 \\
24.6 \\
27.4 \\
30.2 \\
32.5 \\
34.7 \\
34.7 \\
34.8 \\
37.4 \\
35.9 \\
30.6 \\
30.7\end{array}$ & $\begin{array}{l}28.8 \\
27.7 \\
27.7 \\
29.6 \\
33.4 \\
34.5 \\
36.7 \\
38.8 \\
37.5 \\
39.2 \\
39.4 \\
36.2 \\
33.8\end{array}$ \\
\hline 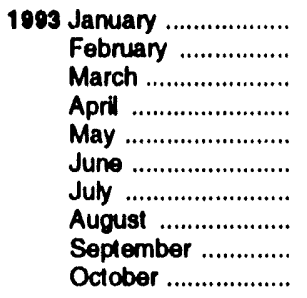 & $\begin{array}{l}36.6 \\
35.5 \\
39.0 \\
38.4 \\
34.7 \\
33.7 \\
32.7 \\
31.5 \\
31.9 \\
31.8\end{array}$ & $\begin{array}{l}40.8 \\
40.8 \\
42.6 \\
43.6 \\
41.9 \\
40.6 \\
41.9 \\
37.2 \\
37.7 \\
38.7\end{array}$ & $\begin{array}{l}27.2 \\
27.1 \\
27.5 \\
29.2 \\
27.8 \\
26.4 \\
24.6 \\
23.7 \\
24.0 \\
25.7\end{array}$ & $\begin{array}{l}32.4 \\
30.8 \\
31.6 \\
32.2 \\
34.1 \\
31.5 \\
28.5 \\
28.7 \\
28.6 \\
29.1\end{array}$ & $\begin{array}{l}31.2 \\
31.1 \\
32.9 \\
33.6 \\
31.0 \\
30.0 \\
27.4 \\
26.9 \\
26.8 \\
28.4\end{array}$ & $\begin{array}{l}35.3 \\
34.4 \\
35.6 \\
36.3 \\
36.8 \\
34.7 \\
33.2 \\
31.9 \\
31.5 \\
31.7\end{array}$ \\
\hline
\end{tabular}

Noles: - Sales for resale are those made to purchasers other than ultimate consumers. Sales to end users are those made directly to the ultimale consumer, including bulk customers, such as agriculture, industry, and electric unilities, as well as commercial customers. - Geographic coverage is the 50 States and the District of Columbia. - Values for the current month are preliminary. - Prices prior to 1983 are Energy information Administration (EIA) estimates. See Note 6 at end of section.

Source: ElA, Petroleum Marketing Monthly, January 1994, Table 17. 
Table 9.6 Refiner Prices of Petroleum Products for Resale (Cents per Gallon, Excluding Taxes)

\begin{tabular}{|c|c|c|c|c|c|c|c|}
\hline & $\begin{array}{l}\text { Finished } \\
\text { Motor } \\
\text { Gasoline }\end{array}$ & $\begin{array}{l}\text { Finishod } \\
\text { Avlation } \\
\text { Gasoline }\end{array}$ & $\begin{array}{c}\text { Kerosene- } \\
\text { Trpe } \\
\therefore \text { Fuel }\end{array}$ & Kerosene & $\begin{array}{c}\text { No. } 2 \\
\text { Fuol } \\
\text { Oll }\end{array}$ & $\begin{array}{c}\text { No. } 2 \\
\text { Dlesed } \\
\text { Fuel }\end{array}$ & $\begin{array}{c}\text { Propano } \\
\text { (Consumer } \\
\text { Grade) }\end{array}$ \\
\hline 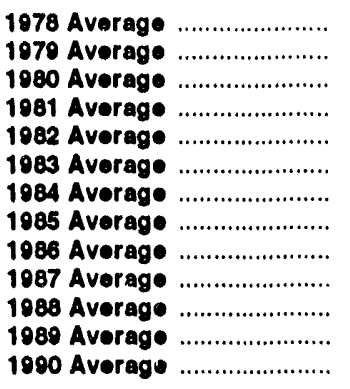 & $\begin{array}{r}43.4 \\
63.7 \\
94.1 \\
106.4 \\
97.3 \\
88.2 \\
83.2 \\
83.5 \\
53.1 \\
58.9 \\
57.7 \\
65.4 \\
78.6\end{array}$ & $\begin{array}{r}53.7 \\
72.1 \\
112.8 \\
125.0 \\
122.8 \\
117.8 \\
116.5 \\
113.0 \\
91.2 \\
85.9 \\
85.0 \\
95.0 \\
106.3\end{array}$ & \begin{tabular}{r|}
38.6 \\
66.0 \\
86.8 \\
101.2 \\
95.3 \\
65.4 \\
83.0 \\
79.4 \\
49.5 \\
53.8 \\
49.5 \\
58.3 \\
77.3
\end{tabular} & \begin{tabular}{r|}
40.4 \\
62.4 \\
86.4 \\
106.6 \\
101.8 \\
80.2 \\
91.6 \\
87.4 \\
60.6 \\
59.2 \\
54.0 \\
66.0 \\
83.9
\end{tabular} & $\begin{array}{l}36.8 \\
56.0 \\
80.3 \\
07.6 \\
01.4 \\
81.5 \\
62.1 \\
77.6 \\
48.6 \\
52.7 \\
47.3 \\
56.5 \\
69.7\end{array}$ & $\begin{array}{l}36.5 \\
57.4 \\
80.1 \\
97.2 \\
91.4 \\
80.8 \\
80.3 \\
77.2 \\
45.2 \\
53.4 \\
47.3 \\
56.7 \\
69.4\end{array}$ & $\begin{array}{l}23.7 \\
29.1 \\
41.5 \\
46.6 \\
42.7 \\
48.4 \\
45.0 \\
39.8 \\
29.0 \\
25.2 \\
24.0 \\
24.7 \\
38.8\end{array}$ \\
\hline 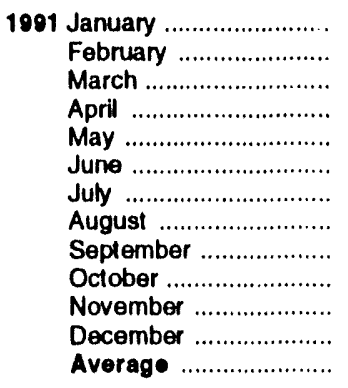 & $\begin{array}{l}76.2 \\
68.0 \\
67.3 \\
70.7 \\
74.2 \\
70.5 \\
69.1 \\
72.7 \\
69.1 \\
68.8 \\
69.9 \\
62.9 \\
69.9\end{array}$ & $\begin{array}{r}111.2 \\
104.2 \\
97.4 \\
97.8 \\
100.3 \\
99.5 \\
98.9 \\
100.2 \\
99.9 \\
98.8 \\
99.5 \\
97.3 \\
100.1\end{array}$ & $\begin{array}{l}82.0 \\
74.0 \\
62.4 \\
58.9 \\
60.8 \\
58.8 \\
59.4 \\
63.3 \\
65.9 \\
67.1 \\
68.2 \\
60.1 \\
65.0\end{array}$ & $\begin{array}{l}88.0 \\
76.1 \\
66.2 \\
63.0 \\
61.4 \\
59.0 \\
62.6 \\
67.1 \\
68.9 \\
73.5 \\
74.6 \\
62.6 \\
72.2\end{array}$ & $\begin{array}{l}76.6 \\
67.9 \\
59.6 \\
57.2 \\
56.0 \\
54.0 \\
56.7 \\
60.6 \\
62.1 \\
66.3 \\
66.6 \\
55.9 \\
62.2\end{array}$ & $\begin{array}{l}75.5 \\
67.4 \\
57.7 \\
57.4 \\
57.2 \\
54.5 \\
57.1 \\
61.9 \\
62.9 \\
65.6 \\
66.5 \\
55.6 \\
61.5\end{array}$ & $\begin{array}{l}42.2 \\
31.6 \\
31.3 \\
31.8 \\
31.9 \\
29.3 \\
27.6 \\
29.6 \\
34.9 \\
40.2 \\
43.0 \\
37.7 \\
34.9\end{array}$ \\
\hline 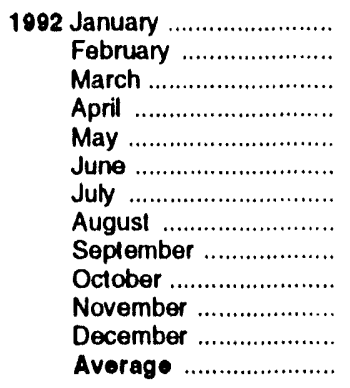 & $\begin{array}{l}60.0 \\
61.7 \\
62.7 \\
66.6 \\
71.5 \\
74.2 \\
71.0 \\
70.6 \\
71.0 \\
70.4 \\
68.1 \\
63.8 \\
67.7\end{array}$ & $\begin{array}{r}94.9 \\
93.1 \\
92.5 \\
96.4 \\
100.5 \\
101.5 \\
102.0 \\
102.6 \\
102.3 \\
100.5 \\
99.7 \\
97.6 \\
99.1\end{array}$ & $\begin{array}{l}53.9 \\
55.2 \\
54.6 \\
56.9 \\
60.8 \\
63.3 \\
64.8 \\
63.9 \\
64.3 \\
66.0 \\
61.5 \\
58.9 \\
60.4\end{array}$ & $\begin{array}{l}59.9 \\
62.0 \\
59.1 \\
61.6 \\
62.1 \\
63.7 \\
65.7 \\
64.2 \\
68.8 \\
70.1 \\
64.5 \\
62.8 \\
63.2\end{array}$ & $\begin{array}{l}51.9 \\
54.0 \\
53.7 \\
56.5 \\
58.8 \\
61.7 \\
61.3 \\
60.1 \\
62.7 \\
64.6 \\
58.8 \\
55.7 \\
57.0\end{array}$ & $\begin{array}{l}51.4 \\
54.1 \\
54.0 \\
57.0 \\
60.1 \\
62.7 \\
61.8 \\
60.4 \\
63.3 \\
65.5 \\
60.4 \\
56.4 \\
59.0\end{array}$ & $\begin{array}{l}30.9 \\
30.2 \\
29.5 \\
29.0 \\
29.4 \\
31.6 \\
31.5 \\
32.9 \\
35.4 \\
36.6 \\
36.2 \\
36.3 \\
32.8\end{array}$ \\
\hline 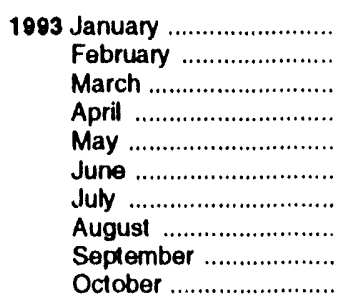 & $\begin{array}{l}63.8 \\
63.8 \\
65.2 \\
67.7 \\
69.2 \\
66.2 \\
62.7 \\
62.9 \\
61.5 \\
61.7\end{array}$ & $\begin{array}{l}96.9 \\
96.5 \\
97.4 \\
97.7 \\
99.4 \\
99.1 \\
97.9 \\
96.9 \\
96.3 \\
94.8\end{array}$ & $\begin{array}{l}57.7 \\
60.5 \\
60.3 \\
59.9 \\
60.1 \\
58.4 \\
55.1 \\
55.2 \\
56.8 \\
60.7\end{array}$ & $\begin{array}{l}61.4 \\
63.7 \\
65.4 \\
60.8 \\
58.3 \\
56.9 \\
53.6 \\
55.6 \\
58.8 \\
65.6\end{array}$ & $\begin{array}{l}54.4 \\
56.9 \\
59.0 \\
57.5 \\
56.9 \\
54.9 \\
51.0 \\
51.0 \\
54.8 \\
59.7\end{array}$ & $\begin{array}{l}54.9 \\
57.4 \\
60.0 \\
59.9 \\
59.6 \\
57.2 \\
53.1 \\
53.2 \\
58.8 \\
66.1\end{array}$ & $\begin{array}{l}40.2 \\
36.7 \\
38.2 \\
36.2 \\
34.0 \\
33.8 \\
33.3 \\
33.3 \\
34.1 \\
34.7\end{array}$ \\
\hline
\end{tabular}

a See Note 5 at end of section.

Noles: - Sales for resale are those made to purchasers other than ultimate consumers. Sales to end users are shown in Table 9.7; they are sales made directly to the uthimate consumer, including bulk customers, such as agriculture, industry, and electric utilities, as well as residential and commercial customers. - Geographic coverage is the 50 States and the District of Columbia. - Values for the current month are preliminary. - Prices prior to 1983 are Energy Information Administration (EIA) estimales. See Note 6 al end of section.

Source: ElA, Petroleum Marketing Monthly, January 1994, Table 4. 
Table 9.7 Refiner Prices of Petroleum Products to End Users

(Cents per Gallon, Excluding Taxes)

\begin{tabular}{|c|c|c|c|c|c|c|c|}
\hline & $\begin{array}{l}\text { Finlehed } \\
\text { Motor } \\
\text { Gasollnea }\end{array}$ & $\begin{array}{l}\text { Finished } \\
\text { Aviation } \\
\text { Gasoline }\end{array}$ & $\begin{array}{c}\text { Keroseno- } \\
\text { Typo } \\
\text { Jet Fuel }\end{array}$ & Kerosene & $\begin{array}{c}\text { No. } 2 \\
\text { Fuel } \\
\text { Oll }\end{array}$ & $\begin{array}{c}\text { No. } 2 \\
\text { Diesed } \\
\text { Fuel } \\
\end{array}$ & $\begin{array}{c}\text { Propene } \\
\text { (Consumer } \\
\text { Grade) }\end{array}$ \\
\hline 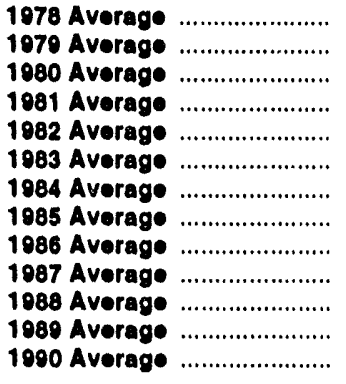 & $\begin{array}{r}48.4 \\
71.3 \\
103.5 \\
114.7 \\
106.0 \\
95.4 \\
90.7 \\
91.2 \\
62.4 \\
66.0 \\
67.3 \\
75.6 \\
88.3\end{array}$ & $\begin{array}{r}51.6 \\
68.0 \\
108.4 \\
130.3 \\
131.2 \\
125.5 \\
123.4 \\
120.1 \\
101.1 \\
90.7 \\
80.1 \\
90.5 \\
112.0\end{array}$ & \begin{tabular}{r|}
38.7 \\
54.7 \\
86.8 \\
102.4 \\
96.3 \\
87.8 \\
64.2 \\
79.6 \\
52.0 \\
54.3 \\
51.3 \\
50.2 \\
76.6
\end{tabular} & $\begin{array}{r}42.1 \\
58.5 \\
90.2 \\
112.3 \\
108.9 \\
96.1 \\
103.6 \\
103.0 \\
79.0 \\
77.0 \\
73.8 \\
70.0 \\
92.3\end{array}$ & $\begin{array}{l}40.0 \\
51.6 \\
78.8 \\
91.4 \\
90.5 \\
91.6 \\
91.6 \\
84.0 \\
56.0 \\
58.1 \\
54.4 \\
58.7 \\
73.4\end{array}$ & $\begin{array}{l}37.7 \\
58.5 \\
81.8 \\
89.5 \\
94.2 \\
82.6 \\
82.3 \\
78.9 \\
47.8 \\
55.1 \\
50.0 \\
58.5 \\
72.5\end{array}$ & $\begin{array}{l}33.5 \\
35.7 \\
48.2 \\
56.5 \\
50.2 \\
70.9 \\
73.7 \\
71.7 \\
74.5 \\
70.1 \\
71.4 \\
61.5 \\
74.5\end{array}$ \\
\hline 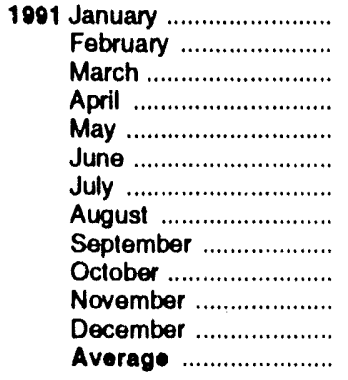 & $\begin{array}{l}88.8 \\
79.5 \\
74.0 \\
77.0 \\
82.0 \\
81.9 \\
78.9 \\
81.1 \\
80.2 \\
77.9 \\
79.1 \\
76.0 \\
79.7\end{array}$ & $\begin{array}{l}112.1 \\
106.4 \\
101.3 \\
101.2 \\
105.3 \\
105.2 \\
103.6 \\
105.8 \\
105.7 \\
104.6 \\
104.3 \\
102.0 \\
104.7\end{array}$ & $\begin{array}{l}81.1 \\
73.7 \\
62.1 \\
58.7 \\
60.1 \\
59.2 \\
59.7 \\
63.8 \\
66.6 \\
67.8 \\
69.6 \\
61.5 \\
65.2\end{array}$ & $\begin{array}{r}105.0 \\
96.9 \\
88.8 \\
73.8 \\
69.3 \\
62.3 \\
64.7 \\
68.7 \\
73.6 \\
81.6 \\
94.3 \\
85.8 \\
83.8\end{array}$ & $\begin{array}{l}84.3 \\
75.2 \\
64.5 \\
61.6 \\
58.9 \\
56.3 \\
59.1 \\
62.3 \\
63.9 \\
68.5 \\
70.9 \\
63.0 \\
66.5\end{array}$ & $\begin{array}{l}80.5 \\
71.4 \\
61.8 \\
60.6 \\
60.1 \\
57.9 \\
59.5 \\
63.3 \\
64.8 \\
68.0 \\
69.7 \\
60.9 \\
64.8\end{array}$ & $\begin{array}{l}86.7 \\
81.4 \\
76.0 \\
67.4 \\
66.7 \\
62.8 \\
61.1 \\
63.6 \\
65.0 \\
68.0 \\
73.7 \\
78.2 \\
73.0\end{array}$ \\
\hline 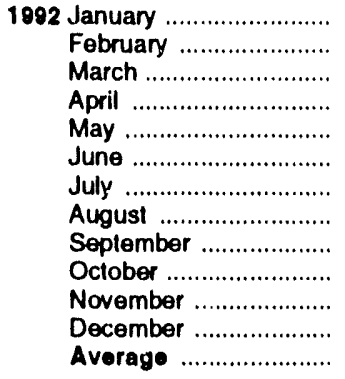 & $\begin{array}{l}71.9 \\
70.8 \\
71.6 \\
75.2 \\
80.8 \\
84.5 \\
83.5 \\
82.3 \\
82.3 \\
81.3 \\
81.5 \\
78.5 \\
78.4\end{array}$ & $\begin{array}{r}98.5 \\
98.5 \\
98.0 \\
99.1 \\
102.4 \\
106.4 \\
106.8 \\
105.7 \\
104.9 \\
104.3 \\
103.4 \\
101.3 \\
102.7\end{array}$ & $\begin{array}{l}54.2 \\
56.5 \\
55.5 \\
57.3 \\
61.0 \\
63.9 \\
64.9 \\
64.2 \\
64.6 \\
66.4 \\
62.7 \\
58.9 \\
61.0\end{array}$ & $\begin{array}{l}83.3 \\
78.3 \\
80.2 \\
78.3 \\
73.3 \\
68.7 \\
70.5 \\
69.0 \\
70.5 \\
87.2 \\
83.3 \\
84.0 \\
78.6\end{array}$ & $\begin{array}{l}59.7 \\
62.0 \\
61.4 \\
60.6 \\
60.9 \\
62.9 \\
62.8 \\
62.3 \\
65.6 \\
68.2 \\
64.3 \\
63.6 \\
62.7\end{array}$ & $\begin{array}{l}55.5 \\
57.1 \\
56.8 \\
59.2 \\
62.1 \\
64.9 \\
64.5 \\
63.4 \\
65.3 \\
67.8 \\
64.5 \\
60.8 \\
61.8\end{array}$ & $\begin{array}{c}71.3 \\
N A \\
66.4 \\
70.3 \\
62.5 \\
54.5 \\
52.3 \\
55.8 \\
60.3 \\
59.9 \\
61.1 \\
68.4 \\
66.2\end{array}$ \\
\hline 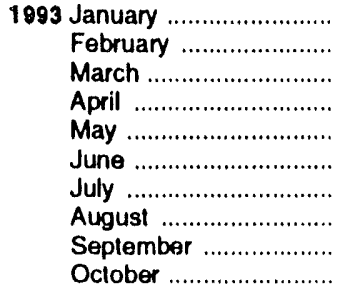 & $\begin{array}{l}76.9 \\
76.1 \\
75.7 \\
77.8 \\
80.1 \\
79.8 \\
77.6 \\
76.2 \\
74.9 \\
75.4\end{array}$ & $\begin{array}{r}100.3 \\
99.9 \\
99.4 \\
100.7 \\
102.2 \\
102.5 \\
99.7 \\
98.8 \\
98.2 \\
98.0\end{array}$ & $\begin{array}{l}58.5 \\
59.8 \\
60.6 \\
59.7 \\
59.9 \\
58.7 \\
55.3 \\
54.6 \\
56.9 \\
61.4\end{array}$ & $\begin{array}{l}82.4 \\
81.3 \\
83.2 \\
77.0 \\
68.8 \\
65.3 \\
61.4 \\
61.9 \\
66.5 \\
75.5\end{array}$ & $\begin{array}{r}62.7 \\
64.6 \\
66.2 \\
61.9 \\
59.8 \\
57.9 \\
54.1 \\
54.6 \\
\text { P } 57.3 \\
63.4\end{array}$ & $\begin{array}{r}59.0 \\
60.6 \\
62.9 \\
62.5 \\
62.3 \\
60.5 \\
56.9 \\
56.2 \\
60.4 \\
67.0\end{array}$ & $\begin{array}{r}74.8 \\
74.3 \\
75.4 \\
69.4 \\
67.3 \\
63.9 \\
62.2 \\
63.1 \\
R 62.8 \\
54.6\end{array}$ \\
\hline
\end{tabular}

a See Note 5 at end of section.

$R=$ Revised data. NA=Not available.

Notes: - Sales to end users are those made directly to the utimate consumer, including bulk customers, such as agriculture, industry, and electric utilities, as well as residential and commercial customers. Sales for resale are shown in Table 9.6; they are sales made to purchasers other than

uhimate consumers. - Geographic coverage is the 50 States and the District of Columbia. - Values for the current month are preliminary. - Prices prior to 1983 are Energy Intormation Administration (EIA) estimates. See Nole 6 at end of section.

Source: EIA, Petroleum Marketing Monthly, January 1994, Table 2. 
Table 9.8a No. 2 Distillate Prices to Residences: Northeastern States (Cents per Gallor Excluding Taxes)

\begin{tabular}{|c|c|c|c|c|c|c|c|c|c|}
\hline & Malne & $\begin{array}{c}\text { Now } \\
\text { Hampshire }\end{array}$ & Vermont & Massachusetts & $\begin{array}{l}\text { Rhode } \\
\text { Island }\end{array}$ & Connectleut & $\begin{array}{l}\text { New } \\
\text { York }\end{array}$ & $\begin{array}{l}\text { New } \\
\text { Jersey }\end{array}$ & Ponneylvanla \\
\hline 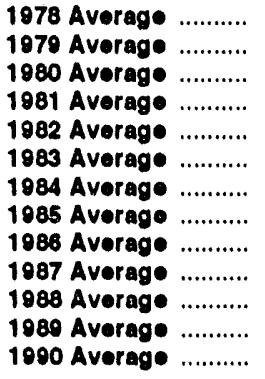 & \begin{tabular}{r|}
48.6 \\
68.8 \\
96.3 \\
120.4 \\
115.5 \\
102.8 \\
103.9 \\
90.7 \\
74.4 \\
74.7 \\
77.7 \\
80.4 \\
98.9
\end{tabular} & $\begin{array}{r}50.3 \\
72.5 \\
100.4 \\
123.7 \\
117.4 \\
104.1 \\
108.4 \\
102.4 \\
75.8 \\
76.5 \\
78.2 \\
89.3 \\
102.8\end{array}$ & $\begin{array}{r}50.8 \\
72.5 \\
101.5 \\
125.4 \\
120.1 \\
112.9 \\
111.9 \\
107.7 \\
86.6 \\
81.1 \\
82.6 \\
90.5 \\
107.0\end{array}$ & $\begin{array}{r}48.8 \\
70.8 \\
97.8 \\
121.3 \\
117.6 \\
109.1 \\
111.6 \\
107.0 \\
82.1 \\
80.6 \\
82.1 \\
92.6 \\
108.4\end{array}$ & $\begin{array}{r}50.7 \\
72.8 \\
101.1 \\
123.8 \\
120.1 \\
110.5 \\
111.4 \\
106.7 \\
82.8 \\
82.5 \\
83.6 \\
93.8 \\
108.6\end{array}$ & $\begin{array}{r}50.1 \\
72.0 \\
98.3 \\
121.7 \\
118.3 \\
109.1 \\
112.1 \\
108.0 \\
89.0 \\
83.4 \\
85.3 \\
92.9 \\
109.8\end{array}$ & $\begin{array}{r}50.1 \\
71.2 \\
98.2 \\
123.2 \\
120.5 \\
112.1 \\
115.5 \\
111.3 \\
91.1 \\
85.2 \\
86.3 \\
95.8 \\
112.5\end{array}$ & $\begin{array}{r}49.6 \\
71.0 \\
97.0 \\
121.5 \\
117.4 \\
107.0 \\
111.0 \\
105.0 \\
90.2 \\
84.3 \\
84.8 \\
91.8 \\
108.7\end{array}$ & $\begin{array}{r}48.8 \\
69.8 \\
96.4 \\
118.1 \\
113.7 \\
103.8 \\
107.0 \\
102.3 \\
81.4 \\
76.0 \\
77.8 \\
85.1 \\
102.8\end{array}$ \\
\hline 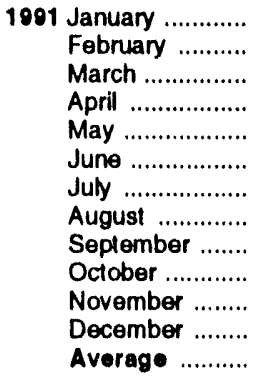 & $\begin{array}{r}114.4 \\
105.9 \\
95.4 \\
87.1 \\
81.9 \\
79.6 \\
82.3 \\
83.4 \\
87.3 \\
91.3 \\
95.1 \\
89.3 \\
96.0\end{array}$ & $\begin{array}{r}107.2 \\
100.7 \\
90.5 \\
83.9 \\
79.4 \\
77.3 \\
77.6 \\
80.6 \\
84.2 \\
87.8 \\
90.1 \\
88.8 \\
91.6\end{array}$ & $\begin{array}{r}117.7 \\
111.3 \\
104.4 \\
98.5 \\
93.5 \\
91.3 \\
88.1 \\
88.6 \\
91.9 \\
93.9 \\
95.7 \\
94.1 \\
101.9\end{array}$ & $\begin{array}{r}118.1 \\
111.3 \\
102.6 \\
96.1 \\
91.7 \\
88.9 \\
88.5 \\
88.7 \\
90.9 \\
94.9 \\
97.5 \\
95.8 \\
103.0\end{array}$ & $\begin{array}{r}113.3 \\
109.5 \\
101.8 \\
94.7 \\
89.7 \\
87.1 \\
88.8 \\
88.7 \\
90.3 \\
94.9 \\
95.8 \\
93.4 \\
99.9\end{array}$ & $\begin{array}{r}122.5 \\
116.0 \\
109.0 \\
101.4 \\
96.5 \\
92.7 \\
90.0 \\
89.7 \\
92.0 \\
96.3 \\
99.8 \\
98.3 \\
106.2\end{array}$ & $\begin{array}{r}124.6 \\
120.2 \\
112.8 \\
106.7 \\
101.2 \\
98.1 \\
93.9 \\
93.0 \\
98.7 \\
103.3 \\
108.1 \\
105.7 \\
111.3\end{array}$ & $\begin{array}{r}119.6 \\
113.2 \\
104.3 \\
98.6 \\
94.4 \\
90.3 \\
88.5 \\
89.0 \\
92.2 \\
96.9 \\
100.7 \\
96.6 \\
104.0\end{array}$ & $\begin{array}{r}117.7 \\
110.9 \\
101.8 \\
95.5 \\
89.9 \\
85.7 \\
80.8 \\
81.8 \\
83.4 \\
88.8 \\
93.6 \\
93.1 \\
99.7\end{array}$ \\
\hline 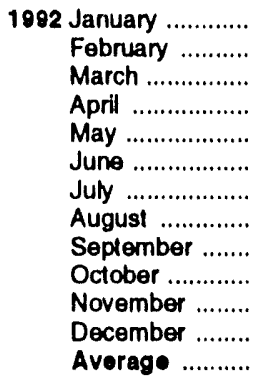 & $\begin{array}{l}87.7 \\
88.2 \\
86.4 \\
85.5 \\
85.5 \\
87.1 \\
87.7 \\
87.8 \\
86.8 \\
89.3 \\
88.3 \\
85.7 \\
87.1\end{array}$ & $\begin{array}{l}88.1 \\
86.5 \\
83.3 \\
81.8 \\
81.7 \\
82.9 \\
82.3 \\
81.8 \\
83.0 \\
87.6 \\
87.6 \\
87.7 \\
85.6\end{array}$ & $\begin{array}{l}92.4 \\
92.8 \\
92.2 \\
91.7 \\
91.5 \\
90.7 \\
89.1 \\
89.4 \\
91.6 \\
92.0 \\
92.6 \\
92.9 \\
92.2\end{array}$ & $\begin{array}{l}93.2 \\
92.5 \\
91.5 \\
91.4 \\
91.0 \\
91.3 \\
90.4 \\
89.6 \\
90.7 \\
93.5 \\
93.8 \\
93.5 \\
92.4\end{array}$ & $\begin{array}{l}90.7 \\
91.7 \\
90.9 \\
90.4 \\
90.9 \\
89.7 \\
89.9 \\
89.4 \\
89.8 \\
92.7 \\
92.5 \\
91.5 \\
91.2\end{array}$ & $\begin{array}{l}96.4 \\
95.5 \\
94.0 \\
93.3 \\
93.1 \\
91.8 \\
93.1 \\
90.5 \\
91.8 \\
94.9 \\
95.8 \\
95.2 \\
94.7\end{array}$ & $\begin{array}{r}103.4 \\
103.8 \\
102.1 \\
101.1 \\
101.1 \\
101.7 \\
100.7 \\
99.0 \\
99.7 \\
102.7 \\
104.7 \\
104.3 \\
102.8\end{array}$ & $\begin{array}{l}95.6 \\
95.1 \\
93.5 \\
92.9 \\
89.2 \\
90.4 \\
90.3 \\
88.1 \\
90.8 \\
94.0 \\
94.6 \\
95.4 \\
93.9\end{array}$ & $\begin{array}{l}91.4 \\
91.5 \\
90.1 \\
89.4 \\
88.6 \\
86.5 \\
83.0 \\
81.7 \\
84.4 \\
87.5 \\
89.6 \\
89.3 \\
88.9\end{array}$ \\
\hline 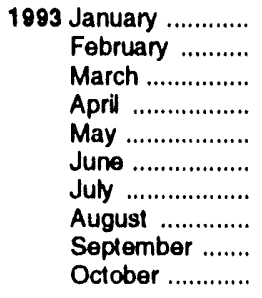 & $\begin{array}{l}85.2 \\
85.4 \\
86.5 \\
83.0 \\
81.5 \\
80.8 \\
78.2 \\
77.3 \\
78.3 \\
83.0\end{array}$ & $\begin{array}{r}87.1 \\
87.0 \\
86.6 \\
85.0 \\
83.8 \\
82.5 \\
78.0 \\
76.1 \\
75.2 \\
77.2\end{array}$ & $\begin{array}{r}93.4 \\
93.3 \\
93.7 \\
91.2 \\
91.2 \\
89.7 \\
85.5 \\
85.6 \\
R \quad 86.6 \\
86.8\end{array}$ & $\begin{array}{l}94.0 \\
94.4 \\
94.8 \\
91.3 \\
90.9 \\
88.6 \\
83.9 \\
83.4 \\
83.8 \\
86.3\end{array}$ & $\begin{array}{r}91.7 \\
91.8 \\
92.4 \\
90.3 \\
90.6 \\
87.6 \\
85.2 \\
82.7 \\
84.1 \\
85.7\end{array}$ & $\begin{array}{l}94.9 \\
96.2 \\
96.7 \\
93.6 \\
91.7 \\
88.6 \\
86.5 \\
84.0 \\
84.3 \\
88.5\end{array}$ & $\begin{array}{r}104.3 \\
104.2 \\
104.2 \\
100.1 \\
99.3 \\
97.8 \\
95.2 \\
92.9 \\
P 93.5 \\
96.1\end{array}$ & $\begin{array}{r}96.5 \\
96.7 \\
96.2 \\
95.1 \\
91.6 \\
88.0 \\
87.9 \\
85.7 \\
\text { ค } 85.9 \\
88.7\end{array}$ & $\begin{array}{r}89.0 \\
89.1 \\
89.8 \\
89.0 \\
86.6 \\
84.0 \\
78.8 \\
77.0 \\
80.4 \\
83.2\end{array}$ \\
\hline
\end{tabular}

$\mathrm{R}=$ Revised data.

Noles: - States are grouped in Tables $9.8 \mathrm{a}, 9.8 \mathrm{~b}$, and $9.8 \mathrm{c}$ by geographic region of the country. - Values for the current month are preliminary.
- Prices prior to 1983 are Energy Information Administration (EIA) estimates. See Note 6 at end of section.

Source: ElA, Petroleum Marketing Monthly, January 1994, Table 16. 
Table 9.8b No. 2 Distillate Prices to Residences: Selected South Atlantic and Midwestern States

(Cents per Gallon, Excluding Taxes)

\begin{tabular}{|c|c|c|c|c|c|c|c|c|c|c|c|}
\hline & Delemere & $\begin{array}{c}\text { District } \\
\text { of } \\
\text { Columbie }\end{array}$ & Maryland & Virginie & $\begin{array}{c}\text { West } \\
\text { Virginle }\end{array}$ & Ohio & Michigan & Indlana & Illinols & Wieconsin & Minncesote \\
\hline 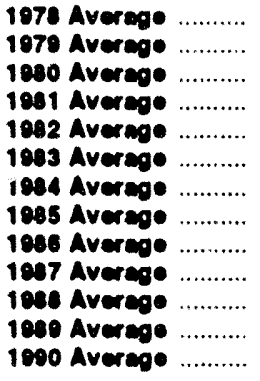 & $\begin{array}{r}17.0 \\
68.2 \\
85.4 \\
117.3 \\
111.3 \\
108.0 \\
100.8 \\
104.6 \\
65.0 \\
70.3 \\
60.1 \\
08.2 \\
105.8\end{array}$ & $\begin{array}{r}50.7 \\
74.2 \\
102.6 \\
127.4 \\
124.5 \\
117.0 \\
118.7 \\
114.3 \\
03.1 \\
91.8 \\
01.6 \\
08.6 \\
107.8\end{array}$ & $\begin{array}{r}40.2 \\
70.1 \\
07.0 \\
121.4 \\
117.1 \\
110.3 \\
113.5 \\
108.8 \\
91.4 \\
86.8 \\
07.0 \\
93.8 \\
111.0\end{array}$ & $\begin{array}{r}49.1 \\
70.4 \\
96.5 \\
120.5 \\
117.7 \\
108.7 \\
110.5 \\
106.3 \\
86.8 \\
70.5 \\
60.5 \\
87.0 \\
110.6\end{array}$ & $\begin{array}{r}46.2 \\
65.1 \\
92.2 \\
115.0 \\
109.3 \\
101.0 \\
102.1 \\
98.0 \\
74.6 \\
76.4 \\
74.2 \\
93.0 \\
99.1\end{array}$ & $\begin{array}{r}47.4 \\
68.6 \\
91.9 \\
113.2 \\
110.2 \\
101.3 \\
102.1 \\
90.7 \\
77.7 \\
74.7 \\
74.7 \\
01.6 \\
98.1\end{array}$ & $\begin{array}{r}47.0 \\
70.0 \\
97.8 \\
118.3 \\
113.0 \\
106.4 \\
105.0 \\
102.1 \\
61.0 \\
77.5 \\
77.5 \\
05.3 \\
100.0\end{array}$ & $\begin{array}{r}48.5 \\
72.7 \\
00.6 \\
118.5 \\
114.3 \\
100.7 \\
103.1 \\
90.1 \\
74.8 \\
75.4 \\
75.4 \\
03.2 \\
90.3\end{array}$ & $\begin{array}{r}46.5 \\
68.0 \\
05.0 \\
114.0 \\
110.0 \\
100.4 \\
100.1 \\
07.5 \\
N A \\
70.8 \\
77.6 \\
80.0 \\
96.1\end{array}$ & $\begin{array}{r}44.7 \\
67.2 \\
01.5 \\
109.1 \\
107.8 \\
101.2 \\
101.0 \\
08.3 \\
75.6 \\
75.1 \\
73.0 \\
81.1 \\
94.2\end{array}$ & $\begin{array}{r}17.8 \\
72.4 \\
0.4 \\
118.4 \\
116.1 \\
108.1 \\
104.1 \\
101.0 \\
70.2 \\
74.4 \\
73.5 \\
12.4 \\
101.4\end{array}$ \\
\hline 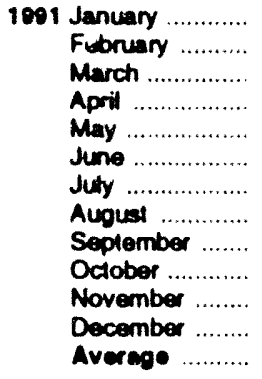 & $\begin{array}{r}113.0 \\
105.4 \\
38.4 \\
92.3 \\
81.5 \\
84.0 \\
81.5 \\
86.0 \\
87.3 \\
92.8 \\
96.9 \\
94.9 \\
00.7\end{array}$ & $\begin{array}{r}124.1 \\
118.6 \\
112.3 \\
105.6 \\
101.1 \\
95.3 \\
98.6 \\
98.6 \\
101.7 \\
104.0 \\
107.3 \\
107.7 \\
112.2\end{array}$ & $\begin{array}{r}122.0 \\
116.1 \\
107.7 \\
102.7 \\
98.7 \\
96.2 \\
93.7 \\
94.0 \\
96.8 \\
100.1 \\
103.2 \\
102.6 \\
108.4\end{array}$ & $\begin{array}{r}117.2 \\
110.3 \\
102.4 \\
96.1 \\
80.7 \\
87.8 \\
86.9 \\
87.5 \\
90.4 \\
93.6 \\
97.0 \\
95.2 \\
101.1\end{array}$ & $\begin{array}{r}110.5 \\
101.5 \\
90.8 \\
87.6 \\
85.8 \\
83.6 \\
81.7 \\
82.4 \\
84.8 \\
89.7 \\
91.8 \\
89.0 \\
93.4\end{array}$ & $\begin{array}{r}105.5 \\
94.6 \\
85.7 \\
83.2 \\
83.1 \\
80.7 \\
79.6 \\
81.1 \\
84.8 \\
88.7 \\
91.8 \\
86.0 \\
91.0\end{array}$ & $\begin{array}{r}109.8 \\
98.5 \\
91.5 \\
90.7 \\
88.1 \\
87.4 \\
83.3 \\
84.4 \\
86.8 \\
89.5 \\
92.8 \\
89.9 \\
94.2\end{array}$ & $\begin{array}{r}105.8 \\
85.4 \\
87.9 \\
86.0 \\
86.3 \\
80.3 \\
78.8 \\
85.5 \\
85.5 \\
86.7 \\
87.8 \\
83.3 \\
81.8\end{array}$ & $\begin{array}{r}102.5 \\
02.0 \\
86.5 \\
88.3 \\
88.5 \\
86.8 \\
82.2 \\
86.5 \\
87.3 \\
88.4 \\
92.4 \\
89.9 \\
02.7\end{array}$ & $\begin{array}{r}102.4 \\
92.4 \\
87.8 \\
84.0 \\
82.8 \\
80.9 \\
78.0 \\
78.8 \\
82.7 \\
85.7 \\
89.9 \\
85.4 \\
88.5\end{array}$ & $\begin{array}{l}105.4 \\
83.5 \\
87.2 \\
87.8 \\
88.1 \\
87.1 \\
84.4 \\
86.3 \\
84.0 \\
86.8 \\
89.2 \\
84.4 \\
91.1\end{array}$ \\
\hline 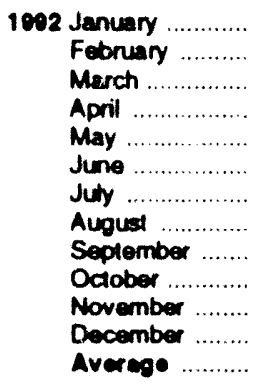 & $\begin{array}{l}94.4 \\
92.7 \\
92.4 \\
91.5 \\
90.2 \\
21.4 \\
90.6 \\
89.5 \\
90.3 \\
93.7 \\
92.8 \\
90.9 \\
92.4\end{array}$ & $\begin{array}{l}107.3 \\
107.3 \\
105.3 \\
104.7 \\
102.3 \\
102.7 \\
102.0 \\
101.9 \\
101.2 \\
104.0 \\
105.7 \\
105.4 \\
105.7\end{array}$ & $\begin{array}{r}101.6 \\
100.9 \\
100.3 \\
99.0 \\
97.2 \\
97.6 \\
95.7 \\
95.2 \\
95.7 \\
98.8 \\
100.4 \\
100.4 \\
00.8\end{array}$ & $\begin{array}{l}94.3 \\
93.7 \\
93.7 \\
92.6 \\
91.7 \\
89.6 \\
90.2 \\
88.4 \\
89.4 \\
91.9 \\
92.1 \\
93.3 \\
92.8\end{array}$ & $\begin{array}{l}85.5 \\
86.9 \\
86.6 \\
85.6 \\
84.2 \\
86.5 \\
82.3 \\
81.4 \\
85.4 \\
88.3 \\
88.0 \\
89.0 \\
86.4\end{array}$ & $\begin{array}{l}82.0 \\
83.0 \\
82.5 \\
82.9 \\
83.5 \\
85.3 \\
81.7 \\
82.3 \\
84.7 \\
86.4 \\
84.6 \\
84.5 \\
83.6\end{array}$ & $\begin{array}{l}86.6 \\
86.5 \\
86.6 \\
86.7 \\
86.4 \\
86.1 \\
85.0 \\
85.7 \\
88.2 \\
90.0 \\
88.2 \\
87.9 \\
87.1\end{array}$ & $\begin{array}{l}77.8 \\
78.7 \\
79.5 \\
80.2 \\
81.2 \\
79.6 \\
82.4 \\
83.1 \\
84.8 \\
85.8 \\
82.7 \\
81.8 \\
81.1\end{array}$ & $\begin{array}{l}85.2 \\
85.6 \\
88.1 \\
88.4 \\
89.0 \\
90.8 \\
87.8 \\
86.4 \\
88.9 \\
90.8 \\
80.4 \\
88.2 \\
87.6\end{array}$ & $\begin{array}{l}80.1 \\
79.8 \\
79.2 \\
80.4 \\
81.5 \\
81.9 \\
81.1 \\
80.6 \\
83.6 \\
84.1 \\
83.7 \\
84.3 \\
81.0\end{array}$ & $\begin{array}{l}79.4 \\
79.6 \\
79.7 \\
81.8 \\
83.9 \\
82.0 \\
84.5 \\
84.1 \\
85.0 \\
87.1 \\
86.0 \\
83.1 \\
82.3\end{array}$ \\
\hline 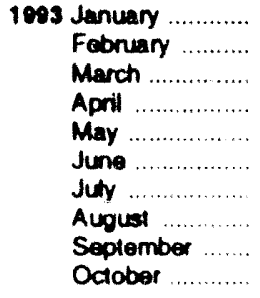 & $\begin{array}{l}90.8 \\
90.8 \\
92.4 \\
91.6 \\
89.4 \\
90.8 \\
90.2 \\
83.5 \\
95.0 \\
88.6\end{array}$ & $\begin{array}{r}105.2 \\
106.8 \\
108.5 \\
107.1 \\
104.3 \\
100.4 \\
1002 \\
96.1 \\
95.0 \\
102.3\end{array}$ & $\begin{array}{r}100.5 \\
101.3 \\
101.6 \\
99.2 \\
96.2 \\
95.2 \\
92.3 \\
91.3 \\
492.6 \\
94.2\end{array}$ & $\begin{array}{r}92.4 \\
93.5 \\
94.2 \\
90.3 \\
88.6 \\
86.0 \\
84.7 \\
840 \\
84.9 \\
85.2\end{array}$ & $\begin{array}{l}88.3 \\
88.6 \\
89.9 \\
86.9 \\
84.8 \\
86.7 \\
31.2 \\
79.1 \\
79.2 \\
83.6\end{array}$ & $\begin{array}{r}84.2 \\
85.5 \\
86.6 \\
86.9 \\
86.0 \\
85.7 \\
79.3 \\
78.6 \\
8.4 \\
85.5\end{array}$ & $\begin{array}{l}88.3 \\
87.6 \\
90.1 \\
90.8 \\
89.8 \\
87.4 \\
83.4 \\
82.1 \\
85.5 \\
90.0\end{array}$ & $\begin{array}{r}81.8 \\
82.3 \\
83.1 \\
84.9 \\
83.6 \\
82.1 \\
79.0 \\
76.6 \\
80.3 \\
83.1\end{array}$ & $\begin{array}{r}87.2 \\
88.2 \\
80.0 \\
N A \\
84.8 \\
81.2 \\
79.4 \\
77.2 \\
80.9 \\
87.6\end{array}$ & $\begin{array}{l}82.1 \\
83.3 \\
84.0 \\
84.7 \\
84.9 \\
84.2 \\
84.1 \\
78.7 \\
82.8 \\
82.0\end{array}$ & $\begin{array}{l}82.0 \\
83.0 \\
83.0 \\
83.3 \\
84.1 \\
83.4 \\
82.0 \\
80.0 \\
83.1 \\
86.8\end{array}$ \\
\hline
\end{tabular}

RxRevised data. NA=Not availabie

Notes: - States are grouped in Tables $9.8 \mathrm{a} .9 .8 \mathrm{~b}$, and $9.8 \mathrm{c}$ by geographic region of the couniry. - Values lor the currert month are preliminary
- Prices prior to 1983 are Energy Intormation Administration (ELA) extimetes. See Note 6 at end of section.

Source: EIA, Petroloum Marketing Monthy, January 1994, Table 16. 
Table 9.8c No. 2 Distillate Prices to Residences: Selected Western States and U.S. Average

(Cents per Gallon, Excluding Taxes)

\begin{tabular}{|c|c|c|c|c|c|}
\hline & Idaho & Washington & Oregon & Alaska & $\begin{array}{c}\text { U.S. } \\
\text { Average }\end{array}$ \\
\hline 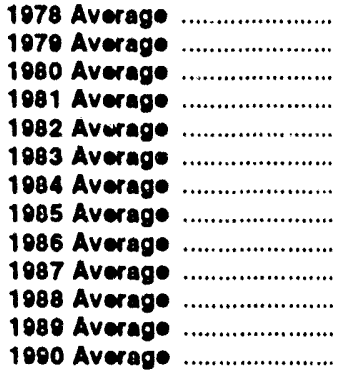 & $\begin{array}{r}43.6 \\
62.1 \\
91.6 \\
110.4 \\
110.4 \\
101.8 \\
98.5 \\
97.2 \\
73.8 \\
68.8 \\
68.8 \\
77.8 \\
97.4\end{array}$ & $\begin{array}{r}48.6 \\
69.7 \\
100.8 \\
116.5 \\
117.6 \\
109.0 \\
102.6 \\
101.1 \\
77.5 \\
78.5 \\
78.5 \\
87.4 \\
102.8\end{array}$ & $\begin{array}{r}458 \\
68.11 \\
97.3 \\
111.4 \\
111.6 \\
103.6 \\
99.3 \\
97.1 \\
70.4 \\
72.5 \\
70.9 \\
80.2 \\
97.0\end{array}$ & $\begin{array}{r}53.2 \\
68.2 \\
97.8 \\
118.0 \\
117.4 \\
108.8 \\
106.0 \\
108.3 \\
94.9 \\
86.5 \\
86.9 \\
96.4 \\
110.1\end{array}$ & $\begin{array}{r}49.0 \\
70.4 \\
97.4 \\
110.4 \\
116.0 \\
107.4 \\
109.1 \\
105.3 \\
83.6 \\
80.3 \\
81.3 \\
80.0 \\
106.3\end{array}$ \\
\hline 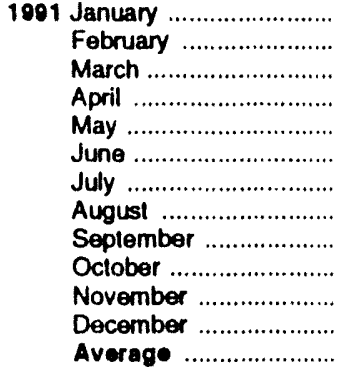 & $\begin{array}{r}110.8 \\
97.3 \\
84.0 \\
83.4 \\
84.4 \\
83.4 \\
80.0 \\
84.6 \\
87.4 \\
87.6 \\
93.3 \\
947 \\
85.1\end{array}$ & $\begin{array}{r}118.4 \\
112.0 \\
95.3 \\
93.5 \\
94.9 \\
91.7 \\
85.5 \\
92.6 \\
93.5 \\
95.2 \\
99.5 \\
96.2 \\
101.6\end{array}$ & $\begin{array}{r}108.4 \\
102.9 \\
88.8 \\
86.4 \\
86.5 \\
85.6 \\
83.6 \\
87.3 \\
908 \\
89.1 \\
90.6 \\
87.0 \\
93.3\end{array}$ & $\begin{array}{r}129.3 \\
122.8 \\
109.5 \\
101.9 \\
101.3 \\
98.2 \\
98.6 \\
96.8 \\
92.4 \\
91.3 \\
96.0 \\
95.2 \\
105.0\end{array}$ & $\begin{array}{r}117.1 \\
110.5 \\
102.6 \\
96.9 \\
92.5 \\
89.3 \\
86.6 \\
87.0 \\
89.7 \\
94.0 \\
98.0 \\
95.9 \\
101.9\end{array}$ \\
\hline 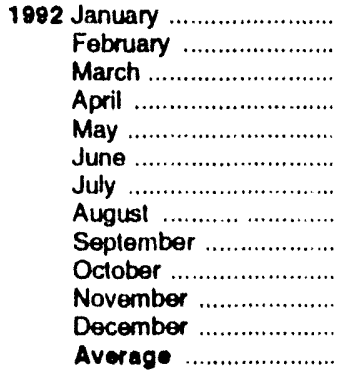 & $\begin{array}{l}86.1 \\
79.2 \\
82.2 \\
84.2 \\
86.1 \\
84.6 \\
86.1 \\
79.4 \\
86.0 \\
89.6 \\
91.7 \\
86.8 \\
85.7\end{array}$ & $\begin{array}{l}92.0 \\
90.9 \\
91.8 \\
92.0 \\
94.3 \\
90.6 \\
88.0 \\
84.0 \\
90.3 \\
94.5 \\
98.7 \\
99.7 \\
94.3\end{array}$ & $\begin{array}{l}85.3 \\
83.5 \\
82.6 \\
85.5 \\
88.9 \\
89.2 \\
87.3 \\
84.0 \\
87.6 \\
91.7 \\
92.8 \\
91.5 \\
87.8\end{array}$ & $\begin{array}{l}92.7 \\
91.1 \\
93.0 \\
92.1 \\
93.6 \\
93.9 \\
93.0 \\
96.8 \\
93.4 \\
96.8 \\
97.7 \\
95.8 \\
94.0\end{array}$ & $\begin{array}{l}94.2 \\
94.2 \\
93.2 \\
92.5 \\
92.3 \\
92.0 \\
90.4 \\
88.6 \\
90.1 \\
93.7 \\
94.8 \\
94.5 \\
93.4\end{array}$ \\
\hline 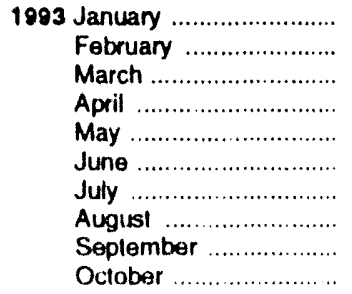 & $\begin{array}{l}84.8 \\
84.2 \\
87.8 \\
84.1 \\
82.9 \\
82.8 \\
80.0 \\
77.0 \\
85.3 \\
94.8\end{array}$ & $\begin{array}{r}100.6 \\
101.4 \\
99.7 \\
101.5 \\
100.3 \\
95.1 \\
91.3 \\
89.3 \\
97.1 \\
105.5\end{array}$ & $\begin{array}{r}91.7 \\
89.9 \\
90.7 \\
92.1 \\
91.3 \\
90.2 \\
86.1 \\
83.5 \\
R 92.0 \\
100.2\end{array}$ & $\begin{array}{r}95.1 \\
95.1 \\
94.2 \\
94.7 \\
96.6 \\
97.1 \\
95.3 \\
95.5 \\
\text { R } \\
94.8 \\
96.5\end{array}$ & $\begin{array}{r}94.3 \\
94.6 \\
95.4 \\
92.5 \\
91.0 \\
88.9 \\
85.6 \\
84.1 \\
85.4 \\
88.6\end{array}$ \\
\hline
\end{tabular}

$R=$ Revised data

Noles: - Slates are grouped in Tables $9.8 \mathrm{a}, 9.8 \mathrm{~b}$, and $9.8 \mathrm{c}$ by geographic region of the country. Values for the current month are preliminary.
- Prices prior to 1983 are Energy Inlormation Administration (EIA) estimates. See Nole 6 at end of section.

Source: EIA, Pelroleum Marketing Monthly, January 1994, Table 16. 
Figure 9.2 Electricity Retall Prices

(Cents per Kilowatthour)

Prices by Sector, 1973-1992

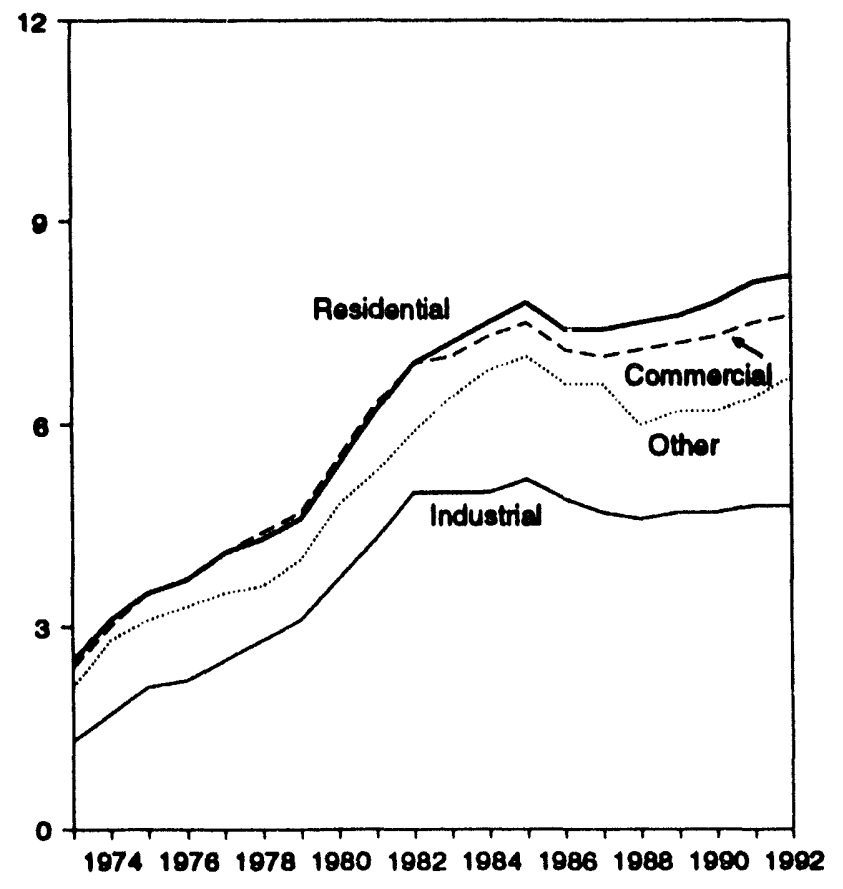

Prices by Sector, Monthly

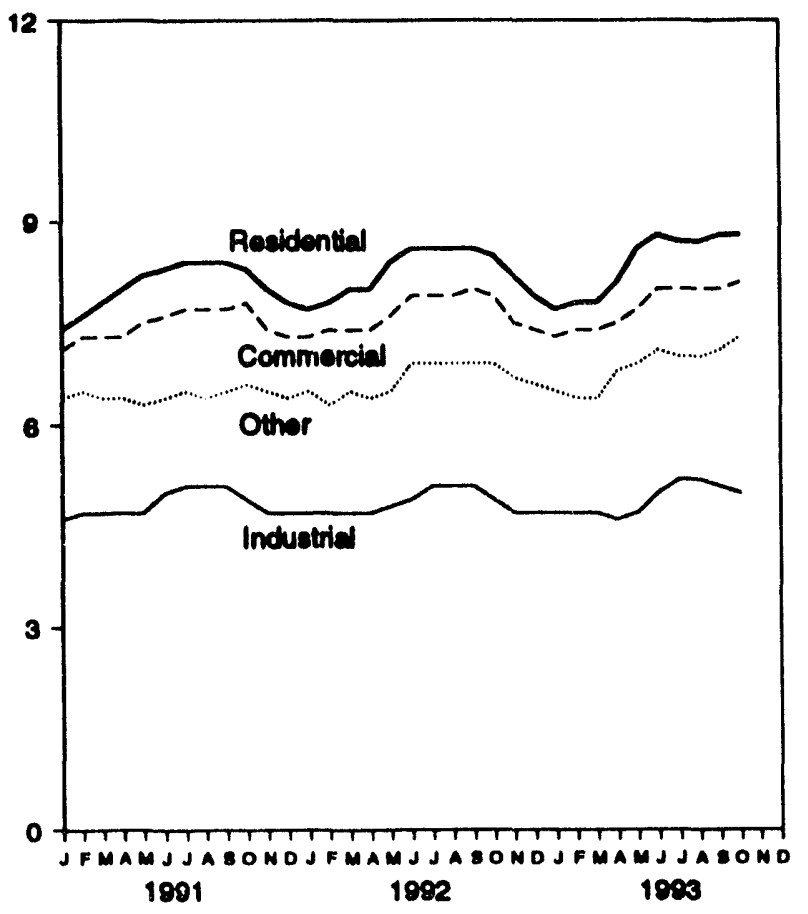

Source: Table 8.8, Monthly Sories.

Figure 9.3 Cost of Fossil-Fuel Receipts at Steam-Electric Plants (Dollars per Million Btu)

Fossil Fuels Costs, 1973-1992

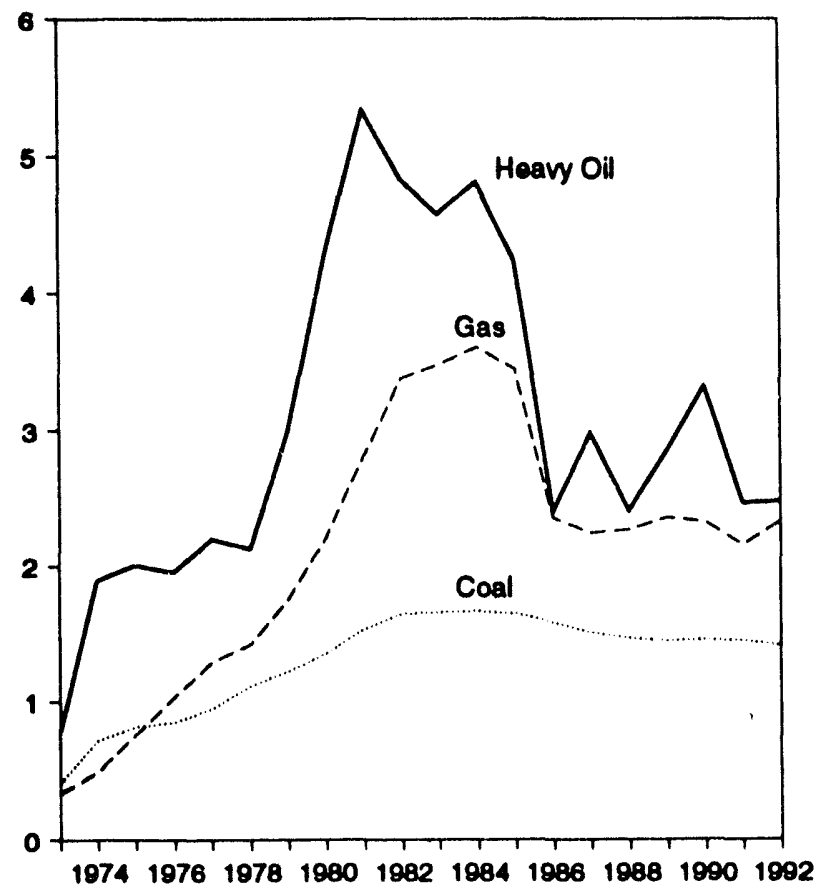

Fossil Fuel Costs, Monthly

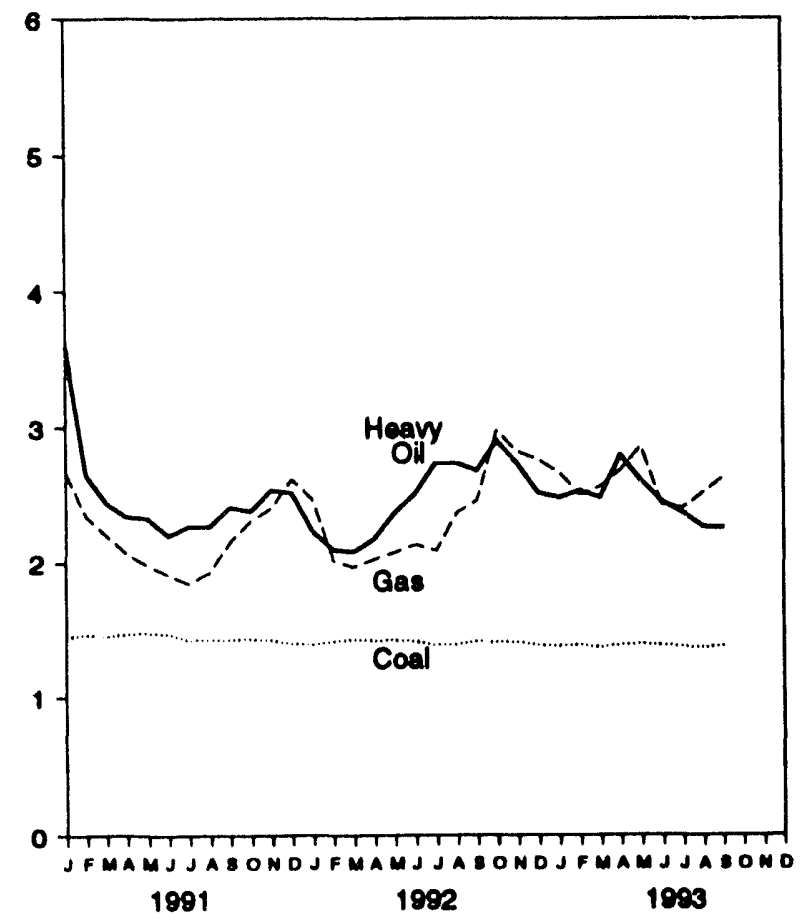


Table 9.9 Electricity Retail Prices

(Cents per Kilowatthour)

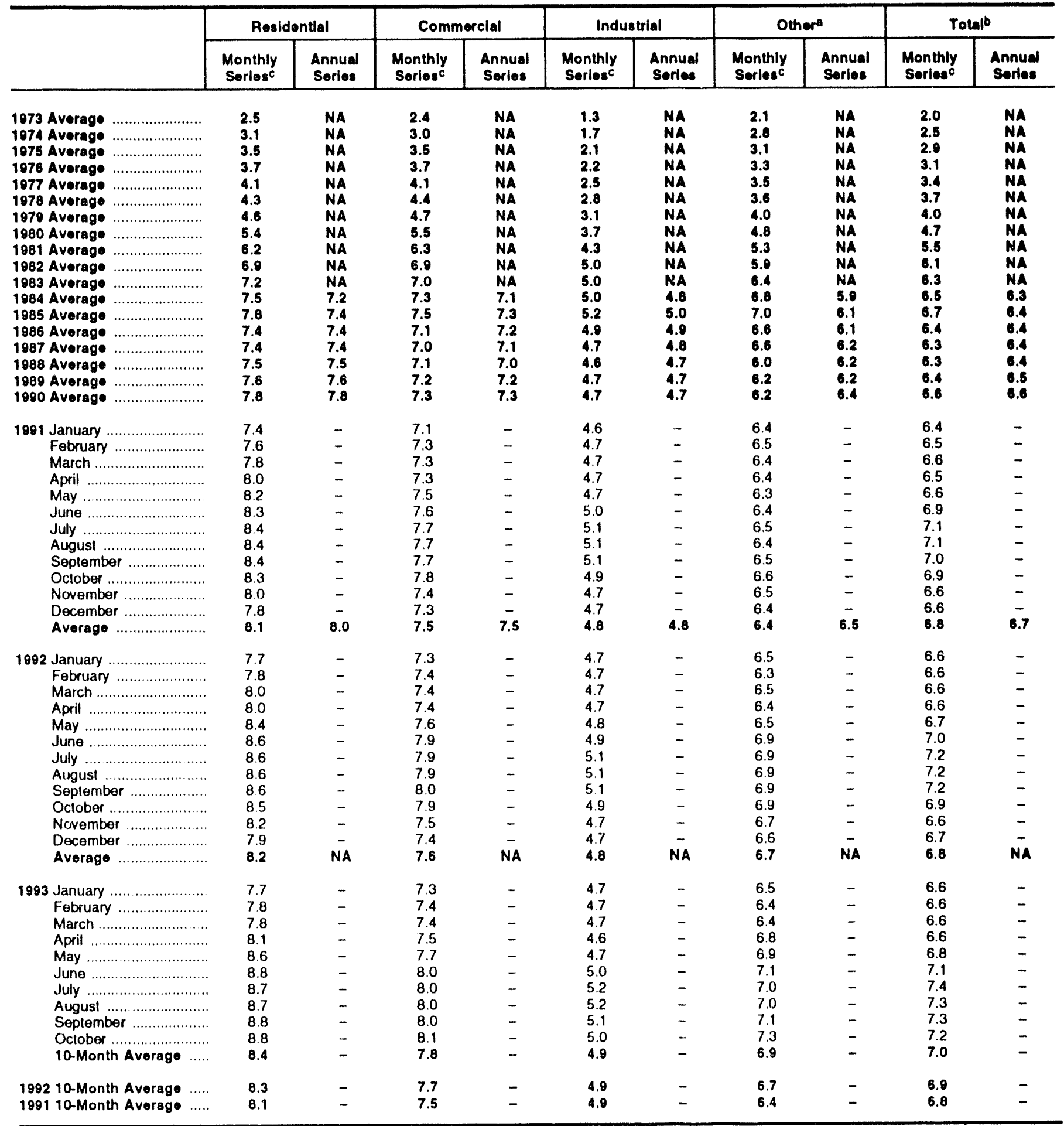

- Other is public street and highway lighting. other sales to public authorities, sales to railroads and railways, and interdepartmental sales.

b Average price for total sales to ultimale consumers.

c Annual values are the sum of the monthly revenue divided by the sum of the morithly sales. Data through 1979 cover privately owned electric utilities in Classes A and B. Dala for 1980-1985 cover selected privalely owned electric utilities in Class $A$ whose electric operating revenue was $\$ 100$ million or more during the previous year. See Nole 7 at end of section.

$\mathrm{NA}=\mathrm{Nol}$ available...$=\mathrm{Not}$ applicable.

Notes: - Prices are calculaled by dividing revenue by sales. Revenue may not correspond to sales for a particular month because of electric utility billing and accounting procedures. That lack of correspondence could result in uncharacteristic increases or decreases in the monthly prices. See Nole 7 at end of section. - Geographic coverage is the 50 Slates and the District of Columbia.

Sources: - Monthly Series: 1973-September 1977-Federal Power Commission, Form FPC-5, Monthly Statement of Electric Operating Revenue and Income." October 1877-February 1980-Federal Energy Regulatory Commission (FERC). Form FERC-5, Electric Operaling Revenue and Income." March 1980-December 1980-FERC, Form FERC-5, "Electric Uility Company Monthly Statement." 1981-Energy Information Administration (EIA), Electric Power Monthly, March 1992, Table 59. 1982 and 1981 monthly dato-EIA, Electric Power Monthly, March 1993. Table 59. 1983 forward (except 1991 monthly data)-ElA. Electric Powel Monthly, January 1994. Table 59. - Annual Series: ElA, Electric Power Monthly, January 1994, Table 59 


\begin{tabular}{|c|c|c|c|c|c|c|c|c|c|}
\hline & \multicolumn{2}{|c|}{ Coal } & \multicolumn{4}{|c|}{ Potroleum } & \multicolumn{2}{|c|}{$\operatorname{Gas}^{a}$} & \multirow{3}{*}{$\begin{array}{c}\begin{array}{c}\text { All Fosell } \\
\text { Fuets }\end{array} \\
\text { Cost } \\
\text { (cents per } \\
\text { million Btu) }\end{array}$} \\
\hline & \multirow[b]{2}{*}{$\begin{array}{l}\text { Quantly } \\
\text { (thousand } \\
\text { short tons; }\end{array}$} & \multirow[b]{2}{*}{$\begin{array}{c}\text { Cost } \\
\text { (cents per } \\
\text { mililon Btu) }\end{array}$} & \multicolumn{2}{|c|}{ Heavy Ollb } & \multicolumn{2}{|c|}{ Totalb,c } & \multirow[b]{2}{*}{$\begin{array}{l}\text { Quantity } \\
\text { (million } \\
\text { cuble foet) }\end{array}$} & \multirow[b]{2}{*}{$\begin{array}{c}\text { Cost } \\
\text { (cents per } \\
\text { million Btu) }\end{array}$} & \\
\hline & & & $\begin{array}{l}\text { Quantity } \\
\text { (thousand } \\
\text { barrels) }\end{array}$ & $\begin{array}{c}\text { Cost } \\
\text { (cents per } \\
\text { million Btu) }\end{array}$ & $\begin{array}{c}\text { Quantity } \\
\text { (thousand } \\
\text { barrels) }\end{array}$ & $\begin{array}{c}\text { Cost } \\
\text { (cents per } \\
\text { million Btu) }\end{array}$ & & & \\
\hline 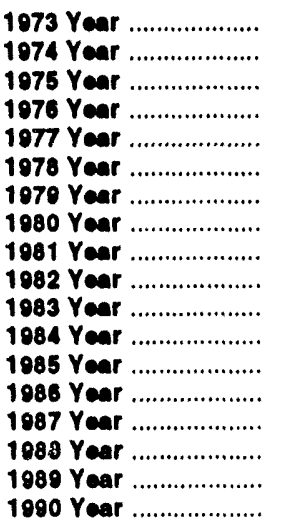 & $\begin{array}{l}374,842 \\
384,868 \\
431,527 \\
454,858 \\
490,415 \\
476,169 \\
556,558 \\
593,095 \\
579,374 \\
601,427 \\
592,728 \\
684,111 \\
666,743 \\
686,964 \\
721,298 \\
727,775 \\
753,217 \\
786,627\end{array}$ & $\begin{array}{r}40.5 \\
70.9 \\
81.4 \\
84.8 \\
94.7 \\
111.6 \\
122.4 \\
135.1 \\
153.2 \\
164.7 \\
165.6 \\
166.4 \\
164.8 \\
157.9 \\
150.6 \\
146.6 \\
144.5 \\
145.5\end{array}$ & $\begin{array}{l}512,650 \\
479,166 \\
457,582 \\
495,363 \\
563,685 \\
546,197 \\
479,705 \\
394,159 \\
327,477 \\
228,200 \\
211,705 \\
193,832 \\
156,410 \\
220,585 \\
187,300 \\
230,234 \\
237,668 \\
202,281\end{array}$ & \begin{tabular}{r|}
78.5 \\
180.0 \\
200.5 \\
195.2 \\
219.8 \\
212.5 \\
298.8 \\
426.7 \\
533.4 \\
483.2 \\
457.8 \\
481.2 \\
424.4 \\
240.1 \\
297.6 \\
240.5 \\
284.6 \\
331.9
\end{tabular} & $\begin{array}{l}535,859 \\
515,217 \\
510,352 \\
549,973 \\
635,556 \\
616,040 \\
515,695 \\
410,140 \\
345,544 \\
230,111 \\
210,652 \\
202,372 \\
164,047 \\
228,522 \\
194,578 \\
236,924 \\
246,422 \\
209,350\end{array}$ & $\begin{array}{r}80.0 \\
191.0 \\
202.3 \\
109.0 \\
224.0 \\
219.1 \\
307.2 \\
435.1 \\
542.5 \\
492.2 \\
462.8 \\
486.3 \\
431.7 \\
243.7 \\
301.1 \\
243.9 \\
289.3 \\
338.4\end{array}$ & $\begin{array}{l}3,382,677 \\
3,225,203 \\
3,034,808 \\
2,962,811 \\
3,106,403 \\
3,140,654 \\
3,368,876 \\
3,588,814 \\
3,573,558 \\
3,161,348 \\
2,732,248 \\
2,878,808 \\
2,808,921 \\
2,387,622 \\
2,605,191 \\
2,362,721 \\
2,472,506 \\
2,490,979\end{array}$ & $\begin{array}{r}33.8 \\
48.2 \\
75.2 \\
103.4 \\
129.1 \\
142.2 \\
174.9 \\
218.9 \\
280.5 \\
337.6 \\
347.4 \\
360.3 \\
344.4 \\
235.1 \\
224.0 \\
226.3 \\
235.5 \\
232.1\end{array}$ & $\begin{array}{r}47.6 \\
91.4 \\
104.4 \\
111.9 \\
129.7 \\
141.1 \\
163.9 \\
192.8 \\
225.6 \\
224.9 \\
220.6 \\
219.1 \\
209.4 \\
175.0 \\
170.6 \\
164.3 \\
167.5 \\
168.9\end{array}$ \\
\hline 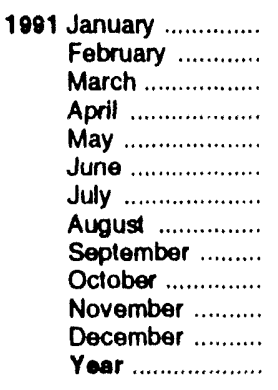 & $\begin{array}{r}63,732 \\
61,407 \\
63,825 \\
61,093 \\
63,259 \\
61,674 \\
65,105 \\
69,794 \\
65,273 \\
66,445 \\
62,779 \\
65,538 \\
769,923\end{array}$ & $\begin{array}{l}145.4 \\
147.0 \\
145.5 \\
147.3 \\
148.3 \\
147.4 \\
142.7 \\
143.1 \\
143.3 \\
143.6 \\
142.8 \\
140.0 \\
144.7\end{array}$ & $\begin{array}{r}11,466 \\
10,429 \\
11,269 \\
13,119 \\
14,711 \\
17,122 \\
17,169 \\
16,831 \\
15,590 \\
9,658 \\
11,289 \\
14,453 \\
163,106\end{array}$ & $\begin{array}{l}359.4 \\
265.8 \\
244.2 \\
234.2 \\
233.1 \\
220.2 \\
227.2 \\
226.7 \\
241.4 \\
238.6 \\
253.9 \\
252.2 \\
246.5\end{array}$ & $\begin{array}{r}12,315 \\
10,899 \\
11,672 \\
13,479 \\
15,256 \\
17,675 \\
17,703 \\
17,323 \\
16,063 \\
10,287 \\
11,835 \\
15,120 \\
169,625\end{array}$ & $\begin{array}{l}373.8 \\
276.0 \\
2513 \\
239.7 \\
240.1 \\
226.1 \\
233.1 \\
232.6 \\
247.7 \\
253.1 \\
264.8 \\
260.3 \\
254.8\end{array}$ & $\begin{array}{r}165,100 \\
1,37,568 \\
182,853 \\
203,893 \\
233,667 \\
244,386 \\
310,738 \\
306,418 \\
248,899 \\
251,458 \\
186,722 \\
159,115 \\
2,630,818\end{array}$ & $\begin{array}{l}267.1 \\
234.8 \\
220.0 \\
206.7 \\
198.2 \\
191.2 \\
184.6 \\
192.7 \\
215.4 \\
231.0 \\
240.7 \\
262.0 \\
215.3\end{array}$ & $\begin{array}{l}169.8 \\
161.3 \\
159.3 \\
160.3 \\
160.8 \\
159.5 \\
156.0 \\
156.6 \\
160.2 \\
160.9 \\
160.4 \\
159.5 \\
160.3\end{array}$ \\
\hline 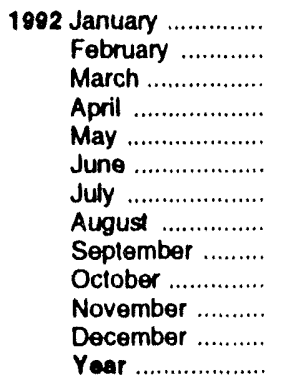 & $\begin{array}{l}64,678 \\
61,603 \\
63,857 \\
60,661 \\
63,407 \\
63,704 \\
64,400 \\
70,241 \\
66,503 \\
66,907 \\
64,005 \\
65,998 \\
775,963\end{array}$ & $\begin{array}{l}139.6 \\
142.1 \\
143.4 \\
142.7 \\
142.9 \\
141.9 \\
139.3 \\
139.6 \\
142.0 \\
141.3 \\
141.5 \\
138.6 \\
141.2\end{array}$ & $\begin{array}{r}12,039 \\
13,634 \\
12,779 \\
10,144 \\
10,079 \\
10,888 \\
12,706 \\
12,152 \\
8,883 \\
10,772 \\
11,161 \\
13,302 \\
138,537\end{array}$ & $\begin{array}{l}223.2 \\
209.8 \\
208.2 \\
217.8 \\
237.1 \\
251.4 \\
274.1 \\
274.1 \\
268.5 \\
290.5 \\
273.5 \\
252.1 \\
247.5\end{array}$ & $\begin{array}{r}12,539 \\
14,107 \\
13,186 \\
10,555 \\
10,498 \\
11,352 \\
13,217 \\
12,664 \\
9,319 \\
11,221 \\
11,636 \\
14,097 \\
144,390\end{array}$ & $\begin{array}{l}230.0 \\
216.1 \\
214.1 \\
225.7 \\
245.1 \\
260.0 \\
281.2 \\
281.2 \\
277.6 \\
297.7 \\
280.5 \\
261.9 \\
255.1\end{array}$ & $\begin{array}{r}159,815 \\
160,328 \\
198,040 \\
218,468 \\
227,857 \\
254,025 \\
315,543 \\
287,373 \\
259,771 \\
205,039 \\
182,505 \\
168,913 \\
2,637,678\end{array}$ & $\begin{array}{l}247.1 \\
201.7 \\
196.8 \\
202.6 \\
207.8 \\
213.6 \\
208.9 \\
237.3 \\
246.3 \\
297.9 \\
282.6 \\
276.5 \\
232.8\end{array}$ & $\begin{array}{l}155.2 \\
152.7 \\
153.7 \\
154.8 \\
156.4 \\
158.3 \\
159.2 \\
161.6 \\
163.0 \\
167.5 \\
164.5 \\
160.0 \\
159.0\end{array}$ \\
\hline 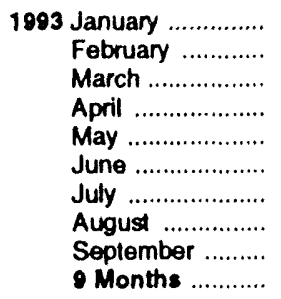 & $\begin{array}{r}65,219 \\
59,229 \\
63,894 \\
63,807 \\
62,599 \\
63,701 \\
59,859 \\
65,739 \\
65,358 \\
569,406\end{array}$ & $\begin{array}{l}138.5 \\
139.3 \\
137.6 \\
139.3 \\
139.9 \\
139.0 \\
138.0 \\
137.4 \\
138.5 \\
138.6\end{array}$ & $\begin{array}{r}8,437 \\
7,002 \\
8,548 \\
10,074 \\
10,392 \\
10,633 \\
15,419 \\
15,099 \\
15,324 \\
100,927\end{array}$ & $\begin{array}{l}248.7 \\
254.1 \\
248.6 \\
280.0 \\
261.2 \\
245.8 \\
237.3 \\
227.0 \\
226.1 \\
244.8\end{array}$ & $\begin{array}{r}9,026 \\
7,421 \\
9,022 \\
10,539 \\
10,825 \\
11,144 \\
16,040 \\
15,624 \\
15,766 \\
105,407\end{array}$ & $\begin{array}{l}259.1 \\
263.8 \\
258.8 \\
286.6 \\
268.1 \\
254.2 \\
243.3 \\
232.2 \\
231.0 \\
251.9\end{array}$ & $\begin{array}{r}159,318 \\
153,681 \\
186,075 \\
169,844 \\
163,925 \\
243,599 \\
312,270 \\
339,454 \\
249,708 \\
1,977,873\end{array}$ & $\begin{array}{l}267.3 \\
250.8 \\
256.6 \\
268.9 \\
286.3 \\
243.2 \\
241.0 \\
252.5 \\
263.6 \\
256.6\end{array}$ & $\begin{array}{l}156.2 \\
155.6 \\
156.5 \\
159.9 \\
161.6 \\
159.8 \\
164.4 \\
165.1 \\
162.9 \\
160.4\end{array}$ \\
\hline $\begin{array}{l}19829 \text { Months ........... } \\
19819 \text { Months .......... }\end{array}$ & $\begin{array}{l}579,054 \\
575,161\end{array}$ & $\begin{array}{l}141.5 \\
145.5\end{array}$ & $\begin{array}{l}103,302 \\
127,707\end{array}$ & $\begin{array}{l}239.5 \\
245.8\end{array}$ & $\begin{array}{l}107,436 \\
132,383\end{array}$ & $\begin{array}{l}246.9 \\
253.5\end{array}$ & $\begin{array}{l}2,081,221 \\
2,033,522\end{array}$ & $\begin{array}{l}218.5 \\
207.4\end{array}$ & $\begin{array}{l}157.4 \\
160.3\end{array}$ \\
\hline
\end{tabular}

Includes supplemental gaseous fuels.

b Heavy oil includes fuel oil nos. 4, 5, and 6, and topped crude oil. The weighted averages for petroleum and all tossil fuels include both heavy and light oil (No. 2 luel oil, kerosene, and jet fuel) prices. Data do not include pelroleum coke. c Data for 1973-1982 do not include small quantities of rerelined motor oil, bunker oil, and liquelied pelroleum gas

Notes: - See Note 8 at end of section. - Geographic coverage is the 50 Stales and the District of Colurnbia

Sources: See end of section. 
Figure 9.4 Natural Gas Prices

(Dollars per Thousand Cubic Feet)

Selected Prices, 1973-1992

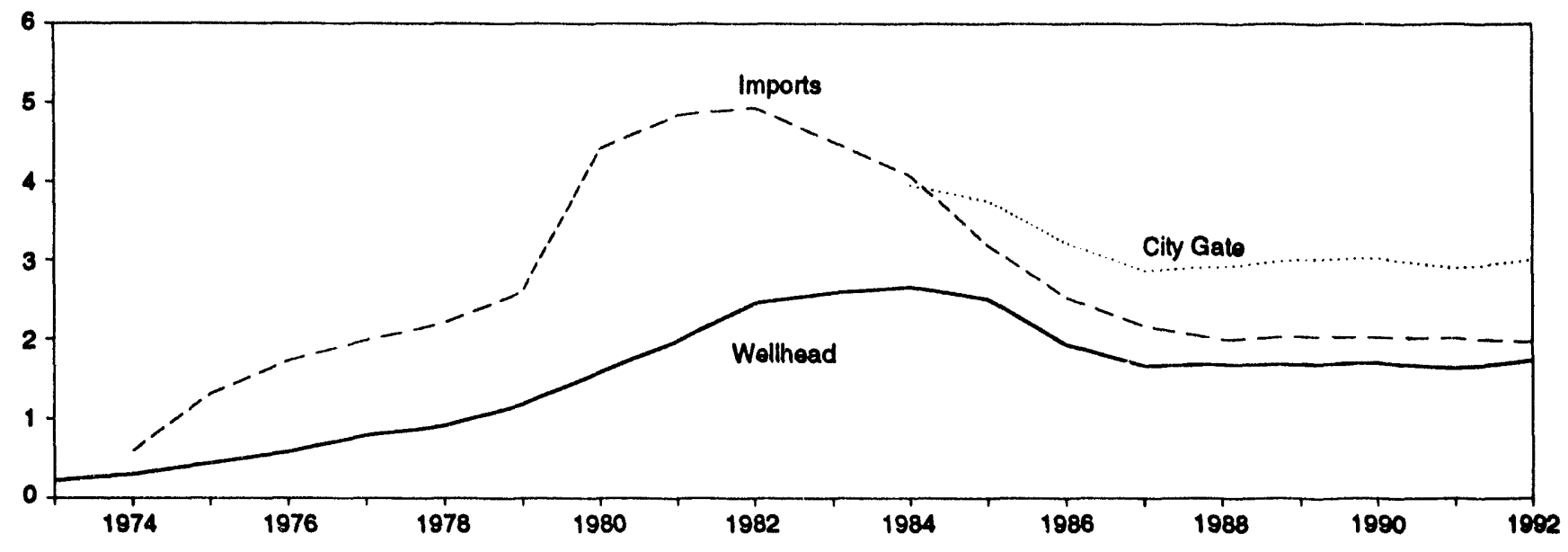

Delivered to Consumers, $1973-1992$

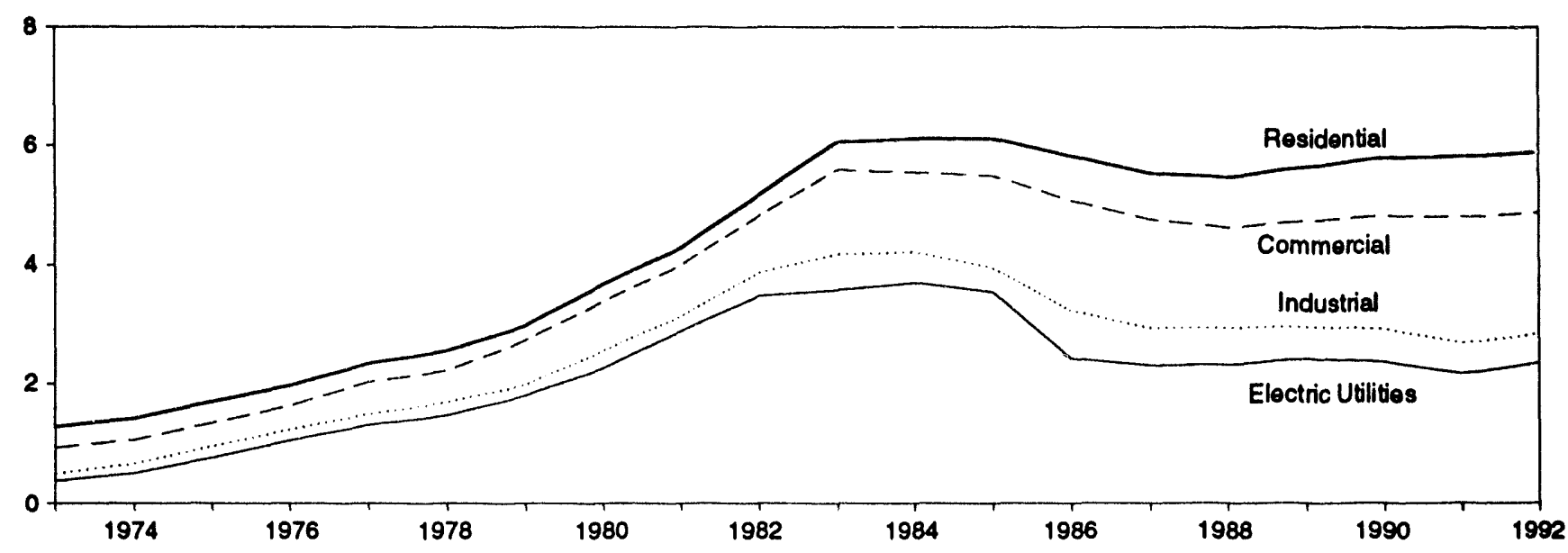

Delivered to Consumers, Monthly

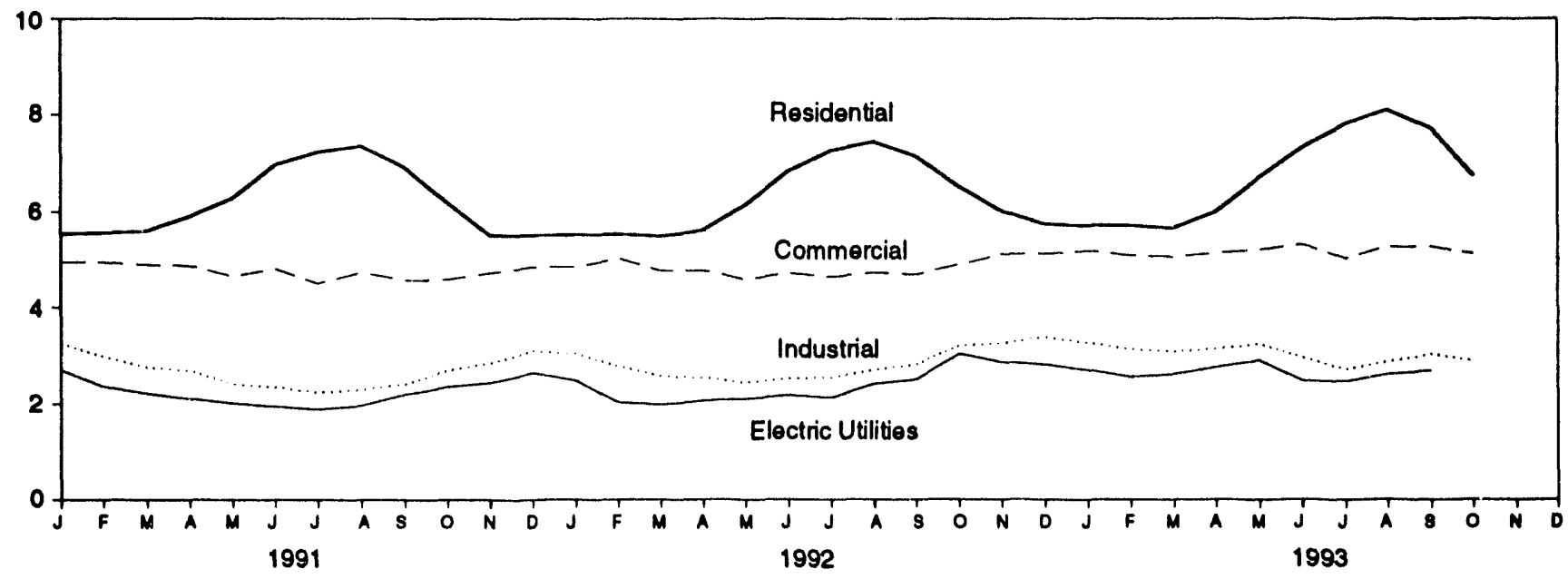

Note: Because vertical scales dffer, graphs should not be compared. Source: Table 9.11. 
Table 9.11 Natural Gas Prices

(Dollars per Thousand Cubic Feet)

\begin{tabular}{|c|c|c|c|c|c|c|c|c|}
\hline & \multirow[b]{2}{*}{ Wollhoad } & \multicolumn{2}{|c|}{$\begin{array}{l}\text { Major Interstate } \\
\text { Pipeline Companles }\end{array}$} & \multirow[b]{2}{*}{$\begin{array}{l}\text { City } \\
\text { Cate }\end{array}$} & \multicolumn{4}{|c|}{ Dollivered to Coneumeren,b } \\
\hline & & Imports & $\begin{array}{c}\text { Purchases from } \\
\text { Producers }\end{array}$ & & Reoldential & Commercial & Industrid & $\begin{array}{l}\text { Electrie } \\
\text { Utillites }\end{array}$ \\
\hline 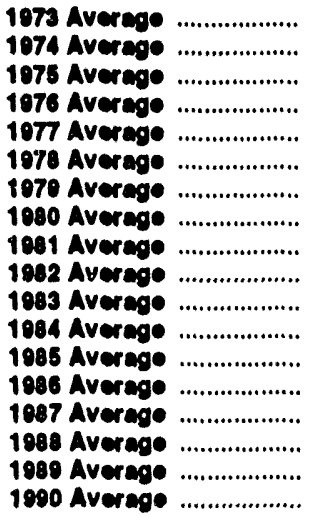 & $\begin{array}{l}0.22 \\
.30 \\
.44 \\
.58 \\
.79 \\
.01 \\
1.18 \\
1.59 \\
1.08 \\
2.46 \\
2.59 \\
2.66 \\
2.51 \\
1.94 \\
1.67 \\
1.60 \\
1.60 \\
1.71\end{array}$ & $\begin{array}{l}\text { NA } \\
.50 \\
1.31 \\
1.73 \\
1.09 \\
2.21 \\
2.60 \\
4.42 \\
4.84 \\
4.94 \\
4.51 \\
4.08 \\
3.10 \\
2.53 \\
2.17 \\
2.00 \\
2.04 \\
2.03\end{array}$ & $\begin{array}{l}\text { NA } \\
.27 \\
.37 \\
.48 \\
.70 \\
.83 \\
1.22 \\
1.63 \\
2.18 \\
2.72 \\
2.93 \\
2.91 \\
2.85 \\
2.39 \\
2.10 \\
2.13 \\
2.18 \\
2.10\end{array}$ & $\begin{array}{l}\text { NA } \\
\text { NA } \\
\text { NA } \\
\text { NA } \\
\text { NA } \\
\text { NA } \\
\text { NA } \\
N A \\
N A \\
N A \\
3.05 \\
3.75 \\
3.22 \\
2.87 \\
2.02 \\
3.01 \\
3.03\end{array}$ & $\begin{array}{l}1.29 \\
1.43 \\
1.71 \\
1.08 \\
2.35 \\
2.56 \\
2.08 \\
3.68 \\
4.29 \\
6.17 \\
6.06 \\
6.12 \\
6.12 \\
5.83 \\
5.54 \\
5.47 \\
5.84 \\
5.80\end{array}$ & $\begin{array}{l}0.94 \\
1.07 \\
1.35 \\
1.04 \\
2.04 \\
2.23 \\
2.73 \\
3.30 \\
4.00 \\
4.82 \\
5.59 \\
5.55 \\
5.50 \\
5.08 \\
4.77 \\
4.63 \\
4.74 \\
4.83\end{array}$ & $\begin{array}{r}0.50 \\
.07 \\
.08 \\
1.24 \\
1.50 \\
1.70 \\
1.00 \\
2.56 \\
3.14 \\
3.87 \\
4.18 \\
4.22 \\
3.95 \\
3.23 \\
2.04 \\
2.95 \\
2.96 \\
2.03\end{array}$ & $\begin{array}{r}0.30 \\
.81 \\
.77 \\
1.06 \\
1.32 \\
1.48 \\
1.81 \\
2.27 \\
2.00 \\
3.40 \\
3.80 \\
3.70 \\
3.58 \\
2.43 \\
2.32 \\
2.33 \\
2.43 \\
2.38\end{array}$ \\
\hline 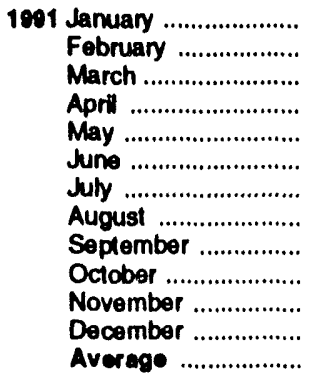 & $\begin{array}{l}1.96 \\
1.62 \\
1.49 \\
1.50 \\
1.48 \\
1.43 \\
1.34 \\
1.43 \\
1.59 \\
1.82 \\
1.89 \\
2.00 \\
1.64\end{array}$ & $\begin{array}{l}2.20 \\
2.10 \\
1.92 \\
2.03 \\
1.99 \\
2.03 \\
2.11 \\
1.71 \\
1.84 \\
2.00 \\
2.20 \\
2.09 \\
2.02\end{array}$ & $\begin{array}{l}2.19 \\
1.93 \\
2.02 \\
1.87 \\
1.96 \\
1.75 \\
1.79 \\
1.71 \\
1.76 \\
1.94 \\
2.02 \\
2.11 \\
1.92\end{array}$ & $\begin{array}{l}3.08 \\
2.94 \\
2.78 \\
2.74 \\
2.76 \\
2.86 \\
2.74 \\
2.78 \\
2.91 \\
2.92 \\
2.92 \\
3.05 \\
2.90\end{array}$ & $\begin{array}{l}5.54 \\
5.56 \\
5.60 \\
5.90 \\
6.28 \\
6.97 \\
7.23 \\
7.36 \\
6.92 \\
6.20 \\
5.51 \\
5.51 \\
5.82\end{array}$ & $\begin{array}{l}4.94 \\
4.94 \\
4.89 \\
4.87 \\
4.65 \\
4.80 \\
4.50 \\
4.73 \\
4.57 \\
4.58 \\
4.71 \\
4.84 \\
4.81\end{array}$ & $\begin{array}{l}3.25 \\
2.97 \\
2.75 \\
2.68 \\
2.40 \\
2.34 \\
2.23 \\
2.29 \\
2.40 \\
2.69 \\
2.84 \\
3.09 \\
2.69\end{array}$ & $\begin{array}{l}2.70 \\
2.35 \\
2.21 \\
2.10 \\
2.01 \\
1.94 \\
1.88 \\
1.96 \\
2.19 \\
2.35 \\
2.43 \\
2.64 \\
2.10\end{array}$ \\
\hline 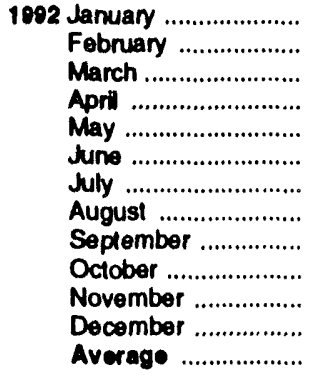 & $\begin{array}{l}1.74 \\
1.26 \\
1.35 \\
1.42 \\
1.51 \\
1.62 \\
1.55 \\
1.84 \\
1.92 \\
2.38 \\
2.13 \\
2.07 \\
1.74\end{array}$ & $\begin{array}{l}2.20 \\
1.98 \\
1.45 \\
2.01 \\
1.79 \\
2.03 \\
1.89 \\
1.85 \\
2.05 \\
2.13 \\
2.32 \\
1.92 \\
1.97\end{array}$ & $\begin{array}{l}2.10 \\
1.70 \\
1.90 \\
1.73 \\
1.99 \\
2.16 \\
1.86 \\
2.14 \\
2.13 \\
2.69 \\
2.37 \\
2.40 \\
2.10\end{array}$ & $\begin{array}{l}2.90 \\
2.70 \\
2.61 \\
2.74 \\
2.90 \\
3.00 \\
3.01 \\
3.18 \\
3.23 \\
3.50 \\
3.33 \\
3.17 \\
3.01\end{array}$ & $\begin{array}{l}5.53 \\
5.54 \\
5.50 \\
5.62 \\
6.15 \\
6.84 \\
7.27 \\
7.45 \\
7.15 \\
6.52 \\
6.02 \\
5.74 \\
5.89\end{array}$ & $\begin{array}{l}4.85 \\
5.03 \\
4.77 \\
4.77 \\
4.59 \\
4.72 \\
4.64 \\
4.73 \\
4.69 \\
4.90 \\
5.12 \\
5.11 \\
4.88\end{array}$ & $\begin{array}{l}3.04 \\
2.78 \\
2.58 \\
2.54 \\
2.44 \\
2.53 \\
2.54 \\
2.71 \\
2.82 \\
3.21 \\
3.26 \\
3.38 \\
2.84\end{array}$ & $\begin{array}{l}2.49 \\
2.03 \\
1.99 \\
2.07 \\
2.11 \\
2.18 \\
2.13 \\
2.42 \\
2.51 \\
3.04 \\
2.87 \\
2.81 \\
2.36\end{array}$ \\
\hline 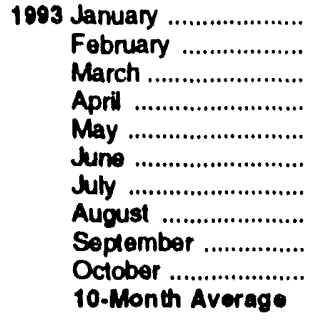 & $\begin{array}{r}1.96 \\
1.72 \\
1.89 \\
2.05 \\
2.30 \\
1.87 \\
1.91 \\
2.00 \\
2.11 \\
1.99 \\
1.98\end{array}$ & $\begin{array}{l}2.02 \\
1.91 \\
1.78 \\
2.15 \\
2.13 \\
1.95 \\
1.78 \\
2.02 \\
2.17 \\
\text { NA } \\
\text { NA }\end{array}$ & $\begin{array}{l}2.17 \\
1.94 \\
2.20 \\
2.34 \\
2.81 \\
2.03 \\
2.02 \\
2.35 \\
2.58 \\
\text { NA } \\
\text { NA }\end{array}$ & $\begin{array}{l}3.11 \\
2.94 \\
3.06 \\
3.24 \\
3.58 \\
3.44 \\
3.34 \\
3.35 \\
3.52 \\
3.15 \\
3.21\end{array}$ & $\begin{array}{l}5.71 \\
5.71 \\
5.66 \\
5.99 \\
6.72 \\
7.32 \\
7.83 \\
8.10 \\
7.74 \\
6.75 \\
6.16\end{array}$ & $\begin{array}{r}5.18 \\
5.08 \\
5.06 \\
5.13 \\
5.21 \\
5.31 \\
5.03 \\
5.26 \\
\text { 9 } 5.27 \\
5.12 \\
5.14\end{array}$ & $\begin{array}{l}3.26 \\
3.12 \\
3.08 \\
3.13 \\
3.24 \\
2.95 \\
2.71 \\
2.86 \\
3.03 \\
2.88 \\
3.04\end{array}$ & $\begin{array}{l}2.70 \\
2.55 \\
2.61 \\
2.75 \\
2.90 \\
2.47 \\
2.46 \\
2.60 \\
2.69 \\
\text { NA } \\
\text { NA }\end{array}$ \\
\hline $\begin{array}{l}1092 \text { 10-Month Average } \\
1001 \text { 10-Month Average }\end{array}$ & $\begin{array}{l}1.66 \\
1.57\end{array}$ & $\begin{array}{l}1.94 \\
1.90\end{array}$ & $\begin{array}{l}2.04 \\
1.89\end{array}$ & $\begin{array}{l}2.94 \\
2.88\end{array}$ & $\begin{array}{l}5.90 \\
5.92\end{array}$ & $\begin{array}{l}4.81 \\
4.82\end{array}$ & $\begin{array}{l}2.73 \\
2.63\end{array}$ & $\begin{array}{l}2.20 \\
2.13\end{array}$ \\
\hline
\end{tabular}

Inchudes supplemental gaseous fuels.

bee Note 9 at end of section.

c See Note 8 at end of section.

$R=$ Revised data. $N A=$ Not available. E=Estimate

Noles: - Prices shown on this page are intended to include all taxes. See Note 9 at end of section. - Geographic coverage is the 50 States and the District of Columbia. - Wellhead annual and year-to-date prices are simple averages of the monthly prices; all other annual and year-lo-date prices are volume-woighted averages of the monthly prices.

Sources: - 1973-1986: Wellhead-Energy Intormation Administration
(EIA), Natural Gas Annual 1991, Table $95 . \quad$ Major Interetate Plpelline Companlos, 1974-1977-Calculated from revenue and sales data reported to the Federal Power Commission (FPC), Form FPC-11. "Natural Gas Pipeline Company Monthly Statement." Major Interstato Plpeline Compenles, 1978-1083-EIA, Natural Gas Monthy, December 1984. Table 10. Major Interstato Pipoline Companies, 1984-1986-EIA, Natural Gas Monthy, December 1989. Table 4. City Gate, 1984-1986-ElA, Natural Gas Monthy, December 1989. Table 4. Delivered to Consumers, 1973-1986-ELA, Natural Gas Annual 1991, Table 98. - 1987 forward: ElA, Natural Gas Monthly, January 1994, Table 4. 


\section{Energy Prices Notes}

1. The average domestic first purchase price represents the average price at which all domestic crude oil is purchased. Prior to February 1976, the price represented an estimate of the average of posted prices; beginning with February 1976, the price represents an average of actual first purchase prices. The data series was previously called "Actual Domestic Wellhead Price."

2. F.O.B. literally means "Free on Board." It denotes a transaction whereby the seller makes the product available with an agreement on a given port at a given price; it is the responsibility of the buyer to arrange for the transportation and insurance.

3. The landed cost of imported crude oil from selected countries does not represent the total cost of all imported crude. Prior 10 March 1975, imported crude costs to U.S. company-owned refineries in the Caribbean were not included in the landed cost, and costs of crude oil from countries that export only small amounts to the United States were also excluded. Beginning in March 1975, however, coverage was expanded to include U.S. company-owned refineries in the Caribbean. Landed costs do not include supplemental fees.

4. Beginning with January 1981, refiner acquisition costs of crude oil are from dita collected on leorm EIA14, "Refiners' Monthly Cost Report." Those costs were previously published from data collected on Form IERA49, "Domestic Crude Oil lintillements Prograun Refiners Monthly Report." loorm IER A-49 was discontinued with the decontrol of crude oil on January 28, 1981. Crude oil purchases and costs are defined for Form EIA-14 in accordance with conventions used for Form ER $\Lambda-49$. Also, the respondents for the two forms are essentially the same. However, due to possible different interpretations of the filing requirements and a different method for handling prior period adjustments, care must be taken when comparing the data collected on the two forms.

The refiner acyuisition cost of crude oil is the average price paid by refiners for crude oil booked into their refineries in accordance with accounting procedures generally accepted and consistently and historically applied by the refiners concerned. Domestic crude oil is that oil produced in the United States or from the outer continental shelf as defined in 43 USC Section 1331. Imported crude oil is either that oil reported on Form ERA-51, "Transfer Pricing Report," or any crude oil that is not domestic oil. The composite cost is the weighted average of domestic and imported crude oil costs.

Crude oil costs and volumes reported on form ER $\Lambda-49$ excluded unfinished oils hut included the Strategic Petroleum Reserve (SPR). ('rude oil costs and volumes reported on Form liEA-Pll(1)-M-1, "Refiners' Monthly Cost Allocation Report," included unlinished oils but excluded SPR. Imported averages derived from form
ERA-49 exclude oil purchased for SPR, whereas the composite averages derived from Form ERA-49 include SPR. None of the prices derived from Form EIA-14 include either unfinished oils or SPR.

5. Several different series of motor gasoline prices are published in this section. U.S. City Average Retail Prices of Motor Gasoline are calculated monthly by the Bureau of Labor Statistics during the development of the Consumer Price Index (CPI). These prices include all Federal, State, and local taxes paid at the time of sale. For the period 1974-1977, prices were collected in 56 urban areas. For the period 1978 forward, prices were collected from a new sample of service stations in 85 urhan areas selected to represent all urban consumersabout 80 percent of the total U.S. population. The service stations are selected initially, and on a replacement basis, in such a way that they represent the purchasing habits of the CPI population. Service stations in the current sample include those providing all types of service (i.e., full-, mini-, and self-serve).

Refiner prices of finished motor gasoline for resale and to end users are determined by the Energy Information Adininistration (EIA) in a monthly survey of refiners and gas plant operators (Form EIA-782A). The prices do not include any Federal, State, or local taxes paid at the time of sale. Estimates of prices prior to January 1983 are based on Form HEA-P302-M-1/EIA-460, "Petroleum Industry Monthly Report for Product Prices," and also exclude all Federal, State, or local taxes paid at the time of sale. Sales for resale are those made to purchasers who are other-than-ultimate consumers. Sales to end users are sales made directly to the consumer of the product, including bulk consumers, such as agriculture, industry, and utilities, as well as residential and commercial consumers.

6. Starting in January 1983, Form EIA-782, "Monthly Petroleum Product Sales Report," replaced 10 previous surveys. Every attempt was made to continue the most important price series. However, prices published through December 1982 and those published since January 1983 do not necessarily form continuous data series due to changes in survey forms, definitions, instructions, populations, samples, processing systems, and statistical procedures. To provide historical data, continuous series were generated for annual data 1978-1982 and for monthly data 1981 and 1982 by estimating the prices that would have been published had Form EIA-782 survey and system been in operation at that time. This form of estimation was performed after detailed adjustment was made for product and sales type matching and for discontinuity due to other factors. An important difference between the previous and present prices is the distinction hetween wholesale and resale and between retail and end user. The resale category continues to include sales anong resellers. However, bulk sales to utility, industrial, and commercial accounts previously included in the wholesale category are now counted as made to end users. The end-user category continues to include retail sales through company owned and operated 
outlets but also includes the bulk utility, industrial, and commercial sales. Additional information may be found in Estimated Historic Time Series for the EIA-782, a feature article reprinted from the December 1983 [3] Petroleum Marketing Monthly, published by EIA.

7. National average electricity prices are shown in two data series. The "Annual Series" is based on data from more than 3,000 publicly and privately owned electric utilities that report on Form EIA-861, "Annual Electric Utility Report." The "Monthly Series" is based on data from over 400 utilities statistically chosen as a stratified sample of the utilities that report on Form EIA-861. The selected utilities report monthly on Form EIA-826, "Monthly Electric Utility Sales and Revenue Report with State Distributions," formerly the "Electric Utility Company Monthly Statement." Annual values shown for the monthly series are the sum of the monthly revenue divided by the sum of the monthly sales. Prior to January 1986, only privately owned utilities were included in the monthly survey and the sample was chosen by using cut-off, rather than stratification, techniques.

8. Data for 1973-1982 cover all electric generating plants at which the generator nameplate capacity of all steam-electric units combined totaled 25 megawatts or greater. From 1974-1982, peaking units were included in the data and counted towards the 25-megawatt-orgreater total. Data for $1983-1990$ cover all electric generating plants at which the generator nameplate capacity of all stean-electric units combined totaled 50 megawatts or greater. Data for 1991 forward cover all electric generating plants at which the generator nameplate capacity of all stean-clectric units and combined-cycle units together totaled 50 megawatts or greater.

9. Natural gas prices are intended to include all taxes. Instructions on the data collection forms specifically direct that all Federal, State, and local taxes, surcharges, and/or adjustments billed to consumers are to be included. However, sales and other taxes itcmized on consumers' bills are sometimes excluded by the reporting utilities.

Delivered-10-consumers prices for 1987 forward represent natural gas delivered and sold to residential, commercial, industrial, and electric utility consumers. They do not include the price of natural gas delivered to industrial and commercial consumers on behalf of third parties. Volumes of natural gas delivered on hehalf of third parties are included in the consumption data shown in Table 4.3. Additional intormation is available in the EIA Natural Gas Monthly, Appendix C.

\section{Sources for Table 9.1}

- Domestic First Purchase Price: 1973-1976-ll.S. Department of the Interior (I)()I), Bureau of Mines
(BOM), Minerals Yearbook, "Crude Petroleum and Petroleum Products" chapter. 1977-Federal Energy Administration (FEA), based on Form FEA-P124, "Domestic Crude Oil Purchaser's Monthly Report." 1978 forward-Energy Information Administration (EIA), Petroleum Marketing Monthly, January 1994, Table 1.

- F.O.B. and Landed Cost of Imports: October 1973September 1977-FEA, Form FEA-1-701-M-0, "Transfer Pricing Report." October-December 1977-EIA, Form FEA-F701-M-0, "Transfer Pricing Report." 1978 forward-EIA, Petroleum Marketing Monthly, January 1994, Table 1.

- Refiner Acquisition Cost: 1973-EIA estimates. The domestic price was derived by adding estimated transportation costs to the reported domestic first purchase price. The imported price was derived by adding an estimated ocean transport cost to the average "liree Alongside Ship" value published by the U.S. Bureau of the Census. 19741976-DOI, BOM, Minerals Yearbook, "Crude Petroleum and Petroleum Products" chapter. 1977-January-September, FEA, based on Form IEA-P110-M-1, "Refiners" Monthly Cost Allocation Report." Ocloher-December, EIA, hased on Form FEA-PII0-M-1, "Refiners' Monthly Cost Allocation Report." 1978 forward-EIA, Petroleum Marketing Monthly, January 1904, Table 1.

\section{Sources for Table 9.10}

- 1973-1979: Annual data for quantily are simple sums of unrounded monthly values and for cost are averages of monthly values, weighted by quantities of Btu, from the following: 1973-May 1977-Federal Power Commission, Form FP('-423, "Monthly Report on Cost and Quality of Fuels for Electric Utility Plants." June 1977. December 1977-Federal Energy Regulatory Commission, Form FIERC-423, "Monthly Report on Cost and Quality of Fucls for Filectric Uhility Plants." 1978 and 1979-Energy Information Administration (EIA), Form IFIRC.423, "Monthly Report on Cost and Quality of Fuels for Blectric Utility Plants."

- 1980: EIA, Electric Poner Monthly, April 1991, Table 3.3 .

- 1981: Ela, Electric Power Monthly, April 1992, Table 33 ,

- 1982 and 1991 monthly data: FIA, Electric Power Monthly, April 1993, Table 33.

- 1983 forward: (except 1991 monthly data): EIA, Electric Power Monthly, January 1094, Table 33. 


\section{Section 10. International Energy}

Crude Oil Production. World crude oil production during October 1993 was 60 million barrels per day, up 0.4 million barrels per day from the level in the previous month.

Organization of Petroleum Exporting Countries (OPEC) production during October 1993 averaged 26 million barrels per day, down 0.1 million barrels per day from the level during the previous month. Production by the Arab members of OPEC in October 1993 averaged 16 million barrels per day, down 0.1 million barrels per day from the September 1993 level. During October 1993, production increased in Kuwait by 25 thousand barrels per day and in Libya by 20 thousand barrels per day. Production decreased in Saudi Arabia by 125 thousand barrels per day. Production remained unchanged in Algeria, Iraq, Qatar, and the United Arab Emirates. Among the non-Arab members of OPEC, production during October 1993 increased in Iran by 50 thousand barrels per day and in Venezuela by 20 thousand barrels per day. Production decreased in Nigeria by 40 thousand barrels per day and in Indonesia by 30 thousand barrels per day.

Among the non-OPEC nations, production during October 1993 increased in the United Kingdom by 115 thousand barrels per day and in the United States by 105 thousand barrels per day. Production decreased in Mexico by 50 thousand barrels per day and in the former U.S.S.R. by 15 thousand barrels per day. Production remained unchanged in Canada and China.

Petroleum Consumption. In August 1993, consumption in all Organization for Economic Cooperation and
Development (OECD) countries was 37.9 million barrels per day, 1 percent ${ }^{9}$ higher than the August 1992 rate. The consumption rate was higher than it was 1 year ago in Canada $(+9$ percent), Italy and the United Kingdom (each +5 percent), Germany ( +3 percent), and the United States $(+1$ percent). Consumption was lower in Japan and France (each -5 percent).

Petroleum Stocks. For all OECD countries, petroleum stocks at the end of August 1993 totaled 3.7 billion barrels, 2 percent higher than the ending stock level in August 1992. Stock levels were higher than the levels 1 year ago in Japan $(+5$ percent), Germany $(+4$ percent), the United States $(+3$ percent), Italy $(+1$ percent), and slightly higher in the United Kingdom. Stocks were lower in France $(-6$ percent) and Canada $(-1$ percent) compared with levels 1 year earlier.

Nuclear Electricity Generation. Based on Nucleonics Week information for October 1993, reporting countries with nuclear capacity generated 151 gross terawatthours of nuclear-generated electricity, slightly more than in October 1992.

A new nuclear unit becaune operable during October 1993. Japan's Hamaoka-4, a 1,137-gross megawatt boiling-water reactor, became commercially operable on September 3, 1993.

As of October 31, 1993, there were 359 operable nuclear generating units in the reporting countries. The units had a collective gross generating capacity of 305.8 gigawatts. The 109 U.S. units accounted for 105.3 gross gigawatts, 34.4 percent of the total reported nuclear generating capacity.

\footnotetext{
- Percentage changes are based on unrounded dala.

${ }^{10}$ One terawatthour equals 1 billion kilowalthours.

"One megawalt equals 1 thousand kllowatts.

${ }^{12}$ One gigawatt equals 1 nillilon kllowatts.
} 
Table 10.1a World Crude Oil Production: Algeria Through Venezuela (Thousand Barrels per Day)

\begin{tabular}{|c|c|c|c|c|c|c|c|c|c|c|c|c|}
\hline & Algerla & Iraq & Kuwalta & Ubya & Qutar & $\begin{array}{c}\text { Saudl } \\
\text { Arablaa }\end{array}$ & $\begin{array}{c}\text { United } \\
\text { Arab } \\
\text { Emirates }\end{array}$ & $\underset{\text { ApEb }}{\text { OPE }}$ & Indonesle & Iran & Nigerle & Venozuele \\
\hline 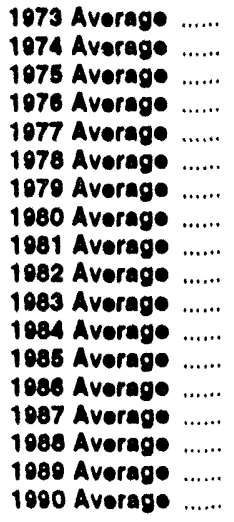 & $\begin{array}{r}1,097 \\
1,009 \\
903 \\
1,075 \\
1,152 \\
1,231 \\
1,224 \\
1,106 \\
1,002 \\
987 \\
968 \\
1,014 \\
1,037 \\
945 \\
1,048 \\
1,040 \\
1,095 \\
1,175\end{array}$ & $\begin{array}{l}2,018 \\
1,071 \\
2,262 \\
2,415 \\
2,348 \\
2,563 \\
3,477 \\
2,514 \\
1,000 \\
1,012 \\
1,005 \\
1,209 \\
1,433 \\
1,690 \\
2,070 \\
2,685 \\
2,897 \\
2,040\end{array}$ & $\begin{array}{r}3,020 \\
2,546 \\
2,084 \\
2,145 \\
1,969 \\
2,131 \\
2,500 \\
1,656 \\
1,125 \\
823 \\
1,064 \\
1,157 \\
1,023 \\
1,410 \\
1,585 \\
1,492 \\
1,783 \\
1,175\end{array}$ & $\begin{array}{r}2,175 \\
1,521 \\
1,480 \\
1,033 \\
2,063 \\
1,983 \\
2,092 \\
1,787 \\
1,140 \\
1,150 \\
1,105 \\
1,087 \\
1,059 \\
1,034 \\
972 \\
1,175 \\
1,150 \\
1,375\end{array}$ & $\begin{array}{l}570 \\
518 \\
438 \\
497 \\
445 \\
487 \\
508 \\
472 \\
405 \\
330 \\
205 \\
304 \\
301 \\
308 \\
293 \\
348 \\
380 \\
406\end{array}$ & $\begin{array}{l}7,598 \\
8,480 \\
7,075 \\
8,577 \\
9,245 \\
8,301 \\
9,532 \\
9,900 \\
9,815 \\
6,483 \\
5,086 \\
4,663 \\
3,388 \\
4,870 \\
4,265 \\
5,086 \\
5,064 \\
6,410\end{array}$ & $\begin{array}{l}1,533 \\
1,670 \\
1,664 \\
1,036 \\
1,990 \\
1,631 \\
1,631 \\
1,709 \\
1,474 \\
1,250 \\
1,140 \\
1,146 \\
1,193 \\
1,330 \\
1,541 \\
1,565 \\
1,660 \\
2,117\end{array}$ & $\begin{array}{r}18,009 \\
17,721 \\
15,985 \\
18,570 \\
19,221 \\
18,525 \\
21,163 \\
10,144 \\
18,081 \\
12,035 \\
10,672 \\
10,670 \\
9,434 \\
11,598 \\
11,783 \\
13,389 \\
14,229 \\
14,698\end{array}$ & $\begin{array}{l}1,330 \\
1,375 \\
1,307 \\
1,504 \\
1,686 \\
1,635 \\
1,501 \\
1,577 \\
1,605 \\
1,330 \\
1,343 \\
1,412 \\
1,328 \\
1,300 \\
1,343 \\
1,342 \\
1,400 \\
1,462\end{array}$ & $\begin{array}{l}8,861 \\
8,022 \\
5,350 \\
5,883 \\
5,863 \\
5,242 \\
3,188 \\
1,662 \\
1,380 \\
2,214 \\
2,440 \\
2,174 \\
2,250 \\
2,036 \\
2,208 \\
2,240 \\
2,810 \\
3,088\end{array}$ & $\begin{array}{l}2,054 \\
2,258 \\
1,783 \\
2,067 \\
2,085 \\
1,607 \\
2,302 \\
2,056 \\
1,433 \\
1,205 \\
1,241 \\
1,380 \\
1,495 \\
1,467 \\
1,341 \\
1,450 \\
1,716 \\
1,810\end{array}$ & $\begin{array}{l}3,368 \\
2,976 \\
2,346 \\
2,204 \\
2,238 \\
2,165 \\
2,358 \\
2,168 \\
2,102 \\
1,808 \\
1,801 \\
1,708 \\
1,677 \\
1,787 \\
1,752 \\
1,008 \\
1,007 \\
2,137\end{array}$ \\
\hline $\begin{array}{l}1991 \text { January ....... } \\
\text { February ...... } \\
\text { March ........... } \\
\text { Aprit ............ } \\
\text { May ............. } \\
\text { June ............ } \\
\text { July ............. } \\
\text { August ........ } \\
\text { Seplember ... } \\
\text { October ....... } \\
\text { November .... } \\
\text { December .... } \\
\text { Average ...... }\end{array}$ & $\begin{array}{l}1,230 \\
1,230 \\
1,230 \\
1,230 \\
1,230 \\
1,230 \\
1,230 \\
1,230 \\
1,230 \\
1,230 \\
1,230 \\
1,230 \\
1,230\end{array}$ & 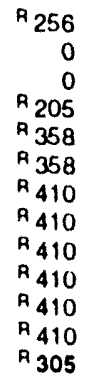 & $\begin{array}{r}R_{51} \\
0 \\
0 \\
0 \\
0 \\
P_{76} \\
P_{167} \\
A_{198} \\
P_{304} \\
P_{436} \\
A_{507} \\
P_{527} \\
P_{190}\end{array}$ & $\begin{array}{l}1,500 \\
1,500 \\
1,450 \\
1,450 \\
1,450 \\
1,450 \\
1,450 \\
1,450 \\
1,500 \\
1,500 \\
1,550 \\
1,550 \\
1,483\end{array}$ & 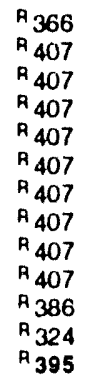 & 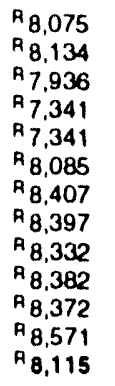 & $\begin{array}{l}{ }^{A} 2,448 \\
A_{2,472} \\
A_{2,496} \\
A_{2,496} \\
A_{2,301} \\
A_{2,301} \\
A_{2,301} \\
A_{2,301} \\
A_{2,292} \\
A_{2,379} \\
{ }_{2} 2,443 \\
{ }_{2} 2,409 \\
{ }_{2}, 386\end{array}$ & $\begin{array}{l}A_{13,925} \\
R_{13,743} \\
A_{13,519} \\
A_{13,129} \\
A_{13,088} \\
A_{13,908} \\
A_{14,373} \\
A_{14,393} \\
A_{14,475} \\
A_{14,744} \\
A_{14,898} \\
P_{15,020} \\
P_{14,104}\end{array}$ & 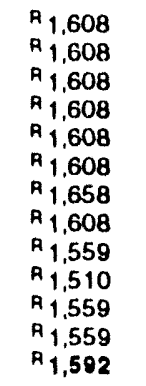 & 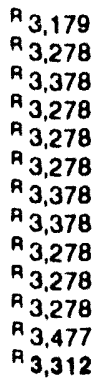 & $\begin{array}{r}1,906 \\
1,908 \\
1,906 \\
1,906 \\
1,906 \\
1,858 \\
1,858 \\
1,906 \\
1,906 \\
1,809 \\
1,906 \\
1,930 \\
1,892\end{array}$ & $\begin{array}{l}2,396 \\
2,396 \\
2,396 \\
2,346 \\
2,346 \\
2,346 \\
2,346 \\
2,346 \\
2,346 \\
2,396 \\
2,396 \\
2,446 \\
2,375\end{array}$ \\
\hline 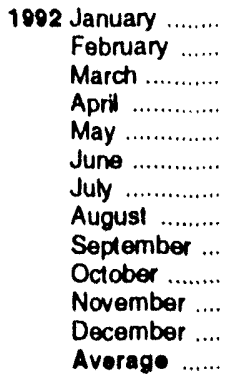 & $\begin{array}{l}1,230 \\
1,230 \\
1,230 \\
1,230 \\
1,210 \\
1,210 \\
1,210 \\
1,210 \\
1,210 \\
1,210 \\
1,210 \\
1,210 \\
1,217\end{array}$ & $\begin{array}{l}450 \\
450 \\
450 \\
450 \\
450 \\
450 \\
450 \\
450 \\
450 \\
450 \\
450 \\
450 \\
450\end{array}$ & $\begin{array}{r}565 \\
630 \\
735 \\
863 \\
915 \\
1,015 \\
1,080 \\
1,130 \\
1,200 \\
1,280 \\
1,375 \\
1,550 \\
1,029\end{array}$ & $\begin{array}{l}1,550 \\
1,550 \\
1,450 \\
1,500 \\
1,450 \\
1,450 \\
1,450 \\
1,425 \\
1,475 \\
1,500 \\
1,500 \\
1,500 \\
1,483\end{array}$ & $\begin{array}{l}350 \\
325 \\
375 \\
375 \\
375 \\
375 \\
400 \\
425 \\
425 \\
440 \\
440 \\
440 \\
396\end{array}$ & $\begin{array}{l}8,790 \\
8,640 \\
8,260 \\
8,213 \\
8,265 \\
8,315 \\
8,350 \\
8,400 \\
8,450 \\
8,505 \\
8,500 \\
8,575 \\
8,438\end{array}$ & $\begin{array}{l}2,435 \\
2,425 \\
2,300 \\
2,300 \\
2,300 \\
2,275 \\
2,300 \\
2,330 \\
2,320 \\
2,310 \\
2,305 \\
2,305 \\
2,325\end{array}$ & $\begin{array}{l}15,370 \\
15,250 \\
14,800 \\
14,930 \\
14,965 \\
15,090 \\
15,240 \\
15,370 \\
15,530 \\
15,695 \\
15,780 \\
16,030 \\
15,338\end{array}$ & $\begin{array}{l}1,580 \\
1,605 \\
1,630 \\
1,605 \\
1,530 \\
1,560 \\
1,550 \\
1,540 \\
1,550 \\
1,550 \\
1,550 \\
1,550 \\
1,566\end{array}$ & $\begin{array}{l}3,500 \\
3,500 \\
3,350 \\
3,250 \\
3,250 \\
3,250 \\
3,300 \\
3,450 \\
3,450 \\
3,650 \\
3,650 \\
3,550 \\
3,429\end{array}$ & $\begin{array}{l}1,975 \\
1,925 \\
1,900 \\
1,925 \\
1,925 \\
1,925 \\
1,975 \\
2,000 \\
2,025 \\
2,050 \\
2,050 \\
2,100 \\
1,982\end{array}$ & $\begin{array}{l}2,390 \\
2,340 \\
2,190 \\
2,190 \\
2,290 \\
2,290 \\
2,290 \\
2,340 \\
2,390 \\
2,440 \\
2,440 \\
2,415 \\
2,334\end{array}$ \\
\hline $\begin{array}{l}1993 \text { January ........ } \\
\text { February ...... } \\
\text { March ........... } \\
\text { April ............ } \\
\text { May ............. } \\
\text { June ............ } \\
\text { July ............. } \\
\text { Augusi ........ } \\
\text { Seplember ... } \\
\text { October ........ } \\
\text { 10-Mo. Avg. }\end{array}$ & $\begin{array}{l}1,210 \\
1,210 \\
1,200 \\
1,200 \\
1,200 \\
1,200 \\
1,180 \\
1,180 \\
1,180 \\
1,180 \\
1,194\end{array}$ & $\begin{array}{r}500 \\
500 \\
500 \\
500 \\
500 \\
500 \\
500 \\
500 \\
R 530 \\
530 \\
506\end{array}$ & $\begin{array}{l}1,675 \\
1,865 \\
1,650 \\
1,645 \\
1,713 \\
1,775 \\
1,940 \\
2,045 \\
2,020 \\
2,045 \\
1,837\end{array}$ & $\begin{array}{l}1,480 \\
1,425 \\
1,350 \\
1,350 \\
1,350 \\
1,350 \\
1,350 \\
1,370 \\
1,370 \\
1,390 \\
1,378\end{array}$ & $\begin{array}{l}450 \\
430 \\
400 \\
400 \\
420 \\
400 \\
410 \\
410 \\
410 \\
410 \\
414\end{array}$ & $\begin{array}{l}8,500 \\
8,440 \\
8,300 \\
8,000 \\
8,000 \\
8,150 \\
8,240 \\
8,345 \\
8,270 \\
8,145 \\
8,238\end{array}$ & $\begin{array}{l}2,295 \\
2,305 \\
2,270 \\
2,270 \\
2,230 \\
2,230 \\
2,210 \\
2,210 \\
2,220 \\
2,220 \\
2,245\end{array}$ & $\begin{array}{r}16,110 \\
16,175 \\
15,670 \\
15,365 \\
15,413 \\
15,605 \\
15,830 \\
16,060 \\
16,000 \\
15,920 \\
15,813\end{array}$ & $\begin{array}{l}1,550 \\
1,530 \\
1,500 \\
1,480 \\
1,510 \\
1,510 \\
1,510 \\
1,510 \\
1,510 \\
1,480 \\
1,500\end{array}$ & $\begin{array}{l}3,650 \\
3,750 \\
3,700 \\
3,500 \\
3,650 \\
3,650 \\
3,800 \\
3,500 \\
3,650 \\
3,700 \\
3,655\end{array}$ & $\begin{array}{l}2,125 \\
2,105 \\
2,075 \\
2,025 \\
2,025 \\
1,995 \\
1,975 \\
2,025 \\
2,045 \\
2,005 \\
2,040\end{array}$ & $\begin{array}{l}2,410 \\
2,390 \\
2,340 \\
2,340 \\
2,340 \\
2,340 \\
2,390 \\
2,390 \\
2,380 \\
2,400 \\
2,372\end{array}$ \\
\hline $\begin{array}{l}1092 \text { 10-Mo. Avg. } \\
1001 \text { 10-Mo. Avg. }\end{array}$ & $\begin{array}{l}1,218 \\
1,230\end{array}$ & $\begin{array}{l}450 \\
284\end{array}$ & $\begin{array}{l}942 \\
124\end{array}$ & $\begin{array}{l}1,480 \\
1,470\end{array}$ & $\begin{array}{l}387 \\
403\end{array}$ & $\begin{array}{l}8,416 \\
8,043\end{array}$ & $\begin{array}{l}2,329 \\
2,378\end{array}$ & $\begin{array}{l}15,224 \\
13,932\end{array}$ & $\begin{array}{l}1,570 \\
1,598\end{array}$ & $\begin{array}{l}3,395 \\
3,299\end{array}$ & $\begin{array}{l}1,963 \\
1,886\end{array}$ & $\begin{array}{l}2,315 \\
2,366\end{array}$ \\
\hline
\end{tabular}

- Includes about one-half of the production in the Kuwait-Saudi Arabia Neutral Zone Irom 1973 through July 1990 and in June 1991. Kuwaili Neutral Zone output was discontinued following Iraq's invasion of Kuwait on August 2 , 1990, but was resumed in June 1991. In October 1993, Neutral Zone production by both Kuwait and Saudi Arabia lotaled about 390 thousand barrels per day.

$b$ The Arab members of the Organization of Petroleum Exporting Countries (OPEC) are Algeria, Iraq, Kuwain, Libya, Qatar, Saudi Arabia, and the United Arab Emirates. Production in the Neutral Zone between Kuwait and Saudi
Arabia is included in "Arab OPEC."

$R=$ Revised dala.

Noles: - Crude oil includes lease condensate but excludes nalural gas plant liquids. - U.S. geographic coverage is the 50 States and the District of Columbia. - Monthly data are otten preliminary ligures and may nol average to the annual tolals because of rounding or because updates to the preliminary monthly data are nol available.

Sources: See end ol section.

Revisions reflect data published in the EIA International Energy Annual 1992. 
Table 10.1b World Crude Oil Production: Total OPEC, Canada Through Former U.S.S.R., and World

(Thousand Barrels per Day)

\begin{tabular}{|c|c|c|c|c|c|c|c|c|c|c|}
\hline & $\begin{array}{l}\text { Total } \\
\text { OPECa }\end{array}$ & $\begin{array}{l}\text { Perslan } \\
\text { Gulf } \\
\text { Nationsb }\end{array}$ & Canada & Mexlco & $\begin{array}{l}\text { Unitod } \\
\text { Kingdom }\end{array}$ & $\begin{array}{l}\text { United } \\
\text { States }\end{array}$ & Chine & $\begin{array}{l}\text { Former } \\
\text { U.8.8.A. }\end{array}$ & Othero & World \\
\hline 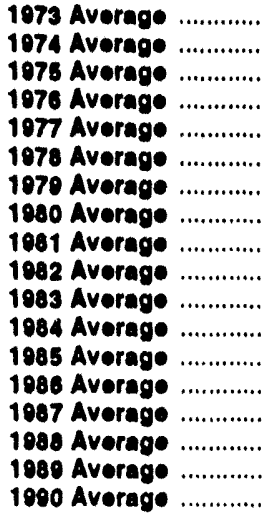 & $\begin{array}{l}30,779 \\
30,562 \\
28,904 \\
30,549 \\
31,115 \\
29,873 \\
30,784 \\
26,781 \\
22,032 \\
18,034 \\
17,854 \\
17,509 \\
16,353 \\
18,441 \\
18,672 \\
20,483 \\
22,270 \\
23,465\end{array}$ & $\begin{array}{r}20,688 \\
21,282 \\
16,934 \\
21,514 \\
21,725 \\
20,606 \\
21,068 \\
17,961 \\
15,245 \\
12,156 \\
11,081 \\
10,784 \\
0,630 \\
11,608 \\
12,103 \\
13,457 \\
14,837 \\
15,278\end{array}$ & $\begin{array}{l}1,798 \\
1,551 \\
1,430 \\
1,314 \\
1,321 \\
1,316 \\
1,500 \\
1,435 \\
1,285 \\
1,271 \\
1,356 \\
1,438 \\
1,471 \\
1,474 \\
1,535 \\
1,616 \\
1,560 \\
1,553\end{array}$ & $\begin{array}{r}465 \\
571 \\
705 \\
831 \\
981 \\
1,200 \\
1,461 \\
1,936 \\
2,313 \\
2,748 \\
2,680 \\
2,780 \\
2,745 \\
2,435 \\
2,548 \\
2,512 \\
2,520 \\
2,553\end{array}$ & $\begin{array}{r}2 \\
2 \\
12 \\
245 \\
768 \\
1,082 \\
1,568 \\
1,622 \\
1,811 \\
2,065 \\
2,201 \\
2,480 \\
2,530 \\
2,530 \\
2,406 \\
2,232 \\
1,802 \\
1,820\end{array}$ & $\begin{array}{l}9,208 \\
8,774 \\
8,375 \\
8,132 \\
8,245 \\
8,707 \\
8,552 \\
8,507 \\
8,572 \\
8,640 \\
8,688 \\
8,870 \\
8,971 \\
8,680 \\
8,349 \\
8,140 \\
7,613 \\
7,355\end{array}$ & $\begin{array}{l}1,000 \\
1,316 \\
1,400 \\
1,670 \\
1,874 \\
2,082 \\
2,122 \\
2,114 \\
2,012 \\
2,045 \\
2,120 \\
2,290 \\
2,508 \\
2,620 \\
2,690 \\
2,730 \\
2,757 \\
2,774\end{array}$ & $\begin{array}{r}8,324 \\
8,912 \\
9,523 \\
10,060 \\
10,603 \\
11,105 \\
11,384 \\
11,706 \\
11,850 \\
11,912 \\
11,072 \\
11,861 \\
11,585 \\
11,895 \\
11,985 \\
11,978 \\
11,625 \\
10,880\end{array}$ & $\begin{array}{r}4,013 \\
4,030 \\
4,300 \\
4,543 \\
4,709 \\
4,084 \\
5,303 \\
5,408 \\
5,601 \\
5,857 \\
6,485 \\
7,155 \\
7,821 \\
8,143 \\
8,416 \\
8,071 \\
9,617 \\
10,070\end{array}$ & 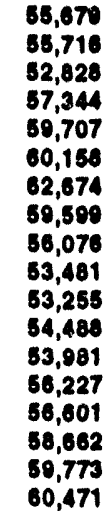 \\
\hline 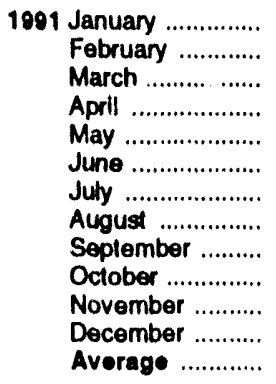 & $\begin{array}{l}A_{23,327} \\
A_{23,245} \\
A_{23,095} \\
A_{22,555} \\
A_{22,513} \\
A_{23,285} \\
A_{23,890} \\
A_{23,918} \\
A_{23,852} \\
A_{24,035} \\
A_{24,335} \\
R_{24,730} \\
A_{23,560}\end{array}$ & $\begin{array}{l}A_{14,413} \\
A_{14,330} \\
A_{14,258} \\
A_{13,766} \\
A_{13,726} \\
A_{14,541} \\
A_{15,106} \\
A_{15,127} \\
A_{15,061} \\
A_{15,329} \\
A_{15,434} \\
A_{15,755} \\
\text { P }_{14,741}\end{array}$ & $\begin{array}{l}1,561 \\
1,621 \\
1,546 \\
1,445 \\
1,505 \\
1,525 \\
1,535 \\
1,581 \\
1,551 \\
1,505 \\
1,621 \\
1,586 \\
1,548\end{array}$ & $\begin{array}{l}A_{2,664} \\
A_{2,678} \\
A_{2,673} \\
A_{2,659} \\
A_{2,699} \\
A_{2,724} \\
A_{2,694} \\
A_{2,664} \\
A_{2,679} \\
A_{2,684} \\
A_{2,664} \\
A_{2,679} \\
A_{2,680}\end{array}$ & $\begin{array}{l}1,675 \\
1,904 \\
2,068 \\
1,526 \\
1,396 \\
1,525 \\
1,805 \\
1,827 \\
1,896 \\
1,990 \\
1,975 \\
1,979 \\
1,797\end{array}$ & $\begin{array}{l}7,500 \\
7,637 \\
7,546 \\
7,509 \\
7,409 \\
7,320 \\
7,347 \\
7,316 \\
7,368 \\
7,437 \\
7,328 \\
7,299 \\
7,417\end{array}$ & $\begin{array}{l}A_{2,822} \\
A_{2,832} \\
A_{2,827} \\
A_{2,832} \\
A_{2,832} \\
A_{2,842} \\
A_{2,842} \\
A_{2,842} \\
A_{2,837} \\
A_{2,837} \\
A_{2,842} \\
A_{2,837} \\
A_{2,835}\end{array}$ & $\begin{array}{r}10,663 \\
9,943 \\
10,367 \\
10,310 \\
10,222 \\
9,808 \\
9,808 \\
9,420 \\
9,886 \\
9,492 \\
9,378 \\
9,347 \\
9,887\end{array}$ & 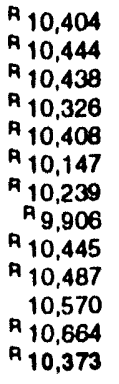 & $\begin{array}{l}A_{60,614} \\
A_{60,304} \\
A_{60,559} \\
A_{59,161} \\
A_{58,984} \\
A_{59,176} \\
A_{60,169} \\
A_{59,473} \\
A_{60,511} \\
A_{60,467} \\
A_{60,712} \\
A_{61,120} \\
A_{60,105}\end{array}$ \\
\hline 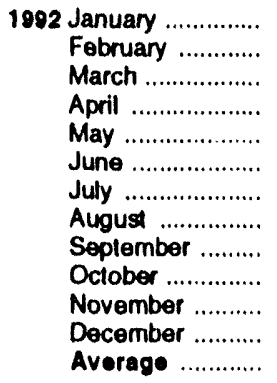 & $\begin{array}{l}25,100 \\
24,880 \\
24,170 \\
24,205 \\
24,265 \\
24,420 \\
24,660 \\
25,005 \\
25,245 \\
25,685 \\
25,770 \\
25,945 \\
24,947\end{array}$ & $\begin{array}{l}16,130 \\
16,010 \\
15,510 \\
15,487 \\
15,592 \\
15,716 \\
15,916 \\
16,220 \\
16,330 \\
16,670 \\
16,755 \\
16,905 \\
16,104\end{array}$ & $\begin{array}{l}1,585 \\
1,560 \\
1,620 \\
1,535 \\
1,510 \\
1,560 \\
1,630 \\
1,675 \\
1,620 \\
1,665 \\
1,640 \\
1,575 \\
1,598\end{array}$ & $\begin{array}{l}2,675 \\
2,665 \\
2,680 \\
2,680 \\
2,660 \\
2,680 \\
2,660 \\
2,685 \\
2,685 \\
2,655 \\
2,640 \\
2,655 \\
2,668\end{array}$ & $\begin{array}{l}1,920 \\
1,905 \\
1,755 \\
1,835 \\
1,700 \\
1,545 \\
1,780 \\
1,825 \\
1,830 \\
1,930 \\
1,945 \\
1,935 \\
1,825\end{array}$ & $\begin{array}{l}7,361 \\
7,389 \\
7,348 \\
7,293 \\
7,169 \\
7,167 \\
7,131 \\
6,922 \\
7,030 \\
7,126 \\
7.024 \\
7,103 \\
7,171\end{array}$ & $\begin{array}{l}2,830 \\
2,865 \\
2,835 \\
2,855 \\
2,835 \\
2,830 \\
2,825 \\
2,815 \\
2,860 \\
2,875 \\
2,845 \\
2,785 \\
2,838\end{array}$ & $\begin{array}{l}9,115 \\
8,650 \\
8,760 \\
9,025 \\
8,455 \\
8,440 \\
8,365 \\
8,130 \\
7,980 \\
7,965 \\
7,910 \\
7,870 \\
8,388\end{array}$ & $\begin{array}{l}10,821 \\
10,670 \\
10,744 \\
10,838 \\
10,566 \\
10,758 \\
10,818 \\
10,802 \\
10,873 \\
11,017 \\
10,847 \\
11,074 \\
10,820\end{array}$ & $\begin{array}{r}61,407 \\
60,584 \\
59,912 \\
\text { P } 60,265 \\
59,160 \\
59,400 \\
59,869 \\
59,858 \\
60,123 \\
60,918 \\
60,621 \\
60,942 \\
60,255\end{array}$ \\
\hline 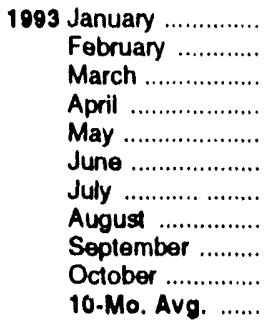 & $\begin{array}{r}26,145 \\
26,250 \\
25,585 \\
25,010 \\
25,238 \\
25,400 \\
25,795 \\
25,775 \\
25,875 \\
25,795 \\
25,684\end{array}$ & $\begin{array}{r}17,105 \\
17,325 \\
16,855 \\
16,350 \\
16,548 \\
16,740 \\
17,135 \\
17,045 \\
17,135 \\
17,085 \\
16,930\end{array}$ & $\begin{array}{l}1,570 \\
1,610 \\
1,635 \\
1,605 \\
1,660 \\
1,725 \\
1,710 \\
1.770 \\
A 1,755 \\
1,755 \\
1,680\end{array}$ & $\begin{array}{r}2,605 \\
2,610 \\
2,635 \\
2,674 \\
2,673 \\
2,675 \\
2,650 \\
2,650 \\
2,700 \\
2,650 \\
2,652\end{array}$ & $\begin{array}{l}A_{1} 1,815 \\
A_{1,925} \\
1,710 \\
1,695 \\
1,745 \\
1,675 \\
1,930 \\
1,940 \\
1,945 \\
2,060 \\
1,844\end{array}$ & $\begin{array}{l}E_{7,008} \\
E_{6,957} \\
E_{6,976} \\
E_{6,897} \\
E_{6,833} \\
E_{6,756} \\
E_{6,654} \\
E_{6,732} \\
E_{6,711} \\
E_{6,816} \\
E_{6,833}\end{array}$ & $\begin{array}{l}2,885 \\
2,875 \\
2,885 \\
2,900 \\
2,925 \\
2,960 \\
2,930 \\
2,855 \\
2,860 \\
2,860 \\
2,894\end{array}$ & $\begin{array}{r}7,800 \\
7,785 \\
7,685 \\
7,665 \\
7,495 \\
7,400 \\
7,120 \\
7,025 \\
\text { म } 6,915 \\
6,900 \\
7,376\end{array}$ & $\begin{array}{r}10,736 \\
10,877 \\
11,044 \\
A_{11,009} \\
A_{11,048} \\
A_{10,731} \\
A_{11,145} \\
A_{11,026} \\
A_{11,008} \\
11,301 \\
10,095\end{array}$ & $\begin{array}{r}A_{60,564} \\
A_{60,889} \\
60,155 \\
R_{59,455} \\
A_{59,617} \\
A_{59,322} \\
A_{59,934} \\
A_{59,773} \\
A_{59,769} \\
60,137 \\
50,957\end{array}$ \\
\hline $\begin{array}{l}1002 \text { 10-Mo. Avg. ...... } \\
1091 \text { 10-Mo. Avg. ...... }\end{array}$ & $\begin{array}{l}24,764 \\
23,375\end{array}$ & $\begin{array}{l}15,959 \\
14,569\end{array}$ & $\begin{array}{l}1,596 \\
1,537\end{array}$ & $\begin{array}{l}2,672 \\
2,681\end{array}$ & $\begin{array}{l}1,802 \\
1,761\end{array}$ & $\begin{array}{l}7,182 \\
7,437\end{array}$ & $\begin{array}{l}2,842 \\
2,834\end{array}$ & $\begin{array}{l}8,488 \\
9,992\end{array}$ & $\begin{array}{l}10,791 \\
10,323\end{array}$ & $\begin{array}{l}60,149 \\
50,941\end{array}$ \\
\hline
\end{tabular}

- "Total OPEL" consists of Algeria, Gabon, Indonesia, Iran, Iraq, Kuwait Libya, Nigeria, Qalar, Saudi Arabia, the United Arab Emirates, and Venezuela. Production from the Neutral Zone between Kuwail and Saudi Arabla is included in "Tolal OPEC."

b The Persian Gulf Nations are Bahrain, Iran, Iraq, Kuwait, Qatar, Saud Arabla, and the Unlied Arab Emirates. Production from the Neutral Zone between Kuwait and Saudi Arabia is included in "Persian Gull Nalions."

c "Other" is a calculated total derived from the difterence between "World" and the sum of production in "Total OPEC." Canada, Mexico, the United
Kingdom, the United Stales, China, and the former U.S.S.R

$R=$ Revised dala. $E=$ Estimale.

Noles: - Crude oil includes lease condensale but excludes natural gas plant liquids. - U.S. geographic coverage is the 50 States and the District of Columbia. - Monthly data are otten preliminary figures and may not average to the annual totals because of rounding or because updates to the preliminary monthly data are not available.

Sources: See end of section. 
Figure 10.1 Crude Oll Production

(Million Barrels per Day)

World Production, 1973-1992

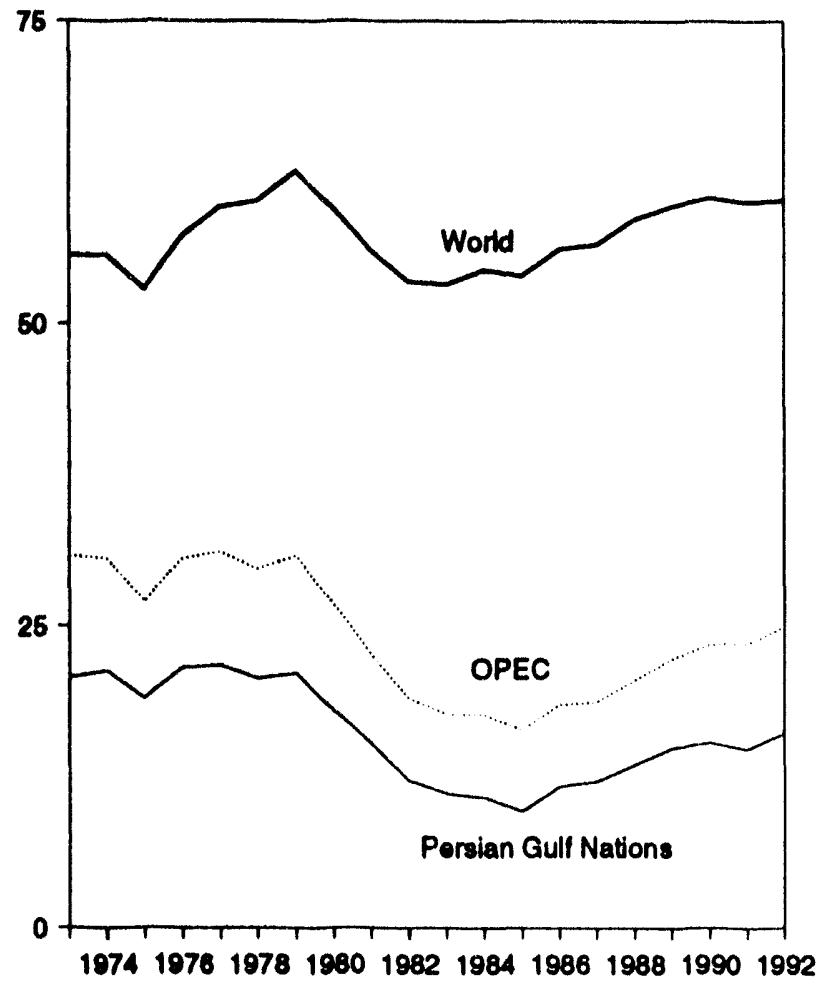

Leading Producers, 1973-1992

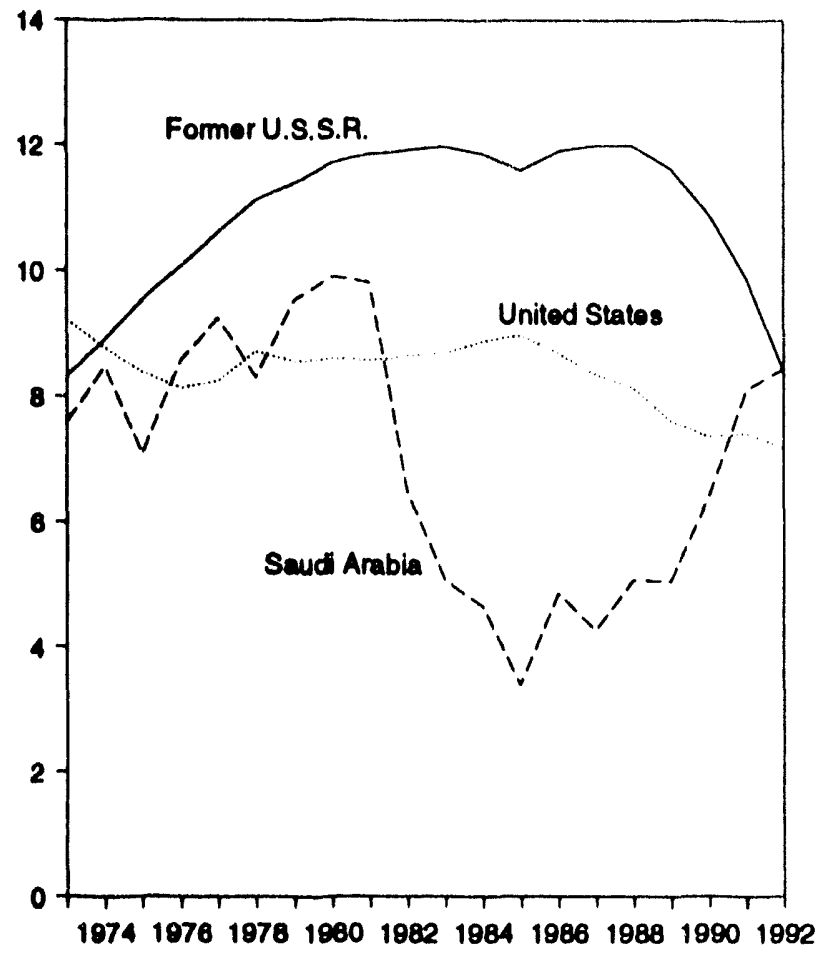

World Production, Monthly

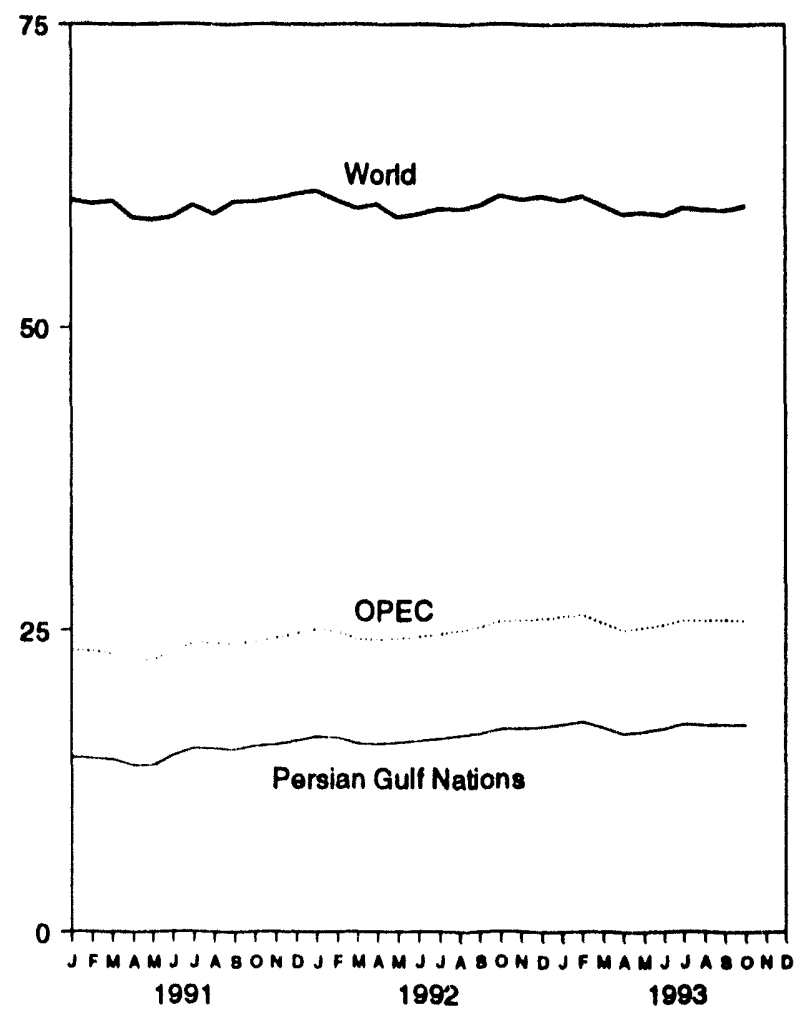

Leading Producers, Monthly

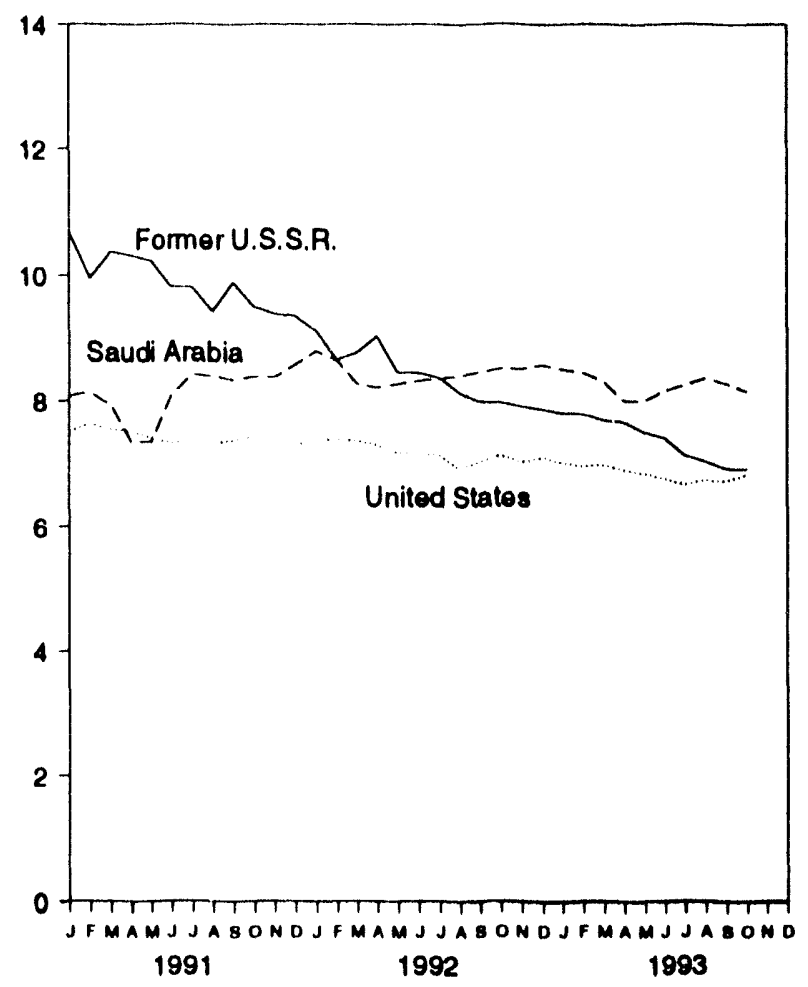

Note: OPEC it the Organization of Petroteum Exporting Countrtes.

8ources: Trbose $10.1 \mathrm{a}$ and 10.16 . 
Figure 10.2 Crude Oll Production by Selected Country

(Million Barrels per Day)

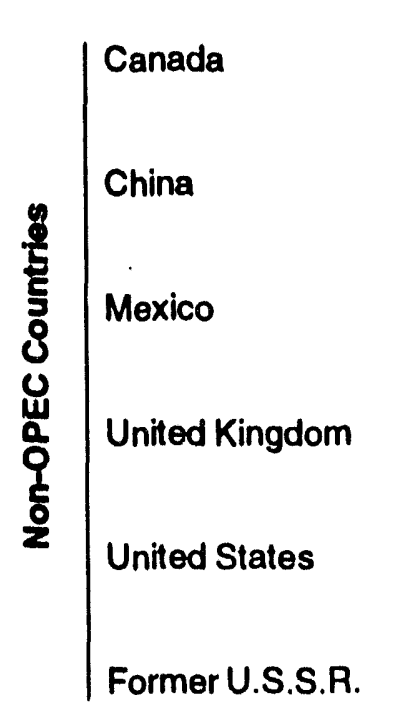

Indonesia

Indonesia
Iran

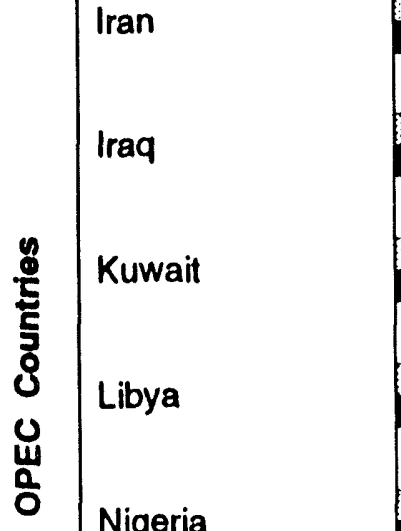

Natar
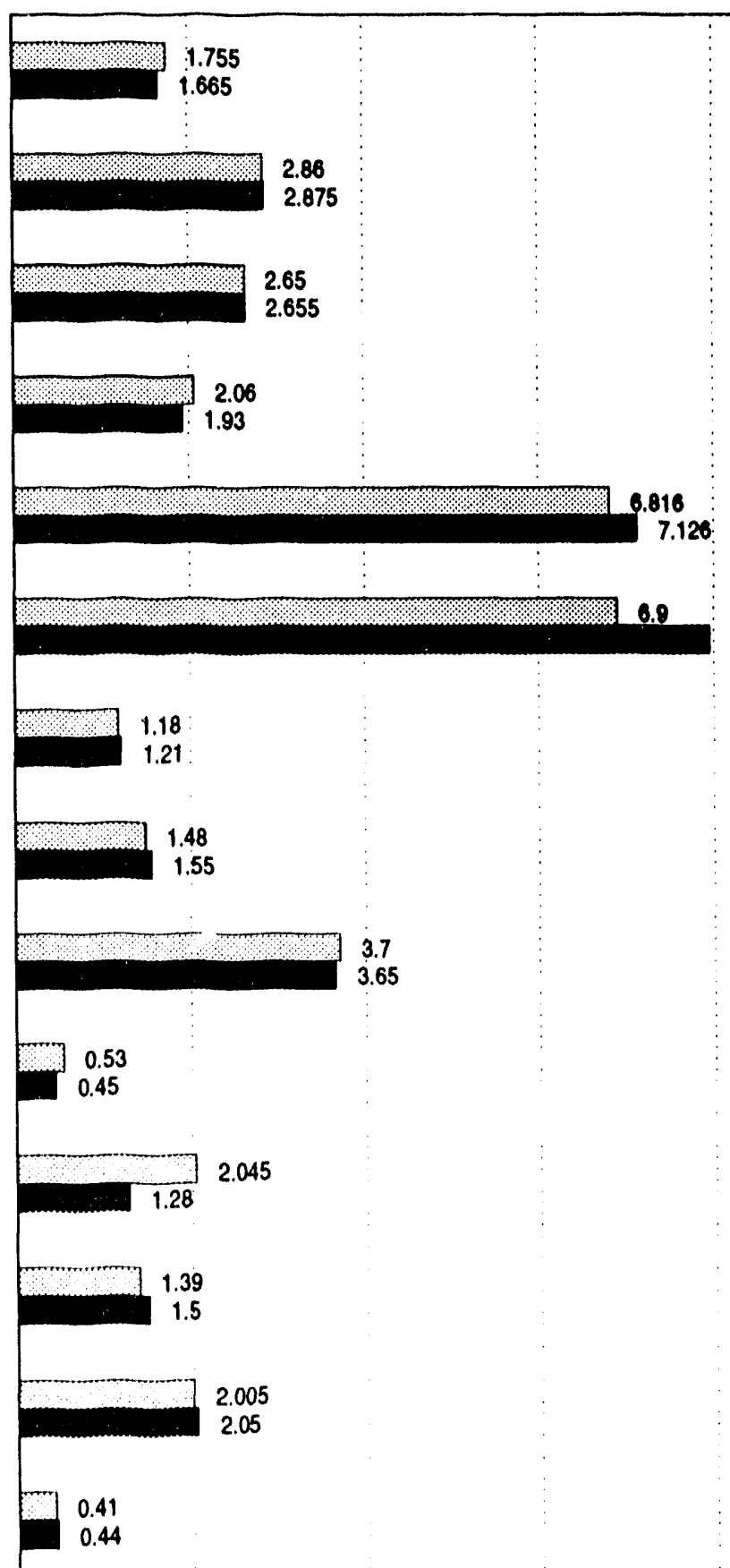

Saudi Arabia

United Arab

Emirates

Venezuela

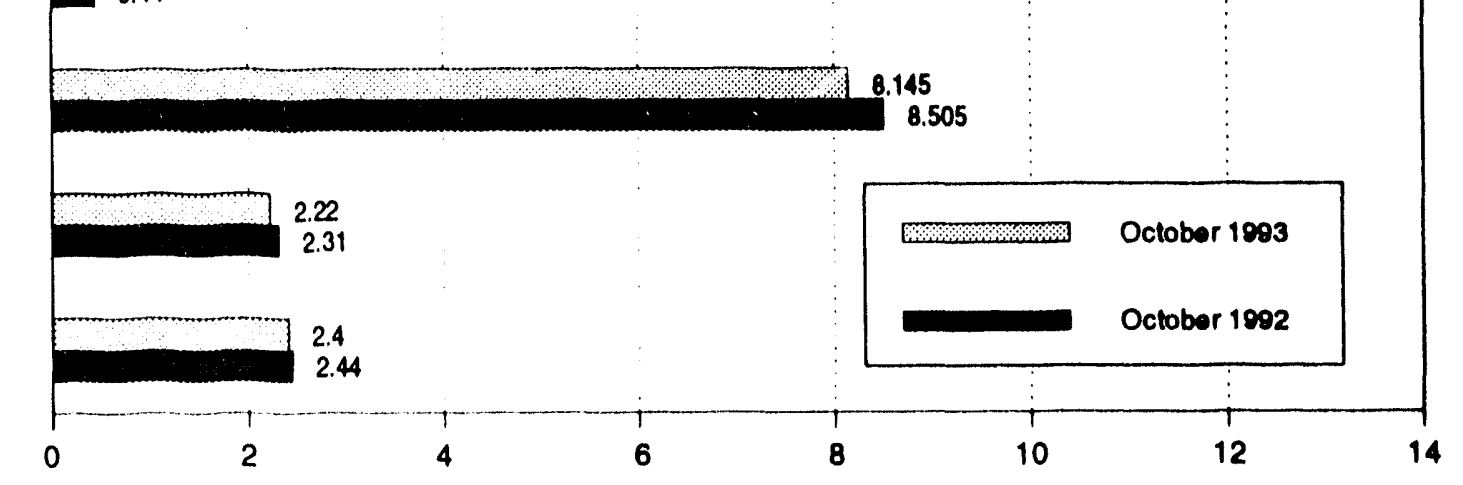

Note: OPEC ts the Organization of Petroleum Exponing Countries.

Sources: Tables 10.1a and 10.1b. 
Fiqure 10.3 Petroleum Consumption in OECD Countries

(Million Barrels per Day)

OECD Consurnption, 1973-1992

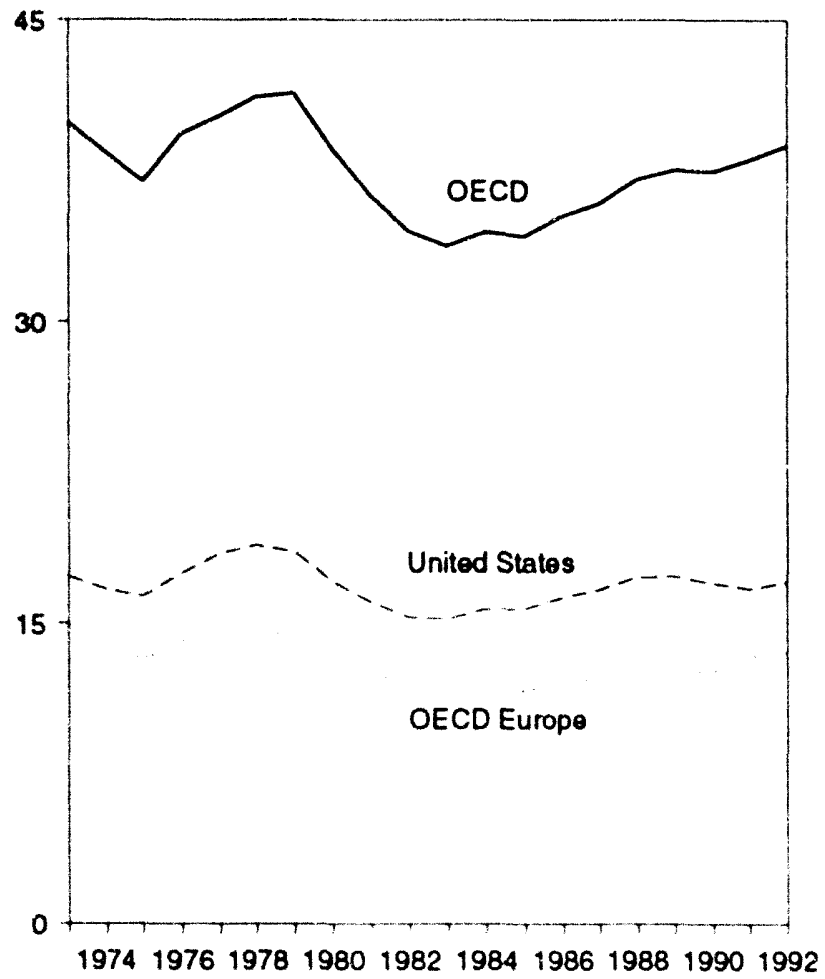

OECD Consumption

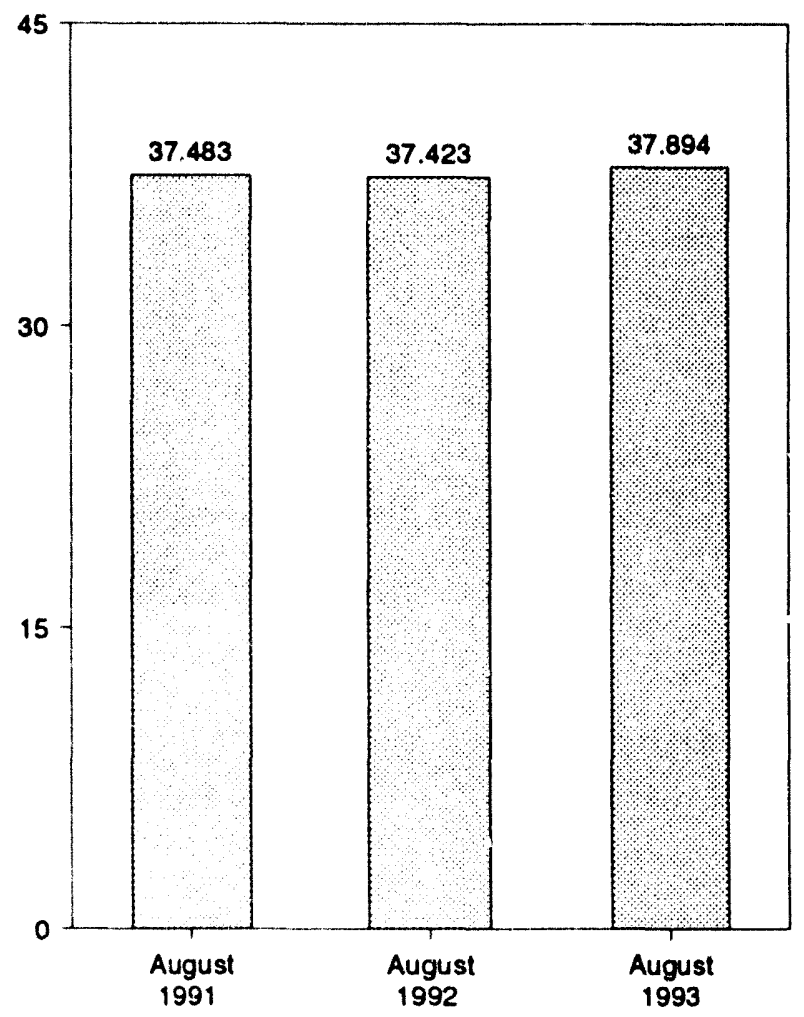

Consumption by Selected OECD Country

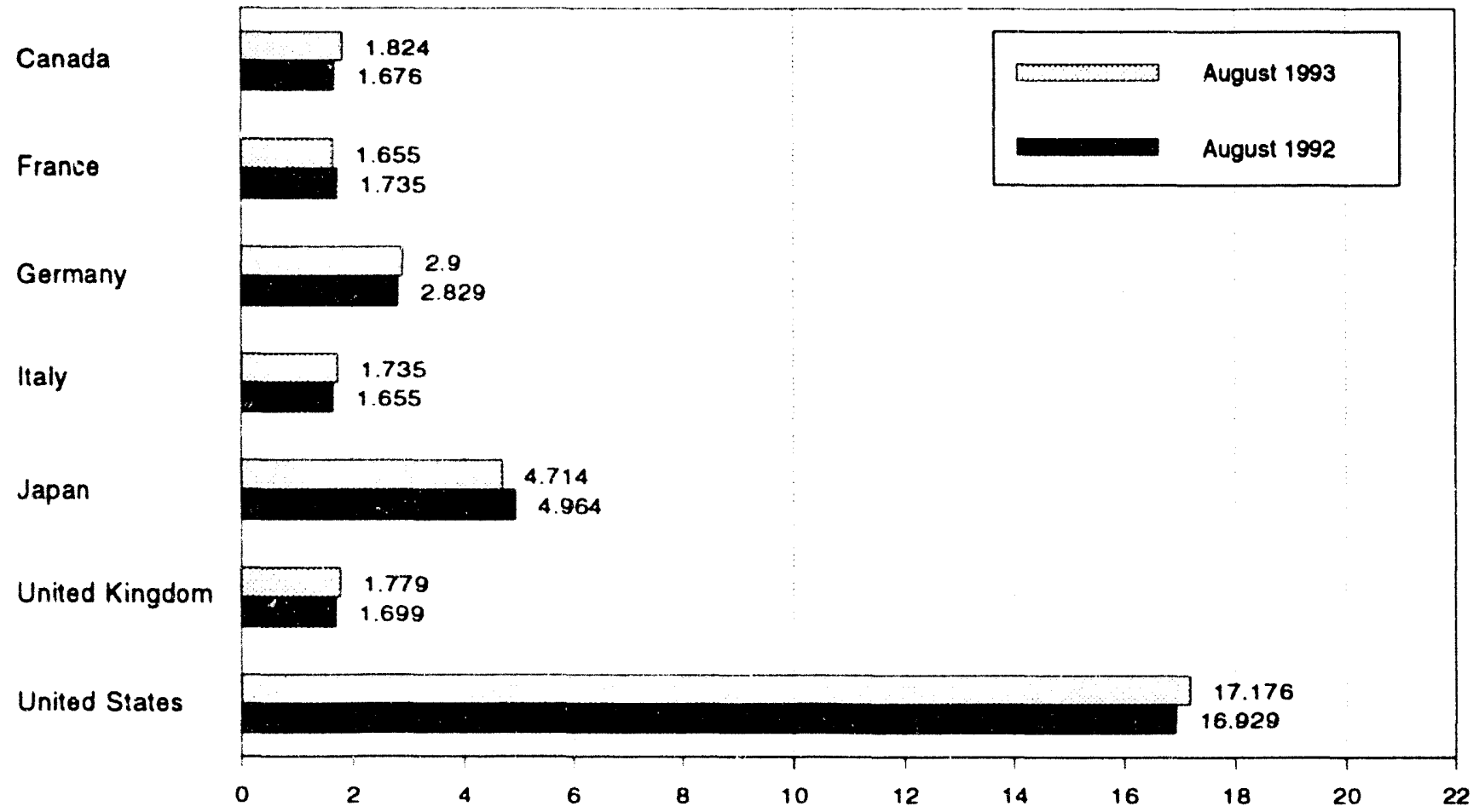

Note: OECD is the Organization for Economic Cooperation and Development.

Source: Table 10.2 
Table 10.2 Petroleum Consumption in OECD Countries

(Thousand Barrels per Day)

\begin{tabular}{|c|c|c|c|c|c|c|c|c|c|c|}
\hline & Canada & France & Germany ${ }^{a}$ & Italy & Japan & $\begin{array}{l}\text { United } \\
\text { Kingdom }\end{array}$ & $\begin{array}{l}\text { United } \\
\text { States }\end{array}$ & $\begin{array}{l}\text { OECD } \\
\text { Europeb }\end{array}$ & $\begin{array}{l}\text { Other } \\
\text { OECDC }\end{array}$ & OECD \\
\hline 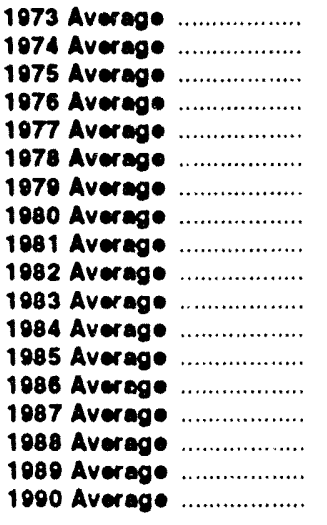 & $\begin{array}{l}1,729 \\
1,770 \\
1,779 \\
1,818 \\
1,850 \\
1,902 \\
1,971 \\
1,873 \\
1,768 \\
1,578 \\
1,448 \\
1,472 \\
1,504 \\
1,506 \\
1,548 \\
1,693 \\
1,733 \\
1,690\end{array}$ & $\begin{array}{l}2,601 \\
2,447 \\
2,252 \\
2,420 \\
2,294 \\
2,408 \\
2,463 \\
2,256 \\
2,023 \\
1,880 \\
1,835 \\
1,754 \\
1,775 \\
1,772 \\
1,789 \\
1,797 \\
1,857 \\
1,818\end{array}$ & $\begin{array}{l}3,055 \\
2,748 \\
2,650 \\
2,877 \\
2,865 \\
2,027 \\
3,003 \\
2,707 \\
2,449 \\
2,372 \\
2,324 \\
2,322 \\
2,338 \\
2,498 \\
2,424 \\
2,422 \\
2,280 \\
2,382\end{array}$ & $\begin{array}{l}2,068 \\
2,004 \\
1,855 \\
1,971 \\
1,807 \\
1,952 \\
2,039 \\
1,934 \\
1,874 \\
1,781 \\
1,750 \\
1,646 \\
1,717 \\
1,738 \\
1,855 \\
1,836 \\
1,930 \\
1,872\end{array}$ & $\begin{array}{l}4,949 \\
4,864 \\
4,621 \\
4,837 \\
4,880 \\
4,945 \\
5,050 \\
4,960 \\
4,848 \\
4,582 \\
4,385 \\
4,576 \\
4,384 \\
4,430 \\
4,484 \\
4,752 \\
4,983 \\
5,140\end{array}$ & $\begin{array}{l}2,341 \\
2,210 \\
1,911 \\
1,892 \\
1,905 \\
1,938 \\
1,971 \\
1,725 \\
1,590 \\
1,590 \\
1,531 \\
1,849 \\
1,634 \\
1,649 \\
1,603 \\
1,697 \\
1,738 \\
1,752\end{array}$ & $\begin{array}{l}17,308 \\
16,653 \\
16,322 \\
17,461 \\
18,431 \\
18,847 \\
18,513 \\
17,056 \\
16,058 \\
15,296 \\
15,231 \\
15,726 \\
15,726 \\
16,281 \\
16,665 \\
17,283 \\
17,325 \\
16,988\end{array}$ & $\begin{array}{l}14,925 \\
13,988 \\
13,217 \\
14,124 \\
13,916 \\
14,290 \\
14,667 \\
13,634 \\
12,515 \\
12,053 \\
11,765 \\
11,736 \\
11,681 \\
12,102 \\
12,255 \\
12,427 \\
12,531 \\
12,629\end{array}$ & $\begin{array}{r}988 \\
1,005 \\
1,041 \\
1,110 \\
1,160 \\
1,204 \\
1,178 \\
1,072 \\
1,080 \\
1,008 \\
954 \\
980 \\
976 \\
951 \\
958 \\
939 \\
998 \\
1,027\end{array}$ & $\begin{array}{l}30,000 \\
38,370 \\
36,080 \\
39,358 \\
40,237 \\
41,187 \\
41,370 \\
38,508 \\
36,260 \\
34,517 \\
33,793 \\
34,500 \\
34,271 \\
35,270 \\
35,011 \\
37,093 \\
37,570 \\
37,475\end{array}$ \\
\hline 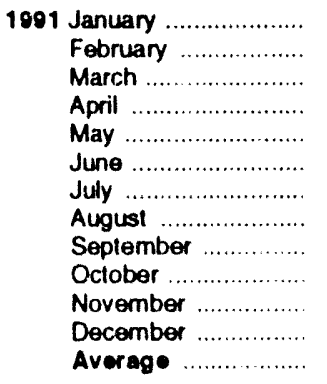 & $\begin{array}{l}1,599 \\
1,613 \\
1,484 \\
1,595 \\
1,637 \\
1,589 \\
1,707 \\
1,693 \\
1,583 \\
1,693 \\
1,602 \\
1,662 \\
1,622\end{array}$ & $\begin{array}{l}2,294 \\
2,009 \\
1,759 \\
1,808 \\
1,773 \\
1,807 \\
1,989 \\
1,795 \\
1,824 \\
2.075 \\
1,953 \\
2,132 \\
1,935\end{array}$ & $\begin{array}{l}2,998 \\
2,783 \\
2,858 \\
2,953 \\
2,912 \\
3,269 \\
2,272 \\
2,609 \\
2,679 \\
2,919 \\
2,860 \\
2,829 \\
2,828\end{array}$ & $\begin{array}{l}2,185 \\
2,025 \\
1,660 \\
1,813 \\
1,722 \\
1,535 \\
1,665 \\
1,546 \\
1,824 \\
2,126 \\
2,031 \\
2,231 \\
1,863\end{array}$ & $\begin{array}{l}5,852 \\
6,155 \\
5,789 \\
5,025 \\
4,880 \\
4,765 \\
5,000 \\
4,888 \\
4,724 \\
4,848 \\
5,581 \\
5,952 \\
5,284\end{array}$ & $\begin{array}{l}1.819 \\
1,837 \\
1.725 \\
1.793 \\
1.799 \\
1.769 \\
1.853 \\
1.812 \\
1.753 \\
1,864 \\
1.829 \\
1.765 \\
1.801\end{array}$ & $\begin{array}{l}16,893 \\
16,339 \\
16,212 \\
16,139 \\
16,189 \\
16,878 \\
16,371 \\
17,183 \\
16,848 \\
16,996 \\
16,730 \\
17,145 \\
16,714\end{array}$ & $\begin{array}{l}14,564 \\
13,804 \\
12,609 \\
13,073 \\
12,965 \\
13,184 \\
12,648 \\
12,727 \\
12,999 \\
14,178 \\
13,736 \\
14,228 \\
13,391\end{array}$ & $\begin{array}{r}A_{1,067} \\
A_{1,043} \\
A_{1}, 096 \\
A_{1,087} \\
A_{1,108} \\
R_{950} \\
R_{1,005} \\
R_{992} \\
R_{1,028} \\
A_{1,117} \\
A_{1,132} \\
A_{1,047} \\
A_{1,056}\end{array}$ & 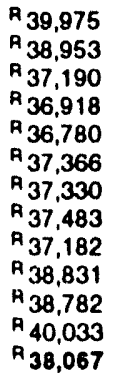 \\
\hline 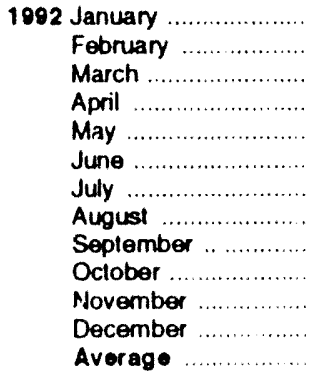 & $\begin{array}{l}1,627 \\
1,623 \\
1,595 \\
1,581 \\
1,589 \\
1,647 \\
1,642 \\
1,676 \\
1,655 \\
1,705 \\
1,714 \\
1,670 \\
1,644\end{array}$ & $\begin{array}{l}2,213 \\
2,108 \\
1,939 \\
1,993 \\
1,632 \\
1,817 \\
1,929 \\
1,735 \\
1,956 \\
1.942 \\
1,890 \\
2,000 \\
1,929\end{array}$ & $\begin{array}{l}2,968 \\
2,814 \\
2,809 \\
2,893 \\
2,588 \\
2,699 \\
3,029 \\
2,829 \\
3,072 \\
2,752 \\
2,823 \\
2,841 \\
2,843\end{array}$ & $\begin{array}{l}2,237 \\
2,149 \\
1,886 \\
1,891 \\
1,671 \\
1,801 \\
1,900 \\
1,655 \\
2,003 \\
1,930 \\
2,053 \\
2,076 \\
1,936\end{array}$ & $\begin{array}{l}5,776 \\
6,347 \\
5,873 \\
5,212 \\
4,845 \\
4,949 \\
5,124 \\
4,964 \\
5,147 \\
5,310 \\
5,644 \\
6,285 \\
5,454\end{array}$ & $\begin{array}{l}1,832 \\
1,819 \\
1,818 \\
1,858 \\
1,694 \\
1,725 \\
1,804 \\
1,699 \\
1,870 \\
1,825 \\
1,852 \\
1,839 \\
1,803\end{array}$ & $\begin{array}{l}17,012 \\
16,893 \\
16,825 \\
16,764 \\
16,485 \\
16,978 \\
17,143 \\
16,929 \\
16,876 \\
17,448 \\
17,091 \\
17,928 \\
17,033\end{array}$ & $\begin{array}{l}14,459 \\
14,052 \\
13,682 \\
13,667 \\
12,347 \\
13,036 \\
13,662 \\
12,909 \\
14,224 \\
13,475 \\
13,806 \\
13,991 \\
13,606\end{array}$ & $\begin{array}{r}1,014 \\
1,045 \\
1,054 \\
1,042 \\
1,002 \\
1,086 \\
1,027 \\
946 \\
1,046 \\
1,014 \\
1,049 \\
1,103 \\
1,035\end{array}$ & $\begin{array}{l}39,888 \\
39,959 \\
39,029 \\
38,267 \\
36,269 \\
37,696 \\
38,600 \\
37,423 \\
38,947 \\
38,953 \\
39,304 \\
40,977 \\
38,772\end{array}$ \\
\hline 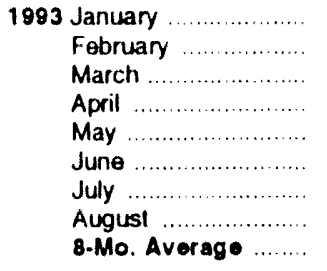 & $\begin{array}{r}1.591 \\
1.728 \\
1.696 \\
1,614 \\
1,622 \\
1.713 \\
1.739 \\
1.824 \\
1,691\end{array}$ & $\begin{array}{l}1,950 \\
2.138 \\
2.010 \\
1.930 \\
1.695 \\
1.970 \\
1.854 \\
1,655 \\
1,897\end{array}$ & $\begin{array}{l}2,521 \\
2,931 \\
2,954 \\
2,814 \\
2,584 \\
3.037 \\
2,950 \\
2.900 \\
2,835\end{array}$ & $\begin{array}{l}1,859 \\
2,106 \\
2,005 \\
1,805 \\
1,701 \\
1,856 \\
1,815 \\
1,735 \\
1,857\end{array}$ & $\begin{array}{r}5,937 \\
6,286 \\
6,238 \\
R 5,456 \\
R 4,765 \\
R_{4,963} \\
4,855 \\
4,714 \\
5,392\end{array}$ & $\begin{array}{r}1,721 \\
1,872 \\
1,881 \\
1,726 \\
1,671 \\
1,902 \\
1,800 \\
1,779 \\
1,781\end{array}$ & $\begin{array}{l}16,320 \\
17,3197 \\
17,688 \\
16,1 ; 73 \\
16,346 \\
17,342 \\
17,208 \\
17,176 \\
15,975\end{array}$ & $\begin{array}{r}12,823 \\
14,214 \\
14,036 \\
A_{13,337} \\
A_{12,140} \\
A_{13,841} \\
A_{13,645} \\
13,083 \\
13,378\end{array}$ & $\begin{array}{r}944 \\
1,104 \\
1,144 \\
1,099 \\
1,110 \\
1,091 \\
\mathrm{P} 1,027 \\
1,097 \\
1,077\end{array}$ & $\begin{array}{r}37,614 \\
40,729 \\
40,803 \\
\text { R }_{38,180} \\
\text { R }_{35,977} \\
\text { म }_{38,639} \\
\text { R }_{38,474} \\
37,894 \\
38,513\end{array}$ \\
\hline $\begin{array}{l}1002 \text { 8-Mo. Average ........ } \\
1081 \text { 8-Mo. Average ........ }\end{array}$ & $\begin{array}{l}1,623 \\
1,615\end{array}$ & $\begin{array}{l}1,819 \\
1,904\end{array}$ & $\begin{array}{l}2,829 \\
2,830\end{array}$ & $\begin{array}{l}1,897 \\
1,766\end{array}$ & $\begin{array}{l}5,381 \\
5,287\end{array}$ & $\begin{array}{l}1,781 \\
1,801\end{array}$ & $\begin{array}{l}16,879 \\
16,604\end{array}$ & $\begin{array}{l}13,473 \\
13,190\end{array}$ & $\begin{array}{l}1,027 \\
1,044\end{array}$ & $\begin{array}{l}38,382 \\
37,740\end{array}$ \\
\hline
\end{tabular}

a Through December 1990, the data for Germany are tor the former West Germany onty. Beginning with January 1991, the data for Germany are for the unified Germany, i.e. the former East Germany and West Germany

- OECD Europe" consists of Austria, Belgium, Denmark, Finland, France, Germany, Greece, Iceland, Ireland, llaly, Luxembourg, the Netherlands, Norway, Portugal, Spain. Sweden, Switzerland, Turkey, and the Unted Kingdom.

"Other OECD" consists of Australia, New Zealand, and the U.S Territories

$R=$ Revised dala
Notes - The Organization for Economic Cooperalion and Development (OECD) consists of Cartada. Japan, and the United States, as well as "OECD Europe" and "Other OECD" - U.S. gengraphic coverage is the 50 States and the District of Columbia. - Totals may not equal sum of components due to independent roundiry. - Dala through 1991 are final. Subsequent data are preliminary

Sources: - United States: Table 3.1a. - All Other Data: 1973-1979-International Energy Agency (IEA), Annual Oil and Gas Statistics of OECD Countries. 1980 forward-IEA, quarterly and monthly computer tapes supporting Quarterly Oil Statistics ana Energy Balances.

Revisions reflect data published in the lis International Energy: Annual 1992. 
Figure 10.4 Petroleum Stocks in OECD Countries

(Billion Barrels)

OECD Stocks, End of Year, 1973-1992

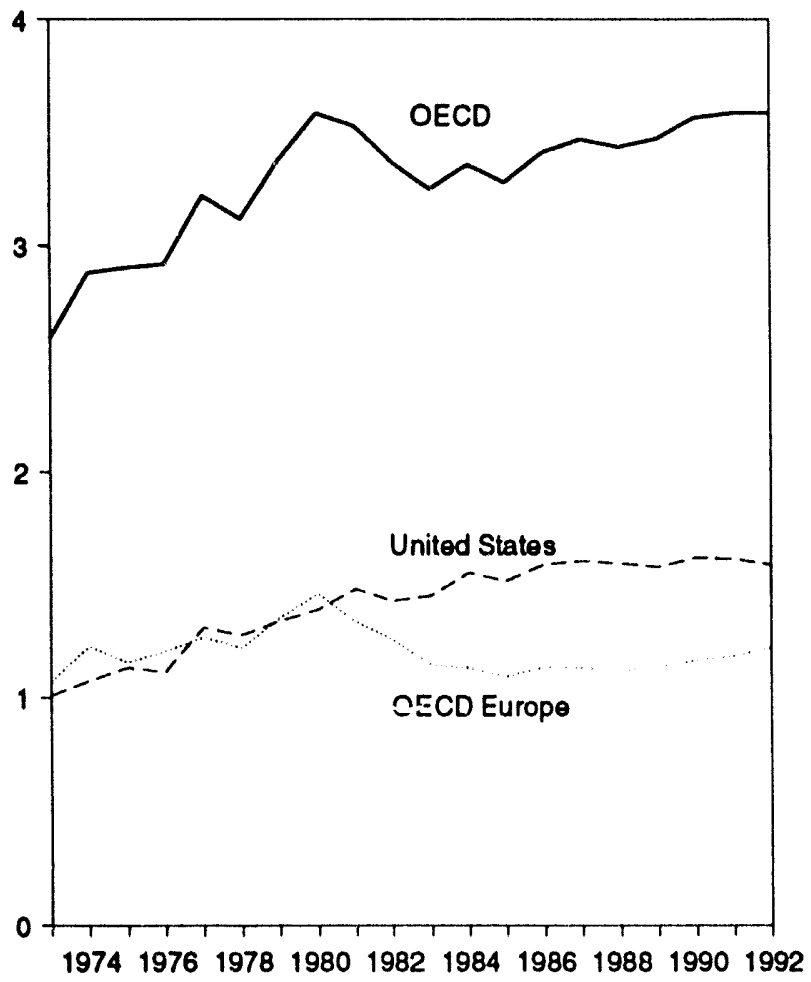

OECD Stocks, End of Month

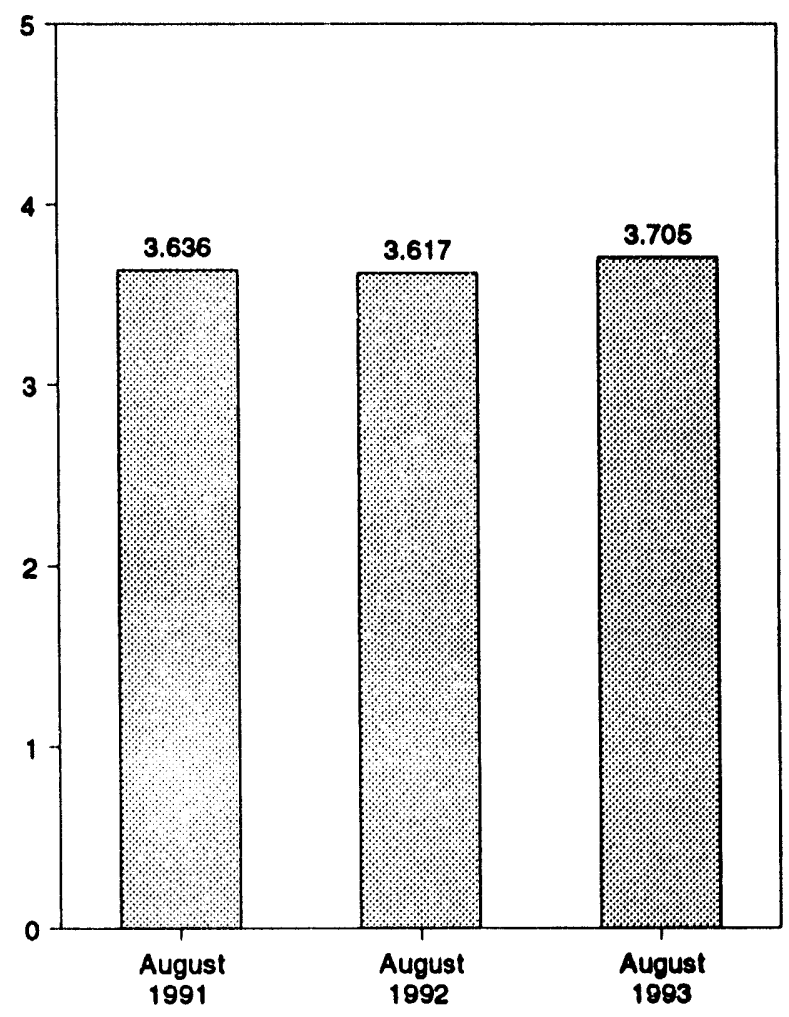

Stocks by Selected Country, End of Month

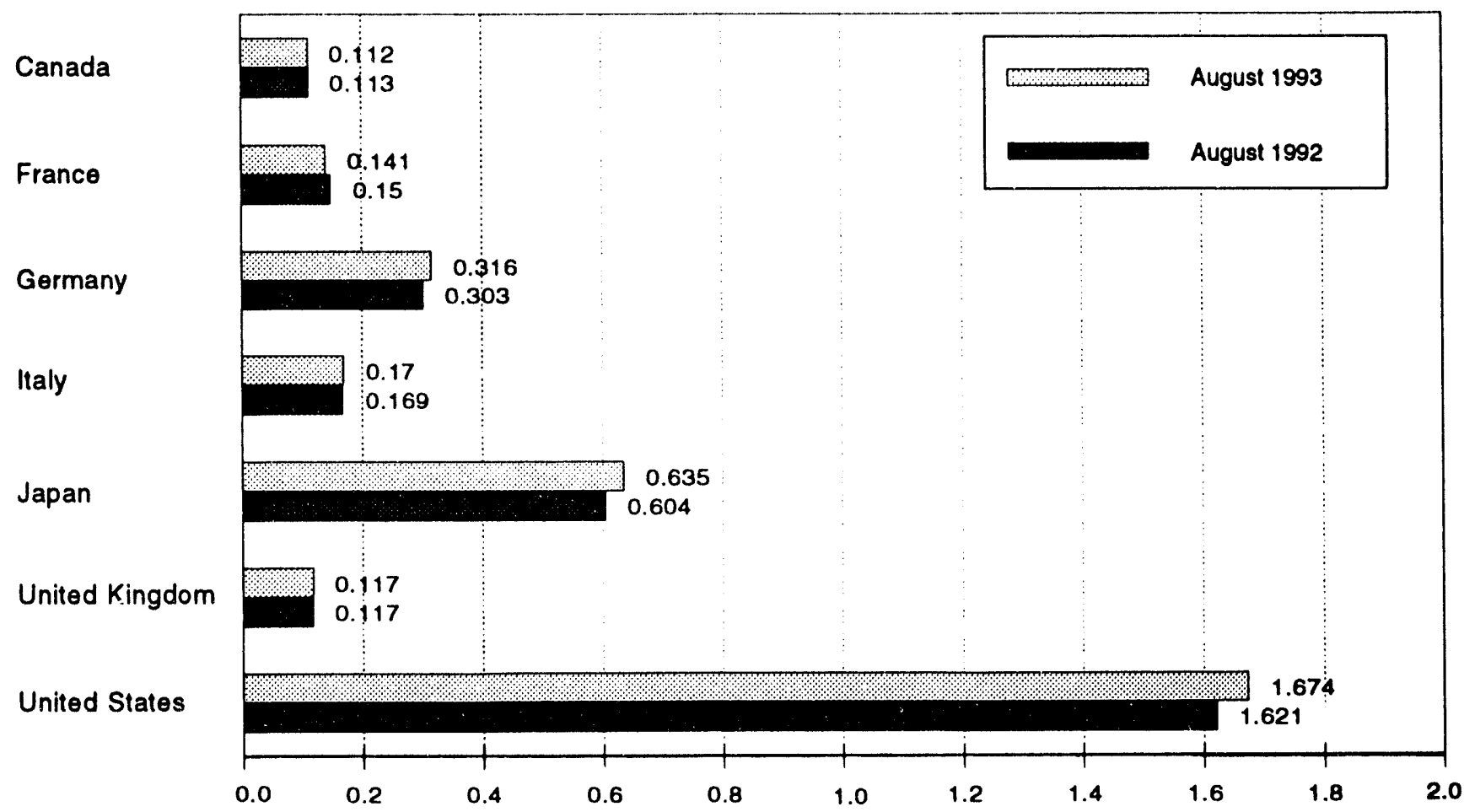

Nole: OECD is the Organization for Economic Cooperation and Development.

Source: Table 10.3. 
Table 10.3 Petroleum Stocks in OECD Countries, End of Period (Million Barrels)

\begin{tabular}{|c|c|c|c|c|c|c|c|c|c|c|}
\hline & Canada & France & Germany ${ }^{8}$ & Italy & Japan & $\begin{array}{l}\text { Unitod } \\
\text { Kingdom }\end{array}$ & $\begin{array}{l}\text { United } \\
\text { States }\end{array}$ & $\begin{array}{l}\text { OECD } \\
\text { Europob }\end{array}$ & $\begin{array}{l}\text { Other } \\
\text { OECDC }\end{array}$ & OECD \\
\hline 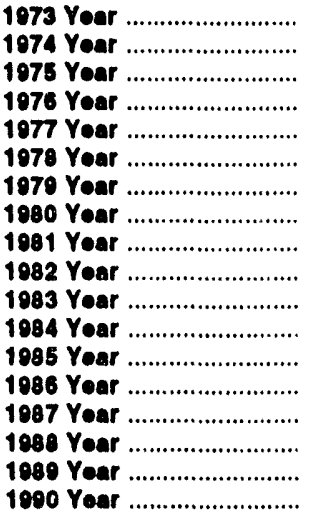 & $\begin{array}{l}140 \\
145 \\
174 \\
153 \\
167 \\
144 \\
150 \\
164 \\
161 \\
136 \\
121 \\
128 \\
113 \\
111 \\
126 \\
116 \\
114 \\
121\end{array}$ & $\begin{array}{l}201 \\
249 \\
225 \\
234 \\
239 \\
201 \\
226 \\
243 \\
214 \\
193 \\
153 \\
152 \\
139 \\
127 \\
127 \\
140 \\
138 \\
140\end{array}$ & $\begin{array}{l}181 \\
213 \\
187 \\
208 \\
225 \\
238 \\
272 \\
318 \\
297 \\
272 \\
249 \\
239 \\
233 \\
252 \\
259 \\
266 \\
271 \\
265\end{array}$ & $\begin{array}{l}152 \\
167 \\
143 \\
143 \\
161 \\
154 \\
163 \\
170 \\
167 \\
178 \\
149 \\
159 \\
157 \\
155 \\
169 \\
155 \\
164 \\
172\end{array}$ & $\begin{array}{l}303 \\
370 \\
375 \\
380 \\
409 \\
413 \\
460 \\
495 \\
482 \\
484 \\
470 \\
470 \\
494 \\
509 \\
540 \\
538 \\
577 \\
590\end{array}$ & $\begin{array}{l}156 \\
191 \\
165 \\
165 \\
148 \\
157 \\
169 \\
168 \\
143 \\
125 \\
118 \\
112 \\
123 \\
124 \\
121 \\
112 \\
118 \\
112\end{array}$ & $\begin{array}{l}1,008 \\
1,074 \\
1,133 \\
1,112 \\
1,312 \\
1,278 \\
1,341 \\
1,392 \\
1,484 \\
1,430 \\
1,454 \\
1,556 \\
1,510 \\
1,593 \\
1,607 \\
1,597 \\
1,581 \\
1,621\end{array}$ & $\begin{array}{l}1,070 \\
1,227 \\
1,154 \\
1,205 \\
1,268 \\
1,210 \\
1,353 \\
1,464 \\
1,337 \\
1,258 \\
1,142 \\
1,130 \\
1,092 \\
1,133 \\
1,130 \\
1,118 \\
1,133 \\
1,163\end{array}$ & $\begin{array}{l}67 \\
64 \\
67 \\
68 \\
68 \\
68 \\
75 \\
72 \\
67 \\
68 \\
68 \\
60 \\
66 \\
72 \\
72 \\
71 \\
71 \\
73\end{array}$ & $\begin{array}{l}2,588 \\
2,880 \\
2,903 \\
2,918 \\
3,224 \\
3,122 \\
3,370 \\
3,587 \\
3,531 \\
3,376 \\
3,255 \\
3,362 \\
3,284 \\
3,418 \\
3,474 \\
3,440 \\
3,476 \\
3,568\end{array}$ \\
\hline 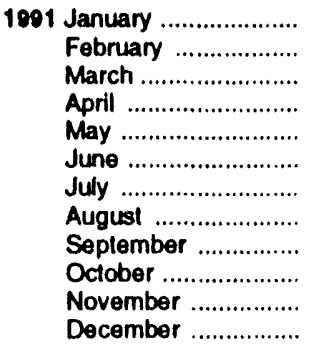 & $\begin{array}{l}116 \\
114 \\
117 \\
110 \\
107 \\
107 \\
118 \\
116 \\
117 \\
118 \\
122 \\
118\end{array}$ & $\begin{array}{l}133 \\
137 \\
142 \\
138 \\
138 \\
144 \\
145 \\
152 \\
150 \\
148 \\
152 \\
153\end{array}$ & $\begin{array}{l}278 \\
278 \\
280 \\
277 \\
279 \\
274 \\
285 \\
284 \\
287 \\
286 \\
289 \\
288\end{array}$ & $\begin{array}{l}174 \\
169 \\
178 \\
177 \\
174 \\
173 \\
169 \\
171 \\
170 \\
165 \\
163 \\
160\end{array}$ & $\begin{array}{l}591 \\
572 \\
593 \\
585 \\
586 \\
590 \\
594 \\
610 \\
622 \\
625 \\
607 \\
607\end{array}$ & $\begin{array}{l}116 \\
119 \\
124 \\
119 \\
113 \\
118 \\
113 \\
118 \\
120 \\
119 \\
120 \\
119\end{array}$ & $\begin{array}{l}1,587 \\
1.573 \\
1,558 \\
1,578 \\
1,626 \\
1,634 \\
1,635 \\
1,648 \\
1,663 \\
1,644 \\
1,647 \\
1,617\end{array}$ & $\begin{array}{l}1,164 \\
1,162 \\
1,178 \\
1,161 \\
1,157 \\
1,161 \\
1,170 \\
1,186 \\
1,195 \\
1,190 \\
1,198 \\
1,182\end{array}$ & $\begin{array}{l}73 \\
72 \\
75 \\
75 \\
75 \\
72 \\
73 \\
76 \\
74 \\
71 \\
70 \\
65\end{array}$ & $\begin{array}{l}3,531 \\
3,493 \\
3,521 \\
3,509 \\
3,551 \\
3,564 \\
3,590 \\
3,636 \\
3,671 \\
3,649 \\
3,643 \\
3,589\end{array}$ \\
\hline 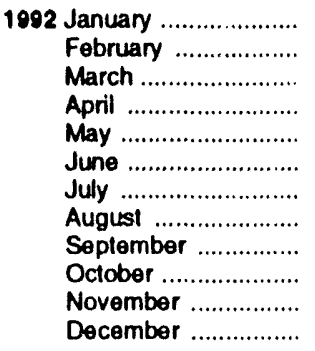 & $\begin{array}{l}117 \\
111 \\
111 \\
111 \\
108 \\
112 \\
110 \\
113 \\
110 \\
108 \\
110 \\
107\end{array}$ & $\begin{array}{l}149 \\
145 \\
142 \\
140 \\
147 \\
148 \\
146 \\
150 \\
148 \\
148 \\
149 \\
146\end{array}$ & $\begin{array}{l}293 \\
303 \\
303 \\
307 \\
311 \\
307 \\
299 \\
303 \\
299 \\
302 \\
306 \\
310\end{array}$ & $\begin{array}{l}167 \\
172 \\
169 \\
165 \\
171 \\
166 \\
166 \\
169 \\
165 \\
166 \\
172 \\
174\end{array}$ & $\begin{array}{l}601 \\
596 \\
586 \\
578 \\
588 \\
583 \\
586 \\
604 \\
608 \\
613 \\
611 \\
603\end{array}$ & $\begin{array}{l}116 \\
118 \\
115 \\
115 \\
115 \\
114 \\
120 \\
117 \\
112 \\
113 \\
116 \\
113\end{array}$ & $\begin{array}{l}1,610 \\
1,588 \\
1,571 \\
1,583 \\
1,602 \\
1,603 \\
1,620 \\
1,621 \\
1,636 \\
1,640 \\
1,636 \\
1,592\end{array}$ & $\begin{array}{l}1,168 \\
1,181 \\
1,162 \\
1,172 \\
1,189 \\
1,190 \\
1,182 \\
1,211 \\
1,194 \\
1,201 \\
1,207 \\
1,219\end{array}$ & $\begin{array}{l}68 \\
66 \\
66 \\
62 \\
63 \\
69 \\
67 \\
69 \\
69 \\
69 \\
71 \\
67\end{array}$ & $\begin{array}{l}3,564 \\
3,542 \\
3,495 \\
3,505 \\
3,551 \\
3,557 \\
3,565 \\
3,617 \\
3,616 \\
3,631 \\
3,634 \\
3,589\end{array}$ \\
\hline 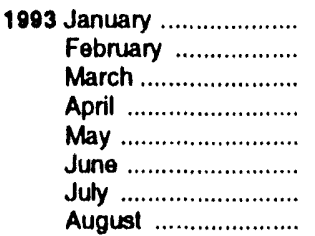 & $\begin{array}{r}110 \\
106 \\
107 \\
110 \\
106 \\
108 \\
113 \\
112\end{array}$ & $\begin{array}{l}148 \\
142 \\
138 \\
139 \\
145 \\
139 \\
141 \\
141\end{array}$ & $\begin{array}{l}319 \\
317 \\
311 \\
311 \\
320 \\
310 \\
312 \\
316\end{array}$ & $\begin{array}{r}171 \\
163 \\
156 \\
158 \\
164 \\
164 \\
R \quad 169 \\
170\end{array}$ & $\begin{array}{r}614 \\
606 \\
593 \\
584 \\
592 \\
601 \\
617 \\
635\end{array}$ & $\begin{array}{l}120 \\
120 \\
120 \\
116 \\
117 \\
119 \\
115 \\
117\end{array}$ & $\begin{array}{l}1,611 \\
1,595 \\
1,584 \\
1,611 \\
1,643 \\
1,660 \\
1,678 \\
1,674\end{array}$ & $\begin{array}{r}1,231 \\
1,213 \\
1,192 \\
A 1,185 \\
A_{1,198} \\
1,185 \\
A 1,194 \\
1,215\end{array}$ & $\begin{array}{l}68 \\
68 \\
66 \\
73 \\
69 \\
69 \\
70 \\
70\end{array}$ & $\begin{array}{r}3,635 \\
3,588 \\
3,541 \\
\text { ค } 3,563 \\
\text { ค } 3,608 \\
3,623 \\
\text { म } 3,673 \\
3,705\end{array}$ \\
\hline
\end{tabular}

a Through December 1990, the data for Germany are for the former West Germany only. Beginning with January 1991, the dala for Germany are for the unitied Germany, i.e., the lormer East Germany and West Gernany.

b "OECD Europe" consists of Austria, Belgium, Denmark, Finland, France, Germany, Greece, Iceland, Ireland, Italy, Luxembourg, the Netherlands, Norway, Porlugal, Spain, Sweden, Swizerland, Turkey, and the United Kingdom.

"Other OECD" consists of Australia, New Zealand, and the U.S. Territories.

$R=$ Revised data

Noles: - Pelroleum stocks include crude oil (including stralegic reserves), untinished oils, natural gas plant liquids, and relined products. Petroleum stocks include all nonmilitary petroleum held for storage, regardless of ownership, within each country in bulk terminals, relinery lanks, pipeline lankage, intercoastal tankers, tankers in port, and intand ship bunkers. Data exclude oil held in pipelines (except for those in the United States), rail and truck cars, sea-going ships' bunkers, service stations, retail stores, and tankers at sea. - The Organization for Economic Cooperation and Development (OECD) consists of Canada, Japan, and the United States, as well as "OECD Europe" and "Other OECD." - U.S. geographic coverage is the 50 Slates and the Districl of Columbia. - Totals may not equal sum of components due to independent rounding. - In the Uniled Slates in January 1975, 1981, and 1983, numerous respondents were added to bulk terminal and pipeline surveys, thereby affecting subsequent stocks reported. Newbasis end-of-year U.S. slocks, in million barrels, would have been 1.121 in 1974, 1,425 in 1980, and 1,461 in 1982. Data through 1991 are final. Subsequent data are preliminary

Sources: - United States: Table 3.1a. - All Other Data: International Energy Agency, quarterly and monthly computer tapes supporting Quarterty Oil Statistics and Energy Balances.

Revisions reflect data published in the liı International Energy Annual 1992. 
Figure 10.5 Nuclear Electricity Gross Generation

(Billion Kilowatthours)

U.S. and Total ${ }^{\star}$ Generation, 1973-1992

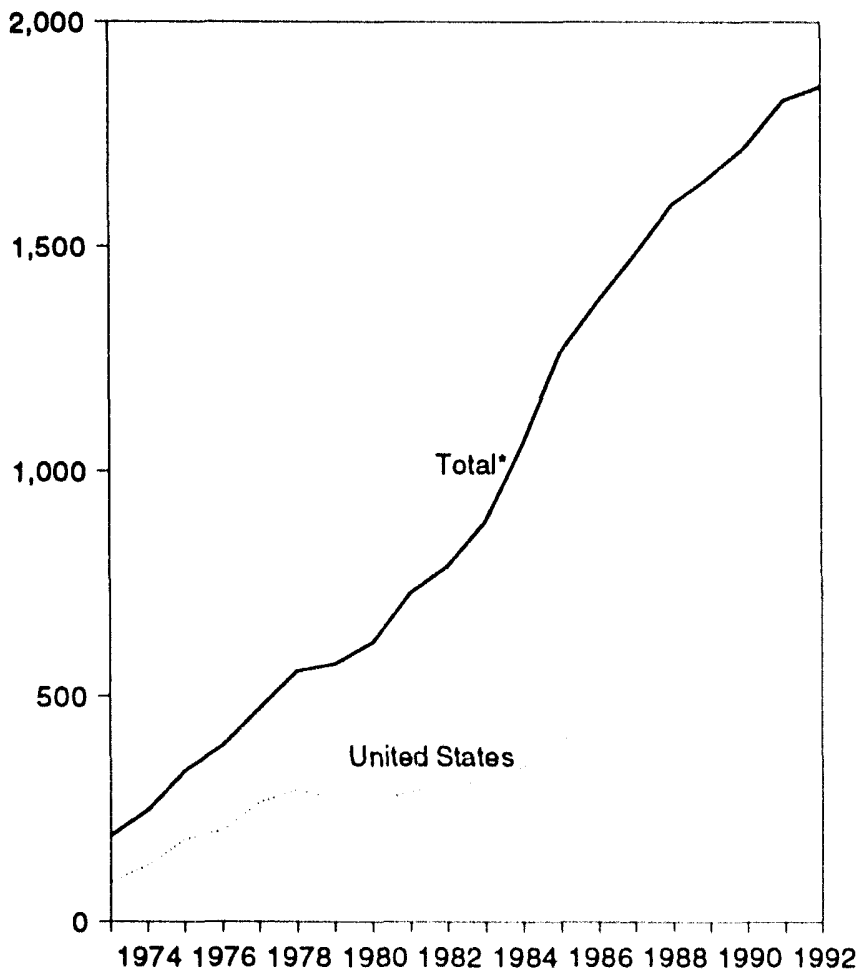

\section{Total ${ }^{*}$ Generation}

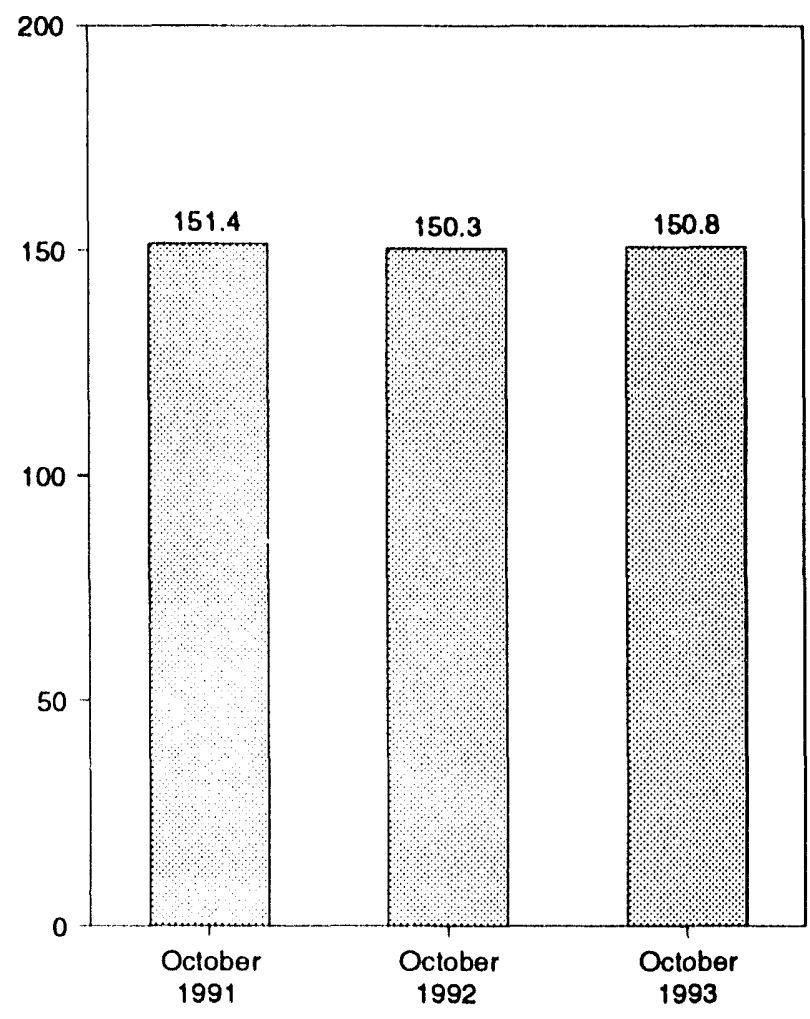

Generation by Selected Country, October 1993

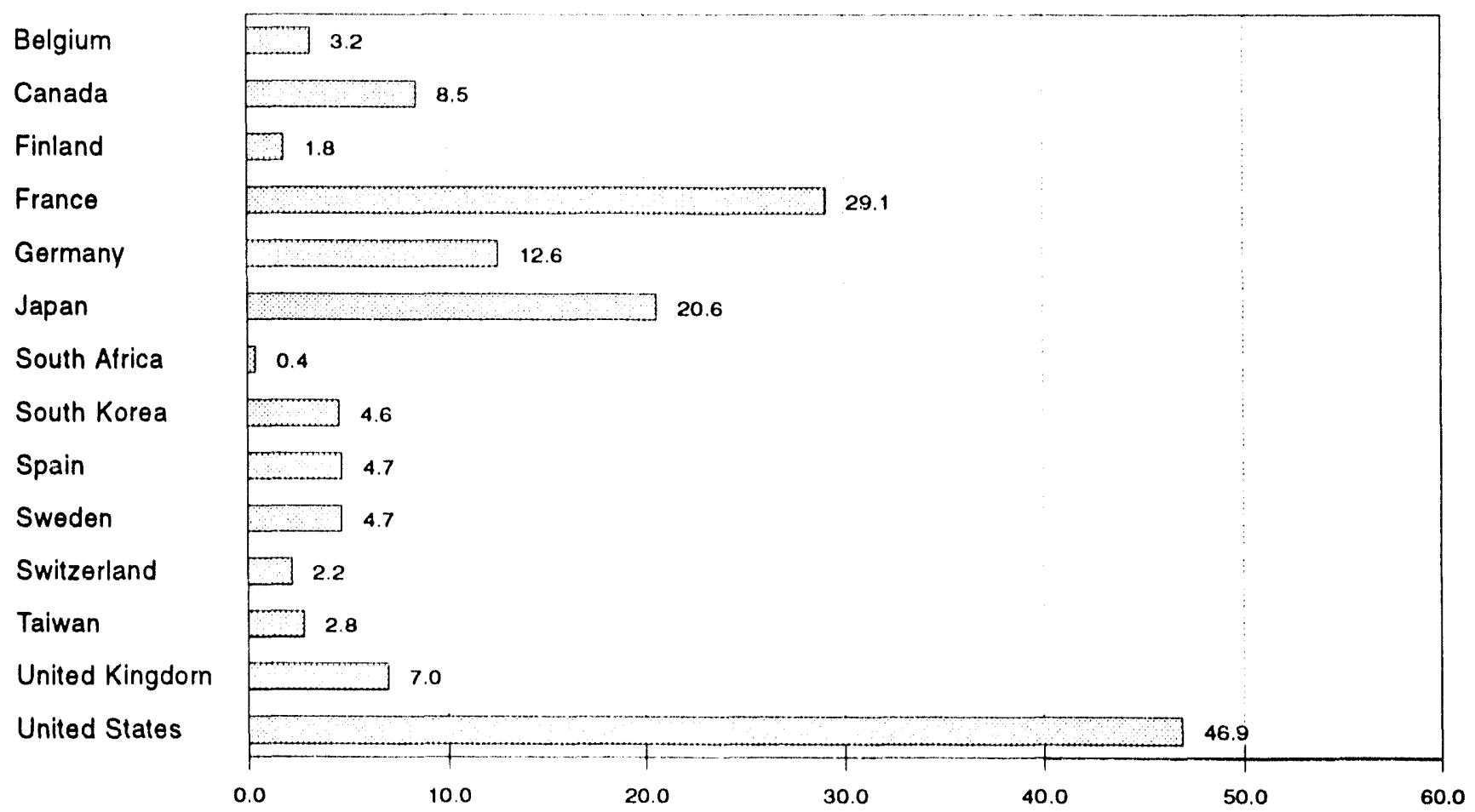

"Total" equals nuclear-generated electricity trom all countries except Bulgaria, China, Cuba, the tormer Czechoslovakia, Hungary, North Korea, Poland, Romanla, the former U.S.S.R., and Slovenla (pan of the tormer Yugoslavla).

Note: Because vertical scales dilfer, graphs should not be compared.

Sources: Tables $10.4 \mathrm{a} \cdot 10.4 \mathrm{c}$ 
Table 10.4a Nuclear Electricity Gross Generation: Argentina Through India (Billion Kilowatthours)

\begin{tabular}{|c|c|c|c|c|c|c|c|c|}
\hline & Argentina & Bolglum & Brazil & Canada & Finland & France & Germany" & Indla \\
\hline 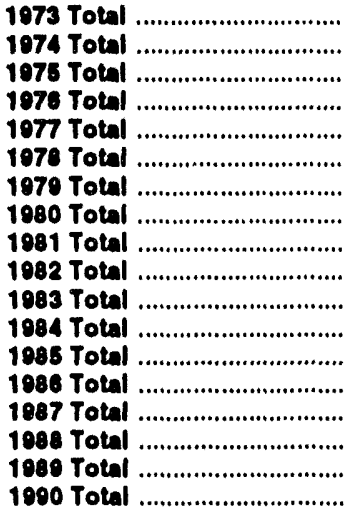 & $\begin{array}{l}0.0 \\
1.0 \\
2.5 \\
2.8 \\
1.6 \\
2.0 \\
2.7 \\
2.3 \\
2.8 \\
1.9 \\
3.4 \\
4.5 \\
5.8 \\
5.7 \\
5.2 \\
5.1 \\
5.0 \\
7.4\end{array}$ & $\begin{array}{r}0.0 \\
.1 \\
6.8 \\
10.0 \\
11.0 \\
12.5 \\
11.4 \\
12.5 \\
12.8 \\
15.6 \\
24.1 \\
27.7 \\
34.5 \\
38.6 \\
41.9 \\
43.1 \\
41.2 \\
42.7\end{array}$ & $\begin{array}{r}0.0 \\
.0 \\
.0 \\
.0 \\
.0 \\
.0 \\
.0 \\
.0 \\
.0 \\
.1 \\
.2 \\
2.1 \\
3.4 \\
.1 \\
1.0 \\
.3 \\
1.6 \\
2.0\end{array}$ & $\begin{array}{l}15.3 \\
15.4 \\
13.2 \\
18.0 \\
26.6 \\
33.0 \\
38.4 \\
40.4 \\
43.3 \\
42.6 \\
53.0 \\
53.8 \\
62.0 \\
74.6 \\
80.6 \\
85.6 \\
83.2 \\
75.8\end{array}$ & $\begin{array}{r}0.0 \\
.0 \\
.0 \\
.0 \\
2.7 \\
3.3 \\
6.7 \\
7.0 \\
14.5 \\
16.5 \\
17.4 \\
18.5 \\
18.8 \\
18.8 \\
10.4 \\
10.3 \\
18.8 \\
18.0\end{array}$ & $\begin{array}{r}14.7 \\
14.7 \\
18.3 \\
15.8 \\
17.9 \\
30.6 \\
39.9 \\
61.2 \\
105.2 \\
108.9 \\
144.2 \\
191.2 \\
224.0 \\
254.3 \\
265.5 \\
274.9 \\
302.5 \\
314.1\end{array}$ & $\begin{array}{r}11.0 \\
12.0 \\
21.7 \\
24.5 \\
36.0 \\
35.7 \\
42.2 \\
43.7 \\
53.4 \\
63.4 \\
65.8 \\
92.6 \\
125.8 \\
118.0 \\
130.2 \\
145.2 \\
149.6 \\
147.2\end{array}$ & $\begin{array}{l}2.5 \\
1.0 \\
2.5 \\
3.2 \\
2.8 \\
2.3 \\
3.2 \\
2.0 \\
3.1 \\
2.2 \\
2.0 \\
4.1 \\
4.5 \\
5.1 \\
5.5 \\
6.1 \\
4.0 \\
6.3\end{array}$ \\
\hline 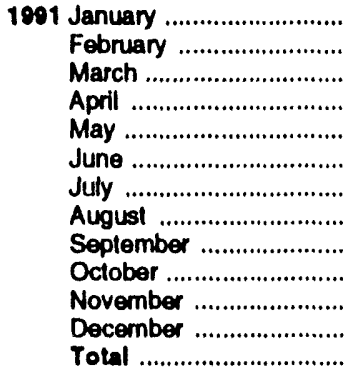 & $\begin{array}{l}.5 \\
.6 \\
.6 \\
.7 \\
.7 \\
.7 \\
.7 \\
.7 \\
.5 \\
.7 \\
.7 \\
.5 \\
7.7\end{array}$ & $\begin{array}{r}4.2 \\
3.9 \\
4.2 \\
3.5 \\
3.4 \\
2.9 \\
3.5 \\
3.8 \\
3.0 \\
3.2 \\
3.3 \\
4.0 \\
42.9\end{array}$ & $\begin{array}{r}.2 \\
.2 \\
.2 \\
.2 \\
.2 \\
.2 \\
.2 \\
.0 \\
.0 \\
.0 \\
.0 \\
.0 \\
1.4\end{array}$ & $\begin{array}{r}7.6 \\
7.3 \\
7.8 \\
6.7 \\
7.2 \\
7.1 \\
7.7 \\
8.6 \\
6.7 \\
6.6 \\
6.3 \\
6.5 \\
86.1\end{array}$ & $\begin{array}{r}1.8 \\
1.6 \\
1.8 \\
1.4 \\
1.5 \\
1.6 \\
1.7 \\
1.4 \\
1.3 \\
1.7 \\
1.7 \\
1.7 \\
19.2\end{array}$ & $\begin{array}{r}33.5 \\
30.0 \\
28.4 \\
25.3 \\
25.3 \\
23.6 \\
23.9 \\
24.5 \\
25.8 \\
28.4 \\
29.8 \\
32.8 \\
331.4\end{array}$ & $\begin{array}{r}15.2 \\
13.6 \\
14.3 \\
12.5 \\
10.6 \\
10.0 \\
11.7 \\
10.0 \\
10.8 \\
11.7 \\
12.9 \\
14.2 \\
147.3\end{array}$ & $\begin{array}{l}.5 \\
.4 \\
.6 \\
.4 \\
.4 \\
.4 \\
.3 \\
.4 \\
.4 \\
.5 \\
.6 \\
.5 \\
5.4\end{array}$ \\
\hline 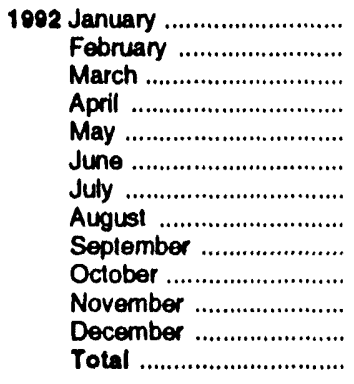 & $\begin{array}{r}.6 \\
.7 \\
.6 \\
.6 \\
.5 \\
.6 \\
.7 \\
.7 \\
.7 \\
.3 \\
.4 \\
\mathrm{E} \\
\mathrm{E} \\
7.1\end{array}$ & $\begin{array}{r}4.3 \\
4.0 \\
4.0 \\
3.4 \\
3.8 \\
3.6 \\
3.1 \\
3.4 \\
3.1 \\
3.6 \\
3.3 \\
3.9 \\
43.5\end{array}$ & $\begin{array}{l}.0 \\
.0 \\
.0 \\
.0 \\
.0 \\
.1 \\
.3 \\
.4 \\
.3 \\
.1 \\
.3 \\
.1 \\
1.8\end{array}$ & $\begin{array}{r}6.9 \\
6.4 \\
7.4 \\
6.4 \\
4.8 \\
5.6 \\
7.2 \\
6.9 \\
6.9 \\
7.2 \\
7.4 \\
8.0 \\
86.4\end{array}$ & $\begin{array}{r}1.8 \\
1.7 \\
1.8 \\
1.7 \\
1.3 \\
1.4 \\
1.6 \\
1.4 \\
1.3 \\
1.6 \\
1.7 \\
1.8 \\
19.0\end{array}$ & $\begin{array}{r}33.5 \\
29.8 \\
30.7 \\
28.0 \\
25.6 \\
22.4 \\
23.7 \\
24.6 \\
25.6 \\
28.5 \\
29.5 \\
33.1 \\
337.6\end{array}$ & $\begin{array}{r}15.6 \\
15.2 \\
15.8 \\
14.1 \\
11.8 \\
11.8 \\
12.0 \\
10.9 \\
11.6 \\
13.2 \\
13.0 \\
13.8 \\
158.8\end{array}$ & $\begin{array}{l}.5 \\
.5 \\
.5 \\
.4 \\
.4 \\
.3 \\
.4 \\
.5 \\
.5 \\
.6 \\
.7 \\
.8 \\
6.5\end{array}$ \\
\hline 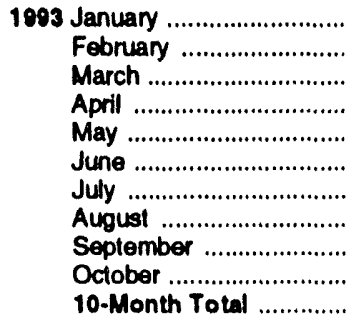 & $\begin{array}{l}.6 \\
.4 \\
.6 \\
.7 \\
.7 \\
.7 \\
.7 \\
.7 \\
.7 \\
.4 \\
6.4\end{array}$ & $\begin{array}{r}4.3 \\
3.7 \\
3.4 \\
3.3 \\
3.1 \\
3.0 \\
3.2 \\
3.4 \\
3.4 \\
3.2 \\
34.0\end{array}$ & $\begin{array}{r}.2 \\
.2 \\
(s) \\
.0 \\
.0 \\
.0 \\
.0 \\
.0 \\
.0 \\
.0 \\
.4\end{array}$ & $\begin{array}{r}8.2 \\
7.4 \\
7.8 \\
7.3 \\
6.7 \\
7.1 \\
9.3 \\
9.1 \\
7.9 \\
8.5 \\
79.3\end{array}$ & $\begin{array}{r}1.8 \\
1.6 \\
1.8 \\
1.7 \\
1.3 \\
1.6 \\
1.8 \\
1.5 \\
1.3 \\
1.8 \\
16.1\end{array}$ & $\begin{array}{r}36.3 \\
32.7 \\
34.3 \\
30.5 \\
26.9 \\
25.4 \\
26.9 \\
25.9 \\
28.8 \\
29.1 \\
286.8\end{array}$ & $\begin{array}{r}15.1 \\
13.9 \\
14.2 \\
12.4 \\
11.8 \\
12.0 \\
12.3 \\
11.1 \\
11.2 \\
12.6 \\
126.6\end{array}$ & $\begin{array}{r}.7 \\
.6 \\
.6 \\
.2 \\
.4 \\
.5 \\
.7 \\
.5 \\
.4 \\
.5 \\
5.1\end{array}$ \\
\hline $\begin{array}{l}199210-\text { Month Total .............. } \\
1091 \text { 10-Month Total ............. }\end{array}$ & $\begin{array}{l}6.0 \\
6.5\end{array}$ & $\begin{array}{l}36.2 \\
35.6\end{array}$ & $\begin{array}{l}1.4 \\
1.4\end{array}$ & $\begin{array}{l}65.9 \\
73.2\end{array}$ & $\begin{array}{l}15.5 \\
15.8\end{array}$ & $\begin{array}{l}272.4 \\
268.7\end{array}$ & $\begin{array}{l}132.1 \\
120.2\end{array}$ & $\begin{array}{l}4.8 \\
4.4\end{array}$ \\
\hline
\end{tabular}

- Through December 1990, the data for Germany are for the former West Germany only. Beginning with January 1991, the data for Germany are for the unitied Germany, I.e., the former East Germany and West Germany.

E=Estimate.

Notes: - Net figures are generally less than gross figures by about 5 percent, the difference being the energy consumed by the generating plants themselves. U.S. geographic coverage is the 50 States and the District of Columbia. - Monthly data may not sum to annual totals due to independert rounding and because precommercial generation is included in some annua tolals but not in the monthly data.

Source: McGraw.Hill Publishing Company, Nucleonics Wook. 
Table 10.4b Nuclear Electricity Gross Generation: Italy Through Spain (Billion Kilowatthours)

\begin{tabular}{|c|c|c|c|c|c|c|c|c|}
\hline & Italy & Japan & Mexico & Netherlands & Pakistan & South Africa & South Korea & Spaln \\
\hline 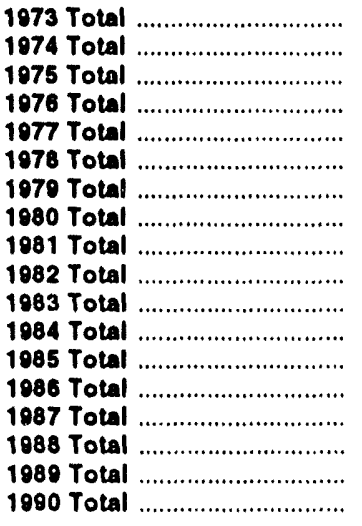 & $\begin{array}{l}3.1 \\
3.4 \\
3.8 \\
3.8 \\
3.4 \\
4.5 \\
2.6 \\
2.2 \\
2.7 \\
6.8 \\
5.8 \\
6.0 \\
7.0 \\
8.7 \\
.2 \\
.0 \\
.0 \\
.0\end{array}$ & $\begin{array}{r}9.4 \\
18.9 \\
21.3 \\
36.6 \\
28.2 \\
53.1 \\
62.0 \\
82.8 \\
86.0 \\
104.5 \\
109.1 \\
127.2 \\
152.0 \\
164.8 \\
182.8 \\
173.6 \\
183.7 \\
191.9\end{array}$ & $\begin{array}{l}0.0 \\
.0 \\
.0 \\
.0 \\
.0 \\
.0 \\
.0 \\
.0 \\
.0 \\
.0 \\
.0 \\
.0 \\
.0 \\
.0 \\
.0 \\
.0 \\
.0 \\
2.1\end{array}$ & $\begin{array}{l}1.1 \\
3.3 \\
3.3 \\
3.9 \\
3.7 \\
4.1 \\
3.5 \\
4.2 \\
3.7 \\
3.9 \\
3.6 \\
3.8 \\
3.8 \\
4.2 \\
3.6 \\
3.7 \\
4.0 \\
3.4\end{array}$ & $\begin{array}{r}0.5 \\
.6 \\
.5 \\
.5 \\
.3 \\
.2 \\
(5) \\
.1 \\
.2 \\
.1 \\
.2 \\
.3 \\
.3 \\
.5 \\
.3 \\
.2 \\
.1 \\
.4\end{array}$ & $\begin{array}{r}0.0 \\
.0 \\
.0 \\
.0 \\
.0 \\
.0 \\
.0 \\
.0 \\
.0 \\
.0 \\
.0 \\
4.2 \\
5.0 \\
0.3 \\
6.6 \\
11.1 \\
11.7 \\
8.0\end{array}$ & $\begin{array}{r}0.0 \\
.0 \\
.0 \\
.0 \\
.1 \\
2.3 \\
3.2 \\
3.5 \\
2.9 \\
3.8 \\
9.0 \\
11.8 \\
16.5 \\
26.1 \\
37.6 \\
38.7 \\
47.2 \\
52.8\end{array}$ & $\begin{array}{r}6.5 \\
7.2 \\
7.5 \\
7.6 \\
6.5 \\
7.6 \\
6.7 \\
5.2 \\
9.4 \\
8.6 \\
10.7 \\
23.1 \\
28.0 \\
37.5 \\
41.2 \\
50.4 \\
56.1 \\
54.3\end{array}$ \\
\hline 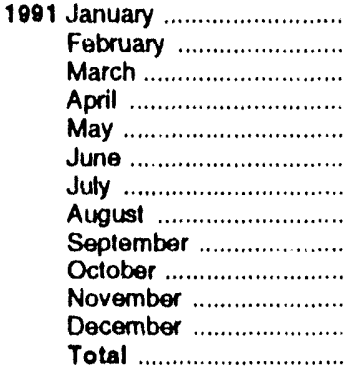 & $\begin{array}{l}.0 \\
.0 \\
.0 \\
.0 \\
.0 \\
.0 \\
.0 \\
.0 \\
.0 \\
.0 \\
.0 \\
.0 \\
.0\end{array}$ & $\begin{array}{r}18.0 \\
15.2 \\
15.6 \\
12.8 \\
12.6 \\
14.8 \\
19.5 \\
22.1 \\
19.7 \\
19.1 \\
17.6 \\
18.9 \\
205.8\end{array}$ & $\begin{array}{l}.5 \\
.4 \\
.5 \\
.5 \\
.5 \\
.4 \\
.4 \\
.4 \\
.0 \\
.0 \\
.2 \\
.5 \\
4.2\end{array}$ & $\begin{array}{r}.3 \\
.2 \\
.1 \\
.2 \\
.4 \\
.4 \\
.4 \\
.4 \\
.1 \\
(3) \\
.4 \\
.4 \\
3.3\end{array}$ & $\begin{array}{l}\text { (s) } \\
\text { (s) } \\
(s) \\
(s) \\
.1 \\
(s) \\
(s) \\
(s) \\
(s) \\
.1 \\
(s) \\
(s) \\
.4\end{array}$ & $\begin{array}{r}.6 \\
.5 \\
1.1 \\
.7 \\
.7 \\
.6 \\
.7 \\
.7 \\
.8 \\
1.2 \\
1.1 \\
1.1 \\
9.7\end{array}$ & $\begin{array}{r}4.1 \\
4.5 \\
4.5 \\
4.1 \\
4.1 \\
4.8 \\
5.5 \\
5.2 \\
4.7 \\
4.9 \\
4.8 \\
5.2 \\
56.3\end{array}$ & $\begin{array}{r}5.3 \\
4.6 \\
4.3 \\
4.2 \\
4.8 \\
4.4 \\
4.7 \\
5.2 \\
4.5 \\
4.7 \\
4.4 \\
4.7 \\
55.6\end{array}$ \\
\hline 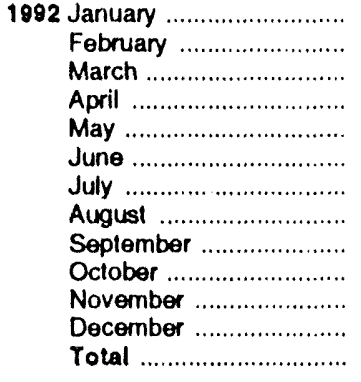 & $\begin{array}{l}.0 \\
.0 \\
.0 \\
.0 \\
.0 \\
.0 \\
0 \\
0 \\
0 \\
.0 \\
0 \\
.0 \\
.0\end{array}$ & $\begin{array}{r}18.5 \\
17.1 \\
17.9 \\
16.0 \\
16.3 \\
17.1 \\
21.1 \\
23.1 \\
17.2 \\
16.2 \\
16.3 \\
19.1 \\
215.8\end{array}$ & $\begin{array}{r}.5 \\
.4 \\
.5 \\
.5 \\
.5 \\
.3 \\
.3 \\
.2 \\
.0 \\
(\mathrm{~s}) \\
.4 \\
.4 \\
3.9\end{array}$ & $\begin{array}{r}.4 \\
.3 \\
.1 \\
.1 \\
.3 \\
.3 \\
.4 \\
.4 \\
.4 \\
.4 \\
.4 \\
.4 \\
3.8\end{array}$ & $\begin{array}{c}(s) \\
.0 \\
(s) \\
(s) \\
(s) \\
.1 \\
.1 \\
.1 \\
.1 \\
.1 \\
.1 \\
.1 \\
.6\end{array}$ & $\begin{array}{r}.9 \\
.4 \\
.4 \\
.4 \\
.7 \\
1.2 \\
1.3 \\
1.0 \\
1.1 \\
1.0 \\
.6 \\
.8 \\
9.8\end{array}$ & $\begin{array}{r}4.6 \\
4.0 \\
4.2 \\
4.5 \\
4.5 \\
4.5 \\
5.3 \\
5.4 \\
4.6 \\
4.9 \\
4.7 \\
5.1 \\
56.4\end{array}$ & $\begin{array}{r}5.4 \\
4.6 \\
4.2 \\
3.6 \\
4.3 \\
4.5 \\
5.0 \\
5.2 \\
4.2 \\
5.0 \\
4.4 \\
5.4 \\
55.8\end{array}$ \\
\hline 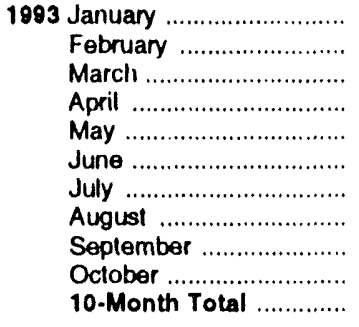 & $\begin{array}{l}.0 \\
.0 \\
.0 \\
.0 \\
.0 \\
.0 \\
.0 \\
.0 \\
.0 \\
.0 \\
.0\end{array}$ & $\begin{array}{r}19.5 \\
17.4 \\
18.9 \\
17.6 \\
17.4 \\
17.9 \\
22.3 \\
24.2 \\
20.5 \\
20.6 \\
196.3\end{array}$ & $\begin{array}{l}.5 \\
.3 \\
.1 \\
.5 \\
.5 \\
.5 \\
.5 \\
.5 \\
.5 \\
.4 \\
4.2\end{array}$ & $\begin{array}{l}.4 \\
.3 \\
.1 \\
.1 \\
.4 \\
.4 \\
.4 \\
.4 \\
.4 \\
.4 \\
3.2\end{array}$ & $\begin{array}{r}(s) \\
.1 \\
.1 \\
.1 \\
(s) \\
(s) \\
.1 \\
(s) \\
.1 \\
\text { (s) } \\
.4\end{array}$ & $\begin{array}{r}.6 \\
.6 \\
.5 \\
.6 \\
.8 \\
.5 \\
1.0 \\
.9 \\
.5 \\
.4 \\
6.5\end{array}$ & $\begin{array}{r}4.8 \\
4.5 \\
4.6 \\
4.8 \\
5.3 \\
5.1 \\
5.5 \\
4.9 \\
4.6 \\
4.6 \\
48.8\end{array}$ & $\begin{array}{r}5.4 \\
4.3 \\
4.9 \\
4.2 \\
4.1 \\
4.4 \\
5.0 \\
5.1 \\
4.6 \\
4.7 \\
46.6\end{array}$ \\
\hline $\begin{array}{l}1992 \text { 10-Month Total ............. } \\
1991 \text { 10-Month Total ............ }\end{array}$ & $\begin{array}{l}.0 \\
.0\end{array}$ & $\begin{array}{l}180.4 \\
169.3\end{array}$ & $\begin{array}{l}3.1 \\
3.5\end{array}$ & $\begin{array}{l}3.0 \\
2.6\end{array}$ & $\begin{array}{l}.4 \\
.4\end{array}$ & $\begin{array}{l}8.5 \\
7.6\end{array}$ & $\begin{array}{l}46.6 \\
46.3\end{array}$ & $\begin{array}{l}46.0 \\
46.5\end{array}$ \\
\hline
\end{tabular}

$\mathrm{R}=$ Revised data. (s)=Less than 0.05 billion kilowatthours

Notes: - Net figures are generally less than gross figures by aboul 5 percent, the difference being the energy consumed by the generating plants themselves. - U.S. geographic coverage is the 50 Stales and the District of
Columbia. - Monthly data may not sum to annual tolats due to independent rounding and because precommercial generation is included in some annual lotals but not in the monthly dala.

Source: McGraw-Hill Publishing Company, Nucleonics Week. 
Table 10.4c Nuclear Electricity Gross Generation: Sweden Through United States and Total

(Billion Kilowatthours)

\begin{tabular}{|c|c|c|c|c|c|c|c|}
\hline & Sweden & Swltzerland & Talwan & $\begin{array}{l}\text { United } \\
\text { KIngdoma }\end{array}$ & $\begin{array}{l}\text { Total } \\
\text { Excluding U.S. }\end{array}$ & $\begin{array}{l}\text { United } \\
\text { States }\end{array}$ & Totalb \\
\hline 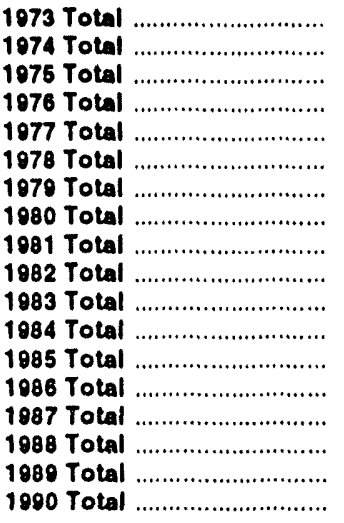 & $\begin{array}{r}2.1 \\
2.3 \\
12.0 \\
16.0 \\
19.9 \\
23.8 \\
21.0 \\
26.7 \\
37.7 \\
38.8 \\
40.4 \\
51.3 \\
58.6 \\
69.9 \\
67.2 \\
69.4 \\
65.6 \\
68.2\end{array}$ & $\begin{array}{r}6.2 \\
7.0 \\
7.7 \\
7.9 \\
8.1 \\
8.3 \\
11.8 \\
14.3 \\
15.2 \\
15.0 \\
15.5 \\
16.3 \\
22.4 \\
22.5 \\
23.0 \\
22.7 \\
22.8 \\
23.6\end{array}$ & $\begin{array}{r}0.0 \\
.0 \\
.0 \\
.0 \\
.1 \\
2.7 \\
6.3 \\
8.2 \\
10.7 \\
13.1 \\
18.0 \\
24.3 \\
28.7 \\
26.9 \\
33.1 \\
29.0 \\
28.3 \\
32.0\end{array}$ & $\begin{array}{l}28.2 \\
33.8 \\
30.5 \\
36.8 \\
38.1 \\
36.6 \\
38.5 \\
37.2 \\
38.0 \\
44.1 \\
49.6 \\
54.1 \\
59.7 \\
58.2 \\
56.2 \\
50.4 \\
71.6 \\
66.1\end{array}$ & $\begin{array}{r}101.4 \\
121.7 \\
151.8 \\
187.1 \\
207.8 \\
263.5 \\
300.1 \\
354.3 \\
442.4 \\
489.9 \\
573.0 \\
717.7 \\
862.7 \\
044.8 \\
1,001.2 \\
1,038.7 \\
1,007.1 \\
1,119.1\end{array}$ & $\begin{array}{r}87.8 \\
124.3 \\
182.3 \\
201.8 \\
264.2 \\
202.4 \\
270.6 \\
265.4 \\
288.5 \\
298.6 \\
313.6 \\
343.8 \\
402.7 \\
434.1 \\
470.5 \\
554.1 \\
557.0 \\
603.4\end{array}$ & $\begin{array}{r}189.3 \\
246.0 \\
334.1 \\
388.0 \\
472.0 \\
555.0 \\
570.7 \\
810.0 \\
730.9 \\
788.5 \\
887.5 \\
1,061.5 \\
1,265.4 \\
1,378.9 \\
1,460.7 \\
1,502.8 \\
1,654.1 \\
1,722.6\end{array}$ \\
\hline 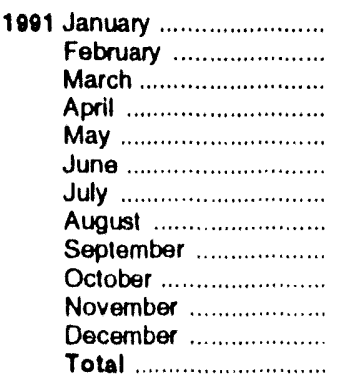 & $\begin{array}{r}7.6 \\
6.9 \\
7.6 \\
6.9 \\
5.7 \\
4.7 \\
4.6 \\
5.2 \\
5.5 \\
7.2 \\
7.3 \\
7.6 \\
76.8\end{array}$ & $\begin{array}{r}2.3 \\
2.1 \\
2.3 \\
2.2 \\
2.0 \\
1.1 \\
1.5 \\
1.0 \\
1.8 \\
2.3 \\
2.2 \\
2.3 \\
22.9\end{array}$ & $\begin{array}{r}2.4 \\
2.2 \\
2.9 \\
2.5 \\
2.8 \\
3.2 \\
3.2 \\
3.6 \\
3.1 \\
3.1 \\
3.0 \\
3.2 \\
35.3\end{array}$ & $\begin{array}{r}6.6 \\
6.8 \\
6.7 \\
5.0 \\
4.5 \\
6.1 \\
5.1 \\
5.4 \\
6.6 \\
5.9 \\
5.2 \\
6.6 \\
70.4\end{array}$ & $\begin{array}{r}111.2 \\
101.1 \\
103.3 \\
89.6 \\
87.3 \\
87.0 \\
95.4 \\
98.6 \\
95.3 \\
101.2 \\
101.7 \\
110.5 \\
1,182.2\end{array}$ & $\begin{array}{r}56.6 \\
50.2 \\
51.6 \\
43.8 \\
49.2 \\
56.9 \\
63.7 \\
61.4 \\
54.4 \\
50.2 \\
48.7 \\
56.3 \\
643.0\end{array}$ & $\begin{array}{r}167.8 \\
151.3 \\
154.9 \\
133.4 \\
136.6 \\
143.9 \\
159.1 \\
160.0 \\
149.7 \\
151.4 \\
150.4 \\
166.8 \\
1,825.2\end{array}$ \\
\hline 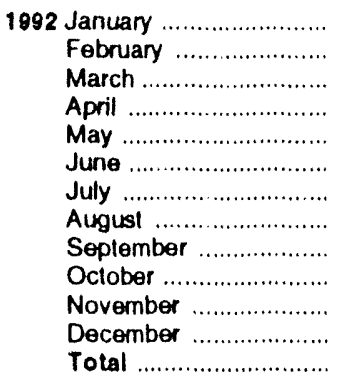 & $\begin{array}{r}7.6 \\
6.8 \\
7.1 \\
6.7 \\
4.7 \\
3.9 \\
3.6 \\
3.5 \\
3.9 \\
5.2 \\
5.2 \\
5.4 \\
63.5\end{array}$ & $\begin{array}{r}2.3 \\
2.1 \\
2.2 \\
1.9 \\
1.9 \\
1.3 \\
1.7 \\
1.1 \\
2.0 \\
2.3 \\
2.2 \\
2.3 \\
23.4\end{array}$ & $\begin{array}{r}3.1 \\
2.2 \\
2.2 \\
2.6 \\
2.6 \\
2.9 \\
3.3 \\
3.6 \\
2.8 \\
2.9 \\
3.2 \\
2.6 \\
33.8\end{array}$ & $\begin{array}{r}6.5 \\
6.3 \\
8.3 \\
5.0 \\
6.0 \\
7.0 \\
4.9 \\
5.5 \\
6.9 \\
5.7 \\
6.1 \\
10.4 \\
78.5\end{array}$ & $\begin{array}{r}113.1 \\
102.6 \\
107.8 \\
95.9 \\
90.1 \\
88.9 \\
96.0 \\
97.9 \\
93.2 \\
98.8 \\
99.9 \\
\text { E } 114.1 \\
\text { E } 1,206.0^{1,20}\end{array}$ & $\begin{array}{r}60.6 \\
55.4 \\
48.3 \\
44.3 \\
48.1 \\
53.7 \\
59.0 \\
61.6 \\
53.2 \\
51.5 \\
53.2 \\
61.0 \\
650.0\end{array}$ & $\begin{array}{r}173.7 \\
158.1 \\
156.1 \\
140.2 \\
138.2 \\
142.7 \\
155.0 \\
159.5 \\
146.4 \\
150.3 \\
153.1 \\
\text { E } 175.1 \\
\text { E } 1,856.0\end{array}$ \\
\hline 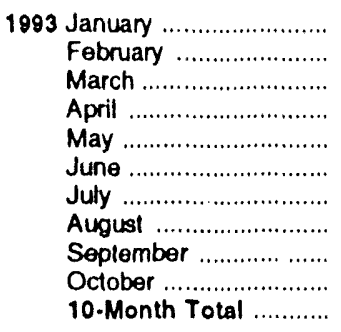 & $\begin{array}{r}5.8 \\
5.9 \\
7.1 \\
6.6 \\
4.6 \\
4.7 \\
3.1 \\
3.2 \\
4.1 \\
4.7 \\
49.8\end{array}$ & $\begin{array}{r}2.3 \\
2.1 \\
2.3 \\
2.0 \\
1.9 \\
1.2 \\
1.8 \\
1.1 \\
1.7 \\
2.2 \\
18.7\end{array}$ & $\begin{array}{r}3.0 \\
2.7 \\
2.8 \\
2.8 \\
2.7 \\
2.6 \\
3.4 \\
3.6 \\
2.9 \\
2.8 \\
29.2\end{array}$ & $\begin{array}{r}7.6 \\
7.9 \\
8.3 \\
7.7 \\
6.0 \\
\mathrm{R}_{8.2} \\
\mathrm{P}_{6.4} \\
6.1 \\
\mathrm{R}_{8.4} \\
\mathrm{E}_{7.0} \\
\mathrm{E}_{73.6}\end{array}$ & $\begin{array}{r}117.0 \\
106.9 \\
112.3 \\
103.2 \\
94.6 \\
P_{95.6} \\
A_{104.2} \\
A_{102.3} \\
A_{102.0} \\
E_{103.9} \\
E_{1,042.0}\end{array}$ & $\begin{array}{r}61.8 \\
53.7 \\
49.8 \\
45.4 \\
52.7 \\
55.4 \\
58.9 \\
58.9 \\
52.5 \\
46.9 \\
536.1\end{array}$ & $\begin{array}{r}178.9 \\
160.6 \\
162.1 \\
148.7 \\
147.3 \\
P_{151.0} \\
163.1 \\
161.2 \\
P_{154.4} \\
E_{150.8} \\
E_{1,578.2}\end{array}$ \\
\hline $\begin{array}{l}1992 \text { 10-Month Total .......... } \\
1991 \text { 10-Month Total ........... }\end{array}$ & $\begin{array}{l}53.0 \\
61.0\end{array}$ & $\begin{array}{l}18.9 \\
18.4\end{array}$ & $\begin{array}{l}28.1 \\
29.1\end{array}$ & $\begin{array}{l}62.0 \\
58.6\end{array}$ & $\begin{array}{l}984.3 \\
970.0\end{array}$ & $\begin{array}{l}535.7 \\
538.0\end{array}$ & $\begin{array}{l}1,520.0 \\
1,508.0\end{array}$ \\
\hline
\end{tabular}

a Monthly data for the United Kingdom are tolals for 4- or 5-week reporting periods, not calendar months.

b - Tolal" equals nuclear-generated electricity from all countries excep Bulgaria, China, Cuba, the lormer Czechostovakia, Hurgary, North Korea, Poland, Romania, the former U.S.S.R., and Slovenia (pant of the former Yugoslavia).

RaRevlsed data. EmEatimate.

Noles: - Nel figures are generally less than gross figures by about 5

percent, the difference being the en rigy consumed by the generating plants themselves. - U.S. geographic coverage is the 50 States and the District of Columbia. - Monthly data may not sum to annual totals due to independent rounding and because precommercial generation is included in some annual totals but nol in the monthly dala. - Data for countries may not sum to world lotaks due to independent rounding.

Source: MCGraw-Hill Publishing Company, Nucloonics Woek. 


\section{Sources for Tables 10.1a and $10.1 b$}

- United States: Table 3.1a.

- Other Countries: Annual Data: 1973-1979-Energy Information Administration (EIA), International Energy Annual 1981, Table 8. 1980-EIA, International Energy Annual 1989, Table 1. 1981-EIA, International Energy Annual 1990, Table 1. 1982EIA, International Energy Annual 1991, Table 1. 1983-1992-EIA, International Energy Annual 1992,
Table 1. Monthly Data: Petroleum Intelligence Weekly, the Oil and Gas Journal, and other industry sources.

- World: Annual Data: 1973-1979-EIA, Internalional Energy Annual 1981, Table 8. 1980-EIA, International Energy Annual 1989, Table 1. 1981EIA, International Energy Annual 1990, Table 1. 1982-EIA, International Energy Annual 1991, Table 1. 1983-1992-EIA, International Energy Annual 1992, Table 1. Monthly Data: EIA, International Petroleum Statistics Report, sum of all countries' monthly data. 


\section{Appendix A. Thermal Conversion Factors}

The thermal conversion factors presented in the following eight tables can be used to estimate the heat content in British thermal units (Btu) of a given amount of energy measured in physical units, such as barrels or cubic feet. For example, 10 barrels of asphalt have a heat content of approximately 66.36 million Btu (10 barrels $\times 6.636$ million Btu/barrel $=$ 66.36 million $\mathrm{Btu})$.

Thermal conversion factors for hydrocarbon mixes (Table A1) are weighted averages of the thermal conversion factors for each hydrocarbon included in the mix. For example, in calculating the thermal conversion factor for a $60-40$ butane-propane mixture, the thernal conversion factor for butane is weighted 1.5 times more heavily than the thermal conversion factor for propane.

In general, the annual thermal conversion factors presented in Tables $A 1$ through $A 8$ are computed from final annual data. However, if the current year's final data are not available in time for publication, thermal conversion factors for the current year are computed from the best available data and are labeled "preliminary." The source of each factor is described in the section entitled "Thermal Conversion Factor Source Documculation," which follows Table A8 in this appendix.

\section{Table A1. Approximate Heat Content of Petroleum Products} (Million Btu per Barrel)

\begin{tabular}{|c|c|c|c|}
\hline Petroleum Product & Heat Content & Potroloum Product & Heat Content \\
\hline 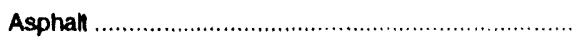 & 6.636 & Petrochemical Feedstocks & \\
\hline Aviation Gasoline ......................... & 5.048 & Naphiha Loss $\operatorname{tran} 401^{\circ} \mathrm{F}$. & 5.248 \\
\hline 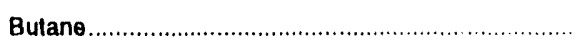 & 4.326 & Other Oils Equal to or Greater Than $401^{\circ} \mathrm{r} \ldots$ & 5.825 \\
\hline Butane-Propane Mixture ${ }^{a}$. & 4.130 & Stifl Gas ............. & 6.000 \\
\hline Distillate Fuel Oll .................. & 5.825 & Petroleum Coke..... & 6.024 \\
\hline Ethane .................................. & 3.082 & Plant Condensate... & 5.418 \\
\hline Ethane-Propane Moxture ${ }^{b} \ldots \ldots$ & 3308 & Propane .................. & 3.836 \\
\hline Isobutane........................... & 3.974 & Residual Fuel Oll. & 6.287 \\
\hline Jet Fuel, Kerosene Type .................................. & 5.670 & Road Oil ............... & 6.636 \\
\hline 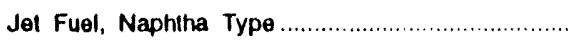 & 5.355 & Special Naphthas ... & 5.248 \\
\hline 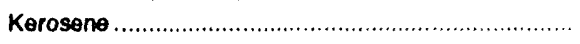 & 5.670 & Still Gas ..................... & 6.000 \\
\hline 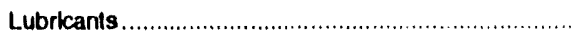 & 6.065 & Untinished Oits ................... & 5.825 \\
\hline 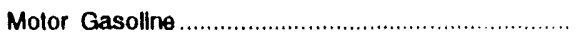 & 5.253 & 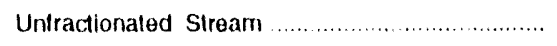 & 5.418 \\
\hline 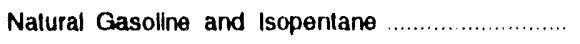 & 4.620 & Waxes............... & 5.537 \\
\hline Pentanes Plus & 4.620 & Miscellarieous ... & 5.796 \\
\hline
\end{tabular}

\footnotetext{
a 60 percent butane and 40 percent propane.

70 percent elhane and 30 percent proparie.

Source: See "Thermal Conversion Factor Source Documentation," which follows Table A8
} 

Table A2. Approximate Heat Content of Crude Oil, Crude Oll and Products, and
Natural Gas Plant Liquids

(Million Btu per Barrel)

\begin{tabular}{|c|c|c|c|c|c|c|}
\hline & \multicolumn{3}{|c|}{ Crude Oil } & \multicolumn{2}{|c|}{ Crude Oll and Products } & \multirow{2}{*}{$\begin{array}{c}\text { Netural am } \\
\text { Plent } \\
\text { Llquide }\end{array}$} \\
\hline & Production & Imports & Exports & Imports & Exports & \\
\hline 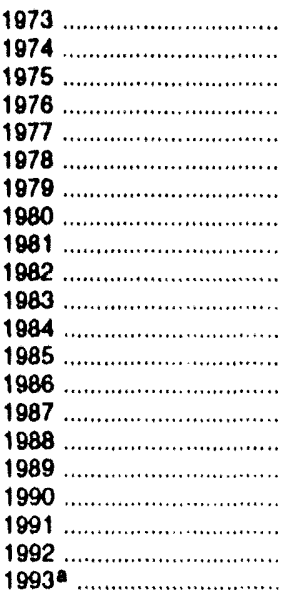 & $\begin{array}{l}5.800 \\
5.800 \\
5.800 \\
5.800 \\
5.800 \\
5.800 \\
5.800 \\
5.800 \\
5.800 \\
5.800 \\
5.800 \\
5.800 \\
5.800 \\
5.800 \\
5.800 \\
5.800 \\
5.800 \\
5.800 \\
5.800 \\
5.800 \\
5.800\end{array}$ & $\begin{array}{l}5.817 \\
5.827 \\
5.821 \\
5.808 \\
5.810 \\
5.802 \\
5.810 \\
5.812 \\
5.818 \\
5.826 \\
5.825 \\
5.823 \\
5.832 \\
5.903 \\
5.901 \\
5.900 \\
5.906 \\
5.934 \\
5.948 \\
5.953 \\
5.953\end{array}$ & $\begin{array}{l}5.800 \\
5.800 \\
5.800 \\
5.800 \\
5.800 \\
5.800 \\
5.800 \\
5.800 \\
5.800 \\
5.800 \\
5.800 \\
5.800 \\
5.800 \\
5.800 \\
5.800 \\
5.800 \\
5.800 \\
5.800 \\
5.800 \\
5.800 \\
5.800\end{array}$ & $\begin{array}{l}5.897 \\
5.884 \\
5.858 \\
5.856 \\
5.834 \\
5.839 \\
5.810 \\
5.796 \\
5.775 \\
5.775 \\
5.774 \\
5.745 \\
5.736 \\
5.808 \\
5.820 \\
5.820 \\
5.833 \\
5.849 \\
5.873 \\
5.877 \\
5.877\end{array}$ & $\begin{array}{l}5.752 \\
5.774 \\
5.748 \\
5.745 \\
5.797 \\
5.808 \\
5.832 \\
5.820 \\
5.821 \\
5.820 \\
5.800 \\
5.850 \\
5.814 \\
5.832 \\
5.858 \\
5.840 \\
5.857 \\
5.833 \\
5.823 \\
5.777 \\
5.777\end{array}$ & $\begin{array}{l}4.049 \\
4.011 \\
3.984 \\
3.964 \\
3.941 \\
3.925 \\
3.955 \\
3.914 \\
3.930 \\
3.872 \\
3.839 \\
3.812 \\
3.815 \\
3.797 \\
3.804 \\
3.800 \\
3.826 \\
3.822 \\
3.807 \\
3.804 \\
3.804\end{array}$ \\
\hline
\end{tabular}

a Preliminary.

Note: Crude oil inchudes lease condensate

Source: See "Thermal Conversion Factor Source Documentation." which follows Table A8.

Table A3. Approximate Heat Content of Petroleur. Product Weighted Averages (Million Btu per Barrel)

\begin{tabular}{|c|c|c|c|c|c|c|c|c|}
\hline & \multicolumn{5}{|c|}{ Consumption } & \multirow[b]{2}{*}{ Imports } & \multirow[b]{2}{*}{ Exports } & \multirow[b]{2}{*}{$\begin{array}{c}\text { LPG } \\
\text { Consumption }\end{array}$} \\
\hline & $\begin{array}{l}\text { Residential } \\
\text { and } \\
\text { Commercial }\end{array}$ & Industrial & Transportation & $\begin{array}{l}\text { Electric } \\
\text { Utilities }\end{array}$ & Total & & & \\
\hline $\begin{array}{l}1973 \ldots \ldots \\
1974 \ldots \ldots \ldots \\
1975 \ldots \ldots \ldots \ldots \ldots \\
1976 \\
1977 \ldots \ldots \ldots \ldots \\
1978 \ldots \ldots \ldots \\
1979 \ldots \ldots \ldots \\
1980 \ldots \ldots \\
1981 \\
1982 \ldots \ldots \ldots \\
1983 \ldots \ldots \ldots \\
1984 \ldots \ldots \ldots \ldots \\
1985 \\
198 \\
198\end{array}$ & $\begin{array}{l}5.387 \\
5.377 \\
5.358 \\
5.383 \\
5.389 \\
5.382 \\
5.471 \\
5.468 \\
5.409 \\
5.392 \\
5.286 \\
5.384 \\
5.326 \\
5.357 \\
5.318 \\
5.323 \\
5.260 \\
5.212 \\
5.163 \\
5.158 \\
5.158\end{array}$ & $\begin{array}{l}5.568 \\
5.538 \\
5.528 \\
5.538 \\
5.555 \\
5553 \\
5.418 \\
5.376 \\
5.313 \\
5.263 \\
5.273 \\
5.223 \\
5.221 \\
5.286 \\
5.253 \\
5.247 \\
5.233 \\
5.272 \\
5.192 \\
5.188 \\
5.188\end{array}$ & $\begin{array}{l}5.395 \\
5.394 \\
5.392 \\
5.395 \\
5.400 \\
5.404 \\
5.428 \\
5.440 \\
5.432 \\
5.422 \\
5.415 \\
5.422 \\
5.423 \\
5.427 \\
5.430 \\
5.434 \\
5.440 \\
5.445 \\
5.442 \\
5.444 \\
5.444\end{array}$ & $\begin{array}{l}6.245 \\
6.238 \\
6.250 \\
6.251 \\
6.249 \\
6.251 \\
6.258 \\
6.254 \\
6.258 \\
6.258 \\
6.255 \\
6.251 \\
6.247 \\
6.257 \\
6.249 \\
6.250 \\
6.241 \\
6.247 \\
6.248 \\
6.243 \\
6.243\end{array}$ & $\begin{array}{l}5.515 \\
5.504 \\
5.494 \\
5.504 \\
5.518 \\
5.519 \\
5.494 \\
5.479 \\
5.448 \\
5.415 \\
5.406 \\
5.395 \\
5.387 \\
5.418 \\
5.403 \\
5.410 \\
5.410 \\
5.411 \\
5.384 \\
5.376 \\
5.376\end{array}$ & $\begin{array}{l}5.983 \\
5.959 \\
5.935 \\
5.980 \\
5.908 \\
5.955 \\
5.811 \\
5.748 \\
5.659 \\
5.664 \\
5.677 \\
5.613 \\
5.572 \\
5.624 \\
5.599 \\
5.618 \\
5.641 \\
5.614 \\
5.636 \\
5.623 \\
5.623\end{array}$ & $\begin{array}{l}5.752 \\
5.773 \\
5.747 \\
5.743 \\
5.796 \\
5.814 \\
5.864 \\
5.841 \\
5.837 \\
5.829 \\
5.800 \\
5.867 \\
5.819 \\
5.839 \\
5.860 \\
5.842 \\
5.869 \\
5.838 \\
5.827 \\
5.774 \\
5.774\end{array}$ & $\begin{array}{l}3.746 \\
3.730 \\
3.715 \\
3.711 \\
3.677 \\
3.669 \\
3.680 \\
3.674 \\
3.643 \\
3.615 \\
3.614 \\
3.599 \\
3.603 \\
3.640 \\
3.659 \\
3.652 \\
3.683 \\
3.625 \\
3.614 \\
3.624 \\
3.624\end{array}$ \\
\hline
\end{tabular}

- Preliminary.

Note: Weighted averages of the products included in each category are calculated by using heal content values shown in Table A1.

Source: See "Thermal Conversion Factor Source Documentation," which follows Table AB. 
Table A4. Approximate Heat Content of Natural Gas (Btu per Cubic Foot)

\begin{tabular}{|c|c|c|c|c|c|c|c|}
\hline & \multicolumn{2}{|c|}{ Production } & \multicolumn{3}{|c|}{ Coneumption } & \multirow[b]{2}{*}{ Imports } & \multirow[b]{2}{*}{ Exporte } \\
\hline & Dry & $\begin{array}{l}\text { Markoted } \\
\text { (Wot) }\end{array}$ & $\begin{array}{c}\text { Than Electrio } \\
\text { Utilities }\end{array}$ & $\begin{array}{l}\text { Electeric } \\
\text { Utilities }\end{array}$ & Totel & & \\
\hline 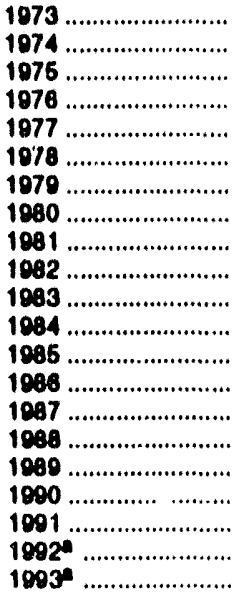 & $\begin{array}{l}1.021 \\
1,024 \\
1,021 \\
1,020 \\
1,021 \\
1,010 \\
1,021 \\
1,028 \\
1.027 \\
1.028 \\
1.031 \\
1,031 \\
1,032 \\
1.030 \\
1,031 \\
1,029 \\
1,031 \\
1.031 \\
1,030 \\
1.030 \\
1.030\end{array}$ & $\begin{array}{l}1,093 \\
1,097 \\
1,095 \\
1,093 \\
1,093 \\
1,088 \\
1,092 \\
1,098 \\
1,103 \\
1,107 \\
1,115 \\
1,109 \\
1,112 \\
1,110 \\
1,112 \\
1,109 \\
1,107 \\
1,105 \\
1,108 \\
1,110 \\
1,110\end{array}$ & $\begin{array}{l}1,020 \\
1,024 \\
1,020 \\
1,019 \\
1,019 \\
1,016 \\
1,018 \\
1,024 \\
1,025 \\
1,028 \\
1,031 \\
1,030 \\
1,031 \\
1,029 \\
1,031 \\
1,029 \\
1,031 \\
1,030 \\
1,031 \\
1,031 \\
1,031\end{array}$ & $\begin{array}{l}1,024 \\
1,022 \\
1,026 \\
1,023 \\
1,029 \\
1,034 \\
1,035 \\
1,035 \\
1,035 \\
1,036 \\
1,030 \\
1,035 \\
1,038 \\
1,034 \\
1,032 \\
1,028 \\
1,030 \\
1,034 \\
1,024 \\
1,022 \\
1,022\end{array}$ & $\begin{array}{l}1,021 \\
1,024 \\
1,021 \\
1,020 \\
1,021 \\
1,019 \\
1,021 \\
1,026 \\
1,027 \\
1,020 \\
1,031 \\
1,031 \\
1,032 \\
1,030 \\
1,031 \\
1,020 \\
1,031 \\
1,031 \\
1,030 \\
1,030 \\
1,030\end{array}$ & $\begin{array}{r}1,026 \\
1,027 \\
1,026 \\
1,026 \\
1,026 \\
1,030 \\
1,037 \\
1,022 \\
1,014 \\
1,018 \\
1,024 \\
1,005 \\
1,002 \\
0097 \\
0009 \\
1,002 \\
1,004 \\
1,012 \\
1,014 \\
1,011 \\
1,011\end{array}$ & $\begin{array}{l}1,023 \\
1,016 \\
1,014 \\
1,013 \\
1,013 \\
1,013 \\
1,013 \\
1,013 \\
1,011 \\
1,011 \\
1,010 \\
1,010 \\
1,011 \\
1,008 \\
1,011 \\
1,018 \\
1,010 \\
1,018 \\
1,022 \\
1,018 \\
1,018\end{array}$ \\
\hline
\end{tabular}

- Proliminary.

Source: See "Thermal Corversion Facior Source Documentalion," which follows Table A8.

Table A5. Approximate Heat Content of Coal (Million Btu per Short Ton)

\begin{tabular}{|c|c|c|c|c|c|c|c|c|}
\hline & \multirow[b]{2}{*}{ Production } & \multicolumn{5}{|c|}{ Coneumption } & \multirow[b]{2}{*}{ Imports } & \multirow[b]{2}{*}{ Exporte } \\
\hline & & $\begin{array}{l}\text { Reoldential } \\
\text { and } \\
\text { Commerclal }\end{array}$ & $\begin{array}{l}\text { Coke } \\
\text { Plante }\end{array}$ & $\begin{array}{c}\text { Other } \\
\text { Induetrlap }\end{array}$ & $\begin{array}{l}\text { Electric } \\
\text { Utiliticeb }\end{array}$ & Total & & \\
\hline 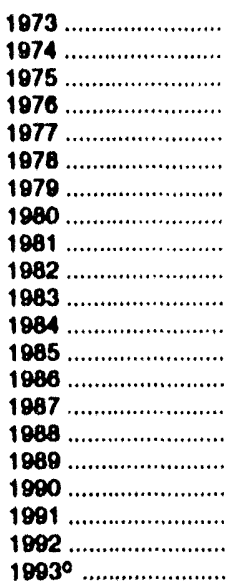 & $\begin{array}{l}23.376 \\
23.072 \\
22.897 \\
22.855 \\
22.597 \\
22.248 \\
22.454 \\
22.415 \\
22.308 \\
22.239 \\
22.052 \\
22.010 \\
21.870 \\
21.913 \\
21.822 \\
21.823 \\
21.765 \\
21.822 \\
21.681 \\
\text { A } 21.646 \\
\text { ค } 21.646\end{array}$ & $\begin{array}{r}22.831 \\
22.479 \\
22.261 \\
22.774 \\
22.918 \\
22.466 \\
22.242 \\
22.543 \\
22.474 \\
22.695 \\
22.775 \\
22.844 \\
22.646 \\
22.947 \\
23.404 \\
23.571 \\
23.650 \\
23.137 \\
23.114 \\
\text { ค } 23.105 \\
23.105\end{array}$ & $\begin{array}{l}26.780 \\
26.778 \\
26.782 \\
26.781 \\
26.787 \\
26.789 \\
26.788 \\
26.790 \\
26.794 \\
26.797 \\
26.798 \\
26.799 \\
26.798 \\
26.798 \\
26.799 \\
26.799 \\
26.800 \\
26.799 \\
26.799 \\
26.799 \\
26.799\end{array}$ & $\begin{array}{r}22.586 \\
22.419 \\
22.436 \\
22.530 \\
22.322 \\
22.207 \\
22.452 \\
22.690 \\
22.585 \\
22.712 \\
22.691 \\
22.543 \\
22.020 \\
22.198 \\
22.381 \\
22.360 \\
22.347 \\
22.457 \\
22.460 \\
22.250 \\
{ }^{A} 22.250\end{array}$ & $\begin{array}{r}22.246 \\
21.781 \\
21.642 \\
21.679 \\
21.508 \\
21.275 \\
21.364 \\
21.285 \\
21.085 \\
21.194 \\
21.133 \\
21.101 \\
20.959 \\
21.084 \\
21.136 \\
20.800 \\
20.848 \\
20.929 \\
20.755 \\
20.787 \\
20.787\end{array}$ & $\begin{array}{r}23.057 \\
22.677 \\
22.516 \\
22.488 \\
22.265 \\
22.017 \\
22.100 \\
21.847 \\
21.713 \\
21.674 \\
21.576 \\
21.573 \\
21.366 \\
21.462 \\
21.517 \\
21.328 \\
21.272 \\
21.331 \\
21.146 \\
\text { ค } 21.143 \\
\text { ค } 21.143\end{array}$ & $\begin{array}{l}25.000 \\
25.000 \\
25.000 \\
25.000 \\
25.000 \\
25.000 \\
25.000 \\
25.000 \\
25.000 \\
25.000 \\
25.000 \\
25.000 \\
25.000 \\
25.000 \\
25.000 \\
25.000 \\
25.000 \\
25.000 \\
25.000 \\
25.000 \\
25.000\end{array}$ & $\begin{array}{r}26.500 \\
28.700 \\
26.562 \\
26.601 \\
26.548 \\
26.478 \\
26.548 \\
26.384 \\
26.160 \\
26.223 \\
26.291 \\
26.402 \\
26.307 \\
26.202 \\
26.201 \\
26.290 \\
26.160 \\
26.202 \\
26.188 \\
26.161 \\
26.161\end{array}$ \\
\hline
\end{tabular}

Inctudes Iraneportaition.

bata shown in this column are not the same as those shown in the Electric Power Monthly (EPM). The EPM data report coel recolpte; the dala shown here reprosent coal consumption.

- Proliminary.

$\mathrm{A}=$ Plovised dala

Source: See "Thermal Conversion Factor Source Documentation," which follows Table AB. 
Table A6. Approximate Heat Content of Bituminous Coal and Lignite (Million Btu per Short Ton)

\begin{tabular}{|c|c|c|c|c|c|c|c|c|}
\hline & \multirow[b]{2}{*}{ Production } & \multicolumn{5}{|c|}{ Consumption } & \multirow[b]{2}{*}{ Importe } & \multirow[b]{2}{*}{ Exporte } \\
\hline & & $\begin{array}{l}\text { Residential } \\
\text { and } \\
\text { Commercial }\end{array}$ & $\begin{array}{l}\text { Coke } \\
\text { Plante }\end{array}$ & $\begin{array}{c}\text { Other } \\
\text { Industriala }\end{array}$ & $\begin{array}{l}\text { Eloctric } \\
\text { Utilitios }\end{array}$ & Total & & \\
\hline 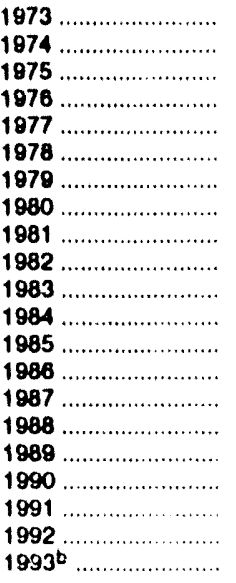 & $\begin{array}{l}23.391 \\
23.087 \\
22.810 \\
22.863 \\
22.597 \\
22.242 \\
22.449 \\
22.411 \\
22.301 \\
22.233 \\
22.048 \\
22.005 \\
21.867 \\
21.908 \\
21.918 \\
21.817 \\
21.759 \\
21.819 \\
21.678 \\
\text { म } 21.643 \\
\text { F } 21.643\end{array}$ & $\begin{array}{r}22.887 \\
22.523 \\
22.258 \\
22.819 \\
22.594 \\
22.078 \\
21.884 \\
22.488 \\
22.010 \\
22.226 \\
22.438 \\
22.406 \\
22.568 \\
22.669 \\
22.800 \\
23.135 \\
22.917 \\
22.678 \\
22.635 \\
22168 \\
22.768\end{array}$ & $\begin{array}{l}26.800 \\
26.800 \\
26.800 \\
26.800 \\
26.800 \\
26.800 \\
26.800 \\
26.800 \\
26.800 \\
26.800 \\
26.800 \\
26.800 \\
26.800 \\
26.800 \\
26.800 \\
26.800 \\
26.800 \\
26.800 \\
26.800 \\
26.800 \\
26.800\end{array}$ & $\begin{array}{l}22.585 \\
22.420 \\
22.439 \\
22.528 \\
22.290 \\
22.175 \\
22.436 \\
22.690 \\
22.572 \\
22.695 \\
22.680 \\
22.525 \\
22.013 \\
22.185 \\
22.360 \\
22.341 \\
22.324 \\
22.444 \\
22.448 \\
22.242 \\
22.242\end{array}$ & $\begin{array}{r}22.262 \\
21.799 \\
21.659 \\
21.692 \\
21.521 \\
21.284 \\
21.372 \\
21.301 \\
21.091 \\
21.200 \\
21.141 \\
21.108 \\
20.965 \\
21.091 \\
21.143 \\
20.905 \\
20.854 \\
20.935 \\
20.761 \\
20.792 \\
20.792\end{array}$ & $\begin{array}{r}23.073 \\
22.694 \\
22.522 \\
22.509 \\
22.266 \\
22.014 \\
22.100 \\
21.950 \\
21.710 \\
21.670 \\
21.576 \\
21.570 \\
21.368 \\
21.462 \\
21.514 \\
21.324 \\
21.268 \\
21.330 \\
21.146 \\
21.142 \\
21.142\end{array}$ & $\begin{array}{l}25.000 \\
25.000 \\
25.000 \\
25.000 \\
25.000 \\
25.000 \\
25.000 \\
25.000 \\
25.000 \\
25.000 \\
25.000 \\
25.000 \\
25.000 \\
25.000 \\
25.000 \\
25.000 \\
25.000 \\
25.000 \\
25.000 \\
25.000 \\
25.000\end{array}$ & $\begin{array}{r}26.612 \\
26.716 \\
26.573 \\
26.613 \\
26.561 \\
26.501 \\
26.570 \\
26.404 \\
26.176 \\
26.231 \\
26.300 \\
26.410 \\
26.320 \\
26.308 \\
26.304 \\
26.308 \\
26.166 \\
26.207 \\
26.192 \\
26.165 \\
\text { R } 26.165\end{array}$ \\
\hline
\end{tabular}

- Includes Iransporiation.

b Preliminary.

$\mathrm{A}=$ Revised data.

Source: See "Thermal Conversion Factor Source Documentation," which follows Table AB

Table A7. Approximate Heat Content of Anthracite and Coal Coke (Million Btu per Short Ton)

\begin{tabular}{|c|c|c|c|c|c|c|}
\hline & \multicolumn{5}{|c|}{ Anthracite } & \multirow{3}{*}{$\begin{array}{l}\text { Coal Coke } \\
\text { Imports } \\
\text { and } \\
\text { Exports }\end{array}$} \\
\hline & & \multicolumn{3}{|c|}{ Consumption } & \multirow[b]{2}{*}{$\begin{array}{l}\text { Imports } \\
\text { and } \\
\text { Exports }\end{array}$} & \\
\hline & Production & $\begin{array}{c}\text { Sectors Other } \\
\text { Than Electric } \\
\text { Utilities }\end{array}$ & Electric Utilities & Total & & \\
\hline 1973 & 22132 & 22674 & 17.920 & 21.464 & 25.400 & 24.800 \\
\hline 1974 & 21.711 & 22330 & 17200 & 20.919 & 25400 & 24.800 \\
\hline $1975 \ldots \ldots \ldots \ldots \ldots \ldots \ldots \ldots \ldots \ldots \ldots \ldots \ldots \ldots \ldots$ & 21.582 & 22272 & 17.064 & 20762 & 25.400 & 24.800 \\
\hline $1976 \ldots \ldots \ldots \ldots \ldots \ldots$ & 22045 & 22618 & 17.526 & 21254 & 25.400 & 24.800 \\
\hline $1977 \ldots \ldots \ldots \ldots \ldots \ldots \ldots \ldots$ & 22661 & 24101 & 17244 & 22006 & 25400 & 24.800 \\
\hline 1978 & 23079 & 24388 & 17.104 & 22398 & 25.400 & 24.800 \\
\hline $1979 \ldots \ldots \ldots \ldots$ & 23110 & 24212 & $174^{5}, 4$ & 22069 & 25.400 & 24.800 \\
\hline $1980 \ldots \ldots \ldots \ldots \ldots \ldots \ldots$ & 22.869 & 27119 & $1766 ?$ & 21405 & 25.400 & 24.800 \\
\hline $1981 \ldots \ldots \ldots \ldots \ldots \ldots \ldots \ldots \ldots \ldots \ldots \ldots$ & 23291 & 23749 & 18168 & 22080 & 25.400 & 24.800 \\
\hline $1982 \ldots \ldots \ldots \ldots \ldots \ldots \ldots$ & 23289 & 24578 & 18160 & 22518 & 25.400 & 24.800 \\
\hline $1983 \ldots \ldots \ldots \ldots \ldots$ & 22734 & 245.36 & 16516 & 21583 & 25.400 & 24.800 \\
\hline 1984 & 23107 & 25128 & 17018 & 22.322 & 25.400 & 24.800 \\
\hline 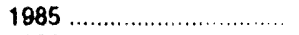 & 22.428 & 23031 & 16784 & 20817 & 25.400 & 24.800 \\
\hline 1986 & 23084 & 24399 & 15578 & 21.512 & 25.400 & 24.800 \\
\hline $1887 \ldots \ldots \ldots \ldots \ldots \ldots$ & 23108 & 26,293 & 15962 & 22435 & 25.400 & $24.8(0)$ \\
\hline $1988 \ldots \ldots \ldots \ldots$ & 23266 & 26021 & 17312 & 22.423 & 25.400 & 24.800 \\
\hline $1989 \ldots \ldots \ldots \ldots \ldots \ldots \ldots \ldots \ldots \ldots \ldots \ldots \ldots$ & 23385 & 27196 & 16310 & 22.623 & 25.400 & 24.800 \\
\hline 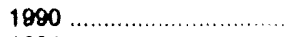 & 22574 & 25199 & 16140 & 21668 & 25.400 & 24.800 \\
\hline $1991 \ldots \ldots \ldots \ldots \ldots \ldots \ldots$ & 22573 & 25,268 & 15.858 & 21410 & 25.400 & 24.800 \\
\hline $1992 \ldots \ldots \ldots \ldots$ & 422572 & 024617 & ค 16.944 & $\mathrm{H}_{21} 423$ & 25.400 & 24.800 \\
\hline $1993^{a}$ & ${ }^{\mathrm{H}} 22572$ & 424617 & H 16944 & ${ }^{2} 1.423$ & 25.400 & 24.800 \\
\hline
\end{tabular}

- Proliminary.

R= Revised data

Source: See "Thermal Conversion Factor Srure Documertation" which follows Table AB 
Table A8. Approximate Heat Rates for Electricity

(Btu per Kilowatthour)

\begin{tabular}{|c|c|c|c|c|}
\hline & \multicolumn{3}{|c|}{ Electricity Generation } & \multirow[b]{2}{*}{$\begin{array}{c}\text { Electricity } \\
\text { Consumption }\end{array}$} \\
\hline & $\begin{array}{c}\text { Foseil-Fueled } \\
\text { Steam-Electric } \\
\text { Plantsa }\end{array}$ & $\begin{array}{c}\text { Nuclear } \\
\text { Steam-Electric } \\
\text { Plants }\end{array}$ & $\begin{array}{c}\text { Geothermal } \\
\text { Energy } \\
\text { Plante }\end{array}$ & \\
\hline $\begin{array}{l}1973 \\
1974 \\
1975 \\
1976 \ldots \\
1977 \\
1978 \ldots \\
1979 .\end{array}$ & $\begin{array}{l}10,389 \\
10,442 \\
10,406 \\
10,373 \\
10,435 \\
10,361 \\
10,353 \\
10,388 \\
10,453 \\
10,454 \\
10,520 \\
10,440 \\
10,447 \\
10,446 \\
10,419 \\
10,324 \\
10,317 \\
10,335 \\
10,352 \\
10,352 \\
10,352\end{array}$ & $\begin{array}{l}10,903 \\
11,161 \\
11,013 \\
11,047 \\
10,769 \\
10,941 \\
10,879 \\
10,908 \\
11,030 \\
11,073 \\
10,905 \\
10,843 \\
10,813 \\
10,799 \\
10,776 \\
10,743 \\
10,724 \\
10,680 \\
10,740 \\
10,740 \\
10,740\end{array}$ & $\begin{array}{l}21,674 \\
21,674 \\
21,611 \\
21,611 \\
21,611 \\
21,611 \\
21,545 \\
21,639 \\
21,639 \\
21,629 \\
21,290 \\
21,303 \\
21,263 \\
21,263 \\
21,263 \\
21,096 \\
21,096 \\
21,096 \\
20,997 \\
20,997 \\
20,997\end{array}$ & $\begin{array}{l}3,412 \\
3,412 \\
3,412 \\
3,412 \\
3,412 \\
3,412 \\
3,412 \\
3,412 \\
3,412 \\
3,412 \\
3,412 \\
3,412 \\
3,412 \\
3,412 \\
3,412 \\
3,412 \\
3,412 \\
3,412 \\
3,412 \\
3,412 \\
3,412\end{array}$ \\
\hline
\end{tabular}

- This thermal conversion factor is used for hydroelectric power generation and for wood and waste, wind, pholovoltaic, and solar thermal energy consumed at electric utilities.

- Preliminary.

Source: See "Thermal Conversion Factor Source Documentation," which follows this table.

\section{Thermal Conversion Factor Source Documentation}

\section{Approximate Heat Content of Petroleum and Natural Gas Plant Liquids}

Asphalt. The Energy Information Administration (EIA) adopted the thermal conversion factor of 6.636 million British thermal units (Btu) per barrel as estimated by the Bureau of Mines and first published in the Petroltum Statement, Annual, 1956.

Aviation Gasoline. EIA adopted the Bureau of Mines thermal conversion factor of 5.048 million Btu per barrel as published for "Gasoline, Aviation" by the Texas Eastern Transmission Corporation in Appendix $\mathrm{V}$ of Competition and Growth in American Energy Markets 1947-1985, a 1968 release of historical and projected statistics.

Butane. EIA adopted the Bureau of Mines thermal conversion factor of 4.326 million Btu per barrel as published in the California Oil World and Petroleum Industry, First Issue, April 1942.

Butane-Propane Mixture. EIA adopted the Bureau of Mines calculation of 4.130 million Btu per barrel based on an assumed mixture of 60 percent butane and 40 percent propane. See Butane and Propane.

Crude Oil, Exports. Assumed by EIA to be 5.800 million Btu per barrel or equal to the thermal conversion factor for crude oil produced in the United States. See Crude Oil and Lease Condensate, Production.

Crude Oil, Imports. Calculated annually by EIA by weighting the thermal conversion factor of each type of crude oil imported by the quantity imported. Thermal conversion factors for each type were calculated on a foreign country basis, by determining the average American Petroleum Institute (API) gravity of crude imported from each foreign country from Form ERA-60 in 1977 and converting average API gravity to average Btu content by using National Bureau of Standards, Miscellaneous Publication No. 97, Thermal Properties of Petroleum Products, 1933.

Crude Oil and Lease Condensate, Production. EIA adopted the thermal conversion factor of 5.800 million Btu per barrel as reported in a Bureau of Mines internal memorandum, "Bureau of Mines Standard Average Heating Values of Various Fuels, adopted January 3, 1950."

Crude Oil and Petroleum Products, Exports. Calculated annually by EIA as the average of the thermal conversion factors for each petroleum product 
exported and crude oil exported weighted by the quantity of each petroleum product and crude oil exported. See Crude Oil, Exports and Petroleum Products, Exports

Crude Oil and Petroleum Products, Imports. Calculated annually by EIA as the average of the thermal conversion factors for each petroleum product and each type of crude oil imported wighted by the quantity of each petroleum product and each type of crude oil imported. See Crude Oil. Imports and Petroleum Products, Imports

Distillate Fuel Oil. ElA adopted the Bureau of Mines thermal conversion tactor of 5.825 million Btu per barrel as reported in a Bureau of Mines internal memorandum. "Bureau of Mines Standard Average Heating Value of Various Fuels, adopted January 3, 1950."

Exhane. FIA adopted the Bureatu of Mines thermal conversion factor of 3.082 million $B(u$ per harrel as published in the California (jil World and Petroleum Industry, First Issue, April 1942.

Ethane-Propane Mixture. LIA calculated 3.308 million Btu per harrel hased on an assumed mixture of 70 percent ethane and 30 percent propane. See Ethane and Propane.

Isobutane. EIA adopted the Bureau of Mines thermal conversion factor of 3.974 millica Blu per harrel as published in the California ()il World and Petroleum Industry. First Issue, April 1942.

Jet Fuel, Kerosene Type I:IA adopted the Bureau of Mines thermal conversion factor of 5.670 million Btu per barrel as published for "lel luel. (ommercial" by the Texas Eastern Transmission Corporation in Appendix $V$ of Competition and Growlh in American Energy Markets 1947-1985. a 1968 release of historical and projected statistics.

Jet Fuel, Naphtha Type. BIA adopled the Bureau of Mines thermal conversion factor of 53.55 million Btu per barrel as published for "Jet Fuel, Military" by the Texas Eastern Transmission corporation in Appendix $\checkmark$ of Competition and Growth in American Energy Markets 1947-1985, a 1968 release of historical and projected statistics.

Kerosene. EIA adopted the Bureau of Mines thermal conversion factor of $\$ .670$ million Btu per barrel as reported in a Bureau of Mines internal memorandum, "Bureau of Mines Standard Average lleating Values of Various Fuels, adopted January 3, 1950."

Liquefied Petroleum Gases (LPG) Consumption. Calculated annually by EIA as the arerage of the thermal conversion factors of each liquetied petroleum gas consumed, weighted by the quantity of each liquefied petroleum gas comsumed.
Lubricants. EIA adopted the thermal conversion factor of 6.065 million Btu per barrel as estimated by the Bureau of Mines and first published in the Petroleum Statement, Annual, 1956.

Miscellaneous Products. EIA adopted the thermal conversion factor of 5.796 million Btu per barrel as estimated by the Bureau of Mines and first published in the Petroleum Statement, Annual, 1956.

Motor Gasoline. EIA adopted the Bureau of Mines thermal conversion factor of 5.253 million Btu per barrel as published for "Gasoline, Motor Fuel" by the Texas Eastern Transmission Corporation in Appendix $\mathrm{V}$ of Competition and Growth in American Energy Markets 1947-1985, a 1968 release of historical and projected statistics.

Natural Gas Plant Liquids, Production. Calculated annually by EIA as the average of the thermal conversion factors of each natural gas plant liquid produced weighted hy the quantity of each natural gas plant liquid produced.

Natural Gasoline. EIA adopted the thermal conversion factor of 4.620 million Blu per barrel as estimated by the Bureau of Mines and first published in the Petroleum Statement. Annual, 1956.

Pentanes Plus. EIA assumed the thermal conversion factor to be 4.620 million Btu per barrel or equal to that for natural gasoline. See Natural Gasoline.

Petrochemical Feedstocks, Naphtha Iess Than 401 Degrees Fahrenheit. Assumed by EIA to be 5.248 million Btu per harrel, equal to the thermal conversion factor for special naphtha. See Special Naphtha.

Petrochemical Feedstocks, (Dils Equal to or Greater Than 401 Degrees Fahrenheit. Assumed by EIA to be 5.825 million Btu per barrel, equal to the thermal conversion factor for distillate fuel oil See Distillate Fuel Oil.

Petrochemical Feedstocks, Still Gas. Assumed by EIA to be 6.000 million Btu per barrel, equal to the thermal conversion factor for still gas. See Still Gas.

Petroleum Coke. EIA adopted the thermal conversion factor of 6.024 million Btu per harrel as reported in Blu per short ton in the Bureau of Mines internal memorandum, "Bureau of Mines Standard Average Heating Value of Various Fuels, adopted January 3, 1950." The Bureau of Mines calculated this factor by dividing $30,120,000)$ Blu per short ton, as given in the referenced Bureau of Mines internal memorandum, by 5.0 barrels per short 10 , as given in the Bureau of Mines Form 6-1300-M and successor EIA forns.

Petroleum Products, Total Consumption. Calculated annually by lils as the average of the 
thermal conversion factors for all petroleum products consumed, weighted hy the quantity of each petroleum product consumed.

Petroleum Products, Consumption by Electric Utilities. Calculated annually by EIA as the average of $\mathrm{U}$ : thermal conversion factors for all petroleum produ is consumed at electric utilities, weighted by the quantity of each petroleum product consumed at electric utilities. The quantity of petroleum consumed is estimated in the State Energy Data System as documented in the State Energy Data Report.

Petroleum Products, Consumption by Industrial Users. Calculated amnually by EIA as the average of the thermal conversion factors for all petroleum products consumed in the industrial sector, weighted by the estimated quantity of each petroleum product consumed in the industrial sector. The quantity of petroleum products consumed is estimated in the State Energy Data System as documented in the State Energy Data Report.

Petroleum Products, Consumption by Residential and Commercial Users. (alculated annually by $\mathrm{EI \Lambda}$ as the average of the thermal conversion factors for all petroleum products consumed hy the residential and commercial sector, weighted by the estimated quantity of each petroleum product consumed in the residential and commercial sector. The quantity of petroleum products consumed is estimated in the State Energy Data System as documented in the State Energy Data Report.

Petroleum Products, Consumption by Transportation Users. Calculated annually hy EIA as the average of the thermal conversion factor for all petroleum products consumed in the transportation sector, weighted by the estimated quantity of each petroleum product consumed in the transportation sector. The qualltity of petroleum products consumed is estimated in the State linergy Data System as documented in the State Energy Data Report.

Petroleum Products, Exports. Calculated annually by EIA as the average of the thermal conversion factors for each petroleum product, weighted by the quantity of each petrolcum product exported.

Petroleum Products, Imports. Calculated annually by EIA as the average of the thermal conversion factors for each petroleum product imported, weighted by the quantily of each petsoleum product imported.

Plant Condensate. Estimated to be 5.418 million Btu per barrel by EIA from data provided by McClanahan Consultants, Inc., Ilouston, Texas.

Propane. EIA adopted the Bureau of Mines thermal conversion factor of 3.836 million Btu per barrel as published in the California Oil World and Petroleum Industry, First Issue, April 1942.
Residual Fuel Oil. ElA adopted the thermal conversion factor of 6.287 million Btu per barrel as reported in the Bureau of Mines internal memorandum, "Bureau of Mines Standard Average Heating Values of Various Fuels, adopled January 3, 1950."

Road Oil. EIA adopted the Bureau of Mines thermal conversion factor of 6.636 million Btu per barrel, which was assumed to be equal to that of asphalt (see Asphalt) and was first published by the Bureau of Mines in the Petroleum Statement, Annual, 1970.

Special Naphtha. EIA adopted the Bureau of Mines thermal conversion factor of 5.248 million Btu per barrel, which was assumed to be equal to that of total gasoline (aviation and motor) factor and was first published in the Petroleum Statement, Annual, 1970.

Still Gas. EIA adopted the Bureau of Mines estimated thermal conversion factor of 6.000 million Btu per barrel and first puhlished in the Petroleum Statement, Annual, 1970.

Unfinished (Oil. ElA assumed the thermal conversion factor 10 be 5.82 .5 million Blu per barrel or equal to that for distillate fuel oil (see Distillate Fuel Oil) and first published in the Annual Report to Congress, Volume 3. 1977.

Unfractionated Stream. EIA assumed the thermal conversion factor to be 5.418 million Btu per barrel or equal to that for plant condensate (see Plant Condensate) and first published in the Annual Report to Congress, Volume 2, 1981.

Waxes. liIA adopted the thermal conversion factor of 5.537 million Biu per barrel as estimated by the Burcau of Mines and first published in the Petroleum Statement, Annual, 1956.

\section{Approximate Heat Content of Natural Gas}

Natural Gas, Total Consumption. 1973-1979: EIA adopted the thermal conversion factor calculated annually by the American Gas $\Lambda$ ssociaticn ( $A G A$ ) and published in Gas Facts, an $A C i A$ annual publication. 1980 forward: Calculated anmually by EIA by dividing the total heat content of natural gas consumed by the total quantity of natural gas consumed. The heat content and quantity consumed are from Form BIA-176. Published sources are: 1980-1990: EIA, Nalural Gas Annual 1990, Volume 2, Table 15. 1991 forward: 1990 value used as an estimate.

Natural Gas, Consumption by Electric Utilities. Calculated annually by EIA by dividing the total heat content of natural gas received at electric utilities by the total quantity received at electric utilities. The heat contents and receipts are from Form FERC-423 and predecessor forms. 
Natural Gas, Consumption by Sectors Other Than Electric Utilities. Calculated annually by EIA by dividing the heat content of all natural gas consumed less the heat content of natural gas consumed at electric utilities by the quantity of all natural gas consumed less the quantity of natural gas consumed at electric utilities. Data are from Forms EIA-176, FERC-423, EIA-759, and predecessor forms.

Natural Gas, Exports. Calculated annually by EIA by dividing the heat content of exported natural gas by the quantity of natural gas exported, both reported on Form FPC-14.

Natural Gas, Imports. Calculated annually by EIA by dividing the heat content of imported natural gas by the quantity of natural gas imported, both reported on Form FPC.14.

Natural Gas Production, Dry. Assumed by EIA to be equal to the thermal conversion factor for the consumption of dry natural gas. See Natural Gas Consumption.

Natural Gas Production, Marketed (Wet). Calculated annually by EIA by adding the heat content of dry natural gas production and the total heat content of natural gas plant liquids production and dividing this sum by the total quantity of marketed (wet) natural gas production.

\section{Approximate Heat Content of Coal and Coal Coke}

Anthracite, Total Consumption. Calculated annually by EIA by dividing the sum of the heat content of anthracite consumed by electric utilities and all other sectors combined by the total quantity of anthracite consumed.

Anthracite, Consumption by Electric Utilities. Calculated annually by EIA hy dividing the heat content of anthracite receipts at electric utilities by the quantity of anthracitr received at electric utilities. Heat contents and re ieipts are from Form FERC-423 and predecessor forms.

Anthracite, Consumption by Sectors Other Than Electric Utilities. Calculated annually by EIA by dividing the heat content of anthracite production less the heat content of the anthracite consumed at electric utilities, net exports, and shipments to U.S. Armed Forces overseas by the quantity of anthracite consumed by sectors other than electric utilities less the quantity of anthracite stock changes, losses, and "unaccounted for."

Anthracite, Imports and Exports. EIA assumed the anthracite imports and exports to be freshly mined anthracite having an estimated heat content of 25.40 million Btu per short ton.
Anthracite, Production. Calculated annually by EIA by dividing the sum of the heat content of freshly mined anthracite (estimated to have an average heat content of 25.400 million Btu per short ton) and the heat content of anthracite recovered from culm banks and river dredging (estimated to have a heat content of 17.500 million Btu per short ton) by the total quantity of anthracite production.

Bituminous Coal and Lignite, Total Consumption. Calculated annually by EIA by dividing the sum of the heat content of bituminous coal and lignite consumed by electric utilities, coal coke plants, other industrial plants, the residential and commercial sector, and the transportation sector by the sum of their respective tonnages.

Bituminous Coal and Lignite, Consumption by Coke Plants. Estimated by EIA to be 26.800 million Blu per short ton on the basis of an input/output analysis of coal carbonization.

Bituminous Coal and Lignite, Consumption by Electric Utilities. Calculated annually by EIA by dividing the total heat content of bituminous coal and lignite received at electric utilities by the total quantity received at electric utilities. Heat contents and receipts are from Form FERC. -423 and predecessor forms.

Bituminous Coal and Lignite, Consumption by Other Industrial and Transportation Users. 1973: Calculated by EIA through regression analysis measuring the difference between the average Btu value of coal consumed by other industrial users and that of coal consumed at electric utilities in the 1974-1982 period. 1974 forward: Calculated annually by EI $\Lambda$ by assuming that the bituminous coal and lignite delivered to other industrial users from each coal-producing area (reported on Form EIA-6 and predecessor Bureau of Mines Form 6-1419-Q) contained a heat value equal to that of bituminous coal and lignite received at electric utilities from each of the same coal-producing areas (reported on Form FERC-423). The average Btu value of coal by coal-producing area was applied to the volume of deliveries io other industrial users from each coal-producing area, and the sum total of the heat content was divided by the total volume of deliveries. Coal-producing areas are the Bureau of Mines coal-producing districts for 1974 through 1989 and coal-producing States for 1990 forward.

Bituminous Coal and Lignite, Consumption by Residential and Commercial Users. 1973: Calculated by ElA through regression analysis measuring the difference between the average Btu value of coal consumed by residential and commercial users and that of coal consumed by electric utilities in the 1974-1982 period. 1974 forward: Calculated annually by EI $\wedge$ by assuming that the bituminous coal and lignite delivered to residential and commercial 
users from each coal-producing area (reported on Form EIA-6 and predecessor Bureau of Mines Form 6-1419-Q) contained a heat value equal to that of bituminous coal and lignite received at electric utilities from each of the same coal-producing areas (reported on Form FERC-423). The average Btu value of coal by coal-producing area was applied to the volume of deliveries to residential and commercial users from each coal-producing area, and the total of the heat value was divided by the total volume of deliveries. Coal-producing areas are the Bureau of Mines coal-producing districts for 1974 through 1989 and coal-producing States for 1990 forward.

Bituminous Coal and Lignite, Exports. Calculated annually by EIA by dividing the sum of the heat content of exported metallurgical coal (estimated to average 27.000 million Btu per short ton) and the heat content of exported steam coal (estimated to have an average thermal content of 25.000 million Btu per short ton) by the total quantity of bituminous coal and lignite exported.

Bituminous Coal and Lignite, Imports. EIA estimated the average thermal conversion factor to be 25.000 million Btu per short ton.

Bituminous Coal and Lignite, Production. Calculated annually by EIA by dividing the sum of the heat content of bituminous coal and lignite consumption, net exports, stock changes, and unaccounted for by the sum of their respective tonnages. Consumers' stock changes by sectors were assumed to have the sane conversion factor as that of the consumption sector. Producers' stock changes and unaccounted for were assumed to have the same conversion factor as that for consumption by all users.

Coal, Consumption. Calculated anmually by ElA by dividing the sum of the heat content of bituminous coal and lignite and anthracite consumption by the sum of their respective tomnages.

Coal, Consumption by Electric Utilities. Calculated annually by EIA by dividing the sum of the heat content of bituminous coal and lignite and anthracite received at electric utilities by the sum of their respective tonnages received.

Coal, Consumption by Sectors Other Than Electric Utilities. Calculated annually by EIA by dividing the sum of the heat content of bituminous coal and lignite and anthracite consumed by sectors other than electric utilities by the sum of their respective tomnages.

Coal, Exports. Calculated annually by EIA by dividing the sum of the heat content of bituminous coal and lignite and anthracite exported by the sum of their respective tonnages.

Coal, Imports. Calculated annually by EIA by dividing the sum of the heat content of bituminous coal and lignite and anthracite imported by the sum of their respective tonnages.

Coal, Production. Calculated annually by ElA by dividing the sum of the total heat content of bituminous coal and lignite and anthracite production by the sum of their respective tonnages.

Coal Coke, Imports and Exports. EIA adopted the Bureau of Mincs estimate of 24.800 million Btu per short ton.

\section{Approximate Heat Rates for Electricity}

Fossil-Fueled Steam-Electric Plant Generation. There is no generally accepted practice for measuring the thermal conversion rates for power plants that generale electricily from hydroelectric, wood and waste, wind, photovo!taic, or solar thermal energy sources. Therefore, EIA has selected a rate that is equal to the prevailing annual average heat rate factor for fossil-fueled steam-electric power plants in the United states. By using that factor, it is possible to evaluate fossil fuel requirements for replacing those sources during periods of interruption such as droughts. The heat content of a kilowatthour of clectricity produced, regardless of the generation process, is 3,412 Btu per kilowatthour. 1973-1990: The weighted annual average heat rate for fossil-fucled steam-electric power plants in the United States, as published by EIA in Electric Plant Cost and Power Production Expenses 1990, Table 11. 1991 forward: 1900) value used as an estimate.

Geothermal Energy Plant Generation. 1973-1981: Calculated anmually by EIA by weighting the average annual heat rates of operating geothermal units by the installed nameplate capacities as reported on Form FPC.-12. 1982 forward: Estimated annually by EIA on the basis of an informal survey of relevant plants.

Nuclear Steam-lilectric Plant Ceneration. Calculated annually by EIA by dividing the total heat content consumed in nuclear generating units by the total (net) electricily generated by nuclear generating units. The heat content and electricity generation are reported on Form FERC-1, Form EIA-412, and predecessor forms. The factors, beginning with 1982 dala, are published in the following EIA reports-1082: Historical Plant Cost and Annual Production Expenses for Selected Electric Plants 1982, page 215. 1983-1990: Electric Plant Cost and Power Production Expenses 1990, Table 15. 1991 forward: 1900 value used as an estimate. 


\section{Appendix B. Metric and Other Physical Conversion Factors}

Data presented in the Monthly Energy Review and in other Energy Information Administration publications are expressed in units, such as British thermal units, barrels, cubic fect, and short tons, that historically have been used in the United States. However, because U.S. activities involve foreign nations, most of which use metric units of measure, the United States is committed to making the transition to the metric system.

The metric conversion factors presented in Table B I can be used to calculate the metric-unit equivalents of values expressed in U.S. custonary mits. For example, 500 shore tons are the equivalent of 453.6 metric tons $(500$ short tons $X 0.9071847$ metric tons/short ton $=453.6$ metric tons). Most of the metric units shown in Table B1 belong to the International System of Units.

The conversion factors presented in Table B2 can be used to calculate equivalents in various physical units commonly used in energy analyses. For example, 10 barrels are the equivalent of 420 U.S. gallons (10 barrels $X 42$ gallons/barrel $=420$ gallons) .

In the metric system of weights and measures, designations of multiples and subdivisions of any unit may be arrived at by combining the name of the unit with prefixes, such as deka, hecto, and kilo, meaning, respectively, 10,100, and $1,()()$, and deci, centi, and milli, meaning, respectively, one-tenth, one-hundredth, and one-thousandth. Common inetric prefixes can be found in Table B3.

\section{Table B1. Metric Conversion Factors}

\begin{tabular}{|c|c|c|c|c|c|}
\hline Type of Unit & U.S. Unit & & Conversion Factor & & Metric Unit \\
\hline Mass & $\begin{array}{l}\text { short tons }(2,000 \mathrm{lb}) \\
\text { short toris uranium oxide }\left(\mathrm{U}_{3} \mathrm{O}_{8}\right) \\
\text { short tons uranium fluoride }\left(\mathrm{UF}_{6}\right) \\
\text { long tons } \\
\text { pounds }(\mathrm{lb}) \\
\text { pounds uranium oxide }\left(\mathrm{lb} \mathrm{U}_{3} \mathrm{O}_{8}\right) \\
\text { ounces, avoirdupois }(\mathrm{avdp} O \mathrm{z})\end{array}$ & $\begin{array}{l}x \\
x \\
x \\
x \\
x \\
x \\
x\end{array}$ & $\begin{array}{l}0.9071847 \\
0.769^{\mathrm{a}} \\
0.613^{\mathrm{a}} \\
1.016047 \\
0.45359237^{\mathrm{b}} \\
0.384645^{\mathrm{a}} \\
28.34952\end{array}$ & $\begin{array}{l}= \\
= \\
= \\
= \\
= \\
=\end{array}$ & $\begin{array}{l}\text { metric tons }(t) \\
\text { metric tons uranium }(t U) \\
\text { metric tons uranium }(t U) \\
\text { metric tons }(t) \\
\text { kilograms }(\mathrm{kg}) \\
\text { kilograms uranium }(\mathrm{kgU}) \\
\text { grams }(\mathrm{g})\end{array}$ \\
\hline Volume & $\begin{array}{l}\text { barrels of oil (bbl) } \\
\text { cubic yards }\left(\mathrm{yd}^{3}\right) \\
\text { cubic feet }\left(\mathrm{ft}^{3}\right) \\
\text { U.S. gallons (gal) } \\
\text { ounces, fluid (floz) } \\
\text { cubic inches (in }{ }^{3} \text { ) }\end{array}$ & $\begin{array}{l}x \\
x \\
x \\
x \\
x \\
x\end{array}$ & $\begin{array}{l}0.1589873 \\
0.764555 \\
0.02831685 \\
3.785412 \\
29.57353^{\mathrm{a}} \\
16.387064\end{array}$ & $\begin{array}{l}= \\
= \\
= \\
= \\
= \\
=\end{array}$ & $\begin{array}{l}\text { cubic meters }\left(\mathrm{m}^{3}\right) \\
\text { cubic meters }\left(\mathrm{m}^{3}\right) \\
\text { cubic meters }\left(\mathrm{m}^{3}\right) \\
\text { liters }(\mathrm{L}) \\
\text { milliliters }(\mathrm{mL}) \\
\text { millititers }(\mathrm{mL})\end{array}$ \\
\hline Length & $\begin{array}{l}\text { miles (mi) } \\
\text { yards (yd) } \\
\text { feet (ft) } \\
\text { inches (in) }\end{array}$ & $\begin{array}{l}x \\
x \\
x \\
x\end{array}$ & $\begin{array}{l}1.609344^{b} \\
0.9144^{b} \\
0.3048^{b} \\
2.54^{b}\end{array}$ & $\begin{array}{l}= \\
= \\
= \\
=\end{array}$ & $\begin{array}{l}\text { kilometers }(\mathrm{km}) \\
\text { meters }(\mathrm{m}) \\
\text { meters }(\mathrm{m}) \\
\text { centimeters }(\mathrm{cm})\end{array}$ \\
\hline Area & $\begin{array}{l}\text { acres } \\
\text { square miles }\left(\mathrm{mi}^{2}\right) \\
\text { square yards }\left(y \mathrm{~d}^{2}\right) \\
\text { square feet }\left(\mathrm{ft}^{2}\right) \\
\text { square inches }\left(\mathrm{in}^{2}\right)\end{array}$ & $\begin{array}{l}x \\
x \\
x \\
x \\
x\end{array}$ & $\begin{array}{l}0.40469 \\
2.589988 \\
0.8361274 \\
0.092903 .04^{\mathrm{b}} \\
6.4516^{\mathrm{b}}\end{array}$ & $\begin{array}{l}= \\
= \\
= \\
=\end{array}$ & $\begin{array}{l}\text { hectares (ha) } \\
\text { square kilometers }\left(\mathrm{km}^{2}\right) \\
\text { square meters }\left(\mathrm{m}^{2}\right) \\
\text { square meters }\left(\mathrm{m}^{2}\right) \\
\text { square centimeters }\left(\mathrm{cm}^{2}\right)\end{array}$ \\
\hline Temperature & degrees Fahrenheit ${ }^{\circ}\left({ }^{\circ} \mathrm{F}\right)$ & $x$ & 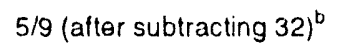 & $=$ & degrees Celsius $\left({ }^{\circ} \mathrm{C}\right)$ \\
\hline Energy & $\begin{array}{l}\text { British thermal units (Btu) } \\
\text { calories (cal) } \\
\text { kilowatthours (kWh) }\end{array}$ & $\begin{array}{l}x \\
x \\
x\end{array}$ & $\begin{array}{c}1,055.05585262^{b, d} \\
4.1868^{d} \\
3.6\end{array}$ & $\begin{array}{l}= \\
= \\
=\end{array}$ & $\begin{array}{l}\text { joules }(\mathrm{J}) \\
\text { joules }(\mathrm{J}) \\
\text { megajoules (M.J) }\end{array}$ \\
\hline
\end{tabular}

Cakculated by the Energy Information Administration.

Exact conversion.

To corvert degrees Celstus $(C)$ ) to degrees fahrenhelt ( F) exactly, multiply by $9 / 5$, then add 32.

The International Table conversion (5th International Conterence on the Propenties of Stearn, London, 1956).

Sources: - General Services Administration. Federal Standard 376B, preprint copy of Prelerred Methc Units lor General Use by the Federal Govemment Washington, DC, January 27, 1993), pp. 9-11, 13, and 16 . National Institute of Standards and Technotogy. Special Publications 330 , 811 , and 814 . American National Standards Institute/Institute of Electrical and Electronic Engineers. ANSI/IEEE SId. 268-1992, pp. 28 and 29. 
Table B2. Other Physical Conversion Factors

\begin{tabular}{|c|c|c|c|c|}
\hline Energy Source & Original Unit & & Conversion Factor & Final Unit \\
\hline $\begin{array}{l}\text { Crude Oil } \\
\text { (Average Gravity) }\end{array}$ & barrels (bbl) & $x$ & $42^{\mathrm{a}}$ & $=\quad$ U.S. gallons (gal) \\
\hline Coal & $\begin{array}{l}\text { short tons } \\
\text { long tons } \\
\text { metric tons (t) }\end{array}$ & $\begin{array}{l}x \\
x \\
x\end{array}$ & $\begin{array}{l}2,000^{a} \\
2,240^{a} \\
1,000^{a}\end{array}$ & $\begin{array}{ll}= & \text { pounds }(\mathrm{lb}) \\
= & \text { pounds }(\mathrm{lb}) \\
= & \text { kilograms }(\mathrm{kg})\end{array}$ \\
\hline $\begin{array}{l}\text { Wood (Average } \\
\text { Dry Hardwood) }\end{array}$ & $\begin{array}{l}\text { cords (cd) } \\
\text { cords (cd) }\end{array}$ & $\begin{array}{l}x \\
x\end{array}$ & $128^{1.25^{b}}$ & $\begin{array}{ll}= & \text { short tons } \\
= & \text { cubic foet }\left(1 t^{3}\right)\end{array}$ \\
\hline
\end{tabular}

"Exact conversion.

'Calculated by the Energy Information Administration.

Source: Natlonal Institule of Standards and Technology, NIST Handbook 44 (1993 Edition) (Washington, DC, October 1992), pp. C-17 and C-21.

\section{Table B3. Metric Prefixes}

\begin{tabular}{llc|ccc}
\hline $\begin{array}{l}\text { Unit } \\
\text { Multiple }\end{array}$ & Prefix & Symbol & $\begin{array}{l}\text { Unit } \\
\text { Subdivision }\end{array}$ & Prefix & Symbol \\
\hline $10^{24}$ & yotta & $Y$ & $10^{-1}$ & deci & $\mathrm{d}$ \\
$10^{21}$ & zetta & $\mathrm{Z}$ & $10^{-2}$ & $\mathrm{centi}$ & $\mathrm{c}$ \\
$10^{18}$ & exa & $\mathrm{E}$ & $10^{-3}$ & milli & $\mathrm{m}$ \\
$10^{15}$ & peta & $\mathrm{P}$ & $10^{-6}$ & micro & $\mathrm{n}$ \\
$10^{12}$ & tera & $\mathrm{T}$ & $10^{-9}$ & nano & $\mathrm{p}$ \\
$10^{9}$ & giga & $\mathrm{G}$ & $10^{-12}$ & $\mathrm{f}$ \\
$10^{6}$ & mega & $\mathrm{M}$ & $10^{-15}$ & femto & $\mathrm{a}$ \\
$10^{3}$ & kilo & $\mathrm{K}$ & $10^{-18}$ & atto & $\mathrm{z}$ \\
$10^{2}$ & hecto & $\mathrm{h}$ & $10^{-21}$ & zepto & $\mathrm{y}$ \\
$10^{1}$ & deka & da & $10^{-24}$ & yocto & \\
\hline
\end{tabular}

Source: National Instltute of Standards and Technology, NIST Special Publication 330 (Washington, DC, August 1991), p. 10.

For information regarding the International System of Units, contact Dr. Barry N. Taylor at Building 221, Room B160, National Institute of Standards and Technology, Gaithersburg, MD 20899, or on telephone number 301-975-4220. 


\section{Appendix C. List of Features}

The following is a complete list of features that have appeared in the Monthly Energy Review since the first issue was published in October 1974. There are four categories of features on the list. "Articles" cover a wide range of energyrelated subjects in depth. "Highlights" summarize the most important information presented in the subject Energy Information Administration (EIA) report. "Energy Previews" provide brief overviews of EIA preliminary energy data on a given topic. "EIA Data News" items present information on recent changes in the scope, design, methodology, and findings of the EIA's energy surveys and data bases. Questions and comments about features may be directed to Barbara T. Fichman by telephone on 202-586-5737 or by fax on 202-586-0018.

\section{Feature}

1993

Energy Preview: Residential Transportation Energy Consumption Survey,

Preliminary Estimates, 1991

EIA Data News: Natural Gas Transported for the Account of Others $\ldots \ldots \ldots \ldots \ldots \ldots \ldots \ldots$ Highlights: Federal Energy Subsidies: Direct and Indirect Interventions in Energy Markets ...... Highlights: Household Energy Consumption and Expenditures $1990 \ldots \ldots \ldots \ldots \ldots \ldots \ldots$ Article: Demand, Supply, and Price Outlook for Low-Sulfur Diesel Fuel . . . . . . . . . . . . Energy Preview: Manufacturing Energy Consumption Survey, Preliminary Estimates, $1991 \ldots \ldots$

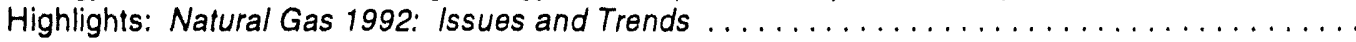

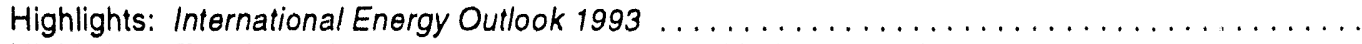

Highlights: The Changing Structure of the U.S. Coal Industry: An Update . . . . . . . . . . . . Highlights: Emissions of Greenhouse Gases in the United States $1985.1990 \ldots \ldots \ldots \ldots \ldots$ Highlights: Assessment of Energy $U_{s e}$ in Multibuilding Facilities $\ldots \ldots \ldots \ldots \ldots \ldots \ldots$

\section{2}

Energy Preview: Residential Energy Consumption and Expenditures

Preliminary Estimates, 1990 .

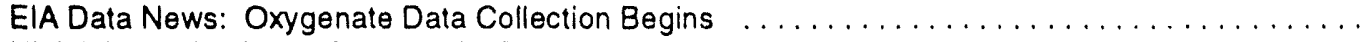

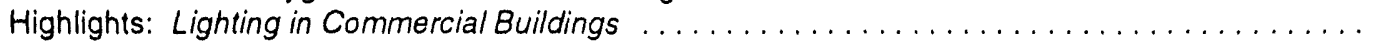
Article: Demand, Supply, and Price Outlook for Oxgenated Gasoline, Winter 1992-1993 . . . . . . EIA Data News: EIA Statistics on Electric Utility Demand-Side Management $\ldots \ldots \ldots \ldots \ldots \ldots$ EIA Data News: EIA Statistics on Nonutility Power Producers . . . . . . . . . . . . . . . . Highlights: Derived Annual Estimates of Manufacturing Energy Consumption, 1974-1988 . . . . . . Article: Energy Efficiency in the Manufacturing Sector

\section{1}

Highlights: U.S. Energy Industry Financial Developments, 1990 Fourth Quarter . . . . . . . . . . Article: U.S. Wholesale Electricity Transactions

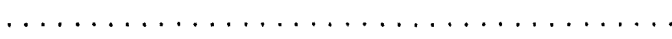

\section{0}

Article: Refining Results Highlight Energy Companies' First-Half Profit Performance . . . . . . . . Highlights: U.S. Oil and Gas Reserves by Year of Field Discovery

\section{9}

Article: A Review of Valdez Oil Spill Market Impacts

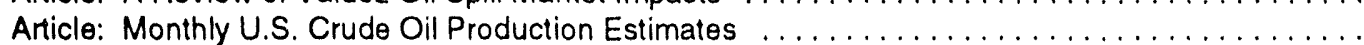

Article: Superconductivity and Energy Production and Consumption . . . . . . . . . . . . Highlights: Commercial Buildings Consumption and Expenditures 1986

Article: Higher Prices Yield Improved Energy Industry Financial Results

in the First Half of 1989

Article: The Future Structure of the U.S. Commercial Nuclear Power Equipment

Manufacturing Industry

Highlights: Manufacturing Energy Consumption Survey: Changes in

Energy Efficiency, 1980-1985

Highlights: Household Energy Consumption and Expenditures 1987, Part 1: National Data ..... Article: Improved Energy Profits Offset by Refining Results in 1989

\section{Cover Date}

January 1993

February 1993

July 1993

August 1993

August 1993

September 1993

September 1993

October 1993

November 1993

December 1993

December 1993

April 1992

May 1992

June 1992

August 1992

September 1992

October 1992

November 1992

December 1992

March 1991

April 1991

June 1990

August 1990

March 1989

March 1989

May 1989

May 1989

June 1989

July 1989

September 1989

October 1989

Novernber 1989

Decernber 1989 


\section{8}

Article: Measures of Energy Consumption, Expenditures, and Prices $\ldots \ldots \ldots \ldots \ldots \ldots$ Highlights: Characteristics of Commercial Buildings 1986

May 1988

Jurie 1988

June 1988

June 1988

July 1988

September 1988

October 1988

November 1988

December 1988

January 1987

Article: Manufacturing Sector Energy Consumption, 1985 Provisional Estimates

Highlights: Consumption and Expenditures, April 1984 Through March 1985,

Part 1: National Data

Highlights: Consumption and Expenditures, April 1984 Through March 1985,

Part 2: Regional Data

Article: U.S. Energy Industry Financial Developments, 1987 Second Quarter

Article: End-Use Consumption of Residential Energy $\ldots \ldots \ldots \ldots \ldots \ldots \ldots \ldots \ldots \ldots \ldots \ldots$

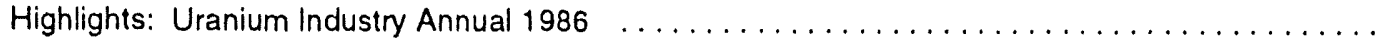

Highlights: Potential Oil Production from ANWR $\ldots \ldots \ldots \ldots \ldots \ldots \ldots \ldots \ldots \ldots \ldots \ldots$

Highlights: Profiles of Foreign Direct Investment in U.S. Energy $1986 \ldots \ldots \ldots \ldots \ldots \ldots \ldots$

Article: The U.S. Energy Industry in 1987: A Slow Recovery

\section{April 1987}

May 1987

June 1987

July 1987

September 1987

October 1987

November 1987

December 1987

March 1986

June 1986

June 1986

September 1986

December 1986

January 1985

February 1985

March 1985

March 1985

April 1985

June 1985

August 1985

August 1985

November 1985

December 1985

February 1984

March 1984

March 1984

May 1984

June 1984

September 1984

September 1984

November 1984

December 1984 


\section{3}

Highlights: Residential Energy Consumption Survey: Consumption and Expenditures . . . . . . . . Highlights: Residential Energy Consumption Survey: Housing Characteristics . . . . . . . . . . .

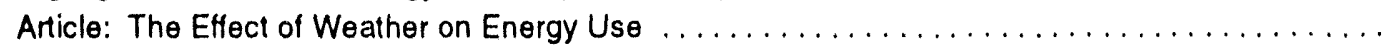

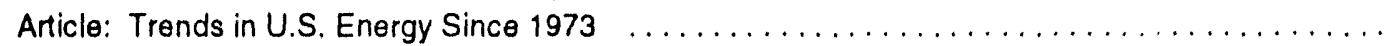
Article: Data Series on Petroleum Use at Electric Utilities $\ldots \ldots \ldots \ldots \ldots \ldots \ldots \ldots \ldots$ Highlights: Energy Price and Expenditure Data Report, 1970-1980 . . . . . . . . . . . . .

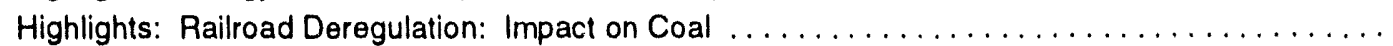
Highlights: Port Deepening and User Fees: Impact on U.S. Coal Exports $\ldots \ldots \ldots \ldots \ldots \ldots$ Highlights: U.S. Crude Oil, Natural Gas, and Natural Gas Liquids Reserves,

1982 Annual Report

Article: Residential Energy Consumption, 1978 Through 1981

Article: Exploring for Oil and Gas

Article: The Influence of Federal Actions on Petroleum Exploration

Article: Aggregate Statistics: Accurate or Misleading?

January 1983

February 1983

April 1983

May 1983

July 1983

July 1983

August 1983

August 1983

September 1983

September 1983

November 1983

December 1983[2]

December 1983[3]

January 1982

February 1982

September 1982

October 1982

November 1982

May 1981

September 1981

December 1981

February 1980

March 1980

June 1980

August 1980

October 1980

November 1980

December 1980

July 1979

October 1979

December 1979

May 1978

Article: Short-Term Petroleum Supply and Demand

1977

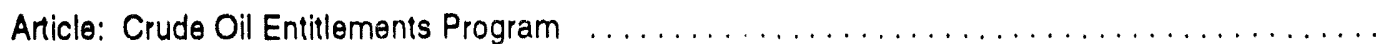

Article: Motor Gasoline Supply and Demand

January 1977

July 1977 


\section{6}

Article: Curtailments of Natural Gas Service

January 1976

Article: Home Heating Conservation Alternatives and the Solar Collector Industry

March 1976

Article: Trends in United States Petroleum Imports

September 1976

\section{5}

Article: Energy Consumption

March 1975

Article: Nuclear Power

March 1975

Article: The Price of Crude Oil

June 1975

Article: U.S. Coal Resources and Reserves

July 1975

Article: Propano-A National Energy Resource

September 1975

Article: Short-Term Energy Supply and Demand Forecasting at FEA

October 1975 


\section{Glossary}

Anthracite: A hard, black, lustrous coal containing a high percentage of fixed carbon and a low percentage of volatile matier. Often referred to as hard coal. It conforms to ASTM Specification D388.84 for anthracite, meta-anthracite, and semianthracite.

Asphalt: A dark-brown-to-black cement-like material containing bitumens as the predominant constituents obtained by petroleum processing. The definition includes crude asphalt as well as the following finished products: cements, fluxes, the asphalt content of emulsions (exclusive of water), and petroleum distillates blended with asphalt to make cutback asphalts.

ASTM: The American Sociecy for Testing and Materials.

Aviation Gasoline Blending Components: Naphthas that are used for blending or compounding into finished aviation gasoline (e.g., straight-run gasoline, alkylate, and reformate). Excludes oxygenates (alcohols and ethers), butane, and pentanes plus.

Aviation Gasoline, Finished: All special grades of gasoline for use in aviation reciprocating engines, as given in ASTM Specification D910 and Military Specification MIL-(i-5.572. Excludes hlending components that will be used in blending or compounding into finished aviation gassoline.

Barrel (petroleum): $\wedge$ unit of volume eyual (1) 42 U.S. gallons.

Base (Cushion) Gas: The volume of gas needed as a permanent inventory to maintain adequate underground storage reservoir pressures and deliverability rates throughout the withdrawal season. All native gats is included in the hase gas volume.

Bituminous Coal: $A$ dense hlack coal, often with well-defined bands of bright and dull material, with a moisture content usually less than 20 percent. (Jften referred to as soft coal. It is the most common coill and is used primarily for generating electricity, making coke, and space heating. It conforms 10 ASTM Specification D388-84 for bituminous coat. In this report, bituminous coal includes subhituminous coal.

British Thermal Unit (Btu): The quantity of heat needed to raise the temperature of 1 pound of watter by $1^{\circ} \mathrm{F}$ at or near $39.2^{\circ} \mathrm{F}$. Sec Heat content of a Quantity of Fuel, Gross and Heat content of a Quantity of Fuel, Net.
Butane: A normally gaseous straight-chain or branched-chain hydrocarbon $\left(\mathrm{C}_{4} \mathrm{H}_{10}\right)$. It is extracted from natural gas or refinery gas streams. It includes isobutane and normal butane and is designated in ASTM Specification D1835 and Cias Processors Association Specifications for commercial butane.

- Isobutane: A normally gaseous branched-chain hydrocarbon. It is a colorless paraffinic gas that boils at a temperature of $10.9^{\circ} \mathrm{F}$. It is extracted from natural gas or refinery gas streams.

- Normal Butane: A normally gaseous straight-chain hydrocarbon. It is a colorless paraffinic gas that boils at a temperature of $31.1^{\circ} \mathrm{F}$. It is extracted from natural gas or refinery gas streams.

Butylene: An olefinic hydrocarbon $\left(C_{4} H_{8}\right)$ recovered from refincry processes.

Capacity Factor: The ratio of the electrical energy produced by a generating unit for a given period of time to the electrical energy that could have been produced at continuous full-power operation during the saune period.

\section{CIF: See Cost, Insurance, freight}

City (iate: $A$ point or measuring station at which a distrihution gat ulility receives gas from a natural gas pipelinc company or transmission system.

Coal: A black or brownish-black solid, combustible substance formed hy the partial decomposition of vegetable matter without access to air. The rank of coal, which includes anthracite, hituminous coal, subhituminous coal, and lignite, is hased on fixed carbom, volatile maller, and heating value. Coal rank indicates the progressive alderation, or coatification, from lignite 10 anthracite. Lignite contains approximately 9 1017 million Btu per $t(0 n$. The heat contents of subhituminous and hituminous coal range from 16 (o) 24 million Btu per ton, and from 19 to 30 million Btu per ton, respectively. Anthracite comtains approximately 22 to 28 million Btu per ton.

Coal Coke: $\wedge$ hard, porous product made from baking bituminous coal in ovens at temperatures as high as $2,(0)()^{\circ} \mathrm{F}$. It is used both as a fuel and as a reducing agent in sonelting iron ore in a blast furnace.

Commercial sector: The commercial sector, as defincd economically, consists of business establishments that are not engaged in transportation or in manufacturing or other lypes of industrial activity (agriculture, mining, or construction). Commercial estahlishments include hotels, motels, 
restaurants, wholesale businesses, retail stores, laundries, and other service enterprises; religious and nonprofit organizations; health, social, and educational institutions; and Federal, State, and local governments. Street lights, pumps, bridges, and public services are also included if the establishment operating them is considered commercial.

Completion: The installation of permanent equipment for the production of oil or gas. If a well is equipped to produce only oil or gas from one zone or reservoir, the definition of a well (classified as an oil well or gas well) and the defintion of a completion are identical. llowever, if a well is equipped to produce oil and/or gas separately from more than one reservoir, a well is not synonymous with a completion.

Conversion Factor: A number that translates units of one system into corresponding values of another system. Conversion factors can be used to translate physical units of measure for various fuels into Btu equivalents.

Cost, Insurance, Freight (CIF): $\wedge$ type of sale in which the huyer of the product agrees to pay a unit price that includes the f.o.h. value of the product at the point of origin plus all costs of insurance and transporation. This type of transaction differs from a "delivered" purchase in that the buyer accepts the quantity as determined at the loadling port (ats certificd by the Bill of Loading and Quality Report) raller than pay on the basis of the quantity and quality ascertained at the unloading port. It is similar (o) the terms of all t.o.h. sale, except that lle seller, as a service for which he is compensated, arranges for transportation and insurance.

Crude Oil follo. Price: The crude oil price actually charged at the oil-producing country's port of loading. Includes deductions for any rehalles and discounts or additions of premiums, where applicable. It is the actual price paid with no adjustment for credit terms.

Crude (Oil (Including lease Condensate): $\wedge$ mixlure of hydrocarbons that exists in liquid phase in underground reservoirs and remains liyuid al atmospheric pressure after passing through surface separating facilities. Included are lease condensale and liquid hydrocarbons produced from lar sands, gilsonile, and oil shale. Drip gases are also included, hul lopped crude oil (residual oil) and other unfinished oils are excluded. Where identifiable, liquids produced at natural gas processing plants and mixed with crude oil are likewise excluded.

Crude Oil I anded cost: The price of crude oil at the port of discharge, including charges associated with the purchase, transporting, and insuring of a cargo from the purchase point to the port of discharge. The cost does not include charges incurred at the discharge port (e.g., import tariffs or fees, wharfage charges, and demurrage).
Crude (Oil Refinery Input: The total crude oil put into processing units at refineries.

Crude (Oil Stocks: Stocks of crude oil and lease condensate held al refincries, in pipelines, at pipeline corminals, and on leases.

Crude (Dil Used Directly: Crude oil consumed as fuel by crude oil pipelines and on crude oil leases.

Cubic Foot (natural gas): $\wedge$ unit of volume equal to 1 cubic foot at a pressure base of 14.73 pounds standard per square inch absolute and a temperature base of $60^{\circ} \mathrm{l}$.

Degree-1)ay Normals: Simple arithmetic averages of monthly or anmual degree-days over a long period of time (usually the 30-year period 1951-1980). The averages may be simple degree-day normals or population-weighted degree-day normals.

Degree-1)ays, (ooling (C(D))): The number of degrees per daty that the daily average temperature is above $65^{\circ} \mathrm{l}$. The daily average lemperature is the mean of the maximum and minimum temperalures for a 24-hour period

Degret-1)ays, Heating (III)I)): The number of degrees per daly llatl lla daily average temperature is below $6,5^{\circ} \mathrm{l}$. The datily average temperature is the mean of the maximum and minimum lemperalures for a 24-hour period

Degre-1)ays, Population-Weighted: Heating or cooling degrec-days weighted by the population of the area in which the degree-days are recorded. To compute State population-weighted degree-days, each Stale is divided into from one to nine climatically homogencous divisions, which are assigned weights batsed on the ratio of the population of the division to the total poputation of the State. Degrec-day readings for each division are multiplied by the corresponding population weight for each division and those products are lhen summed to arrive at the State population-weighted degree-day figure. To compute national population-weighted degrec-days, the Nation is divided inlo nine: ('ensus regions comprised of from three 10 eight Stalles, which are assigned weights based on the ratio of the population of the region to the total population of the Nation. I)egrec-day readings for each region are multiplied by the corresponding population weight for each region and those products are then summed to arrive at the national population-weighted degree-day figure.

Design Electrical Rating, Net: The nominal net electrical output of a nuclear unit as specified by the electric utility for the purpose of plant design.

Development Well: $\Lambda$ well drilled within the proved area of all oil or gats reservoir to the depth of a stratigraphic horizon known to be productive. 
Distillate Fuel Oll: A general classification for one of the petroleum fractions produced in conventional distillation operations. Included are products known as No. 1, No. 2, and No. 4 fuel oils and No. 1, No. 2 , and No. 4 diesel fuels. It is used primarily for space heating, on- and off-highway diesel engine fuel (including railroad engine fuel and fuel for agricultural machinery), and electric power generation.

Dry Hole: An exploratory or development well found to be incapable of producing either oil or gas in sufficient quantities to justify completion as an oil or gas well.

Dry Natural Gas Production (as a decrement from gas reserves): The volume of natural gas withdrawn from reservoirs during the report year less (1) the volume returned to such reservoirs in cycling, repressuring of oil reservoirs, and conservation operations; (2) shrinkage resulting from the removal of lease condensate and plant liquids; and (3) nonhydrocarbon gases, where they occur in sufficient quantity to render the gas unmarketable. Volumes of gas withdrawn from gas storage reservoirs and native gas that has been transferred to the storage category are not considered production. This is not the same as marketed production, since the latter also excludes vented and flared gas hut contains liquids.

Dry Natural Gas Production (as an increment to gas supply): Gross withdrawals from production reservoirs less gas used in reservoir repressuring, amounts vented and flared, nonhydrocarbons removed, and various natural gas constituents, such as ethane, propane, and butane, removed at natural gas processing plants. The paraneters for measureineut are $60^{\circ} \mathrm{F}$ and 14.73 pounds standard per square inch absolute.

Electrical System Energy Losses: The amount of energy lost during generation, transmission, and distribution of electricity, including plant and unaccounted-for uses.

Electricity Generation: The process of producing electric energy or transforming other forms of energy into electric energy. Also the anount of electric energy produced or expressed in watthours (Wh).

Electricity Generation, Gross: The total anount of electric energy produced by the generating station or stations, measured at the generator terminals.

Electricity Generation, Net: Giross generation less electricity consumed at the generating plant for station use. Electricity required for pumping at pumped-storage plants is regarded as plant use and is deducted from gross generation.

Electricity Production: Net electricily (gross electricity output measured at generator terminals minus power plant use) generated by publicly and privately owned electric utilities. Excludes industrial electricity generation (except autogencration of hydroclectric power).

Electricity Sales: The amount of kilowatthours sold in a given period of time; usually grouped by classes of service, such as residential, commercial, industrial, and other. "Other" sales include sales for public street and highway lighting and other sales to public authorities, sales to railroads and railways, and interdepartmental sales.

Electric Power Plant: A station containing prime movers, electric generators, and auxiliary equipment for converting mechanical, chemical, and/or fission energy into electric energy.

Electric Utility: A corporation, person, agency, authority, or other legal entity or instrumentality that owns and/or operates facilities for the generation, transmission, distribution, or sale of electric energy, primarily for use hy the public, and that files forms listed in the Code of Federal Regulations, Title 18, Part 141. Facilities that qualify as cogenerators or small power producers under the Public lliblity Regulatory Policies Act are not considered electric utilitics.

Electric Utility Sector: The electric utility sector consists of privalely and publicly owned establishments that generate, transmit. distribute, or sell electricity primarily for use by the public and that meet the definition of an electric utility. Nonutility power producers are not included in the electric utility sector.

End-Use Sectors: The residential, commercial, industrial, and transportation sectors of the economy.

Energy: The capacity for doing work as measured by the capahility of doing work (potential energy) or the conversion of this capability to motion (kinetic energy). Energy has several forms, some of which are easily convertible and can be changed to another form useful for work. Most of the world's convertible energy comes from fossil fuels that are burned (1) produce heat that is then used as a transfer medium to mechanical or other means in order 10 accomplish lasks. Electrical energy is usually measured in kilowatthours, while heat energy is usually measured in British thermal units.

Energy Consumption: The use of energy as a source of heat or power or as an input in the manulacturing process.

Energy Consumption, End-Use: Primary end-use energy consumption is the sum of fossil fuel consumption by the four end-use sectors (residential, commercial, industrial, and transportation) and gencration of hydroclectric power by nonelectric utilities. Net end-use energy consumption includes 
electric utility sales to those sectors but excludes electrical system energy losses. Total end-use energy consumption includes both electric utility sales to the four end-use sectors and electrical system energy losses.

Energy Consumption, Total: The sum of fossil fuel consumption by the five sectors (residential, commercial, industrial, transportation, and electric utility) plus hydroelectric power, nuclear electric power, net imports of coal coke, and electricity generated for distribution from wood, waste, geothermal, wind, photovoltaic, and solar thermal energy.

Energy Source: A substance, such as petroleum, natural gas, or coal, that supplies heat or power. In Energy Information Administration reports, electricity and renewable forms of energy, such as biomass, geothermal, wind, and solar, are considered to be energy sources.

Ethane: A normally gaseous straight-chaill hydrocarbon $\left(\mathrm{C}_{2} \mathrm{H}_{6}\right)$. $\mathrm{It}$ is a colorless, paraffinic gas that boils at a temperature of $-127.48^{\circ} \mathrm{F}$. It is extracted from natural gas and refinery gas streams.

Ethylene: An olefinic hydrocarbon $\left(\mathrm{C}_{2} \mathrm{H}_{4}\right)$ recovered from refinery processes or petrochemical processes.

Exploratory Well: $\Lambda$ well drilled to find and produce oil or gas in an unproved area, to find a new reservoir in a field previously found 10 be productive of oil or gas in another reservoir, or 10 extend the limil of a known oil or gas reservoir.

Exports: Shipments of goods from the 50 States and the District of Columbia to foreign countries and 10 Puerto Rico, the Virgin Islands, and other U.S. possessions and territories.

\section{f.a.s.: See Free Alongside Ship.}

Federal Energy Regulatory Commission (FlKC): The Federal agency with jurisdiction over interstate electricity sales, wholesale electric rates, hydrocketric licensing, natural gas pricing, oil pipeline rates, and gas pipeline certification. FERC is an independent regulatory agency within the Departunent of Energy and is the successor to the Federal Power Commission.

Federal Power Commission (FPC): The predecessor agency of the Federal Energy Regulatory Commission. The Federal Power Commission was created by an Act of Congress under the lederal Water Power Act on June 10,1920 . It was charged originally with regulating the electric power and natural gas industries. It was abolished on September 30, 1977. when the Department of Energy was created. Its functions were divided between the Department of
Energy and the Federal Energy Regulatory Commission, an independent regulatory agency.

First Purchase Price: The marketed first sales price of domestic crude oil, consistent with the removal price defined by the provisions of the Windfall Profits Tax on Domestic Crude Oil (Public Law 96-223, Sec. 4998 (c)).

Flared Natural Gas: Natural gas burned in flares on the base site or at gas processing plants.

\section{f.o.b.: Sec Free on Board.}

Footage Drilled: Total footage for wells in various categories, as reported for any specified period, includes (1) the deepest total depth (length of well bores) of all wells drilled from the surface, (2) the total of all bypassed footage drilled in connection with reported wells, and (3) all new footage drilled for directional sidetrack wells. Footage reported for directional sidetrack wells does not include footage in the common bore, which is reported as footage for the original well. In the case of old wells drilled deeper, the reported footage is that which was drilled below the total depth of the old well.

\section{Former U.S.S.R.: See U.S.S.R.}

Fossil Fuel: Any naiurally occurring organic fuel, such as petroleum, coal, and matural gas.

Fossil Fuel Steam-Electric Power Plant: An electricity gencration plant in which the prime mover is a turbine rotated by high-pressure steam produced in a boiler by heat from burning fossil fuels.

Free Alongside Ship (f.a.s.): The value of a commodity at the port of exportation, generally including the purchase price, plus all charges incurred in placing the commodity alongside the carrier at the port of exportation.

Free on Board (f.o.l.): $\wedge$ transaction whereby the seller makes the product available within an agreed-on period at a given port at a given price. It is the responsibility of the buyer 10 arrange for the transportation and insurance.

Fuel Ethanol: An anhydrous, denatured aliphatic alcohol $\left(\mathrm{C}_{2} \mathrm{H}_{5}(\mathrm{OH})\right.$ intended for motor gasoline blending. Sec Oxygenates.

Full-Power Operation: Operation of a nuclear generating unit at 100 percent of its design capacity. Full-power operation precedes commercial operation.

Gasohol: $\Lambda$ blend of finished motor gasoline (leaded or unleaded) and alcohol (generally ethanol but sometimes methanol) limited to 10 percent by volume 
of alcohol. Gasohol is included in finished leaded and unleaded motor gasoline.

Gas-Turbine Electric Power Plant: A plant in which the prime mover is a gas turbine. A gas turbine typically consists of an axial-flow air compressor, one or more combustion chambers where liquid or gaseous fuel is burned and the hot gases expand to drive the generator and then are used to run the compressor.

Gas Well: A well completed for the production of natural gas from one or more gas zones or reservoirs. (Wells producing both crude oil and natural gas are classified as oil wells.)

Geothermal Energy: Energy from the internal heat of the Earth, which may be residual heat, friction heat, or a result of radioactive decay. The heat is found in rocks and fluids at various depths and can be extracted by drilling and/or pumping.

Geothermal Energy (as used at electric utilities): Hot water or steam extracted from geothermal reservoirs in the Earth's crust and supplied 10 stean turbines at electric utilities that drive generators to produce electricity.

Gross Domestic Product (GDP): The total value of goods and services produced by labor and property located in the United States. As long as the labor and property are located in the United States, the supplier (that is, the workers and. for property, the owners) may be either U.S. residents or residents of foreign countries.

Heat Content of a Quantity of Fuel, (iross: The total amount of heat released when a fuel is burned. Coal, crude oil, and natural gas all include chemical compounds of carbon and hydrogen. When those fuels are burned, the carbon and hydrogen combine with oxygen in the air to produce carbon dioxide and water. Some of the energy released in burning goes into transforming the water into steam and is usually lost. The amount of heat spent in transforning the water into steam is counted as part of gross heat content but is not counted as part of net heat content. Also referred to as the higher heating value. Btu conversion factors typically used in EIA represent gross heat content.

Heat Content of a Quantity of Fuel, Net: The amount of usable heat energy released when a fuel is burned under conditions similar to those in which it is normally used. Also referred to as the lower heating value. Btu conversion factors typically used in EIA represent gross heat content.

Heavy Oil: The fuel oils remaining after the lighter oils have been distilled off during the refining process. Except for start-up and fliune stabilization, virtually all petroleum used in stean-electric power plants is heavy oil.
Hydrocarbon: An organic chemical compound of hydrogen and carbon in the gaseous, liquid, or solid phase. The molecular structure of hydrocarbon compounds varies from the simplest (methane, the primary constituent of natural gas) to iute very hedvy and very complex.

Hydroelectric Power: The production of electricity from the kinetic energy of falling water.

Hydruelectric Power Plant: A plant in which the turbine generators are driven by falling water.

Imports: Receipts of goods into the 50 States and the District of Columbia from foreign countries and from Puerto Rico, the Virgin Islands, and other U.S. possessions and territories.

Industrial Sector: The industrial sector comprises manufacturing industries, which make up the largest part of the sector, along with mining, construction, agriculture, fisheries, and forestry. Establishments in the sector range from steel mills, to small farms, to companies assembling electronic components.

Internal Combustion Electric Power Plant: A power plant in which the prime mover is an internal combustion engine. Diesel or gas-fired engines are the principal types used in electric power plants. The plant is usually operated during periods of high demand for electricity.

Jet Fuel: The term includes kerosene-type jet fuel and naphtha-type jet fucl. Kerosene-type jet fuel is a kerosene-quality product used primarily for commercial turbojet and turboprop aircraft engines. Naphtha-type jet fuel is a fuel in the heavy naphthas range used primarily for military turbojet and turboprop aircraft engines.

Kerosene: $\Lambda$ petroleum distillate that has a maximum distillation temperature of $401^{\circ} \mathrm{F}$ at the 10-percent recovery point, a final boiling point of $572^{\circ} \mathrm{F}$, and a minimum flash point of $100^{\circ} \mathrm{F}$. Included are the two grades designated in ASTM D3699 (No. 1-K and No. $2-\mathrm{K}$ ) and all grades of kerosene called range or stove oil. Kerosene is used in space heaters, cook stoves, and water heaters; it is suitable for use as an illuminant when burned in wick lamps.

Lease and Plant Fuel: Natural gas used in well, field, and lease operations (such as gas used in drilling operations, heaters, dehydrators, and field compressors), and as fuel in natural gas processing plants.

Lease Condensate: A natural gas liquid recovered from gas well gas (associated and non-associated) in lease separators or natural gas ficld facilities. Lease condensate consists primarily of pentanes and heavier iiydrocarbons. 
Light Oil: Lighter fuel oils distilled off during the refining process. Virtually all petroleum used in internal combustion and gas-turbine engines is light oil.

Lignite: A brownish-black coal of low rank with a high content of moisture and volatile matter. Often referred to as brown coal. It is used almost exclusively for electric power generation. It conforms to ASTM Specification D388-84 for lignite.

Liquefied Natural Gas (LNG): Natural gas (primarily methane) that has been liquefied by reducing its temperature to $-260^{\circ} \mathrm{F}$ at atmospheric pressure.

Liquefied Petroleum Gases (LPG): Ethane, ethylene, propane, propylene, normal butane, butylene, and isobutane produced at refineries or natural gas processing plants, including plants that fractionate new natural gas plant liquids.

Low-Power Testing: The period of time between a nuclear generating unit's initial fucl loading date and the issuance of its operating (full-power) license. The maximum level of operation during that period is 5 percent of the unit's design thermal rating.

Lubricants: Substances used to reduce friction between bearing surfaces or as process materials either incorporated into other materials used as processing aids in the manufacturing of other products or as carriers of other materials. Petroleum lubricants may be produced either from distillates or residues. Other substances may be added to impart or improve certain required properties. Excluded are byproducts of lubricating oil refining, such as aromatic extracts derived from solvent extraction or tars derived from deasphalting. Included are all grades of lubricating oils from spindle oil to cylinder oil and those used in greases. Lubricant categories are paraffinic and naph:henic.

Marketed Production: Gross withdrawals less gas used for repressuring, quantities vented and flared, and nonhydrocarbon gases removed in treating or processing operations. Includes all quantitics of gas used in field and processing operations.

Methanol: A light, volatile alcohol $\left(\mathrm{CH}_{3} \mathrm{OHI}\right)$ eligible for motor gasoline blending. See Oxygenates.

Miscellaneous Petroleum Products: All finished petroleum products not classified elsewhere-for example, petrolatum, lube refining byproducts (aromatic extracts and tars), absorption oils, ran-jet fuel, petroleum rocket fuels, synthetic natural gas feedstocks, and specialty oils.

Motor Gasoline Blending Components: Naphthas that will be used for blending or compounding into finished motor gasoline (e.g., straight-run gasoline, alkylate, reformate, henzene, toluene, and zylene).
Excluded are oxygenates (alcohols and ethers), butane, and pentanes plus.

Motor Gasoline, Finished: A complex mixture of relatively volatile hydrocarbons, with or without small quantities of additives, that has been blended to form a fuel suitable for use in spark-ignition engines. Motor gasoline, as given in ASTM Specification D439 or Federal Specification VV-G-1690B, includes a range in distillation temperatures from 122 to $158^{\circ} \mathrm{F}$ at the 10-percent recovery point and from 365 to $374^{\circ} \mathrm{F}$ at the 90 -percent recovery point. Motor gasoline includes reformulated motor gasoline, oxygenated motor gasoline, and other finished motor gasoline. Blendstock is excluded until blending has been completed.

- Reformulated Motor Gasoline: Motor gasoline, formulated for use in motor vehicles, the composition and properties of which are certified as "reformulated motor gasoline" by the Environmental Protection Agency.

- Oxygenated Motor Gasoline: Motor gasoline, formulatı $\mathrm{d}$ for use in motor vehicles, that has an oxygen content of 1.8 percent or higher by weight.

- Other Finished Motor Gasoline: Motor gasc ine that is not included in the reformulated or oxygenated categories.

Motor Gasoline, Finished Gasohol: $\wedge$ blend of finished motor gasoline (leaded or unleaded) and alcohol (gencrally ethanol, but sometimes methanol) in which 10 percent or more of the product is alcohol.

Motor Gasoline, Finished Leaded: Motor gasoline that contains more than 0.05 gram of lead per gallon or more than 0.005 gram of phosphorus per gallon. Premium and regular grades are included, depending on the octane rating. Includes leaded gasohol. Blendstock is excluded until blending has been completed. Alcohol that is to be used in the blending of gasohol is also excluded.

Motor Gasoline, Finished Leaded Premium: Motor gasoline having an antiknock index, calculated as $(R+M) / 2$, greater than 90 and containing more than 0.05 gram of lead per gallon or more than 0.005 gram of phosphorus per gallon.

Motor Gasoline, Finished Leaded Regular: Motor gasoline having an antiknock index, calculated as $(R+M) / 2$, greater than or equal to 87 and less than or equal to 90 and containing more than 0.05 gram of lead or 0.005 gram of phosphorus per gallon.

Motor Gasoline, Finished Unleaded: Motor gasoline containing not more than 0.05 gram of lead per gallon and not more than 0.005 gram of phosphorus per gallon. Premium and regular grades are included, depending on the octane rating. Includes unleaded gasohol. Blendstock is excluded until blending has 
been completed. Alcohol that is to be used in the blending of gasohol is also excluded.

Motor Gasoline, Finished Unleaded Midgrade: Motor gasoline having an antiknock index, calculated as $(R+M) / 2$, greater than or equal to 88 and less than or equal to 90 and containing not more than 0.05 gram of phosphorus per gallon.

Motor Gasoline, Finished Unleaded Premium: Motor gasoline having an antiknock index, calculated as $(R+M) / 2$, greater than 90 and containing not more than 0.05 gram of lead or 0.005 gram of phosphorus per gallon.

Motor Gasoline, Finished Unleaded Regular: Motor gasoline having an antiknock index, calculated as $(R+M) / 2$, of 87 containing not more than 0.05 sram of lead per gallon and not more than 0.005 gram of phosphorus per gallon.

Motor Gasoline Retail Prices: Motor gasoline prices calculated each month by the Bureau of Labor Statistics (BLS) in conjunction with the construction of the Consumer Price Index (CPI). Those price: are collected in 85 urban areas selected to represent a!! urban consumers-about 80 percent of the total U.S. population. The service stations are selected initially, and on a replacement basis, in such a way that they represent the purchasing habits of the CPI population. Service stations in the current sample include those providing all types of service (i.e., full-, mini-, and self-service).

Motor Gasoline, Total: Includes finished leaded motor gasoline (premium and regular), finished unleaded motor gasoline (premium, midgrade, and regular), motor gasoline blending components, and gasohol.

MTBE (Methyl Tertiary Butyl Ether): An ether, $\left(\mathrm{CH}_{3}\right)_{3} \mathrm{COCH}_{3}$, intended for motor gasoline blending. See Oxygenates.

Naphtha: A genetic term applied to a petroleum fraction with an approximate boiling range between 122 and $400^{\circ} \mathrm{F}$.

Natural Gas: A mixture of hydrocarbons (principally methane) and small quantities of various nonhydrocarbons existing in the gaseous phase or in solution with crude oil in underground reservoirs.

Natural Gas, Dry: The marketable portion of natural gas production, which is obtained by subtracting extraction losses, including natural gas liquids removed at natural gas processing plants, from total production.

Natural Gas Marketed Production: Gross withdrawals of natural gas from production reservoirs, less gas used for reservoir repressuring; nonhydrocarbon gases removed in treating and processing operations; and quantities vented and flared.

Natural Gas Plant Liquids (NGPL): Natural gas liquids recovered from natural gas in processing plants and, in some situations, from natural gas field facilities, as well as those extracted by fractionators. Natural gas plant liquids are defined according to the published specifications of the Gas Processors Association and the American Society for Testing and Materials as follows: ethane, propane, normal butane, isobutane, pentanes plus, and other products from natural gas processing plants (i.e., products meeting the standards for finished petroleum products produced at natural gas processing plants, such as finished motor gasoline, finished aviation gasoline, special naphthas, kerosene, distillate fuel oil, and miscellaneous products).

Natural Gas Wellhead Price: The wellhead price of natural gas is calculated by dividing the total reported value at the wellhead by the total quantity produced as reported by the appropriate agencies of individual producing States and the U.S. Mincrals Management Service. The price includes all costs prior to shipment from the lease, including gathering and compression costs, in addition to State production, severance, and similar charges.

Natural Gas, Wet: Natural gas prior to the extraction of liquids and other miscellaneous products.

Net Consumption: See Energy Consumption, End-Use.

Nonhydrocarbon Gases: Typical nonhydrocarbon gases that may be present in reservoir natural gas are carbon dioxide, helium, hydrogen sulfide, and nitrogen.

Nuclear Electric Power: Electricity generated by an electric power plant whose turbines are driven by steam generated in a reactor by heat from the fissioning of nuclear fucl.

Nuclear Electric Power Plant: A single-unit or multiunit facility in which heat produced in one or more reactors by the fissioning of nuclear fuel is used to drive one or more steam lurbines.

Nuclear Reactor: An apparatus in which the nuclear fission chain can be initiated, maintained, and controlled so that energy is released at a specific rate. The reactor includes fissionable material (fuel), such as uranium or plutonium; fertile material; moderating material (unless it is a fast reactor); a heavy-walled pressure vessel; shielding to protect personnel; provision for heat removal; and control elements and instrumentation. 
Offshore: That geographic area that lies seaward of the coastline. In general, the coastline is the line of ordinary low water along with that portion of the coast that is in direct contact with the open sea or the line marking the seaward limit of inland water.

\section{Oil: See Crude Oil (Including Lease Condensate).}

Oil Well: A well completed for the production of crude oil from one or more oil zones or reservoirs. Wells producing both crude oil and natural gas are classified as oil wells.

Operable (nuclear): A U.S. nuclear generating unit is considered operable after it completes low-power testing and is issued a full-power operating license by the Nuclear Regulatory Commission. A foreign nuclear generating unit is considered operable once it has generated electricity to the grid.

Organization for Economic Cooperation and Development (OECD): Curresit members are Australia, Austria, Belgium, Canada, Denmark, Finland, France, Greece, Iceland, Ireland, Italy, Japan, Luxembourg, the Netherlands, New Zealand, Norway, Portugal, Spain, Sweden, Switzerland, Turkey, the United Kingdom, the United States and its territories (Guam, Puerto Rico, and the Virgin Islands), and Germany.

Organization of Petroleum Exporting Countries (OPEC): Countries that have organized for the purpose of negotiating with oil companies on malters of oil production, prices, and future concession rights. Current members are Algeria, Gabon, Indonesia, Iran, Iraq, Kuwait, Libya, Nigeria, Qatar, Saudi Arabia, the United Arab Emirates, and Venezuela.

Oxygenated Motor Gasoline: See Motor Gasoline, Finished.

Oxygenates: Any substance which, when added to motor gasoline, increases the amount of oxygen in that motor gasoline blend. Through a series of waivers and interpretive rules, the Environmental Protection Agency (EPA) has determined the allowable limits for oxygenates in unleaded gasoline. The "Substantially Similar" Interpretive Rules (56 FR [February 11, 1991]) allows blends of aliphatic alcohols other than methanol and aliphatic ethers, provided the oxygen content does not exceed 2.7 percent by weight. The "Substantially Similar" Interpretive Rules also provide for blends of methanol up to 0.3 percent by volume exclusive of other oxygenates, and butanol or alcohols of a higher molecular weight up to 2.75 percent by weight. Individual waivers pertaining to the use of oxygenates in unleaded motor gasoline have been issued by the EPA. They include:

- Fuel Ethanol. Blends of up to 10 percent by volume anhydrous ethanol (200 proof).

- Methanol. Blends of methanol and gasoline-grade tertiary butyl alcohol (GTBA) such that the total oxygen content does not exceed 3.5 percent by weight and the ratio of methanol to GTBA is less than or equal to 1 . It is also specified that this blended fuel must meet ASTM volatility specifications.

Blends of up to 5.0 percent by volume methanol with a minimum of 2.5 percent by volume cosolvent alcohols having carbon number of 4 or less (i.e., ethanol, propanol, butanol, and/or GTBA). The total oxygen must not exceed 3.7 percent by weight, and the blend must meet ASTM volaiility specifications as well as phase separation and alcohol purity specifications.

- MTBE (Methyl tertiary butyl ether). Blends up to 15.0 percent by volume MTBE that must meet the ASTM D4814 specifications. Blenders must take precautions that the blends are not used as base gasolines for other oxygenated blends.

Pentanes Plus: A mixture of hydrocarbons, mostly pentanes and heavier, extracted from natural gas. Includes isopentane, natural gasoline, and plant condensate.

Petrochemical Feedstocks: Chemical feedstocks derived from petroleum principally for the manufacture of chemicals, synthetic rubber, and a variely of plastics. The categories reported are naphthas less than $401^{\circ} \mathrm{F}$ endpoint and other oils equal to or greater than $401^{\circ} \mathrm{F}$ endpoint.

Petroleum: $\wedge$ generic term applied to oil and oil products in all forms, such as crude oil, lease condensate, unfinished oils, petroleum products, natural gas plant liquids, and nonhydrocarbon compounds blended into finished petroleum products.

Petroleum Coke: $\Lambda$ residue that is the final product of the condensation process in cracking. The product is either marketable petroleum coke or catalyst petroleum coke.

Petroleum Coke, Catalyst: The carbonaceous residue that is deposited on and deactivates the catalyst used in many catalytic operations (e.g., catalytic cracking). Carbon is deposited on the catalyst, thus deactivating the catalyst. The catalyst is reactivated by burning off the carbon, which is used as a fuel in the refining process. That carbon or coke is not recoverable in a concentrated form.

Petroleum Coke, Marketable: Those grades of coke produced in delayed or fluid cokers that may be recovered as relatively pure carbon. Marketable petroleum coke may be sold as is or further purified by callcining.

Petroleum Consumption: The sum of all refined petroleum products supplied. For each refined petroleum product, the amount supplied is calculated by adding production and imports, then subtracting 
changes in primary stocks (net withdrawals are a plus quantity and net additions are a minus quantity) and exports.

Petroleum Imports: Imports of petroleum into the $\mathbf{5 0}$ States and the District of Columbia from foreign countries and from Puerto Rico, the Virgin Islands, and other U.S. territories and possessions. Included are imports for the Strategic Petroleum Reserve and withdrawals from bonded warehouses for onshore consumption, offshore bunker use, and military use. Excluded are receipts of foreign petroleum into bonded warehouses and into U.S. territories and U.S. Foreign Trade Zones.

Petroleum Products: Products obtained from the processing of crude oil (including lease condensate), natural gas, and other hydrocarbon compounds. Petroleum products include unfinished oils, liquefied petroleum gases, pentanes plus, aviation gasoline, motor gasoline, naphtha-type jet fuel, kerosene-type jet fuel, kerosene, distillate fuel oil, residual fucl oil, petrochemical feedstocks, special naphthas, lubricants, waxes, petroleum coke, asphalt, road oil, still gas, and miscellaneous products.

Petroleum Products Supplied: See Petroleum Consumption.

Petroleum Stocks, Primary: For individual products, quantities that are held at refincries, in pipelines, and at bulk terminals that have a capacity of 50,000 barrels or more, or that are in transit thereto. Stocks held by product retailers and resellers, as well as tertiary stocks held at the point of consumption, are excluded. Stocks of individual products held at gas processing plants are excluded from individual product estimates but are included in other oils estimates and total.

Photovoltaic and Solar Thermal Energy (as used at electric utilities): Energy radiated by the sun as electromagnetic waves (electromagnetic radiation) that is converted at e'ectric utilities into electricity by means of solar (plotovoltaic) cells or concentrating (focusing) collectors.

Pipeline Fuel: Gas consumed in the operation of pipelines, primarily in compressors.

Primary Consumption: Sce Energy Consumption, End-Use.

Propane: $\wedge$ normally gaseous straight-cuain hydrocarbon $\left(\mathrm{C}_{3} \mathrm{H}_{8}\right)$. It is a colorless paraffinic gas that boils at a temperature of $-43.67^{\circ} \mathrm{F}$. It is extracted from natural gas or refinery gas streams. It includes all products designated in $\triangle$ STM Specification D1835 and Gas Processors Association Specifications for commercial propane and IID-5 propane.

Propylene: An olefinic hydrocarbon $\left(\mathrm{C}_{3} \mathrm{H}_{6}\right)$ recovered from refinery or petrochemical processes.
Refiner Acquisition Cost of Crude Oil: The cost of crude oil to the refiner, including transportation and fees. The composite cost is the weighted average of domestic and imported crude oil costs.

Refinery (petroleum): A $n$ installation that manufactures finished petroleum products from crude oil, unfinished oils, natural gas liquids, other hydrocarbons, and alcohol.

Renewable Energy: Energy obtained from sources that are essentially inexhaustible (unlike, for example, the fossil fuels, of which there is a finite supply). Renewable sources of energy include wood, waste, photovoltaic, and solar thermal energy.

Repressuring: The injection of a pressurized fluid (such as air, gas, or water) into oil and gas reservoir formations to effect greater ultimate recovery.

Residential Sector: The residential sector is considered to consist of all private residences, whether occupied or vacant, owned or rented, including single-family homes, multifamily housing units, and mobile homes. Secondary homes, such as summer homes, are also included. Institutional housing, such as school dormitories, hospitals, and military barracks, generally are not included in the residential sector; they are included in the commercial sector.

Residual Fuel Oil: The heavier oils that remain after the distillate fuel oils and lighter hydrocarbons are distilled away in refinery operations and that conform to ASTM Specifications D396 and 975. Included are No. 5, a residual fuel oil of medium viscosity; Navy Special, for use in steam-powered vessels in government service and in shore power plants; and No. 6, which includes Bunker C fuel oil and is used for commercial and industrial heating, electricity generation, and to power ships. Imports of residual fucl oil include imported crude oil burned as fuel.

Road Oil: Any heavy petroleum oil, including residual asphaltic oil used as a dust palliative and surface treatment on roads and highways. It is generally produced in six grades, from 0 , the most liquid, to 5 , the most viscous.

Rotary Rig: A machine used for drilling wells that employs a rotating tube allached to a bit for boring holes through rock.

Short Ton (coal): $\Lambda$ unit of weight equal to 2,000 pounds.

SIC: See Standard Industrial Classification.

Solar Enesgy: The radiant energy of the sun, which can be converted into other forms of energy, such as heal or electricity. 
Standard Industrial Classification (SIC): $\wedge$ set of codes developed by the Office of Management and Budget which categorizes industries into groups with similar economic activities.

Startup Test Phase of Nuclear Power Plant: A nuclear power plant that has been licensed by the Nuclear Regulatory Commission to operate but is still in the initial testing phase, during which the production of electricity may not be continuous. In general, when the electric utility is satisfied with the plant's performance, it formally accepts the plant from the manufacturer and places it in commercial operation status. $A$ request is then submitted to the appropriate utility rate commission to include the power plant in the rate base calculation.

Steam-Electric Power Plant: $\wedge$ plant in which the prime mover is a steam turbine. The steam used to drive the lurbine is produced in a boiler where fossil fuels are burned.

Strategic Petroleum Reserve (SPR): Petroleum stocks maintained by the federal (iovermment for use during periods of major supply interruption.

Supplemental Gaseous Fuels: Any gaseous substance thitt, introduced into or commingled with hatural gas, increases the volume available for disposition. Such substances include, but are not limited to, propane-air, refinery gas, coke oven gas, still gas, manufactured gas, hiomass gas, or air or inert gases added for Btu stabilization.

Synthetic Natural Gas (SN(i): A manufactured product chemically similar in most respects 10 natural gas, resulting from the conversion or reforming of petroleum hydrocarbons. It may easily be substituted for, or interchanged with, pipeline quality natural gas. Also reterred to as substitute natural gas.

Total Consumption: See Energy Consumption, Eowl-Use.

Transportation Sector: The transporation sector consists of private and public vehicles that move perple and commodities. Included are automobiles, trucks, buses, motorcycles, railroads and railways (including streetcars), aircraft, ships, barges, and natural gas pipelines.

Unaccounted-for Crude Oil: Arithmetic difference between the calculated supply and the calculated disposition of crude oil. The calculated supply is the sum of crude oil production and imports, less changes in crude oil stocks. The calculated disposition of crude oil is the sum of crude oil input to refineries, crude oil exports, crude oil burned as fucl, and crude oil losses.
Underground Storage: The storage of natural gas in underground reservoirs at a different location from which it was produced.

United States: Unless otherwise noted, "United States" in this publication means the 50 States and the District of Columbia. U.S. exports include shipments to U.S. territories, and imports include receipts from U.S. territories.

U.S.S.K.: The Union of Soviet Socialist Republics consisted of 15 constituent republics: Armenia, Azerbaijan, Belorussia, Estonia, Georgia, Kazakhstan, Kirghizia, Latvia, Lithuania, Moldavia, Russia, Tadzhikistan, Turkmenistan, Ukraine, and Uzbekistan. As a political entity, the U.S.S.R. ceased to exist as of December 31, 1991.

Vented Natural Gas: Gas released into the air on the base site or at processing plants.

Wellhead Price: The value of crude oil or natural gas at the mouth of the well.

Well Servicing Unit: Truck-mounted equipment generally used for downhole services after a well is drilled. Services include well completions and recompletions, maintenance, repairs, workovers, and well plugging and ahandonments. Jobs range from minor operations, such as pulling the rods and rod pumps out of an oil well, replacing the pump and rerunning the assemblage into the well, to major workovers, such as milling out and repairing collapsed casing. Well depth and characteristics determine the type of equipment used.

Wind Energy (as used at electric utilities): The kinetic energy of wind converted at electric utilities into mechanical energy by wind turbines (i.e., blades rotating from a hub) that drive generators to produce electricity for distribution.

Wood and Waste (as used at electric utilities): Wood energy, garbage, hagasse, sewerage gas, and other industrial, agricultural, and urban refuse used to generate electricily for distribution.

Wood Energy: Wood and wood products used as fuel, including round wood (cord wood), limb wood, wood chips, bark, sawdust, forest residues, charcoal, pulp waste, and spent pulping liquor.

Working (aas: The gas in a reservoir that is in addition (o) the base (cushion) gas. It may or may not be completely withdrawn during any particular withdrawal season. Conditions permitting, the total working capacity could be used more than once during any given searon. 

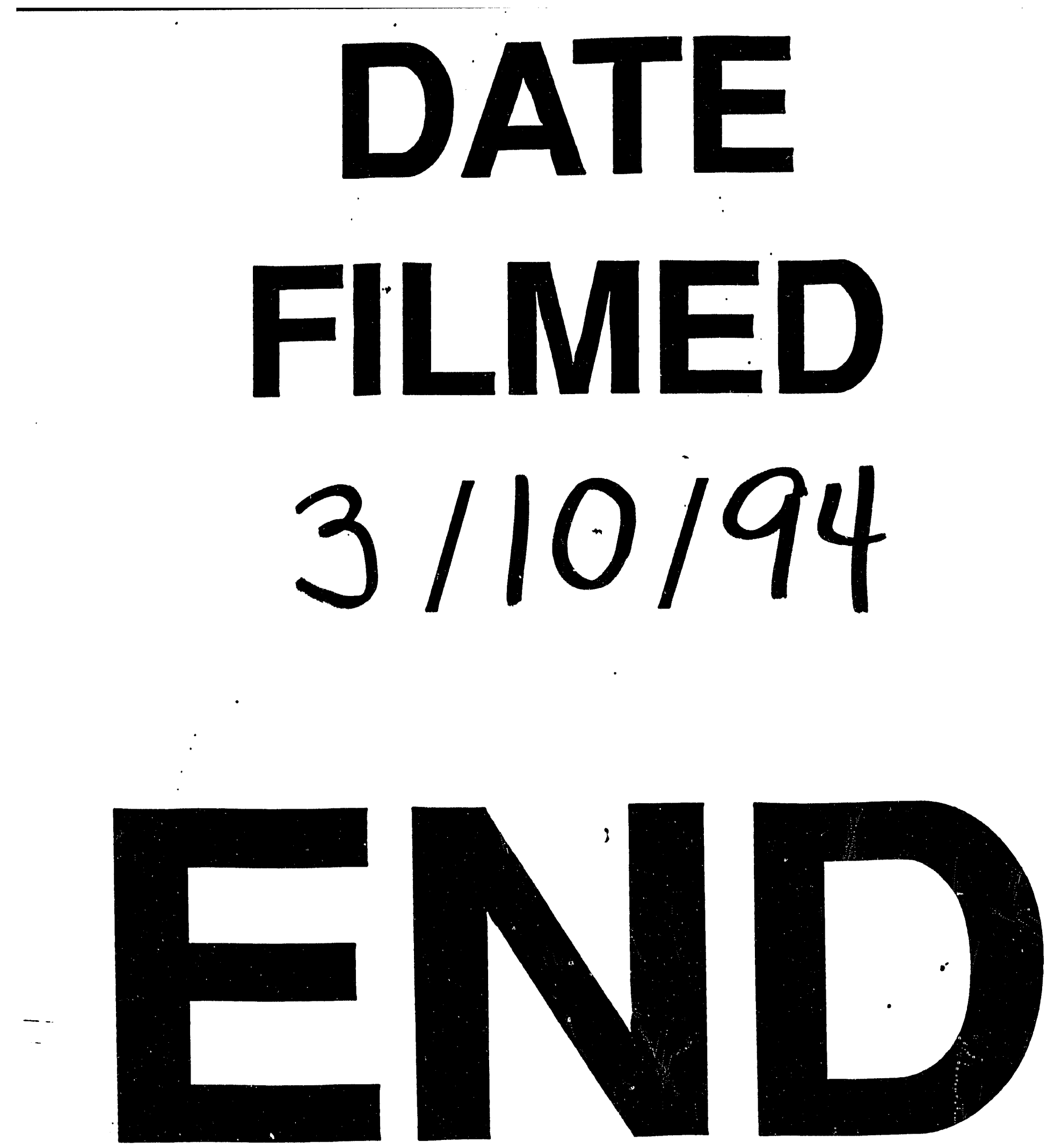


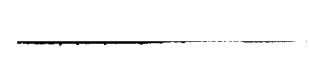

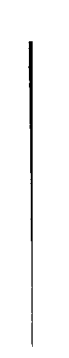

